MARCELO FIGUEIREDO MASSULO AGUIAR

Avaliação do uso de rejeito de caulim como fíler em concretos asfálticos

\title{
Programa de Pós-graduação em
} Engenharia de Transportes da EESC-USP

Exemplar definitivo (corrigido). 0 exemplar original está disponível na CPG da EESC-USP

São Carlos, 26/03/2019

RESOLUÇÃO CoPGr N 6018, DE 13 DE OUTUBRO DE 2011, artigo 5

Tese apresentada ao Departamento de Engenharia de Transportes da Escola de Engenharia de São Carlos da Universidade de São Paulo (STT/EESC/USP) como parte dos requisitos para a obtenção do título de Doutor em Ciências.

Área de concentração: Infraestrutura de Transportes

Orientadora: Profa. Dra. Ana Paula Furlan

São Carlos 
AUTORIZO A REPRODUÇÃO TOTAL OU PARCIAL DESTE TRABALHO, POR QUALQUER MEIO CONVENCIONAL OU ELETRÔNICO, PARA FINS DE ESTUDO E PESQUISA, DESDE QUE CITADA A FONTE.

Ficha catalográfica elaborada pela Biblioteca Prof. Dr. Sérgio Rodrigues Fontes da EESC/USP com os dados inseridos pelo(a) autor(a).

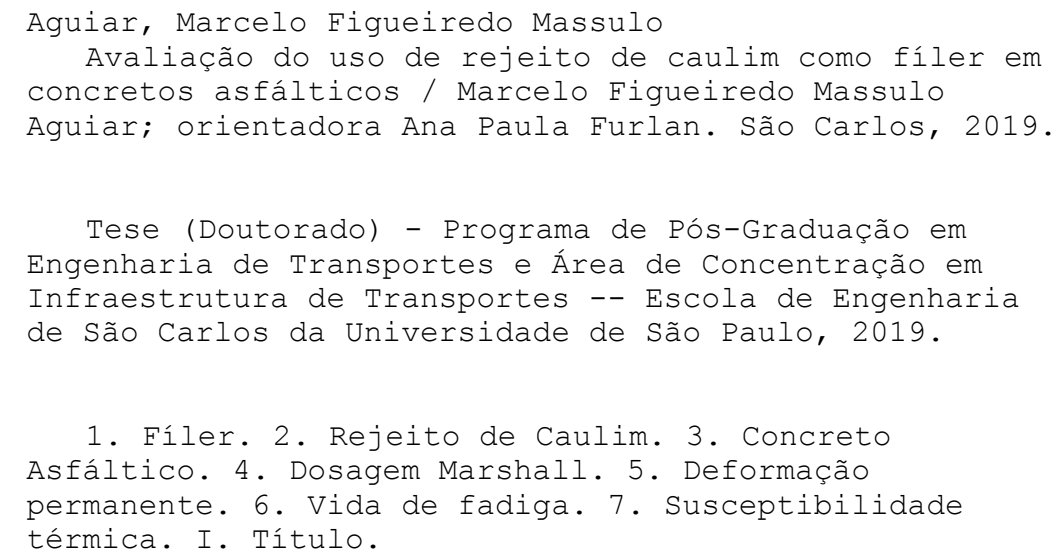

Eduardo Graziosi Silva - CRB - 8/8907 


\section{FOLHA DE JULGAMENTO}

Candidato: Engenheiro MARCELO FIGUEIREDO MASSULO AGUIAR.

Título da tese: "Avaliação do uso de rejeito de caulim como fíler em concretos asfálticos".

Data da defesa: 26/03/2019.

Comissão Julgadora:

Resultado:

Profa. Dra. Ana Paula Furlan

Aprovido

(Orientadora)

(Escola de Engenharia de São Carlos/EESC)

Prof. Dr. Glauco Tulio Fabbri

(Escola de Engenharia de São Carlos/EESC)

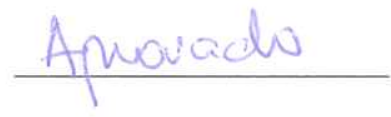

Profa. Titular Liedi Légi Bariani Bernucci

(Escola Politécnica/EP-USP)

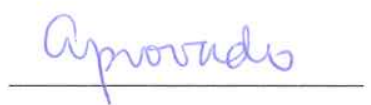

Profa. Dra. Consuelo Alves da Frota

(Universidade Federal do Amazonas/UFAM)

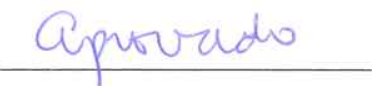

Profa. Dra. Lêda Christiane de Figueirêdo Lopes Lucena_CPprouado (Universidade Federal de Campina Grande/UFCG)

Coordenadora do Programa de Pós-Graduação em Engenharia de Transportes:

Profa. Associada Ana Paula Camargo Larocca

Presidente da Comissão de Pós-Graduação:

Prof. Titular Murilo Araujo Romero 

À minha esposa, Valéria, e às minhas filhas, Mariana "Mocinha" e Manuela "Xuxutas", por todo o amor, carinho, companheirismo, incentivo e muita compreensão ao longo da elaboração desta tese. Sem vocês, que graça teria?

Ao meu pai, Orlando Massulo Aguiar, que infelizmente deixou a vida no dia 09/03/2019 e não pode ver minha defesa de tese. Te amo! 



\section{AGRADECIMENTOS}

A Deus.

Aos meus pais Orlando (in memoriam) e Elaene, por me darem os ensinamentos básicos para trilhar uma vida correta. Por todo o amor, torcida e confiança.

À minha esposa Valéria, por todo o incentivo e apoio para que este trabalho chegasse ao fim e também pela paciência e compreensão nos momentos em que estive "imerso" na tese.

Às minhas filhas Mariana e Manuela, por serem minha fonte de inspiração.

Ao meu irmão Maurício e família (Cinthya e Alice), pela amizade e suporte.

À família da minha esposa (Luiz, Dirce, Nadja, Luiz Neto, Mauro e Gabriel), por sempre serem solícitos em ajudar nos momentos necessários.

À Prof. Ana Paula Furlan, pelos ensinamentos, disponibilidade, orientação honesta e pelas fundamentais contribuições para o aprimoramento deste trabalho.

Ao Prof. Glauco Fabbri, pelo apoio para a realização dos ensaios de módulo de resiliência, fadiga por compressão diametral à tensão controlada e creep estático.

Aos professores do STT, pela grande contribuição à minha carreira docente.

Aos técnicos do Laboratório de Estradas do Departamento de Engenharia de Transportes da EESC/USP, Antonio Carlos Gigante (in memoriam) pelos conselhos referentes a otimização de materiais nas dosagens Marshall e Paulo Toyama pelo apoio nos ensaios de caracterização dos materiais e nas dosagens Marshall e pela amizade e descontração.

Agradecimento especial ao João Domingos Pereira Filho, técnico do Laboratório de Estradas do Departamento de Engenharia de Transportes da EESC/USP, parceiro de duas corridas "São Silvestre", pela amizade e por ter ajudado de maneira cordial e profissional na confecção de aproximadamente 400 corpos de prova. 
À Faculdade de Engenharia Civil do Campus Universitário de Tucuruí da Universidade Federal do Pará (CAMTUC/UFPA), pela liberação em tempo total para dedicar-me ao doutorado.

Ao Prof. Manoel Sória, pela confiança de me ceder o uso de sua residência no início desta jornada.

Ao Matheus Francisco da Silva, pela fundamental ajuda nos trâmites de impressão, encadernação e entrega dos exemplares de defesa.

À CAPES, pela bolsa de estudos concedida.

À Pedreira Usina Paulista de Britagem Pedreira São Jerônimo LTDA, pela cessão do agregado.

À empresa Brasquímica, pelo fornecimento dos ligantes asfálticos.

À Engenharia e Comércio Bandeirantes, pela doação da cal.

À Imerys, pela cessão do caulim e compartilhamento de informações. 


\section{RESUMO}

AGUIAR, Marcelo Figueiredo Massulo. Avaliação do uso de rejeito de caulim como fíler em concretos asfálticos. 2019. 235 p. Tese (Doutorado em Ciências) - Departamento de Engenharia de Transportes, Escola de Engenharia de São Carlos, Universidade de São Paulo, São Carlos, 2019.

A atividade de mineração de caulim, no Pará, produz cerca de 1,5 milhões de toneladas/ano de caulim beneficiado para uso na indústria de papel e, em consequência, é gerado um grande volume de rejeito de caulim, cujo aproveitamento como material de pavimentação pode reduzir o passivo ambiental. O objetivo desta pesquisa foi avaliar a viabilidade técnica do uso de rejeito de caulim como fíler em concretos asfálticos, considerando aspectos relacionados à dosagem Marshall e propriedades de engenharia. Para isso, foram produzidas doze misturas asfálticas, que resultaram da combinação dos fatores: tipo de ligante asfáltico (CAP 50/70 e CAP 30/45) e tipo/teor de fíler (granito, 1,5\%, 3,0\% e 6,0\% de caulim, $1,5 \%$ de cal e 3,0\% de caulim $+1,5 \%$ de cal), as quais foram avaliadas à luz dos resultados de dosagens Marshall, de ensaios mecânicos (RT, MR, fadiga e creep estático) e relacionados à durabilidade (de susceptibilidade térmica e ao dano por umidade). Adicionalmente, foram testadas correlações entre os parâmetros de caracterização do fíler "teor de caulim", "D10", "D30", "D60" e "módulo de finura" (MF) versus parâmetros de dosagens e propriedades mecânicas e de durabilidade. Os resultados das dosagens indicaram que as mudanças do tipo de CAP e/ou do tipo e teor de fíler não influenciaram significativamente os teores de projeto (TP variaram entre 5,3 e 5,6\%); no entanto, os valores de estabilidade das misturas com CAP 30/45 foram superiores aos das misturas com CAP 50/70, e as misturas com 6,0\% de caulim apresentaram baixa estabilidade e elevada fluência, para ambos os ligantes asfálticos. As misturas sem cal não atenderam a RRT mínima de 70\%, o que foi atribuído à má adesividade do granito com os ligantes asfálticos. Por isso, em termos de dosagem, apenas as misturas contendo cal atenderam a todas as exigências do DER/SP. Quanto aos ensaios mecânicos, constatou-se que nas misturas com CAP 30/45, a rigidez e as resistências à tração e à fadiga foram maiores e a susceptibilidade térmica foi menor em relação às misturas com CAP 50/70. Para ambos ligantes asfálticos, a adição de rejeito de caulim aumentou a rigidez e a vida de fadiga e melhorou a susceptibilidade térmica, porém reduziu as resistências à tração e à deformação permanente. Identificou-se que o efeito do tipo de ligante asfáltico está mais relacionado às propriedades mecânicas e à susceptibilidade térmica, e o efeito do tipo de fíler, às propriedades volumétricas, aos parâmetros de deformação permanente e de susceptibilidade ao dano por umidade. Complementarmente, mostrou-se que os parâmetros de caracterização "teor de caulim" e "MF" se correlacionaram melhor com os parâmetros das dosagens Marshall e do ensaio de creep estático, respectivamente. Por fim, conclui-se que o uso de rejeito de caulim como fíler em concreto asfáltico é tecnicamente viável, para ambos os tipos de ligante asfáltico, em teores de adição de até 3,0\% e associado à cal.

Palavras-chave: Fíler. Rejeito de caulim. Concreto asfáltico. Dosagem Marshall. Deformação permanente. Vida de fadiga. Susceptibilidade térmica. 



\begin{abstract}
AGUIAR, Marcelo Figueiredo Massulo. Evaluation of kaolin waste as filler in hot mix asphalt. 2019. 235 p. D.Sc. Thesis - Department of Transportation Engineering, São Carlos School of Engineering, University of São Paulo, São Carlos, 2019.
\end{abstract}

Mining activity of kaolin, in Pará, produces around 1.5 million ton/year of processed Kaolin for paper industry, as a consequence, a substantial volume of waste is generated. The use of kaolin waste might reduce the environmental legacy. The main purpose of this research was to evaluate the technical feasibility of kaolin waste as filler in hot mix asphalt, considering aspects related to mix design and engineering properties. For this, twelve asphalt mixtures were produced from the combination of factors: type of asphalt binder (CAP 50/70 e CAP 30/45) and type/content of filler (granite, 1.5, 3.0 and $6.0 \%$ of kaolin waste, $1.5 \%$ of lime and $3.0 \%$ of kaolin waste $+1.5 \%$ of lime). Asphalt mixtures were evaluated based on results from Marshall design, mechanical (ITS, RM, fatigue and static creep) and durability (thermal and moisture susceptibilities) tests. Additionally, filler-characterization parameters (kaolin content, D10, D30, D60 and fineness modulus, FM) were correlated to the Marshall's parameters and to the mechanical and durability properties. Marshall design results indicated that the changes of asphalt binder and types/content of filler did not significantly influence asphalt content (variation from 5.3 to 5.6\%), however, stability values of mixtures with CAP 30/45 were higher than the mixtures with CAP 50/70. Mixtures containing 6\% of Kaolin presented low stability and high flow, for both asphalt binders. Mixtures without lime did not reach minimum TSR value $(70 \%)$, which was attributed to the poor adhesion between granite aggregates and asphalt binders. Therefore, regarding Marshall parameters, only asphalt mixtures with lime met all of DOT/Sao Paulo's standard requirements. Concerning mechanical tests, it was showed that, in mixtures with CAP 30/45, stiffness, tensile strength and fatigue resistance were higher and the thermal susceptibility was lower when compared to mixtures with CAP 50/70. Kaolin addition increased stiffness and fatigue life, but, decreased tensile strength and rutting resistance. Mechanical properties and thermal susceptibility were quite affected by asphalt binder whereas volumetric and rutting properties and moisture damage were most influenced by filler type and content. Furthermore, kaolin content and FM well correlated with Marshall and rutting parameters, respectively. Finally, it was concluded that the use of kaolin waste as filler in hot mix asphalt is technically feasible, for both tested asphalt binders, at contents up to $3.0 \%$ and combined with $1.5 \%$ of lime.

keywords: Filler. Kaolin waste. Asphalt concrete. Marshall mix design. Rutting. Fatigue. Thermal susceptibility. 



\section{LISTA DE FIGURAS}

Figura 2.1 - Variação de rigidez em função da temperatura (Resultados de Taira et al. (2003), Gigante (2007), Loulizi et al. (2006) e Anitelli (2013)) ........

Figura 2.2 - Imagem aérea da mina PPSA e localização das minas e minerodutos da Imerys no Pará (IMERYS, 2016)

Figura 2.3 - Localização da camada de caulim SFC e equipamentos utilizados na exploração do minério

Figura 3.1 - Curvas de viscosidade rotacional versus temperatura para CAP 50/70 e CAP $30 / 45$

Figura 3.2 - Distribuição granulométrica da faixa C do DNIT ou III do DER/SP .... 39

Figura 3.3 - Caulim SFC bruto (a) e caulim SFC passado na peneira \#200 (b) .......... 41

Figura 3.4 - Distribuição granulométrica do caulim ............................................. 41

Figura 3.5 - Distribuições granulométricas dos fíleres obtidas com ensaio de sedimentação

Figura 3.6 - Ensaios de sedimentação

Figura 3.7 - Imagens de MEV e principais elementos químicos dos fíleres 44

Figura 3.8 - Módulo de Resiliência: (a) tela do programa do ensaio (b) aparato do ensaio

Figura 3.9 - Aparato do ensaio de resistência à tração por compressão diametral .....

Figura 3.10 - Ciclo de carga e aparato do ensaio de fadiga por compressão diametral à tensão controlada

Figura 3.11 - Creep estático: (a) tela do programa do ensaio (b) aparato do ensaio .... 58

Figura 3.12 - Estruturas dos tipos de pavimentos considerados na análise mecanística

Figura 4.1 - Teores de Projeto das 10 misturas asfálticas testadas .....

Figura 4.2 - Influência do tipo de fíler e do tipo de ligante asfáltico no Vv, para $5,0 \% \leq \mathrm{P}_{\mathrm{b}} \leq 6,0 \%$

Figura 4.3 - Volume de vazios por tipo de mistura asfáltica para $\mathrm{P}_{\mathrm{b}}=5,5 \%$ 70

Figura 4.4 - Influência do tipo de fíler e do tipo de ligante asfáltico no VAM, para $5,0 \% \leq \mathrm{P}_{\mathrm{b}} \leq 6,0 \%$ 71

Figura 4.5 - VAM por tipo de mistura asfáltica para $\mathrm{Pb}=5,5 \%$ 72 
Figura 4.6 - Influência do tipo de fíler e do tipo de ligante asfáltico na RBV, para $5,0 \% \leq \mathrm{P}_{\mathrm{b}} \leq 6,0 \%$

Figura $4.7-$ RBV por tipo de mistura asfáltica para $\mathrm{P}_{\mathrm{b}}=5,5 \%$

Figura 4.8 - Influência do tipo de fíler e do tipo de ligante asfáltico na estabilidade,

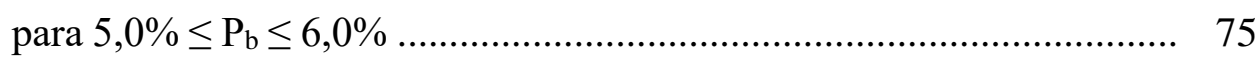

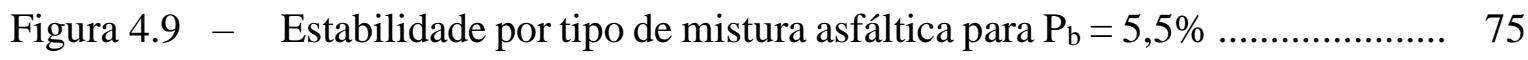

Figura 4.10 - Influência do tipo de fíler e do tipo de ligante asfáltico na fluência, para $5,0 \% \leq \mathrm{P}_{\mathrm{b}} \leq 6,0 \%$ 76

Figura 4.11 - Fluência por tipo de mistura asfáltica para $\mathrm{P}_{\mathrm{b}}=5,5 \%$ 77

Figura 4.12 - Módulo de Resiliência à $25^{\circ} \mathrm{C}$ por tipo de mistura 84

Figura 4.13 - Resistência à tração por tipo de mistura 86

Figura 4.14 - Relação MR/RT por tipo de mistura 87

Figura 4.15 - Relação de Resistência à Tração 89

Figura 4.16 - Inspeção visual dos corpos de prova após o término do ensaio de DUI... 91

Figura 4.17 - Relação de Módulo de Resiliência 92

Figura $4.18-\mathrm{MR}_{4 \%}$ e $\mathrm{MR}_{7} \%$ a $25^{\circ} \mathrm{C}$, por tipo de ligante asfáltico .... 102

Figura $4.19-\quad \mathrm{MR}_{4 \%}$ e $\mathrm{MR}_{7} \%$ a $10^{\circ} \mathrm{C}$, por tipo de ligante asfáltico .... 103

Figura 4.20 - Figura 4.20 - MR4\% e MR7\% a $40^{\circ} \mathrm{C}$, por tipo de ligante asfáltico ..... 105

Figura 4.21 - $\quad$ PST para $\mathrm{Vv} \approx 4 \%$ na faixa de temperatura de 10 a $25^{\circ} \mathrm{C}$ 107

Figura 4.22 - $\quad$ PST para $V v \approx 7 \%$ na faixa de temperatura de 10 a $25^{\circ} \mathrm{C}$ 109

Figura 4.23 - $\quad$ PST para $\mathrm{Vv} \approx 4 \%$ na faixa de temperatura de 25 a $40^{\circ} \mathrm{C}$

Figura 4.24 - $\quad$ PST para $\mathrm{Vv} \approx 7 \%$ na faixa de temperatura de 25 a $40^{\circ} \mathrm{C}$

Figura 4.25 - $\quad$ PST para $V v \approx 4 \%$ na faixa de temperatura de 10 a $40^{\circ} \mathrm{C}$

Figura 4.26 - $\quad$ PST para $V v \approx 7 \%$ na faixa de temperatura de 10 a $40^{\circ} \mathrm{C}$

Figura 4.27 - Representação gráfica dos modelos de fadiga para misturas com CAP $50 / 70$

Figura 4.28 - Representação gráfica dos modelos de fadiga para misturas com CAP $30 / 45$

Figura 4.29 - Representação gráfica da comparação da vida de fadiga para diferentes níveis de tensão

Figura 4.30 - Variação percentual da vida de fadiga em função do tipo de ligante asfáltico

Figura 4.31 - Variação percentual da vida de fadiga em função do tipo de fíler 
Figura 4.32 - Vida de fadiga por tipo de pavimento no cenário de referência 130

Figura 4.33 - Análise de sensibilidade dos pavimentos com capa esbelta 132

Figura 4.34 - Análise de sensibilidade dos pavimentos com capa espessa ... 134

Figura 4.35 - Deformação total no ensaio de creep estático por tipo de mistura 141

Figura 4.36 - Módulo de fluência no ensaio de creep estático por tipo de mistura ....... 141

Figura 4.37 - Recuperação da deformação no ensaio de creep estático por tipo de mistura

Figura 4.38 - Inclinação do estágio secundário da curva de fluência no ensaio de creep estático por tipo de mistura

Figura 4.39 - Curvas de fluência do ensaio de creep estático por tipo de ligante asfáltico

Figura 4.40 - Curvas de fluência do ensaio de creep estático por tipo de fíler 144

Figura 4.41 - Resistência à tração após o ensaio de creep estático por tipo de mistura. 150

Figura 4.42 - Valores de $\mathrm{R}^{2}$ das regressões lineares entre os parâmetros das dosagens Marshall

Figura 4.43 - Valores de $\mathrm{R}^{2}$ das regressões lineares entre os parâmetros caracterização mecânica básica

Figura 4.44 - Valores de $\mathrm{R}^{2}$ das regressões lineares entre os parâmetros da caracterização mecânica complementar, para $\mathrm{Vv}=4 \%$

Figura 4.45 - Valores de $\mathrm{R}^{2}$ das regressões lineares entre os parâmetros da caracterização mecânica complementar, para $\mathrm{Vv}=7 \%$

Figura 4.46 - Valores de $\mathrm{R}^{2}$ das regressões lineares entre os parâmetros da Etapa 1 x Etapa 2

Figura 4.47 - Valores de $\mathrm{R}^{2}$ das regressões lineares entre os parâmetros da Etapa $1 \mathrm{x}$ Etapa 3

Figura 4.48 - Valores de $\mathrm{R}^{2}$ das regressões lineares entre os parâmetros da Etapa $2 \mathrm{x}$ Etapa 3

Figura 4.49 - Modelos de regressão linear MR x Vv e RT x Vv, por tipo de ligante asfáltico

Figura B.1 - Gráficos das Dosagens Marshall para as misturas de referência (5070 e 3045)

Figura B.2 - Gráficos das Dosagens Marshall para as misturas com 1,5\% de caulim $(5070 \mathrm{C} 1,5$ e $3045 \mathrm{C} 1,5)$ 
Figura B.3 - Gráficos das Dosagens Marshall para as misturas com 3,0\% de caulim $(5070 \mathrm{C} 3,0$ e $3045 \mathrm{C} 3,0)$

Figura B.4 - Gráficos das Dosagens Marshall para as misturas com 6,0\% de caulim (5070C6,0 e 3045C6,0)

Figura B.5 - Gráficos das Dosagens Marshall para as misturas com cal (5070L e $3045 \mathrm{~L})$

Figura C.1 - Verificação de normalidade dos dados de deformação total do ensaio creep

Figura C.2 - Tela do SPSS contendo o teste t dos valores de MR das misturas 3045 x $3045 \mathrm{C} 3,0 \mathrm{~L}$

Figura D.1 - Exemplos de regressões lineares entre os parâmetros de caracterização do fíler versus TP

Figura H.1 - Exemplo de regressão linear entre Estabilidade versus MR 


\section{LISTA DE TABELAS}

Tabela 2.1 - Faixa granulométrica para que um material seja considerado fíler

Tabela 2.2 - Critério de resistência à DP em função do módulo de fluência após 1 hora de carregamento (Fonte: Little, Button e Youssef, 1993) .............. 22

Tabela 3.1 - Características dos ligantes asfálticos .............................................. 38

Tabela 3.2 - Faixas de Temperatura de Usinagem e Compactação (TUC) dos ligantes asfálticos

Tabela 3.3 - Porcentagem de massa passando para o centro da faixa III e massa retida por peneira para compor um CP com $1.200 \mathrm{~g}$ de agregado ........... 40

Tabela 3.4 - Resultados da caracterização do agregado .......................................... 40

Tabela 3.5 - Resultados da caracterização do caulim .............................................. 42

Tabela 3.6 - Parâmetros de caracterização dos fíleres .............................................. 44

Tabela 3.7 - Resumo do método empregado na tese ................................................. 45

Tabela 3.8 - Indicação do ${ }^{\circ}$ de golpes do soquete Marshall, por face do CP, para

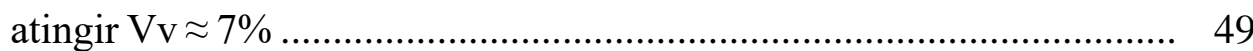

Tabela 3.9 - Descrição dos testes de hipóteses utilizados nos ensaios de fadiga ........ 62

Tabela 4.1 - Descrição das misturas asfálticas dosadas na Etapa 1 ........................... 63

Tabela 4.2 - Resultados das Dosagens Marshall para as 10 misturas asfálticas

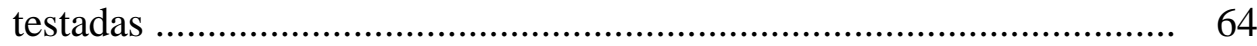

Tabela 4.3 - Valores dos parâmetros das dosagens Marshall para teor de ligante

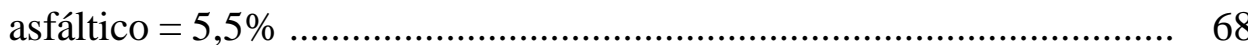

Tabela 4.4 - Variação percentual média dos parâmetros das dosagens Marshall, em função do tipo de fíler (adição de caulim ou de cal) e do tipo de ligante

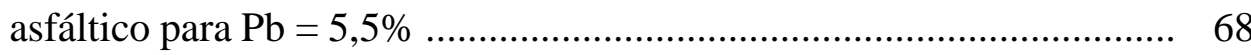

Tabela $4.5-$ Valores dos quocientes Marshall para teor de ligante asfáltico $=5,5 \% \ldots \quad 78$

Tabela 4.6 - Valores de $\mathrm{R}^{\mathbf{2}}$ das regressões lineares entre parâmetros de caracterização do fíler versus variáveis-resposta da Etapa 1 ................ 80

Tabela 4.7 - Descrição das misturas asfálticas utilizadas na Etapa 2, com indicação do TP

Tabela 4.8 - Resultados dos ensaios de dano por umidade induzida 
Tabela 4.9 - Valores de $\mathrm{R}^{2}$ das regressões lineares entre parâmetros de caracterização do fíler versus parâmetros da caracterização mecânica básica

Tabela 4.10 - Resumo da influência das variáveis de entrada nas variáveis-resposta da Etapa 2

Tabela 4.11 - Valores dos parâmetros das dosagens Marshall para as misturas $5070 \mathrm{C} 3,0 \mathrm{~L}$ e $3045 \mathrm{C} 3,0 \mathrm{~L}$ 98

Tabela 4.12 - Descrição das oito misturas asfálticas utilizadas na Etapa 3, com indicação do TP 100

Tabela 4.13 - Valores médios de MR4\% e MR7\% a 10, 25 e $40^{\circ} \mathrm{C}$

Tabela 4.14 - Ranking de misturas em relação à susceptibilidade térmica e valores do PST $_{10,25}$

Tabela 4.15 - Ranking de misturas em relação à susceptibilidade térmica e valores do $\mathrm{PST}_{25,40}$

Tabela 4.16 - Ranking de misturas em relação à susceptibilidade térmica e valores do $\operatorname{PST}_{10,40}$

Tabela 4.17 - Valores de $\mathrm{R}^{2}$ das regressões lineares entre MR e PST versus parâmetros de caracterização do fíler

Tabela 4.18 - Resultados dos ensaios de fadiga para todas as misturas

Tabela 4.19 - Valores dos coeficientes $\mathrm{k}_{1}$ e $\mathrm{k}_{2}$ dos modelos de fadiga de todas as misturas

Tabela 4.20 - Variação da vida de fadiga em função do nível de diferença de tensões..

Tabela 4.21 - Propriedades mecânicas e espessuras das camadas dos pavimentos, no cenário de referência

Tabela 4.22 - Diferenças de tensões na fibra inferior da capa e vida de fadiga, em função do tipo de pavimento e do tipo de mistura

Tabela 4.23 - Parâmetros de entrada para a análise de sensibilidade da vida de fadiga nos pavimentos de capa esbelta e valor correspondente de $\mathrm{N}$

Tabela 4.24 - Dados de entrada para a análise de sensibilidade da vida de fadiga nos pavimentos de capa espessa e valor correspondente de $\mathrm{N}$

Tabela 4.25 - Valores de $\mathrm{R}^{\mathbf{2}}$ das regressões lineares entre parâmetros de vida de fadiga $\left(\mathrm{k}_{1}, \mathrm{k}_{2}\right.$ e valores de $\left.\mathrm{N}\right)$ versus parâmetros de caracterização do fíler 
Tabela 4.26 - Resultados dos ensaios de creep estático

Tabela 4.27 - Ranking de susceptibilidade à deformação permanente das misturas em função dos parâmetros do ensaio de creep estático

Tabela 4.28 - Valores de $\mathrm{R}^{2}$ das regressões lineares entre parâmetros de caracterização do fíler e Vv versus variáveis-resposta do ensaio de creep estático

Tabela 4.29 - Ranking de $\mathrm{RT}_{\text {Creep }}$

Tabela 4.30 - Resumo da influência das variáveis de entrada nas variáveis-resposta da Etapa 3

Tabela 4.31 - Resultados dos testes t de Student para verificar se as médias de MR por condição de ensaio são significativamente diferentes

Tabela 4.32 - Resultados dos testes t de Student para verificar se as médias de RT por condição de ensaio são significativamente diferentes

Tabela 4.33 - Resultados dos testes de hipóteses para verificar a aleatoriedade das relações entre Vv, MR e ST versus N, considerando $\pi=0,5, \alpha=0,05$ e distribuição binomial 170

Tabela A.1 - Resultados da dosagem Marshall para a mistura 5070 195

Tabela A.2 - Resultados dos ensaios RICE para a mistura 5070 195

Tabela A.3 - Resultados da dosagem Marshall para a mistura 5070C1,5 195

Tabela A.4 - Resultados dos ensaios RICE para a mistura 5070C1,5 195

Tabela A.5 - Resultados da dosagem Marshall para a mistura 5070C,30 196

Tabela A.6 - Resultados dos ensaios RICE para a mistura 5070C3,0 ... 196

Tabela A.7 - Resultados da dosagem Marshall para a mistura 5070C6,0 196

Tabela A.8 - Resultados dos ensaios RICE para a mistura 5070C6,0 196

Tabela A.9 - Resultados da dosagem Marshall para a mistura 5070L 196

Tabela A.10- Resultados dos ensaios RICE para a mistura 5070L 196

Tabela A.11- Resultados da dosagem Marshall para a mistura 3045 197

Tabela A.12- Resultados dos ensaios RICE para a mistura 3045 . 197

Tabela A.13- Resultados da dosagem Marshall para a mistura 3045C1,5 197

Tabela A.14- Resultados dos ensaios RICE para a mistura 3045C1,5 197

Tabela A.15- Resultados da dosagem Marshall para a mistura 3045C,30 ................. 198

Tabela A.16- Resultados dos ensaios RICE para a mistura 3045C3,0 ...................... 198

Tabela A.17- Resultados da dosagem Marshall para a mistura 3045C6,0 ................. 198 
Tabela A.18- Resultados dos ensaios RICE para a mistura 3045C6,0

Tabela A.19- Resultados da dosagem Marshall para a mistura 3045L ...................... 198

Tabela A.20 - Resultados dos ensaios RICE para a mistura 3045L _.......................... 198

Tabela C.1 - Resultados dos testes t para o Volume de Vazios, $\mathrm{P}_{\mathrm{b}}=5,5 \%$ (Etapa 1).. 206

Tabela C.2 - Resultados dos testes t para o VAM, $\mathrm{Pb}=5,5 \%$ (Etapa 1) ................... 207

Tabela C.3 - Resultados dos testes t para o RBV, $\mathrm{Pb}=5,5 \%$ (Etapa 1) .................... 207

Tabela C.4 - Resultados dos testes t para a estabilidade, $\mathrm{Pb}=5,5 \%$ (Etapa 1) .......... 207

Tabela C.5 - Resultados dos testes t para a fluência, $\mathrm{Pb}=5,5 \%$ (Etapa 1) ................ 207

Tabela C.6 - Resultados dos testes t para a MR4\%, 25 ${ }^{\circ} \mathrm{C}($ Etapas 2 e 3) .................... 207

Tabela C.7 - Resultados dos testes t para a RT (Etapa 2) ....................................... 208

Tabela C.8 - Resultados dos testes t para MR $7 \%, 25^{\circ} \mathrm{C}$ (Etapa 3) ............................. 208

Tabela C.9 - Resultados dos testes t para MR $4 \%, 10^{\circ} \mathrm{C}$ (Etapa 3) .............................. 208

Tabela C.10 $\quad$ Resultados dos testes t para MR $7 \%, 10^{\circ} \mathrm{C}$ (Etapa 3) ............................. 208

Tabela C.11- Resultados dos testes t para MR $4 \%, 40^{\circ} \mathrm{C}$ (Etapa 3) ............................. 208

Tabela C.12- $\quad$ Resultados dos testes t para MR7\%, 40 ${ }^{\circ} \mathrm{C}$ (Etapa 3) ........................... 209

Tabela C.13- Resultados dos testes t para Dt - creep estático (Etapa 3) ...................... 209

Tabela C.14- Resultados dos testes t para Mf - creep estático (Etapa 3) ..................... 209

Tabela C.15- Resultados dos testes t para Recuperação - creep estático (Etapa 3) ...... 209

Tabela C.16- Resultados dos testes t para Icurva - creep estático (Etapa 3) ............... 209

Tabela C.17- Resultados dos testes t para $\mathrm{RT}_{\text {creep }}($ Etapa 3$)$....................................... 210

Tabela D.1 - Cálculo dos parâmetros D10, D30, D60 e MF para as misturas

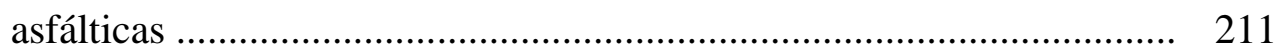

Tabela E.1 - Resultados da caracterização mecânica básica para a mistura 5070 (TP $=5,3 \%$ )

Tabela E.2 - Resultados da caracterização mecânica básica para a mistura 5070C1,5 $(\mathrm{TP}=5,3 \%)$

Tabela E.3 - Resultados da caracterização mecânica básica para a mistura 5070C3,0 $(\mathrm{TP}=5,3 \%)$

Tabela E.4 - Resultados da caracterização mecânica básica para a mistura 5070C6,0 $(\mathrm{TP}=5,5 \%)$

Tabela E.5 - Resultados da caracterização mecânica básica para a mistura 5070L $(\mathrm{TP}=5,5 \%)$ 
Tabela E.6 - Resultados da caracterização mecânica básica para a mistura $5070 \mathrm{C} 3,0 \mathrm{~L}(\mathrm{TP}=5,3 \%)$

Tabela E.7 - Resultados da dosagem Marshall para a mistura 5070C3,0L

Tabela E.8 - Resultados da caracterização mecânica básica para a mistura 3045 (TP $=5,3 \%)$

Tabela E.9 - Resultados da caracterização mecânica básica para a mistura 3045C1,5 $(\mathrm{TP}=5,3 \%)$

Tabela E.10 - Resultados da caracterização mecânica básica para a mistura 3045C3,0 $(\mathrm{TP}=5,5 \%)$

Tabela E.11- Resultados da caracterização mecânica básica para a mistura 3045C6,0 $(\mathrm{TP}=5,6 \%)$

Tabela E.12- Resultados da caracterização mecânica básica para a mistura 3045L $(\mathrm{TP}=5,5 \%)$

Tabela E.13- Resultados da caracterização mecânica básica para a mistura $3045 \mathrm{C} 3,0 \mathrm{~L}(\mathrm{TP}=5,5 \%)$ 218

Tabela E.14- Resultados da dosagem Marshall para a mistura 3045C3,0L 218

Tabela F.1 - Resultados da caracterização mecânica complementar para a mistura $5070(\mathrm{TP}=5,3 \%)$

Tabela F.2 - Resultados da caracterização mecânica complementar para a mistura 5070C $3,0(\mathrm{TP}=5,3 \%)$

Tabela F.3 - Resultados da caracterização mecânica complementar para a mistura 5070L $(\mathrm{TP}=5,5 \%)$

Tabela F.4 - Resultados da caracterização mecânica complementar para a mistura 5070C3,0L $(\mathrm{TP}=5,3 \%)$

Tabela F.5 - Resultados da caracterização mecânica complementar para a mistura $3045(\mathrm{TP}=5,3 \%)$

Tabela F.6 - Resultados da caracterização mecânica complementar para a mistura $3045 \mathrm{C} 3,0(\mathrm{TP}=5,5 \%)$

Tabela F.7 - Resultados da caracterização mecânica complementar para a mistura $3045 \mathrm{~L}(\mathrm{TP}=5,5 \%)$

Tabela F.8 - Resultados da caracterização mecânica complementar para a mistura 5070C3,0L $(\mathrm{TP}=5,5 \%)$

Tabela G.1 - Diâmetro, altura e Vv dos CPs antes e após o ensaio de creep estático... 
Tabela H.1 - Valores de $\mathrm{R}^{2}$ e sinal do coeficiente angular das regressões lineares entre os parâmetros das dosagens Marshall (Etapa 1)

Tabela H.2 - Valores de $\mathrm{R}^{2}$ e sinal do coeficiente angular das regressões lineares entre os parâmetros da caracterização mecânica básica (Etapa 2)

Tabela H.3 - Valores de $\mathrm{R}^{2}$ e sinal do coeficiente angular das regressões lineares entre os parâmetros da Etapa 1 x Etapa 2

Tabela H.4 - Valores de $\mathrm{R}^{2}$ e sinal do coeficiente angular das regressões lineares entre os parâmetros da caracterização mecânica complementar (Etapa 3) - Parte 1

Tabela H.5 - Valores de $\mathrm{R}^{2}$ e sinal do coeficiente angular das regressões lineares entre os parâmetros da caracterização mecânica complementar (Etapa 3) - Parte 2

Tabela H.6 - Valores de $\mathrm{R}^{2}$ e sinal do coeficiente angular das regressões lineares entre os parâmetros da caracterização mecânica complementar (Etapa 3) - Parte 3

Tabela H.7 - Valores de $\mathrm{R}^{2}$ e sinal do coeficiente angular das regressões lineares entre os parâmetros da Etapa 1 x Etapa 3

Tabela H.8 - Valores de $\mathrm{R}^{2}$ e sinal do coeficiente angular das regressões lineares entre os parâmetros da Etapa 2 x Etapa 3

Tabela I.1 - Modelos de regressão linear MR x Vv por tipo de mistura

Tabela I.2 - Modelos de regressão linear RT x Vv por tipo de mistura

Tabela J.1 - Resultados completos dos ensaios de fadiga por compressão diametral à tensão controlada 


\section{LISTA DE SIGLAS}

AASHTO American Association of State Highway and Transportation Officials

AAUQ Areia asfalto usinada a quente

ASAC Agregado sinterizado de argila calcinada

ASTM American Society for Testing and Materials

BRP Borracha reciclada de pneus

CAP Cimento Asfáltico de Petróleo

CAUQ Concreto asfáltico usinado a quente

CBR California Bearing Ratio

$\mathrm{CP} \quad$ Corpos de prova

DUI Dano por Umidade Induzida

DER/SP Departamento de Estradas de Rodagem do Estado de São Paulo

DMT Densidade máxima teórica

DNIT Departamento Nacional de Infraestrutura de Transportes

DNER Departamento Nacional de Estradas de Rodagem

DNPM Departamento Nacional de Produção Mineral

EDS Energy Dispersive Spectoscopy

ESRD Eixo simples de rodas duplas

FCL Fator campo laboratório

gl Graus de liberdade

$\mathrm{G}_{\mathrm{mb}} \quad$ Densidade aparente da mistura asfáltica compactada

$\mathrm{G}_{\mathrm{mm}} \quad$ Densidade máxima teórica em amostras não compactadas

GS Grau de saturação

IST Índice de Susceptibilidade térmica

LVDT Linear variable differential transducer

MEV Microscopia Eletrônica de Varredura

MF Módulo de Finura

$\mathrm{M}_{\mathrm{f}} \quad$ Módulo de fluência

MR Módulo de Resiliência

$\mathrm{P}_{\mathrm{b}} \quad$ Teor de ligante asfáltico

PMF Pré-misturado à frio

PST Parâmetro de susceptibilidade térmica

$\mathrm{R}^{2} \quad$ Coeficiente de determinação 
RBV Relação betume vazios

RCD Resíduo de construção e demolição

REM Relação de estabilidade Marshall

RMR Relação de módulo de resiliência

RRT Relação de Resistência à Tração

RT Resistência à Tração

SMA Stone matrix asphalt

SFC Super Fine Clay

ST Susceptibilidade térmica

TRB Transportation Research Board

TP Teor de projeto

TUC Temperatura de Usinagem e Compactação

VAM Vazios do agregado mineral

Vv Volume de vazios 


\section{SUMÁRIO}

$1 \quad$ INTRODUÇÃ

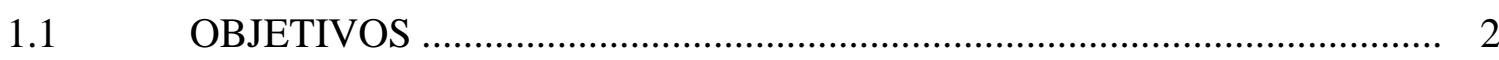

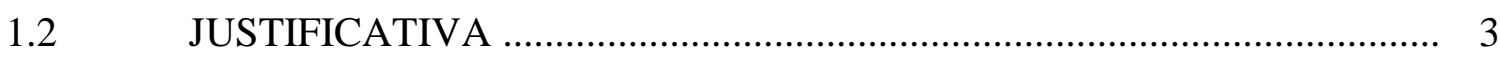

1.3 ESTRUTURA DO TRABALHO …................................................... 3

2 REVISÃO BIBLIOGRÁFICA _............................................................. 5

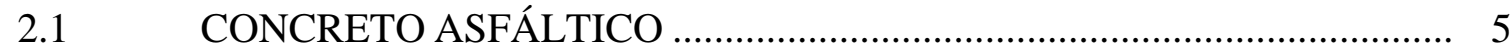

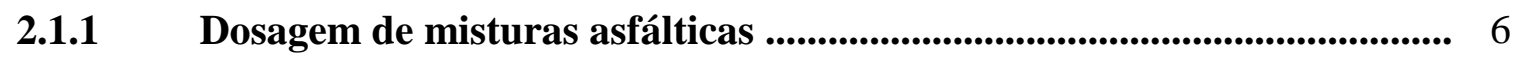

2.1.2 Caracterização mecânica de concretos asfálticos .................................... 13

2.1.2.1 Módulo de resiliência e susceptibilidade térmica ....................................... 13

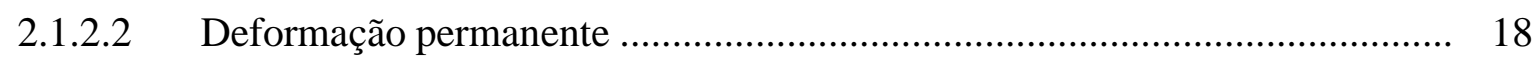

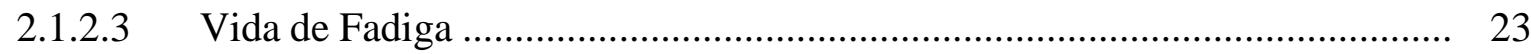

2.2 APROVEITAMENTO DE MATERIAIS ALTERNATIVOS EM PAVIMENTAÇÃO _........................................................................... 27

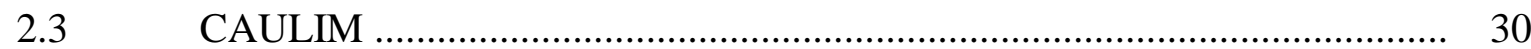

2.3.1 Rejeito de Caulim de Ipixuna do Pará/PA ................................................ 31

2.3.1 Uso de caulins em misturas asfálticas ........................................................ 33

3 MATERIAIS E MÉTODOS ........................................................... 37

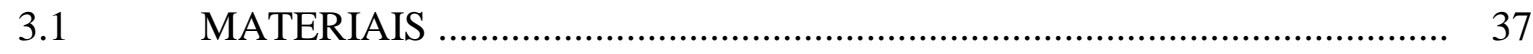

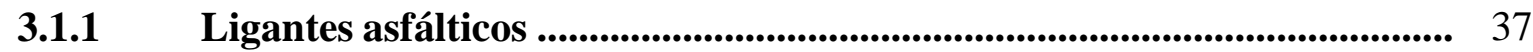

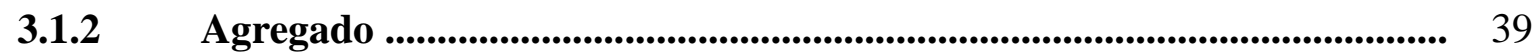

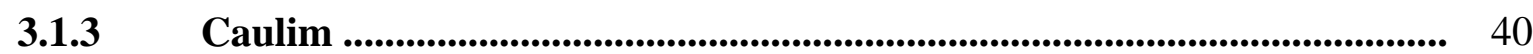

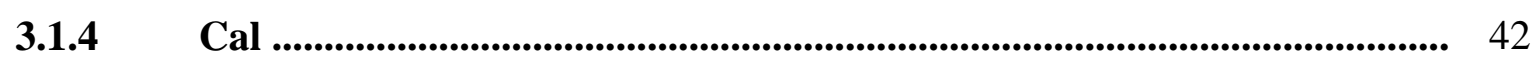

3.1.5 Caracterização complementar dos fíleres ................................................. 42

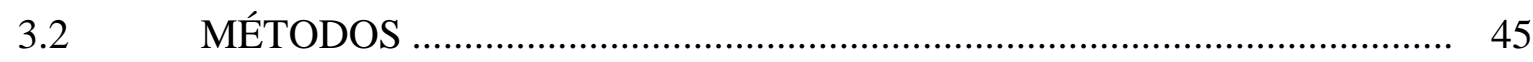

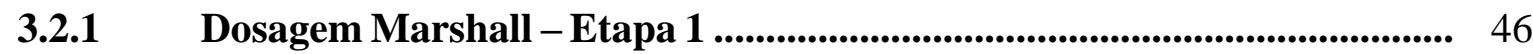

3.2.1 Caracterização Mecânica Básica - Etapa 2 ...................................................... 47

3.2.2.1 Ensaio de Módulo de Resiliência (MR) ..................................................... 49

3.2.2.2 Ensaio de Resistência à Tração por Compressão Diametral (RT) .................. 50

3.2.2.3 Ensaio de Dano por umidade induzida (DUI) .......................................... 51

3.2.3 Caracterização Mecânica Complementar - Etapa 3 ................................. 52 
3.2.3.1 Ensaio de Módulo de Resiliência (MR) em diferentes temperaturas para avaliação da susceptibilidade térmica

3.2.3.2 Ensaio de fadiga por compressão diametral à tensão controlada ................... 55

3.2.3.3 Ensaio de fluência por compressão uniaxial estática - creep estático ............ 56

3.2.3.4 Análise mecanística de pavimentos no software mePADS .......................... 58

3.2.4 Tratamento dos dados e análises estatísticas ............................................... 60

3.2.5 Análises complementares ................................................................................. 60

3.2.5.1 Estudo de possíveis correlações lineares entre as variáveis-resposta ............ 61

3.2.5.2 Comparações dos resultados das diversas condições de ensaios de RT e MR. 61

3.2.5.3 Relações entre a vida de fadiga $(\mathrm{N})$ versus $\mathrm{Vv}$, rigidez e realização prévia de ensaios de MR em diferentes temperaturas para avaliação de susceptibilidade térmica (ST) ................................................................. 62

$4 \quad$ APRESENTAÇÃO E DISCUSSÃO DOS RESULTADOS ..................... 63

4.1 DOSAGENS MARSHALL - ETAPA 1

4.1.1 Definição do teor de projeto ..................................................................... 63

4.1.2 Avaliação preliminar da viabilidade técnica do uso de rejeito de caulim como fíler em concretos asfálticos: Aspectos da dosagem .......................... 65

4.1.3 Avaliação da influência do tipo de fíler e do tipo de ligante asfáltico nos parâmetros das Dosagens Marshall .................................................................. 67

4.1.3.1 Influência do tipo de fíler e do tipo de ligante asfáltico no volume de vazios.. 69

4.1.3.2 Influência do tipo de fíler e do tipo de ligante asfáltico nos vazios do agregado mineral ................................................................................... 71

4.1.3.3 Influência do tipo de fíler e do tipo de ligante asfáltico na relação betume vazios

4.1.3.4 Influência do tipo de fíler e do tipo de ligante asfáltico na estabilidade .......... 74

4.1.3.5 Influência do tipo de fíler e do tipo de ligante asfáltico na fluência ................ 76

4.1.3.6 Observações adicionais ......................................................................... 78

4.1.4 Análise da influência dos parâmetros de caracterização do fíler nos parâmetros das dosagens Marshall ................................................................ 79

4.1.5 Consolidação dos resultados da Etapa 1 .................................................. 81

4.2 CARACTERIZAÇÃO MECÂNICA BÁSICA - ETAPA 2 ......................... 83

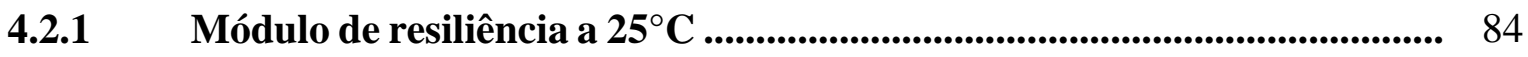

4.2.2 Resistência à tração por compressão diametral ............................................. 85 
4.2.3 Dano por umidade induzida ....................................................................... 88

4.2.3.1 Relação de resistência à tração ................................................................. 89

4.2.3.2 Relação de módulo de resiliência .......................................................... 92

4.2.4 Análise estatística da influência dos parâmetros de caracterização do fíler nos parâmetros da caracterização mecânica básica ............................ 93

4.2.5 Consolidação dos resultados da Etapa 2 ….................................................. 95

4.3 CONSIDERAÇÕES SOBRE A VIABILIDADE TÉCNICA DO USO DE REJEITO DE CAULIM COMO FÍLER EM CONCRETO ASFÁLTICO .... 96

4.4 CARACTERIZAÇÃO MECÂNICA COMPLEMENTAR - ETAPA 3 ....... 99

4.4.1 Avaliação da Susceptibilidade Térmica ....................................................... 101

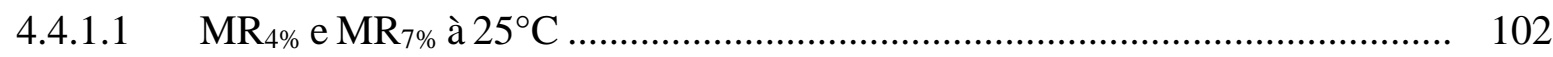

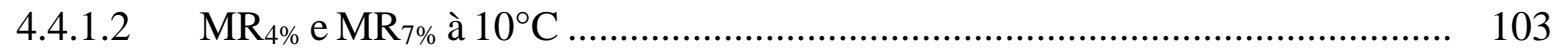

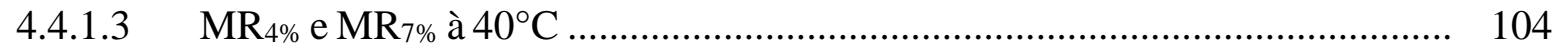

4.4.1.4 Avaliação da susceptibilidade térmica entre 10 e $25^{\circ} \mathrm{C}$.................................. 106

4.4.1.5 Avaliação da susceptibilidade térmica entre 25 e $40^{\circ} \mathrm{C}$............................... 110

4.4.1.6 Avaliação da susceptibilidade térmica entre 10 e $40^{\circ} \mathrm{C}$................................ 112

4.4.1.7 Influência dos parâmetros de caracterização do fíler nos valores de módulo de resiliência a 10,25 e $40^{\circ} \mathrm{C}$ e do parâmetro de susceptibilidade térmica

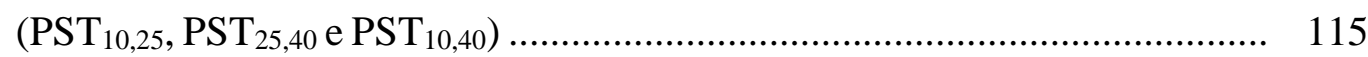

4.4.1.8 Consolidação dos resultados das análises referentes à susceptibilidade térmica

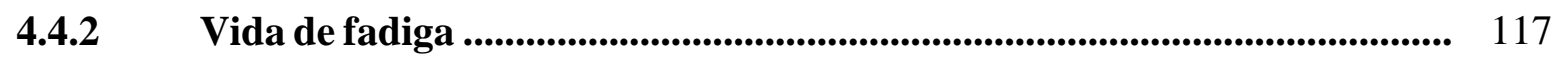

4.4.2.1 Apresentação e análise dos modelos de fadiga .......................................... 117

4.4.2.2 Comparação da vida de fadiga das misturas asfálticas ................................. 121

4.4.2.2.1 Comparação da vida de fadiga em função do nível de diferença de tensões... 121

4.4.2.2.2 Comparação da vida de fadiga em função da análise mecanística de pavimentos

4.4.2.3 Análise de sensibilidade da vida de fadiga

4.4.2.4 Análise estatística da influência dos parâmetros de caracterização do fíler nos parâmetros da vida de fadiga

4.4.2.5 Consolidação dos resultados de vida de fadiga ......................................... 137

4.4.3 Fluência por compressão uniaxial estática - Creep estático ....................... 138 
4.4.3.1 Influência do tipo de ligante asfáltico e do tipo de fíler nos resultados dos ensaios de Creep estático

4.4.3.2 Ranking de susceptibilidade permanente das misturas em função dos parâmetros do ensaio de creep estático

4.4.3.3 Análise estatística da influência dos parâmetros de caracterização do fíler e do volume de vazios nos parâmetros do ensaio de creep estático

4.4.3.4 Consolidação dos resultados dos ensaios de creep estático

4.4.4 RT após creep estático

4.4.4.1 Considerações adicionais sobre as dimensões e volume de vazios dos CPs utilizados nos ensaios de creep estático

4.4.5 Consolidação dos resultados da Etapa 3

4.5 ANÁLISES COMPLEMENTARES

4.5.1 Estudo de correlações lineares entre as variáveis-resposta da pesquisa .

4.5.1.1 Correlações internas entre as variáveis-resposta das Etapa 1, 2 e 3

4.5.1.2 Correlações entre as variáveis-resposta das Etapa 1, 2 e 3, Etapa versus Etapa

4.5.2 Comparações entre os resultados das diversas condições de ensaios de RT e MR

4.5.3 Relações entre a vida de fadiga $(N)$ versus $V v$, rigidez e realização prévia de ensaios de MR em diferentes temperaturas para avaliação da susceptibilidade térmica (ST)

4.5.4 Consolidação dos resultados das análises complementares

4.6.1 Sobre a viabilidade técnica do uso de rejeito de caulim como fíler em concreto asfáltico

4.6.2 Sobre a influência do tipo de ligante asfáltico

4.6.3 Sobre a influência do tipo de fíler 175

4.6.4 Sobre os parâmetros de caracterização do fíler . 176

4.6.5 Sobre a Etapa 1 - Dosagem Marshall .......................................................... 177

4.6.6 Sobre a Etapa 2 - Caracterização mecânica básica ................................... 178

4.6.7 Sobre a Etapa 3 - Caracterização mecânica complementar ...................... 178

4.6.8 Sobre as análises complementares ........................................................ 179 
5.1 SUGESTÕES PARA TRABALHOS FUTUROS

REFERÊNCIAS

APÊNDICE A

APÊNDICE B 199

APÊNDICE C 205

APÊNDICE D 211

APÊNDICE E 213

APÊNDICE $F$

APÊNDICE G 223

APÊNDICE H 225

APÊNDICE I 



\section{INTRODUÇÃO}

A pavimentação de uma rodovia consome grande quantidade de insumos não renováveis como ligantes asfálticos, solos e agregados. Por isso, a utilização de materiais reciclados, rejeitos ou resíduos de outras atividades econômicas na construção de rodovias tem sido encorajada. O uso de materiais alternativos em pavimentos, desde que atenda minimamente aos requisitos técnicos, pode, por exemplo, reduzir a exploração de novas jazidas de materiais pétreos.

Além disso, em algumas localidades da Região Norte do Brasil, há carência de material pétreo para a produção de agregados britados, sendo comum a utilização de materiais menos convencionais, como seixos rolados, lateritas (AMARAL, 2000, 2004), agregados sinterizados de argila calcinada (ASAC) (CUNHA et al., 2018) e de resíduos de construção e demolição (RCD) (VALENÇA, 2012) como agregados nos concretos asfálticos. Neste contexto, a busca por materiais alternativos é ainda mais importante.

Há um grande número de pesquisas que se dedicaram a investigar o uso de resíduos de outras atividades econômicas, como agregado, fíler e aditivo em misturas asfálticas. Dentre estes resíduos destacam-se: borracha de pneus (ODA, 2000; BERTOLLO, 2002), areia de fundição (COUTINHO NETO; FABBRI, 2004; KLINSKY, 2013), rejeitos de mineração (FABBRI et al., 2006; LUCENA, 2009), escória de aciaria (FREITAS; MOTTA, 2008; COSME et al., 2014), vidro, polietileno tereftalato (PET) (AMERICAN SOCIETY FOR TESTING AND MATERIALS, 1993), dentre outros. Na maioria dos casos, são realizadas avaliações técnicas com base nas características do material alternativo e nas propriedades mecânicas e de desempenho das misturas asfálticas compostas com esses materiais, tentando de alguma maneira atender a determinado volume de tráfego.

O Brasil é o sexto maior produtor mundial de caulim. Sua produção se concentra nos estados do Pará e do Amapá e é majoritariamente destinada à exportação para uso na indústria de papel. De acordo com Departamento Nacional de Produção Mineral (DNPM), em 2016, apenas no estado do Pará, foram produzidas cerca de 1.600 .000 t de caulim beneficiado (BRASIL, 2017). Do material extraído na lavra de caulim, somente $20 \%$ se enquadra como produto final beneficiado, gerando um passivo de cerca de $80 \%$, que é considerado como rejeito. Assim, em virtude do volume de rejeito gerado, essa atividade pode ser potencialmente fornecedora de insumos alternativos para pavimentação. 
O caulim é um minério composto predominantemente por argilominerais de caulinita, que apresenta graduação muito fina (cerca de $85 \%$ das partículas tem diâmetro inferior à $5 \mu \mathrm{m}$ ). Devido às características granulométricas, o rejeito de caulim pode ser interessante como fíler em misturas asfálticas densas. No entanto, nem sempre os produtos compostos exclusivamente de materiais alternativos atendem aos requisitos de projeto ou apresentam desempenhos satisfatórios. Nas misturas asfálticas, pode-se também recorrer a soluções combinadas de uso do material alternativo com aditivos convencionais, como cal, cimento ou agentes melhoradores de adesividade (dopes).

De modo geral, um estudo de viabilidade técnica da utilização de determinado material em misturas asfálticas deve ser conduzido a partir de um amplo programa de experimentos, a fim de responder: (i) se o material em estudo pode substituir outro material convencional, observando características físicas; (ii) se sua influência no comportamento da mistura asfáltica tem implicações negativas, investigando possíveis remediações; (iii) se há limite na quantidade adicionada do material em estudo, indicando uso integral ou combinado a outros materiais para manter propriedades requeridas das misturas, e; (iv) se é possível prever comportamentos, introduzindo modelos que correlacionem a adição, ou teor de adição, do material em estudo aos valores das propriedades mecânicas e de durabilidade das misturas asfálticas.

Configura-se, portanto, a relevância de pesquisas dessa natureza, isto é, que busquem realizar a caracterização mecânica de misturas asfálticas produzidas com materiais convencionais e alternativos (agregados, fíleres e ligante asfálticos) disponíveis nas diversas regiões brasileiras.

\subsection{OBJETIVOS}

O objetivo principal desta pesquisa é avaliar a viabilidade técnica do uso de rejeito de caulim, proveniente da mina PPSA no município de Ipixuna do Pará/PA, como fíler em misturas asfálticas densas. Além disso, como objetivo secundário, pretende-se contribuir para o entendimento do efeito do tipo de ligante asfáltico e do tipo de fíler nos parâmetros da dosagem Marshall, nas propriedades mecânicas e nas susceptibilidades térmica e ao dano por umidade do concreto asfáltico. 


\subsection{JUSTIFICATIVA}

Anualmente são gerados, aproximadamente, um milhão de toneladas de rejeito de caulim do tipo super fine clay (SFC) na mina PPSA em Ipixuna do Pará (SILVA, 2014). Proporcionar uso tecnicamente viável a este rejeito industrial, hoje inservível, com inerente benefício ambiental, é uma das principais motivações para a execução desta pesquisa. Mesmo sendo utilizado apenas como fíler em concreto asfáltico, assumindo o valor médio de $6 \%$ em peso do agregado para o centro da faixa $\mathrm{C}$ do Departamento Nacional de Infraestrutura de Transportes (DNIT), é possível utilizar cerca de 90 toneladas de rejeito de caulim para a construção de $1 \mathrm{~km}$ de rodovia, considerando uma camada de concreto asfáltico de 7,20 m de largura e 0,10 m de espessura.

A carência de estudos com materiais oriundos da Região Norte do país também configura uma das justificativas do trabalho. Além disso, ao se efetuar dosagens Marshall, caracterização de rigidez, resistência à tração, vida de fadiga e de susceptibilidades térmica, ao dano por umidade e à deformação permanente em diferentes misturas asfálticas, variando o tipo de ligante asfáltico (CAP 50/70 e CAP 30/45) e o tipo de fíler (granito, caulim e cal), a pesquisa contribui para o entendimento do papel destes fatores nas propriedades mecânicas e na durabilidade do concreto asfáltico.

Há poucos estudos sobre a utilização de caulins em misturas asfálticas. Esta pesquisa pretende preencher parte dessa lacuna de conhecimento ao englobar, dentre outras, a investigação: (i) do desempenho de misturas com diferentes tipos de ligantes asfálticos e o rejeito de caulim; (ii) do desempenho de misturas que utilizam rejeito de caulim e cal, simultaneamente, e; (iii) da vida da fadiga de misturas asfálticas contendo rejeito de caulim.

\subsection{ESTRUTURA DO TRABALHO}

Além desta introdução, a tese é composta por mais quatro capítulos. Na Revisão bibliográfica, Capítulo 2, discorre-se sobre três grandes temas: (i) concreto asfáltico, onde são apresentadas definições, parâmetros avaliados nas dosagens e na caracterização mecânica quanto à rigidez, resistência à deformação permanente e resistência à fadiga; (ii) aproveitamento de materiais alternativos em pavimentação, destacando-se a importância dessa prática e relatando pesquisas sobre o tema, e; (iii) caulim, onde são apresentadas as características do material, o 
detalhamento do rejeito de caulim da mina PPSA do município de Ipixuna do Pará/PA e a descrição de pesquisas que utilizaram caulins em misturas asfálticas.

No Capítulo 3, Materiais e métodos, são apresentados os materiais empregados nas misturas asfálticas e a caracterização dos agregados, ligantes asfálticos, caulim e cal. É feita uma descrição do programa experimental e dos métodos de dosagem Marshall e dos ensaios de caracterização mecânica e das susceptibilidades térmica e ao dano por umidade do concreto asfáltico. O capítulo também contempla a descrição do tratamento estatístico e de análises complementares ao programa experimental.

Na apresentação e discussão dos resultados, Capítulo 4, estão indicados os principais resultados do trabalho, divididos em três etapas: Dosagem Marshall, Caracterização mecânica básica (resistência à tração, módulo de resiliência e dano por umidade induzida) e Caracterização mecânica complementar (susceptibilidade térmica, vida de fadiga, creep estático e $\mathrm{RT}_{\text {creep }}$ ). Cada etapa contém discussões acerca das tendências gerais de comportamento das misturas asfálticas e da influência do tipo do tipo de fíler e do tipo de ligante asfáltico, assim como o tratamento estatístico que dá suporte às discussões. Também se apresentam análises estatísticas complementares para explorar melhor os dados disponíveis, bem como as considerações finais.

No Capítulo 5, apresentam-se as principais conclusões do trabalho e também sugestões de investigações para a continuidade desta pesquisa. 


\section{REVISÃO BIBLIOGRÁFICA}

Neste capítulo são abordados três temas principais: concreto asfáltico, aproveitamento de materiais alternativos em pavimentação e caulim.

Inicialmente, apresenta-se uma revisão bibliográfica voltada ao entendimento dos efeitos do uso de diferentes tipos de ligantes asfálticos e de fíleres na dosagem, nas propriedades mecânicas e na durabilidade de misturas asfálticas do tipo concreto asfáltico usinado a quente (CAUQ). Em seguida, é destacada a importância do aproveitamento de materiais alternativos em pavimentação e são apresentados relatos de pesquisas que empregaram materiais não convencionais, tais como borracha de pneus, areia de fundição e bauxita refratária, na estrutura de pavimentos, principalmente no revestimento asfáltico. Por fim, apresenta-se brevemente o mercado brasileiro de mineração de caulim e descreve-se a forma como é gerado o rejeito de caulim proveniente da mina PPSA de Ipixuna do Pará. O capítulo encerra com a descrição de pesquisas que utilizaram caulim em concretos asfálticos.

\subsection{CONCRETO ASFÁLTICO}

Concreto asfáltico é um material utilizado como revestimento de pavimentos. É um dos tipos de revestimentos asfálticos mais utilizados no Brasil, especialmente quando se trata de rodovias e vias urbanas com volume de tráfego pesado. As misturas do tipo concreto asfáltico, que incluem aquelas usadas em capas de rolamento e camadas de ligação, são obtidas a partir da mistura e homogeneização de agregados minerais bem graduados incluindo fíler, se necessário, e cimento asfáltico de petróleo (CAP). Trata-se de mistura asfáltica elaborada a quente, em usina apropriada, espalhada e compactada a quente.

Pode-se entender o concreto asfáltico como um sistema formado por três fases: agregados (incluindo fíler), ligante asfáltico e ar. Em massa, o agregado compõe cerca de $95 \%$ dessa mistura e o ligante asfáltico, 5\%. A fase ar é representada pelo volume de vazios, que representa, aproximadamente, $4 \%$ do volume da mistura. Cada componente influencia de modo particular o comportamento mecânico da camada asfáltica em resposta às cargas do tráfego e em função das condições ambientais. 
Por isso, cada novo projeto de mistura asfáltica, convencional ou alternativo, demanda uma caracterização detalhada dos materiais, resolvendo os problemas típicos da dosagem, ou seja, encontrar combinação de materiais que satisfaça aos requisitos de propriedades volumétricas e mecânicas. Complementarmente, é importante entender como a mistura se comporta frente aos principais mecanismos de deterioração, por exemplo, a deformação permanente e a fadiga. As demais seções definem e detalham os fatores intervenientes na dosagem, caracterização mecânica e susceptibilidades térmica e ao dano por umidade dos concretos asfálticos.

\subsubsection{Dosagem de misturas asfálticas}

A proporção entre os componentes das misturas asfálticas é definida na dosagem. Segundo o Harvey e Tsai (1996), o objetivo de qualquer dosagem é determinar, dentro dos limites das especificações de projeto e com custo razoável, uma combinação de tipo e graduação de agregados, e de tipo e teor de ligante asfáltico que leve a mistura a apresentar resistência, estabilidade e durabilidade.

A dosagem determina um teor de projeto (TP) de ligante asfáltico que, em dadas condições, melhora propriedades indiretamente relacionadas às resistências à deformação permanente, à fadiga e à oxidação. Para isso, são observados alguns parâmetros que, se bem ajustados, proporcionam o bom desempenho de uma mistura asfáltica. Para o Asphalt Institute (1995), o volume de vazios (Vv) igual a $4 \%$ é a característica que leva a melhor estimativa de TP de misturas asfálticas densas aplicadas como revestimento.

Há vários métodos de dosagem de misturas asfálticas, por exemplo, os métodos de Hveem, Marshall e Superpave. Mesmo com a popularização do método de Dosagem Superpave, a partir da década de 1990, especialmente nos Estados Unidos e em pesquisas acadêmicas, a dosagem Marshall ainda é largamente empregada no Brasil e em vários países conforme Assis et al. (2017) e Taherkhani e Arshadi (2017).

O método Marshall foi desenvolvido na década de 1940. Originalmente, a dosagem Marshall utilizava uma energia de compactação baixa (25 golpes), mas, ao longo do tempo, foram adaptados acréscimos de energia de compactação. Atualmente empregam-se 50 ou 75 golpes por face do corpo de prova $(\mathrm{CP})$, em função do tráfego (DEPARTAMENTO DE ESTRADAS DE RODAGEM DO ESTADO DE SÃO PAULO, 1960, 2005). 
Outra mudança importante se refere à consideração da absorção de ligante asfáltico pelos agregados. Na norma de 1960 (DER/SP M 120), o cálculo dos parâmetros volumétricos era efetuado sem a consideração da absorção do ligante asfáltico, utilizando-se a Densidade Máxima Teórica (DMT) calculada em função da ponderação das densidades reais dos componentes da mistura (ligante asfáltico, agregados e, eventualmente, aditivos). Na norma mais recente, de 2005, (ET-DE-P00/027) a densidade máxima teórica da mistura asfáltica solta $\left(\mathrm{G}_{\mathrm{mm}}\right)$ pode ser medida diretamente com o ensaio Rice (NBR 15.619/2012) ou calculada pela mesma expressão matemática da DMT, porém adotando a densidade efetiva, que é o valor médio entre as densidades real e aparente do agregado. Essa mudança tem influência significativa nos parâmetros volumétricos, implicando em mudanças dos valores limites.

Na dosagem Marshall, a determinação do TP consiste da avaliação conjunta de valores de densidade, volume de vazios, vazios do agregado mineral, relação betume-vazios, estabilidade e fluência. Mais recentemente, as principais normas brasileiras, DNIT (031/2006 - ES) e DER/SP (ET-DE-P00/027), incorporaram também valores mínimos de resistência à tração (RT) e da relação de resistência à tração (RRT) do ensaio de dano por umidade induzida como requisitos da seleção de TP.

O teor de projeto de certa mistura asfáltica é aquele que satisfaz a todos os requisitos simultaneamente, garantindo, que:

haja quantidade de ligante asfáltico suficiente para que o revestimento seja durável, isto significa que deve resistir ao clima e ao envelhecimento;

$>$ quantidade de vazios adequada, para permitir alguma compactação adicional devida ao tráfego sem a ocorrência de exsudação, fluência e ou ruptura, e

apresente estabilidade mínima, a fim de suportar o tráfego sem deformações excessivas.

Além do controle desses parâmetros, deve-se assegurar a trabalhabilidade adequada, nas etapas construtivas, e uma textura superficial que proporcione a boa aderência entre pneu e pavimento, quando da operação da rodovia ou via urbana (ASPHALT INSTITUTE, 1995).

No entanto, mudanças substanciais dos parâmetros Marshall ocorrem em função da composição da mistura. Por exemplo, é comum observar que dosagens Marshall de misturas contendo os mesmos agregados e granulometria resultam em teores de projeto (TP) distintos em função do tipo de ligante asfáltico. 
Prudente (2015), trabalhando com agregados gnáissicos-granitóides do estado de Goiás e granulometria no centro da faixa $\mathrm{C}$ do DNIT, observou maior TP para a mistura com CAP 50/70 $(\mathrm{TP}=5,3 \%)$ que para a mistura com CAP 30/45 (TP = 5,0\%). Nogueira (2008), trabalhando com agregados graníticos do estado de São Paulo, também no centro da faixa C do DNIT, obteve resultados opostos, nos quais a mistura com CAP 30/45 apresentou TP superior (TP = $5,0 \%)$ ao da mistura com CAP 50/70 (TP = 4,7\%). É importante destacar que mesmo apresentando tendências diferentes, o TP das misturas com CAP 30/45 foram iguais e os com CAP 50/70 diferem em 0,6\%.

Gigante (2007), pesquisando a suscetibilidade térmica de misturas densas compostas por diferentes agregados e ligantes asfálticos, explicou, com base na graduação do agregado e na consistência do CAP, porque os valores de TP variam muito pouco. As misturas com a mesma curva granulométrica e mesmo tipo de agregado possuem a mesma superfície específica e, por isso, devem demandar consumos muito parecidos de ligante asfáltico. Além disso, CAPs convencionais, na temperatura usinagem, devem apresentar valores de viscosidade dentro de uma faixa relativamente pequena $(0,17 \pm 0,02 \mathrm{~Pa} . \mathrm{s})$, levando a capacidades de recobrimento ou molhagem muito próximas, concorrendo para que misturas com ligantes asfálticos convencionais de classes diferentes apresentem teores de projeto similares para condições semelhantes de granulometria e de tipo de agregado.

Para ligantes asfálticos modificados essa regra não deve ser aplicada, uma vez que os modificadores efetuam alterações não somente na consistência, mas na composição química e no comportamento viscoelástico do CAP. Por exemplo, Taira, Furlan e Fabbri (2003) avaliando o efeito da modificação de ligante asfáltico convencional (CAP-20) com polímero (SBS) nas propriedades de misturas asfálticas densas, observaram que, apesar da mesma base asfáltica (CAP-20), a modificação de polímero tornou o ligante asfáltico muito mais viscoso que o CAP convencional: a viscosidade absoluta do CAP-20+SBS foi cerca de 5 vezes maior, seu ponto de amolecimento foi $10^{\circ} \mathrm{C}$ mais alto e a penetração foi $28 \%$ maior.

No entanto, a dosagem Marshall das misturas asfálticas (Faixa C) com agregados basálticos e CAP-20+SBS resultou num TP de 5,5\% e o da mistura com o CAP 20 foi de 6,0\%. A mistura com CAP-20+SBS apresentou maiores nos valores de densidade aparente e estabilidade (TAIRA; FURLAN; FABBRI, 2003). 
NG (2013) observou temperaturas de usinagem e compactação (TUC) maiores $\left(\sim 30^{\circ} \mathrm{C}\right)$ para um CAP 50/70 modificado com polímero (SBS) em comparação com o convencional (CAP 50/70). Porém, diferentemente de Taira, Furlan e Fabbri (2003), o TP das misturas com CAP50/70+SBS (Faixa C) e agregados graníticos foi ligeiramente maior (em 0,2\%) que o TP da mistura com CAP 50/70.

As características dos CAPs e, consequentemente, das misturas asfálticas também podem mudar devido à presença de fíleres. Fíler ou material de enchimento é um material mineral, finamente dividido, passando pelo menos $65 \%$ na peneira $n^{\circ} 200$. Poderá ser cimento Portland, cal hidratada, cinza volante, pó calcário, pó de pedra ou outro material mineral conveniente preparado para satisfazer a graduação indicada na Tabela 2.1 (DEPARTAMENTO NACIONAL DE ESTRADAS DE RODAGEM, 1997).

Tabela 2.1 - Faixa granulométrica para que um material seja considerado fíler

\begin{tabular}{cc}
\hline Abertura de malha (mm) & \% em peso, passando \\
\hline 0,42 & 100 \\
0,18 & $95-100$ \\
0,075 & $65-100$ \\
\hline
\end{tabular}

Fonte: Departamento Nacional de Estradas de Rodagem (DNER), 1997.

Devido a sua inércia química, o pó de pedra não reage com o ligante asfáltico. Entretanto, alguns fíleres, chamados ativos, favorecem interações e reações químicas com o CAP, modificando sua consistência, e também as propriedades das misturas asfálticas. Essas mudanças dependem da geometria, da quantidade e da natureza dos fíleres.

Em geral, fíleres mais grossos, com diâmetros superiores a $20 \mu \mathrm{m}$, podem ser considerados como uma continuação da fração de agregados da mistura asfáltica e assim aumentam os pontos de contato do esqueleto mineral conferindo algum ganho de resistência às misturas. Por outro lado, as partículas menores incorporam-se ao ligante asfáltico. Para Kandhal, Lynn e Parker (1998), fíleres muito finos aumentam a área superficial a ser recoberta pelo ligante asfáltico, demandando mais CAP para a lubrificação e entrosamento das partículas nas operações de mistura e compactação. Por isso, na dosagem, essas misturas apresentam um TP mais alto, o que pode influenciar negativamente na estabilidade e fluência.

Bardini (2013) avaliou o efeito do teor de diferentes tipos de fíleres no TP de misturas asfálticas e observou que, independentemente da natureza do fíler (calcário, cal, cimento e sílica), o TP 
da mistura reduziu. Esse comportamento contraria a tendência que vem sendo observada por muitos pesquisadores (KAVUSSI; HICKS, 1997). O projeto das misturas de Bardini (2013) seguiu as recomendações Método Superpave, que utiliza o compactador giratório na produção dos corpos de prova. Essa pode ser uma provável explicação para a diminuição de TP com o aumento do percentual do fíler.

O efeito de diferentes tipos de fíleres em misturas asfálticas também foi estudado por Leite e Motta (2002). As autoras encontraram que, em geral, o fíler enrijeceu o mástique (ligante asfáltico e fíler) sendo que a cal hidratada propiciou um efeito mais intenso que o calcário e o cimento. Em consequência do enrijecimento do mástique, as misturas asfálticas com cal hidratada passaram a exibir melhores desempenhos mecânicos, principalmente, em altas temperaturas. Apesar dos efeitos da cal em termos mecânicos estarem bem compreendidos, sua influência sobre os parâmetros volumétricos da dosagem Marshall ainda não é consensual, ora resultando em maiores TP, ora menores. Esta constatação pode estar associada à interação que a cal tem com CAPs de diferentes composições.

A inclusão de valores mínimos de resistência à tração (RT) e da relação da resistência à tração (RRT), do ensaio de dano por umidade induzida (DUI), como parâmetros de dosagem Marshall foi muito adequada. Esses parâmetros aferem e ajudam a compreender a resistência e a durabilidade do material, respectivamente.

A resistência à tração das misturas asfálticas é afetada por diversos fatores. A viscosidade do CAP é fator preponderante para a definição do valor de RT, observando-se em misturas com ligantes asfálticos mais viscosos, maiores valores de RT. Furlan (2006) observou valores de RT cerca de $30 \%$ maiores para as misturas com CAP-40 e granito em comparação com misturas com CAP-20. Bardini (2013), estudando misturas com CAP50/70 e CAP 85/100 e granito, também encontrou RT maiores $(\sim 45 \%)$ para o ligante mais viscoso. Taira, Furlan e Fabbri (2003) e NG (2013) observaram uma mesma proporção de ganho de RT ( 20\%) para CAPs modificados com SBS em relação a CAPs convencionais.

No que se refere ao fíler, Bardini (2013) conseguiu observar importantes influências na RT. Misturas contendo fíler de cimento Portland apresentaram RT superiores a misturas com outros tipos de fíleres. Além disso, não foi detectada variação importante de RT entre as misturas com cal e fíler mineral (calcário). NG (2013) comparou misturas com CAP 50/70 e não observou 
diferença significativa entre valores de RT devido à adição de cal. Por outro lado, as misturas com CAP 50/70+SBS apresentaram redução de RT ( 10\%) em relação à mistura com CAP convencional.

A cal hidratada é utilizada tradicionalmente como melhorador de adesividade em misturas asfálticas, e costuma ser empregada substituindo parte da fração fina do agregado (pó de pedra), em teores entre 1 e $3 \%$, em peso. O que se pode observar mecanicamente é que as misturas asfálticas com cal conseguem reter melhor as propriedades originais após ação da água. Nas décadas de 1970 e 1980, muitos pesquisadores se concentraram em observar o efeito da cal do ponto de vista mecânico, usando para isso diferentes tipos de ensaios. Os estudos de Lottman (1978) e Tunnicliff e Root (1984) conduziram aos procedimentos que foram incorporados aos métodos de dosagem atuais.

Esses estudos deram origem às normas AASHTO T 283, ASTM D 4867 e ABNT NBR 15617, que são capazes de indicar misturas asfálticas suscetíveis ou sensíveis à ação da água. Os procedimentos avaliam a retenção de RT que uma mistura asfáltica parcialmente saturada apresenta após determinado ciclo térmico. As principais especificações técnicas brasileiras (DNIT e DER/SP) exigem o valor mínimo de $70 \%$ para a RRT.

Esses procedimentos têm em comum que possíveis problemas na adesividade entre o ligante asfáltico e o agregado são potencializados pela presença da água, o que acelera o processo de degradação do revestimento e favorece a evolução de inúmeros defeitos como trincas por fadiga, desgaste e panelas, reduzindo a durabilidade da mistura asfáltica. Assim, entende-se que o ensaio de dano por umidade induzida é um bom parâmetro para avaliar a durabilidade de misturas asfálticas.

Algumas variáveis têm influência preponderante na resistência da mistura asfáltica à ação da água, por exemplo:

$>$ tipo de agregado: rochas graníticas apresentam pior adesividade com o ligante asfáltico, devido à presença de quartzo (MAJIDZADEH; BROVOLD, 1968);

tipo de ligante asfáltico: misturas com ligantes asfálticos mais viscosos devem resistir melhor à ação da água, em consequência da maior consistência da película de recobrimento (HICKS, 1991); 
teor de ligante asfáltico: misturas mais ricas em ligante asfáltico são menos sensíveis à ação danosa da água, em função do aumento da espessura da película asfáltica (EPPS et al., 2000);

uso de aditivos: a cal hidratada usada como fíler em misturas asfálticas aumenta a resistência ao dano por umidade induzida (HICKS, 1991).

Furlan (2006) pesquisou sobre o dano por umidade de misturas asfálticas compostas por diferentes agregados (granito, basalto e gabro). Seus resultados comprovaram que a composição do agregado é decisiva para a resistência ao dano por umidade, uma vez que somente os agregados graníticos foram considerados suscetíveis ao dano por umidade (RRT 60\%). No entanto, a adição de 1,5\% de cal, em substituição ao pó de pedra, aumentou os valores de RRT para valores próximos a $100 \%$.

Com relação ao papel do ligante asfáltico no dano por umidade induzida, Anitelli (2013), pesquisando misturas graníticas com CAP convencional e modificado com polímero, encontrou que a RRT das misturas com polímero (CAP 50/70+SBS) foram maiores do que as das misturas com CAP convencional (CAP 50/70) e não dependeram da adição de cal para apresentar bons comportamentos (RRT 100\%). Já para as misturas com CAP convencional, a adição de cal foi necessária e eficiente, pois aumentou a RRT de 73 para 108\% ( 48\%).

Furlan (2006) ratificou a afirmação de que misturas mais ricas em ligante asfáltico apresentam menor susceptibilidade ao dano por umidade ao constatar que ao elevar o teor de CAP de 5,0 para $5,5 \%$ e de $5,5 \%$ para $6,0 \%$, a RRT aumentou cerca de $30 \%$ e $11 \%$, respectivamente, nas misturas com CAP-20. Contudo, o efeito da adição de 1,5\% de cal foi mais relevante para elevar os valores de RRT.

O conhecimento do efeito das variáveis nos parâmetros e propriedades de dosagem das misturas asfálticas deve levar a melhores seleções de materiais. No entanto, nem sempre, é possível lançar mão de certos materiais em detrimento de outros, como ocorre com os agregados. Em algumas regiões do Brasil, por exemplo, não há ocorrência de agregados adequados para as obras de pavimentação, nem com relação ao volume, nem com relação à composição mineralógica, restando ao projetista combinar ligantes asfálticos e aditivos a fim de melhorar o comportamento das misturas asfálticas (BERNUCCI et al., 2008). Para isso, a dosagem não é suficiente, logo, faz-se necessário entender outras propriedades dos materiais, principalmente, 
aquelas que se relacionam diretamente com os principais mecanismos de degradação dos pavimentos, como se observa a seguir.

\subsubsection{Caracterização mecânica de concretos asfálticos}

No passado, o projeto e a construção de rodovias foram alicerçados em ensaios e propriedades empíricas dos materiais, tais como o Índice de Suporte Califórnia (ISC ou CBR) e os parâmetros de estabilidade e fluência da dosagem Marshall. Posteriormente, passou-se a exigir valores mínimos para a RT e RRT das misturas asfálticas. Com o desenvolvimento de técnicas com base racional para o projeto de pavimentos, são necessários ensaios e modelos para avaliar as propriedades fundamentais dos materiais das camadas do pavimento (HUANG, 2004).

No Brasil, o novo método de dimensionamento nacional (MeDiNa) de pavimentos asfálticos, no Nível A, requer que: (i) todas as camadas da estrutura e subleito sejam caracterizadas pelo valor de MR, além do ensaio de deformação permanente, e; (ii) misturas asfálticas e camadas cimentadas sejam representadas por um modelo de vida de fadiga obtido por meio do ensaio por compressão diametral à tensão controlada (FRITZEN, 2016). Neste contexto, o módulo de resiliência (MR), a vida de fadiga e a deformação permanente se tornaram importantes propriedades de projeto.

A caracterização das propriedades mecânicas das misturas asfálticas não é tarefa simples, visto que elas são influenciadas não só pelas propriedades intrínsecas dos materiais constituintes e da interação eles, mas também de fatores extrínsecos como temperatura e as cargas do tráfego. As próximas subseções abordam os temas: (i) módulo de resiliência e aspectos relativos à susceptibilidade térmica; (ii) deformação permanente, e; (iii) vida de fadiga.

\subsubsection{Módulo de resiliência e susceptibilidade térmica}

O módulo de resiliência (MR) de misturas asfálticas é a relação entre a tensão de tração aplicada repetidamente no plano diametral vertical de uma amostra cilíndrica e a deformação específica recuperável correspondente à tensão aplicada (DNIT, 2010). O MR é uma medida de rigidez do material e pode ser entendido como o módulo de elasticidade, mensurado em condições de carregamentos repetidos e de baixa magnitude, a fim de assegurar deformações recuperáveis do regime elástico (HUANG, 2004). 
Vários fatores influenciam na rigidez do concreto asfáltico. No que se refere ao CAP, observouse que ligantes asfálticos mais consistentes implicam em misturas mais rígidas. Além da consistência, o comportamento resiliente das misturas asfálticas pode mudar em função da composição do CAP, por exemplo, de origem diferentes e CAPs modificados (polímeros, borracha, fíleres e aditivos) (BAHIA et al., 2001).

Alguns valores de referência de MR são apresentados por Bernucci et al (2006). Na temperatura de $25^{\circ} \mathrm{C}$, o valor MR de uma mistura asfáltica densa (CAUQ) composta por um CAP 50/70 é da ordem de $3000 \mathrm{MPa}$. Quando composta por um CAP 30/45, a mistura apresenta um valor de MR da ordem de $3600 \mathrm{MPa}$. A partir desses valores, nota-se que a mudança de classe do CAP (aumento da consistência) conferiu um aumento de $20 \%$ de MR.

Taira (2003), estudando o efeito da modificação do CAP com o polímero SBS nas propriedades de misturas asfálticas densas (Faixa C), observou que a mistura com agregados basálticos e CAP 20 apresentou MR maior que a mistura com CAP 20+SBS, sendo, respectivamente, 2985 e $2402 \mathrm{MPa}$. Por outro lado, Anitelli (2013) comparou o MR (à $25^{\circ} \mathrm{C}$ ) de misturas asfálticas densas compostas com agregados graníticos e CAP 50/70 e CAP 50/70+SBS e encontrou os valores de 5331 e 5287, respectivamente; são valores próximos (diferem em 1\%), podendo ser considerados praticamente iguais. Portanto, a mistura com CAP 20+SBS foi menos rígida que a mistura com CAP convencional. A modificação com SBS implicou em aumento significativo da viscosidade, porém sem reflexo na rigidez.

Os valores de MR das misturas de Anitelli (2013) foram, aproximadamente, 80\% (para CAP 50/70) e 120\% (para CAP 50/70+SBS) maiores que os das misturas de Taira (2003). Essas variações podem ser atribuídas, dentre outros fatores, aos diferentes:

$>$ tipos de agregados: o granito usado por Anitelli tem forma mais cubica e resulta em mistura com melhor intertravamento;

$>$ teores de projeto: as misturas de Anitelli tem teores baixos de ligante asfáltico;

$>$ modos de preparo de mistura: as misturas de Taira foram compactadas imediatamente após a mistura, enquanto que as de Anitelli foram compactadas após 2 horas em estufa na temperatura de compactação;

tipos de compactação: as misturas de Anitelli foram produzidas no compactador giratório. 
Furlan et al. (2007) avaliaram o MR das misturas com agregados de basalto, granito e gabro em função do tipo de ligante (CAP 20 e CAP 40) preparadas de modos diferentes, a saber: compactadas após mistura (Marshall), compactadas após 2 horas em estufa na temperatura de compactação (ASTM) e compactadas após envelhecimento (16 horas em estufa ventilada, a 60 C) e 2 horas em estufa na temperatura de compactação (AASHTO). Os autores concluíram que:

$>$ o modo de preparo influenciou significativamente no valor de MR, aumentando cerca de 1, 20 e 40\% para os preparos tipo Marshall, ASTM e AASHTO, respectivamente;

$>$ as misturas com gabro apresentaram os maiores valores de MR, seguidas pelas misturas com granito e as com basalto;

$>$ as misturas com CAP 40 foram as que apresentaram maior rigidez (MRmédio 13000 MPa), principalmente, quando preparadas com agregado granítico e de acordo com o modo ASTM (MRmáx 16000 MPa). A mudança do CAP 20 para o CAP 40 aumentou os MR de 60 a $120 \%$.

Nessa mesma pesquisa, Furlan et al. (2007) observaram o efeito da substituição de $1 \%$ do fíler mineral por cal hidratada (CH I). Os autores constataram que, em geral, a cal aumentou o MR das misturas com CAP 20, contudo, a intensidade de seu efeito é diferente em função do tipo de agregado, uma vez que as misturas com granito exibiram menores ganhos MR com a adição de cal; do modo de preparo, porque o aumento de MR em função da adição de cal foi maior para preparos que combinam períodos mais longos de tempo de exposição em temperaturas mais altas (ASTM e AASHTO).

A observação isolada do ganho de MR pelo uso de CAPs mais consistentes, a incorporação de agentes de modificação e a adição de fíleres de diferentes naturezas pode não representar uma vantagem porque a rigidez das misturas asfálticas muda dependendo das condições ambientais às quais estão expostas.

Como os revestimentos asfálticos estão sujeitos a variados gradientes de temperaturas, em função do local que está aplicado, é apropriado entender a variação da rigidez do material em um espectro maior de temperaturas. Com isso, é possível entender o comportamento dos pavimentos em diferentes condições climáticas. Taira, Furlan e Fabbri et al. (2003), Gigante (2007) e Anitelli (2013) monitoraram o MR de diferentes misturas asfálticas com objetivo de entender seus comportamentos de suscetibilidade térmica, ou seja, entender a 
influência da temperatura no ganho ou perda de rigidez. Na Figura 2.1 são apresentados alguns resultados de MR versus temperatura desses autores.

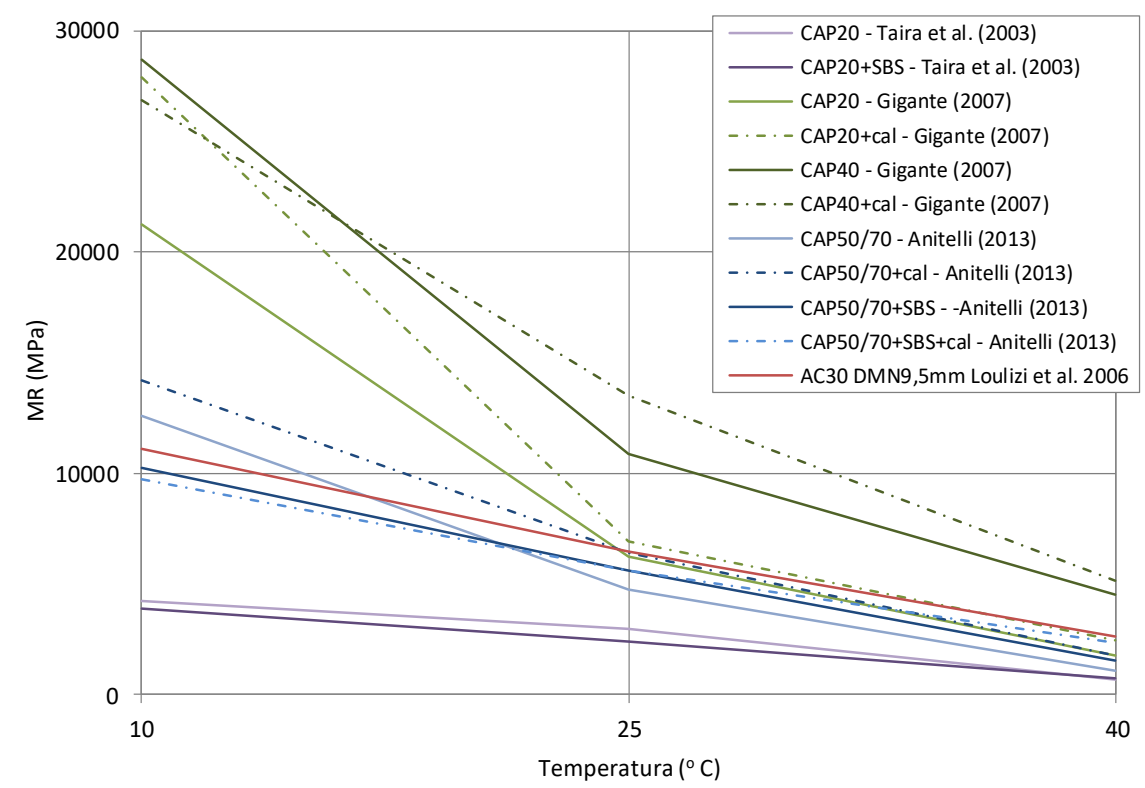

Figura 2.1 - Variação de rigidez em função da temperatura (Resultados de Taira et al. (2003), Gigante (2007), Loulizi et al. (2006) e Anitelli (2013))

Observando-se o comportamento de MR em função da temperatura da Figura 2.1, nota-se forte dependência do tipo de CAP. A modificação do CAP manteve ou melhorou a suscetibilidade térmica das misturas, o que é principalmente observado na faixa de temperaturas de 10 a $25^{\circ} \mathrm{C}$.

$\mathrm{Na}$ faixa de $25 \mathrm{a} 40^{\circ} \mathrm{C}$, os MR tendem a valores muito próximos (entre 1000 e $2000 \mathrm{MPa}$ ) para as misturas com ligantes asfáltico com penetração entre 50 e 70 décimos de milímetros (incluem-se os CAP20+SBS). Nesta faixa de temperatura, as misturas com CAP 40 e CAP $40+$ cal já mostram MR notadamente maiores. Na temperatura de $10^{\circ} \mathrm{C}$, todas as misturas asfálticas estudadas por Gigante (2007) exibiram valores altíssimos de MR (acima de $15000 \mathrm{MPa}$ a $\left.10^{\circ} \mathrm{C}\right)$.

Se por um lado, pode ser vantajoso que o material exiba alta rigidez, por outro lado, é necessário garantir menores variações da propriedade com a temperatura. Misturas com menor susceptibilidade térmica tendem a apresentar maior durabilidade. Neste sentido, o que se observa é que as misturas de Gigante (2007) foram as mais suscetíveis à temperatura, apresentando na faixa de temperatura de 10 a $25^{\circ} \mathrm{C}$, uma taxa de redução de MR média de $1200 \mathrm{MPa} / 1^{\circ} \mathrm{C}$. 
As misturas estudadas por Taira, Furlan e Fabbri (2003) foram as menos rígidas, com o valor médio de $\mathrm{MR}$, à $25^{\circ} \mathrm{C}$, de $2700 \mathrm{MPa}$; ao mesmo tempo, foram as menos suscetíveis à temperatura, com uma taxa média de redução de $\mathrm{MR}$ de $100 \mathrm{MPa} / 1^{\circ} \mathrm{C}$. As misturas estudadas por Anitelli (2013) tiveram um comportamento intermediário, com valores de MR médio de $5100 \mathrm{MPa}$ e taxa média de redução de $\mathrm{MR}$ de $333 \mathrm{MPa} / 1^{\circ} \mathrm{C}$.

Complementarmente, a curva (em vermelho) de Loulizi et al. (2006) foi incluída na Figura 2.1. Trata-se de uma mistura asfáltica mais fina (DMN 9,5 mm), produzida num compactador giratório e com volume de vazios de 6,2\%. Mesmo com características diferentes, os valores de MR em diferentes temperaturas mostram uma tendência muito próxima às observadas por Anitelli (2013), para misturas com CAP modificado, valendo destacar a (quase) linearidade do comportamento dessas misturas em todo o intervalo $\left(10-40^{\circ} \mathrm{C}\right)$. Por contraste, as misturas com CAP convencional exibiram mudança de comportamento e foram, em geral, mais suscetíveis à mudança de temperatura no intervalo de temperatura de 10 a $25^{\circ}$.

O efeito da adição de cal como fíler nas misturas asfálticas também pode ser observado nas curvas de suscetibilidade térmica. Em decorrência do diminuto tamanho das partículas, o fíler pode agir como material ativo na interface fíler/ligante asfáltico, podendo melhorar o comportamento mecânico e reduzir a susceptibilidade térmica das misturas asfálticas.

Quatro misturas com cal estão incluídas na Figura 2.1 (linhas tracejadas), de onde se pode constatar que a cal aumentou o MR das misturas em diferentes intensidades, para as misturas estudadas por Gigante (2007), por exemplo, seu efeito pode ser considerado negativo para CAP 20 na temperatura entre 10 e $25^{\circ} \mathrm{C}$, porque aumentou a suscetibilidade térmica das (aumento da inclinação), para a mistura com CAP 40 isso ocorreu na faixa de temperatura de 25 a $40^{\circ} \mathrm{C}$.

Mohammad et al. (2000) também efetuaram estudo de susceptibilidade térmica nas temperaturas de 5,25 e $40^{\circ} \mathrm{C}$. Eles produziram oito tipos de misturas densas variando o ligante asfáltico, o agregado e aditivo em 2 níveis cada, ligante convencional e ligante modificado com SBS, agregado de calcário e de cascalho britado e com ou sem a adição de cal. Para todas as misturas os valores de $\mathrm{MR}$ a $5^{\circ}$ foram da ordem de $6300 \mathrm{MPa}$, a $25^{\circ}$ da ordem de $4200 \mathrm{MPa}$ e a $40^{\circ} \mathrm{C}$ a rigidez foi, em média, de $2000 \mathrm{MPa}$. De modo geral, o uso de agregado de cascalho 
britado e uso de cal aumentaram o MR. Não se detectou tendência de variação de MR com o uso do SBS.

As particularidades de rigidez e de suscetibilidade térmica das misturas asfálticas são importantes para entender o comportamento do material e podem sinalizar indicações ou contraindicações. Contudo, conclusões mais substanciadas acerca do desempenho de uma mistura asfáltica devem ser baseadas, também, em resultados de ensaios relacionados a processos específicos de deterioração, como a fadiga e a deformação permanente.

\subsubsection{Deformação permanente}

A deformação permanente (DP) é um dos principais defeitos dos pavimentos. Ela é causada pela ação repetitiva das cargas oriundas do tráfego as quais provocam danos sucessivos e acumulativos que resultam em deformações plásticas ou permanentes (KALOUSH; WITCZAK; SULLIVAN, 2003). A DP prejudica a fluidez e a segurança do tráfego de veículos e ainda reduz a espessura da camada asfáltica, potencializando a ocorrência de trincas por fadiga (GANDOMI et al., 2011).

A DP em misturas asfálticas pode ocorrer em forma de densificação e/ou ruptura plástica (fluência) sob a ação do tráfego. Na densificação, observa-se a redução no volume da camada asfáltica com consequente redução de vazios. Na deformação por fluência, observam-se mudanças na forma da camada asfáltica, com afundamento nas trilhas de roda e elevação lateral, sem alteração volumétrica importante (BROWN; KANDHAL; ZHANG, 2001). A densificação costuma ocorrer logo no início da vida de serviço, enquanto que a ruptura plástica ocorre posteriormente (IRFAN et al., 2018).

No revestimento asfáltico, a deformação permanente tem maior propensão a ocorrer em situações que combinam elevadas temperaturas com tráfego pesado e em baixa velocidade. Em consequência da maior pressão de enchimento dos pneus e do maior volume de tráfego de veículos pesados os defeitos de deformação permanente têm se tornado cada vez mais frequentes (MOHAMED; YUE, 1994).

A intensidade da deformação permanente está vinculada a diversos fatores, intrínsecos e extrínsecos às propriedades e componentes das misturas asfálticas. Como fatores intrínsecos, 
citam-se o esqueleto pétreo (tipo de agregado, graduação, forma dos grãos, textura superficial e angularidade), o nível de compactação das misturas (volume de vazios), o tipo e o teor do ligante asfáltico e o tipo e teor de fíler. Como fatores extrínsecos, destacam-se a magnitude e a velocidade de aplicação das cargas do tráfego e a temperatura.

A capacidade de uma mistura resistir à deformação permanente depende de vários fatores, dentre os quais citam-se:

$>$ Tipo de ligante asfáltico: o uso de CAPs mais consistentes torna a mistura mais rígida e mais resistente à DP. O uso de ligantes asfálticos modificados com polímeros aumenta a resposta elástica da mistura e também diminui a DP (BERNUCCI et al. 2006);

$>$ Teor de ligante asfáltico: misturas com menor teor de ligante asfáltico podem resistir melhor à DP devido a menor fluência (TAIRA, 2001);

$>$ Tipo de agregado: O uso de agregados britados, cúbicos e de curvas granulométricas densas contribuem para mitigar a ocorrência da DP (AMARAL, 2004);

$>$ Presença de fíler: certos fíleres podem enrijecer o mástique e consequentemente reduzir a susceptibilidade à DP (MOTTA et al., 1996);

Volume de Vazios: Redução no nível de volume de vazios passando de 7 para $4 \%$ tende a deixar a mistura menos suscetível a DP (NG, 2013).

Dentre os fatores intrínsecos, o esqueleto pétreo é o mais importante. Observa-se que o uso de graduações densas, com agregados de forma cúbica e com boa angularidade confere às misturas menor susceptibilidade à DP em função do melhor intertravamento entre as partículas e maior resistência ao cisalhamento (ROBERTS et al., 1996). Onofre (2012) ratificou que a resistência à deformação permanente é consideravelmente mais afetada pelo agregado do que pelo ligante asfáltico. Gouveia (2006) concluiu haver diferenças importantes na susceptibilidade à deformação permanente de misturas asfálticas quando se varia a granulometria do agregado e a energia de compactação.

Teoricamente, quanto maior o volume de vazios de uma mistura asfáltica, maior será a propensão de haver afundamentos na trilha de roda (MAHMOUD; BAHIA, 2004). NG (2013) obteve conclusão semelhante ao relatar que a susceptibilidade à deformação permanente de misturas asfálticas com $\mathrm{Vv}=7 \%$ foi maior que em misturas com $\mathrm{Vv}=4 \%$, independentemente da presença de cal, do tipo de carregamento (estático ou dinâmico) e da temperatura do ensaio (40 ou $50^{\circ} \mathrm{C}$ ) dos ensaios de creep. Entretanto, a ocorrência de baixo volume de vazios não é 
garantia de que a mistura asfáltica esteja imune a deformação permanente. Segundo Souza, Craus e Monismith (1991), quando o baixo Vv é uma consequência do excesso de ligante asfáltico, a ocorrência de DP por fluência do ligante asfáltico pode ser potencializada pois o CAP pode atuar como lubrificante das partículas, favorecendo a movimentação dos agregados.

O uso de ligantes asfálticos mais consistentes e/ou modificados tende a elevar a rigidez e reduzir à susceptibilidade à deformação permanente. Bernucci, Leite e Moura (2002) constataram que misturas asfálticas produzidas com o CAP 40 apresentaram menor percentual de deformação permanente do que as misturas produzidas com o CAP 20, para a mesma graduação e natureza dos agregados, em ensaio conduzido no simulador de tráfego desenvolvido pelo Laboratoire Central des Ponts et Chaussées (LCPC). Os autores também reportaram que misturas com maior teor de ligante asfáltico acumularam maior DP. Na situação mais extrema, o percentual de deformação permanente do CAP 20 aumentou quatro vezes quando o teor de ligante asfáltico se elevou de 5,6 para 6,1\%. Onofre et. al. (2013) avaliaram o efeito de ligantes asfálticos modificados na resistência à deformação permanente de misturas asfálticas densas e indicaram que todas as modificações feitas no ligante asfáltico CAP 50/70, com a adição de SBS, PPA, borracha moída de pneus, dentre outros, proporcionaram aumento da resistência à deformação permanente, à luz do ensaio de Flow Number.

A contribuição das propriedades dos fíleres para mitigar a ocorrência de deformação permanente nas misturas asfálticas depende de suas propriedades físico-químicas e ainda não está bem compreendida (WANG et al., 2011). Resultados contrários vem sendo reportados. Tayebali, Malpass e Khosla (1998) detectaram alterações significativas na resistência à deformação permanente em função do fíler. Eles concluíram que o aumento no teor de fíler, no intervalo de 4 a $12 \%$ do pó de pedra do agregado, melhorou o desempenho das misturas asfálticas em termos de DP. Antagonicamente, Huang, Shu e Chen (2007) relataram aumento na susceptibilidade à deformação permanente quando se aumentou o teor de fíler de 2 para 5\%, em misturas asfálticas densas, em avaliação feita no Asphalt Pavement Analyzer.

Algumas pesquisas investigaram a influência da graduação do fíler na rigidez e na susceptibilidade à deformação permanente. Kandhal, Lynn e Parker (1998) encontraram forte correlação inversamente proporcional entre D60 (diâmetro das partículas do fíler com 60\% de material passante) e $\mathrm{G}^{*} / \operatorname{sen} \delta$ (parâmetro de resistência à deformação permanente da mistura 
asfáltica). Assim, concluíram que fíleres mais finos conduziram a misturas mais rígidas e com menor susceptibilidade à deformação permanente.

Wang et al. (2011) encontraram correlações entre os módulos de finura (MF) dos fíleres e aumento da rigidez do mástique, porém não detectaram relações entre o MF e a susceptibilidade à DP, avaliada com o ensaio de flow number. O MF é calculado ao se dividir por 100 a soma da porcentagem retida de cada material, referentes aos diâmetros dos grãos de 0,075, 0,050, 0,030, 0,020, 0,010, 0,005, 0,003 e 0,001 mm.

Dentre os fatores extrínsecos à mistura asfáltica que afetam a rigidez e a resistência à deformação permanente, destacam-se a temperatura e a magnitude das cargas. Os ligantes asfálticos são termossensíveis, ou seja, são semi-sólidos em baixas temperaturas e líquidos viscosos em altas temperaturas, por isso, podem ser menos resistentes à deformação permanente em temperaturas mais altas. NG (2013) observou que ensaios de creep estático e dinâmico conduzidos a $50^{\circ} \mathrm{C}$ foram mais severos do que os ensaios realizados a $40^{\circ} \mathrm{C}$, resultando em parâmetros de deformações permanentes mais elevados. Além disso, constatou que ensaios de creep realizados com maior nível de tensão $(0,4 \mathrm{MPa})$ resultaram em maior DP do que ensaios realizados com tensão de $0,1 \mathrm{MPa}$.

Há diversos ensaios para a avaliar a deformação permanente, dentre os quais se destacam os simuladores de laboratório tais como French Pavement Rutting Tester, Hamburg Wheel Tracking Device, Asphalt Pavement Analyzer e Georgia Loaded-wheel Tester e os ensaios que mensuram as deformações em função do carregamento aplicado, por exemplo, triaxial com carregamento repetido, compressão uniaxial não confinada (creep estático e dinâmico), flow number e flow time.

No Brasil, o ensaio normalizado é o de Flow Number (NBR 16505/2016) que mede a resistência à DP de misturas asfálticas utilizando o ensaio uniaxial de carga repetida. No entanto, as dimensões requeridas para os CPs neste ensaio, altura de $150 \pm 2,5 \mathrm{~mm}$, são incompatíveis com a alturas dos CPs produzidos no aparato Marshall.

Uma solução interessante para avaliar a susceptibilidade à deformação permanente nos CPs produzidos no aparato Marshall é a adoção do ensaio de fluência por compressão uniaxial estática ou creep estático desenvolvido na década de 1970, devido à simplicidade do ensaio e 
da lógica que pode ser estabelecida entre o teste de fluência e a deformação permanente de revestimentos asfálticos. No entanto, não há um parâmetro de consenso para o correlacionar os resultados dos ensaios de creep com o desempenho da mistura asfáltica em campo, havendo autores que defendem apenas a avaliação da deformação total após 3600 segundos de carregamento e o correspondente módulo de fluência e outros pesquisadores que também levam em consideração a inclinação do estágio secundário da curva de fluência e os valores de deformação e módulo de fluência após um certo período de repouso, para melhor representar a deformação não recuperável ou permanente da mistura asfáltica (LITTLE; BUTTON; YOUSSEF, 1993).

Little, Button e Youssef (1993) propuseram um critério de desempenho relacionado ao módulo de fluência $\left(\mathrm{M}_{\mathrm{f}}\right)$ após 1 hora de carregamento, a fim de correlacionar os resultados dos ensaios de creep estático à susceptibilidade à deformação permanente das misturas asfálticas em campo, conforme apresentado na Tabela 2.2. $\mathrm{O} \mathrm{M}_{\mathrm{f}} 3600$ s é obtido pela relação entre a tensão constante aplicada sobre a deformação total ocorrida após 1 hora de aplicação de carga.

Tabela 2.2 - Critério de resistência à DP em função do módulo de fluência após 1 hora de carregamento (Fonte: Little, Button e Youssef, 1993)

\begin{tabular}{|c|c|c|c|c|}
\hline \multirow{2}{*}{$\begin{array}{l}\text { Resistência à } \\
\text { Deformação } \\
\text { Permanente }\end{array}$} & \multirow{2}{*}{$\begin{array}{l}\text { Intensidade } \\
\text { do Tráfego }\end{array}$} & \multicolumn{3}{|c|}{$\begin{array}{l}\text { Módulo de Fluência Mínimo (MPa) em função } \\
\text { do nível de tensão no ensaio de creep estático }\end{array}$} \\
\hline & & 0,207 MPa & 0,354 MPa & 0,483 Мра \\
\hline \multirow{4}{*}{$\begin{array}{l}\text { Elevada resistência à } \\
\text { deformação permanente }\end{array}$} & IV & 103,4 & 120,7 & 155,1 \\
\hline & III & 48,3 & 69,0 & 96,5 \\
\hline & II & 34,5 & 44,8 & 60,3 \\
\hline & I & 20,7 & 27,6 & 41,4 \\
\hline \multirow{4}{*}{$\begin{array}{l}\text { Moderada resistência à } \\
\text { deformação permanente }\end{array}$} & IV & 51,7 & 69,0 & 96,5 \\
\hline & III & 34,5 & 50,0 & 69,0 \\
\hline & II & 24,1 & 41,4 & 51,7 \\
\hline & I & 17,2 & 20,7 & 27,6 \\
\hline
\end{tabular}

I - Intensidade de tráfego baixa: $<10^{5}$ ESALs / II - Intensidade tráfego moderada: entre $10^{5}$ e $5 \times 10^{5} \mathrm{ESALs} / \mathrm{III}$

- Intensidade tráfego alta: entre $5 \times 10^{5}$ e $10^{6}$ ESALs / IV - Intensidade tráfego muito alta: > $10^{6}$ ESALs / ESALs

- Solicitação equivalente do eixo padrão de 8,2t.

A tensão de compressão uniaxial não confinada entre 0,34 e 0,41 MPa no ensaio de creep estático é apropriada para avaliar a susceptibilidade à deformação permanente de misturas asfálticas densas, pois é semelhante à pressão aplicada pelos pneus. A temperatura de $40^{\circ} \mathrm{C}$ é a mais comum para a realização dos ensaios de creep estático, facultando, assim, a comparação entre resultados de diversas pesquisas (LITTLE; BUTTON; YOUSSEF, 1993). Esta 
temperatura também tem o ponto positivo de ocorrer frequentemente no revestimento asfáltico nas condições climáticas brasileiras, em especial da Região Norte do país.

Ainda que a avaliação da deformação permanente seja de extrema importância, notadamente em locais de clima quente, também há necessidade de se investigar os parâmetros relacionados à vida de fadiga de modo a melhorar o desempenho dos revestimentos asfálticos e prevenir a formação de trincas por fadiga, as quais são um tipo de defeito estrutural muito comum nas rodovias e vias urbanas brasileiras.

\subsubsection{Vida de Fadiga}

A fadiga é um dos principais mecanismos de deterioração pavimentos asfálticos e é causada pela flexão alternada da camada asfáltica decorrente do carregamento do tráfego de veículos. Ela se desenvolve mesmo em níveis baixos de tensões, ou seja, cada passagem de veículo produz pequenos danos em forma de deformação plástica, que evoluem para fissuras localizadas na parte inferior da camada asfáltica, que ascendem e se propagam como trincas na superfície do revestimento até sua ruptura (ADEDIMILA; KENNEDY, 1975; KHALID, 2000).

As fissuras dão início a um processo progressivo de deterioração e acúmulo de danos em um pavimento, modificando a distribuição de tensões e deformações na estrutura e comprometendo seu desempenho, o que pode ser traduzido como o consumo da vida de fadiga.

Em ensaios de laboratório, a vida de fadiga pode ser mensurada em termos de vida de fratura e vida de serviço. A vida de fratura é o número total de aplicações de carga que levam à ruptura do material e a vida de serviço é o número de aplicações de carga que reduz o valor de uma determinada propriedade mecânica do material, usualmente a rigidez, para abaixo de um nível pré-estabelecido (ADEDIMILA; KENNEDY, 1975).

Ensaios laboratoriais de fadiga de misturas asfálticas não conseguem reproduzir com acurácia o que ocorre em campo (PINTO, 1991; BALBO, 2007), porque são realizados em temperatura constante (normalmente $25^{\circ} \mathrm{C}$ ), e com aplicação de cargas de magnitude constante e ciclos de aplicação de carga com frequência de $1 \mathrm{hz}$. Em campo, os revestimentos asfálticos estão sujeitos a temperatura e carregamentos de magnitudes e frequências bastante variáveis. Desta forma, as condições de realização do ensaio de fadiga no laboratório acabam sendo mais severas do que 
se observa na vida de serviço dos pavimentos (FRANCO, 2007; FRITZEN, 2016), sendo necessária uma função de transferência ou fator laboratório campo (FLC). O FLC normalmente aplicado para misturas asfálticas é da ordem de $10^{4}$ proposto por Pinto (1991), ou seja, assumese que em campo a mistura irá resistir 10.000 vezes mais do que no laboratório.

Há uma dificuldade na interpretação da vida de fadiga dos materiais, pois ela é dependente de diferentes configurações de ensaios e das amostras. Os ensaios podem ser realizados à tensão ou à deformação controlada; reproduzindo esforços de flexão, torção, tração direta ou tração indireta. Além disso, os corpos de prova podem ser de geometrias diferentes (cilíndricos, trapezoidais, vigotas). No Brasil, apenas em 2018, foi lançada a norma DNIT 183/2018 ME para executar ensaio de vida de fadiga por compressão diametral à tensão controlada em CPs cilíndricos.

Os ensaios de fadiga à tensão controlada são mais usados, pois melhor reproduzem as condições de campo, onde ocorre a aplicação de cargas ao pavimento sem qualquer controle das deformações decorrentes (KHALID, 2000). Neste tipo de teste, uma tensão constante é aplicada ao corpo de prova causando gradativa redução em sua rigidez e, consequentemente, níveis crescentes de deformações que culminam na ruptura do CP.

Testes de tração por compressão diametral têm sido usados para diversas avaliações de misturas asfálticas, pois são fáceis de executar e efetivos para caracterizar as propriedades mecânicas fundamentais das misturas asfálticas tais como RT, MR e vida de fadiga (HARTMAN; GILCHRIST; WALSH, 2001). Rao Tangella et al. (1990) destacaram algumas vantagens do teste de fadiga por compressão diametral: (i) simplicidade do ensaio, (ii) possibilidade de aproveitar o aparato de teste utilizado para os ensaios de RT e MR, (iii) ocorrência de trincas em regiões com tensões de tração relativamente uniformes, (iv) formação de um estado biaxial de tensões, que, em tese, representa melhor o que ocorre em campo, e (v) possibilidade de ser executado tanto em CP produzidos em laboratórios como em amostras extraídas em campo. Contudo, os autores chamam a atenção para a subestimação da vida de fadiga em comparação com outros tipos de ensaio, a não ocorrência de inversão de tensões, como ocorre em campo, e a preocupação com a influência do acúmulo de deformação permanente na vida de fadiga.

Os resultados dos ensaios de vida de fadiga por compressão diametral à tensão controlada são expressos em forma de um modelo de fadiga, conforme equação 2.1, no qual o denominador 
"X" pode ser a tensão de tração aplicada, a deformação de tração inicial ou a diferença de tensões no centro da amostra, $\mathrm{N}$ é a vida de fadiga, ou seja, o número de aplicações de carga até a ruptura do $\mathrm{CP}, \mathrm{k}_{1}$ e k $\mathrm{k}_{2}$ são coeficientes obtidos por meio de regressão.

$$
N=k_{1} \cdot\left(\frac{1}{X}\right)^{k_{2}}
$$

Os coeficientes $\mathrm{k}_{1}$ e $\mathrm{k}_{2}$ podem ser usados como indicadores do efeito de determinada variável na vida de fadiga de uma mistura asfáltica. Comparativamente, quando se aumenta $\mathrm{k}_{1}$, mantido constante o valor de $\mathrm{k}_{2}$, há um incremento na vida de fadiga. Quando se aumenta $\mathrm{k}_{2}$, mantido constante o valor de $\mathrm{k}_{1}$, a vida de fadiga torna-se mais suscetível à variação do parâmetro do denominador da equação 2.1, isto é, quanto maior o valor de $\mathrm{k}_{2}$, maior será a inclinação do modelo de fadiga (ALI et. al., 1996).

É precipitado inferir sobre a vida de fadiga de uma mistura asfáltica ou mesmo comparar diretamente duas misturas asfálticas analisando somente seus modelos de fadiga (PINTO, 1991). É mais indicado avaliar as tensões e deformações no revestimento asfáltico em dada estrutura de pavimento e para determinada configuração de tráfego. Esta avaliação pode ser feita com base na resolução de um sistema elástico-linear, mediante uso de softwares de análise mecanística de pavimentos.

Bueno et. al. (2017) adotaram o modelo de fadiga proposto por Franco (2007), que considera o MR e a deformação horizontal de tração no fundo da capa asfáltica, e efetuaram várias simulações no software SisPav para identificar mudanças na vida de fadiga. Suas principais conclusões foram: (i) quanto maior a espessura e o MR de quaisquer camadas, maior será a vida de fadiga da capa asfáltica; (ii) A vida de fadiga de pavimentos de capa espessa $(12,5 \mathrm{~cm})$ é mais suscetível à variação da carga do eixo, já a vida de fadiga de pavimentos de capa delgada $(5,0 \mathrm{~cm})$ é mais suscetível à variação da pressão de enchimento dos pneus.

Assim como na susceptibilidade à deformação permanente, vários fatores intrínsecos e extrínsecos à mistura asfáltica intervêm na vida de fadiga (N). Santos (2005) investigou a influência do tipo de ligante asfáltico e do volume de vazios na vida de fadiga de misturas asfálticas, produzidas com agregado de basalto no centro da faixa C do DNIT. Ele testou misturas com três tipos de ligante asfáltico, CAP 20, CAP 20+SBS e CAP 20+borracha 
reciclada de pneus (BRP) em 3 níveis de $\mathrm{Vv}$ (3, 4 e 5\%), e concluiu que: (i) quanto menor o Vv, maior será a vida de fadiga das misturas; (ii) a mistura com CAP $20+$ SBS apresentou a maior vida de fadiga, e; (iii) a mistura com CAP 20, apresentou a menor vida de fadiga.

O incremento de $\mathrm{N}$ em decorrência do uso de ligantes modificados também foi observado por Morilha Júnior (2004), que produziu misturas com agregado de granito e uso de cal hidratada. Novamente as misturas com SBS apresentaram maior vida de fadiga, seguidas das misturas com ligante modificado por EVA. Morilha Júnior (2004) também indicou que misturas com CAP 40 exibiram maior vida de fadiga que as misturas com CAP 20 e estas, por sua vez, apresentaram maior $\mathrm{N}$ que as misturas com CAP 7, ou seja, quanto maior a consistência do ligante asfáltico, maior a vida de fadiga.

Iwanaga (2007) também verificou que as misturas com ligante asfáltico mais consistente (CAP 40) apresentaram maiores vidas de fadiga. O autor mostrou que misturas com gabro apresentaram vidas de fadiga superiores às misturas compostas por basalto e estas exibiram maior $\mathrm{N}$ do que as misturas com granito. Quanto ao efeito da cal, foi observado que as misturas contendo o fíler de cal hidratada foram mais resistentes à fadiga que as misturas sem cal.

Benefícios à vida de fadiga em virtude da adição de fíler também foram reportados por Yilmaz, Kök e Kuloğlu (2013). Eles adicionaram fíler de asfaltito a misturas com ligante convencional PG 64-34 e agregados de calcário, em cinco teores, de 1 a 5\%, e constaram que à medida que se elevou o teor de asfaltito (fíler), $\mathrm{N}$ aumentou.

Gouveia, Fernandes Júnior e Soares (2007) investigaram a influência da energia de compactação e do tipo de agregado na vida de fadiga, ao produzir misturas com ligante asfáltico CAP 50/70, com agregados de gabro e basalto e variando a energia de compactação do soquete Marshall em 75, 110 e 155 golpes por face do CP. Seus resultados foram ao encontro daqueles obtidos por Iwanaga (2007) pois as misturas com gabro apresentaram maior vida de fadiga, independentemente da energia de compactação. Os autores observaram um ponto de máximo nas curvas de energia de compactação versus vida de fadiga referente a energia de 110 golpes, e concluíram que o aumento na energia de compactação para misturas com agregados angulosos, rugosos e com boa resistência parece promissora, pois foi possível obter um melhor entrosamento entre os grãos, utilizando menor teor de ligante asfáltico sem comprometer a vida de fadiga. 


\subsection{APROVEITAMENTO DE MATERIAIS ALTERNATIVOS EM PAVIMENTAÇÃO}

Para a construção de uma rodovia ou via urbana são utilizados grandes volumes de recursos naturais finitos tais como agregados, solos e ligantes asfálticos. À luz dos conceitos de sustentabilidade, da indisponibilidade de materiais convencionais próximos a algumas obras rodoviárias e em função de legislações ambientais, como por exemplo a Resolução CONAMA $n^{\circ} 258 / 1999$, é crescente a utilização de materiais alternativos ou rejeitos de outras atividades econômica em camadas de pavimento. Isto pode reduzir os custos de construção do pavimento, conservar recursos naturais e reduzir problemas ambientais (TAHAMI, ARABANI, MIRHOSSEINI, 2018). A seguir citam-se pesquisas que utilizaram borracha de pneus, areia de fundição, rejeitos de mineração, resíduos de chapas de gesso, agregado sinterizado de argila calcinada e até conchas do mar em camadas de pavimento.

Chen et al. (2015) utilizaram borracha moída de pneus como fíler e procederam testes nos mástiques e misturas asfálticas. Eles verificaram que a adição de borracha moída elevou o ponto de amolecimento e reduziu a penetração e a ductilidade do mástique. Em relação às misturas asfálticas, produzidas com agregado de basalto, observaram melhoria nos resultados do ensaio de creep estático, com menor acúmulo de deformação permanente e maior recuperação, porém relataram maior susceptibilidade ao dano por umidade induzida nas misturas com a borracha moída de pneus.

Bertollo (2002) substituiu parte do agregado de basalto por borracha reciclada de pneus, no denominado "processo seco", e testou as misturas asfálticos quanto a RT, MR, dano por umidade induzida e deformação permanente. A autora detectou aumento na resistência à deformação permanente, mas relatou redução na rigidez e na resistência à tração com a adição de borracha reciclada. Oda (2000), em "processo úmido", incorporou resíduos de borrachas de pneus em um CAP 20, de modo a contemplar os requisitos para que o ligante modificado se enquadrasse, no mínimo, como um PG 64-10. A autora concluiu que o ligante modificado asfalto-borracha apresentou maior rigidez em elevadas temperaturas e maior elasticidade, melhorando assim, simultaneamente, a resistência ao acúmulo de deformações permanentes e à formação de trincas por fadiga.

O estudo do reaproveitamento de areia fundição como agregado miúdo em misturas asfálticas densas foi o objetivo de Coutinho Neto (2004). Ele incorporou ao concreto asfáltico percentuais 
de 5, 10 e $15 \%$ em massa do rejeito e submeteu as misturas aos ensaios de módulo de resiliência, resistência à tração, dano por umidade induzida, ensaio de cântabro e creep estático obtendo resultados satisfatórios em todas as condições. $\mathrm{O}$ autor destacou ainda que os elementos tóxicos contidos na areia de fundição, quando misturados e "encapsulados" na mistura asfáltica, respeitaram os limites da norma brasileira de resíduos sólidos.

Klinsky (2013) também estudou o reaproveitamento da areia de fundição, mas a aplicou em areias asfálticas usinadas à quente (AAUQ) destinadas a camadas de base ou sub-base de pavimentos. A AAUQ apresentou graduação uniforme, requerendo assim o uso de ligante asfáltico muito rígido como Trindad Lake Asphalt ou a correção de parte de sua graduação com a adição de 3,0\% de cal e de $10 \%$ de agregado fino britado para que pudesse apresentar comportamento satisfatório como camada de base ou sub-base de pavimentos.

A preocupação com o dano por umidade induzida norteou o estudo de Dave e Baker (2013), que investigaram a diferença de comportamento entre uma mistura asfáltica produzida com um agregado convencional de granito e outra contendo como agregados apenas rejeitos de taconita, que é um subproduto da mineração de ferro. A graduação de ambos os materiais se assemelha àquela prevista na faixa IV do DER/SP. Os autores submeteram as misturas asfálticas a dois tipos de condicionamento para a avaliação do dano por umidade induzida: (i) AASHTO T 283, e; (ii) condicionamento de campo, no qual os CPs foram expostos às intempéries durante 6 meses. Em ambos os casos, a RRT foi sempre satisfatória, acima de $80 \%$. Destaca-se que as misturas asfálticas contendo granito apresentaram RRT mais elevada do que aquelas contendo rejeito de taconita, no condicionamento da AASHTO T 283. No condicionamento de campo, a RRT foi praticamente igual para as duas misturas.

Fabbri et al. (2006) efetuaram estudo preliminar para avaliar a possibilidade aproveitar o rejeito de bauxita refratária do município de Almeirim/PA em substituição aos agregados convencionais. O rejeito foi originado nas fases de calcinação e sinterização da bauxita beneficiada, dentro do processo de produção de alumínio. Os autores concluíram que o uso do rejeito foi viável, pois várias propriedades mecânicas das misturas como a RT, MR, RRT, estabilidade, fluência e desgaste por abrasão do tráfego, medido pelo ensaio de cântabro, apresentaram resultados satisfatórios. No entanto, há a ressalva de que o rejeito não deve ser utilizado em vias de volume de tráfego pesado, uma vez que as misturas que continham o rejeito 
de bauxita refratária apresentaram, simultaneamente, elevado Vv e alto teor de ligante asfáltico, situação na qual a ocorrência de deformação permanente fica potencializada.

Gouveia (2013) avaliou o efeito da adição de fíler proveniente de resíduos de chapas de gesso acartonado do tipo dry wall em misturas e mástiques asfálticos. A autora destacou o benefício ambiental, pois a disposição de resíduo em aterros sanitários propicia o aparecimento de gás sulfídrico, nocivo à saúde humana. Nos ensaios com o mástique, o fíler de gesso provocou enrijecimento e redução do Índice de Susceptibilidade Térmica (IST). Nos ensaios de misturas asfálticas, os maiores percentuais de adição de gesso $(60 \%$ a $100 \%$ de substituição do fíler mineral) resultaram em misturas com maior RT e menor susceptibilidade à deformação permanente. No entanto, níveis elevados de adição do gesso aumentaram consideravelmente a susceptibilidade ao dano por umidade induzida. Gouveia (2013) concluiu ser tecnicamente viável substituir somente até $20 \%$ do fíler mineral (centro da faixa C do DNIT) por fíler de resíduos de chapas de gesso acartonado.

Cunha et al. (2018) verificaram o efeito da temperatura nas propriedades mecânica de misturas produzidas com agregados de seixo rolado e agregados sinterizados de argila calcinada (ASAC). As misturas foram ensaiadas nas temperaturas de $25,30,40,50$ e $60^{\circ} \mathrm{C}$ nos ensaios de RT, MR e vida de fadiga. À medida que a temperatura cresceu, observou-se redução nos valores de RT, MR e N. As misturas com o ASAC apresentaram maior resistência à fadiga do independentemente da temperatura, e foram mais rígidas e com maior RT quando a temperatura foi superior à $40^{\circ} \mathrm{C}$.

Arabani et al. (2015) detectaram que o uso de conchas do mar trituradas como fíler em concretos asfálticos proporcionaram menor susceptibilidade à deformação permanente ao conduzirem testes de creep estático e dinâmico em quatro tipos de misturas que variavam entre si apenas no teor de adição das conchas do mar (0, 35, 70 e 100\%). Quanto maior o teor de adição, menor a deformação permanente, tanto no creep estático como no dinâmico. As conchas do mar apresentam elevado teor de óxido de cálcio $(\mathrm{CaO})$, portanto os autores indicam que este material alternativo tem efeitos semelhantes à adição de cal hidratada.

Percebe-se a grande quantidade de pesquisas que investigam a utilização de materiais não convencionais em pavimentação. Na próxima seção apresentam-se as características do caulim, 
a descrição de como o rejeito é formado e também relatos de pesquisas que utilizaram caulins em misturas asfálticas.

\subsection{CAULIM}

Define-se caulim como uma rocha constituída de material argiloso, com baixo teor de ferro, de cor branca ou quase branca. O caulim é composto, basicamente, por caulinita, que é um argilomineral cuja composição química é de, aproximadamente, $40 \%$ de óxido de alumínio $\left(\mathrm{Al}_{2} \mathrm{O}_{3}\right)$, $46 \%$ de óxido de silício $\left(\mathrm{SiO}_{2}\right)$ e $14 \%$ de água $(\mathrm{H} 2 \mathrm{O})$. Ele é um mineral versátil que apresenta uma gama de aplicações industriais devido às seguintes características: é quimicamente inerte; possui baixa condutividade térmica e elétrica; é macio e não abrasivo; apresenta satisfatório poder de cobertura quando utilizado como pigmento; é branco ou quase branco, e; apresenta custo competitivo em relação aos materiais concorrentes. Suas principais aplicações são na indústria de papel (fíler e coating) e na composição de pastas cerâmicas. Em menor escala, é utilizado na fabricação de plásticos, borrachas, cimentos, gesso, adesivos, além de cargas e enchimentos para diversas finalidades (LUZ; DAMASCENO, 1993; MÁRTIRES, 2009).

O Brasil é o sexto maior produtor mundial de caulim e o estado do Pará concentra algo em torno de $80 \%$ da produção nacional. As reservas paraenses de caulim, além de extensas, são consideradas de boa qualidade, uma vez que os depósitos são do tipo sedimentar, cuja característica é a alta porcentagem de caulinita, resultando em um produto com as especificações adequadas para a indústria de papel (LUZ; DAMASCENO, 1993; FIPE, 2009; CAMPOS et al., 2018).

A maior parcela da produção brasileira é de caulim beneficiado para indústria de papel, destinada à exportação, sendo Bélgica, Estados Unidos e Canadá os maiores mercados consumidores do caulim brasileiro, e é oriunda das minas CADAM (no Amapá - Vale), PPSA e RCC (no Pará - Imerys). No mercado interno destacam-se duas formas de aplicação do caulim: fabricação de cimento pozolana no Pará e utilização na indústria de cerâmica de louças sanitárias (CAMPOS et al., 2018).

É relevante destacar que a demanda global de caulim vem arrefecendo nos últimos anos. Este fato tem levado as empresas produtoras a realizar pesquisas com caulins inapropriados para papel, visando diversificar o uso deste mineral. Já foram alcançados bons resultados na indústria 
cerâmica (ICHIHARA, 2016). Esta informação é pertinente no contexto dessa pesquisa que investiga a possibilidade do uso de rejeito de caulim como fíler em concretos asfálticos.

\subsubsection{Rejeito de Caulim de Ipixuna do Pará/PA}

O caulim utilizado nessa pesquisa é proveniente da mina PPSA, localizada no município de Ipixuna do Pará/PA. Esta mina pertencia ao grupo Vale do Rio Doce, mas foi adquirida em 2010 pela empresa Imerys que já possuía a mina Rio Capim Caulim (RCC), no mesmo município. As duas minas juntas constituem a maior planta de beneficiamento de caulim no mundo e respondem por 92,5\% da produção brasileira (CAMPOS et al., 2018). O caulim extraído em Ipixuna do Pará é transportado até a cidade portuária de Barcarena/PA por meio de minerodutos, onde recebe beneficiamento e é embarcado para o mercado internacional (IMERYS, 2016). A Figura 2.2 apresenta uma imagem aérea da mina PPSA e a localização das minas e minerodutos no Pará.

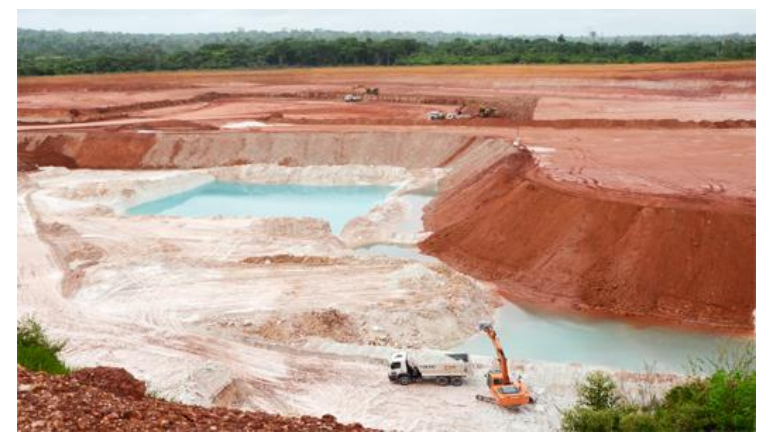

(a)

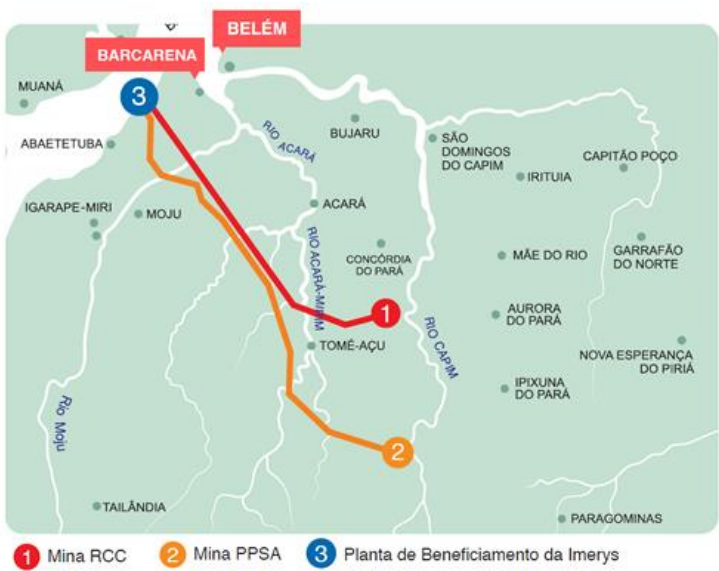

(b)

Figura 2.2 - Imagem aérea da mina PPSA e localização das minas e minerodutos da Imerys no Pará (IMERYS, 2016)

O método de lavra utilizado na mina PPSA é a extração a céu aberto em aluvião sub-horizontal (stripping mine). As operações realizadas são: desmatamento, decapeamento e remoção de estéreis, extração, carregamento e transporte do minério para o beneficiamento primário em instalação próxima à mina. Para isto, utilizam-se equipamentos convencionais de terraplenagem como escavadeiras, tratores de esteira e caminhões (SILVA, 2014). 
O rejeito de caulim utilizado neste trabalho recebe a denominação de Super Fine Clay (SFC) e compõe uma camada de aproximadamente 4,0 metros espessura, cujo topo se encontra, em média, a 6,0 metros de profundidade. A camada de caulim SFC está localizada abaixo do decapeamento e acima da camada de caulim macio, o qual é mais adequado para a indústria de papel. A Figura 2.3 apresenta o perfil do terreno da mina com a localização da camada de caulim SFC e alguns dos equipamentos utilizados na lavra da mina PPSA.

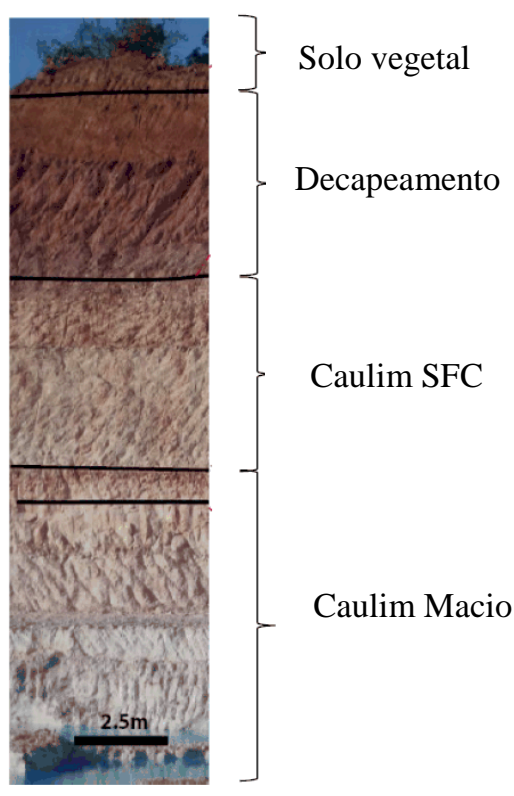

(a)

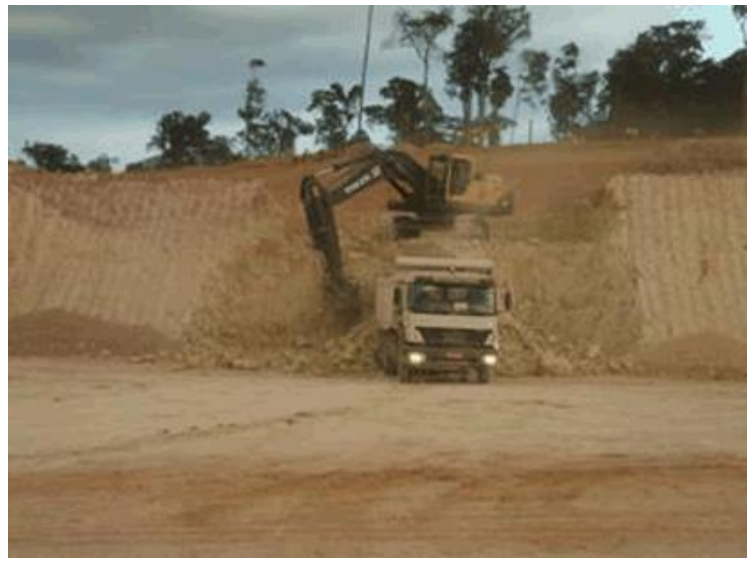

(b)

Figura 2.3 - Localização da camada de caulim SFC e equipamentos utilizados na exploração do minério ${ }^{1}$.

Em virtude do grande volume da camada de caulim SFC, a empresa mineradora tem procurado utilizar parte deste material como insumo para a produção de louças cerâmicas em outras unidades de produção. Destaca-se que este tipo caulim não recebe qualquer tipo de beneficiamento na mina PPSA, sendo apenas escavado para que se tenha acesso à camada de caulim macio e depositado em outro local da própria mina.

\footnotetext{
${ }^{1}$ Fotos do acervo pessoal do engenheiro da Imerys Renê Sousa, enviadas ao e-mail mmasulo@ufpa.br em 12 jul. 2016
} 


\subsubsection{Uso de caulins em misturas asfálticas}

A maioria das especificações de misturas asfálticas densas, incluindo as principais referências brasileiras DNIT e DER/SP, contraindica o uso de argila, pois sua presença influencia negativamente a adesividade entre o ligante asfáltico e os agregados. Assim, não é comum a utilização de caulim (argilo-mineral) em misturas asfálticas, embora haja artigos relatando este tipo de utilização em países como Índia, Irã e Nigéria. No campo acadêmico, destacam-se os trabalhos de Kavussi e Hicks (1997), Costa (2006), Lucena (2009) e Zulkati, Diew e Delai (2012).

Kavussi e Hicks (1997) efetuaram estudo do fíler nas misturas asfálticas, ao investigar a influência de quatro tipos de fíler (calcário, quartzo, cinzas volantes e caulim) nas propriedades dos mástiques e nos parâmetros Marshall. Especificamente em relação ao caulim, os autores observaram que: (i) foi o fíler mais fino; (ii) à medida que se elevou o teor de adição de caulim no mástique foram observados aumentos do ponto de amolecimento e da viscosidade e redução na penetração; (iii) o caulim, devido à sua finura, interagiu bastante com o ligante asfáltico, aumentando a rigidez da mistura asfáltica resultante, e; (iv) à medida que se elevou o teor de caulim de 1,5 para 4,5\% na mistura asfáltica, o TP se elevou de 5,4 para 6,1\%, a estabilidade aumentou de 4,8 para 8,0 kN e a fluência apresentou suave redução de 3,3 para 3,2 mm.

Costa (2006) avaliou a viabilidade de utilização do resíduo grosso (retido na peneira $\mathrm{n}^{\circ} 200$ ) oriundo do beneficiamento de caulim, extraído no município de Equador/RN. Adotou-se uma mistura de referência com CAP 50/70, teor de ligante asfáltico $=5,5 \%$, agregados de granito atendendo ao centro da faixa C do DNIT e $1 \%$ de cimento Portland. À essa mistura de referência foram gradativamente adicionados percentuais de 5 a $40 \%$ do resíduo grosso de caulim, em substituição ao agregado pétreo convencional. Houve o cuidado de se atender à faixa $\mathrm{C}$ do DNIT, porém, dentro desta faixa a graduação das diferentes misturas variou bastante.

À medida que se aumentou o percentual de uso de caulim grosso, as tendências de comportamento dos parâmetros avaliados foram (i) reduções de: densidade aparente das misturas, da relação betume vazios, da resistência à tração e da RRT do ensaio de dano por umidade induzida e; (ii) aumentos de: volume de vazios, vazios do agregado mineral e da estabilidade, embora este último resultado pareça contraditório. De modo a atender à especificação do DNIT, a autora concluiu que a utilização de caulim grosso foi viável quando 
se substituiu somente até $25 \%$ do agregado convencional, com a ressalva de que nenhuma mistura, nem mesmo a de referência, atingiu o valor mínimo de 0,65 MPa para a resistência à tração.

Lucena (2009) utilizou fíler de rejeito de caulim oriundo do estado da Paraíba em concretos asfálticos. As misturas foram produzidas com CAP 50/70, agregados graúdos de granito, areia de rio (quartzosa) e pó de pedra de granito, enquadrados na faixa B do DNIT. O TP foi de 5\%. Os teores de fíler variaram de 3 a $6 \%$. Além do rejeito de caulim, também foram produzidas misturas com fíler de serragem de granito.

As misturas contendo fíler de rejeito de caulim apresentaram elevada estabilidade Marshall, da ordem de $3.000 \mathrm{kgf}$ e valores adequados de VAM, independentemente do teor de caulim. As misturas com fíler de rejeito de caulim apresentaram elevado MR, 9.000 MPa, e foram significativamente mais rígidas que as misturas com fíler de serragem de granito. Os valores de $\mathrm{RT}$, cerca de 1,20 MPa, e de RRT, 80\%, foram superiores aos valores mínimos exigidos pelo DNIT de 0,65 MPa e 70\%, respectivamente (LUCENA, 2009). Destaca-se, contudo, que durante o condicionamento térmico do ensaio AASHTO T 283 as misturas não foram resfriadas à $-18^{\circ} \mathrm{C}$ e sim a apenas $10^{\circ} \mathrm{C}$, de modo a representar as temperaturas mais frias da região Nordeste do Brasil, o que pode ser considerado um erro de método de ensaio, prejudicando a comparação dos resultados desta pesquisa.

Zulkati, Diew e Delai (2012) compararam os efeitos de três tipos de fíler (cal hidratada, caulim e fíler mineral de granito) em mistura asfáltica densa. Os parágrafos seguintes apresentam as principais conclusões deste estudo.

A mistura contendo caulim apresentou o maior teor de projeto, $\mathrm{TP}=5,25 \%$, seguida pela mistura contendo cal, $\mathrm{TP}=5,10 \%$, e, por fim, a mistura contendo granito $\mathrm{TP}=4,6 \%$. A mistura com cal exibiu o maior módulo de resiliência a $25^{\circ} \mathrm{C}(\sim 3.900 \mathrm{MPa})$, seguida da mistura contendo fíler granito ( $\sim 3.400 \mathrm{MPa})$ e por último a mistura contendo caulim $(\sim 3.100 \mathrm{MPa})$. No ensaio de creep dinâmico, realizado segundo a norma Australian Standard Method $12.1\left(50^{\circ} \mathrm{C}\right.$, tensão de 0,2 $\mathrm{MPa}, 0,5 \mathrm{~s}$ de carregamento e 1,5 de recuperação), a mistura com caulim apresentou melhor performance e a mistura com fíler granito apresentou o pior resultado. 
A mistura contendo cal hidratada apresentou o melhor resultado em relação à susceptibilidade ao dano por umidade. Foi constatado que a mistura contendo o caulim apresentou menor susceptibilidade à umidade do que a mistura contendo fíler de granito, sendo que a sensibilidade à umidade foi avaliada pela Relação de Estabilidade Marshall (REM) que a razão entre a estabilidade de um grupo de CPs que ficou imerso à $60^{\circ} \mathrm{C}$ por 24 horas (grupo condicionado) e a estabilidade Marshall de um grupo de CPs que ficou imerso à $60^{\circ} \mathrm{C}$ por somente 30 minutos (grupo de controle). A mistura contendo caulim apresentou REM =87,6\% (estabilidade de 1234 kgf para o grupo de controle e de $1081 \mathrm{kgf}$ para o grupo condicionado), enquanto que a mistura contendo o fíler mineral teve $\mathrm{REM}=78,9 \%$ (estabilidade do grupo controle $=1305 \mathrm{kgf}$ e estabilidade do grupo condicionado $=1030 \mathrm{kgf}$ ).

Por ser um tipo de argila, o comportamento esperado para misturas asfálticas contendo caulim seria um mau resultado de susceptibilidade ao dano por umidade. No entanto, para Zulkati, Diew e Delai (2012) o ligante asfáltico parece ter encapsulado as partículas de caulim, protegendo-as do contato com a água. Assim, houve boa adesividade entre ligante e os agregados. Os mesmos pesquisadores sugerem mais testes para corroborar esta hipótese. 


\section{MATERIAIS E MÉTODOS}

Neste capítulo são apresentados os materiais, o programa experimental e os ensaios laboratoriais empregados para o estudo de viabilidade técnica das misturas asfálticas testadas nesta pesquisa. Para isso, o capítulo é apresentado em cinco partes, que são detalhadas nas seguintes seções:

$>$ Caracterização dos materiais;

$>$ Dosagem Marshall (Etapa 1);

> Caracterização mecânica básica (Etapa 2), envolvendo os ensaios de resistência à tração por compressão diametral, módulo de resiliência a $25^{\circ} \mathrm{C}$ e dano por umidade induzida;

> Caracterização mecânica complementar (Etapa 3), envolvendo os ensaios de vida de fadiga por compressão diametral à tensão controlada, MR em diferentes temperaturas para avaliar a susceptibilidade térmica, fluência por compressão uniaxial estática (creep estático) para avaliação da susceptibilidade à deformação permanente e RT após o ensaio de creep;

$>$ Análises estatísticas e descrição de análises complementares para melhor explorar os dados disponíveis.

\subsection{MATERIAIS}

Nesta seção são apresentados os ensaios de caracterização dos materiais empregados na pesquisa, bem como a caracterização complementar dos fíleres que incluem ensaios de sedimentação, de espectroscopia de dispersão de energia (EDS - Energy Dispersive Spectroscopy) e imagens de microscopia eletrônica de varredura (MEV).

\subsubsection{Ligantes asfálticos}

Foram utilizados dois tipos de ligantes asfálticos, CAP 30/45 e CAP 50/70, a fim de observar a influência do tipo de ligante asfáltico nas propriedades volumétricas, características mecânicas e susceptibilidades térmica e ao dano por umidade das misturas asfálticas.

Ambos os CAPs foram fornecidos pela empresa Brasquímica e são oriundos da refinaria de Paulínia/SP (REPLAN). As principais características destes ligantes asfálticos, conforme certificados de ensaios emitidos pelo laboratório da REPLAN, estão indicadas na Tabela 3.1. 
Tabela 3.1 - Características dos ligantes asfálticos

\begin{tabular}{ccc}
\hline Propriedade & CAP 30/45 & CAP 50/70 \\
\hline Penetração, 25 ${ }^{\circ} \mathrm{C}, 5 \mathrm{~s}, 100 \mathrm{~g}(0,1 \mathrm{~mm})$ & 39 & 56 \\
Ponto de Amolecimento $\left({ }^{\circ} \mathrm{C}\right)$ & 52,4 & 49,2 \\
Índice de Susceptibilidade Térmica & $-1,2$ & $-1,1$ \\
Ductilidade, 25 $\mathrm{C},(\mathrm{cm})$ & $>140$ & $>140$ \\
Densidade & 1,009 & 1,006 \\
\hline
\end{tabular}

Segundo o Asphalt Institute (1995), a temperatura de usinagem (ou mistura) do ligante asfáltico ao agregado deve ser tal que sua viscosidade esteja situada entre $170 \pm 20 \mathrm{cP}$. Na compactação das misturas, a temperatura deve ser tal que o ligante apresente viscosidade na faixa de $280 \pm$ 30 cP. Para identificar as Temperaturas de Usinagem e Compactação (TUC), foi realizado o ensaio de viscosidade com o viscosímetro rotacional, conhecido por Brookfield, conforme a norma ASTM D4402/4402M - 15. Foi utilizado o spindle $\mathrm{n}^{\circ} 21$ e a viscosidade foi medida nas temperaturas de $135^{\circ}, 143^{\circ}, 150^{\circ}, 163^{\circ}$ e $177^{\circ} \mathrm{C}$. Na Figura 3.1 estão indicadas as curvas de temperatura versus viscosidade e as faixas de viscosidade das operações de usinagem e compactação, as quais são também apresentadas na Tabela 3.2.

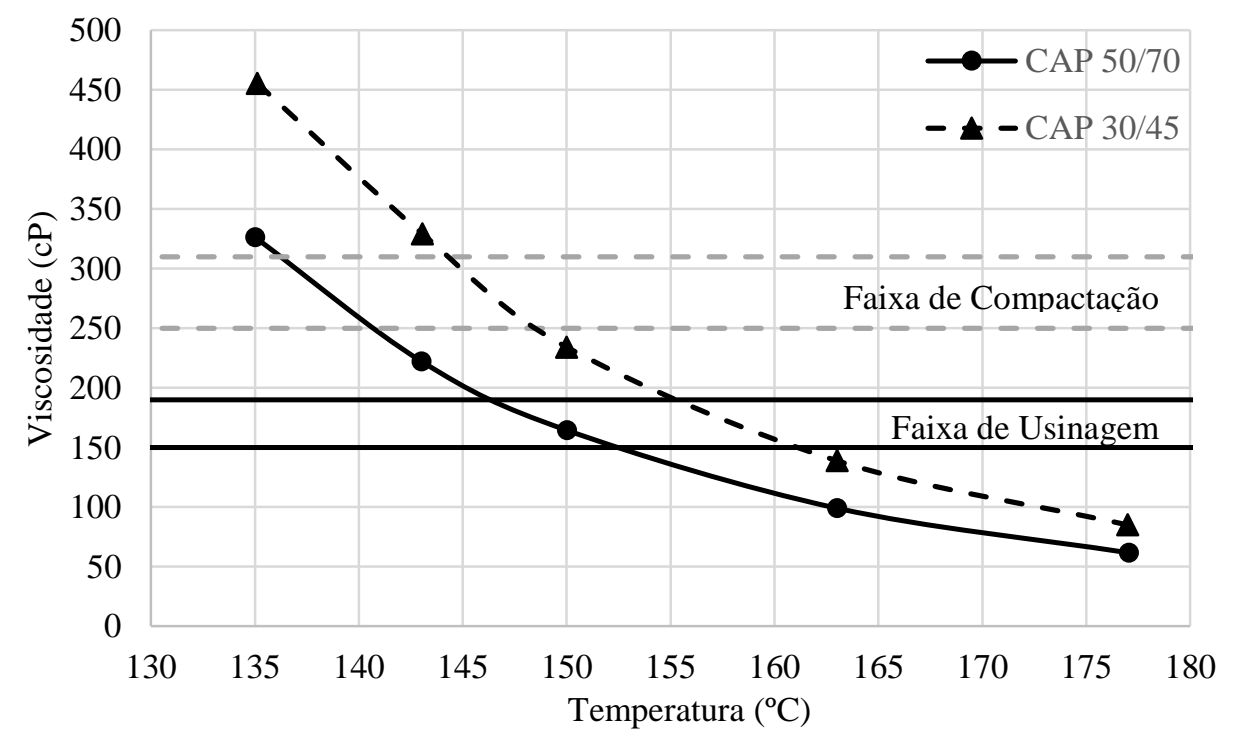

Figura 3.1 - Curvas de viscosidade rotacional versus temperatura para CAP 50/70 e CAP 30/45

Tabela 3.2 - Faixas de Temperatura de Usinagem e Compactação (TUC) dos ligantes asfálticos

\begin{tabular}{ccc}
\hline $\begin{array}{c}\text { Tipo de ligante } \\
\text { asfáltico }\end{array}$ & $\begin{array}{c}\text { Faixa de } \\
\text { usinagem }\end{array}$ & $\begin{array}{c}\text { Faixa de } \\
\text { compactação }\end{array}$ \\
\hline CAP 30/45 & $155-161^{\circ} \mathrm{C}$ & $144-149^{\circ} \mathrm{C}$ \\
CAP 50/70 & $146-152^{\circ} \mathrm{C}$ & $136-141^{\circ} \mathrm{C}$ \\
\hline
\end{tabular}


Trabalhou-se no centro das faixas, assim o CAP $30 / 45$ foi aquecido à $158^{\circ} \mathrm{C}$ para a mistura com os agregados e a compactação foi realizada a uma temperatura de $147^{\circ} \mathrm{C}$. O CAP 50/70 foi aquecido à $149^{\circ} \mathrm{C}$ para a usinagem e as misturas asfálticas resultantes foram compactadas à $139^{\circ} \mathrm{C}$. Em todas as condições os agregados foram aquecidos à uma temperatura entre $10 \mathrm{e}$ $15^{\circ} \mathrm{C}$ superior à temperatura de usinagem do ligante, a fim de evitar quedas de temperaturas.

\subsubsection{Agregado}

O agregado utilizado nas misturas asfálticas foi um granito, fornecido pela empresa Usina Paulista de Britagem Pedreira São Jerônimo LTDA, localizada em Valinhos/SP. Escolheu-se o granito, pois também é o agregado disponível na região próxima à mina de caulim no Pará.

Após lavagem e secagem em estufa, peneirou-se manualmente o agregado de modo a enquadrálo no centro da faixa III do DER/SP (ET-DE-P00/027), equivalente à faixa C do DNIT (DNIT 031/2006 - ES). A distribuição granulométrica da faixa adotada está apresentada na Figura 3.2. Na Tabela 3.3 são indicadas as quantidades passadas e retidas de agregado em cada peneira para compor um corpo de prova (CP) de $1.200 \mathrm{~g}$ de agregado no centro da faixa de trabalho. $42 \%$ do agregado é enquadrado como graúdo, $52 \%$ agregado como miúdo e $6 \%$ como fíler.

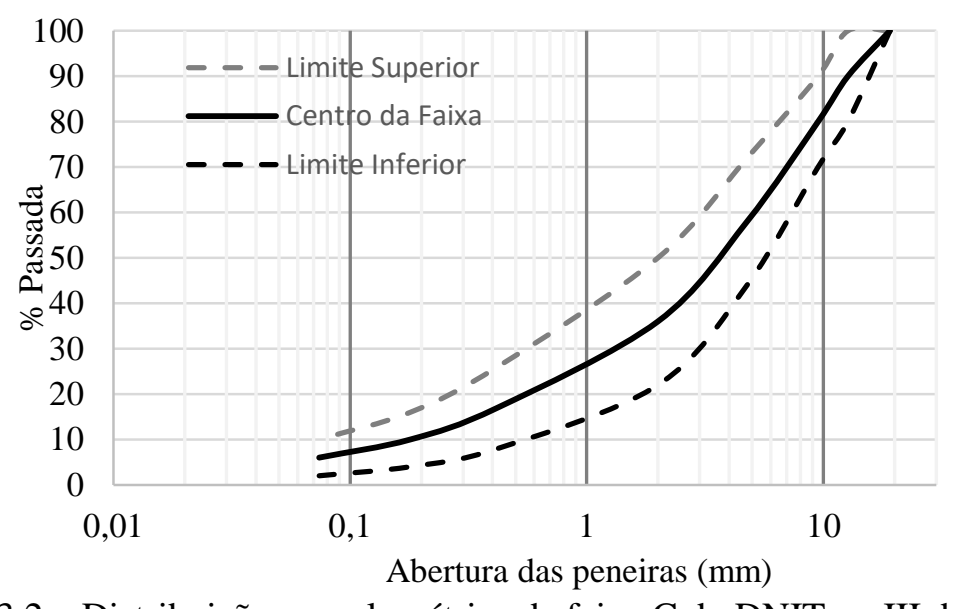

Figura 3.2 - Distribuição granulométrica da faixa C do DNIT ou III do DER/SP 
Tabela 3.3 - Porcentagem de massa passando para o centro da faixa III e massa retida por peneira para compor um CP com $1.200 \mathrm{~g}$ de agregado

\begin{tabular}{cccccc}
\hline $\begin{array}{c}\text { Abertura } \\
\text { da } \\
\text { peneira } \\
(\mathbf{m m})\end{array}$ & $\begin{array}{c}\text { Porcentagem em massa passando (\%) } \\
\text { Limite }\end{array}$ & $\begin{array}{c}\text { Limite } \\
\text { inferior }\end{array}$ & $\begin{array}{c}\text { Superior } \\
\text { Centro da } \\
\text { Faixa C }\end{array}$ & $\begin{array}{c}\text { Massa } \\
\text { total } \\
\text { passando } \\
\text { por CP }(\mathbf{g})\end{array}$ & $\begin{array}{c}\text { Massa } \\
\text { retida em } \\
\text { cada } \\
\text { peneira por } \\
\text { CP }(\mathbf{g})\end{array}$ \\
\hline 19,1 & 100 & 100 & 100 & 1200 & 0 \\
12,7 & 80 & 100 & 90 & 1080 & 120 \\
9,5 & 70 & 90 & 80 & 960 & 120 \\
4,76 & 44 & 72 & 58 & 696 & 264 \\
2,00 & 22 & 50 & 36 & 432 & 264 \\
0,42 & 8 & 26 & 17 & 204 & 228 \\
0,018 & 4 & 16 & 10 & 120 & 84 \\
0,074 & 2 & 10 & 6 & 72 & 48 \\
Fundo & - & - & - & - & 72 \\
\hline
\end{tabular}

Para a caracterização do agregado foram realizados os ensaios de abrasão Los Angeles, absorção e densidade real e aparente dos agregados graúdos e miúdos. Os resultados destes ensaios estão apresentados na Tabela 3.4. O valor de Abrasão Los Angeles foi inferior ao limite máximo de 50\% previsto nas normas do DNIT e DER/SP e os valores de densidades e absorção foram semelhantes aos encontrados em pesquisas com o mesmo agregado (IWANAGA, 2007; NG, 2013 e BARDINI, 2013).

Tabela 3.4 - Resultados da caracterização do agregado

\begin{tabular}{ccc}
\hline Propriedade & Valores & Norma \\
\hline Abrasão Los Angeles & $20 \%$ & DNER-ME 035/98 \\
Densidade Aparente - Ag. Graúdo & 2,617 & ASTM C127-15 \\
Densidade Real - Ag. Graúdo & 2,641 & ASTM C127-15 \\
Absorção - Ag. Graúdo & $0,35 \%$ & ASTM C127-15 \\
Densidade Aparente - Ag. Miúdo & 2,587 & ASTM C128-15 \\
Densidade Real - Ag. Miúdo & 2,616 & ASTM C128-15 \\
Absorção - Ag. Miúdo & $0,33 \%$ & ASTM C128-15 \\
\hline
\end{tabular}

\subsubsection{Caulim}

Foi utilizado o caulim do tipo super fine clay (SFC), cedido pela empresa Imerys e proveniente da mina PPSA de Ipixuna do Pará/PA. O material é um rejeito do processo de lavra da mina. O caulim foi destorroado, seco em estufa e peneirado. Utilizou-se somente o material passado na peneira $\mathrm{n}^{\mathrm{o}}$ 200. O caulim foi adicionado em três teores $(1,5 \%, 3,0 \%$ e 6,0\%) sempre em substituição ao fíler de granito, ou seja, mantendo-se a curva granulométrica de agregado + caulim no centro da faixa III do DER/SP. Trabalhou-se com três teores para que fosse possível 
aferir a influência do teor de caulim nas diversas características e propriedades das misturas asfálticas e, também, encontrar um teor "ótimo" de adição de caulim na dosagem.

Na Figura 3.3a ilustra-se o caulim SFC bruto, ou seja, da forma como foi recebido, antes do processo de destorroamento, e na Figura 3.3b mostra-se o de caulim SFC após peneiramento.

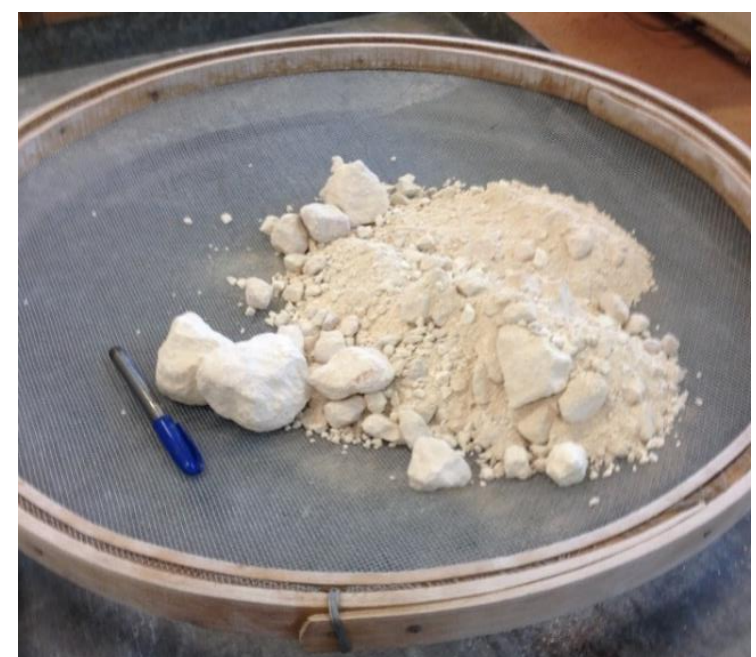

(a)

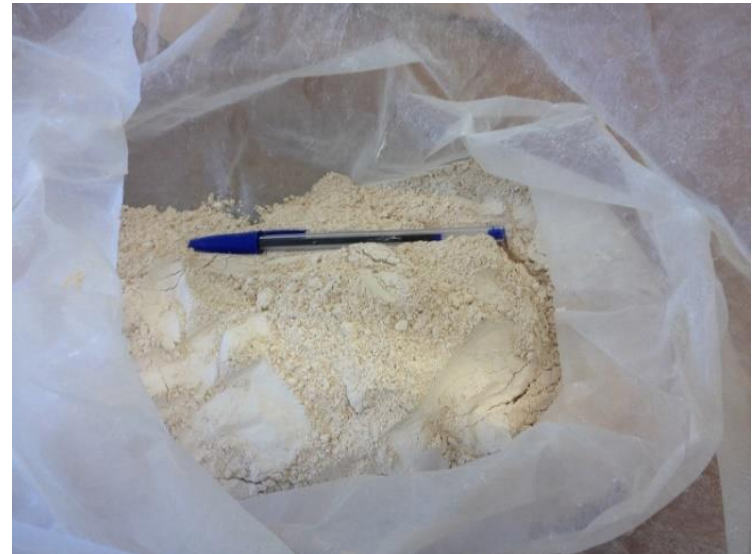

(b)

Figura 3.3 - Caulim SFC bruto (a) e caulim SFC passado na peneira \#200 (b)

Na Figura 3.4 apresenta-se a curva granulométrica do caulim e na Tabela 3.5 é mostrado um resumo dos ensaios de caracterização do material. Ele apresenta graduação fina, com mais de $80 \%$ passando na peneira $\mathrm{n}^{\circ} 200$, possui densidade real levemente superior a do agregado de granito, pH básico e é classificado como solo A-7-5 pelo sistema de classificação do Transportation Research Board (TRB).

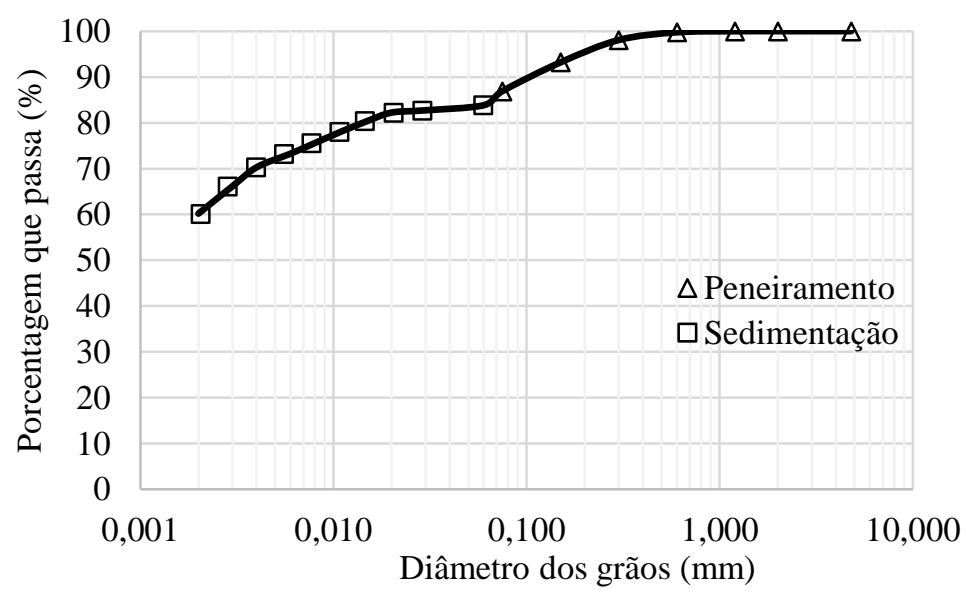

Figura 3.4 - Distribuição granulométrica do caulim 
Tabela 3.5 - Resultados da caracterização do caulim

\begin{tabular}{ccc}
\hline Ensaio & Valores & Norma \\
\hline Análise granulométrica & Ver Figura 3.4 & ABNT NBR 7181/1994 \\
Limite de Liquidez & $54 \%$ & ABNT NBR 6459/2016 \\
Limite de Plasticidade & $36 \%$ & ABNT NBR 7180/2016 \\
Índice de Plasticidade & $18 \%$ & ABNT NBR 7180/2016 \\
Densidade Real & 2,664 & DER/SP M 3-61 \\
pH & 10,44 & ASTM D 4972-13 \\
\hline
\end{tabular}

\subsubsection{Cal}

Utilizou-se cal hidratada dolomítica, do tipo CH I, cedida pela empresa Bandeirantes da cidade de São Carlos/SP. A cal foi adicionada em teor único de 1,5\% em substituição ao fíler de granito, ou seja, mantendo-se a curva granulométrica de agregado + cal no centro da faixa III. O teor de $1,5 \%$ de cal tem sido empregado em pesquisas conduzidas no Departamento de Transportes da EESC/USP com resultados satisfatórios, dentre as quais citam-se De Grande (2011), NG (2013) e Anitelli (2013). Além disso, 1,5\% é o teor usual de adição de cal nas usinas de asfalto da região de São Carlos/SP.

Optou-se por utilizar cal como fíler para possibilitar comparações entre propriedades mecânicas e volumétricas, bem como entre as susceptibilidades térmicas e ao dano por umidade das misturas asfálticas com três diferentes tipos de fíler: (i) granito, que compõe as misturas de referência; (ii) caulim, material alternativo cujas propriedades precisam ser melhor estudadas, e; (iii) cal, fíler reconhecido por incrementar as propriedades mecânicas e reduzir as susceptibilidades das misturas asfálticas.

\subsubsection{Caracterização complementar dos fíleres}

Considerando que grande parte das análises da pesquisa envolve a influência do tipo de fíler em determinada propriedade, foi efetuada a caracterização complementar dos três tipos de fíler, mediante ensaio de sedimentação (ABNT NBR 7181/1994), imagens de MEV e ensaio de EDS.

Na Figura 3.5 estão representados os resultados dos ensaios de sedimentação dos fíleres. Percebe-se que o caulim possui a graduação mais fina e que o granito tem a graduação mais grossa. A cal apresenta comportamento intermediário no início do ensaio, entretanto a curva granulométrica cai abruptamente para o diâmetro dos grãos da ordem de 0,01 mm. Este 
comportamento pode ser explicado por eventuais reações de hidratação da cal quando em contato com a solução defloculante de hexametafosfato de sódio, originando a formação de partículas maiores e mais pesadas que sedimentam quase que totalmente após meia hora de ensaio.

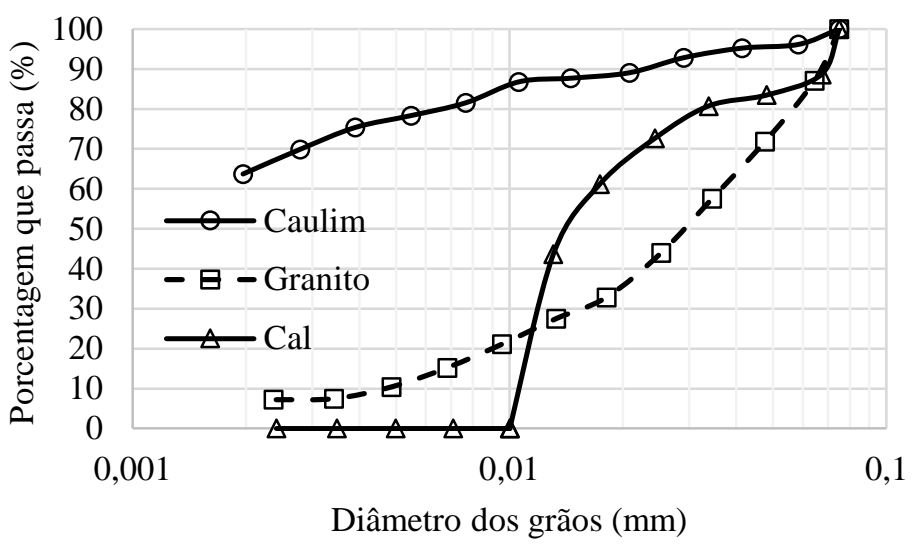

Figura 3.5 - Distribuições granulométricas dos fíleres obtidas com ensaio de sedimentação

Na Figura 3.6 são apresentadas imagens do ensaio de sedimentação do granito, caulim e cal, após 1 hora de ensaio. É possível perceber a total sedimentação da cal.

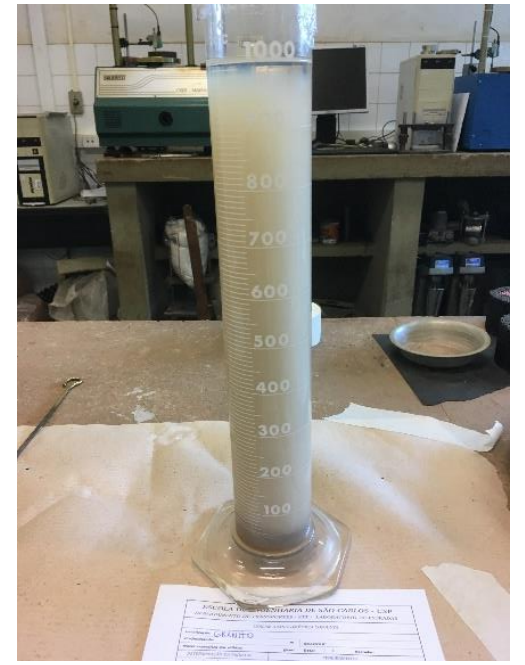

Granito

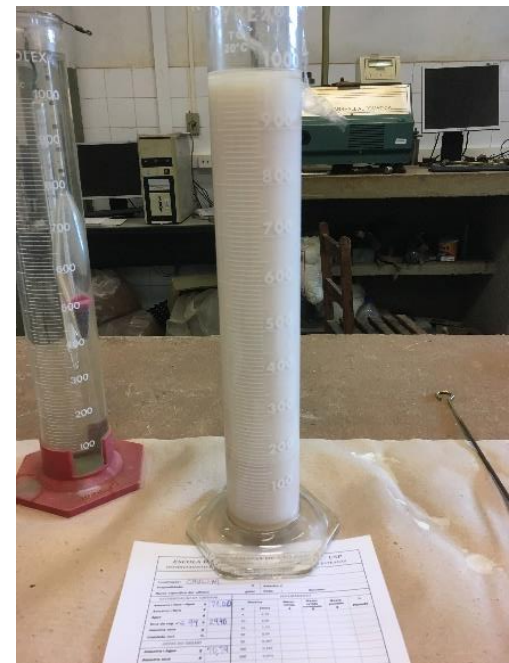

Caulim

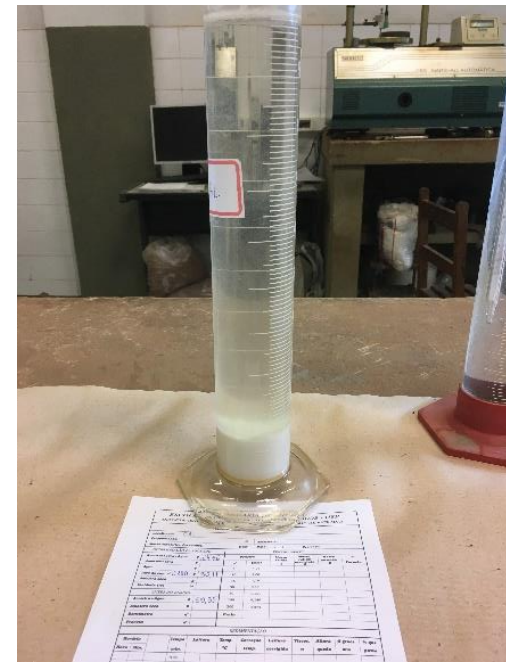

Cal

Figura 3.6 - Ensaios de sedimentação

A partir dos ensaios de sedimentação, foi possível obter os seguintes parâmetros para caracterizar os fíleres, conforme procedimento descrito em Kandhal, Lynn e Parker (1998): 
D10, D30 e D60: Estes parâmetros são os diâmetros dos grãos (mm) que correspondem respectivamente, a 10, 30 e $60 \%$ de material passante. Quanto menores forem os valores de D10, D30 e D60, mais fino é o fíler;

Módulo de Finura (MF): O MF é calculado ao se dividir por 100 a soma da porcentagem retida de cada material, referentes aos diâmetros dos grãos de 0,075, 0,050, 0,030, 0,020, 0,010, 0,005, 0,003 e 0,001 mm. Quanto menor o valor de MF, mais fino é o fíler.

Estes parâmetros de caracterização dos fíleres, indicados na Tabela 3.6, e também o teor de caulim $(1,5 \%, 3,0 \%$ ou $6,0 \%)$ foram correlacionados às propriedades volumétricas e mecânicas e às susceptibilidades das misturas asfálticas, com o intuito de ajudar a explicar a influência do tipo de fíler e teor de caulim em uma determinada variável-resposta.

Tabela 3.6 - Parâmetros de caracterização dos fíleres

\begin{tabular}{cccc}
\hline Parâmetro & Granito & Caulim & Cal \\
\hline D10 $(\mathrm{mm})$ & 0,00441 & 0,00008 & 0,01050 \\
D30 $(\mathrm{mm})$ & 0,01515 & 0,00027 & 0,01258 \\
D60 $(\mathrm{mm})$ & 0,03640 & 0,00157 & 0,01799 \\
MF & 4,92 & 1,24 & 4,71 \\
\hline
\end{tabular}

Na Figura 3.7 são apresentadas as imagens de MEV e os percentuais dos principais elementos químicos dos fíleres, conforme ensaio EDS, realizado no equipamento FEI Inspect F-50 do Departamento de Engenharia de Materiais da EESC/USP.

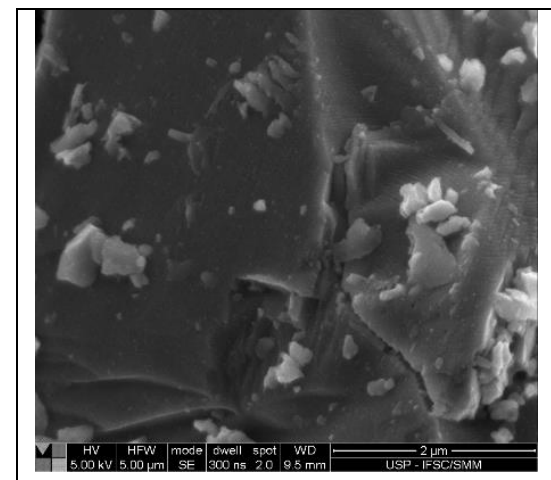

Granito

$\mathrm{O}-48,5 \%$

$\mathrm{Si}-33,3 \%$

$\mathrm{Al}-9,2 \%$

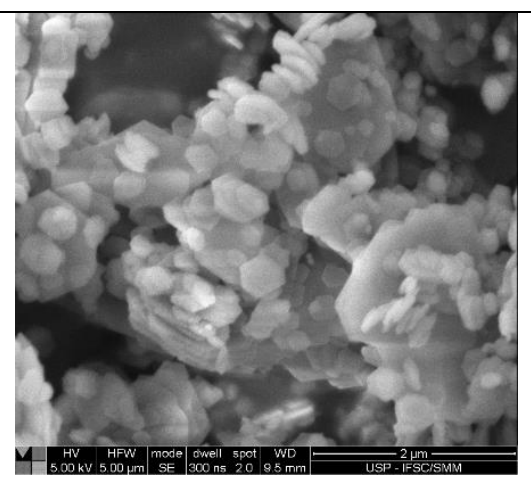

Caulim

$\mathrm{O}-50,2 \%$

$\mathrm{Si}-24,4 \%$

$\mathrm{Al}-24,4 \%$

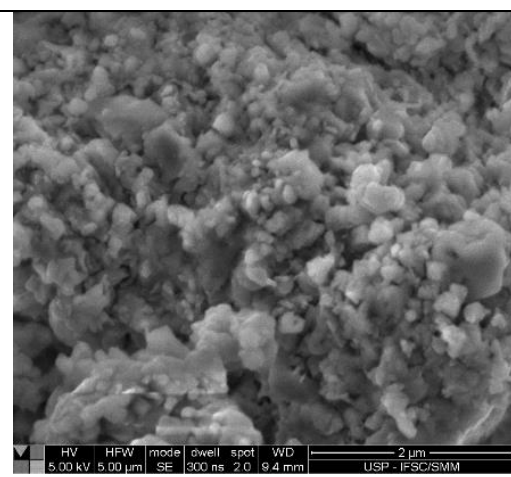

Cal

$\mathrm{Ca}-45,4 \%$

$\mathrm{O}-32,9 \%$

$\mathrm{Mg}-20,8 \%$

Figura 3.7 - Imagens de MEV e principais elementos químicos dos fíleres

A cal apresenta composição química bastante diferente dos outros fíleres, com predomínio de cálcio, o qual produz compostos cimentantes $(\mathrm{CaO})$, e apresenta estrutura mais compacta. 
Caulim e granito possuem os mesmos elementos químicos principais $(\mathrm{O}, \mathrm{Si}, \mathrm{Al})$, porém divergem na forma das partículas (hexagonais e placóides para o caulim, aproximadamente cúbicas para o granito), tamanho das partículas (as partículas de caulim são menores e mais uniformes) e no arranjo entre as mesmas.

\subsection{MÉTODOS}

De modo a atingir os objetivos do trabalho, delineou-se o método da tese, o qual está resumidamente mostrado na Tabela 3.7 e apresentado em detalhes nas seções seguintes. $\mathrm{O}$ programa experimental está dividido em três etapas - Dosagem Marshall, Caracterização mecânica básica e Caracterização mecânica complementar. Além destas etapas, este capítulo também apresenta a descrição: (i) do tratamento dos dados e das análises estatísticas utilizadas e; (ii) de análises complementares para melhor explorar os dados disponíveis.

Tabela 3.7 - Resumo do método empregado na tese

\begin{tabular}{|c|c|c|c|c|c|}
\hline Etapa & Objetivos & $\begin{array}{l}\text { Variáveis- } \\
\text { resposta }\end{array}$ & $\begin{array}{c}\text { Variáveis de } \\
\text { entrada }\end{array}$ & \multicolumn{2}{|c|}{ Misturas utilizadas } \\
\hline $\begin{array}{l}\text { Etapa 1: } \\
\text { Dosagem } \\
\text { Marshall }\end{array}$ & $\begin{array}{c}\text { 1- Definir do teor de } \\
\text { projeto; } \\
2 \text { - Avaliar viabilidade } \\
\text { técnica do rejeito de } \\
\text { caulim; } \\
3 \text { - Avaliar influência } \\
\text { das variáveis de entrada } \\
\text { nas variáveis-resposta }\end{array}$ & $\begin{array}{c}\mathrm{G}_{\mathrm{mb}} \\
\mathrm{Vv} \\
\mathrm{RBV} \\
\mathrm{VAM} \\
\text { Estabilidade } \\
\text { Fluência } \\
\mathrm{G}_{\mathrm{mm}} \\
\text { Teor de Projeto }\end{array}$ & $\begin{array}{l}\text { Tipo de Ligante } \\
\text { Asfáltico } \\
\text { Tipo de fíler } \\
\text { Parâmetros de } \\
\text { caracterização } \\
\text { do fíler }\end{array}$ & $\begin{array}{c}5070 \\
5070 \mathrm{C} 1,5 \\
5070 \mathrm{C} 3,0 \\
5070 \mathrm{C} 6,0 \\
5070 \mathrm{~L}\end{array}$ & $\begin{array}{c}3045 \\
3045 \mathrm{C} 1,5 \\
3045 \mathrm{C} 3,0 \\
3045 \mathrm{C} 6,0 \\
3045 \mathrm{~L}\end{array}$ \\
\hline $\begin{array}{c}\text { Etapa 2: } \\
\text { Caracterização } \\
\text { Mecânica } \\
\text { Básica }\end{array}$ & $\begin{array}{l}1 \text { - Avaliar viabilidade } \\
\text { técnica do rejeito de } \\
\text { caulim; }\end{array}$ & $\operatorname{MR}\left(25^{\circ} \mathrm{C}\right)$ & $\begin{array}{c}\text { Tipo de Ligante } \\
\text { Asfáltico } \\
\text { Tipo de fíler }\end{array}$ & $\begin{array}{c}5070 \\
5070 \mathrm{C} 1,5 \\
5070 \mathrm{C} 3,0 \\
5070 \mathrm{C} 6,0 \\
5070 \mathrm{~L} \\
5070 \mathrm{C} 3,0 \mathrm{~L}\end{array}$ & $\begin{array}{c}3045 \\
3045 \mathrm{C} 1,5 \\
3045 \mathrm{C} 3,0 \\
3045 \mathrm{C} 6,0 \\
3045 \mathrm{~L} \\
3045 \mathrm{C} 3,0 \mathrm{~L}\end{array}$ \\
\hline $\begin{array}{c}\text { Etapa 3: } \\
\text { Caracterização } \\
\text { Mecânica } \\
\text { Complementar }\end{array}$ & $\begin{array}{l}2 \text { - Avaliar influência } \\
\text { das variáveis de entrada } \\
\text { nas variáveis-resposta }\end{array}$ & $\begin{array}{l}\text { Susceptibilidade } \\
\text { térmica; } \\
\text { Vida de Fadiga; } \\
\text { Parâmetros do } \\
\text { ensaio creep; } \\
\text { RT }_{\text {creep }}\end{array}$ & $\begin{array}{l}\text { Parâmetros de } \\
\text { caracterização } \\
\text { do fíler }\end{array}$ & $\begin{array}{c}5070 \\
5070 \mathrm{C} 3,0 \\
5070 \mathrm{~L} \\
5070 \mathrm{C} 3,0 \mathrm{~L}\end{array}$ & $\begin{array}{c}3045 \\
3045 \mathrm{C} 3,0 \\
3045 \mathrm{~L} \\
3045 \mathrm{C} 3,0 \mathrm{~L}\end{array}$ \\
\hline
\end{tabular}

As misturas listadas na Tabela 3.7 resultaram da combinação dos seguintes fatores: (i) Tipo de agregado (1 nível): Granito - centro da faixa III do DER/SP; (ii) Tipo de ligante asfáltico (2 níveis): CAP 50/70 (5070) e CAP 30/45 (3045), e; (iii) Fíler (6 níveis): Granito (sem sufixo 
após o número indicativo do ligante), 1,5\% de caulim (sufixo C1,5), 3,0\% de caulim (sufixo C3,0), 6,0\% de caulim (sufixo C6,0), 1,5\% de cal (sufixo L) e 3,0\% de caulim e 1,5\% de cal, simultaneamente (sufixo C3,0L). As misturas asfálticas contendo somente granito (3045 e 5070) são denominadas de misturas de referência.

As 12 misturas permitem avaliar a influência dos fatores "tipo de ligante asfáltico", "tipo de fíler" e "parâmetros de caracterização do fíler (teor de caulim, D10, D30, D60 e MF)", que podem ser entendidas como variáveis de entrada, nos parâmetros da Dosagem Marshall, nas propriedades mecânicas e nas susceptibilidades do concreto asfáltico, as quais podem ser entendidas como variáveis-resposta.

\subsubsection{Dosagem Marshall - Etapa 1}

Como o objetivo principal da tese é avaliar a viabilidade técnica do uso de rejeito de caulim como fíler em concreto asfáltico, foram efetuadas dosagens Marshall apenas nas 10 condições experimentais indicadas na Tabela 3.7. Não foram efetuadas dosagens nas condições em que se usou, simultaneamente, caulim e cal, pois a viabilidade do uso de rejeito de caulim como fíler não poderia, a princípio, ficar vinculada ao uso simultâneo de cal.

Para as misturas de referência, 5070 e 3045, foram produzidos 20 corpos de prova, sendo 4 CPs para cada teor de ligante $(4,5 \%, 5,0 \%, 5,5 \%, 6,0 \%$ e $6,5 \%)$, dos quais três CPs foram moldados, compactados e desmoldados para posteriormente serem medidos, pesados e submetidos aos ensaios de estabilidade e fluência, conforme DNER-ME 043/95. A massa asfáltica sobressalente (equivalente ao quarto CP) foi submetida ao ensaio de determinação da densidade máxima teórica em amostras não compactadas $\left(\mathrm{G}_{\mathrm{mm}}\right)$, Ensaio Rice - NBR 15.619/2012. Nas demais misturas, foram produzidos somente $12 \mathrm{CPs}$, pois foram excluídos os testes com os teores de ligante de $4,5 \%$ e $6,5 \%$, de modo a otimizar as dosagens e economizar materiais. Esta etapa consumiu 136 corpos de prova.

Os ligantes asfálticos e agregados foram misturados em uma panela na quantidade necessária para produzir um CP de cada vez. Em seguida, as misturas foram mantidas em estufa na temperatura de compactação por 2 horas antes da moldagem e receberam 75 golpes do soquete Marshall em cada face, o que corresponde a energia para tráfego pesado. 
O cálculo dos parâmetros volumétricos das misturas asfálticas seguiu as recomendações da NBR 16.273/2014. Escolheu-se como teor de projeto a quantidade de ligante asfáltico que levou a mistura asfáltica a apresentar um volume de vazios de 4,0\%, conforme recomendação do DER/SP. Verificou-se então se os parâmetros volumétricos, estabilidade e fluência atendiam aos valores recomendados pela especificação do DER/SP, de modo a atestar a viabilidade técnica preliminar do uso de rejeito de caulim como fíler em misturas asfálticas. A viabilidade técnica somente foi completada ao término da Etapa 2, com os ensaios de resistência à tração por compressão diametral e dano por umidade induzida.

Inicialmente, pretendia-se utilizar a norma do DNIT (DNIT 031/2006 - ES), em virtude de sua abrangência nacional. Entretanto, há uma incompatibilidade entre o método de cálculo das propriedades volumétricas adotado (NBR 16.273/2014) e os parâmetros que o DNIT estabelece para RBV e vazios do agregado mineral (VAM). Além disso o DER/SP é mais rigoroso quanto à estabilidade, fluência e RT. Assim, atendendo à especificação do DER/SP, também se estará contemplando a especificação do DNIT para estes quesitos.

A variação dos parâmetros densidade aparente da mistura asfáltica compactada $\left(\mathrm{G}_{\mathrm{mb}}\right), \mathrm{Vv}$, $\mathrm{RBV}$, VAM, estabilidade, fluência, $\mathrm{G}_{\mathrm{mm}}$ e teor de projeto entre as diferentes misturas asfálticas foi analisada à luz do tipo de ligante asfáltico e do tipo de fíler, de modo a compreender o papel destes fatores nos resultados das Dosagens Marshall. Adicionalmente, foi efetuada uma análise estatística para verificar, mediante regressão linear, se há boas correlações entre os parâmetros de caracterização do fíler e os parâmetros da Dosagem Marshall.

\subsubsection{Caracterização Mecânica Básica - Etapa 2}

A caracterização mecânica básica envolveu a realização dos ensaios de módulo de resiliência à $25^{\circ} \mathrm{C}$, resistência à tração por compressão diametral e dano por umidade induzida, o qual é utilizado para caracterizar a susceptibilidade ao dano por umidade.

Nesta etapa houve a necessidade de acrescentar mais dois tipos de mistura (3045C3,0L e 5070C3,0L) em relação à Etapa 1, em virtude de resultados insatisfatórios dos ensaios de dano por umidade induzida nas misturas que não continham cal. Priorizou-se dar uso a maior quantidade possível de caulim, assim a cal foi acrescentada nas misturas com 3,0\% de caulim em função dos seguintes motivos: (i) não seria possível adicionar 1,5\% de cal às misturas com 
6,0\% de caulim sem alterar a curva granulométrica; (ii) as misturas com 1,5\% de caulim utilizam pouco rejeito, e; (iii) qualquer outro teor de caulim ensejaria uma nova dosagem.

Foram produzidos 9 CPs, por condição experimental, no teor de projeto definido na Etapa 1, para a execução dos ensaios de caracterização mecânica básica, perfazendo um subtotal de 108 CPs. Adotaram-se os teores de projeto das condições experimentais 5070C3,0L e 3045C3,0L como sendo iguais aos das misturas 5070C3,0 e 3045C3,0, respectivamente. Adicionalmente, foram produzidos 4 CPs extras para cada uma das novas condições experimentais de modo a executar os ensaios RICE, estabilidade e fluência, além de calcular os parâmetros volumétricos, para avaliar se as novas misturas atendiam à especificação técnica do concreto asfáltico, conforme Etapa 1. A Etapa 2 consumiu, portanto, um total de 116 CPs.

Para a caracterização mecânica básica foi adotado o seguinte esquema de ensaios:

Módulo de resiliência - Todos os corpos de prova foram previamente submetidos ao ensaio de MR na temperatura de $25^{\circ} \mathrm{C}$. Como o ensaio é não-destrutivo e executado sob condições que não danificam o corpo de prova, os mesmos foram reaproveitados para os demais ensaios. Assim foi possível conhecer a rigidez de todos os $108 \mathrm{CPs}$;

Resistência à tração - $3 \mathrm{CPs}$, por condição experimental, foram submetidos ao ensaio de $\mathrm{RT}$, à $25^{\circ} \mathrm{C}$ e na condição de $\mathrm{Vv} \approx 4,0 \%$. Isto possibilitou a verificação do atendimento do valor mínimo normativo $(\mathrm{RT} \geq 0,80 \mathrm{MPa})$ e a definição de carga a ser aplicada no ensaio de fadiga por compressão diametral à tensão controlada (Etapa 3). Foram consumidos 36 CPs neste ensaio;

> Dano por umidade induzida - 6 CPs, por condição experimental, foram submetidos ao ensaio de dano por umidade induzida, para avaliação da susceptibilidade ao dano por umidade, na condição de $\mathrm{Vv} \approx 7 \%$. Isto permitiu a verificação do atendimento do valor mínimo normativo (RRT $\geq 70 \%)$ e, alternativamente, a análise da relação de módulo de resiliência (RMR) que é a relação entre o MR após o condicionamento térmico do protocolo do ensaio e o MR antes do condicionamento térmico. Foram consumidos 72 CPs nesta análise.

Para se chegar ao $\mathrm{Vv} \approx 4 \%$, que é o volume de vazios-alvo da dosagem Marshall, os CPs foram compactados com a energia padrão, ou seja, 75 golpes do soquete Marshall por face. Para produzir CPs com $\mathrm{Vv} \approx 7 \%$, foi necessário realizar uma série de testes de compactação, onde corpos de prova de algumas misturas foram compactados com diferentes números de golpes e 
então calculou-se o volume de vazios correspondente. Em seguida, foram traçadas curvas relacionando o número de golpes por face do $\mathrm{CP}$ ao volume de vazios. A partir destas curvas, concluiu-se que o número de golpes necessário para atingir $\mathrm{Vv} \approx 7 \%$ variou de 19 a 26 golpes do soquete Marshall por face, para cada tipo de mistura, conforme indicado na Tabela 3.8.

\begin{tabular}{|c|c|c|c|}
\hline Tipo de mistura & $\begin{array}{l}\mathrm{N}^{\circ} \text { de golpes } \\
\text { para } \mathrm{VV}_{\mathrm{V}} \approx 7 \%\end{array}$ & Tipo de mistura & $\begin{array}{l}\mathrm{N}^{\circ} \text { de golpes } \\
\text { para } \mathrm{VV}_{\mathrm{V}} \approx 7 \%\end{array}$ \\
\hline 5070 & 26 & 3045 & 25 \\
\hline $5070 \mathrm{C} 1,5$ & 26 & $3045 \mathrm{C} 1,5$ & 24 \\
\hline $5070 \mathrm{C} 3,0$ & 23 & $3045 \mathrm{C} 3,0$ & 19 \\
\hline $5070 \mathrm{C} 6,0$ & 19 & $3045 \mathrm{C} 6,0$ & 19 \\
\hline $5070 \mathrm{~L}$ & 19 & $3045 \mathrm{~L}$ & 19 \\
\hline $5070 \mathrm{C} 3,0 \mathrm{~L}$ & 26 & $3045 \mathrm{C} 3,0 \mathrm{~L}$ & 23 \\
\hline
\end{tabular}

As variações nos valores de MR, RT, RRT e RMR entre as diferentes misturas asfálticas foram analisadas à luz do tipo de ligante asfáltico e do tipo de fíler, de modo a compreender o papel destes fatores nos resultados da caracterização mecânica básica. Complementarmente, foi efetuada uma análise estatística para verificar, mediante regressões lineares, se há correlações significativas entre os parâmetros de caracterização do fíler e MR, RT, RRT e RMR.

A seguir, descrevem-se os procedimentos dos ensaios de $\mathrm{MR}\left(25^{\circ} \mathrm{C}\right)$, RT e DUI. Estes ensaios foram realizados no Laboratório de Estradas do Departamento de Engenharia de Transportes da EESC/USP.

\subsubsection{Ensaio de Módulo de Resiliência (MR)}

O MR foi obtido mediante ensaio de compressão diametral sob carga repetida (DNIT 135/2010), com aplicação de 100 ciclos de carregamento constante, com duração total de 1,0 s, dos quais, $0,1 \mathrm{~s}$ correspondem ao período de carregamento e $0,9 \mathrm{~s}$ ao período de repouso. Os CPs ficaram em câmara térmica a $25^{\circ} \mathrm{C}$ por, no mínimo, 4 horas para condicionamento térmico, antes da execução do ensaio.

Aplicaram-se cargas de baixa magnitude (entre 100 e $150 \mathrm{kgf}$ ), de modo a obter deslocamentos da ordem de 0,0025 $\pm 0,0005 \mathrm{~mm}$, medidos por meio de um linear variable differential transducer (LVDT). Este procedimento consta na norma, mas foi necessário para evitar danos ou degradação dos CPs, tendo em vista o posterior uso destes para os demais ensaios. 
Na Figura 3.8 são mostradas a tela do software, em plataforma Labview 7.1, utilizado para aquisição de dados do ensaio e o aparato de execução do ensaio, indicando a posição do CP e LVDT.

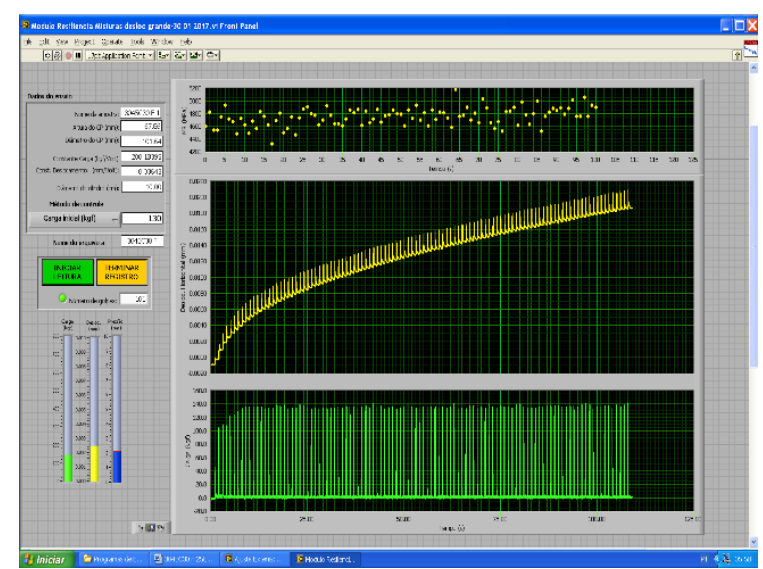

(a)

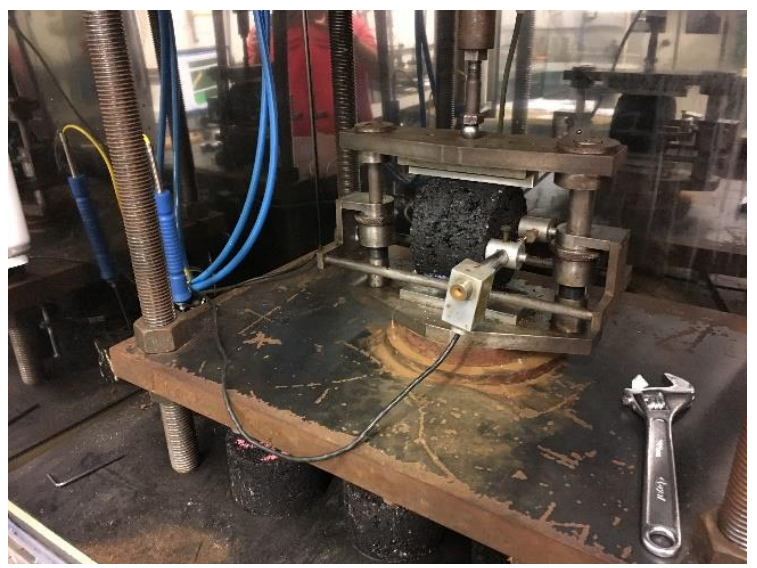

(b)

Figura 3.8 - Módulo de Resiliência: (a) tela do programa do ensaio (b) aparato do ensaio

O valor do módulo de resiliência (MPa) é expresso conforme a equação 3.1, em que F é carga aplicada diametralmente no CP (kgf); $\Delta$ é a deformação resiliente, para aplicação de $\mathrm{F}(\mathrm{cm}) ; \mathrm{H}$ é altura do CP (cm), e; $\mu$ é o coeficiente de Poisson, para o qual se adotou o valor 0,30 .

$$
M R=\frac{F}{(\Delta \times H)} \times(0,9976 \mu+0,2692) \times 0,0981
$$

Os MRs foram calculados para cada um dos 100 ciclos por meio de um programa em plataforma Labview 7.1. Para escolher o valor representativo do CP, adotou-se o seguinte critério: desprezaram-se os 30 primeiros ciclos de carregamento, por se entender que se tratava de um período de condicionamento. Dos 70 ciclos restantes, escolhia-se um intervalo, não inferior a 15 ciclos consecutivos, cuja média de MR apresentasse o menor valor de coeficiente de variação.

\subsubsection{Ensaio de Resistência à Tração por Compressão Diametral (RT)}

O ensaio foi realizado conforme a NBR 15.087/2012. Os corpos de prova foram submetidos a uma carga de compressão diametral estática progressiva até o momento de sua ruptura em temperatura de $25^{\circ} \mathrm{C}$. Os CPs ficaram em câmara térmica a $25^{\circ} \mathrm{C}$ por no mínimo 4 horas para 
estabilização de temperatura, antes da execução do ensaio. Na Figura 3.9 é mostrado o aparato utilizado no ensaio.

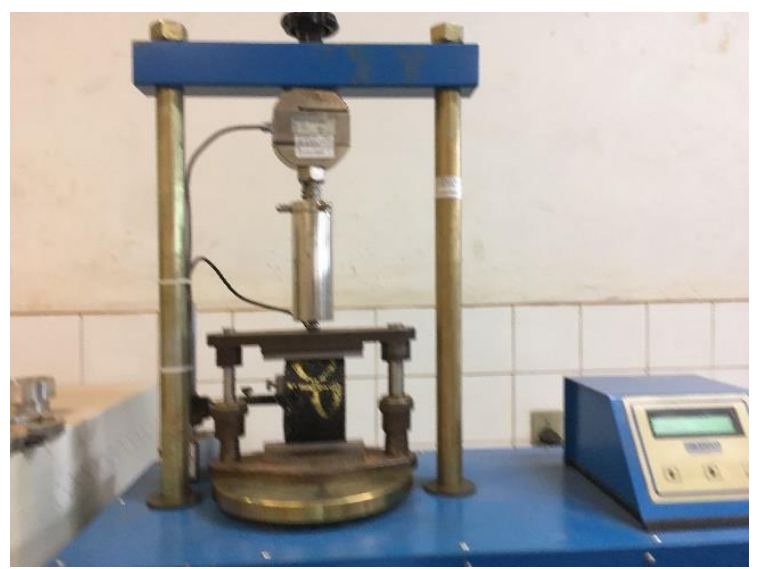

Figura 3.9 - Aparato do ensaio de resistência à tração por compressão diametral

A RT, em MPa, é calculada pela equação 3.2, em que "F" é a carga de ruptura $(\mathrm{N})$, "D" é o diâmetro do CP (mm) e "H" é a altura do CP (mm).

$$
R T=\frac{2 F}{\pi D H}
$$

3.2.2.3 Ensaio de Dano por umidade induzida (DUI)

Os ensaios de DUI foram feitos segundo a norma AASHTO T 283-99. A quantidade de mistura necessária para compor os seis CPs, por condição experimental, foi colocada em estufa ventilada a $60^{\circ} \mathrm{C}$ por 16 horas. Este procedimento tenta simular um envelhecimento de longo prazo na mistura asfáltica. Após este envelhecimento, a mistura asfáltica não compactada foi posta em estufa na temperatura de compactação por 2 horas para, em seguida, ser compactada até atingir o $\mathrm{Vv}=7 \pm 1 \%$.

Dividiu-se o conjunto de 6 CPs em 2 subconjuntos de 3 CPs, de modo que o volume de vazios médio dos subconjuntos fosse aproximadamente igual. Um subconjunto passou pelo condicionamento térmico, composto por saturação de 55 a $80 \%$ dos vazios, congelamento à $18^{\circ} \mathrm{C}$ por 16 horas e aquecimento à $60^{\circ} \mathrm{C}$, em banho-maria, por 24 horas (grupo condicionado), enquanto que o outro subconjunto não recebeu condicionamento térmico (grupo de controle). Ambos subconjuntos foram submetidos ao ensaio de RT, conforme NBR 15.087/2012. A relação de resistência à tração (RRT), é dada pela equação 3.3. O protocolo da norma também 
exige a inspeção visual dos corpos de prova após ruptura por tração para avaliar se no plano de ruptura ocorreu descolamento da película de ligante asfáltico e/ou quebra de agregados.

$$
R R T=\frac{R T_{\text {grupo condiconado }}}{R T_{\text {grupo de controle }}} \times 100
$$

Embora se tenha seguido todos os procedimentos da norma americana AASHTO T 283, houve o cuidado de compatibilizar o grau de saturação (GS) dos vazios com as recomendações de grau de saturação da norma brasileira NBR 15.617/2016. Para tanto os valores de GS foram mantidos mais próximos ao limite mínimo da norma americana, para que não extrapolassem o valor limite máximo da norma brasileira.

Todos os CPs do ensaio de DUI foram submetidos ao ensaio de MR antes do condicionamento térmico. Além disso, os CPs que fazem parte do grupo condicionado também foram submetidos ao ensaio de MR após o condicionamento térmico. Assim foi possível calcular um parâmetro adicional no ensaio de DUI, a relação de módulo de resiliência (RMR), dada pela Equação 3.4, em que: "MR," é a média dos módulos de resiliência de 6 CPs antes do condicionamento térmico, em MPa, e "MR2" é média dos módulos de resiliência de 3 CPs do grupo condicionado, após serem submetidos ao condicionamento térmico (MPa).

$$
R M R=\frac{M R_{2}}{M R_{1}} \times 100
$$

\subsubsection{Caracterização Mecânica Complementar - Etapa 3}

A caracterização mecânica complementar envolve os ensaios de módulo de resiliência a 10, 25 e $40^{\circ} \mathrm{C}$ para avaliação da susceptibilidade térmica, fadiga por compressão diametral à tensão controlada, fluência por compressão uniaxial estática (creep estático) para avaliação da susceptibilidade à deformação permanente e RT após ensaio de creep.

Nesta etapa, visando otimização e economia de materiais, os ensaios foram conduzidos em apenas 8 condições experimentais resultantes de 2 tipos de ligante asfáltico (CAP 50/70 e CAP 30/45) e 4 tipos de fíler (granito, 3,0\% de caulim, 1,5\% de cal e 3,0\% de caulim e 1,5\% de cal, simultaneamente). 
Foram produzidos $11 \mathrm{CPs}$, por condição experimental, no teor de projeto definido na Etapa 1. A Etapa 3 consumiu $88 \mathrm{CPs}$. Considerando toda a pesquisa, foram produzidos e ensaiados 340 corpos de prova.

Para a caracterização mecânica complementar foi adotado o seguinte esquema de ensaios:

$>$ Módulo de resiliência para avaliação da susceptibilidade térmica - Por se tratar de ensaio não destrutivo foram realizados ensaios de $\mathrm{MR}$ a 10, 25 e $40^{\circ} \mathrm{C}$ (ainda em regime elástico) em todos os corpos de prova destinados aos ensaios de creep estático e em metade dos CPs destinados aos ensaios de fadiga. Na outra metade dos CPs de fadiga o MR foi executado somente a $25^{\circ} \mathrm{C}$. Desta forma, foram avaliados todos os $88 \mathrm{CPs}$;

- Fadiga por compressão diametral à tensão controlada - Em cada condição experimental, $8 \mathrm{CPs}$, com $\mathrm{Vv} \approx 4,0 \%$, foram submetidos ao ensaio de fadiga. Escolheuse este volume de vazios pois o fenômeno de fadiga costuma ocorrer após alguns anos da vida de serviço do pavimento, quando já ocorreu compactação adicional em virtude do tráfego, assim imagina-se estar representando uma situação mais próxima do que acontece em campo. A avaliação dos modelos de fadiga envolveu a análise mecanística de pavimentos no software mePADS. Foram consumidos 64 CPs nesta avaliação;

> Fluência por compressão uniaxial estática - $3 \mathrm{CPs}$, por cada tipo de mistura, foram submetidos ao ensaio de creep estático, à $40^{\circ} \mathrm{C}$, com tensão de $0,4 \mathrm{MPa} \mathrm{e} \mathrm{Vv} \approx 7,0 \%$ para avaliações relativas à deformação permanente. $\mathrm{O}$ Vv mais elevado foi escolhido de modo a melhor representar a condição da massa asfáltica no início da vida de serviço, antes de sofrer a compactação adicional do tráfego, e, portanto, mais propensa a apresentar deformação permanente. 24 CPs foram utilizados nos ensaios de creep e depois reaproveitados nos ensaios de $\mathrm{RT}_{\text {creep }}$;

> RT após creep estático - Como o ensaio de creep estático é não destrutivo, optou-se por realizar ensaio de RT em todos os CPs após a execução do ensaio de avaliação da susceptibilidade à deformação permanente. Assim foi possível comparar os valores de RT após diferentes usos prévios do CP (virgem, após condicionamento térmico do ensaio DUI e após creep). Foram consumidos 24 CPs nesta análise.

Os parâmetros da caracterização mecânica complementar foram analisados à luz dos fatores “tipo de ligante asfáltico" e "tipo de fíler". Adicionalmente foi realizada análise estatística, por meio de regressão linear, para entender se há correlações significativas entre os parâmetros de caracterização do fíler e os resultados dos ensaios de caracterização mecânica complementar. 
Destaca-se que na Etapa 3 os parâmetros de caracterização do fíler resumem-se a D10, D30, D60 e MF. Como há somente 2 teores de caulim nesta Etapa (0 e 3\%) a regressão linear fica inviabilizada.

A seguir, descrevem-se os procedimentos de: (i) ensaio de módulo de resiliência $\left(10\right.$ e $\left.40^{\circ} \mathrm{C}\right)$; (ii) ensaio de fadiga por compressão diametral à tensão controlada, (iii) ensaio de fluência por compressão uniaxial estática, e; (iv) análise mecanística de pavimentos no software mePADS. Os procedimentos do ensaio de RT após creep são exatamente os mesmos descritos na seção 3.2.2.2. Todos os ensaios foram realizados no Laboratório de Estradas do Departamento de Engenharia de Transportes da EESC/USP.

3.2.3.1 Ensaio de Módulo de Resiliência (MR) em diferentes temperaturas para avaliação da susceptibilidade térmica

O método de execução do ensaio, forma de cálculo e de escolha do valor representativo do MR foram os mesmos dos ensaios a $25^{\circ} \mathrm{C}$, havendo diferenças na magnitude das cargas aplicadas para atingir o nível de deformação estabelecido $(0,0025 \pm 0,0005 \mathrm{~mm})$, no tempo de condicionamento térmico e nos valores de coeficiente de Poisson. Para $10^{\circ} \mathrm{C}$, as cargas foram da ordem de $250 \mathrm{kgf}$, enquanto que para $40^{\circ} \mathrm{C}$, aplicaram-se cargas de aproximadamente 50 kgf. Em ambos os casos, os CPs permaneceram 24 horas na câmara térmica na temperatura do ensaio para estabilização de temperatura. Para $10^{\circ} \mathrm{C}, \mu=0,21$ e para $40^{\circ} \mathrm{C}, \mu=0,47$, sendo que os valores de coeficiente de Poisson foram adotados com base em Mohammad et al. (2000).

Os corpos de prova foram ensaiados na seguinte ordem de temperatura: primeiro, a $25^{\circ} \mathrm{C}$, de modo a possibilitar comparações entre os MR de todos os CPs, sem prévia realização de qualquer outro ensaio; segundo, a $10^{\circ} \mathrm{C}$ e, por último, a $40^{\circ} \mathrm{C}$ para evitar acúmulos de danos e deformações permanentes nos corpos de prova.

A susceptibilidade térmica foi avaliada por meio do Parâmetro de Susceptibilidade Térmica (PST), que corresponde à taxa de variação de MR, em um determinado intervalo de temperatura $(\Delta \mathrm{t})$, conforme indicado na Equação 3.5, em que A representa a menor temperatura e B a maior temperatura. Assim: (i) PST $\geq 1,00$ e; (ii) valores de PST próximos a 1,00 indicam misturas menos susceptíveis a variação de rigidez devido à variação de temperatura, ou seja, misturas 
com menor susceptibilidade térmica. Por outro lado, quanto maior o valor de PST, maior será a susceptibilidade térmica.

$$
\operatorname{PST}_{A, B}=\frac{M R_{A}}{M R_{B}}
$$

\subsubsection{Ensaio de fadiga por compressão diametral à tensão controlada}

O protocolo do ensaio consistiu na aplicação de cargas cíclicas de compressão diametral com frequência de $1 \mathrm{~Hz}$ (60 ciclos por minuto), sendo que o período de carregamento é de $0,1 \mathrm{~s}$ e o período de repouso é de $0,9 \mathrm{~s}$, até a ruptura do $\mathrm{CP}$, a uma temperatura de $25^{\circ} \mathrm{C}$. As cargas aplicadas correspondem aos valores de tensão de 10, 20, 30 e 40\% da RT, obtidos na Etapa 2, para cada tipo de mistura. Na Figura 3.10 são apresentados o ciclo de carregamento (a) e o aparato utilizado no ensaio de fadiga por compressão diametral à tensão controlada (b).

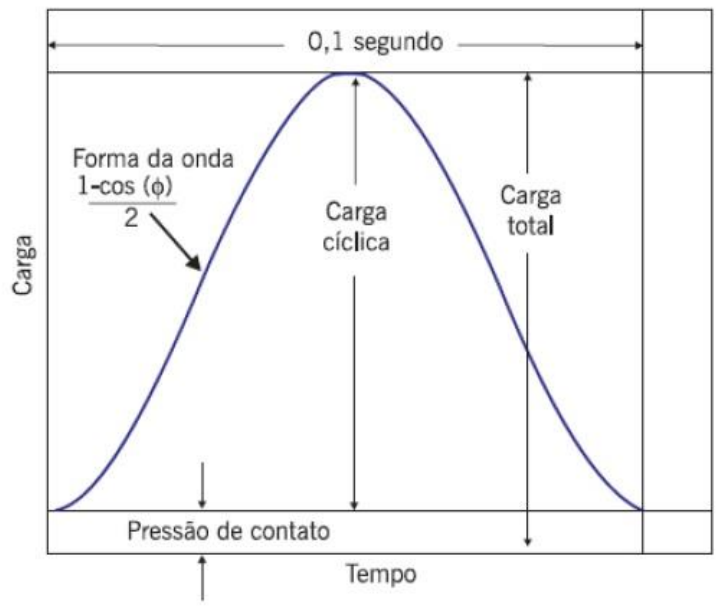

(a)

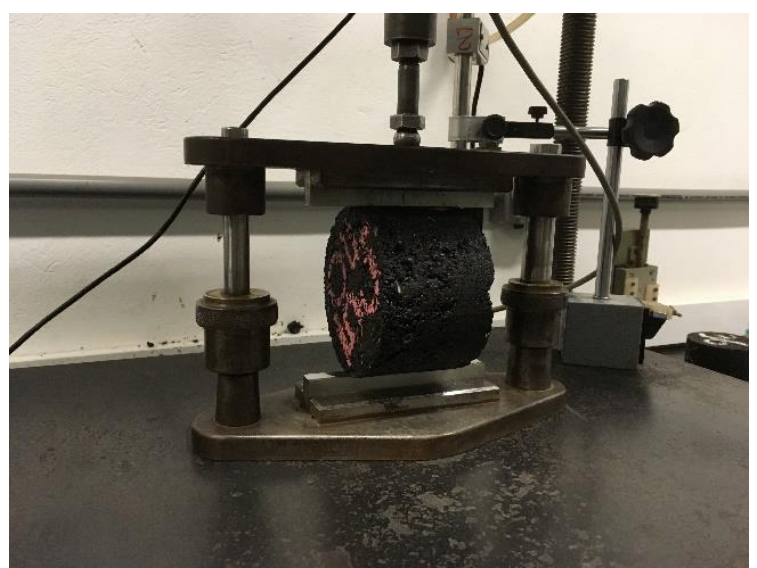

(b)

Figura 3.10 - Ciclo de carga e aparato do ensaio de fadiga por compressão diametral à tensão

Fonte: (a) Norma DNIT 183/2018 - ME. controlada

Correlaciona-se a diferença de tensões $(\Delta \sigma)$ a qual o $\mathrm{CP}$ está submetido, calculada pela equação 3.6, ao número de aplicações de carga até a ruptura do corpo de prova $(\mathrm{N})$, mediante a equação 3.7. Obtém-se os coeficientes $\mathrm{k}_{1}$ e $\mathrm{k}_{2}$ por regressão. Para cada tipo de mistura asfáltica da Etapa 3 foi gerado um modelo de fadiga.

$$
\Delta \sigma=\frac{8 \times F \times 9,81}{\pi \times D \times H}
$$




$$
N=k_{1} \times\left(\frac{1}{\Delta \sigma}\right)^{k_{2}}
$$

Em que:

$\Delta \sigma=$ Diferença de tensões no centro do $\mathrm{CP}(\mathrm{MPa}) / \mathrm{F}=$ carga de aplicada no ensaio (kgf), correspondente a 10, 20, 30 ou $40 \%$ da carga de ruptura do ensaio de RT / D = diâmetro do CP $(\mathrm{mm}) / \mathrm{H}=$ altura do $\mathrm{CP}(\mathrm{mm}) / \mathrm{N}=$ Vida de fadiga $/ \mathrm{k}_{1}$ e $\mathrm{k}_{2}=$ parâmetros determinados por regressão (modelo de potência).

Houve um intervalo de no mínimo sete dias entre a execução dos ensaios de MR em diferentes temperaturas para avaliação da susceptibilidade térmica e a realização do ensaio de vida de fadiga para um mesmo CP.

Em cada nível de tensão (10, 20, 30 e 40\% da RT) foram ensaiados 2 CPs, sendo que um foi previamente submetido aos ensaios de $\mathrm{MR}$ a $10^{\circ}, 25^{\circ}$ e $40^{\circ} \mathrm{C}$ para avaliação da susceptibilidade térmica (ST) e o outro recebeu ensaio de MR somente a $25^{\circ} \mathrm{C}$. Uma vez observada essa condição, a escolha dos CPs por nível de tensão foi aleatória. Antes de executar o ensaio, o CP foi colocado em câmara térmica a $25^{\circ} \mathrm{C}$ por no mínimo 4 horas.

Cabe destacar que quando os ensaios de fadiga desta tese foram realizados ainda não havia a norma DNIT 183/2018 - ME. O procedimento descrito foi utilizado por Iwanaga (2007) e Bardini (2013) no Laboratório de Estradas do Departamento de Engenharia de Transportes da EESC/USP.

\subsubsection{Ensaio de fluência por compressão uniaxial estática - creep estático}

Este ensaio consistiu na aplicação de uma carga contínua de compressão de 0,4 MPa, durante 3600 s, imediatamente sucedida por um período de recuperação (sem aplicação de carga) de $900 \mathrm{~s}$, totalizando $4500 \mathrm{~s}$, na temperatura de $40^{\circ} \mathrm{C}$. A escolha da tensão de $0,4 \mathrm{MPa}$ e temperatura de $40^{\circ} \mathrm{C}$ estão baseadas em Little, Button e Youssef (1993). As leituras dos carregamentos e deslocamentos axiais sofridos pelo CP foram obtidas por dois LVDTs e os resultados dos ensaios referem-se à média das leituras destes dispositivos. 
Antes da execução do ensaio foram necessários os seguintes procedimentos: (i) lixamento das faces do CP para remoção de irregularidades superficiais, visando garantir paralelismo das faces e melhor acomodação da placa que faz a aplicação da carga; (ii) condicionamento térmico de 24 horas na temperatura do ensaio, e (iii) pré-condicionamento de carregamento onde os CPs receberam a aplicação da tensão de 0,4 MPa por 300 segundos, seguidos de um período de recuperação de mesma duração.

O ensaio de creep estático fornece parâmetros para analisar a susceptibilidade da mistura asfáltica à deformação permanente. Dentre eles destacam-se: (i) Deformação total da mistura durante os $4500 \mathrm{~s}$ do ensaio $\left(\mathrm{D}_{\mathrm{t}}\right)$, expressa em $\mathrm{mm} / \mathrm{mm}$ e calculada pela na equação 3.8 ; (ii) Recuperação da deformação (Rec), expressa em porcentagem e calculada pela equação 3.9; (iii) Módulo de fluência (MPa) após o período de recuperação da mistura $\left(\mathrm{M}_{\mathrm{f}}\right)$, calculado pela equação 3.10, e; (iv) Inclinação do estágio secundário da curva de deformação versus tempo de carregamento ( $\mathrm{I}_{\text {curva }}$ ), adimensional e calculada pela equação 3.11 .

$$
\begin{gathered}
D_{t}=\frac{\Delta h_{4500}}{h_{0}} \\
\operatorname{Rec}=\left(\frac{\frac{\Delta h_{3600}}{h_{0}}-D_{t}}{\frac{\Delta h_{3600}}{h_{0}}}\right) \times 100 \\
M_{f}=\frac{\sigma}{D_{t}} \\
I_{\text {curva }}=\frac{\log \varepsilon_{3600}-\log \varepsilon_{1000}}{\log 3600-\log 1000}
\end{gathered}
$$

Em que:

$\Delta \mathrm{h}_{4500}=$ variação da altura do corpo de prova após $4500 \mathrm{~s}(\mathrm{~mm}) / \mathrm{h}_{0}=$ altura inicial do CP $(\mathrm{mm})$ $/ \Delta \mathrm{h}_{3600}=$ variação da altura do corpo de prova após $3600 \mathrm{~s}(\mathrm{~mm}) / \sigma=$ nível de tensão do ensaio $(\mathrm{MPa}) / \log \varepsilon_{3600}=$ deformação para $3600 \mathrm{~s}$ de ensaio $/ \log \varepsilon_{1000}=$ deformação para $1000 \mathrm{~s}$ de ensaio. 
A aquisição dos dados dos LVDTs e os cálculos dos parâmetros indicados acima foram efetuados por meio de um programa em plataforma Labview 7.1. Na Figura 3.11 são mostradas: (a) a tela do software em plataforma Labview 7.1 e (b) foto do CP em posição de ensaio.

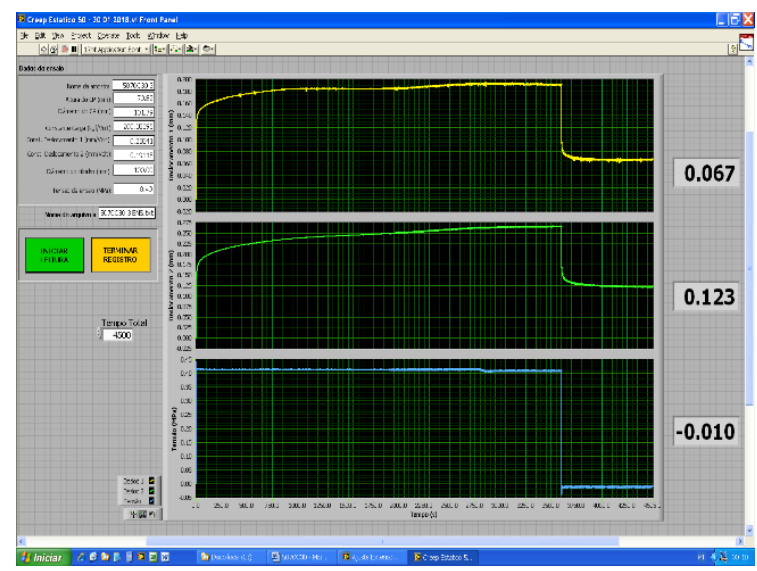

(a)

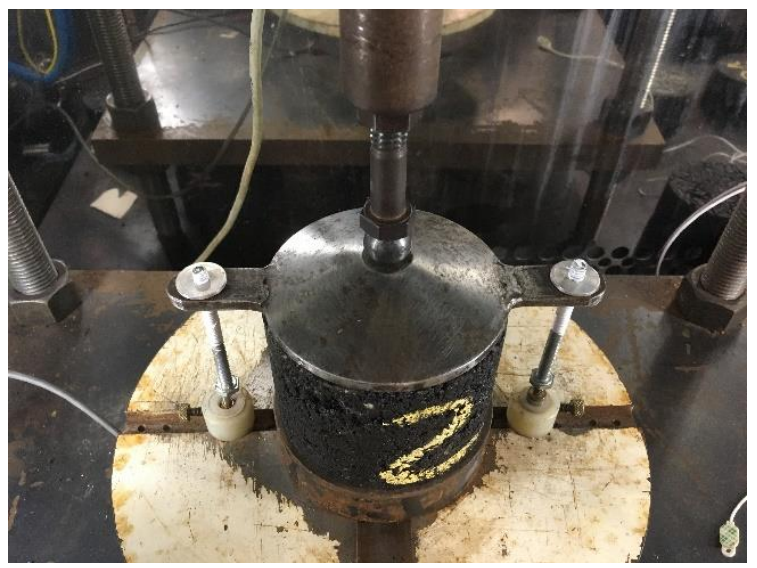

(b)

Figura 3.11 - Creep estático: (a) tela do programa do ensaio (b) aparato do ensaio

Houve um intervalo de no mínimo sete dias entre a execução dos ensaios de MR em diferentes temperaturas para avaliação da susceptibilidade térmica e a realização do ensaio de creep estático para um mesmo $\mathrm{CP}$.

Apesar de haver norma brasileira para ensaios de avaliação de susceptibilidade à deformação permanente de misturas asfálticas (NBR 16.505/2016), optou-se por usar o ensaio de creep estático pois a altura dos CPs requeridos pela NBR 16.505/2016 (150 $\pm 2,5 \mathrm{~mm})$ é incompatível com a altura dos CPs produzidos no aparato Marshall. Os procedimentos aqui descritos vêm sendo utilizado com frequência no Laboratório de Estradas do STT/EESC/USP, como se observa nos trabalhos de Taira (2001), Gouveia (2006) e NG (2013).

\subsubsection{Análise mecanística de pavimentos no software mePADS}

Avaliou-se a vida de fadiga por meio de simulação de quatro estruturas de pavimentos (A, B, $\mathrm{C}$ e D) no software sul-africano mePADS (Mechanistic-Empirical Pavement Design and Analysis Software) que calcula tensões, deformações e deflexões na estrutura de pavimentos, mediante análise elástico-linear de múltiplas camadas (análise mecanística). 
Os quatro pavimentos foram dimensionados pelo método do DNIT e resultaram da combinação de dois diferentes subleitos com CBR de 5 e $10 \%$, e dois níveis de tráfego $\left(\mathrm{N}=10^{6}\right.$ e $\left.\mathrm{N}=10^{7}\right)$. Arbitrou-se que os pavimentos seriam compostos apenas por capa asfáltica e base granular. As diferenças de tensões na fibra inferior da capa $(\Delta \sigma)$ foram analisadas em 3 pontos $(1,2$ e 3$)$, indicados na Figura 3.12, na qual também são detalhadas as estruturas dos 4 pavimentos, as condições de carregamento (eixo padrão com $20 \mathrm{kN}$ por roda e pressão de enchimento de pneus $\left.=560 \mathrm{kgf} / \mathrm{cm}^{2}\right)$ e os valores de MR e coeficiente de Poisson $(\mu)$ de cada camada, adotados em conformidade com a Instrução de Projeto IP-DE-P00/001 do DER/SP.

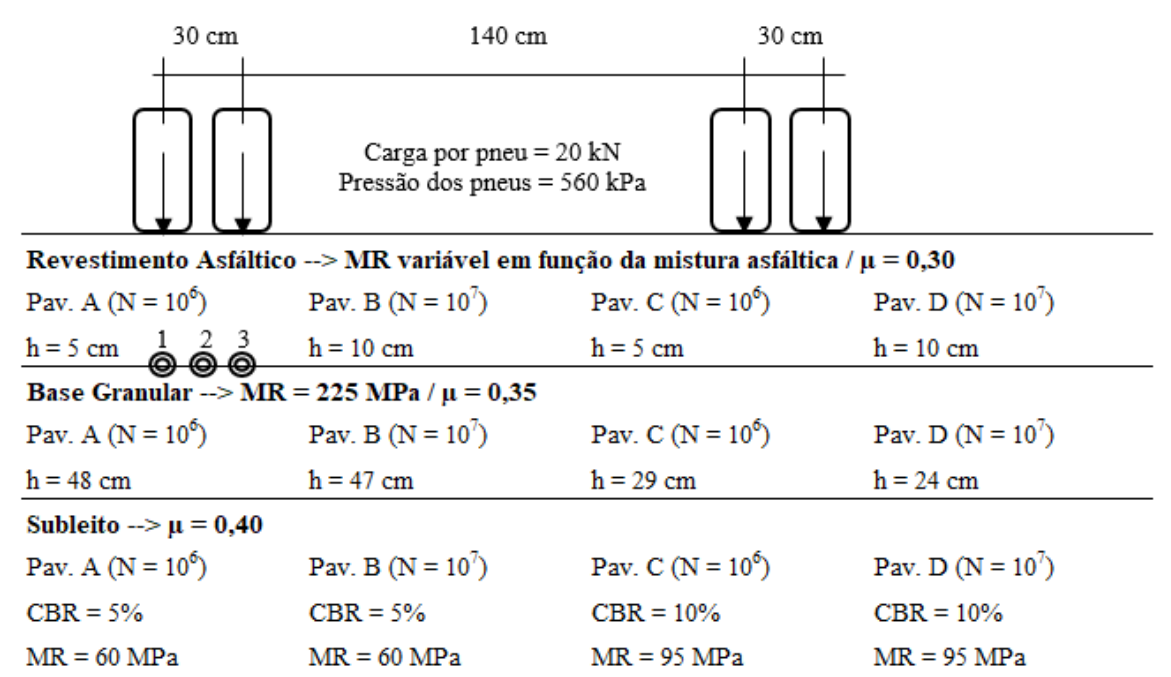

Figura 3.12 - Estruturas dos tipos de pavimentos considerados na análise mecanística

Após os cálculos do mePADS, as máximas diferenças de tensões na fibra inferior da capa foram incluídas nos modelos de fadiga para comparação entre os diferentes tipos de mistura.

Considerando a grande a variabilidade das propriedades mecânicas das camadas dos pavimentos em função de alterações de temperatura, níveis de tensão, grau de compactação, dentre outros, e a grande variabilidade de carregamentos aos quais um pavimento está submetido em razão da variação da carga e pressão de enchimento de pneus, foi realizada uma análise de sensibilidade da vida de fadiga. Para tanto, alterou-se isoladamente o valor de cada parâmetro de entrada de dados no software em $\pm 25 \%$ (condições de carregamento, propriedades mecânicas e espessuras das camadas), mantendo os demais parâmetros de entrada em seus valores de referência. 


\subsubsection{Tratamento dos dados e análises estatísticas}

Adotou-se o método de Grubbs para realizar o tratamento prévio dos dados, reduzir os desvios de grupo, identificar e retirar da análise valores discrepantes (outliers) em todas as variáveisresposta analisadas, desde os parâmetros da dosagem até a caracterização mecânica complementar. Os valores de quase todas as variáveis-resposta da pesquisa foram calculados em função da média de 3 CPs, caso o valor de determinada variável-resposta de um CP seja excluído pelo método de Grubbs, a média será recalculada somente em função dos outros 2 corpos de prova. Os cálculos necessários foram realizados no software Excel, conforme procedimentos descritos em Real Statistics (2013).

Realizou-se também o teste t de Student para averiguar se os valores médios das variáveisrespostadas de misturas eram diferentes entre si, para um nível de significância de 5\%. Estes testes foram executados no programa IBM SPSS Statistics 22.

Alguns resultados foram analisados a luz de regressão linear e do coeficiente de determinação $\left(\mathrm{R}^{2}\right)$. As variáveis consideradas nas regressões foram os parâmetros de caracterização do fíler: teor de caulim (0\% - misturas de referência, 1,5\%, 3,0\% e 6,0\%), D10, D30, D60 e MF, as quais foram correlacionadas com as todas as variáveis-resposta das Etapas 1, 2 e 3, com a ressalva de que não foram feitas correlações com o teor de caulim na Etapa 3. Estas análises foram realizadas no software Excel, com o uso da ferramenta Análise de Dados - Regressão. Além dos valores de $\mathrm{R}^{2}$, também se indica, por meio de análise de variância, se a relação entre as variáveis em estudo pode ser considerada linear a um nível de significância de 5\%. Para tanto, compara-se a estatística $\mathrm{F}$ do teste $\operatorname{com} \alpha=0,05$. Se $\mathrm{F} \leq \alpha$, a relação é considerada linear.

\subsubsection{Análises complementares}

A execução do extenso programa experimental gerou uma série de dados que não se vincularam diretamente aos objetivos do trabalho, mas que puderam ser explorados gerando resultados interessantes sob outros enfoques. As demais seções relatam os métodos empregados nestas análises complementares. 
3.2.5.1 Estudo de possíveis correlações lineares entre as variáveis-resposta

O método principal do trabalho consistiu em analisar os efeitos das variáveis de entrada "tipo de ligante asfáltico", "tipo de fíler" e "parâmetros de caracterização do fíler", nas diversas variáveis-resposta, ou seja, estabilidade, RT, vida de fadiga, dentre outras.

Nesta análise complementar, buscou-se encontrar correlações diretamente entre as variáveisresposta de todas as condições experimentais, por exemplo, entre a fluência da dosagem Marshall e o módulo de fluência medido no ensaio de creep estático, mediante regressão linear e análise de $\mathrm{R}^{2}$. Estas análises são promissoras, pois podem indicar relações e tendências de comportamentos a partir de parâmetros da Dosagem Marshall.

\subsubsection{Comparações dos resultados das diversas condições de ensaios de RT e MR}

Os ensaios de MR e RT foram realizados em 4 condições, compondo os grupos indicados abaixo:

- Grupo MR (11 CPs dos ensaios de RT ou fadiga) e Grupo RT (3 CPs dos ensaios de RT). Os CPs destes grupos têm as seguintes características: $\mathrm{Vv} \approx 4 \%$, sem envelhecimento e sem condicionamento térmico. $\mathrm{O}$ ensaio de RT foi realizado após um ensaio de $\mathrm{MR}$ a $25^{\circ} \mathrm{C}$;

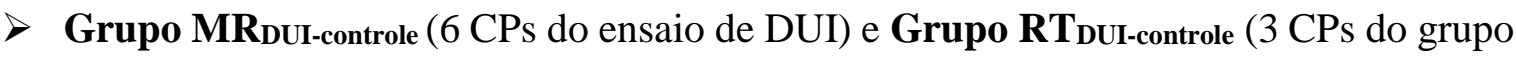
de controle do ensaio de DUI). Os CPs destes grupos têm as seguintes características: $\mathrm{Vv} \approx 7 \%$, com envelhecimento e sem condicionamento térmico. $\mathrm{O}$ ensaio de RT foi efetuado após um ensaio de MR a $25^{\circ} \mathrm{C}$;

> Grupo MRdul-condicionado (3 CPs do grupo condicionado do ensaio de DUI) e Grupo RT DUI-condicionado (3 CPs do grupo condicionado do ensaio de DUI). Os CPs destes grupos têm as seguintes características: $\mathrm{Vv} \approx 7 \%$, com envelhecimento e com condicionamento térmico. O ensaio de RT foi realizado após 2 ensaios de $\mathrm{MR}$ a $25^{\circ} \mathrm{C}$;

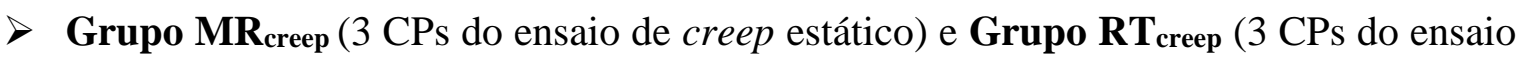
de creep estático). Os CPs destes grupos têm as seguintes características: $\mathrm{Vv} \approx 7 \%$, sem envelhecimento e sem condicionamento térmico. O ensaio de RT foi efetuado após ensaios de MR em 3 temperaturas e creep estático. 
As análises contemplaram a realização de testes t para verificar se a média dos valores de RT e MR entre as condições de ensaios são significativamente diferentes considerando $\alpha=0,05$ e a busca de correlações entre as RTs e MRs dos diferentes grupos versus volume de vazios.

3.2.5.3 Relações entre a vida de fadiga $(\mathrm{N})$ versus $\mathrm{Vv}$, rigidez e realização prévia de ensaios de MR em diferentes temperaturas para avaliação de susceptibilidade térmica (ST)

Visando identificar, nos ensaios de fadiga por compressão diametral à tensão controlada, se há relação entre: (i) Vv; (ii) MR, e; (iii) realização prévia de ensaios de MR para avaliar a ST, com a obtenção de valores maiores de $\mathrm{N}$, foram feitos os testes de hipótese indicados na Tabela 3.9.

Tabela 3.9 - Descrição dos testes de hipóteses utilizados nos ensaios de fadiga

\begin{tabular}{ccc}
\hline Teste de Hipótese (Vv x N) & Teste de Hipótese (MR x N) & Teste de Hipótese (ST x N) \\
\hline $\begin{array}{c}\mathrm{H}_{0} \text { : A relação entre menor Vv e } \\
\text { maior N } e \text { aleatória. }\end{array}$ & $\begin{array}{c}\mathrm{H}_{0} \text { : A relação entre maior MR } \\
\text { e maior N } e ́ \text { aleatória. }\end{array}$ & $\begin{array}{c}\mathrm{H}_{0} \text { : A relação entre ter ocorrido } \\
\text { ensaios de ST e maior N } e ́ \\
\text { aleatória. }\end{array}$ \\
$\begin{array}{c}\mathrm{H}_{1} \text { : A relação entre menor Vv e } \\
\text { maior N não é aleatória. }\end{array}$ & $\begin{array}{c}\mathrm{H}_{1} \text { : A relação entre maior MR } \\
\text { e maior N não é aleatória. }\end{array}$ & $\begin{array}{c}\mathrm{H}_{1} \text { : A relação entre ter ocorrido } \\
\text { ensaios de ST e maior N não é } \\
\text { aleatória. }\end{array}$ \\
\hline
\end{tabular}

Em cada par de CPs ensaiados a um mesmo nível de tensão, compararam-se os valores de Vv, MR e N, sendo que os menores valores receberam o código “_” e os maiores “+”. Também se indicou se o CP recebeu (S) ou não $(\mathrm{N})$ os ensaios prévios para análise de ST. Em sequência concatenaram-se os códigos, em função do teste de hipótese a ser feito. Por exemplo, para testar a relação entre $\mathrm{Vv}$ e $\mathrm{N}$, o código “- + " significa que o $\mathrm{CP}$ com menor $\mathrm{Vv}$ apresentou maior valor de N. Com os dados codificados, utilizou-se a distribuição binomial (equação 3.12) para calcular a estatística $\mathrm{p}(\mathrm{x})$. Se $\mathrm{p}(\mathrm{x})$ acumulado for inferior a $\alpha=0,05$, rejeita-se $\mathrm{H}_{0}$.

$$
p(x)=\left(\frac{n !}{(n-x) ! \cdot x !}\right) \cdot \pi^{x} \cdot(1-\pi)^{n-x}
$$

Em que:

$\mathrm{p}(\mathrm{x})=$ estatística de referência do teste $/ \mathrm{x}=\mathrm{n}^{\mathrm{o}}$ de ocorrências do caso em análise, por exemplo $\mathrm{n}^{\circ}$ de vezes em que um CP com Vv “_” apresenta $\mathrm{N}$ “+”, no teste de hipótese $\mathrm{Vv}$ x N / n = n total de casos na amostra $/ \pi=$ probabilidade de ocorrência do fenômeno em teste. Como se quer testar aleatoriedade das relações entre Vv, MR e ST com N, $\pi=0,5$. 


\section{APRESENTAÇÃO E DISCUSSÃO DOS RESULTADOS}

Neste capítulo são apresentados e analisados os resultados das três etapas da pesquisa e das análises complementares descritas no método. Inicialmente discutem-se os resultados das Dosagens Marshall (Etapa 1) e Caracterização Mecânica Básica (Etapa 2). Em seguida, são feitas considerações sobre a viabilidade técnica do uso de rejeito de caulim como fíler em concretos asfálticos. O capítulo prossegue com a discussão dos resultados da Caracterização Mecânica Complementar (Etapa 3) e encerra com os resultados das análises complementares.

\subsection{DOSAGENS MARSHALL - ETAPA 1}

As dosagens Marshall foram processadas com três objetivos:

Definir o teor de projeto das misturas asfálticas;

$>$ Avaliar a viabilidade técnica preliminar do rejeito de caulim como fíler em concretos asfálticos, e;

$>$ Avaliar a influência do tipo de ligante asfáltico, do tipo de fíler e dos parâmetros de caracterização do fíler nos parâmetros das dosagens Marshall: $\mathrm{Vv}$, teor de projeto, $\mathrm{G}_{\mathrm{mb}}$, $\mathrm{G}_{\mathrm{mm}}, \mathrm{RBV}, \mathrm{VAM}$, Estabilidade e Fluência.

Foram dosadas 10 misturas asfálticas (condições experimentais) resultantes da combinação de: 2 níveis de tipo de ligante asfáltico (CAP 50/70 e CAP 30/45) e 5 níveis de tipo de fíler (granito, $1,5 \%, 3,0 \%$ e $6,0 \%$ de caulim e $1,5 \%$ de cal), conforme indicado na Tabela 4.1 .

Tabela 4.1 - Descrição das misturas asfálticas dosadas na Etapa 1

\begin{tabular}{lccccc}
\hline $\begin{array}{l}\text { Tipo } \\
\text { de ligante } \\
\text { asfáltico }\end{array}$ & Granito & $\begin{array}{c}\mathbf{1 , 5 \%} \text { de } \\
\text { caulim }\end{array}$ & $\begin{array}{c}\mathbf{3 , 0 \%} \text { de } \\
\text { caulim }\end{array}$ & $\begin{array}{c}\mathbf{6 , 0 \%} \text { de } \\
\text { caulim }\end{array}$ & $\begin{array}{c}\mathbf{1 , 5 \%} \text { de } \\
\text { cal }\end{array}$ \\
\hline $\begin{array}{l}\text { CAP 50/70 } \\
\text { CAP 30/45 }\end{array}$ & 5070 & $5070 \mathrm{C} 1,5$ & $5070 \mathrm{C} 3,0$ & $5070 \mathrm{C} 6,0$ & $5070 \mathrm{~L}$ \\
\hline
\end{tabular}

\subsubsection{Definição do teor de projeto}

Todos os parâmetros das dosagens Marshall foram mensurados e/ou calculados em relação aos valores médios de três réplicas, por teor de ligante asfáltico e por tipo de mistura asfáltica. As exceções, ou seja, quando houve exclusão de valores discrepantes pelo teste de Grubbs, estão 
indicadas no texto. O Apêndice $\mathrm{A}$ traz os valores relativos às dimensões, massas, parâmetros volumétricos, densidades, estabilidade e fluência de cada corpo de prova da Etapa 1, agrupados por tipo de mistura. O cálculo dos parâmetros volumétricos foi efetuado conforme a NBR 16.273/2014, com $\mathrm{G}_{\mathrm{mm}}$ calculado ensaio RICE. O Apêndice B contém os gráficos das Dosagens Marshall, elaborados a partir dos dados do Apêndice A, que balizaram a escolha dos teores de projeto, definidos para $\mathrm{Vv}=4 \%$, conforme recomendação do DER/SP e Asphalt Institute.

Na Figura 4.1 estão apresentados os teores de projeto das 10 misturas asfálticas da Etapa 1, os quais variaram de 5,3\% a 5,6\%, sendo que os maiores valores de TP ocorreram nas misturas com 6,0\% de caulim e nas misturas com cal, e os menores valores de TP ocorreram nas misturas de referência (5070 e 3045) e nas misturas com 1,5\% de caulim. As misturas de referência, 5070 e 3045 , apresentaram o mesmo $\mathrm{TP}=5,3 \%$.

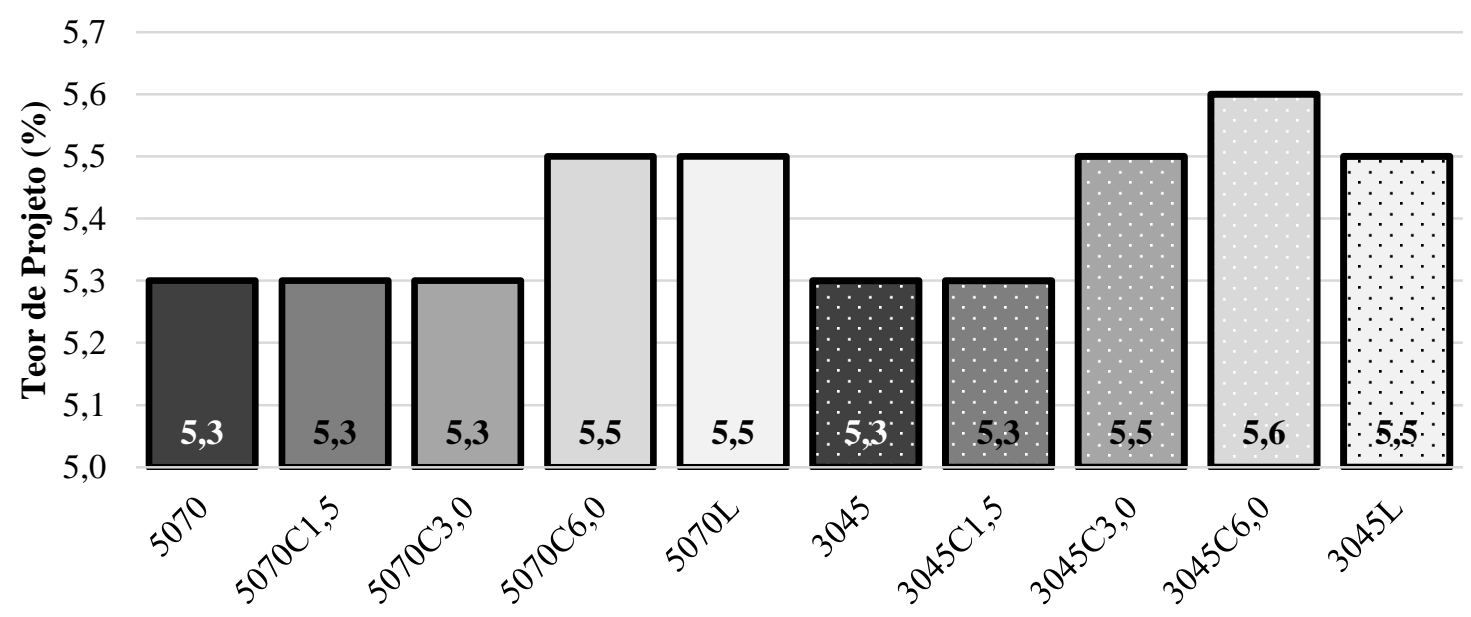

Figura 4.1 - Teores de Projeto das 10 misturas asfálticas testadas

Do ponto de vista prático, considerando a tolerância de $\pm 0,3 \%$ em torno do teor de projeto considerada nas principais normas brasileiras (DNIT e DER/SP), pode-se dizer que os teores de projeto de todas as misturas asfálticas são iguais. Do ponto de vista do custo de execução das misturas asfálticas, aquelas que têm menor TP são mais baratas e, portanto, mais recomendadas.

O tipo de fíler influiu de maneira importante na definição do teor de projeto. Percebeu-se uma tendência de que quanto maior o teor de caulim, maior o teor de projeto. A adição de cal elevou o TP em 0,2\%, independentemente do tipo de ligante asfáltico, em relação às misturas de referência. Tanto na adição de caulim como na adição de cal, o maior consumo de ligante 
asfáltico pode estar relacionado à maior superfície específica do agregado + fíler. Resultados semelhantes foram encontrados por Zulkati, Diew e Delai (2012).

Destaca-se que: (i) as misturas com 1,5\% de caulim apresentaram o mesmo valor de TP das misturas de referência; (ii) a mistura 5070C6,0 tem TP igual ao da mistura 5070L, e; (iii) a mistura 3045C3,0 tem o mesmo TP da mistura 3045L. Assim, espera-se que estas misturas apresentem comportamentos semelhantes nos demais parâmetros das dosagens Marshall.

Ao se avaliar o teor de projeto à luz do tipo de ligante asfáltico, percebe-se que em três situações, misturas de referência (5070 $x$ 3045), misturas com 1,5\% de caulim $(5070 \mathrm{C} 1,5 x$ 3045C1,5) e misturas com cal (5070L x 3045L), os TPs são iguais corroborando a explanação de Gigante (2007). Nas outras duas situações, misturas com 3,0\% de caulim (5070C3,0 $x$ $3045 \mathrm{C} 3,0)$ e misturas com 6,0\% de caulim $(5070 \mathrm{C} 6,0 \times 3045 \mathrm{C} 6,0)$, o teor de projeto foi superior nas misturas com CAP 30/45. Estes resultados são semelhantes aos obtidos por Nogueira (2008). Uma possível explicação para o maior TP das misturas com CAP 30/45 é a maior diferença entre as temperaturas de usinagem e compactação desse ligante asfáltico em relação à temperatura ambiente, fazendo com que haja uma perda mais rápida de temperatura o que pode vir a ocasionar mistura e/ou compactação com viscosidades inadequadas e, em consequência, maior dificuldade de compactação requerendo mais ligante asfáltico para se atingir o volume de vazios-alvo de $4 \%$. Ou ainda, em virtude de uma pior interação entre o ligante asfáltico mais consistente e fíleres com maior superfície específica.

\subsubsection{Avaliação preliminar da viabilidade técnica do uso de rejeito de caulim como fíler em concretos asfálticos: Aspectos da dosagem}

Na Tabela 4.2 estão sumarizados os resultados dos parâmetros volumétricos, densidades, estabilidade e fluência das misturas asfálticas, no teor de projeto. Para avaliar a viabilidade técnica preliminar do uso de rejeito de caulim como fíler em concretos asfálticos, os valores indicados na Tabela 4.2 foram confrontados aos valores limites estabelecidos pelo DER/SP na especificação técnica ET-DE-P00/027. 
Tabela 4.2 - Resultados das Dosagens Marshall para as 10 misturas asfálticas testadas

\begin{tabular}{ccccccccc}
\hline $\begin{array}{c}\text { Condições } \\
\text { Experimentais }\end{array}$ & $\begin{array}{c}\mathbf{T P} \\
(\mathbf{\%})\end{array}$ & $\begin{array}{c}\mathbf{V} \mathbf{( \% )} \\
(\mathbf{G})\end{array}$ & $\mathbf{G}_{\mathbf{m m}}$ & $\mathbf{G}_{\mathbf{m b}}$ & $\begin{array}{c}\text { VAM } \\
(\mathbf{\%})\end{array}$ & $\begin{array}{c}\mathbf{R B V} \\
(\mathbf{\%})\end{array}$ & $\begin{array}{c}\text { Estabilidade } \\
(\mathbf{k g f})\end{array}$ & $\begin{array}{c}\text { Fluência } \\
(\mathbf{m m})\end{array}$ \\
\hline 5070 & $\mathbf{5 , 3}$ & 4,1 & 2,416 & 2,317 & 15,6 & 74,0 & 1070 & 2,80 \\
$5070 \mathrm{C} 1,5$ & $\mathbf{5 , 3}$ & 4,2 & 2,417 & 2,316 & 15,7 & 73,5 & 905 & 2,70 \\
$5070 \mathrm{C} 3,0$ & $\mathbf{5 , 3}$ & 4,0 & 2,409 & 2,312 & 15,9 & 74,9 & 1025 & 3,40 \\
$5070 \mathrm{C} 6,0$ & $\mathbf{5 , 5}$ & 4,1 & 2,413 & 2,314 & 16,0 & 74,5 & 840 & 3,70 \\
5070L & $\mathbf{5 , 5}$ & 3,9 & 2,402 & 2,309 & 16,1 & 76,0 & 1040 & 2,75 \\
3045 & $\mathbf{5 , 3}$ & 4,2 & 2,415 & 2,313 & 15,8 & 73,2 & 1190 & 3,25 \\
3045C1,5 & $\mathbf{5 , 3}$ & 4,0 & 2,410 & 2,314 & 15,7 & 75,0 & 1185 & 3,40 \\
3045C3,0 & $\mathbf{5 , 5}$ & 4,0 & 2,408 & 2,311 & 16,1 & 74,9 & 1010 & 3,50 \\
3045C6,0 & $\mathbf{5 , 6}$ & 4,2 & 2,404 & 2,303 & 16,5 & 74,5 & 1055 & 4,20 \\
3045L & $\mathbf{5 , 5}$ & 3,9 & 2,405 & 2,312 & 16,0 & 75,9 & 1135 & 3,20 \\
\hline
\end{tabular}

Os TPs das misturas variaram entre 5,3 e 5,6\%. Portanto, todos eles estão contidos no intervalo de 4,5 a $6,5 \%$ de teor de ligante especificado pelo DER/SP para a faixa granulométrica adotada;

$>$ Os valores de VAM ficaram entre 15,6 e 16,5\%, ou seja, acima do limite mínimo de $\mathrm{VAM} \geq 14,0 \%$, para misturas com agregado de tamanho nominal máximo de 12,5 mm;

$>$ Os valores de RBV variaram de 73,2 a 76,0\%, ficando contidos no intervalo recomendado, $65,0 \leq \mathrm{RBV} \leq 80,0$;

$>$ Os valores de estabilidade variaram entre 840 e $1190 \mathrm{kgf}$, atendendo assim ao valor mínimo de estabilidade de $8 \mathrm{kN} \approx 816 \mathrm{kgf}$;

Todas as misturas atenderam ao intervalo aceitável de fluência, entre 2,0 e 4,0 mm, exceto a mistura 3045C6,0, que apresentou fluência de 4,2 mm.

Assim, as dosagens Marshall indicaram, de modo geral, ser possível do ponto de vista técnico a utilização do rejeito de caulim como fíler em misturas asfálticas densas nas condições desta pesquisa, ou seja, utilizando agregado de granito no centro da faixa III do DER/SP e ligantes asfálticos CAP 50/70 ou CAP 30/45. A verificação completa da viabilidade depende da Etapa 2, na qual foram testadas a resistência à tração e a resistência ao dano por umidade induzida, cujos valores mínimos também constam da especificação técnica ET-DE-P00/027.

A mistura 3045C6,0, além de não atender ao critério de fluência do DER/SP, apresentou o inconveniente de ter elevado o TP em $0,3 \%$ em relação à mistura de referência, o que encarece a mistura. O fato de a estabilidade da mistura 5070C6,0 ter ficado muito próxima do valor mínimo especificado merece especial atenção. Por essas razões, não se recomenda trabalhar 
com teores muito elevados de caulim. Para teores mais baixos, 1,5 ou 3,0\%, o uso de rejeito de caulim como fíler em concretos asfálticos mostrou-se tecnicamente viável.

\subsubsection{Avaliação da influência do tipo de fíler e do tipo de ligante asfáltico nos parâmetros das Dosagens Marshall}

Nesta seção do trabalho foram efetuados dois tipos de análise para investigar a influência do tipo de fíler e do tipo de ligante asfáltico nos parâmetros das dosagens Marshall:

$>$ Análise da tendência de comportamento dos parâmetros das dosagens Marshall no intervalo de 5,0 a 6,0\% de teor de ligante asfáltico $\left(\mathrm{P}_{\mathrm{b}}\right)$, mediante interpretação de gráficos, e;

$>$ Análise comparativa dos valores médios dos parâmetros das dosagens Marshall das misturas asfálticas, para $\mathrm{P}_{\mathrm{b}}=5,5 \%$, com aplicação do teste t de Student para avaliar se eles são diferentes a um nível de significância de 5\%.

$\mathrm{O} \mathrm{P}_{\mathrm{b}}=5,5 \%$ foi escolhido primeiramente porque é mais próximo aos teores de projeto do que os demais teores da dosagem (5,0 e 6,0\%). Além disso, como todas as misturas asfálticas foram produzidas neste teor, usam-se dados reais, efetivamente medidos nos CPs, o que não ocorreria trabalhando com os dados referentes aos teores de projeto de 5,3\% e 5,6\%, visto que na Etapa 1, tais CPs não haviam sido produzidos. Por fim, há melhor qualidade nas análises pois se eliminam os efeitos que o teor de ligante asfáltico exerce nos parâmetros das dosagens Marshall.

Na Tabela 4.3 estão indicados os valores de volume de vazios (Vv), densidade máxima teórica da mistura asfáltica solta $\left(\mathrm{G}_{\mathrm{mm}}\right)$, densidade aparente da mistura asfáltica compactada $\left(\mathrm{G}_{\mathrm{mb}}\right)$, vazios do agregado mineral (VAM), relação betume vazios (RBV), estabilidade e fluência de todas as misturas asfálticas para $\mathrm{P}_{\mathrm{b}}=5,5 \%$.

Na Tabela 4.4 são apresentadas as variações percentuais médias de cada parâmetro da dosagem Marshall em função da adição de caulim (em cada teor isoladamente e em relação à média dos 3 teores) e da adição de cal, em relação às misturas de referência, e em função do tipo de ligante asfáltico (misturas com CAP 30/45 / misturas com CAP 50/70). Indica-se, em negrito, qual fator é preponderante para causar maior variação no parâmetro da Dosagem Marshall. A Tabela 4.4 foi calculada a partir dos dados da Tabela 4.3. 
Tabela 4.3 - Valores dos parâmetros das dosagens Marshall para teor de ligante asfáltico $=5,5 \%$

\begin{tabular}{cccccccc}
\hline $\begin{array}{c}\text { Condições } \\
\text { Experimentais }\end{array}$ & $\begin{array}{c}\mathbf{V} \mathbf{v} \\
(\boldsymbol{\%})\end{array}$ & $\mathbf{G}_{\mathbf{m m}}$ & $\mathbf{G}_{\mathbf{m b}}$ & $\begin{array}{c}\text { VAM } \\
(\boldsymbol{\%})\end{array}$ & $\begin{array}{c}\mathbf{R B V} \\
(\boldsymbol{\%})\end{array}$ & $\begin{array}{c}\text { Estabilidade } \\
(\mathbf{k g f})\end{array}$ & $\begin{array}{c}\text { Fluência } \\
(\mathbf{m m})\end{array}$ \\
\hline 5070 & 3,5 & 2,409 & 2,325 & 15,5 & 77,6 & 1080 & 2,95 \\
$5070 \mathrm{C} 1,5$ & 3,5 & 2,410 & 2,326 & 15,5 & 77,6 & 920 & 2,85 \\
5070C3,0 & 3,3 & 2,401 & 2,322 & 15,7 & 79,0 & 1060 & 3,50 \\
5070C6,0 & 4,1 & 2,413 & 2,314 & 16,0 & 74,5 & 840 & 3,70 \\
5070L & 3,9 & 2,402 & 2,309 & 16,1 & 76,0 & 1040 & 2,75 \\
3045 & 3,5 & 2,406 & 2,322 & 15,6 & 77,6 & 1210 & 3,25 \\
3045C1,5 & 3,1 & 2,403 & 2,329 & 15,4 & 79,8 & 1250 & 3,70 \\
3045C3,0 & 4,0 & 2,408 & 2,311 & 16,1 & 74,9 & 1010 & 3,50 \\
3045C6,0 & 4,5 & 2,408 & 2,299 & 16,6 & 72,8 & 1050 & 4,10 \\
3045L & 3,9 & 2,405 & 2,312 & 16,0 & 75,9 & 1135 & 3,20 \\
\hline
\end{tabular}

Tabela 4.4 - Variação percentual média dos parâmetros das dosagens Marshall, em função do tipo de fíler (adição de caulim ou de cal) e do tipo de ligante asfáltico para $\mathrm{P}_{\mathrm{b}}=5,5 \%$

\begin{tabular}{|c|c|c|c|c|c|c|c|c|}
\hline Fator & $\begin{array}{l}\mathbf{V v} \\
(\%)\end{array}$ & $\begin{array}{l}\mathbf{G}_{\mathrm{mm}} \\
(\%)\end{array}$ & $\begin{array}{l}\mathbf{G}_{\mathbf{m b}} \\
(\%)\end{array}$ & $\begin{array}{c}\text { VAM } \\
(\%)\end{array}$ & $\begin{array}{c}\text { RBV } \\
(\%)\end{array}$ & $\begin{array}{c}\text { Estabi- } \\
\text { lidade } \\
(\%)\end{array}$ & $\begin{array}{l}\text { Fluên- } \\
\text { cia } \\
(\%)\end{array}$ & $\begin{array}{l}\text { TP } \\
(\%)\end{array}$ \\
\hline $1,5 \%$ de caulim & $-5,7$ & 0,0 & 0,2 & $-0,6$ & 1,4 & $-5,8$ & 5,2 & 0,0 \\
\hline $3,0 \%$ de caulim & 4,3 & $-0,1$ & $-0,3$ & 2,2 & $-0,8$ & $-9,2$ & 13,2 & 1,9 \\
\hline $6,0 \%$ de caulim & 22,9 & 0,1 & $-0,7$ & 4,8 & $-5,1$ & $-17,7$ & 25,8 & 4,7 \\
\hline $\begin{array}{c}\text { Média dos } 3 \text { teores } \\
\text { de caulim }\end{array}$ & 7,1 & 0,0 & $-0,3$ & 2,1 & $-1,5$ & $-10,9$ & 14,7 & 2,2 \\
\hline Cal & 11,4 & $-0,2$ & $-0,6$ & 3,2 & $-2,1$ & $-5,0$ & $-4,2$ & $\mathbf{3 , 8}$ \\
\hline Tipo de ligante & 3,9 & 0,0 & $-0,2$ & 1,1 & $-1,0$ & 15,5 & 13,4 & 1,1 \\
\hline Fator preponderante & $\mathrm{Cal}$ & $\mathrm{Cal}$ & $\mathrm{Cal}$ & $\mathrm{Cal}$ & $\mathrm{Cal}$ & Ligante & Caulim & $\mathrm{Cal}$ \\
\hline
\end{tabular}

Quando se avaliou a influência de cada teor de caulim isoladamente, verificou-se que a adição de $6,0 \%$ de caulim foi o fator preponderante para alterar os valores de $\mathrm{Vv}, \mathrm{G}_{\mathrm{mb}}, \mathrm{VAM}, \mathrm{RBV}$, estabilidade, fluência e TP. Isso indica que tais parâmetros são bastante suscetíveis a presença de grande quantidade de caulim na mistura asfáltica. Apenas a $G_{m m}$ foi mais afetada pela cal. Por outro lado, quando se considerou o efeito médio da adição de caulim em relação aos 3 teores, percebeu-se que a adição de cal foi o fator preponderante para alterar os valores de Vv, $\mathrm{G}_{\mathrm{mm}}, \mathrm{G}_{\mathrm{mb}}$, VAM, RBV e TP, ou seja, dos parâmetros volumétricos das misturas asfálticas e o uso de CAP 30/45 (tipo de ligante asfáltico) foi o fator preponderante para alterar os valores de estabilidade. Mesmo neste cenário, o caulim causou maior impacto nos valores de fluência.

Os valores de $G_{m m}$ e $G_{m b}$ são muito próximos em todas as misturas asfálticas, com variações inferiores a 1,0\%. Assim, assumiu-se que não houve influência significativa nem do tipo de fíler nem do tipo de ligante de asfáltico na $\mathrm{G}_{\mathrm{mm}}$ e $\mathrm{G}_{\mathrm{mb}}$. As subseções seguintes trazem as análises da influência do tipo de fíler e do tipo de ligante asfáltico em: Vv, VAM, RBV, estabilidade e fluência. 
4.1.3.1 Influência do tipo de fíler e do tipo de ligante asfáltico no volume de vazios

Na Figura 4.2 são apresentados gráficos da influência da adição de caulim e da cal no Vv das misturas com CAP 50/70 e com CAP 30/45, os quais também permitem avaliar a influência do tipo de ligante asfáltico no Vv. Os gráficos foram gerados a partir dos dados de dosagem no intervalo 5,0\% $\leq \mathrm{P}_{\mathrm{b}} \leq 6,0 \%$ (Apêndice $\mathrm{A}$ ).
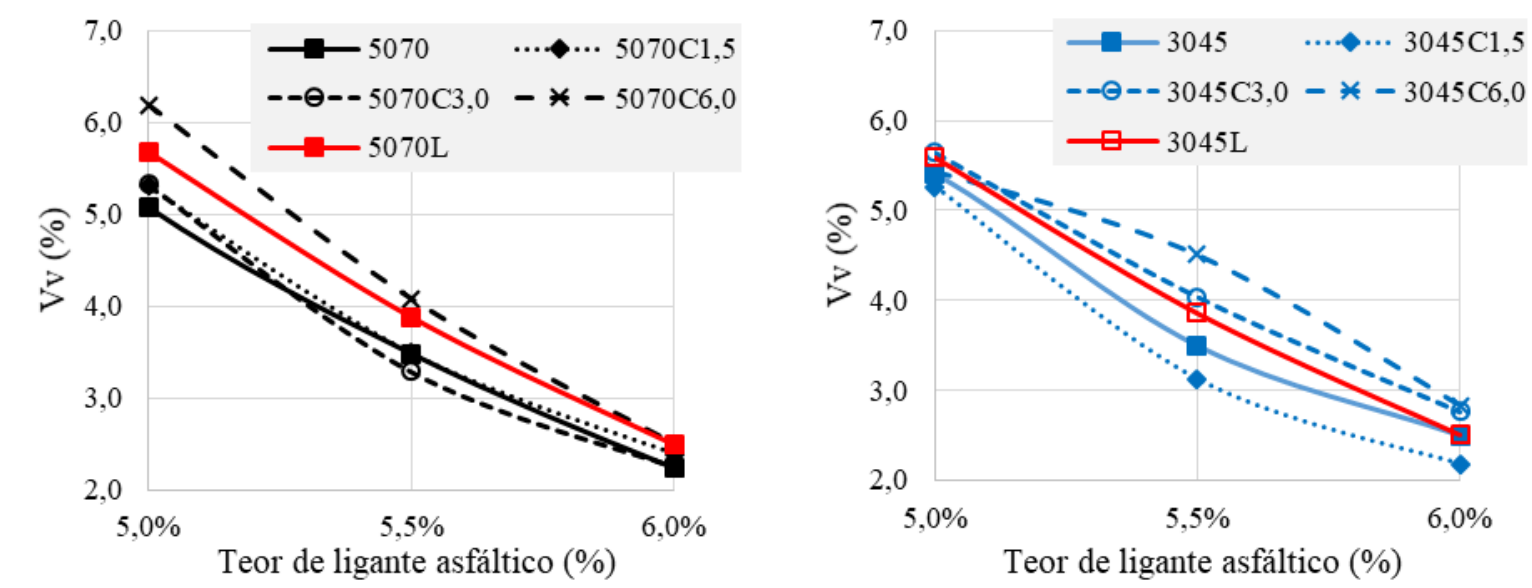

Figura 4.2 - Influência do tipo de fíler e do tipo de ligante asfáltico no $\mathrm{Vv}$, para $5,0 \% \leq \mathrm{P}_{\mathrm{b}} \leq 6,0 \%$

Todas as misturas apresentaram o comportamento típico que é a redução do Vv, à medida que se eleva o $\mathrm{P}_{\mathrm{b}}$. De modo geral, a adição de caulim elevou os valores de Vv, para ambos os tipos de ligante asfáltico, em relação às misturas de referência, com elevação mais importante nas misturas com $6 \%$ de caulim. A adição de cal também elevou o volume de vazios em comparação com as misturas de referência. A tendência de comportamento de $\mathrm{Vv}$ em função do tipo de ligante asfáltico não foi clara.

Na Figura 4.3 são mostrados os valores médios de Vv para cada tipo de mistura e os valores individuais de cada CP utilizado no cálculo das médias para $\mathrm{P}_{\mathrm{b}}=5,5 \%$. Observou-se grande dispersão dos resultados, o que é comum em dosagens Marshall. Ademais são indicadas linhas que representam o valor de $\mathrm{Vv}$ das misturas de referência para facilidade de compreensão das análises. Observa-se que há um ponto da mistura 3045C1,5, representado por um losango, que foi excluído do cálculo da média do volume de vazios desta mistura por ser considerado como outlier pelo teste de Grubbs. 


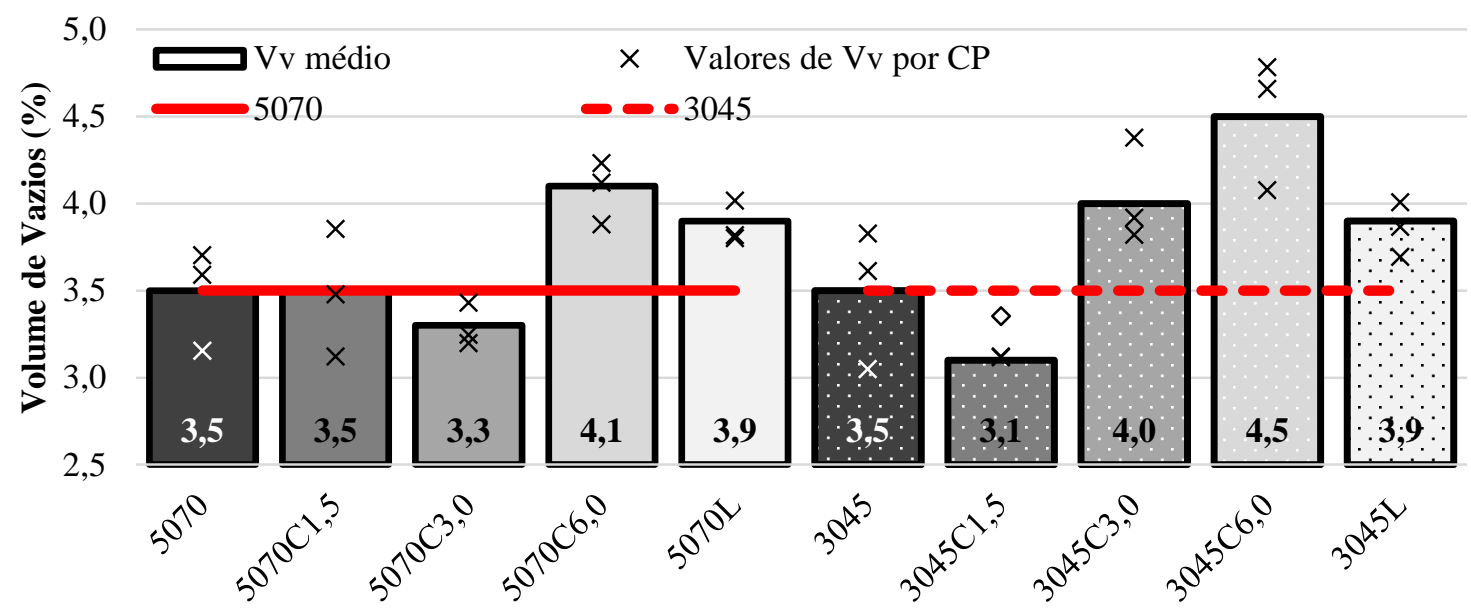

Figura 4.3 - Volume de vazios por tipo de mistura asfáltica para $\mathrm{P}_{\mathrm{b}}=5,5 \%$

Observando-se a Figura 4.3, nota-se que as misturas de referência apresentaram o mesmo valor de $\mathrm{Vv}=3,5 \%$. Não se observou tendência de comportamento de $\mathrm{Vv}$ com a adição de 1,5 ou $3,0 \%$ de caulim. No entanto, quando se adicionou $6,0 \%$ de caulim, independentemente do tipo de ligante asfáltico, houve importante elevação no $\mathrm{Vv}$, em média de $23 \%$, em relação às misturas de referência. Também se observou elevação de $11 \%$ no Vv quando há adição de cal (Vv passou de 3,5 para 3,9\% para ambos os ligantes asfálticos).

Um maior volume de vazios para um mesmo teor de ligante asfáltico indica maior dificuldade para compactar as misturas com 6,0\% de caulim ou com cal, havendo, portanto, necessidade de maior quantidade de ligante asfáltico para aumentar a lubrificação e melhorar o entrosamento entre as partículas dessas misturas. Por fim, não se detectou tendência de comportamento do volume de vazios em função do tipo de ligante asfáltico.

O Apêndice $\mathrm{C}$ traz a descrição dos procedimentos empregados e os resultados dos testes $\mathrm{t}$ de Student utilizados para comparar os valores médios de todas as propriedades medidas na pesquisa. Os testes $t$ apontaram que: (i) o tipo de fíler foi mais importante para diferenciar os valores de Vv do que o tipo de ligante asfáltico; (ii) apenas as misturas com 6,0\% de caulim $(5070 \mathrm{C6}, 0$ e 3045C6,0) apresentaram Vv significativamente diferentes em relação às misturas de referência. 
4.1.3.2 Influência do tipo de fíler e do tipo de ligante asfáltico nos vazios do agregado mineral

Na Figura 4.4 são apresentados dois gráficos que ilustram a influência do tipo de fíler e do tipo de ligante asfáltico no VAM, no intervalo de $5,0 \% \leq \mathrm{P}_{\mathrm{b}} \leq 6,0 \%$.
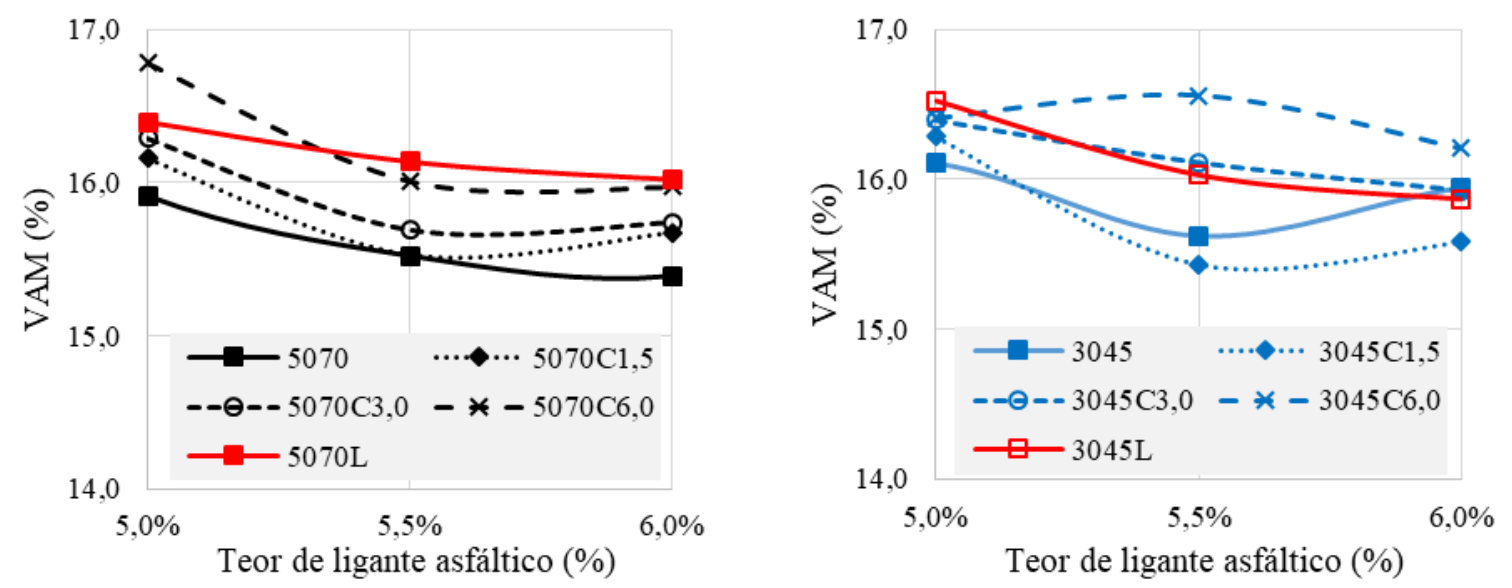

Figura 4.4 - Influência do tipo de fíler e do tipo de ligante asfáltico no VAM, para $5,0 \% \leq \mathrm{P}_{\mathrm{b}} \leq 6,0 \%$

$\mathrm{O}$ comportamento típico é o decréscimo do VAM à medida que se aumenta $\mathrm{o} \mathrm{P}_{\mathrm{b}}$, até se atingir um ponto mínimo, a partir do qual o VAM cresce com o aumento do teor de asfalto. Cinco misturas $(5070 \mathrm{C} 1,5,5070 \mathrm{C} 3,0,5070 \mathrm{C} 6,0,3045$ e 3045C1,5) exibiram o comportamento típico, quatro misturas $(5070,5070 \mathrm{~L}, 3045 \mathrm{C} 3,0$ e 3045L) apresentaram valores de VAM sempre decrescentes no intervalo de $\mathrm{P}_{\mathrm{b}}$ analisado e a mistura 3045C6,0 apresentou um comportamento atípico pois o VAM dessa mistura exibiu um ponto de máximo. Trata-se de mais um indício de que não é recomendado trabalhar com percentuais elevados de adição de caulim.

De modo geral, a adição de fíler, seja caulim, seja cal, provocou importante elevação no VAM. Por outro lado, não foi possível identificar tendência clara de comportamento da variação de VAM em função do tipo de ligante asfáltico.

Na Figura 4.5 são mostrados os valores médios de VAM para cada tipo de mistura, os valores individuais de cada CP utilizado no cálculo da média e linhas que representam o valor de VAM das misturas de referência para $\mathrm{P}_{\mathrm{b}}=5,5 \%$. Como corriqueiro em dosagens Marshall, observouse grande dispersão destes resultados. Percebe-se que há um ponto da mistura 3045C1,5, representado por um losango, que foi excluído do cálculo da média do VAM desta mistura por ser considerado como outlier pelo teste de Grubbs. 


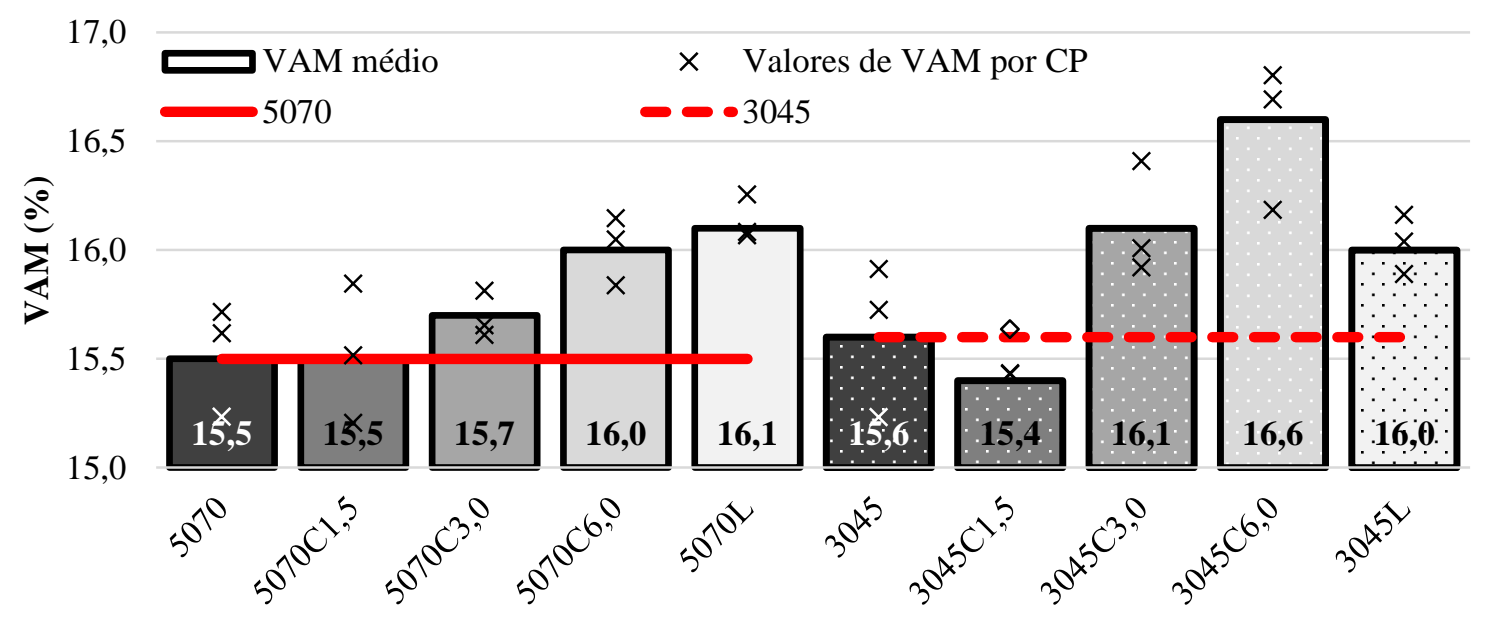

Figura 4.5 - VAM por tipo de mistura asfáltica para $P_{b}=5,5 \%$

Ao se interpretar a Figura 4.5, verifica-se que as misturas de referência apresentaram valores de VAM que podem ser considerados iguais (15,5 e 15,6\%). Observou-se uma tendência de aumento no valor de VAM à medida que se elevou o teor de adição de caulim na mistura. A adição de cal, em média, proporcionou o maior acréscimo relativo de VAM em relação às misturas de referência $(3,5 \%)$. Houve discreta tendência de elevação no VAM com o uso de CAP 30/45, especialmente nas misturas com 3,0 e 6,0\% de caulim.

Devido à maior superfície específica das misturas contendo caulim e cal, para o mesmo teor de ligante asfáltico, tende a haver ocorrência de redução no VAM destas misturas em função da menor espessura do filme de ligante asfáltico (CHADBOURN et. al., 2000). No entanto, o VAM é composto, além do volume efetivo de ligante asfáltico, dos vazios preenchidos por ar. Como descrito anteriormente, as misturas contendo elevado teor de caulim $(6,0 \%)$ ou cal apresentaram-se mais difíceis de compactar e, portanto, exibiram maiores valores de Vv que terminaram por elevar também o VAM.

Os testes t (Apêndice C) indicaram que: (i) o tipo de fíler foi mais importante para diferenciar os valores de VAM do que o tipo de ligante asfáltico; (ii) o VAM foi o parâmetro da dosagem Marshall que apresentou o maior número de casos em que as médias de valores entre as misturas asfálticas foram significativamente diferentes em função do tipo de fíler; (iii) As misturas 5070C6,0, 5070L e 3045C6,0 apresentaram VAM significativamente diferentes das misturas de referência. 
4.1.3.3 Influência do tipo de fíler e do tipo de ligante asfáltico na relação betume vazios

Na Figura 4.6 são apresentados dois gráficos que ilustram a influência do tipo de fíler e do tipo de ligante asfáltico no RBV, no intervalo de $5,0 \% \leq \mathrm{P}_{\mathrm{b}} \leq 6,0 \%$.
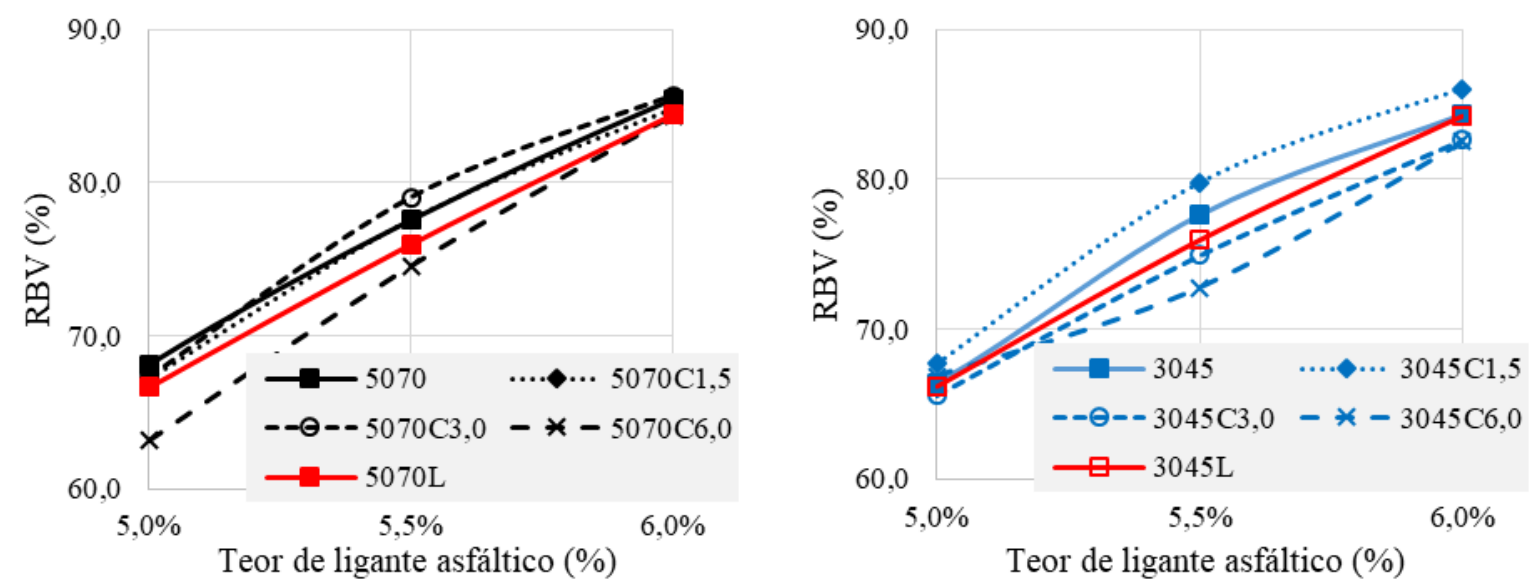

Figura 4.6 - Influência do tipo de fíler e do tipo de ligante asfáltico na RBV, para 5,0\% $\leq \mathrm{P}_{\mathrm{b}} \leq 6,0 \%$

Todas as misturas apresentaram o comportamento típico que é o aumento da RBV, à medida que se eleva o $\mathrm{P}_{\mathrm{b}}$. Com relação à adição de caulim, somente foi possível identificar tendência de redução de RBV quando se trabalhou com teor de caulim $=6,0 \%$. A adição de cal reduziu a RBV em comparação com as misturas de referência. Não foi possível observar tendência de comportamento de RBV em função do tipo de ligante asfáltico.

Na Figura 4.7 são mostrados os valores médios de RBV para cada tipo de mistura, os valores individuais de cada CP utilizado no cálculo da média e linhas que representam o valor de RBV das misturas de referência para facilidade de compreensão das análises. Observa-se que há um ponto da mistura $3045 \mathrm{C} 1,5$, representado por um losango, que foi excluído do cálculo da média do RBV desta mistura por ser considerado como outlier pelo teste de Grubbs.

Conforme a Figura 4.7, as misturas de referência apresentaram o mesmo valor de RBV =77,6\%. Não se observou tendência de comportamento de RBV com a adição de 1,5 ou 3,0\% de caulim. No entanto, quando se adicionou 6,0\% de caulim, independentemente do tipo de ligante asfáltico, houve redução no RBV, em média de 5\%, em relação às misturas de referência. Também se observou discreta redução de 2\% no RBV quando há adição de cal. De modo geral, pode-se afirmar que o comportamento de RBV em função do tipo de fíler é o oposto daquele 
observado quando se avaliou a variação do Vv entre as misturas. Tal resultado é explicado pela relação matemática inversamente proporcional que estes parâmetros exibem. Não foi possível detectar tendência de comportamento do RBV em função do tipo de ligante asfáltico.

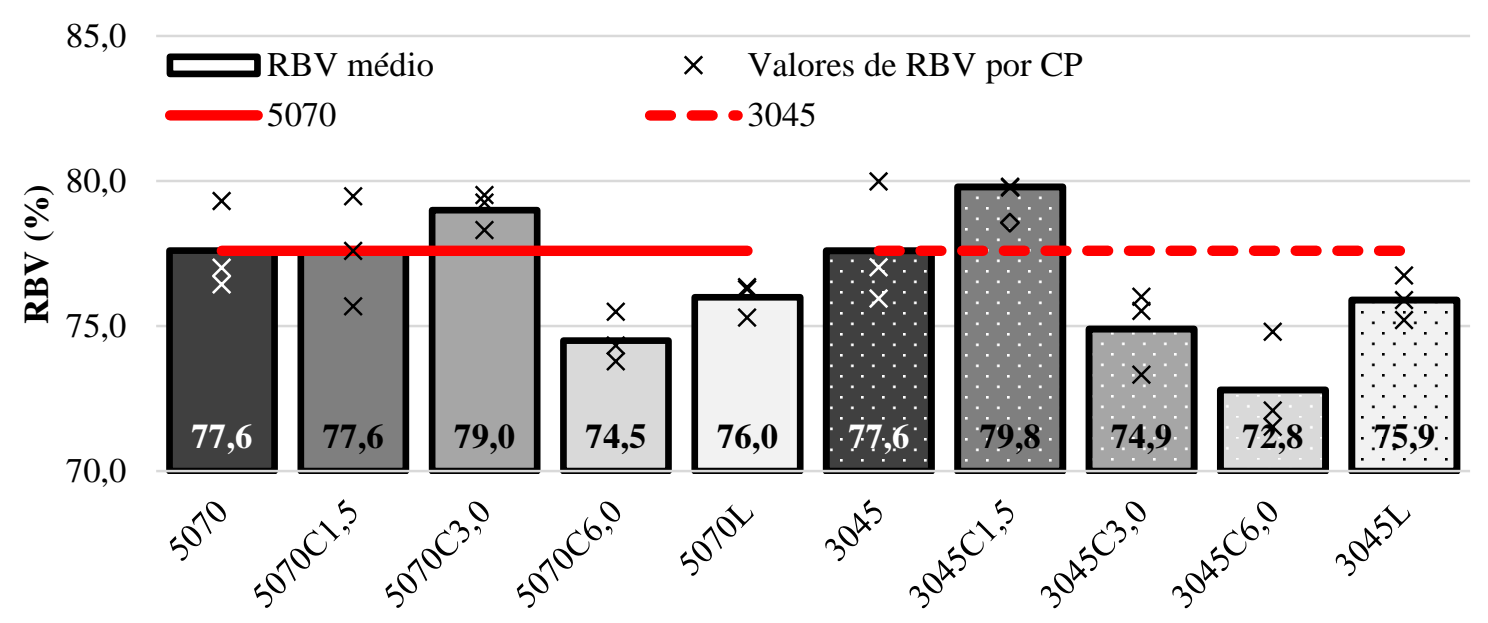

Figura 4.7-RBV por tipo de mistura asfáltica para $\mathrm{P}_{\mathrm{b}}=5,5 \%$

Os testes $\mathrm{t}$ (Apêndice C) ratificam as observações feitas, indicando que: (i) o tipo de fíler foi mais importante para diferenciar os valores de RBV do que o tipo de ligante asfáltico; (ii) apenas as misturas com 6,0\% de caulim apresentaram RBV significativamente diferentes em relação às misturas de referência.

\subsubsection{Influência do tipo de fíler e do tipo de ligante asfáltico na estabilidade}

Na Figura 4.8 são apresentados dois gráficos que ilustram a influência do tipo de fíler e do tipo de ligante asfáltico na estabilidade, no intervalo de $5,0 \% \leq \mathrm{P}_{\mathrm{b}} \leq 6,0 \%$.

O comportamento típico desse parâmetro é o aumento da estabilidade à medida que se aumenta o $\mathrm{P}_{\mathrm{b}}$, até se atingir um ponto máximo, a partir do qual a estabilidade decresce com o aumento do teor de asfalto. Cinco misturas (5070, 5070C3,0, 5070C6,0, 3045 e 3045C1,5) exibiram o comportamento típico, quatro misturas $(5070 \mathrm{C} 1,5,5070 \mathrm{~L}, 3045 \mathrm{C} 3,0$ e 3045L) apresentaram valores de estabilidade sempre crescentes no intervalo de $\mathrm{P}_{\mathrm{b}}$ analisado e a mistura 3045C6,0 apresentou um comportamento atípico pois a estabilidade dessa mistura exibiu um ponto de mínimo. Mais uma vez, antecipa-se que pode não ser recomendado trabalhar com percentuais elevados de adição de caulim. 

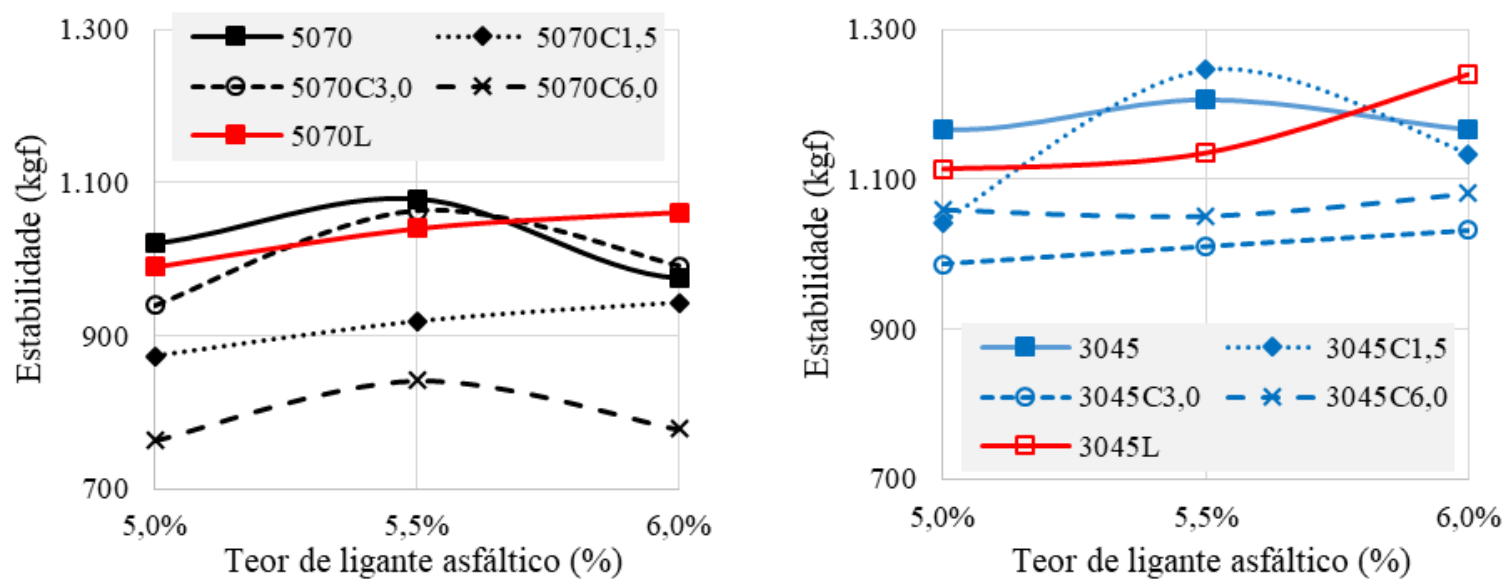

Figura 4.8 - Influência do tipo de fíler e do tipo de ligante asfáltico na estabilidade, para $5,0 \% \leq \mathrm{P}_{\mathrm{b}} \leq$ $6,0 \%$

De modo geral, a adição de fíler provocou importante redução na estabilidade, em virtude da diminuição dos pontos de contato do esqueleto mineral com uso de fíleres mais finos. Por outro lado, o uso de CAP 30/45 (tipo de ligante mais consistente) elevou os valores de estabilidade.

Na Figura 4.9 são mostrados os valores médios de Estabilidade para cada tipo de mistura, os valores individuais de cada $\mathrm{CP}$ utilizado no cálculo da média e linhas que representam o valor da estabilidade das misturas de referência. Observa-se que há um ponto da mistura 3045C6,0, representado por um losango, que foi excluído do cálculo da média da Estabilidade desta mistura por ser considerado como outlier pelo teste de Grubbs.

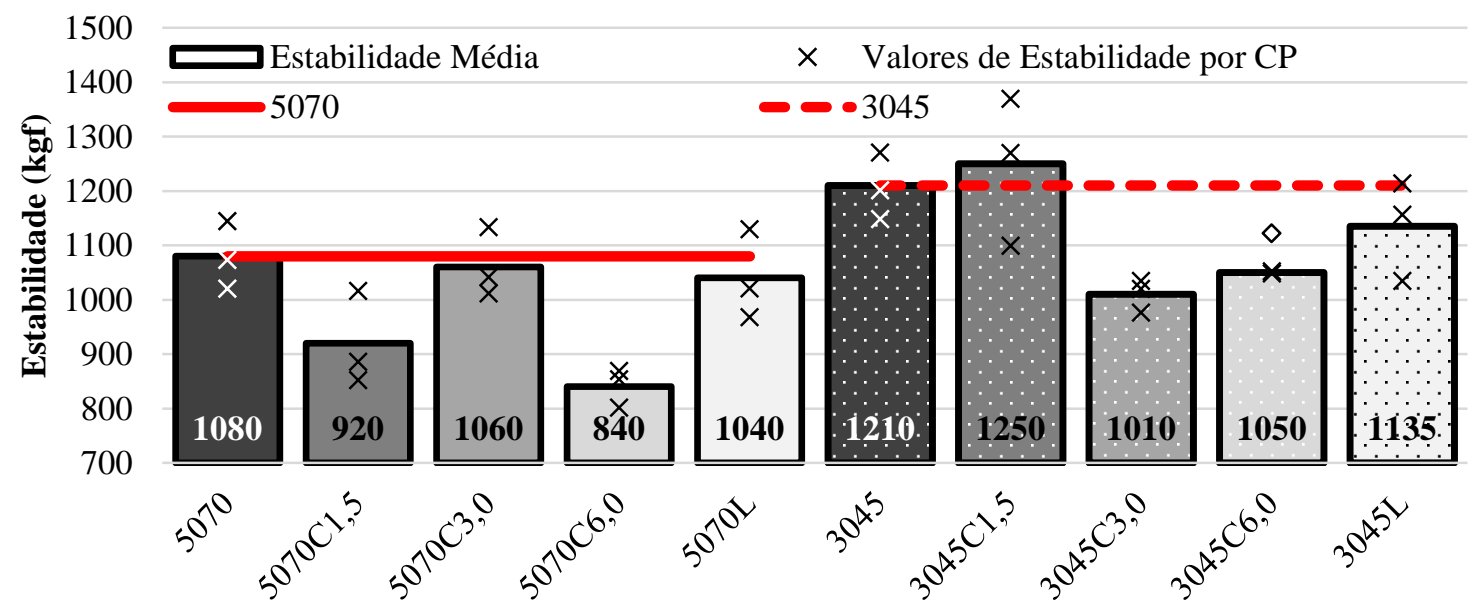

Figura 4.9 - Estabilidade por tipo de mistura asfáltica para $\mathrm{P}_{\mathrm{b}}=5,5 \%$ 
Ao se avaliar a Figura 4.9, verifica-se que as misturas de referência, via de regra, apresentaram os maiores valores de estabilidade. Isto indica que a adição de caulim ou cal, independentemente do tipo de ligante asfáltico, reduziu a estabilidade das misturas. As reduções na estabilidade em função da adição de caulim são de maior magnitude que as reduções de estabilidade em função da adição de cal. Todavia, não foi possível identificar tendência de que à medida que se elevou o teor de caulim, reduziu-se proporcionalmente a estabilidade. Redução na estabilidade de misturas asfálticas com a adição de caulim já havia sido relatada por Zulkati, Diew e Delai (2012). As misturas com CAP 30/45 exibiram maior estabilidade quando comparadas às misturas corrrelatas com CAP 50/70. Este comportamento pode ser atribuído à maior viscosidade do CAP 30/45.

Os testes t (Apêndice C) revelaram que: (i) o tipo de ligante asfáltico foi mais importante para diferenciar os valores de estabilidade do que o tipo de fíler; (ii) a estabilidade foi o parâmetro da dosagem Marshall que apresentou o maior número de casos em que as médias de valores entre as misturas asfálticas foram significativamente diferentes em função do tipo de ligante asfáltico (iii) as misturas 5070C6,0, 3045C3,0 e 3045C6,0 caulim apresentaram estabilidade significativamente diferente em relação às misturas de referência.

\subsubsection{Influência do tipo de fíler e do tipo de ligante asfáltico na fluência}

Na Figura 4.10 são apresentados dois gráficos que ilustram a influência do tipo de fíler e do tipo de ligante asfáltico na fluência, no intervalo de $5,0 \% \leq \mathrm{P}_{\mathrm{b}} \leq 6,0 \%$.
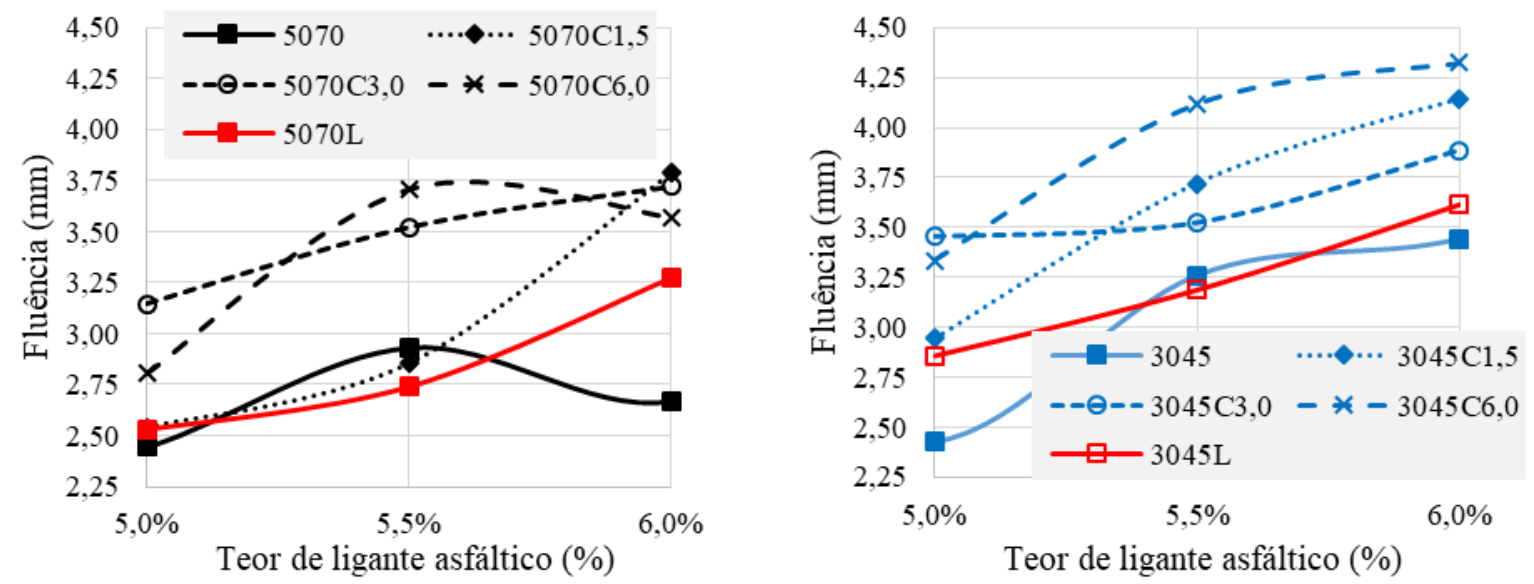

Figura 4.10 - Influência do tipo de fíler e do tipo de ligante asfáltico na fluência, para $5,0 \% \leq \mathrm{P}_{\mathrm{b}} \leq$ $6,0 \%$ 
O comportamento típico desse parâmetro é o aumento da fluência à medida que se aumenta o $\mathrm{P}_{\mathrm{b}}$. Todas as misturas exibiram o comportamento padrão, exceto 5070 e 5070C6,0 que apresentaram pontos de máximo nos gráficos de fluência.

De modo geral, a adição de caulim provocou aumento na fluência, resultando em maior deformação nas misturas. A adição de cal reduziu a fluência somente na condição de $\mathrm{P}_{b}=5,5 \%$, tendo provocado aumento de fluência nos demais teores de asfalto. O uso de CAP 30/45 (tipo de ligante asfáltico) provocou aumento nos valores de fluência.

Na Figura 4.11 são mostrados os valores médios de fluência para cada tipo de mistura, os valores individuais de cada CP utilizado no cálculo da média e linhas que representam o valor da fluência das misturas de referência. Observa-se que há dois pontos, um na mistura 5070 e outro na mistura 3045C3,0, ambos representados por losangos, que foram excluídos do cálculo da média da fluência destas misturas por serem considerados como outliers pelo teste de Grubbs, cujos valores significativamente mais baixos que os demais.

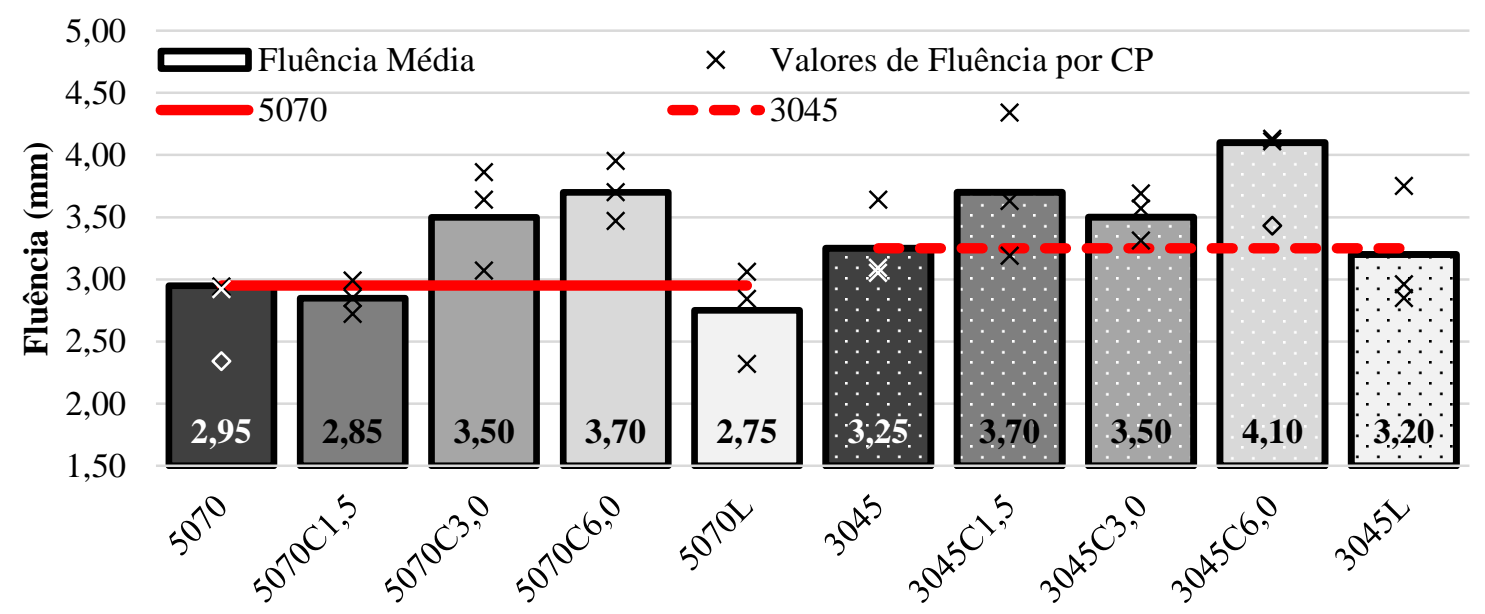

Figura 4.11 - Fluência por tipo de mistura asfáltica para $\mathrm{P}_{\mathrm{b}}=5,5 \%$

Ao se interpretar as informações da Figura 4.11, percebe-se que as misturas de referência, via de regra, apresentaram menores valores de fluência quando comparadas às misturas contendo caulim. Foi possível perceber também uma discreta relação de linearidade entre o aumento do teor de caulim e o aumento nos valores de fluência, especialmente para as misturas com CAP 50/70. A adição de cal, ao contrário da adição de caulim, reduziu a fluência. O uso de CAP 30/45 elevou a fluência em todas as comparações, exceto 5070C3,0 x 3045C3,0, indicando que 
o uso de ligante mais consistente, paradoxalmente, resultou em misturas com maior deformação.

Tal resultado pode ser compreendido à luz do Quociente Marshall (QM), apresentado na Tabela 4.5, que faz a relação entre a estabilidade e a fluência. Como os CPs das misturas com CAP 30/45 suportam maiores cargas (maior estabilidade), acabam deformando mais (maior fluência), e assim se mantém o quociente Marshall com pequena variação, em função do tipo de ligante asfáltico. Analisando os dados da Tabela 4.5 em função do tipo de fíler, percebe-se que os valores de quociente Marshall das misturas de referência e com cal são semelhantes entre si e consideravelmente superiores aos valores das misturas contendo caulim. O quociente Marshall das misturas com 6,0\% de caulim são os mais baixos, indicando que é necessário um menor valor de carga para produzir uma importante deformação na mistura, constituindo, assim, mais um mau resultado da adição de $6,0 \%$ caulim.

$\underline{\text { Tabela } 4.5 \text { - Valores dos quocientes Marshall para teor de ligante asfáltico }=5,5 \%}$

\begin{tabular}{ccccc}
\hline Mistura & $\begin{array}{c}\text { Quociente } \\
\text { Marshall } \\
\text { (kgf/mm) }\end{array}$ & Mistura & $\begin{array}{c}\text { Quociente } \\
\text { Marshall } \\
\text { (kgf/mm) }\end{array}$ & $\begin{array}{c}\text { Variação de QM } \\
\text { CAP 30/45 / } \\
\text { CAP 50/70 }\end{array}$ \\
\hline 5070 & 366 & 3045 & 372 & $+1,70 \%$ \\
$5070 \mathrm{C} 1,5$ & 323 & $3045 \mathrm{C} 1,5$ & 338 & $+4,66 \%$ \\
$5070 \mathrm{C} 3,0$ & 303 & $3045 \mathrm{C} 3,0$ & 289 & $-4,72 \%$ \\
$5070 \mathrm{C} 6,0$ & 227 & $3045 \mathrm{C} 6,0$ & 256 & $+12,80 \%$ \\
$5070 \mathrm{~L}$ & 378 & $3045 \mathrm{~L}$ & 355 & $-6,21 \%$ \\
\hline
\end{tabular}

Os testes $\mathrm{t}$ (Apêndice C) apontaram que: (i) o tipo de fíler foi mais importante para diferenciar os valores de fluência do que o tipo de ligante asfáltico; (ii) a fluência foi o parâmetro da dosagem Marshall que apresentou o menor número de casos em que as médias de valores entre as misturas asfálticas foram significativamente diferentes seja em função do tipo de ligante asfáltico, seja em função do tipo de fíler, e; (iii) apenas as misturas com 6,0\% de caulim apresentaram fluência significativamente diferente em relação às misturas de referência.

\subsubsection{Observações adicionais}

Os parâmetros volumétricos Vv, VAM e RBV e, em consequência, o teor de projeto, foram mais afetados pelo tipo de fíler do que pelo tipo de ligante asfáltico. Também foi possível constatar que as misturas com 1,5\% de caulim e as misturas de referência apresentaram parâmetros volumétricos semelhantes entre si, assim como as misturas 5070C6,0 $x$ 5070L e 
3045C3,0 $x$ 3045L. Atribui-se esse comportamento ao fato destas misturas possuírem os mesmos teores de projeto.

Nos parâmetros mecânicos da dosagem, estabilidade e fluência, houve maior influência do tipo de ligante asfáltico. Foram detectados comportamentos mecânicos diferentes em misturas que possuem parâmetros volumétricos muito similares tais como misturas de referência x misturas com 1,5 de caulim, 5070C6,0 x 5070L e 3045C3,0 x 3045L. Além disso, as misturas contendo caulim apresentaram menores valores de estabilidade e maiores valores de fluência quando comparadas às misturas de referência e com cal. Estes resultados indicam que o tipo de fíler pode alterar as propriedades mecânicas das misturas asfálticas. Tais verificações serão efetuadas nas Etapas 2 e 3 da pesquisa.

Os testes $\mathrm{t}$ indicaram que as misturas contendo 1,5 e 3,0\% de caulim apresentaram valores médios de Vv, VAM, RBV, estabilidade e fluência que puderam ser considerados estatisticamente iguais aos das misturas de referência. Adicionalmente, estas misturas exibiram comportamento típico nos gráficos das dosagens Marshall.

Quando se adicionou 6,0\% de caulim, independentemente do tipo de ligante asfáltico, os valores de todos os parâmetros das dosagens Marshall foram significativamente diferentes dos valores das misturas 5070 e 3045, sendo que a mudança foi sempre negativa (maior Vv, menor estabilidade, maior fluência). Além disso, a mistura 3045C6,0 ainda apresentou comportamentos atípicos nos gráficos de VAM e estabilidade. Tudo isso concorre para se recomendar a adição de caulim em teores de até 3,0\% e contraindicar o percentual de $6 \%$.

\subsubsection{Análise da influência dos parâmetros de caracterização do fíler nos parâmetros das dosagens Marshall}

Os parâmetros de caracterização do fíler (teor de caulim, D10, D30, D60 e módulo de finura) influenciaram os parâmetros das dosagens Marshall, o que foi avaliado por meio de regressão linear e coeficiente de determinação $\left(\mathrm{R}^{2}\right)$, a exemplo de Assis et al. (2017), cujos procedimentos estão descritos no Apêndice D. Para melhor interpretação dos resultados as correlações foram realizadas em três cenários considerando os dados das misturas (i) com CAP 50/70; (ii) com CAP 30/45, e; (iii) com ambos tipos de CAP. 
Na Tabela 4.6 são apresentados os valores de $\mathrm{R}^{2}$ das regressões lineares efetuadas entre os parâmetros de caracterização do fíler versus variáveis-resposta (TP, Vv, $\mathrm{G}_{\mathrm{mm}}, \mathrm{G}_{\mathrm{mb}}, \mathrm{VAM}, \mathrm{RBV}$, estabilidade e fluência) e indicação se a relação entre as variáveis é direta (+) ou inversamente proporcional (-). Apenas os valores em negrito indicam que há relação linear entre as variáveis, a um nível de significância de 5\%, segundo a análise de variância (teste do valor da estatística F, conforme Apêndice D). É interessante observar que há casos, por exemplo, VAM CAP 30/45 versus teor de caulim que apresentaram valores de $R^{2}$ elevados $\left(R^{2}=0,89\right)$, no entanto não passaram no teste de avaliação de correlação linear entre as variáveis. Isto é explicado pelo reduzido número de pares de pontos para gerar os modelos de regressão linear nesta condição.

Tabela 4.6 - Valores de $\mathrm{R}^{2}$ das regressões lineares entre parâmetros de caracterização do fíler versus variáveis-resposta da Etapa 1

\begin{tabular}{|c|c|c|c|c|c|}
\hline Variável-resposta & $\begin{array}{l}\text { Teor de } \\
\text { Caulim }\end{array}$ & D10 & D30 & D60 & MF \\
\hline TP CAP 50/70 & 0,77 & 0,01 & 0,13 & 0,19 & 0,11 \\
\hline TP CAP 30/45 & 0,89 & 0,24 & 0,51 & 0,59 & 0,49 \\
\hline $\mathrm{TP}$ todas as misturas & $0,73(+)$ & $0,09(-)$ & $0,29(-)$ & $0,36(-)$ & $0,27(-)$ \\
\hline Vv CAP 50/70 & 0,54 & 0,04 & 0,18 & 0,24 & 0,17 \\
\hline Vv CAP 30/45 & 0,79 & 0,33 & 0,58 & 0,64 & 0,56 \\
\hline Vv todas as misturas & $0,61(+)$ & $0,17(-)$ & $0,36(-)$ & $0,42(-)$ & $0,34(-)$ \\
\hline $\mathrm{G}_{\mathrm{mm}}$ CAP 50/70 & 0,06 & 0,26 & 0,17 & 0,14 & 0,18 \\
\hline $\mathrm{G}_{\mathrm{mm}} \mathrm{CAP} 30 / 45$ & 0,36 & 0,36 & 0,40 & 0,40 & 0,40 \\
\hline $\mathrm{G}_{\mathrm{mm}}$ todas as misturas & $0,10(+)$ & $0,24(-)$ & $0,19(-)$ & $0,17(-)$ & $0,19(-)$ \\
\hline $\mathrm{G}_{\mathrm{mb}}$ CAP 50/70 & 0,89 & 0,01 & 0,04 & 0,09 & 0,03 \\
\hline $\mathrm{G}_{\mathrm{mb}} \mathrm{CAP} 30 / 45$ & 0,83 & 0,33 & 0,59 & 0,66 & 0,57 \\
\hline $\mathrm{G}_{\mathrm{mb}}$ todas as misturas & $0,63(-)$ & $0,08(+)$ & $0,26(+)$ & $0,32(+)$ & $0,24(+)$ \\
\hline VAM CAP 50/70 & $0,94(+)$ & 0,00 & 0,12 & 0,19 & 0,10 \\
\hline VAM CAP 30/45 & 0,89 & 0,42 & 0,69 & 0,75 & 0,67 \\
\hline VAM todas as misturas & $0,69(+)$ & $0,15(-)$ & $0,36(-)$ & $0,42(-)$ & $0,34(-)$ \\
\hline RBV CAP 50/70 & 0,46 & 0,07 & 0,21 & 0,25 & 0,19 \\
\hline RBV CAP 30/45 & 0,74 & 0,35 & 0,57 & 0,62 & 0,55 \\
\hline $\mathrm{RBV}$ todas as misturas & $0,56(-)$ & $0,19(+)$ & $0,37(+)$ & $0,42(+)$ & $0,35(+)$ \\
\hline Estabilidade CAP 50/70 & 0,52 & 0,48 & 0,56 & 0,56 & 0,56 \\
\hline Estabilidade CAP 30/45 & 0,53 & 0,29 & 0,45 & 0,48 & 0,43 \\
\hline Estabilidade todas as misturas & $0,33(-)$ & $0,24(+)$ & $0,31(+)$ & $0,32(+)$ & $0,31(+)$ \\
\hline Fluência CAP 50/70 & 0,80 & $0,84(-)$ & $0,83(-)$ & $\mathbf{0 , 8 0}(-)$ & $\mathbf{0 , 8 4}(-)$ \\
\hline Fluência CAP 30/45 & 0,79 & $0,83(-)$ & $0,83(-)$ & $0,79(-)$ & $\mathbf{0 , 8 3}(-)$ \\
\hline Fluência todas as misturas & $0,59(+)$ & $\mathbf{0 , 6 3}(-)$ & $0,63(-)$ & $\mathbf{0 , 6 0}(-)$ & $0,63(-)$ \\
\hline
\end{tabular}

De posse dos dados da Tabela 4.6, verificou-se que à medida que se eleva o teor de caulim há tendência de elevação dos parâmetros $\mathrm{TP}, \mathrm{Vv}, \mathrm{G}_{\mathrm{mm}}$, VAM e fluência e de redução dos parâmetros $\mathrm{G}_{\mathrm{mb}}, \mathrm{RBV}$ e estabilidade. Antagonicamente, à medida que se elevam os valores de D10, D30, D60 e MF, ou seja, quanto mais grosso for o fíler, há tendência de elevação nos valores de $G_{m b}$, RBV e estabilidade e de redução em TP, Vv, $G_{m m}$, VAM e fluência. 
O parâmetro de caracterização do fíler que melhor se correlacionou com as variáveis-resposta das dosagens Marshall foi o teor de caulim. Quando se analisam os dados de todas as misturas, há moderadas correlações $\left(0,56<\mathrm{R}^{2}<0,73\right)$ entre o teor de caulim versus: TP, Vv, $\mathrm{G}_{\mathrm{mb}}, \mathrm{VAM}$, RBV e fluência. O teor caulim das misturas com CAP 50/70 tem excelente correlação diretamente proporcional com o VAM $\left(\mathrm{R}^{2}=0,94\right)$.

Os parâmetros D10, D30, D60 e módulo de finura conseguiram explicar apenas a variação da fluência, não se correlacionando linearmente com os demais parâmetros das dosagens Marshall. Houve boas correlações $\left(0,79<\mathrm{R}^{2}<0,84\right)$ de D10, D30, D60 e MF com a fluência das misturas com CAP 50/70 ou com CAP 30/45. Quando se consideram todas as misturas, a qualidade da correlação passou a ser apenas moderada $\left(0,60<\mathrm{R}^{2}<0,63\right)$. As relações são sempre inversamente proporcionais, isto é, quanto menores forem os valores de D10, D30, D60 e MF e, portanto, quanto mais fino for o fíler, maior será o valor da fluência.

O parâmetro das dosagens Marshall cujas diferenças de valores são mais bem explicadas pelos parâmetros de caracterização do fíler é a fluência, visto que todos os parâmetros de caracterização do fíler se correlacionaram com ela. Por outro lado, a $G_{m m}$ e a estabilidade não apresentaram quaisquer correlações lineares com os parâmetros de caracterização do fíler.

É interessante destacar que os resultados das análises estatísticas à luz dos parâmetros de caracterização do fíler ratificaram os resultados das análises qualitativas à luz do tipo de ligante asfáltico e do tipo de fíler, pois, para as 5 variáveis-respostas (TP, Vv, VAM, RBV e fluência) nas quais o tipo de fíler foi a variável de entrada mais importante, também foram identificadas correlações com os parâmetros de caracterização do fíler. Para a única variável-resposta que é mais afetada pelo tipo de ligante asfáltico, a estabilidade, não se encontraram correlações com os parâmetros de caracterização do fíler.

\subsubsection{Consolidação dos resultados da Etapa 1}

Quanto ao teor de projeto:

As dosagens Marshall permitiram definir os teores de projetos das 10 misturas asfálticas. Nas misturas de referência, nas misturas com 1,5\% de caulim e 5070C3,0 o TP =5,3\%. Nas misturas com cal, 5070C6,0 e 3045C3,0 o TP = 5,5\%. A mistura 3045C6,0 apresentou $\mathrm{TP}=5,6 \%$. 
Quanto à avaliação da viabilidade técnica preliminar do rejeito de caulim como fíler em concretos asfálticos:

Todas as misturas asfálticas atenderam à especificação técnica do DER/SP, no que tange a: teor de ligante asfáltico, Vv, VAM, RBV, estabilidade e fluência. A única exceção foi a mistura 3045C6,0 que apresentou fluência acima do limite normativo. As misturas com 6,0\% de caulim apresentaram vários pontos negativos tais como TP mais alto, diminuição da estabilidade, aumento do Vv e da fluência e alguns comportamentos atípicos nos gráficos das dosagens Marshall.

Dentre os teores testados, é possível considerar viável o uso de rejeito de caulim como fíler em misturas asfálticas, desde que o teor de adição seja de até 3,0\%. A análise de viabilidade técnica será concluída ao final da Etapa 2 com a análise dos resultados dos ensaios de RT e DUI.

> Quanto à avaliação da influência dos fatores tipo de ligante asfáltico, tipo de fíler e parâmetros de caracterização do fíler nos parâmetros das dosagens Marshall (TP, Vv, $\mathrm{G}_{\mathrm{mb}}, \mathrm{G}_{\mathrm{mm}}, \mathrm{RBV}, \mathrm{VAM}$, Estabilidade e Fluência).

A adição de caulim (tipo de fíler) teve maior impacto no aumento dos valores de fluência. $\mathrm{O}$ caulim também contribuiu para elevar os valores TP, Vv e VAM e reduzir os valores de estabilidade e RBV. Não foram encontradas alterações significativas de $G_{m m}$ e $G_{m b}$ com a adição de caulim. Grosso modo, à luz do teste t, pode-se dizer que as misturas com 1,5\% e 3,0\% de caulim exibiram valores dos parâmetros das dosagens Marshall iguais aos valores das misturas de referência. Apenas as misturas com 6,0\% de caulim apresentaram parâmetros das dosagens Marshall com valores significativamente diferentes das misturas de referência.

O uso de cal (tipo de fíler) teve maior influência no aumento de Vv. A adição de cal elevou os valores de TP e VAM e reduziu os valores de estabilidade, fluência e RBV. Não foram encontradas alterações significativas de $\mathrm{G}_{\mathrm{mm}}$ e $\mathrm{G}_{\mathrm{mb}}$ com a adição de cal.

O uso de CAP 30/45 (tipo de ligante asfáltico) teve influência mais importante no aumento da estabilidade. Ele também contribuiu para elevar os valores de fluência, Vv, TP e VAM. Não foram encontradas alterações significativas de $\mathrm{RBV}, \mathrm{G}_{\mathrm{mm}}$ e $\mathrm{G}_{\mathrm{mb}}$ com o tipo de ligante asfáltico.

O parâmetro de caracterização do fíler que melhor explicou o comportamento da variação dos parâmetros das dosagens Marshall foi o teor de caulim, o qual apresentou correlação linear 
válida diretamente proporcional com TP, Vv, VAM e fluência e inversamente proporcional com $\mathrm{G}_{\mathrm{mb}}$ e RBV. O pior parâmetro de caracterização do fíler foi D10, em virtude de ter apresentado, de modo geral, o menor valor de $\mathrm{R}^{2}$ nas análises realizadas. A fluência foi a variável-resposta mais bem explicada pelos parâmetros de caracterização do fíler. Por outro lado, a variação de valores de $\mathrm{G}_{\mathrm{mm}}$ e estabilidade entre as diferentes misturas asfálticas não foi bem explicada pelos parâmetros de caracterização do fíler.

\subsection{CARACTERIZAÇÃO MECÂNICA BÁSICA - ETAPA 2}

A Caracterização Mecânica Básica foi efetuada com dois objetivos:

Completar a análise de viabilidade técnica do rejeito de caulim como fíler em concretos asfálticos com base em requisitos Marshall (RT e DUI);

$>$ Avaliar a influência do tipo de fíler, tipo de ligante asfáltico e parâmetros de caracterização do fíler nos valores de MR, RT, e dos parâmetros do ensaio de DUI.

São apresentados e discutidos os resultados dos ensaios de módulo de resiliência a $25^{\circ} \mathrm{C}$, resistência a tração por compressão diametral e dano por umidade induzida. Cabe ressaltar que nesta etapa foram incluídos dois tipos de mistura asfáltica, 5070C3,0L e 3045C3,0L, cujos teores de projeto foram assumidos como sendo iguais às condições 5070C $3,0(5,3 \%) \mathrm{e}$ 3045C3,0 (5,5\%), respectivamente. Na Tabela 4.7, estão indicadas as misturas asfálticas da Etapa 2. Todos os CPs foram moldados nos teores de projeto definidos na Etapa 1, os quais estão indicados entre parênteses abaixo do nome da mistura.

Tabela 4.7 - Descrição das misturas asfálticas utilizadas na Etapa 2, com indicação do TP

\begin{tabular}{ccccccc}
$\begin{array}{l}\text { Tipo } \\
\text { de ligante }\end{array}$ & Granito & $\begin{array}{c}\mathbf{1 , 5 \%} \text { de } \\
\text { caulim }\end{array}$ & $\begin{array}{c}\mathbf{3 , 0 \%} \text { de } \\
\text { caulim }\end{array}$ & $\begin{array}{c}\mathbf{6 , 0 \%} \text { de } \\
\text { caulim }\end{array}$ & $\begin{array}{c}\mathbf{1 , 5 \%} \text { de } \\
\text { cal }\end{array}$ & $\begin{array}{c}\mathbf{3 , 0 \%} \text { de } \\
\text { caulim + } \\
\mathbf{1 , 5 \%} \text { de } \\
\text { cal }\end{array}$ \\
\hline $\begin{array}{c}\text { CAP 50/70 } \\
\text { (TP) }\end{array}$ & 5070 & $5070 \mathrm{C} 1,5$ & $5070 \mathrm{C} 3,0$ & $5070 \mathrm{C} 6,0$ & $5070 \mathrm{~L}$ & $5070 \mathrm{C} 3,0 \mathrm{~L}$ \\
$\begin{array}{c}\text { CAP 30/45 } \\
\text { (TP) }\end{array}$ & $(5,3 \%)$ & $(5,3 \%)$ & $(5,3 \%)$ & $(5,5 \%)$ & $(5,5 \%)$ & $(5,3 \%)$ \\
& $(5,3 \%)$ & $3045 \mathrm{C} 1,5$ & $3045 \mathrm{C} 3,0$ & $3045 \mathrm{C} 6,0$ & $3045 \mathrm{~L}$ & $3045 \mathrm{C} 3,0 \mathrm{~L}$ \\
& $(5,3 \%)$ & $(5,5 \%)$ & $(5,6 \%)$ & $(5,5 \%)$ & $(5,5 \%)$ \\
\hline
\end{tabular}

As propriedades mecânicas foram analisadas em relação aos valores médios de três réplicas. As exceções a esta regra estão indicadas no texto. O Apêndice $E$ traz os valores relativos às dimensões, volume de vazios e propriedades mecânicas de cada corpo de prova utilizado da Etapa 2, agrupados por tipo de mistura asfáltica. Os CPs destinados aos ensaios de MR e RT 
foram produzidos com 75 golpes do soquete Marshall de modo a atingir Vv $=4 \pm 1 \%$, e os CPs destinados aos ensaios de DUI foram compactados com número variável de golpes (Tabela 3.8) de modo a atingir $\mathrm{Vv}=7 \pm 1 \%$.

A estrutura de apresentação e análise dos resultados inicia pela exposição dos valores médios da propriedade mecânica (MR, RT, RRT e RMR), seguida da análise técnica da influência do tipo de fíler e do tipo de ligante asfáltico nos valores da propriedade em estudo e da verificação se as misturas atendem aos valores mínimos normalizados para a propriedade em foco (viabilidade técnica do uso de rejeito de caulim como fíler). Posteriormente, faz-se a análise estatística da influência dos parâmetros de caracterização do fíler nos valores de MR, RT, RRT e RMR, e, em sequência, tecem-se considerações finais.

\subsubsection{Módulo de resiliência a $25^{\circ} \mathrm{C}$}

Apresentam-se, nesta seção, os resultados e análises dos ensaios de $\mathrm{MR}$ a $25^{\circ} \mathrm{C}$ que caracterizam a rigidez da mistura asfáltica para fins de análise mecanística. Na Figura 4.12, são mostrados os valores médios de módulo de resiliência de cada mistura, linhas que representam os MRs das misturas de referência e os valores individuais de cada CP utilizado no cálculo da média, que ilustram a grande dispersão dos resultados, inerente ao ensaio de MR. Nenhum valor foi excluído pelo método de Grubbs.

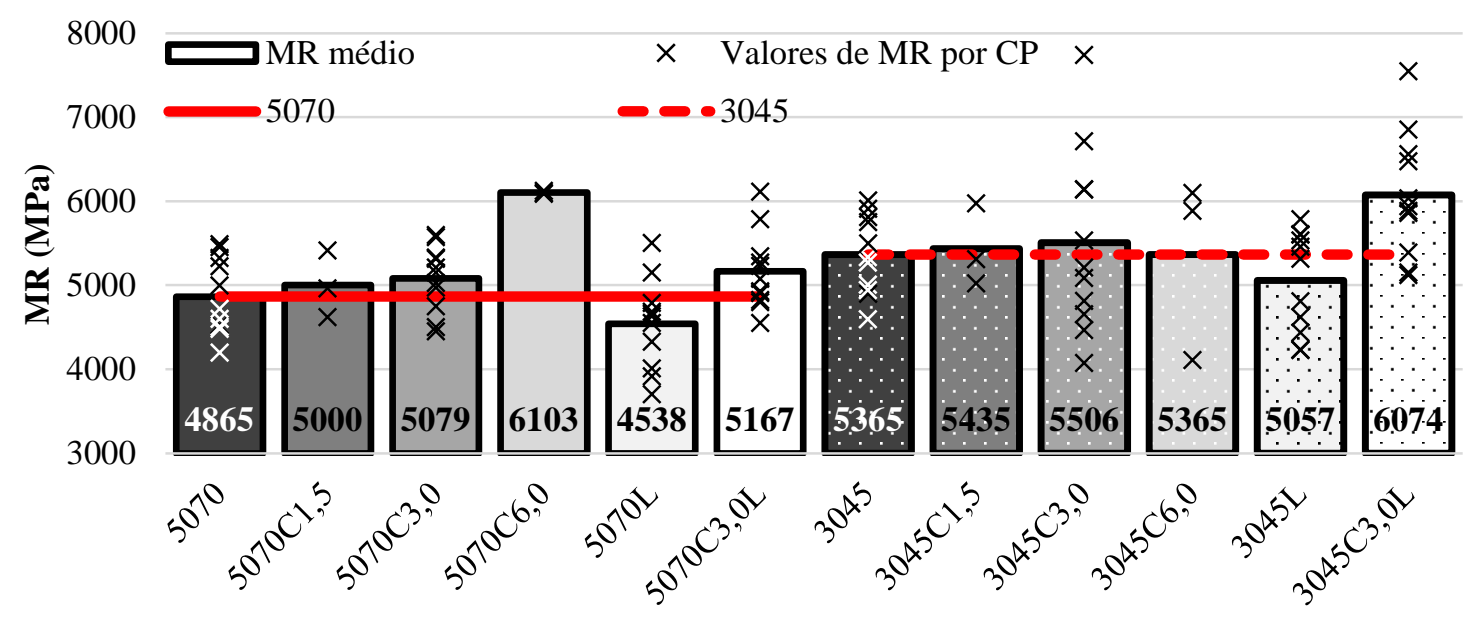

Figura 4.12 - Módulo de Resiliência à $25^{\circ} \mathrm{C}$ por tipo de mistura

A partir da Figura 4.12, observou-se, que a mistura 3045 apresentou MR 10\% superior ao MR da mistura 5070 e esta diferença foi significativa à luz do teste t de Student (Apêndice C). 
Atribuiu-se este resultado à maior consistência do CAP 30/45. A adição de caulim tendeu a elevar o MR, independentemente do tipo de CAP. Este resultado corrobora aquele encontrado por Lucena (2009) e pode ser explicado pelo provável enrijecimento do mástique, em virtude da elevada superfície específica do caulim. Foi possível identificar uma tendência de relação linear entre o MR e o teor de caulim, até 3,0\%. No teor de caulim de 6,0\%, os comportamentos foram antagônicos dependendo do tipo de ligante asfáltico, havendo aumento importante do MR na mistura com CAP 50/70 e a manutenção do valor de MR na mistura com CAP 30/45. À luz do teste t, os MRs das misturas contendo caulim são iguais aos das misturas de referência, exceto na condição 5070C6,0 cujo MR é significativamente superior ao da mistura 5070.

Ainda analisando a Figura 4.12, percebeu-se que a adição de cal provocou reduções de aproximadamente $6 \%$ nos valores de MR em relação às misturas de referência, independentemente do tipo de ligante asfáltico. A redução no valor de MR em função da adição de cal também foi encontrada por Anitelli (2013). Por outro lado, a adição simultânea cal e caulim elevou o MR em cerca de $10 \%$. Atribuiu-se este resultado ao enrijecimento do mástique com uso de fíler mais fino resultante da combinação granito + cal + caulim. Por fim, verificouse que o uso de CAP 30/45 elevou o MR em todas as situações, exceto na comparação 5070C6,0 $x$ 3045C6,0. Os testes t indicaram que o tipo de ligante asfáltico é mais importante para alterar os valores médios de MR do que o tipo de fíler.

Não há especificação normativa de valores limites para o MR, nem uma diretriz clara de que maiores valores de módulo são desejáveis ou contraindicados, pois esta avaliação depende da análise mecanística do pavimento. Assim, para ponderar a viabilidade técnica do uso de caulim como fíler em concreto asfáltico, partiu-se do princípio de que a adição de caulim não alterou de forma significativa a rigidez das misturas, exceto na condição 5070C6,0 onde o MR foi $25 \%$ superior à mistura de referência. Portanto, o comportamento de MR também é indício da viabilidade técnica do rejeito de caulim como fíler em concretos asfálticos.

\subsubsection{Resistência à tração por compressão diametral}

Nesta seção são apresentados os resultados e respectivas análises dos ensaios de resistência à tração por compressão diametral, cujos valores foram confrontados com os valores mínimos exigidos pela especificação do DER/SP, para avaliação da viabilidade técnica do uso de caulim como fíler em misturas asfálticas. Além disso, esses valores são referências para a definição 
das cargas a serem aplicadas nos ensaios de fadiga por compressão diametral à tensão controlada (Etapa 3).

Na Figura 4.13 são mostrados os valores médios de RT de cada mistura, os valores individuais de cada CP utilizado no cálculo das médias (pequena dispersão), linhas que representam os valores de RT das misturas de referência e o valor mínimo de RT exigido na dosagem pelo $\mathrm{DER} / \mathrm{SP}(\mathrm{RT} \geq 0,80 \mathrm{MPa})$. Houve a exclusão de um valor pelo método de Grubbs, na condição $3045 \mathrm{C} 1,5$, representado por um losango (valor significativamente maior que as outras réplicas).

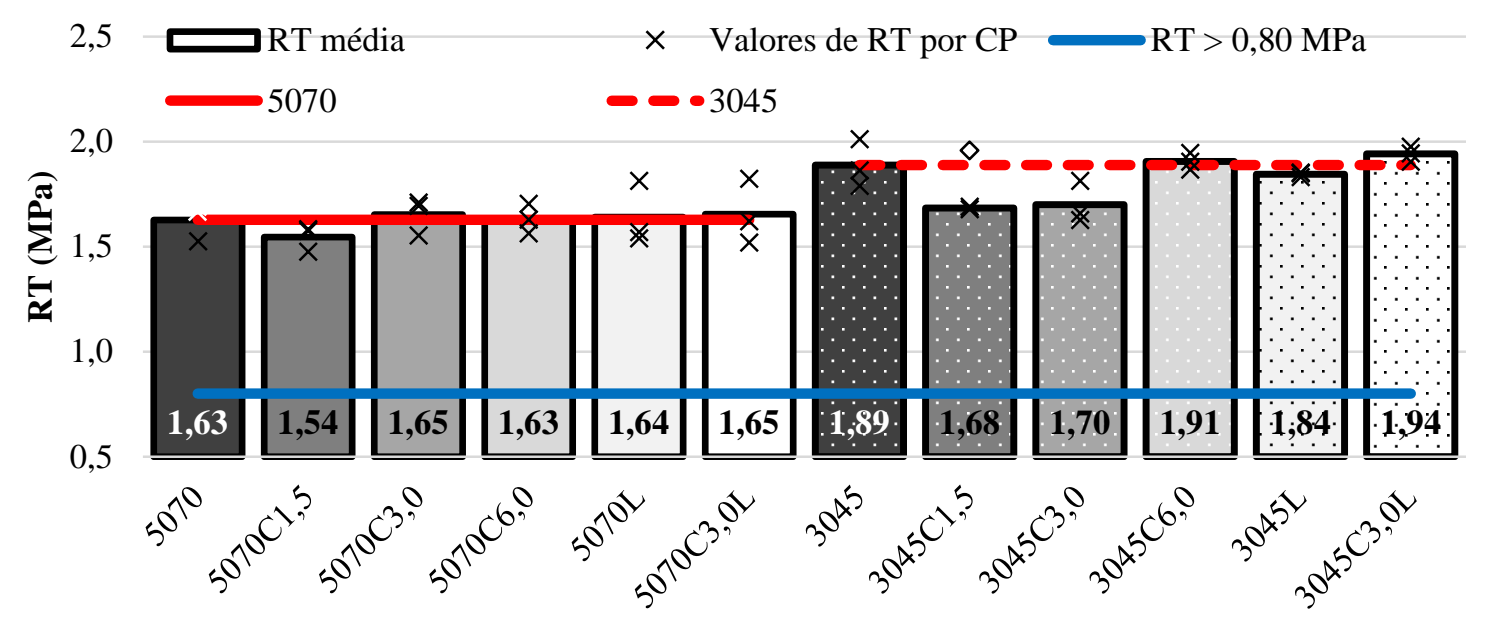

Figura 4.13 - Resistência à tração por tipo de mistura

Avaliando a Figura 4.13, observou-se que a mistura 3045 apresentou RT 16\% superior à RT da mistura 5070 e esta diferença foi significativa à luz do teste t de Student (Apêndice C). Uma vez mais, esse aumento foi atribuído à maior consistência do CAP 30/45. De modo geral, o tipo de fíler tem pouca influência nos valores de RT. Para as misturas com CAP 50/70, todas as RTs podem ser consideradas iguais, à luz do teste t. Nas misturas com CAP 30/45, 3045, 3045C6,0, 3045L e 3045C3,0L formam um "patamar" de valores da ordem de 1,90 MPa, enquanto que as misturas 3045C1,5 e 3045C3,0 formam outro "patamar", mais baixo, com valores da ordem de $1,70 \mathrm{MPa}$.

A adição de caulim tendeu a reduzir os valores de RT, como observado por Costa (2006). As misturas com 1,5\% de caulim apresentaram menor RT do que as misturas de referência e ambas misturas apresentam o mesmo teor de ligante asfáltico. Não se verificou maior nível de redução de RT nas misturas com maiores teores de caulim, uma vez que elas possuem maior teor de ligante asfáltico, o que favorece algum aumento de RT. É pertinente destacar que, mesmo com 
a tendência de redução nos valores de RT, todas as misturas contendo caulim atenderam, com folga, a RT mínima preconizada pelo DER/SP. Não foi possível perceber tendência de comportamento da RT em função da adição de cal e se observou tendência de pequena elevação da RT, estatisticamente insignificante, quando se adicionou simultaneamente caulim e cal.

O tipo de ligante asfáltico teve influência muito importante sobre os valores de RT. Todas as misturas contendo o CAP 30/45 apresentaram maior valor de RT em relação às misturas correspondentes com CAP 50/70. Os testes t (Apêndice C) indicaram que o tipo de ligante asfáltico foi mais importante do que o tipo de fíler para alterar os valores médios de RT.

A adição de caulim como fíler em misturas asfálticas também foi positiva quanto à RT, uma vez que todas as misturas contendo caulim apresentaram valores muito superiores ao mínimo exigido $(0,80 \mathrm{MPa})$.

\subsubsection{Relação MR/RT}

Com os valores de MR e RT, foi possível calcular a relação MR/RT, cujos valores por tipo de mistura asfáltica estão indicados na Figura 4.14. A relação MR/RT não constitui uma variávelresposta da pesquisa e, portanto, suas análises são simplificadas. Ela foi calculada a fim de verificar correlações entre esta propriedade e demais parâmetros da caracterização mecânica complementar, especialmente em relação aos resultados de vida de fadiga.

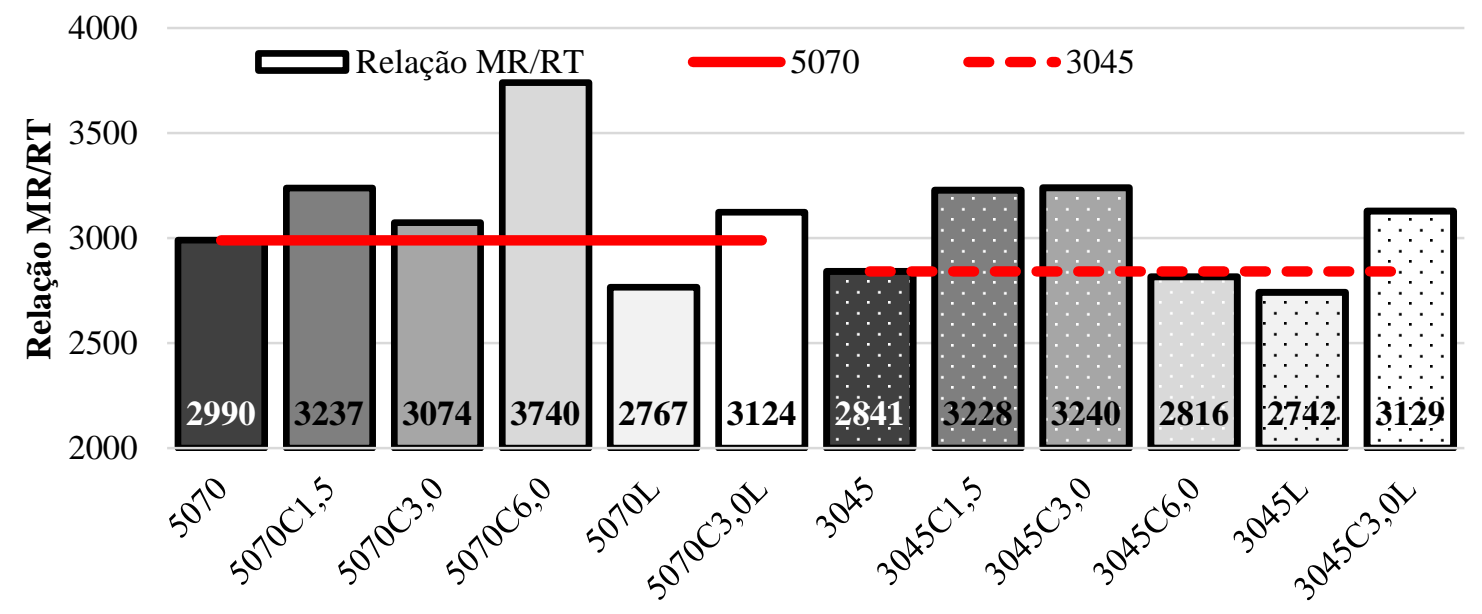

Figura 4.14 - Relação MR/RT por tipo de mistura 
Ao se interpretar os dados da Figura 4.14, percebe-se que a mistura de referência 3045 apresenta relação MR/RT menor ( 5\%) que a mistura 5070. A adição de caulim tendeu a elevar a relação MR/RT, porém não foi possível identificar uma tendência de linearidade entre o teor de caulim $x$ relação MR/RT. As misturas com cal apresentaram valores de relação MR/RT, em média, $5,5 \%$ menores que os das misturas de referência, enquanto que as misturas com adição simultânea de caulim e cal exibiram relação MR/RT maiores $(\sim 7,3 \%)$ que as misturas de referência. De modo geral, o comportamento da relação MR/RT em função do tipo de fíler é governado pela variação do MR, uma vez que os valores de RT, especialmente para as misturas com CAP 50/70, são praticamente iguais.

O uso de CAP 30/45 tendeu a reduzir a relação MR/RT. Este resultado é explicado em função dos valores mais altos de RT das misturas com CAP 30/45, fazendo com que esta relação seja menor nas misturas com este ligante, ainda que o MR seja maior.

\subsubsection{Dano por umidade induzida}

Na Tabela 4.8, é apresentado um resumo dos resultados dos ensaios utilizados para avaliar a susceptibilidade ao dano por umidade de todas as misturas asfálticas. Estão indicados os valores médios de volume de vazios, resistência à tração e módulo de resiliência antes e após o condicionamento térmico preconizado no ensaio de DUI, o grau de saturação (GS) do grupo condicionado e os parâmetros que medem a retenção das propriedades mecânicas após o ciclo térmico, ou seja, relações de resistência à tração (RRT) e de módulo de resiliência (RMR).

$\mathrm{O}$ volume de vazios atendeu ao intervalo de $7 \pm 1 \%$. As novas condições experimentais (5070C3,0L e 3045C3,0L), devido à má estimativa do número de golpes necessários para atingir $\mathrm{Vv} \approx 7 \%$, ficaram com volume de vazios inferior às demais condições. No entanto, como atenderam ao intervalo especificado na norma AASHTO T 283 e apresentaram os volumes de vazios dos grupos condicionado e de controle muito próximos, foram incluídos na análise sem a necessidade de uma nova moldagem de CPs. O GS foi mantido mais próximo ao limite inferior (55\%) pois neste nível de GS, atende-se simultaneamente as normas AASHTO T 283 e NBR 15617. 
Tabela 4.8 - Resultados dos ensaios de dano por umidade induzida

\begin{tabular}{|c|c|c|c|c|c|c|c|c|c|}
\hline \multirow[b]{2}{*}{$\begin{array}{c}\text { Condições } \\
\text { Experimentais }\end{array}$} & \multicolumn{3}{|c|}{ Sem Condicionamento } & \multicolumn{4}{|c|}{ Com Condicionamento } & \multirow[b]{2}{*}{$\begin{array}{c}\text { RRT } \\
(\%)\end{array}$} & \multirow[b]{2}{*}{$\underset{(\%)}{\text { RMR }}$} \\
\hline & $\begin{array}{l}\mathbf{V v} \\
(\%)\end{array}$ & $\begin{array}{c}\mathbf{R T}^{\mathbf{1}} \\
(\mathbf{M P a})\end{array}$ & $\begin{array}{c}\mathbf{M R}^{2} \\
(\mathrm{MPa})\end{array}$ & $\begin{array}{l}\mathrm{Vv} \\
(\%)\end{array}$ & $\begin{array}{c}\mathbf{R T}^{3} \\
(\mathbf{M P a})\end{array}$ & $\begin{array}{c}\mathrm{MR}^{4} \\
(\mathrm{MPa})\end{array}$ & $\begin{array}{l}\text { GS } \\
(\%)\end{array}$ & & \\
\hline 5070 & 7,2 & 1,32 & 3581 & 7,2 & 0,60 & 4294 & 65,7 & 45,5 & 119,9 \\
\hline $5070 \mathrm{C} 1,5$ & 7,2 & 1,34 & 3838 & 7,2 & 0,48 & 4332 & 66,9 & 35,8 & 112,9 \\
\hline $5070 \mathrm{C} 3,0$ & 7,6 & 1,19 & 3330 & 7,6 & 0,42 & 3689 & 58,1 & 35,3 & 110,8 \\
\hline $5070 \mathrm{C} 6,0$ & 7,3 & 1,37 & 4244 & 7,4 & 0,52 & 3767 & 62,8 & $\mathbf{3 8 , 0}$ & $\mathbf{8 8 , 8}$ \\
\hline $5070 \mathrm{~L}$ & 7,6 & 1,19 & 3612 & $7,8^{5}$ & $0,99^{5}$ & $4967^{5}$ & $60,4^{5}$ & 83,2 & 137,5 \\
\hline $5070 \mathrm{C} 3,0 \mathrm{~L}$ & 6,2 & 1,32 & 4061 & 6,3 & 1,04 & 3361 & 63,1 & 78,8 & 82,8 \\
\hline 3045 & 7,2 & 1,28 & 3340 & 7,1 & 0,69 & 3370 & 57,5 & $\mathbf{5 3 , 9}$ & 100,9 \\
\hline $3045 C 1,5$ & 7,3 & 1,33 & 3385 & 7,4 & 0,57 & 3539 & 61,9 & 42,9 & 104,5 \\
\hline $3045 C 3,0$ & 7,4 & 1,24 & 2926 & 7,5 & 0,59 & 3286 & 58,7 & 47.6 & 112,3 \\
\hline $3045 C 6,0$ & 7,0 & 1,46 & 4041 & $6,6^{5}$ & $0,93^{5}$ & $3933^{5}$ & $67,0^{5}$ & 63,7 & 97,3 \\
\hline $3045 \mathrm{~L}$ & 7,3 & 1,37 & 4074 & 7,3 & 1,23 & 4096 & 59,7 & 89,8 & 100,5 \\
\hline $3045 \mathrm{C} 3,0 \mathrm{~L}$ & 6,7 & 1,54 & 4089 & 6,9 & 1,28 & 3765 & 66,1 & 83,1 & 92,1 \\
\hline
\end{tabular}

A média de MR DUI-controle foi calculada com os dados de todos os 6 CPs utilizados no ensaio de

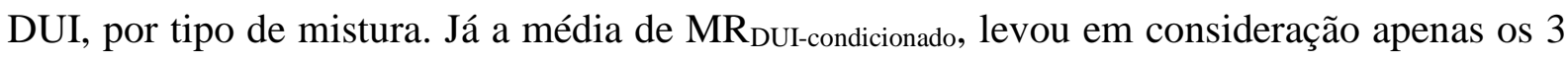
CPs do grupo condicionado, após o ciclo térmico.

\subsubsection{Relação de resistência à tração}

Os valores médios de RRT e o limite mínimo exigido são mostrados na Figura 4.15. A RRT variou de 35,3 (5070C3,0) a 89,8\% (3045L), ou seja, em nenhum tipo de mistura asfáltica houve ganho de RT após o condicionamento térmico. Somente as misturas contendo cal (L e C3,0L) atingiram o limite de $\mathrm{RRT} \geq 70 \%$.

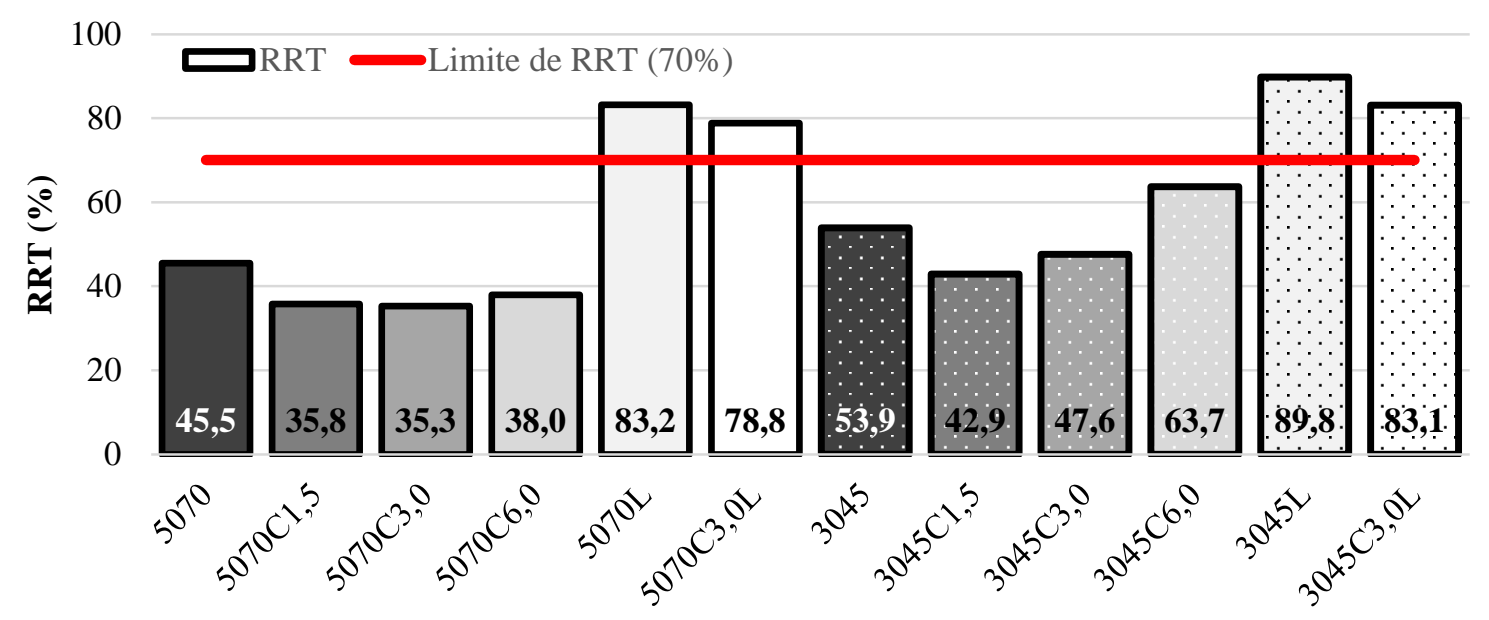

Figura 4.15 - Relação de Resistência à Tração 
O tipo de fíler, especialmente a adição de cal, teve impacto expressivo nos valores de RRT.

A A adição de caulim reduziu a RRT. Nas condições 5070C1,5, 5070C3,0 e 3045C1,5, ou seja, as que apresentam o mesmo teor de projeto (5,3\%) das misturas de referência, a redução de RRT foi da ordem de 21\%. Nas misturas com TP de 5,5\% (5070C6,0 e 3045C3,0) a redução de RRT provocada pela adição de caulim foi de cerca de $14 \%$. Apenas na condição 3045C6,0, com TP $=5,6 \%$, houve acréscimo de 18,2\% na RRT. Entretanto, este aumento de RRT pode estar relacionado ao menor volume de vazios do grupo condicionado em relação ao grupo de controle e ao maior teor de ligante dessa mistura e não à presença do caulim;

A adição de cal foi o parâmetro que mais alterou os valores de RRT, fazendo, inclusive, com que as misturas passem a atender o valor mínimo especificado (70\%). As misturas 5070L e 3045L apresentaram incrementos de 82,9 e 66,6\%, respectivamente, em suas RRTs em relação às misturas correlatas de referência;

A adição simultânea de cal e caulim também fez com que as misturas atendessem ao valor mínimo de RRT (70\%). No entanto, a presença de caulim reduziu as RRTs das condições 5070C3,0L e 3045C3,0L em relação às misturas 5070L e 3045L, respectivamente. A redução foi da ordem de $6 \%$.

Os efeitos positivos da adição de cal na redução da susceptibilidade ao dano por umidade são largamente reconhecidos no meio técnico e os resultados deste trabalho confirmam este benefício, ratificando, também, os resultados de Furlan (2006) e Anitelli (2013). Zulcati, Diew e Delai (2012) e Lucena (2009) relataram bons resultados de suscetibilidade à umidade com adição de caulim como fíler em misturas asfálticas, constituindo resultados divergentes dos aqui expostos. Por outro lado, Costa (2006) detectou que à medida que se elevou o teor de caulim nas misturas asfálticas, a RRT decresceu. Estes comportamentos antagônicos da adição de caulim em misturas com o mesmo agregado (granito) e ligantes asfálticos similares, pode, eventualmente, ser entendido à luz de alguma interação química entre os elementos da mistura, os quais não puderam ser aquilatados nos ensaios de dano por umidade induzida.

O tipo de ligante asfáltico tem influência muito importante sobre os valores de RRT. Todas as misturas contendo o CAP 30/45 apresentaram maiores RRTs em relação às misturas com CAP 50/70, em função da maior consistência do primeiro ligante asfáltico. A maior diferença ocorreu na condição $(\mathrm{C} 6,0)$ onde a mistura $3045 \mathrm{C} 6,0$ apresentou RRT $67,6 \%$ superior à mistura 
5070C6,0. A menor diferença ocorreu na condição (C3,0L) em que a mistura 3045C3,0L teve RRT apenas 5,5\% superior à mistura 5070C3,0L.

O protocolo da norma AASHTO T 283 exige a inspeção visual do plano de ruptura dos CPs. Na Figura 4.16 (a) estão mostrados CPs do grupo condicionado das misturas 3045, 3045C1,5, 3045C3,0, 3045C6,0 e 3045L, nessa ordem da esquerda para direita, de cima para baixo. É possível perceber que os CPs das 4 condições que não contém cal apresentaram vários pontos onde houve descolamento ou ruptura adesiva da película de ligante asfáltico, revelando os agregados (pontos em tonalidade rosa). O CP da mistura 3045L (inferior direito) apresentou quantidade bem menor de problemas de adesividade (superfície quase toda da cor preta do ligante asfáltico). Assim, a inspeção visual ratificou os resultados de RRT.

Na Figura 4.16 (b) comparam-se CPs das misturas 5070C3,0 (à esquerda) e 5070C3,0L (à direita) dos grupos de controle (superior) e condicionado (inferior). Ao se comparar os CPs do grupo condicionado (parte inferior) percebe-se que o CP da direita (com cal) possui menor quantidade de agregados expostos do que o $\mathrm{CP}$ da esquerda (sem cal), confirmando o resultado satisfatório de RRT das misturas que contém cal (L ou C3,0L).

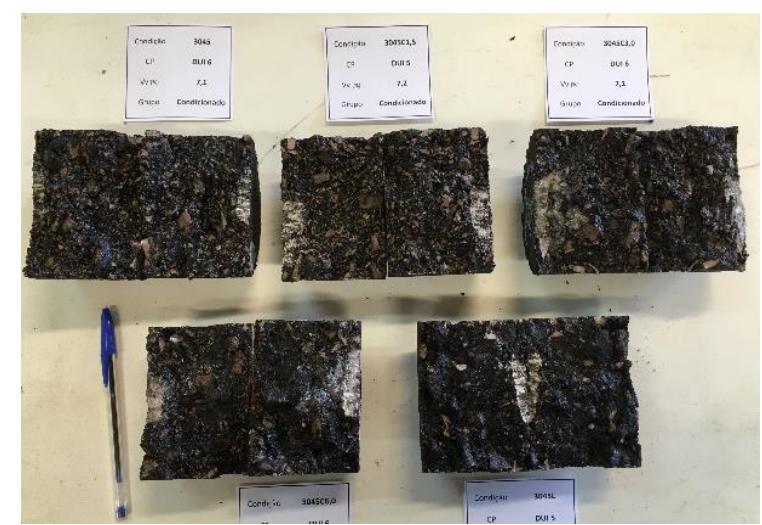

(a)

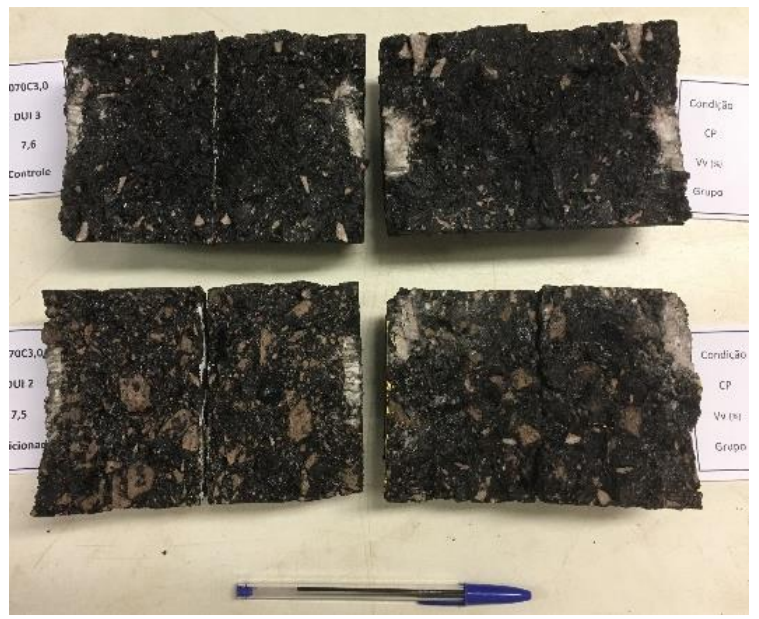

(b)

Figura 4.16 - Inspeção visual dos corpos de prova após o término do ensaio de DUI

Apenas as misturas contendo cal ( $\mathrm{L}$ ou C3,0L) atenderam ao valor mínimo de $\mathrm{RRT} \geq 70 \%$. Embora o caulim tenha reduzido os valores de RRT, entende-se que ele não é maior responsável pela elevada susceptibilidade ao dano por umidade das misturas, mas, sim, a baixa adesividade entre o agregado de granito e os ligantes asfálticos, visto que mesmo as misturas de referência não atingiram $\mathrm{RRT} \geq 70 \%$. 
4.2.3.2 Relação de módulo de resiliência

Os valores médios de RMR e a linha indicativa de RMR $=100 \%$ são indicados na Figura 4.17. A RMR variou de 82,8 (5070C3,0L) a 137,5\% (5070L). Nas misturas: de referência, C1,5, C3,0 e L, houve enrijecimento após o condicionamento térmico, ou seja, os valores de RMR são superiores a 100\%. Nas condições C6,0 e C3,0L, ocorreu redução na rigidez dos CPs após o condicionamento térmico, representado pelo valor de MR abaixo de $100 \%$.

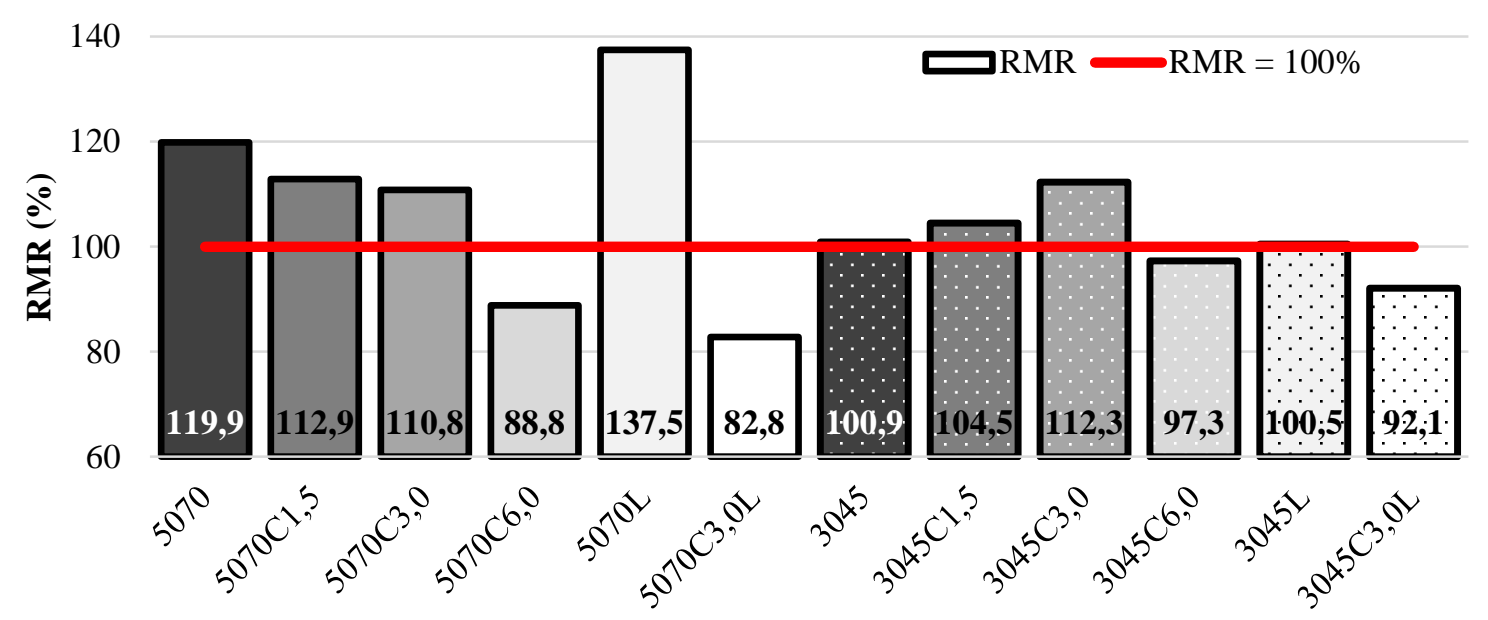

Figura 4.17 - Relação de Módulo de Resiliência

Sobre a influência do tipo de fíler na RMR, pode-se observar que:

Quando associada ao CAP 50/70, a adição de caulim diminuiu a RMR, sendo que, quanto maior o teor de caulim, menor o valor de RMR. Quando associada ao CAP 30/45, a adição de caulim aumentou a RMR nas condições C1,5 e C3,0 e reduziu RMR na condição C6,0;

$>$ Não se percebeu tendência de comportamento em relação à adição de cal. Nas misturas com CAP 50/70, a adição de cal elevou a RMR em 14,7\%. Nas misturas com CAP 30/45, o uso de cal praticamente não alterou a RMR;

A adição simultânea de cal e caulim reduziu os valores de RMR, para ambos os ligantes, evitando o enrijecimento das misturas após ciclo térmico.

Em relação ao tipo de ligante asfáltico, observou-se que as misturas com CAP 50/70 foram mais susceptíveis à variação do MR em decorrência do condicionamento térmico, uma vez que seus valores de RMR se afastaram mais da linha de RMR $=100 \%$, em comparação às misturas com CAP 30/45. Em outras palavras, as misturas com CAP 30/45 apresentaram alterações 
menos significativas em sua rigidez após o ciclo térmico do ensaio de DUI. Ao se analisar os valores de RMR em função do tipo de ligante asfáltico, houve 3 casos (C3,0, C6,0 e C3,0L) nos quais as misturas com CAP 30/45 apresentaram RMR superior às misturas com CAP 50/70. Nas outras 3 situações (referência, C1,5 e L) as misturas com CAP 50/70 tiveram relações de módulo de resiliência com valores mais altos.

Não há especificação normativa de valores limites para a relação de módulo de resiliência, sequer referências de valores adequados para este parâmetro. Assim, para ponderar sobre a viabilidade técnica do uso de caulim como fíler em concreto asfáltico, partiu-se do princípio de que os valores ideais da relação de módulo de resiliência fossem próximos de $100 \%$. Isto indicaria que a rigidez da mistura praticamente não é afetada pelo condicionamento térmico. Considerando que as RMRs das misturas com caulim estão próximas de $100 \%$, esse pode ser mais um indício da viabilidade técnica do rejeito de caulim como fíler em concretos asfálticos.

\subsubsection{Análise estatística da influência dos parâmetros de caracterização do fíler nos parâmetros da caracterização mecânica básica}

$\mathrm{Na}$ Tabela 4.9, são apresentados os valores de $\mathrm{R}^{2}$ das regressões lineares efetuadas entre os parâmetros de caracterização do fíler versus valores de $M R, R T$, relação $M R / R T, R R T$ e RMR e a indicação se a relação é direta (+) ou inversamente proporcional (-). Valores em negrito indicam que há relação linear entre as variáveis (Apêndice D).

Tabela 4.9 - Valores de $\mathrm{R}^{2}$ das regressões lineares entre parâmetros de caracterização do fíler versus parâmetros da caracterização mecânica básica

\begin{tabular}{cccccc}
\hline Variável-resposta & $\begin{array}{c}\text { Teor de } \\
\text { Caulim }\end{array}$ & D10 & D30 & D60 & MF \\
\hline MR CAP 50/70 & 0,89 & $\mathbf{0 , 8 8 ( - )}$ & $\mathbf{0 , 8 7}(-)$ & $\mathbf{0 , 8 1 ( - )}$ & $\mathbf{0 , 8 9}(-)$ \\
MR CAP 30/45 & 0,00 & 0,03 & 0,13 & 0,15 & 0,12 \\
MR todas as misturas & $0,41(+)$ & $0,34(-)$ & $0,41(-)$ & $0,40(-)$ & $0,41(-)$ \\
\hline RT CAP 50/70 & 0,11 & 0,00 & 0,05 & 0,08 & 0,04 \\
RT CAP 30/45 & 0,06 & 0,00 & 0,04 & 0,07 & 0,03 \\
RT todas as misturas & $0,03(+)$ & $0,00(+)$ & $0,01(-)$ & $0,02(-)$ & $0,01(-)$ \\
\hline MR/RT CAP 50/70 & 0,78 & $\mathbf{0 , 8 6}(-)$ & $\mathbf{0 , 7 5}(-)$ & $\mathbf{0 , 6 7}(-)$ & $\mathbf{0 , 7 7}(-)$ \\
MR/RT CAP 30/45 & 0,04 & 0,04 & 0,02 & 0,01 & 0,02 \\
MR/RT todas as misturas & $0,15(+)$ & $0,35(-)$ & $0,28(-)$ & $0,25(-)$ & $0,29(-)$ \\
\hline RRT CAP 50/70 & 0,26 & 0,46 & 0,09 & 0,03 & 0,11 \\
RRT CAP 30/45 & 0,40 & 0,18 & 0,00 & 0,01 & 0,00 \\
RRT todas as misturas & $0,03(+)$ & $0,29(+)$ & $0,03(+)$ & $0,00(+)$ & $0,04(+)$ \\
\hline RMR CAP 50/70 & $\mathbf{0 , 9 5}(-)$ & 0,47 & 0,66 & $\mathbf{0 , 6 8}(+)$ & 0,66 \\
RMR CAP 30/45 & 0,06 & 0,01 & 0,04 & 0,08 & 0,03 \\
RMR todas as misturas & $0,46(-)$ & $0,18(+)$ & $0,33(+)$ & $0,35(+)$ & $0,32(+)$ \\
\hline$--y$
\end{tabular}


Observando os sinais e valores de $\mathrm{R}^{2}$ da Tabela 4.9, referentes aos dados de todas as misturas, verificou-se que aumento do teor de caulim aumentou MR e, consequentemente, a relação MR/RT, no entanto, reduziu a RMR. À medida que se elevaram os valores de D10, D30, D60 e MF, ou seja, quanto mais grosso for o fíler, houve tendência de elevação na RMR e de redução no MR e na relação MR/RT.

Em nenhum caso houve correlação válida entre os valores de RT ou RRT e os parâmetros de caracterização do fíler, ou seja, estes parâmetros não conseguem explicar adequadamente as diferenças de valores de RT e RRT entre as misturas. Conforme relatado anteriormente, a variação de RT é melhor explicada pelo tipo de ligante asfáltico (também é explicada pela graduação do agregado, porém esta não variou) e a variação na RRT é melhor entendida pela adição de cal. No entanto, a cal modifica a RRT em função de suas propriedades químicas, não em função da granulometria representada por D10, D30, D60 e MF. Logo, as análises de regressão linear corroboraram as observações técnicas acerca da influência do tipo de fíler e tipo de ligante asfáltico nas propriedades mecânicas mensuradas na Etapa 2.

O teor de caulim apresentou excelente correlação $\left(R^{2}=0,95\right)$ inversamente proporcional com a RMR das misturas com CAP 50/70. Os parâmetros D10, D30, D60 e MF apresentaram boas e moderadas correlações $\left(0,67<\mathrm{R}^{2}<0,89\right)$ inversamente proporcionais ao MR e à relação MR/RT das misturas com CAP 50/70, ou seja, quanto mais fino for o fíler maiores serão os valores de $\mathrm{MR}$ e da relação $\mathrm{MR} / \mathrm{RT}$. Além disso, $\mathrm{D} 60$ apresentou moderada correlação $\left(\mathrm{R}^{2}=\right.$ 0,68) diretamente proporcional com a RMR das misturas com CAP 50/70, ou seja, uso de fíler mais grosso aumentou a RMR.

O parâmetro de caracterização do fíler que melhor explicou a variação das variáveis-resposta da Etapa 2 foi D60, pois apresentou correlações válidas com 3 parâmetros (MR, relação MR/RT e RMR), enquanto o teor de caulim teve o pior desempenho visto que se correlacionou apenas com RMR. Analisando as médias dos valores de $\mathrm{R}^{2}$ notou-se que o parâmetro da caracterização mecânica básica mais bem explicado pelos parâmetros de caracterização do fíler foi o MR, enquanto que a RT foi variável-resposta menos explicada por estes parâmetros. Assim, entendese que a granulometria e o tipo de fíler influenciam mais os valores de rigidez enquanto que a RT é majoritariamente regida pelo tipo de ligantes asfáltico. Fíleres mais finos enrijecem o mástique, o que se traduz em maior MR, porém exercem pouca influência na RT. 


\subsubsection{Consolidação dos resultados da Etapa 2}

Quanto ao complemento da análise de viabilidade técnica do rejeito de caulim como fíler em concretos asfálticos:

Todas as misturas contendo caulim atenderam ao valor mínimo de RT $(0,80 \mathrm{MPa})$ e apresentaram valores de MR e RMR sem alterações significativas em relação às misturas de referência. Entretanto, somente as misturas que contém cal (L e C3,0L) atenderam ao valor mínimo de resistência ao dano por umidade induzida (RRT $\geq 70 \%$ ). Assim, o uso de rejeito de caulim como fíler em concretos asfálticos com agregado de granito e ligantes asfálticos convencionais fica vinculado à adição concomitante de cal.

Quanto à análise da influência dos fatores tipo de fíler, tipo de ligante asfáltico e parâmetros de caracterização do fíler nas variáveis-resposta da caracterização mecânica básica.

Na Tabela 4.10 é apresentado um resumo sobre a influência dos fatores tipo de ligante asfáltico, tipo de fíler e parâmetros de caracterização do fíler nas variáveis-resposta MR, RT, RRT e RMR. As análises são comparativas em relação às misturas com CAP 50/70 para o tipo de ligante asfáltico e em relação às misturas de referência para o tipo de fíler. O sinal (+) indica que a presença de CAP 30/45; cal; caulim; cal e caulim simultaneamente aumentam os valores da variável-resposta em análise. Por outro lado, o sinal (-) denota que a presença de CAP 30/45; cal; caulim; cal e caulim simultaneamente reduzem os valores da propriedade em estudo.

Tabela 4.10 - Resumo da influência das variáveis de entrada nas variáveis-resposta da Etapa 2

\begin{tabular}{|c|c|c|c|c|c|}
\hline \multirow{3}{*}{$\begin{array}{l}\text { Variável } \\
\text { resposta }\end{array}$} & \multicolumn{5}{|c|}{ Influência das variáveis de entrada } \\
\hline & \multirow{2}{*}{$\begin{array}{c}\text { Tipo de } \\
\text { ligante } \\
\text { asfáltico }\end{array}$} & \multicolumn{3}{|c|}{ Tipo de fíler } & \multirow{2}{*}{$\begin{array}{c}\text { Parâmetros de } \\
\text { caracterização do } \\
\text { fíler }\end{array}$} \\
\hline & & Cal & Caulim & $\begin{array}{c}\text { Cal e } \\
\text { caulim }\end{array}$ & \\
\hline MR & $\begin{array}{l}\text { Importante } \\
\qquad(+)\end{array}$ & $\begin{array}{l}\text { Importante } \\
(-)\end{array}$ & $\begin{array}{l}\text { Importante } \\
(+)\end{array}$ & $\begin{array}{c}\text { Muito } \\
\text { Importante } \\
(+)\end{array}$ & $\begin{array}{c}\mathrm{D} 10, \mathrm{D} 30, \mathrm{D} 60 \text { e MF } \\
\text { muito importantes } \\
(\mathrm{CAP} 50 / 70)\end{array}$ \\
\hline RT & $\begin{array}{c}\text { Muito } \\
\text { Importante } \\
(+)\end{array}$ & Inconclusivo & $\begin{array}{l}\text { Importante } \\
(-)\end{array}$ & $\begin{array}{l}\text { Importante } \\
(+)\end{array}$ & Não importante \\
\hline RRT & $\begin{array}{l}\text { Importante } \\
(+)\end{array}$ & $\begin{array}{c}\text { Muito } \\
\text { Importante } \\
(+)\end{array}$ & $\begin{array}{c}\text { Importante } \\
(-)\end{array}$ & $\begin{array}{l}\text { Importante } \\
(+)\end{array}$ & Não importante \\
\hline RMR & Importante & Inconclusivo & $\begin{array}{l}\text { Importante } \\
(-)\end{array}$ & $\begin{array}{c}\text { Muito } \\
\text { Importante } \\
(-)\end{array}$ & $\begin{array}{l}\text { Teor de caulim - } \\
\text { muito importante e } \\
\text { D60 - importante } \\
(\text { CAP 50/70) }\end{array}$ \\
\hline
\end{tabular}


Em relação ao tipo de fíler, a adição de cal foi preponderante no aumento dos valores de RRT, fazendo com que as misturas atendessem ao limite de RRT $\geq 70 \%$. A adição de cal reduziu o MR e teve resultados inconclusivos em relação à RT e à RMR. A adição de caulim contribuiu de forma menos importante que os demais tipos de fíler para a modificação dos valores das variáveis-resposta da caracterização mecânica básica. De modo geral, a adição de caulim reduziu os valores de RT, RRT e RMR e elevou os valores de MR. A adição simultânea de cal e caulim proporcionou os efeitos mais importantes para a variação dos valores MR e RMR, aumentando o MR e diminuindo a RMR. A adição concomitante de cal e caulim também elevou a RT e a RRT, porém de forma menos intensa que o tipo de ligante asfáltico e a adição de cal, respectivamente.

O tipo de ligante asfáltico (uso de CAP 30/45) foi o fator que proporcionou as maiores variações nos valores de RT, sendo importante também para elevar os valores de MR e RRT. O uso do CAP 30/45 foi determinante para fazer os valores de RMR ficarem menos distantes de RMR = $100 \%$, porém não houve tendência de que o tipo de ligante asfáltico aumente ou reduza a RMR. Por isso, o efeito foi considerado "importante" sem o sinal de $(+)$ ou $(-)$.

Os parâmetros de caracterização do fíler não conseguiram explicar satisfatoriamente, mediante regressão linear, a variação dos valores das variáveis-resposta da caracterização mecânica básica, tomando por base os dados de todas as misturas. Apenas as variações de MR e RMR das misturas com CAP 50/70 puderam ser compreendidas à luz do teor de caulim, D10, D30, D60 e MF. Nestas misturas, a presença de fíleres mais finos ou maior teor de caulim aumenta a rigidez dos CPs virgens e reduz a rigidez após o ciclo térmico do ensaio de DUI.

\subsection{CONSIDERAÇÕES SOBRE A VIABILIDADE TÉCNICA DO USO DE REJEITO DE CAULIM COMO FÍLER EM CONCRETO ASFÁLTICO}

Após a conclusão das Etapas 1 (Dosagens Marshall) e 2 (Caracterização Mecânica Básica) já se tem elementos suficientes para concluir acerca da viabilidade técnica do uso de rejeito de caulim como fíler em misturas asfálticas.

Na Etapa 1, verificou-se que as misturas 5070C1,5, 5070C3,0, 5070C6,0, 3045C1,5 e 3045C3,0 atenderam a todos os requisitos normativos do DER/SP (ET-DE-P00/027) quanto ao teor de 
ligante asfáltico, parâmetros volumétricos (VAM e RBV), estabilidade e fluência. A mistura 3045C6,0 também atendeu a esses parâmetros, exceto em relação à fluência. De modo geral, as misturas contendo $6,0 \%$ de caulim foram as mais problemáticas, pois elevaram o teor de projeto, o que encarece a mistura asfáltica, e ficaram muito próximas de não atender ao limite mínimo de estabilidade, no caso da mistura 5070C6,0, ou excederam o limite máximo de fluência, no caso da mistura 3045C6,0. Recomenda-se, então, não utilizar o teor mais elevado de caulim. Nos teores de $1,5 \%$ e 3,0\% de caulim, não há restrições quanto aos parâmetros avaliados na Etapa 1 (TP, VAM, RBV, estabilidade e fluência).

Na Etapa 2, verificou-se que todas as misturas contendo caulim atenderam, com folga, a resistência à tração mínima exigida pelo DER/SP. Elas também apresentaram valores de MR e RMR semelhantes aos das misturas de referência. Contudo, nenhuma mistura contendo caulim atendeu ao valor mínimo de RRT $\geq 70 \%$. Assim, nas condições desta pesquisa, ou seja, utilizando de agregado de granito e ligantes asfálticos convencionais (CAP 50/70 e CAP 30/45), não é possível atestar a viabilidade técnica do uso do rejeito de caulim como fíler em concretos asfálticos, em virtude da elevada susceptibilidade ao dano por umidade.

No entanto, as misturas de referência (3045 e 5070) também não alcançaram o valor mínimo de RRT. Assim, concluiu-se que a elevada susceptibilidade ao dano por umidade das misturas com caulim seja mais bem explicada pela baixa adesividade entre os ligantes asfálticos convencionais e o agregado de granito do que pela presença do rejeito de caulim. Em outras palavras, o caulim não foi efetivo em reverter o problema da adesividade ligante - agregado, como a cal, mas não foi o responsável pela elevada susceptibilidade ao dano por umidade aqui relatado.

Então, para viabilizar tecnicamente a utilização do rejeito de caulim como fíler em concreto asfáltico fez-se necessário contornar o problema da elevada susceptibilidade ao dano por umidade oriunda da baixa adesividade do ligante asfáltico ao agregado de granito. As possíveis soluções seriam: (i) substituição do granito por basalto, que tem boa adesividade com ligantes asfálticos convencionais; (ii) utilização de dope no ligante asfáltico, e (iii) adição de cal, simultaneamente ao caulim, como melhorador de adesividade da mistura asfáltica. As duas primeiras opções ensejariam coleta e caracterização dos novos materiais, além de novas dosagens Marshall. Assim, optou-se pela adição de cal. 
A escolha de acrescentar cal às misturas com 3,0\% de caulim norteou-se em: (i) não seria possível adicionar $1,5 \%$ de cal às misturas com $6,0 \%$ de caulim sem alterar a curva granulométrica e nem seria desejável, já que as misturas contendo 6,0\% de caulim apresentaram alguns resultados problemáticos quanto aos parâmetros das dosagens Marshall; (ii) utilizar a maior quantidade de caulim possível, visto que é um rejeito industrial gerado em grandes volumes, e o teor de 3,0\% utiliza o dobro de caulim em relação do teor de 1,5\%, e; (iii) qualquer outro teor de caulim ensejaria uma nova dosagem.

As duas novas condições experimentais 5070C3,0L e 3045C3,0L (adição de 1,5\% de cal, em substituição ao pó de pedra de granito), cujos teores de projeto foram assumidos como iguais às condições 5070C3,0 $(\mathrm{TP}=5,3 \%)$ e 3045C3,0 $(\mathrm{TP}=5,5 \%)$, respectivamente, foram então submetidas a todos os ensaios de caracterização mecânica da Etapa 2 e aos ensaios de estabilidade (E) e fluência (F) da Etapa 1, além do cálculo dos parâmetros volumétricos, cujos resultados estão indicados na Tabela 4.11. Destaca-se que, embora o Vv não tenha atingido o alvo de $4 \%$, com a adoção do TP, o volume de vazios ficou dentro da tolerância de $4 \pm 1 \%$.

Tabela 4.11 - Valores dos parâmetros das dosagens Marshall para as misturas 5070C3,0L e $3045 \mathrm{C} 3,0 \mathrm{~L}$

\begin{tabular}{|c|c|c|c|c|c|c|c|c|c|c|c|c|}
\hline Condição & $\begin{array}{l}\text { TP } \\
(\%) \\
\end{array}$ & $\begin{array}{l}\text { Vv } \\
(\%)\end{array}$ & $\mathbf{G}_{\mathrm{mm}}$ & $\mathbf{G}_{\mathbf{m b}}$ & $\begin{array}{c}\text { VAM } \\
(\%)\end{array}$ & $\begin{array}{c}\text { RBV } \\
(\%)\end{array}$ & $\underset{(\mathbf{k g f})}{\mathrm{E}}$ & $\begin{array}{c}\mathbf{F} \\
(\mathbf{m m})\end{array}$ & $\begin{array}{c}\text { MR } \\
\text { (MPa) }\end{array}$ & $\begin{array}{c}\text { RT } \\
\text { (Mpa) } \\
\end{array}$ & $\begin{array}{l}\text { RRT } \\
(\%)\end{array}$ & $\begin{array}{c}\text { RMR } \\
(\%)\end{array}$ \\
\hline $5070 \mathrm{C} 3,0 \mathrm{~L}$ & 5,3 & 3,5 & 2,408 & 2,323 & 15,5 & 77,2 & 1005 & 2,70 & 5724 & 1,65 & 78,8 & 82,8 \\
\hline $3045 \mathrm{C} 3,0 \mathrm{~L}$ & 5,5 & 3,6 & 2,407 & 2,321 & 15,7 & 77,4 & 1305 & 3,05 & 6381 & 1,94 & 83,1 & 92,1 \\
\hline
\end{tabular}

As misturas 5070C3,0L e 3045C3,0L atenderam a todos valores da especificação do DER/SP. Desta forma, pode-se recomendar o uso de rejeito de caulim como fíler em misturas asfálticas compostas por agregados de granito e ligantes asfálticos convencionais, desde que em teores moderados de adição (até 3,0\%) e em associação com a cal, para contornar a elevada susceptibilidade ao dano por umidade.

Pode se indicar, com restrições, uso de rejeito de caulim como fíler em misturas asfálticas com agregado de granito, ligantes asfálticos convencionais e sem a presença de cal somente em vias de baixo volume de tráfego, ou em regiões com baixo índice de pluviosidade e/ou com satisfatórias condições de drenagem de pavimento.

Outras maneiras de proporcionar o uso de rejeito de caulim como fíler em misturas asfálticas são: (i) a utilização de agregados com boa adesividade aos ligantes asfálticos e/ou; (ii) uso de 
ligantes asfálticos modificados. No entanto, recomendam-se pesquisas para comprovar melhora de comportamento.

\subsection{CARACTERIZAÇÃO MECÂNICA COMPLEMENTAR - ETAPA 3}

A Caracterização Mecânica Complementar foi efetuada com dois objetivos principais:

Analisar e comparar o desempenho das misturas em relação à susceptibilidade térmica, resistência à fadiga, susceptibilidade à deformação permanente e resistência à tração após ensaio de creep estático, com ênfase no desempenho das misturas contendo caulim;

Avaliar a influência dos fatores tipo de fíler, tipo de ligante asfáltico e parâmetros de caracterização do fíler nas diversas variáveis-resposta da caracterização mecânica complementar (MR nas temperaturas de 10, 25 e 40 , parâmetro de susceptibilidade térmica - PST, N - vida de fadiga, parâmetros do ensaio de creep estático e $\mathrm{RT}_{\text {crepp }}$ ).

São apresentados e discutidos os resultados dos ensaios de: (i) módulo de resiliência a 10, 25 e $40^{\circ} \mathrm{C}$, realizados para avaliar a susceptibilidade térmica; (ii) fadiga por compressão diametral à tensão controlada, compreendida com auxílio de análise mecanística de pavimentos, para avaliar a resistência à fadiga; (iii) fluência por compressão uniaxial estática (creep estático), para avaliar a susceptibilidade à deformação permanente (DP), e; (iv) RT após o ensaio de creep estático, para entender o efeito da degradação das misturas asfálticas depois de submetidas a esforços de compressão uniaxial estática e propiciar comparações dos valores de RT em diferentes condições de uso prévio do CP e em diferentes níveis de Vv.

Foi discutido na seção anterior que somente as misturas contendo cal ( $\mathrm{L}$ e C3,0L) atenderam integralmente as especificações técnicas do DER/SP. Mesmo assim, foram produzidas as misturas de referência e misturas com 3,0\% de caulim para possibilitar comparações de desempenho em quatro cenários, em relação ao tipo de fíler, 1 - misturas de referência; 2 misturas com 3,0\% de caulim; 3 - misturas com 1,5\% de cal, e; 4 - misturas com cal (1,5\%) e caulim $(3,0 \%)$ simultaneamente.

Assim, trabalhou-se com oito condições experimentais diferentes, resultantes da combinação de: 2 níveis de tipo de ligante asfáltico e 4 níveis de tipo de fíler. Na Tabela 4.12 estão indicados os 8 tipos de misturas asfálticas da Etapa 3. Todos os CPs foram moldados nos teores de projeto 
definidos na dosagem Marshall (Etapa 1) os quais estão indicados entre parênteses abaixo do nome da mistura.

Tabela 4.12 - Descrição das oito misturas asfálticas utilizadas na Etapa 3, com indicação do TP

\begin{tabular}{|c|c|c|c|c|}
\hline $\begin{array}{l}\text { Tipo de fíler } \\
\text { Tipo } \\
\text { de ligante } \\
\text { asfáltico }\end{array}$ & Granito & $\begin{array}{l}3,0 \% \text { de } \\
\text { caulim }\end{array}$ & $\begin{array}{c}1,5 \% \text { de } \\
\text { cal }\end{array}$ & $\begin{array}{c}3,0 \% \text { de } \\
\text { caulim }+ \\
1,5 \% \text { de } \\
\text { cal } \\
\end{array}$ \\
\hline $\begin{array}{c}\text { CAP 50/70 } \\
(\text { TP) }\end{array}$ & $\begin{array}{c}5070 \\
(5,3 \%)\end{array}$ & $\begin{array}{c}5070 \mathrm{C} 3,0 \\
(5,3 \%)\end{array}$ & $\begin{array}{l}5070 \mathrm{~L} \\
(5,5 \%)\end{array}$ & $\begin{array}{c}5070 \mathrm{C} 3,0 \mathrm{~L} \\
(5,3 \%)\end{array}$ \\
\hline $\begin{array}{c}\text { CAP 30/45 } \\
\text { (TP) }\end{array}$ & $\begin{array}{c}3045 \\
(5,3 \%)\end{array}$ & $\begin{array}{c}3045 \mathrm{C} 3,0 \\
(5,5 \%)\end{array}$ & $\begin{array}{l}3045 \mathrm{~L} \\
(5,5 \%)\end{array}$ & $\begin{array}{c}3045 \mathrm{C} 3,0 \mathrm{~L} \\
(5,5 \%)\end{array}$ \\
\hline
\end{tabular}

Foram produzidos $11 \mathrm{CPs}$, por mistura, dos quais 8 foram moldados com $\mathrm{Vv}=4 \pm 1 \% \mathrm{e}$ destinados aos ensaios para avaliação de resistência à fadiga e susceptibilidade térmica e 3 foram confeccionados com $\mathrm{Vv}=7 \pm 1 \%$ para serem utilizados nos ensaios de avaliação das susceptibilidades térmica e à deformação permanente (creep), além da $\mathrm{RT}_{\text {creep }}$.

Conforme descrito no método, os CPs utilizados para os ensaios de creep foram moldados com $\mathrm{Vv} \approx 7 \%$ e os CPs para os ensaios de fadiga foram produzidos $\mathrm{Vv}_{\mathrm{v}} \approx 4 \%$ pois a DP tende a ocorrer no início da vida útil do pavimento quando há maior volume de vazios. Já as trincas por fadiga tendem a aparecer posteriormente quando a camada asfáltica já recebeu compactação adicional do tráfego.

Os 3 CPs, por tipo de mistura, produzidos para o ensaio de creep estático foram previamente submetidos ao ensaio de $\mathrm{MR}$ nas temperaturas de 10,25 e $40^{\circ} \mathrm{C}$ para avaliação da susceptibilidade térmica e posteriormente submetidos ao ensaio de RT. Os 8 CPs, por tipo de mistura, produzidos para o ensaio de vida de fadiga foram previamente submetidos ao ensaio de MR a $25^{\circ} \mathrm{C}$. Metade dos CPs foi também submetida ao ensaio de MR a 10 e $40^{\circ} \mathrm{C}$, para avaliação de susceptibilidade térmica. Isto possibilitou investigar a influência da realização prévia de ensaios de MR nos valores da vida de fadiga.

Os resultados dos ensaios foram analisados sempre em relação à média de todas as réplicas, conforme quantidade de CPs indicadas no parágrafo anterior e os dados foram submetidos ao método de Grubbs para descartar valores discrepantes. No Apêndice F, encontram-se os valores de dimensões, volume de vazios, $\operatorname{MR}\left(10,25\right.$ e $\left.40^{\circ} \mathrm{C}\right)$, parâmetros do ensaio de fadiga, 
parâmetros do ensaio de creep estático e $\mathrm{RT}_{\text {creep }}$ de cada corpo de prova da Etapa 3, agrupados por tipo de mistura asfáltica.

\subsubsection{Avaliação da Susceptibilidade Térmica}

A susceptibilidade térmica (ST) das misturas foi avaliada com base na variação de MR no intervalo de 10 a $40^{\circ} \mathrm{C}$, tanto para os CPs destinados à avaliação de fadiga (MR $4 \%$, quanto para os CPs destinados à avaliação de deformação permanente e $\mathrm{RT}_{\text {creep }}\left(\mathrm{MR}_{7 \%}\right)$.

Na Tabela 4.13 são apresentados os valores médios de $\mathrm{MR}_{4 \%}$ e $\mathrm{MR}_{7 \%}$ nas temperaturas de 10, 25 e $40^{\circ} \mathrm{C}$. Não houve exclusão de nenhum valor de rigidez pelo método de Grubbs.

Tabela 4.13 - Valores médios de $\mathrm{MR}_{4 \%}$ e $\mathrm{MR}_{7 \%}$ a 10,25 e $40^{\circ} \mathrm{C}$

\begin{tabular}{|c|c|c|c|c|c|c|}
\hline \multirow[b]{2}{*}{$\begin{array}{l}\text { Tipo de } \\
\text { Mistura }\end{array}$} & \multicolumn{2}{|c|}{$10^{\circ} \mathrm{C}$} & \multicolumn{2}{|c|}{$25^{\circ} \mathrm{C}$} & \multicolumn{2}{|c|}{$40^{\circ} \mathrm{C}$} \\
\hline & $\begin{array}{l}\mathbf{M R}_{\mathbf{4}} \\
\text { (MPa) }\end{array}$ & $\begin{array}{l}\mathbf{M R}_{7 \%} \\
(\mathrm{MPa})\end{array}$ & $\begin{array}{l}\mathbf{M R}_{4 \%} \\
\text { (MPa) }\end{array}$ & $\begin{array}{l}\mathbf{M R}_{7 \%} \\
(\mathrm{MPa})\end{array}$ & $\begin{array}{l}\mathbf{M R}_{4 \%} \\
\text { (MPa) }\end{array}$ & $\begin{array}{l}\mathbf{M R}_{7 \%} \\
\text { (MPa) }\end{array}$ \\
\hline 5070 & 13935 & 8850 & 4865 & 3342 & 1031 & 759 \\
\hline $5070 \mathrm{C} 3,0$ & 12687 & 9780 & 5079 & 4003 & 966 & 895 \\
\hline $5070 \mathrm{~L}$ & 12405 & 8288 & 4538 & 3599 & 976 & 740 \\
\hline $5070 \mathrm{C} 3,0 \mathrm{~L}$ & 13909 & 9418 & 5167 & 4460 & 1137 & 1076 \\
\hline Média 5070 & 13234 & 9084 & 4912 & 3851 & 1028 & 868 \\
\hline 3045 & 12726 & 10259 & 5365 & 4506 & 1180 & 1157 \\
\hline $3045 C 3,0$ & 12618 & 8461 & 5506 & 3428 & 1588 & 1009 \\
\hline $3045 \mathrm{~L}$ & 12894 & 7624 & 5057 & 3341 & 1239 & 1152 \\
\hline $3045 \mathrm{C} 3,0 \mathrm{~L}$ & 14907 & 9100 & 6074 & 3823 & 1487 & 1290 \\
\hline Média 3045 & 13286 & 8861 & 5501 & 3775 & 1374 & 1152 \\
\hline Média geral & 13260 & 8973 & 5206 & 3813 & 1201 & 1010 \\
\hline
\end{tabular}

Em função dos dados da Tabela 4.13, percebe-se que a rigidez diminui com o aumento da temperatura e com o aumento no volume de vazios. Considerando a média geral de todas as misturas tem-se que: (i) Para $\mathrm{MR}_{4} \%$, a rigidez a $10^{\circ} \mathrm{C}$ é 2,55 vezes superior à rigidez a $25^{\circ} \mathrm{C}$, que por sua vez é 4,34 vezes maior que a rigidez a $40^{\circ} \mathrm{C}$; (ii) Para $\mathrm{MR}_{7} \%$, a rigidez a $10^{\circ} \mathrm{C}$ é 2,35 vezes maior que a rigidez a $25^{\circ} \mathrm{C}$, que por sua vez é 3,78 vezes superior à rigidez a $40^{\circ} \mathrm{C}$, e; (iii) os $\mathrm{MR}_{4 \%}$ são 47,8\%, 36,5\% e 18,9\% maiores que os $\mathrm{MR}_{7 \%}$ a 10,25 e $40^{\circ} \mathrm{C}$, respectivamente. Ao se avaliar os valores médios de MR por tipo de ligante asfáltico, percebese que quanto maior a temperatura, maior é a diferença percentual a favor do CAP 30/45.

Primeiramente apresentam-se as análises sobre a influência dos fatores do tipo de fíler e do tipo de ligante asfáltico nos valores de MR na ordem de execução dos ensaios, ou seja, 25, 10 e 
$40^{\circ} \mathrm{C}$, para depois se discutir a influência desses fatores na susceptibilidade térmica das misturas nos intervalos de: (i) $10-25^{\circ} \mathrm{C}$; (ii) $25-40^{\circ} \mathrm{C}$; (iii) $10-40^{\circ} \mathrm{C}$.

\subsubsection{1 $\mathrm{MR}_{4 \%}$ e $\mathrm{MR}_{7 \%}$ à $25^{\circ} \mathrm{C}$}

Conforme relatado na seção 4.2.1, o tipo de ligante asfáltico foi mais importante que o tipo de fíler para diferenciar os valores de MR à $25^{\circ} \mathrm{C}$. Assim, na Figura 4.18 estão indicados os valores médios de $\mathrm{MR}_{4 \%}$ e $\mathrm{MR}_{7 \%}$ a $25^{\circ} \mathrm{C}$ de todas as misturas, separadas por tipo de ligante asfáltico. Embora não tenham significado físico ou matemático, as linhas entre os valores de MR foram traçadas com o intuito de elucidar a tendência de comportamento da rigidez, facilitando a comparação das misturas com caulim versus misturas de referência e misturas com cal.

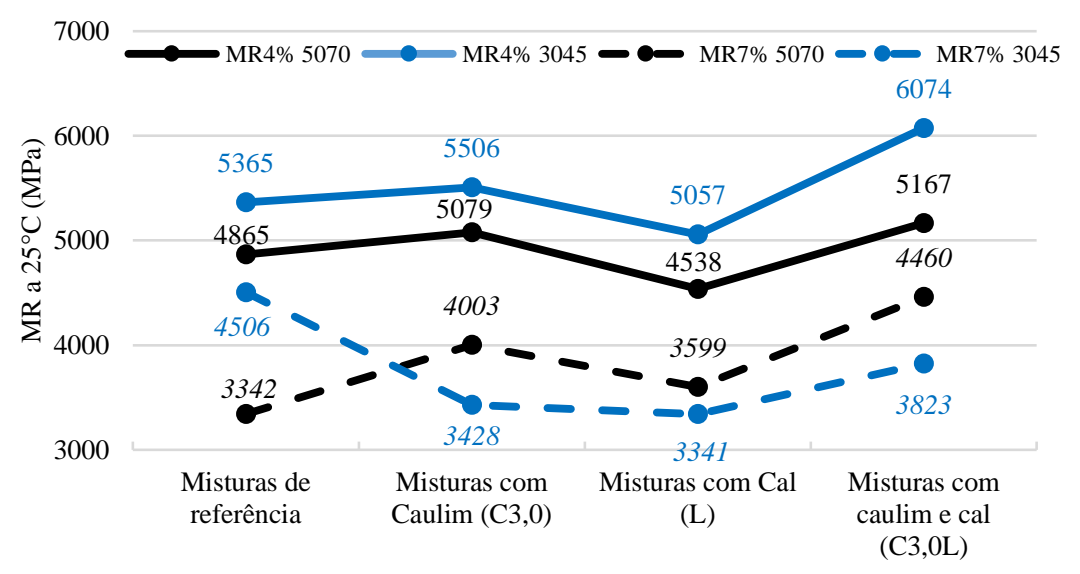

Figura $4.18-\mathrm{MR}_{4 \%}$ e $\mathrm{MR}_{7 \%}$ a $25^{\circ} \mathrm{C}$, por tipo de ligante asfáltico

O uso de CAP 30/45 elevou significativamente a rigidez das misturas. Em média, os valores de $\mathrm{MR}_{4 \%}$ a $25^{\circ} \mathrm{C}$ das misturas com CAP 30/45 foram $12 \%$ maiores que os das misturas com CAP 50/70. O aumento da rigidez ocorreu devido à maior consistência do CAP 30/45. A adição de caulim elevou a rigidez em $4 \%$, a adição de cal reduziu a rigidez em $6 \%$ e o uso simultâneo de caulim e cal aumentou o $\mathrm{MR}_{4} \%$ a $25^{\circ} \mathrm{C}$ em $10 \%$. Os testes $\mathrm{t}$ (Apêndice $\mathrm{C}$ ) indicaram que o tipo de CAP foi mais importante para diferencias as médias de $\mathrm{MR}_{4} \%$ a $25^{\circ} \mathrm{C}$ do que o tipo de fíler.

As curvas de $\mathrm{MR}_{4} \%$ a $25^{\circ} \mathrm{C}$ para o CAP 50/70 (traço preto contínuo) e para o CAP30/45 (traço azul contínuo) são praticamente paralelas indicando que o comportamento da rigidez em função do tipo de fíler e do tipo de ligante asfáltico está bem compreendido. Levando em consideração que os valores médios de $\mathrm{MR}_{4} \%$ foram calculados a partir dos resultados de $11 \mathrm{CPs}$, uma amostra que pode ser considerada grande para experimentos com misturas asfálticas, assumiu- 
se que a influência do tipo de fíler (aumento de rigidez nas misturas $\mathrm{C} 3,0$ e $\mathrm{C} 3,0 \mathrm{~L}$ e redução de rigidez nas misturas L) e do tipo de ligante asfáltico (aumento de rigidez com uso de CAP 30/45) aqui observada seja o comportamento típico para todas as misturas independentemente da temperatura e do volume de vazios.

Para $\mathrm{MR}_{7 \%}$ a $25^{\circ} \mathrm{C}$, de modo geral, não foi possível observar tendências de comportamento da variação de rigidez em função do tipo de fíler e do tipo de ligante asfáltico. Apenas as misturas de referência apresentaram maior $\mathrm{MR}_{7 \%}$ nas misturas com CAP 30/45. A não ocorrência do comportamento típico nas demais misturas pode ser atribuída ao maior volume de vazios dos corpos de prova $(\mathrm{Vv} \approx 7 \%)$ e a maior heterogeneidade das misturas contendo fíleres de cal e caulim. Isto acarreta menor número de pontos de contato entre os grãos de agregado e um maior espaço para a expansão/fluência do ligante asfáltico sob o carregamento cíclico, alterando assim a resposta mecânica da mistura asfáltica heterogênea e, consequentemente, sua rigidez. Os testes $\mathrm{t}$ (Apêndice $\mathrm{C}$ ) indicaram que o tipo de fíler foi mais importante para diferencias as médias de $\mathrm{MR}_{7 \%}$ a $25^{\circ} \mathrm{C}$ do que o tipo de ligante asfáltico.

Em todas as misturas $\mathrm{MR}_{7 \%}$ é menor que $\mathrm{MR}_{4} \%$, ou seja, quanto maior o volume de vazios, menor a rigidez das misturas asfálticas a $25^{\circ} \mathrm{C}$.

\subsubsection{2 $\mathrm{MR}_{4 \%}$ e $\mathrm{MR}_{7 \%}$ à $10^{\circ} \mathrm{C}$}

Na Figura 4.19, gerada a partir dos dados da Tabela 4.13, estão indicados os valores médios de $\mathrm{MR}_{4 \%}$ e $\mathrm{MR}_{7} \%$ a $10^{\circ} \mathrm{C}$ de todas as misturas, em função do tipo de ligante asfáltico.

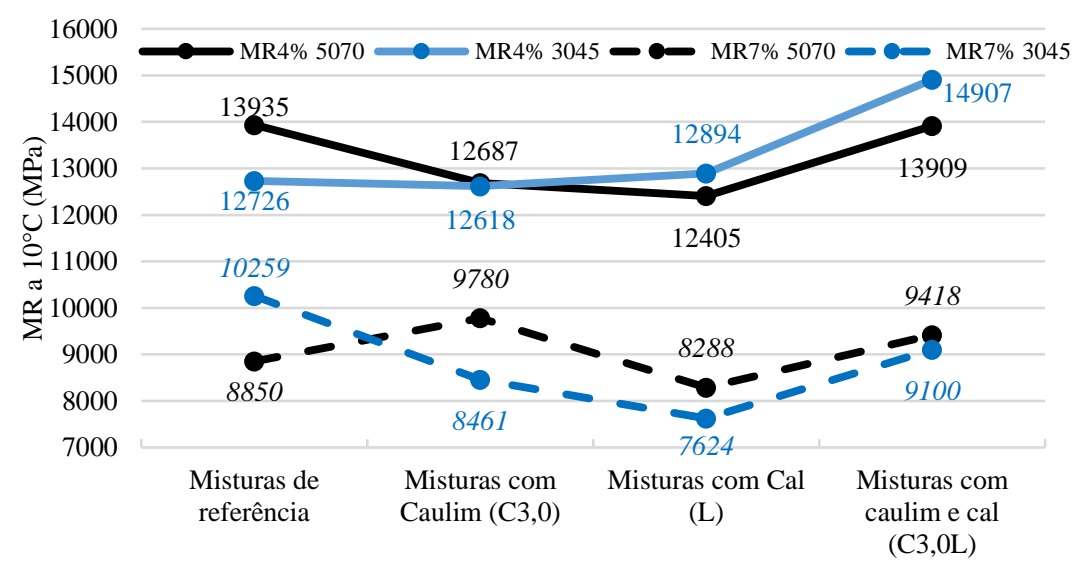

Figura $4.19-\mathrm{MR}_{4 \%}$ e $\mathrm{MR}_{7 \%}$ a $10^{\circ} \mathrm{C}$, por tipo de ligante asfáltico 
Para $\mathrm{MR}_{4 \%}$ a $10^{\circ} \mathrm{C}$, as misturas com CAP 30/45 apresentaram rigidez igual ou superior às misturas correspondentes com CAP 50/70, exceto nas misturas de referência. Não foi possível detectar tendência de comportamento da variação da rigidez em função do tipo fíler. À luz do teste $\mathrm{t}$ (Apêndice $\mathrm{C}$ ), o único par de misturas com valores médios de $\mathrm{MR}_{4} \%$ a $10^{\circ} \mathrm{C}$ significativamente diferentes é $3045 \times 3045 \mathrm{C} 3,0 \mathrm{~L}$. Neste caso, adição simultânea de caulim e cal proporcionou o comportamento típico, ou seja, aumentou a rigidez.

Houve maior dificuldade para se obter valores de qualidade de MR de cada CP na temperatura de $10^{\circ} \mathrm{C}$. Conforme relatado no método do trabalho, o software Labview 7.1 calcula o valor de MR para cada um dos 100 ciclos de aplicação de carga. Acontece que à $10^{\circ} \mathrm{C}$ o coeficiente de variação de MR foi muito alto, sendo necessário repetir os ensaios para conseguir uma sequência de, no mínimo, 15 ciclos consecutivos com baixo valor de coeficiente de variação.

Para $\mathrm{MR}_{7 \%}$ a $10^{\circ} \mathrm{C}$, as misturas de referência apresentaram o comportamento típico de maior rigidez nas misturas com CAP 30/45. As misturas com cal também exibiram o comportamento típico, ou seja, independentemente do tipo de ligante asfáltico se mostraram menos rígidas $(\sim 16 \%)$ que as misturas de referência. As misturas com CAP 50/70 apresentaram o comportamento típico em função do tipo de fíler, isto é, aumento na rigidez com uso de caulim e de caulim e cal simultaneamente e redução de rigidez com uso de cal. À luz dos testes t, o tipo de ligante asfáltico foi mais importante do que o tipo de fíler para diferenciar as médias de valores de $\mathrm{MR}_{7 \%}$ a $10^{\circ} \mathrm{C}$.

Na temperatura de $10^{\circ} \mathrm{C}$, todas as misturas exibiram $\mathrm{MR}_{7} \%$ menores que $\mathrm{MR}_{4 \%}$, ou seja, quanto maior o volume de vazios, menor a rigidez das misturas asfálticas. Também foi detectada a maior diferença média entre os valores de $\mathrm{MR}_{4} \%$ e $\mathrm{MR}_{7 \%}$, ou seja, em baixas temperaturas as misturas mais densas são consideravelmente mais rígidas que as misturas menos densas. Uma possível explicação para este fenômeno é que o esqueleto pétreo mais denso (menor Vv) proporciona maior quantidade de pontos de contato para atuação do ligante asfáltico com elevada viscosidade/rigidez.

\subsubsection{3 $\mathrm{MR}_{4 \%}$ e $\mathrm{MR}_{7 \%}$ à $40^{\circ} \mathrm{C}$}

Na Figura 4.20, gerada a partir dos dados da Tabela 4.13, estão indicados os valores médios de $\mathrm{MR}_{4 \%}$ e $\mathrm{MR}_{7 \%}$ a $40^{\circ} \mathrm{C}$ de todas as misturas, em função do tipo de ligante asfáltico. 


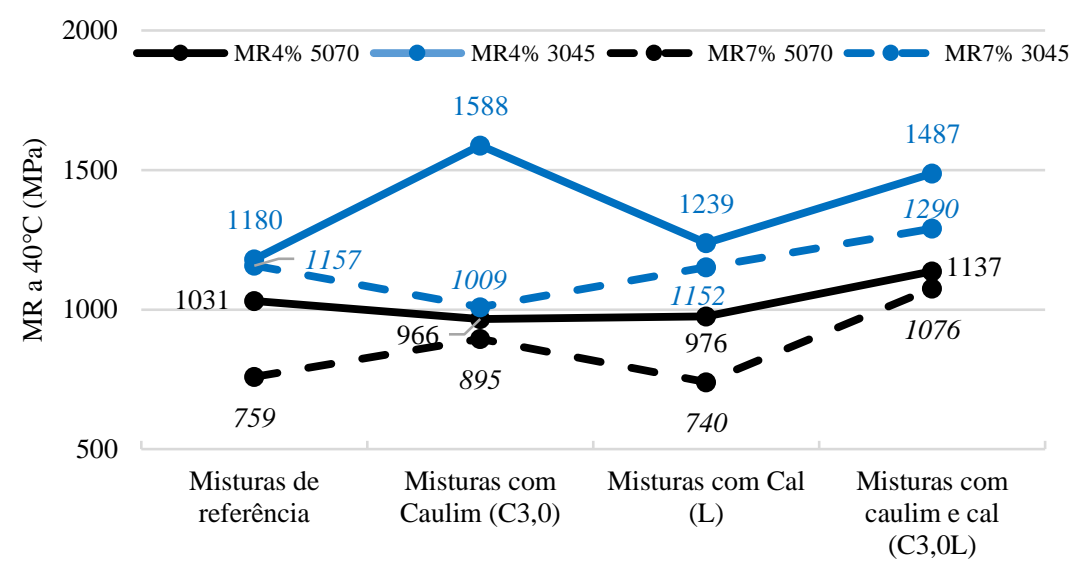

Figura $4.20-\mathrm{MR}_{4 \%}$ e $\mathrm{MR}_{7 \%}$ a $40^{\circ} \mathrm{C}$, por tipo de ligante asfáltico

A variação de $\mathrm{MR}_{4} \%$ à $40^{\circ} \mathrm{C}$, em função do tipo de ligante asfáltico, exibiu o comportamento típico, com as misturas com CAP 30/45 sempre mais rígidas que as misturas com CAP 50/70. As diferenças de $\mathrm{MR}_{4 \%}$ à $40^{\circ} \mathrm{C}$, em função do tipo de ligante asfáltico, são estatisticamente significantes à luz do teste t, exceto na comparação 5070C3,0 x 3045C3,0. Com relação à variação de $\mathrm{MR}_{4 \%}$ à $40^{\circ} \mathrm{C}$ em função do tipo de fíler, a única tendência de comportamento detectada foi o aumento da rigidez com o uso concomitante de cal e caulim.

Para $\mathrm{MR}_{7 \%}$ à $40^{\circ} \mathrm{C}$, as tendências de comportamento da rigidez em função do tipo de ligante asfáltico e do tipo de fíler foram as mesmas daquelas observadas para $\mathrm{MR}_{4 \%}$, isto é, $\mathrm{MR}_{7 \%}$ à $40^{\circ} \mathrm{C}$ aumenta com o uso de CAP 30/45 e com a adição de cal e caulim simultaneamente. Além disso, observou-se que a adição de cal provocou discreta redução na rigidez. Não foi possível observar tendência de comportamento em relação à adição de caulim. Os testes t (Apêndice C) indicam que o tipo de ligante asfáltico, mais uma vez, foi mais importante que o tipo de fíler para modificar os valores de $\mathrm{MR}_{7} \%$ à $40^{\circ} \mathrm{C}$.

Cumpre relatar que a execução do ensaio de $\mathrm{MR}$ a $40^{\circ} \mathrm{C}$ é mais trabalhosa que em outras temperaturas, devido à maior dificuldade de ajustar o LVDT para iniciar o ensaio. Nessa temperatura, os CPs começam a deformar somente com o apoio dos frisos de aplicação de carga (sem aplicação de carga), havendo necessidade de aguardar a estabilização dessa deformação para então reajustar o LVDT e iniciar o ensaio.

À $40^{\circ} \mathrm{C}$, todas as misturas exibiram $\mathrm{MR}_{7 \%}$ menores que $\mathrm{MR}_{4 \%}$, ou seja, quanto maior o volume de vazios, menor a rigidez das misturas asfálticas. Nesta temperatura foi detectada a menor 
diferença média entre os valores de $\mathrm{MR}_{4 \%}$ e $\mathrm{MR}_{7} \%$, ou seja, em temperaturas elevadas as misturas tendem a apresentar rigidez semelhante, independentemente do volume de vazios. Uma possível explicação para este fenômeno é que, à $40^{\circ} \mathrm{C}$, o CAP se encontra próximo do seu ponto de amolecimento, com sua rigidez muito reduzida, assim os valores de MR da mistura passam a receber maior influência do agregado, cuja rigidez tem menor intervalo de variação.

Destaca-se que em todas as medidas de MR, independentemente do tipo de ligante asfáltico, temperatura ou volume de vazios, a rigidez das misturas com caulim e cal simultaneamente (C3,0L) foi sempre superior à rigidez das misturas com cal (L). Desta forma, constatou-se que a adição de caulim, em virtude de sua elevada superfície específica, atua enrijecendo o ligante asfáltico (mástique).

\subsubsection{Avaliação da susceptibilidade térmica entre 10 e $25^{\circ} \mathrm{C}$}

Conforme relatado no Capítulo 3, a avaliação da susceptibilidade térmica será feita por meio do cálculo do parâmetro de susceptibilidade térmica (PST), que é a relação entre o MR da temperatura mais baixa sobre o MR da temperatura mais elevada (ver equação 3.5). Desta maneira, os valores de PST são sempre superiores a 1,00 e quanto mais próximos da unidade, menor será a taxa de variação da rigidez no intervalo de temperatura analisado, consequentemente, menor será a susceptibilidade térmica.

No intervalo de 10 a $25^{\circ} \mathrm{C}$, a ocorrência de trincas por fadiga pode ser potencializada, tendo em vista que a rigidez se eleva com a diminuição da temperatura e consequentemente a capa asfáltica mais rígida irá absorver maiores tensões, que resultam em maiores deformações que podem vir a iniciar fissuras e trincas. Em momento oportuno o $\mathrm{PST}_{10,25}$ na condição $\mathrm{Vv} \approx 4 \%$ será correlacionado com os resultados dos ensaios de fadiga por compressão diametral à tensão controlada.

Na Tabela 4.14 são apresentados os valores de $\mathrm{PST}_{10,25}$ nas condições de $\mathrm{Vv} \approx 4 \%$ e Vv $\approx 7 \%$, ranqueados do menor para o maior valor, ou seja, da mistura com menor susceptibilidade térmica para a mistura mais suscetível à variação de rigidez em função da variação de temperatura. 
Tabela 4.14 - Ranking de misturas em relação à susceptibilidade térmica e valores do PST ${ }_{10,25}$

\begin{tabular}{cccccc}
\hline \multicolumn{3}{c}{ Vv $\approx$ 4\% (Fadiga) } & \multicolumn{3}{c}{ Vv $\approx \mathbf{7 \%}($ Creep) } \\
Ranking & Mistura & PST $_{\mathbf{1 0}, \mathbf{2 5}}$ & Ranking & Mistura & PST $_{\mathbf{1 0}, \mathbf{2 5}}$ \\
\hline $1^{\mathrm{a}}$ & $3045 \mathrm{C} 3,0$ & 2,29 & $1^{\mathrm{a}}$ & $5070 \mathrm{C} 3,0 \mathrm{~L}$ & 2,11 \\
$2^{\mathrm{a}}$ & 3045 & 2,37 & $2^{\mathrm{a}}$ & $3045 / 3045 \mathrm{~L}$ & 2,28 \\
$3^{\mathrm{a}}$ & $3045 \mathrm{C} 3,0 \mathrm{~L}$ & 2,45 & & & \\
$4^{\mathrm{a}}$ & $5070 \mathrm{C} 3,0$ & 2,50 & $4^{\mathrm{a}}$ & $5070 \mathrm{~L}$ & 2,30 \\
$5^{\mathrm{a}}$ & $3045 \mathrm{~L}$ & 2,55 & $5^{\mathrm{a}}$ & $3045 \mathrm{C} 3,0 \mathrm{~L}$ & 2,38 \\
$6^{\mathrm{a}}$ & $5070 \mathrm{C} 3,0 \mathrm{~L}$ & 2,69 & $6^{\mathrm{a}}$ & $5070 \mathrm{C} 3,0$ & 2,44 \\
$7^{\mathrm{a}}$ & $5070 \mathrm{~L}$ & 2,73 & $7^{\mathrm{a}}$ & $3045 \mathrm{C} 3,0$ & 2,47 \\
$8^{\mathrm{a}}$ & 5070 & 2,86 & $8^{\mathrm{a}}$ & 5070 & 2,65 \\
\hline
\end{tabular}

Ambas as misturas com menor susceptibilidade térmica, 3045C3,0 para Vv $\approx 4 \%$ e $5070 \mathrm{C} 3,0 \mathrm{~L}$ na condição de $\mathrm{Vv} \approx 7 \%$, apresentaram caulim em sua composição. Este resultado é interessante, pois inseriu-se na massa asfáltica um rejeito industrial, hoje inservível, e ele trouxe melhora ao desempenho da mistura, reduzindo a variação de rigidez em função da variação de temperatura. A mistura de referência 5070 destacou-se negativamente por ter apresentado a maior susceptibilidade térmica, independentemente do nível de Vv. De modo geral, as misturas com $\mathrm{Vv} \approx 7 \%$ apresentaram menor susceptibilidade térmica, em virtude de terem apresentado valores de rigidez consideravelmente mais baixos a $10^{\circ} \mathrm{C}$ em virtude da menor compacidade do esqueleto pétreo dos agregados (numerador mais baixo da expressão de cálculo de PST).

Na Figura 4.21 são apresentados gráficos contendo os parâmetros de susceptibilidade térmica ( $\mathrm{PST}_{10,25}$ ) das misturas com $\mathrm{Vv} \approx 4 \%$. Para melhor visualização, do lado esquerdo apresentamse os valores de PST $_{10,25}$ das misturas CAP 50/70 e, à direita, das misturas com CAP 30/45. Com base nestes gráficos e nos dados da Tabela 4.14 será discutida a influência do tipo de ligante asfáltico e do tipo de fíler na susceptibilidade térmica entre 10 e $25^{\circ} \mathrm{C}$.
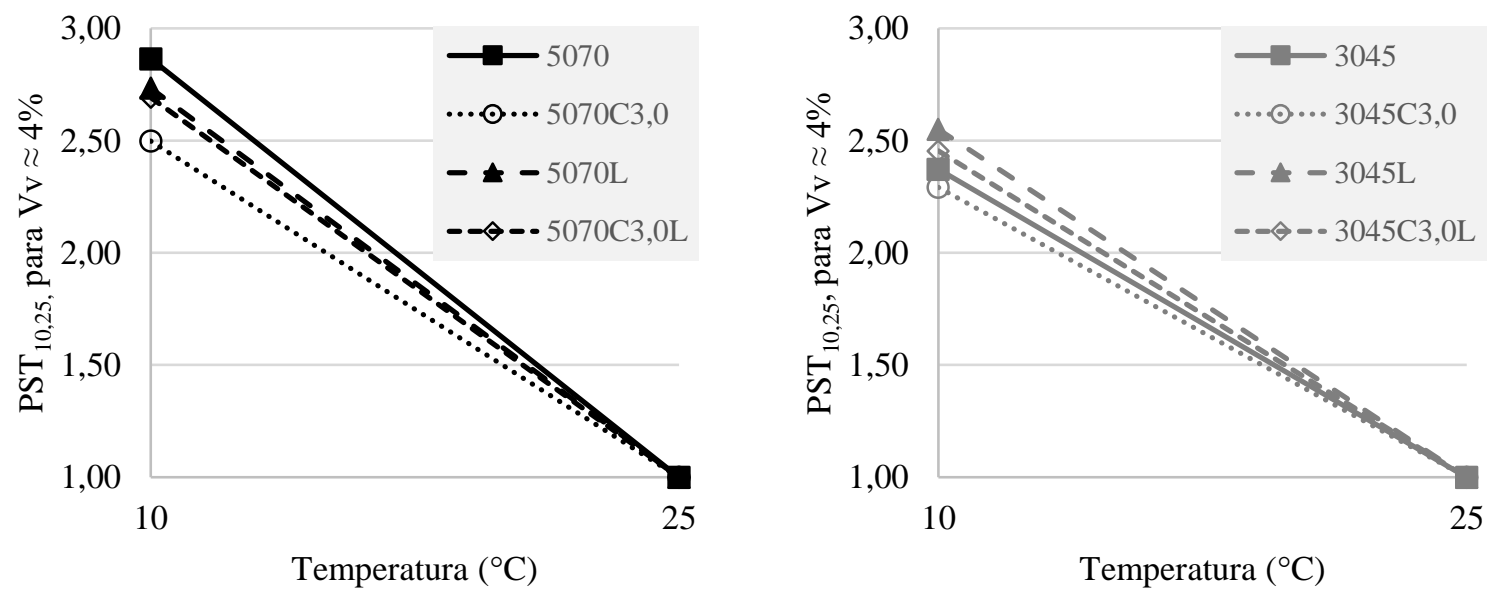

Figura 4.21 - PST para $\mathrm{Vv} \approx 4 \%$ na faixa de temperatura de 10 a $25^{\circ} \mathrm{C}$ 
O uso de CAP 30/45 reduziu a susceptibilidade térmica, em consonância com o observado por Furlan (2006). Em média, a redução do $\mathrm{PST}_{10,25}$ foi da ordem de $10 \%$. O MR $4 \%$ à $25^{\circ} \mathrm{C}$ das misturas com CAP 30/45 é superior ao das misturas com CAP 50/70, devido a maior consistência do primeiro ligante asfáltico, assim o denominador da expressão de cálculo do parâmetro de susceptibilidade térmica foi maior nas misturas com CAP 30/45. Para baixas temperaturas, os valores de $\mathrm{MR}_{4 \%}$ à $10^{\circ} \mathrm{C}$, numerador da expressão de cálculo do PST, foram similares entre as misturas com diferentes ligantes. Assim, ao se dividir um numerador praticamente igual por um denominador maior, o resultado foi um menor valor de PST para as misturas com CAP 30/45.

A adição de caulim, dentre os fíleres empregados, teve a atuação mais destacada no PST 10,25 das misturas com $\mathrm{Vv} \approx 4 \%$. O caulim contribuiu para reduzir a susceptibilidade térmica e essa redução foi, em média, de $8 \%$. As misturas com caulim $(\mathrm{C} 3,0)$ mostraram-se mais rígidas que as misturas de referência à $25^{\circ} \mathrm{C}$, em virtude do enrijecimento do mástique provocado pela elevada superfície específica do fíler. Com isso, o denominador da expressão de cálculo do PST $_{10,25}$ aumentou.

Na temperatura de $10^{\circ} \mathrm{C}$, o MR variou pouco entre as misturas de referência e com caulim. Novamente, incorreu-se na situação de numerador praticamente igual sendo dividido por um denominador maior, resultando em menores valores do parâmetro de susceptibilidade térmica das misturas contendo caulim. Não se detectou tendência de comportamento do PST $_{10,25}$, quando da adição de cal ou da adição simultânea de cal e caulim.

Na Figura 4.22 são apresentados gráficos contendo os valores de PST $_{10,25}$ das misturas na condição de $\mathrm{Vv} \approx 7 \%$. Com base nestes gráficos e nos dados da Tabela 4.14 é discutida a influência do tipo de ligante asfáltico e do tipo de fíler no $\mathrm{PST}_{10,25}$ para $\mathrm{Vv} \approx 7 \%$. 

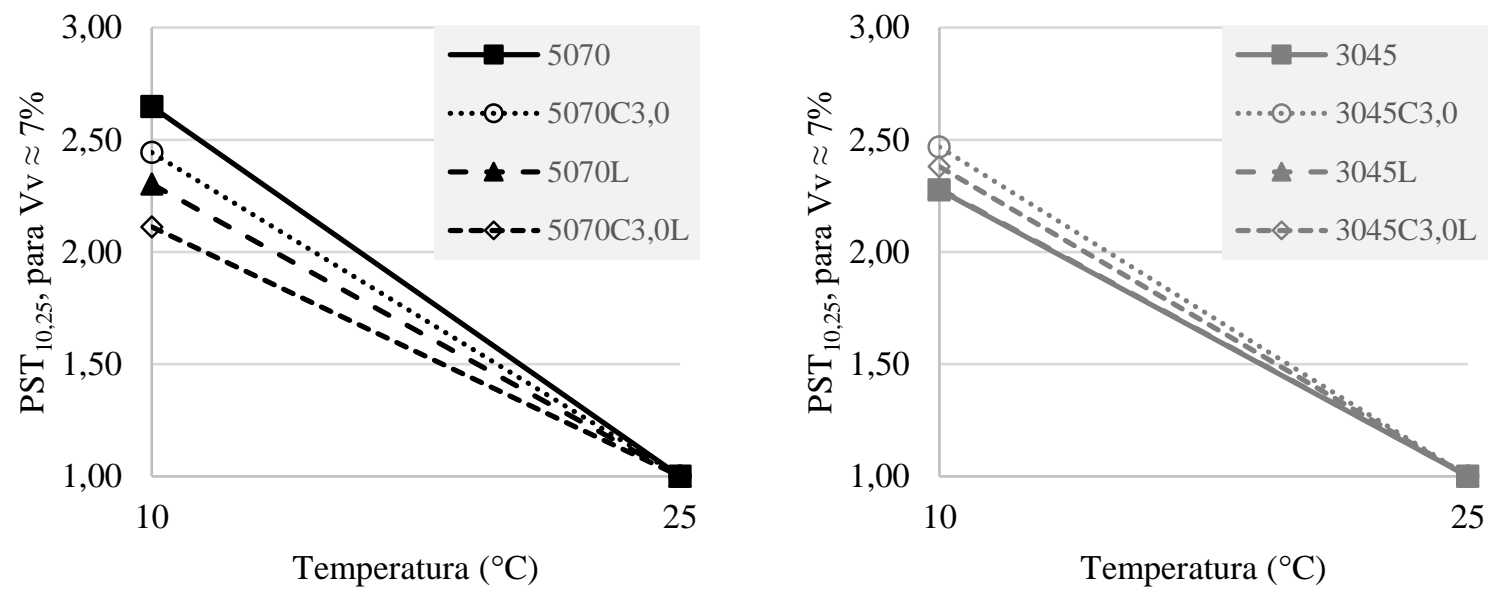

Figura 4.22 - PST para $\mathrm{Vv} \approx 7 \%$ na faixa de temperatura de 10 a $25^{\circ} \mathrm{C}$

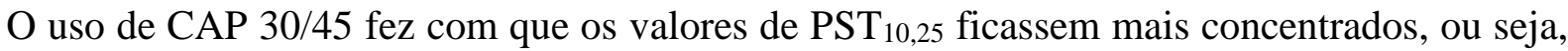
nas misturas com este ligante asfáltico o tipo de fíler praticamente não alterou a susceptibilidade térmica. Por outro lado, nas misturas com CAP 50/70, os valores PST $_{10,25}$ são bem mais dispersos, isto é, nestas misturas a susceptibilidade térmica parece ser afetada pelo tipo de fíler. À diferença da condição com $\mathrm{Vv} \approx 4 \%$, não foi encontrada tendência de redução do $\operatorname{PST}_{10,25}$ com o uso de CAP 30/45.

A influência do tipo de fíler é melhor compreendida analisando-se em função do tipo de ligante asfáltico. Para as misturas com CAP 50/70, adições de fíler reduziram a susceptibilidade térmica, sendo que a adição concomitante de caulim e cal produziu o melhor resultado (PST 10,25 reduziu 20\%). A explicação para isso é o fato de a mistura de referência (5070) ter apresentado o menor $\mathrm{MR}_{7 \%}$ a $25^{\circ} \mathrm{C}$ (menor denominador da expressão de cálculo do PST) e, conforme discutido previamente, na temperatura de $10^{\circ} \mathrm{C}$, os MRs das misturas foram proporcionalmente mais próximos entre si. Portanto, ao se dividir um numerador praticamente constante por um denominador maior, tem-se um maior valor de $\mathrm{PST}_{10,25}$ para a mistura 5070.

Por outro lado, nas misturas com CAP 30/45, a adição de fíler as tornou mais suscetíveis à variação de rigidez, sendo que a adição concomitante de caulim e cal produziu o pior resultado (PST 10,25 majorado em 5\%). Compreende-se este fenômeno em virtude do maior valor de $\mathrm{MR}_{7 \%}$ a $25^{\circ} \mathrm{C}$ da mistura de referência (3045), aumentando o denominador da expressão de cálculo do PST e, consequentemente, reduzindo o valor deste parâmetro. 
4.4.1.5 Avaliação da susceptibilidade térmica entre 25 e $40^{\circ} \mathrm{C}$

No intervalo de 25 a $40^{\circ} \mathrm{C}$, a ocorrência de deformação permanente é potencializada, tendo em vista que a rigidez reduz com a elevação da temperatura e, consequentemente, com a capa asfáltica menos rígida fica mais propensa a se deformar plasticamente sob ação de carregamento. Em momento oportuno o $\mathrm{PST}_{25,40}$ na condição $\mathrm{Vv} \approx 7 \%$ será correlacionado aos resultados do ensaio de creep estático visando encontrar relações entre estes fatores.

Na Tabela 4.15, são apresentados os rankings do $\mathrm{PST}_{25,40}$ das misturas na condição de $\mathrm{Vv} \approx 4 \%$ $\mathrm{e} \mathrm{Vv} \approx 7 \%$.

Tabela 4.15 - Ranking de misturas em relação à susceptibilidade térmica e valores do PST $_{25,40}$

\begin{tabular}{cccccc}
\hline & $\mathbf{V v} \approx \mathbf{4 \%}$ (Fadiga) & & \multicolumn{3}{c}{$\mathbf{V v} \approx \mathbf{7 \%}($ Creep) } \\
Ranking & Condição & PST $_{\mathbf{2 5}, \mathbf{4 0}}$ & Ranking & Condição & PST $_{\mathbf{2 5}, \mathbf{4 0}}$ \\
\hline $1^{\mathrm{a}}$ & $3045 \mathrm{C} 3,0$ & 3,47 & $1^{\mathrm{a}}$ & $3045 \mathrm{~L}$ & 2,90 \\
$2^{\mathrm{a}}$ & $3045 \mathrm{~L} / 3045 \mathrm{C} 3,0 \mathrm{~L}$ & 4,08 & $2^{\mathrm{a}}$ & $3045 \mathrm{C} 3,0 \mathrm{~L}$ & 2,96 \\
& & $3^{\mathrm{a}}$ & $3045 \mathrm{C} 3,0$ & 3,40 \\
$4^{\mathrm{a}}$ & $3045 / 5070 \mathrm{C} 3,0 \mathrm{~L}$ & 4,55 & $4^{\mathrm{a}}$ & 3045 & 3,90 \\
$6^{\mathrm{a}}$ & $5070 \mathrm{~L}$ & 4,65 & $5^{\mathrm{a}}$ & $5070 \mathrm{C} 3,0 \mathrm{~L}$ & 4,14 \\
$7^{\mathrm{a}}$ & 5070 & 4,72 & $6^{\mathrm{a}}$ & 5070 & 4,40 \\
$8^{\mathrm{a}}$ & $5070 \mathrm{C} 3,0$ & 5,26 & $7^{\mathrm{a}}$ & $5070 \mathrm{C} 3,0$ & 4,47 \\
& & & & & \\
\hline
\end{tabular}

Novamente a mistura $3045 \mathrm{C} 3,0$ apresentou a menor susceptibilidade térmica para $\mathrm{Vv} \approx 4 \%$. Para $\mathrm{Vv} \approx 7 \%$, a mistura $3045 \mathrm{~L}$ ficou no primeiro lugar do ranking das misturas menos suscetíveis. Por outro lado, as misturas 5070C3,0 e 5070L apresentaram as maiores susceptibilidades térmicas, para $\mathrm{Vv}_{\mathrm{V}} \approx 4 \% \mathrm{e} \mathrm{Vv} \approx 7 \%$, respectivamente. Os rankings indicaram claramente que as misturas com CAP 30/45 exibiram menor susceptibilidade térmica. De modo geral, as misturas com maior volume de vazios $(\mathrm{Vv} \approx 7 \%)$ apresentaram menor susceptibilidade térmica, majoritariamente em função dos menores valores de $\mathrm{MR}$ a $25^{\circ}$, visto que a $40^{\circ} \mathrm{C}$ o $\mathrm{MR}$ das misturas com $\mathrm{Vv} \approx 4 \% \mathrm{e} \mathrm{Vv} \approx 7 \%$ foram similares.

Ao se comparar os dados das Tabelas 4.14 e 4.15, é possível perceber que, no intervalo de temperatura de 25 a $40^{\circ} \mathrm{C}$, há maior variação de rigidez, como observado pelos maiores valores de PST, independentemente do Vv, ou seja, as misturas têm maior susceptibilidade térmica no intervalo de 25 a $40^{\circ} \mathrm{C}$ do que no intervalo de 10 a $25^{\circ} \mathrm{C}$. Uma possível explicação para esse fenômeno é que em temperaturas próximas a $40^{\circ} \mathrm{C}$ o ligante asfáltico já está próximo ao seu 
ponto de amolecimento, o que reduz significativamente sua consistência e, por consequência, o MR da mistura.

Na Figura 4.23, são apresentados gráficos contendo os $\operatorname{PST}_{25,40}$ das misturas com $\mathrm{Vv} \approx 4 \%$. Com base nestes gráficos e nos dados da Tabela 4.15, é discutida a influência do tipo de ligante asfáltico e do tipo de fíler na susceptibilidade térmica entre 25 e $40^{\circ} \mathrm{C}$, para $\mathrm{Vv} \approx 4 \%$.
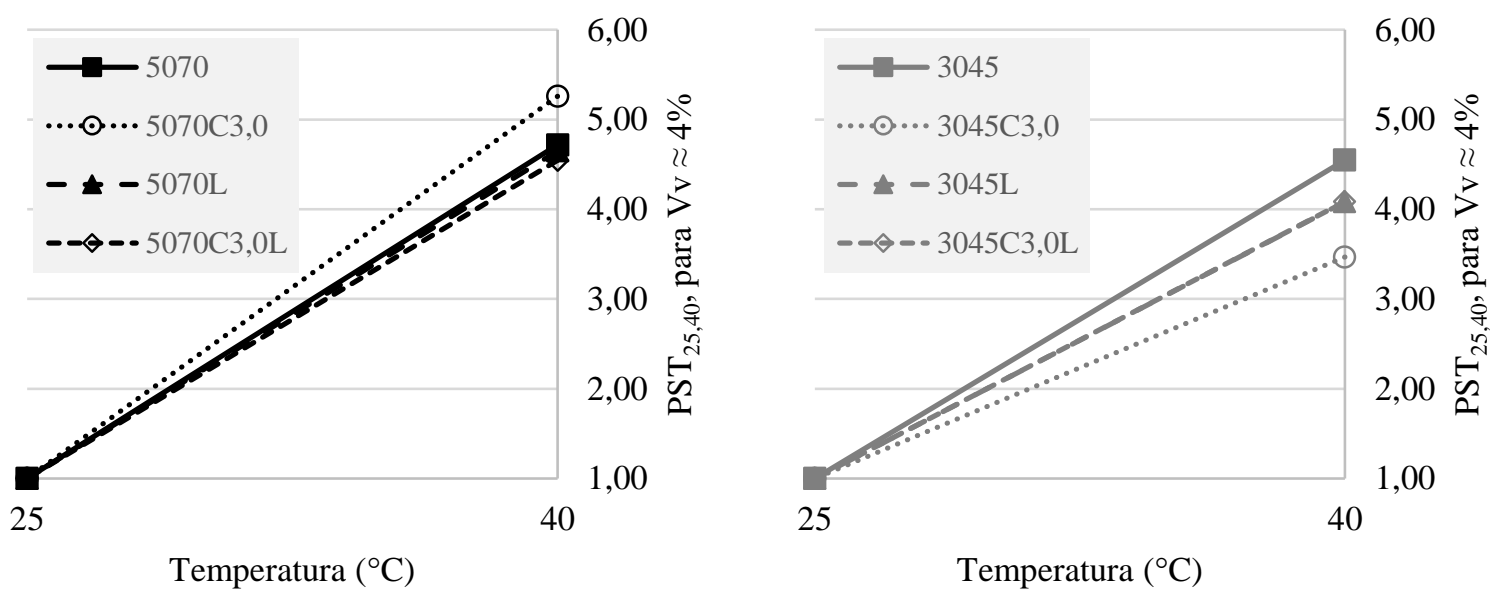

Figura 4.23 - PST para $V v \approx 4 \%$ na faixa de temperatura de 25 a $40^{\circ} \mathrm{C}$

O CAP 30/45 sempre reduziu a susceptibilidade térmica. A maior alteração no PST 25,40 ocorreu na condição com 3,0\% de caulim, onde o CAP 30/45 reduziu o PST $_{25,40}$ em 34\% (PST 25,40 passou de 5,26 - 5070C3,0 para 3,47-3045C3,0).

A adição de fíleres quase sempre reduziu a ST. O único caso em que a adição de fíler deixou a mistura mais suscetível à variação de rigidez foi na comparação entre as misturas $5070 x$ 5070C3,0, onde o PST 25,40 aumentou de 4,72 para 5,26. Por outro lado, a maior redução de $\operatorname{PST}_{25,40}(24 \%)$ ocorreu com a adição de caulim $(C 3,0)$ nas misturas com CAP 30/45.

Na Figura 4.24, são apresentados os gráficos contendo os parâmetros de susceptibilidade térmica $\left(\mathrm{PST}_{25,40}\right)$ das misturas com $\mathrm{Vv} \approx 7 \%$. Com base nestes gráficos e nos dados da Tabela 4.15 é discutida a influência do tipo de ligante asfáltico e do tipo de fíler na susceptibilidade térmica entre 25 e $40^{\circ} \mathrm{C}$, para o nível de volume de vazios de $7 \%$. 

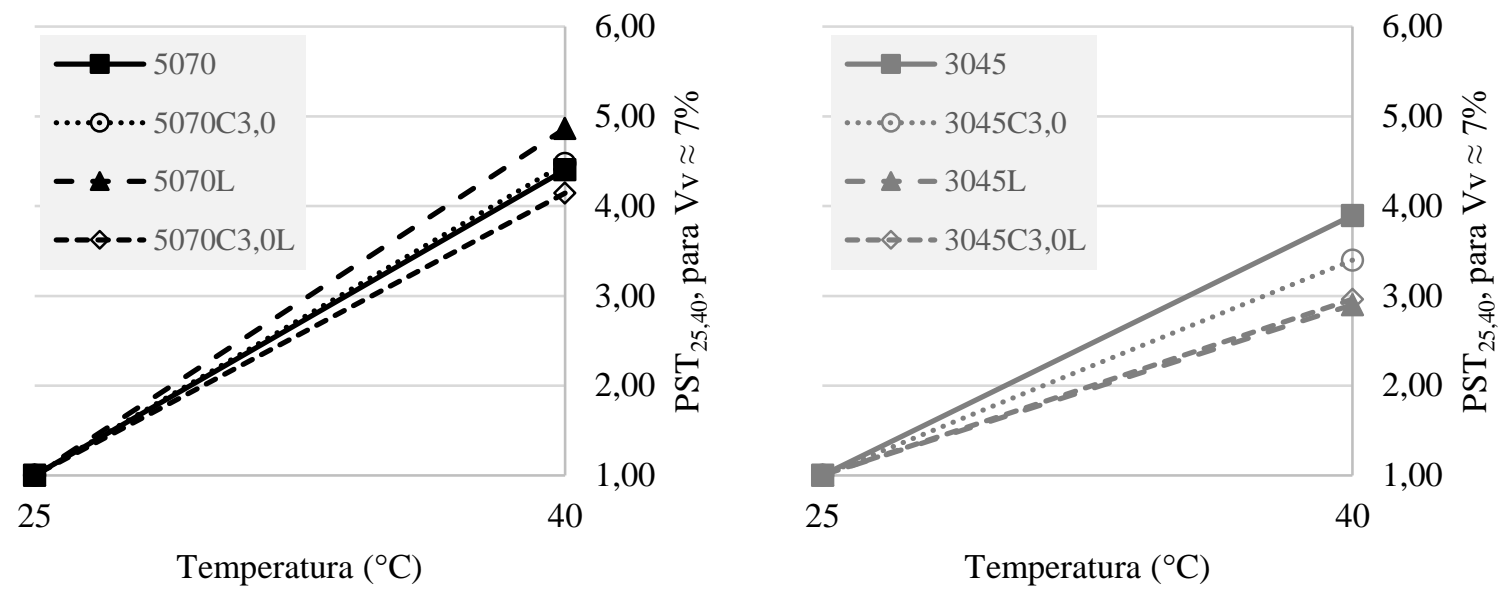

Figura 4.24 - PST para $\mathrm{Vv} \approx 7 \%$ na faixa de temperatura de 25 a $40^{\circ} \mathrm{C}$

Mais uma vez o uso de CAP 30/45 atuou de maneira importante para reduzir à susceptibilidade térmica em relação a todas as misturas correlatas com CAP 50/70. A maior redução de PST 25,40 (40\%) se deu nas misturas com cal (L) e a menor redução de PST25,40 (12\%) ocorreu nas misturas de referência.

A influência do tipo de fíler é melhor compreendida ao se segmentar a análise por tipo de ligante asfáltico. Para as misturas com CAP 30/45 a adição de fíler sempre reduziu a susceptibilidade térmica, sendo que o melhor resultado se dá com a adição de cal, redução de $26 \%$ no $\mathrm{PST}_{25,40}$. Para misturas com CAP 50/70 somente a adição de cal e caulim simultaneamente proporcionou redução na susceptibilidade térmica.

\subsubsection{Avaliação da susceptibilidade térmica entre 10 e $40^{\circ} \mathrm{C}$}

Na Tabela 4.16, são apresentados os rankings do parâmetro de susceptibilidade térmica tanto na condição de $\mathrm{Vv} \approx 4 \%$, como na condição de $\mathrm{Vv} \approx 7 \%$, no intervalo de 10 a $40^{\circ} \mathrm{C}$.

Tabela 4.16 - Ranking de misturas em relação à susceptibilidade térmica e valores do PST 10,40

\begin{tabular}{cccccc}
\hline \multicolumn{3}{c}{ Vv $\approx$ 4\% (Fadiga) } & \multicolumn{3}{c}{ Vv $\approx \mathbf{7 \%}$ (Creep) } \\
Ranking & Condição & PST $_{\mathbf{1 0}, \mathbf{4 0}}$ & Ranking & Condição & PST $_{\mathbf{1 0}, \mathbf{4 0}}$ \\
\hline $1^{\mathrm{a}}$ & $3045 \mathrm{C} 3,0$ & 7,95 & $1^{\mathrm{a}}$ & $3045 \mathrm{~L}$ & 6,62 \\
$2^{\mathrm{a}}$ & $3045 \mathrm{C} 3,0 \mathrm{~L}$ & 10,02 & $2^{\mathrm{a}}$ & $3045 \mathrm{C} 3,0 \mathrm{~L}$ & 7,05 \\
$3^{\mathrm{a}}$ & $3045 \mathrm{~L}$ & 10,41 & $3^{\mathrm{a}}$ & $3045 \mathrm{C} 3,0$ & 8,39 \\
$4^{\mathrm{a}}$ & 3045 & 10,78 & $4^{\mathrm{a}}$ & $5070 \mathrm{C} 3,0 \mathrm{~L}$ & 8,75 \\
$5^{\mathrm{a}}$ & $5070 \mathrm{C} 3,0 \mathrm{~L}$ & 12,24 & $5^{\mathrm{a}}$ & 3045 & 8,88 \\
$6^{\mathrm{a}}$ & $5070 \mathrm{~L}$ & 12,71 & $6^{\mathrm{a}}$ & $5070 \mathrm{C} 3,0$ & 10,93 \\
$7^{\mathrm{a}}$ & $5070 \mathrm{C} 3,0$ & 13,13 & $7^{\mathrm{a}}$ & $5070 \mathrm{~L}$ & 11,20 \\
$8^{\mathrm{a}}$ & 5070 & 13,51 & $8^{\mathrm{a}}$ & 5070 & 11,66 \\
\hline
\end{tabular}


A mistura 3045C3,0 exibiu a menor susceptibilidade térmica nos três intervalos de temperatura investigados $\left(10-25^{\circ}, 25-40^{\circ} \mathrm{C}\right.$ e $\left.10-40^{\circ} \mathrm{C}\right)$ para $\mathrm{Vv} \approx 4 \%$. Verificou-se que as misturas contendo caulim $(\mathrm{C} 3,0)$ sempre apresentaram menor susceptibilidade térmica entre 10 e $40^{\circ} \mathrm{C}$ do que as misturas de referência, para ambos os níveis de volume de vazios. As misturas com caulim e cal simultaneamente $(\mathrm{C} 3,0 \mathrm{~L})$ sempre apresentaram menor susceptibilidade térmica entre 10 e $40^{\circ} \mathrm{C}$ do que as misturas com cal (L), exceto na comparação 3045C3,0L $x$ 3045L, para $\mathrm{Vv} \approx 7 \%$. Estes resultados são encorajadores, pois indicam que a utilização do caulim como fíler em mistura asfáltica, além de proporcionar ganhos ambientais oriundos do aproveitamento de um rejeito industrial, pode melhorar o desempenho da mistura. O caulim atua no sentido de enrijecer o mástique e isto aumenta a rigidez, especialmente nas temperaturas mais elevadas, contribuindo para reduzir os valores de PST.

Para $\mathrm{Vv} \approx 7 \%$, a mistura menos suscetível à variação de rigidez em função da temperatura foi 3045L. Destaca-se negativamente a mistura de referência 5070 por ter apresentado a maior susceptibilidade térmica no intervalo entre 10 e $40^{\circ}$, fato que já havia ocorrido para a faixa mais baixa de temperatura. Em consonância com o que ocorreu nas demais faixas de temperatura, as misturas com maior volume de vazios $(\mathrm{Vv} \approx 7 \%)$ apresentaram menor susceptibilidade térmica.

Na Figura 4.25, são apresentados os gráficos contendo os parâmetros de susceptibilidade térmica $\left(\mathrm{PST}_{10,40}\right)$ das misturas com $\mathrm{Vv} \approx 4 \%$. À luz destes gráficos e dos dados da Tabela 4.16 é discutida a influência do tipo de ligante asfáltico e do tipo de fíler no $\mathrm{PST}_{10,40}$.
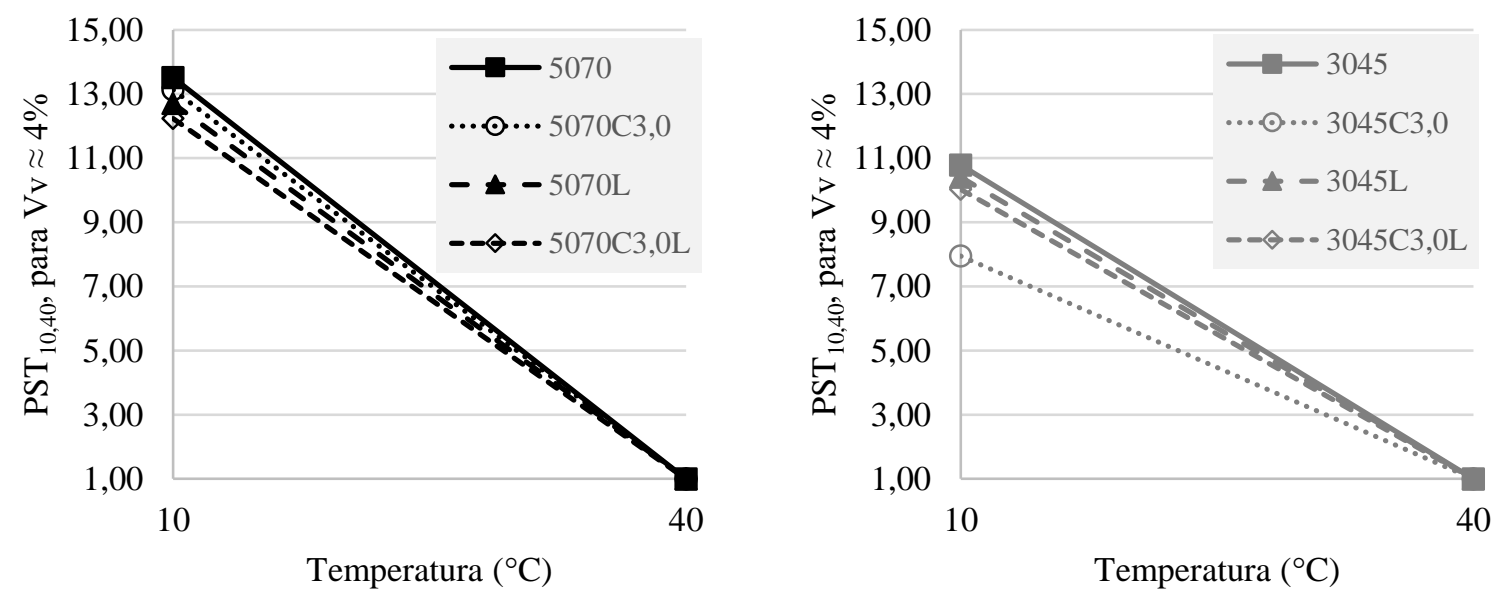

Figura 4.25 - PST para $V_{v} \approx 4 \%$ na faixa de temperatura de 10 a $40^{\circ} \mathrm{C}$ 
O uso de CAP 30/45 reduziu, de forma importante, a susceptibilidade térmica. PST 10,40 está sempre acima de 12 para as misturas com CAP 50/70, enquanto que para as misturas com CAP 30/45, o PST 10,40 é sempre inferior a 11. Este fenômeno é compreendido pela maior consistência do ligante que confere maior rigidez às misturas nas temperaturas mais elevadas.

A adição de fíleres sempre reduziu a susceptibilidade térmica. Nas misturas com CAP 50/70, a adição concomitante de cal e caulim levou ao melhor resultado em termos de ST. Já para as misturas com CAP 30/45, o caulim foi o fíler que proporcionou o melhor desempenho quanto ao $\mathrm{PST}_{10,40}$, fazendo com que este parâmetro reduzisse $26 \%$.

Na Figura 4.26, são apresentados os gráficos contendo os parâmetros de susceptibilidade térmica $\left(\mathrm{PST}_{10,40}\right.$ ) das misturas com $\mathrm{Vv} \approx 7 \%$. Com base nestes gráficos e nos dados da Tabela 4.16, é discutida a influência do tipo de ligante asfáltico e do tipo de fíler na susceptibilidade térmica entre 10 e $40^{\circ} \mathrm{C}$, para o nível de volume de vazios de $7 \%$.
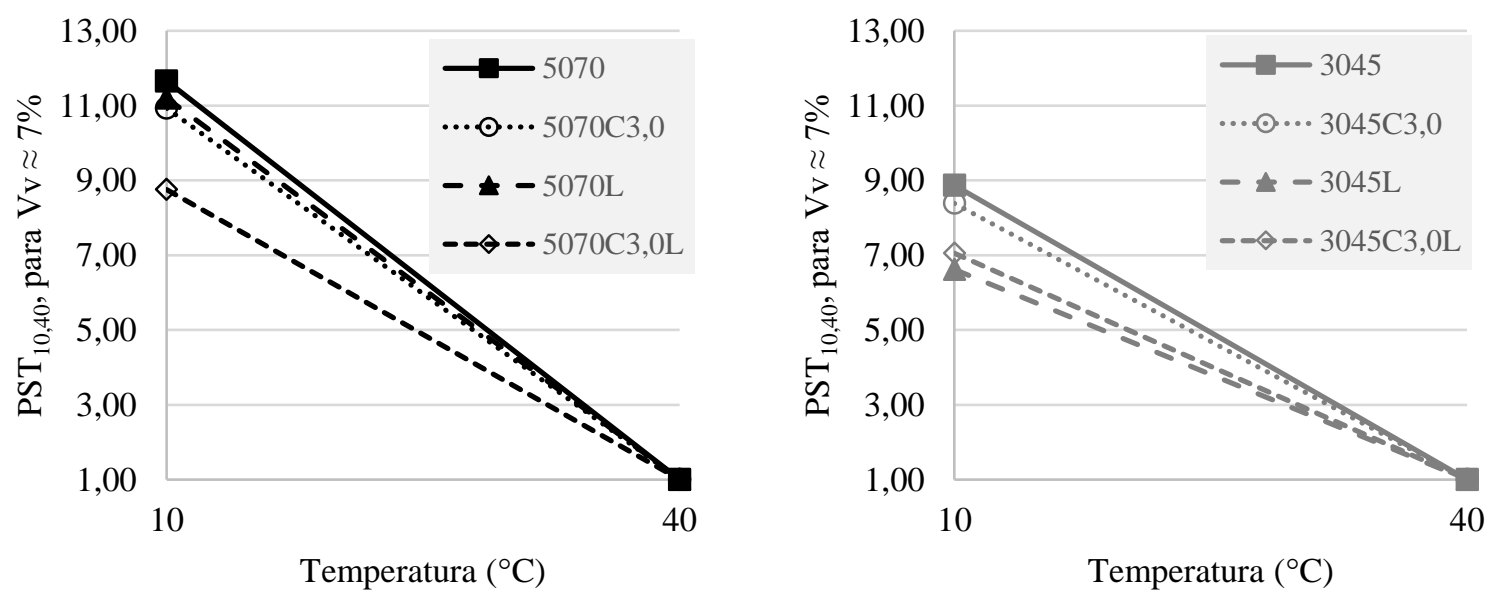

Figura 4.26 - PST para $V v \approx 7 \%$ na faixa de temperatura de 10 a $40^{\circ} \mathrm{C}$

Mais uma vez o uso de CAP 30/45 atuou de maneira importante para reduzir à susceptibilidade térmica em relação às misturas correspondentes com CAP 50/70.

O tipo de fíler também contribuiu de maneira importante no sentido de reduzir a susceptibilidade térmica das misturas. A adição simultânea de cal e caulim fez o PST 10,40 da mistura 5070C3,0L reduzir 25\% em relação à mistura de referência. O mesmo percentual de redução de PST $_{10,40}$ foi encontrado quando da adição de cal nas misturas com CAP 30/45 
(3045L x 3045). Furlan (2006) também relatou redução na susceptibilidade térmica com a adição de cal.

4.4.1.7 Influência dos parâmetros de caracterização do fíler nos valores de módulo de resiliência a 10,25 e $40^{\circ} \mathrm{C}$ e do parâmetro de susceptibilidade térmica ( $\mathrm{PST}_{10,25}, \mathrm{PST}_{25,40}$ e $\mathrm{PST}_{10,40}$ )

$\mathrm{Na}$ Tabela 4.17, são apresentados os valores de $\mathrm{R}^{2}$ das regressões lineares efetuadas entre os parâmetros de caracterização do fíler versus valores de $\mathrm{MR}_{4 \%}$ e $\mathrm{MR}_{7 \%}$ à 10,25 e $40^{\circ} \mathrm{C}$ e valores de PST $_{10,25}$, PST $_{25,40}$ e PST 10,40 para ambos os níveis de Vv. Também consta a indicação se a relação entre as variáveis é direta (+) ou inversamente proporcional (-). Apenas os valores em negrito indicam que há relação linear entre as variáveis, a um nível de significância de 5\%, segundo a análise de variância (teste do valor da estatística F - Apêndice D). Como na Etapa 3 há um único teor de caulim (3,0\%), os parâmetros de caracterização do fíler nesta etapa ficam restritos a D10, D30, D60 e MF.

Tabela 4.17 - Valores de $\mathrm{R}^{2}$ das regressões lineares entre MR e PST versus parâmetros de caracterização do fíler

\begin{tabular}{|c|c|c|c|c|c|c|c|c|c|}
\hline $\begin{array}{l}\text { Variável- } \\
\text { resposta }\end{array}$ & D10 & D30 & D60 & MF & $\begin{array}{l}\text { Variável- } \\
\text { resposta }\end{array}$ & D10 & D30 & D60 & MF \\
\hline $\mathrm{MR}_{4 \%} 10^{\circ} \mathrm{C} 50 / 70$ & 0,02 & 0,01 & 0,00 & 0,01 & $\mathrm{PST}_{10,25} 50 / 704 \%$ & 0,50 & 0,58 & 0,52 & 0,60 \\
\hline $\mathrm{MR}_{4 \%} 10^{\circ} \mathrm{C}$ todas & $0,01(-)$ & $0,12(-)$ & $0,16(-)$ & $0,11(-)$ & $\mathrm{PST}_{10,25}$ todas $4 \%$ & $0,24(+)$ & $0,14(+)$ & $0,10(+)$ & $0,16(+)$ \\
\hline $\mathrm{MR}_{7 \%} 10^{\circ} \mathrm{C} 50 / 70$ & $0,96(-)$ & 0,76 & 0,60 & 0,80 & $\mathrm{PST}_{10,25} 50 / 707 \%$ & 0,01 & 0,33 & 0,50 & 0,28 \\
\hline $\mathrm{MR}_{7 \%} 10^{\circ} \mathrm{C} 30 / 45$ & 0,05 & 0,02 & 0,05 & 0,01 & $\mathrm{PST}_{10,25} 30 / 457 \%$ & 0,81 & 0,80 & 0,68 & 0,83 \\
\hline $\mathrm{MR}_{4 \%} 25^{\circ} \mathrm{C} 30 / 45$ & 0,29 & 0,64 & 0,65 & 0,62 & $\mathrm{PST}_{25,40} 30 / 454 \%$ & 0,40 & 0,48 & 0,43 & 0,49 \\
\hline $\mathrm{MR}_{4 \%} 25^{\circ} \mathrm{C}$ todas & $0,22(-)$ & $0,34(-)$ & $0,32(-)$ & $0,34(-)$ & $\mathrm{PST}_{25,40}$ todas $4 \%$ & $0,00(+)$ & $0,03(+)$ & $0,04(+)$ & $0,04(+)$ \\
\hline $\mathrm{MR}_{7 \%} 25^{\circ} \mathrm{C} 50 / 70$ & 0,24 & 0,87 & $0,95(-)$ & 0,83 & $\mathrm{PST}_{25,40} 50 / 707 \%$ & 0,35 & 0,38 & 0,33 & 0,39 \\
\hline $\mathrm{MR}_{7 \%} 25^{\circ} \mathrm{C} 30 / 45$ & 0,00 & 0,13 & 0,18 & 0,11 & $\mathrm{PST}_{25,40} 30 / 457 \%$ & 0,09 & 0,12 & 0,24 & 0,09 \\
\hline $\mathrm{MR}_{7 \% 25^{\circ} \mathrm{C} \text { todas }}$ & $0,05(-)$ & $0,07(-)$ & $0,06(-)$ & $0,07(-)$ & $\mathrm{PST}_{25,40}$ todas $7 \%$ & $0,00(+)$ & $0,05(+)$ & $0,06(+)$ & $0,04(+)$ \\
\hline $\mathrm{MR}_{7 \%} 40^{\circ} \mathrm{C} 30 / 45$ & 0,17 & 0,00 & 0,02 & 0,00 & $\mathrm{PST}_{10,40} 30 / 457 \%$ & 0,30 & 0,01 & 0,07 & 0,00 \\
\hline $\mathrm{MR}_{7 \%} 40^{\circ} \mathrm{C}$ todas & $0,01(-)$ & $0,11(-)$ & $0,14(-)$ & $0,10(-)$ & $\mathrm{PST}_{10,40}$ todas $7 \%$ & $0,00(-)$ & $0,07(+)$ & $0,11(+)$ & $0,06(+)$ \\
\hline
\end{tabular}

De modo geral, observou-se que os parâmetros de caracterização do fíler exibiram relação inversamente proporcional ao MR, independentemente de temperatura e de nível de volume de vazios, ou seja, quanto menores os valores de D10, D30, D60 e MF (fíler mais fino), maior será rigidez. Os parâmetros de caracterização do fíler apresentaram relação diretamente proporcional com os PSTs, independentemente do intervalo de temperatura e do nível de volume de vazios. Logo, quanto mais fino for o fíler, menor será o PST e, portanto, menor a susceptibilidade térmica. 
Contudo, os valores de $\mathrm{R}^{2}$ são muito baixos e há correlações válidas somente entre os parâmetros de caraterização do fíler e o MR, não ocorrendo qualquer relação linear entre D10, D30, D60 e MF versus parâmetros de susceptibilidade térmica.

As análises de regressão ratificaram as análises técnicas sobre a influência do tipo de fíler e do tipo de ligante asfáltico nos valores de MR e PST, ao detectar a tendência de que misturas com fíleres mais finos apresentam maiores valores de rigidez e menores valores de PST. Na grande maioria dos casos, as relações entre os parâmetros de caracterização do fíler versus parâmetros de susceptibilidade térmica e módulo de resiliência não foram estatisticamente relevantes, o que confirma o papel preponderante do tipo de ligante asfáltico na diferenciação dos valores de MR e PST entre as misturas da pesquisa.

Em função da análise dos valores médios de $\mathrm{R}^{2}$, é possível dizer que, dentre os valores de MR e PST: (i) $\mathrm{MR}_{4 \%}$ a $25^{\circ}$ e $\mathrm{MR}_{4} \%$ a $10^{\circ}$ foram as variáveis-resposta melhor e pior explicadas, respectivamente, pelos parâmetros de caracterização do fíler, e; (ii) D60 e D10 são os parâmetros de caracterização do fíler que melhor e pior explicam, respectivamente, as variações nos valores de MR e PST.

\subsubsection{Consolidação dos resultados das análises referentes à susceptibilidade térmica}

> As misturas com maior volume de vazios $(\mathrm{Vv} \approx 7 \%)$ apresentaram, sempre, menor susceptibilidade térmica dos que as misturas com menor $\mathrm{Vv}(\mathrm{Vv} \approx 4 \%)$;

A mistura 3045C3,0 apresentou a menor susceptibilidade térmica, para o nível de volume de vazios $\approx 4 \%$ nos 3 intervalos de temperatura;

A mistura 3045L exibiu a menor susceptibilidade térmica, para $\mathrm{Vv} \approx 7 \%$, considerando os intervalos de 10 a $40^{\circ} \mathrm{C}$ e $25^{\circ}$ a $40^{\circ} \mathrm{C}$;

> A mistura 5070 apresentou a maior susceptibilidade térmica em ambos os níveis de volume de vazios, nos intervalos de 10 a $40^{\circ} \mathrm{C}$ e de 10 a $25^{\circ} \mathrm{C}$;

$>$ Considerou-se muito positivo o desempenho das misturas contendo caulim, visto que quase sempre apresentaram susceptibilidade térmica inferior às misturas de referência;

$>\mathrm{O}$ tipo de ligante asfáltico foi o fator que mais afetou os valores do parâmetro de susceptibilidade térmica (PST), nas diversas faixas de temperatura e níveis de Vv, sendo que o uso de CAP 30/45 reduziu significativamente os valores de PST; 
$>$ O tipo de fíler também contribuiu, na maioria das vezes, para reduzir a susceptibilidade térmica das misturas. O caulim ajudou a fazer da condição 3045C3,0, no nível de Vv $\approx$ $4 \%$, a menos suscetível à variação de rigidez em função da alteração da temperatura. De modo geral, as misturas C3,0 tiveram menor susceptibilidade térmica que as misturas de referência, assim como as misturas C3,0L exibiram menores valores de PST do que as misturas L. A cal teve atuação destacada para reduzir os valores de PST, quando associada ao CAP 30/45 e nas misturas com $\mathrm{Vv} \approx 7 \%$. A adição simultânea de cal e caulim teve papel mais destacado na redução da susceptibilidade térmica quando associado ao CAP 50/70, independentemente do nível de Vv;

$>$ Os parâmetros de caracterização do fíler (D10, D30, D60 e MF) não possuem quaisquer correlações lineares com os valores de PST, embora se tenha detectado a tendência de que fíleres mais finos estão associados à menor suscetibilidade térmica.

\subsubsection{Vida de fadiga}

A apresentação dos resultados e análises referentes à vida de fadiga está dividida em 5 partes: (i) apresentação e análise dos modelos de fadiga; (ii) comparação do desempenho à fadiga das misturas em função do nível de diferença de tensões; (iii) comparação do desempenho à fadiga das misturas em função do tipo de pavimento - análise mecanística; (iv) análise de sensibilidade da vida de fadiga, e; (v) consolidação dos resultados.

\subsubsection{Apresentação e análise dos modelos de fadiga}

O passo inicial para analisar e comparar a vida de fadiga das misturas foi a geração dos modelos de fadiga, os quais foram obtidos pela correlação entre a diferença de tensões no centro do CP $(\Delta \sigma)$ e o número de aplicações de carga que levou ao rompimento do corpo de prova $(\mathrm{N}$ - vida de fadiga), oriundos dos ensaios de fadiga por compressão diametral à tensão controlada. Relacionam-se as variáveis $\mathrm{N}$ e $\Delta \sigma$ por meio de um modelo de potência.

Na Tabela 4.18 são apresentados os resultados dos ensaios de fadiga por compressão diametral à tensão controlada de todas as misturas. As tabelas contêm os valores médios de carga, \%RT, $\Delta \sigma$ e $\mathrm{N}$ obtidos a partir de 2 CPs por nível de carga, indicação de RT e MR da mistura, além dos modelos de fadiga e respectivos valores de $\mathrm{R}^{2}$. Em função dos elevados valores de $\mathrm{R}^{\mathbf{2}}(0,97$ a 0,99$)$, destaca-se a boa qualidade dos modelos. 
Tabela 4.18 - Resultados dos ensaios de fadiga para todas as misturas

\begin{tabular}{|c|c|c|c|c|c|c|c|}
\hline \multicolumn{4}{|c|}{ Mistura 5070 } & \multicolumn{4}{|c|}{ Mistura 3045} \\
\hline \multicolumn{2}{|c|}{$\mathrm{RT}=1,63 \mathrm{MPa}$} & \multicolumn{2}{|c|}{$\mathrm{MR}=4865 \mathrm{MPa}$} & \multicolumn{2}{|c|}{$\mathrm{RT}=1,89 \mathrm{MPa}$} & \multicolumn{2}{|c|}{$\mathrm{MR}=5365 \mathrm{MPa}$} \\
\hline $\begin{array}{c}\text { Cargaa } \\
\text { (kgf) }\end{array}$ & $\% \mathbf{R T}$ & $\Delta \sigma(\mathrm{MPa})$ & $\mathbf{N}$ & $\begin{array}{c}\text { Carga } \\
\text { (kgf) }\end{array}$ & $\%$ RT & $\Delta \sigma(\mathrm{MPa})$ & $\mathbf{N}$ \\
\hline 182 & 10 & 0,65 & 16174 & 208 & 10 & 0,76 & 78978 \\
\hline 360 & 20 & 1,31 & 1203 & 409 & 20 & 1,51 & 4620 \\
\hline 543 & 30 & 1,96 & 203 & 629 & 30 & 2,27 & 1095 \\
\hline 722 & 40 & 2,61 & 140 & 838 & 40 & 3,02 & 550 \\
\hline $\begin{array}{c}\text { Modelo de } \\
\text { Fadiga } \\
5070\end{array}$ & $N=312$ & $\left(\frac{1}{\Delta \sigma}\right)^{3,571}$ & $\mathbf{R}^{2}=\mathbf{0 , 9 7}$ & $\begin{array}{c}\text { Modelo de } \\
\text { Fadiga } \\
\mathbf{3 0 4 5}\end{array}$ & $N=248$ & $\times\left(\frac{1}{\Delta \sigma}\right)^{3,670}$ & $\mathbf{R}^{2}=\mathbf{0 , 9 8}$ \\
\hline \multicolumn{4}{|c|}{ Mistura 5070C3,0 } & \multicolumn{4}{|c|}{ Mistura 3045C3,0 } \\
\hline \multicolumn{2}{|c|}{$\mathrm{RT}=1,65 \mathrm{MPa}$} & \multicolumn{2}{|c|}{$\mathrm{MR}=5079 \mathrm{MPa}$} & \multicolumn{2}{|c|}{$\mathrm{RT}=1,70 \mathrm{MPa}$} & \multicolumn{2}{|c|}{$\mathrm{MR}=5506 \mathrm{MPa}$} \\
\hline $\begin{array}{c}\text { Carga } \\
\text { (kgf) }\end{array}$ & $\% \mathbf{R T}$ & $\Delta \sigma(\mathrm{MPa})$ & $\mathbf{N}$ & $\begin{array}{c}\text { Carga } \\
\text { (kgf) }\end{array}$ & $\% \mathbf{R T}$ & $\Delta \sigma(\mathrm{MPa})$ & $\mathbf{N}$ \\
\hline 184 & 10 & 0,66 & 33685 & 187 & 10 & 0,68 & 105075 \\
\hline 367 & 20 & 1,32 & 3512 & 375 & 20 & 1,36 & 9040 \\
\hline 550 & 30 & 1,98 & 1239 & 561 & 30 & 2,04 & 1719 \\
\hline 734 & 40 & 2,64 & 434 & 748 & 40 & 2,72 & 659 \\
\hline $\begin{array}{l}\text { Modelo de } \\
\text { Fadiga } \\
\text { 5070C3,0 }\end{array}$ & $N=905$ & $\left(\frac{1}{\Delta \sigma}\right)^{3,086}$ & $\mathbf{R}^{2}=\mathbf{0 , 9 9}$ & $\begin{array}{c}\text { Modelo de } \\
\text { Fadiga } \\
\text { 3045C3,0 }\end{array}$ & $N=\mathbf{2 5 0}$ & $\times\left(\frac{1}{\Delta \sigma}\right)^{3,654}$ & $\mathbf{R}^{2}=\mathbf{0 , 9 9}$ \\
\hline \multicolumn{4}{|c|}{ Mistura 5070L } & \multicolumn{4}{|c|}{ Mistura 3045L } \\
\hline \multicolumn{2}{|c|}{$\mathrm{RT}=1,64 \mathrm{MPa}$} & \multicolumn{2}{|c|}{$\mathrm{MR}=4538 \mathrm{MPa}$} & \multicolumn{2}{|c|}{$\mathrm{RT}=1,84 \mathrm{MPa}$} & \multicolumn{2}{|c|}{$\mathrm{MR}=5057 \mathrm{MPa}$} \\
\hline $\begin{array}{c}\text { Carga } \\
\text { (kgf) }\end{array}$ & $\% \mathbf{R T}$ & $\Delta \sigma(\mathbf{M P a})$ & $\mathbf{N}$ & $\begin{array}{c}\text { Carga } \\
\text { (kgf) }\end{array}$ & $\%$ RT & $\Delta \sigma(\mathrm{MPa})$ & $\mathbf{N}$ \\
\hline 182 & 10 & 0,66 & 28867 & 203 & 10 & 0,74 & 134218 \\
\hline 365 & 20 & 1,31 & 2184 & 406 & 20 & 1,47 & 4263 \\
\hline 544 & 30 & 1,97 & 718 & 609 & 30 & 2,21 & 1309 \\
\hline 730 & 40 & 2,62 & 224 & 813 & 40 & 2,94 & 408 \\
\hline $\begin{array}{l}\text { Modelo de } \\
\text { Fadiga } \\
\text { 5070L }\end{array}$ & $N=642$ & $\left(\frac{1}{\Delta \sigma}\right)^{3,463}$ & $\mathbf{R}^{2}=\mathbf{0 , 9 9}$ & $\begin{array}{c}\text { Modelo de } \\
\text { Fadiga } \\
\text { 3045L }\end{array}$ & $N=300$ & $\times\left(\frac{1}{\Delta \sigma}\right)^{4,099}$ & $\mathbf{R}^{2}=\mathbf{0 , 9 8}$ \\
\hline \multicolumn{4}{|c|}{ Mistura 5070C3,0L } & \multicolumn{4}{|c|}{ Mistura 3045C3,0L } \\
\hline \multicolumn{2}{|c|}{$\mathrm{RT}=1,65 \mathrm{MPa}$} & \multicolumn{2}{|c|}{$M R=5167 \mathrm{MPa}$} & \multicolumn{2}{|c|}{$\mathrm{RT}=1,94 \mathrm{MPa}$} & \multicolumn{2}{|c|}{$\mathrm{MR}=6074 \mathrm{MPa}$} \\
\hline $\begin{array}{c}\text { Carga } \\
\text { (kgf) }\end{array}$ & $\% \mathbf{R T}$ & $\Delta \sigma(\mathrm{MPa})$ & $\mathbf{N}$ & $\begin{array}{c}\text { Carga } \\
\text { (kgf) }\end{array}$ & $\% \mathbf{R T}$ & $\Delta \sigma(\mathbf{M P a})$ & $\mathbf{N}$ \\
\hline 184 & 10 & 0,67 & 39867 & 213 & 10 & 0,78 & 155334 \\
\hline 365 & 20 & 1,33 & 2542 & 428 & 20 & 1,55 & 4695 \\
\hline 550 & 30 & 1,99 & 782 & 641 & 30 & 2,33 & 1273 \\
\hline 730 & 40 & 2,66 & 353 & 806 & 37,5 & 2,92 & 653 \\
\hline $\begin{array}{c}\text { Modelo de } \\
\text { Fadiga } \\
\text { 5070C3,0L }\end{array}$ & $N=859$ & $\left(\frac{1}{\Delta \sigma}\right)^{3,431}$ & $\mathbf{R}^{2}=0,99$ & $\begin{array}{c}\text { Modelo de } \\
\text { Fadiga } \\
\text { 3045C3,0L }\end{array}$ & $N=42$ & $\times\left(\frac{1}{\Delta \sigma}\right)^{4,130}$ & $\mathbf{R}^{2}=\mathbf{0 , 9 8}$ \\
\hline
\end{tabular}

A partir dos dados da Tabela 4.18, nota-se que à medida que se aumentou a carga aplicada, a vida de fadiga (N) reduziu bastante para todas as misturas. Para o nível de carga correspondente a $10 \%$ da RT, a variação de resultados entre as misturas é muito maior do que para o nível equivalente a $40 \%$ da RT. 
Nas Figuras 4.27 e 4.28 estão indicados graficamente os modelos de fadiga das misturas com CAP 50/70 e CAP 30/45, respectivamente. Analisando as figuras é possível perceber que: (i) as misturas com CAP 30/45 apresentaram maior vida de fadiga, para um mesmo nível de diferença de tensões, do que as misturas com CAP 50/70, e; (ii) a influência do tipo de fíler na vida de fadiga foi mais importante nas misturas com CAP 50/70 do que nas misturas com CAP 30/45, tendo em vista que as curvas dos modelos da Figura 4.26 ficaram mais separadas entre si, do que as representadas na Figura 4.27, onde as curvas ficaram quase que sobrepostas, especialmente nos níveis de diferença de tensões mais elevados.

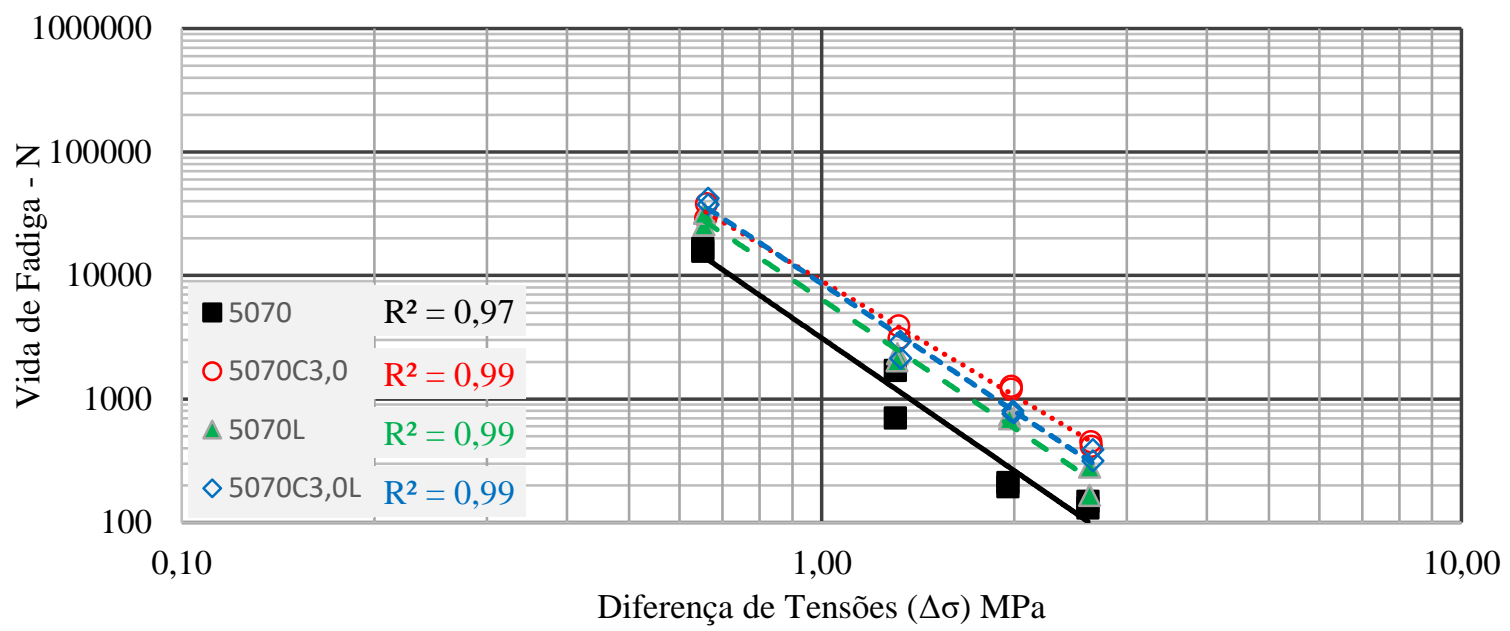

Figura 4.27 - Representação gráfica dos modelos de fadiga para misturas com CAP 50/70

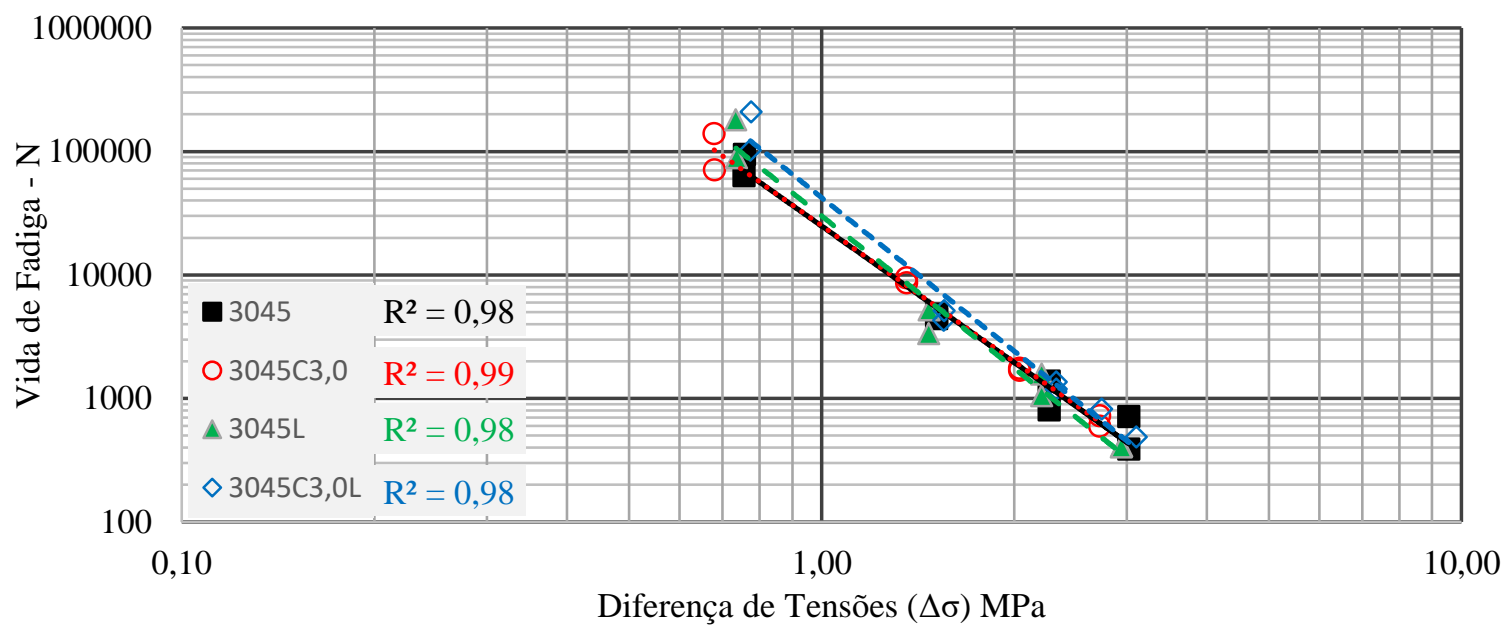

Figura 4.28 - Representação gráfica dos modelos de fadiga para misturas com CAP 30/45

$\mathrm{Na}$ Tabela 4.19, estão resumidos os valores de $\mathrm{k}_{1}$ e $\mathrm{k}_{2}$ dos modelos de fadiga de todas as misturas. $\mathrm{O}$ coeficiente $\mathrm{k}_{1}$ indica o valor de $\mathrm{N}$, quando $\Delta \sigma=1 \mathrm{MPa}$. Desta forma, quanto maior o valor de $\mathrm{k}_{1}$, para um mesmo valor de $\mathrm{k}_{2}$, maior será a vida de fadiga. $\mathrm{O}$ coeficiente $\mathrm{k}_{2}$ indica 
a "inclinação" do modelo de fadiga. Assim, baixos valores de $\mathrm{k}_{2}$ representam modelos de fadiga pouco inclinados, nos quais $\mathrm{N}$ fica menos suscetível à variação da diferença de tensões. Por outro lado, modelos de fadiga com $\mathrm{k}_{2}$ elevados indicam misturas cujas vidas de fadiga são muito afetadas pela diferença de tensões, apresentando maior inclinação na representação gráfica. Portanto, ao se comparar hipoteticamente duas misturas com diferentes valores de $\mathrm{k}_{2}$ e mesmos valores de $\mathrm{k}_{1}$, a mistura com maior valor de $\mathrm{k}_{2}$ apresentará maior vida de fadiga quando $\Delta \sigma<1$ MPa e menor vida de fadiga para $\Delta \sigma>1 \mathrm{MPa}$.

Tabela 4.19 - Valores dos coeficientes $\mathrm{k}_{1}$ e $\mathrm{k}_{2}$ dos modelos de fadiga de todas as misturas

\begin{tabular}{ccc}
\hline Condição & $\mathbf{k}_{\mathbf{1}}$ & $\mathbf{k}_{\mathbf{2}}$ \\
\hline 5070 & 3123 & 3,571 \\
$5070 \mathrm{C} 3,0$ & 9059 & 3,086 \\
$5070 \mathrm{~L}$ & 6420 & 3,463 \\
$5070 \mathrm{C} 3,0 \mathrm{~L}$ & 8595 & 3,431 \\
\hline 3045 & 24886 & 3,670 \\
$3045 \mathrm{C} 3,0$ & 25086 & 3,654 \\
$3045 \mathrm{~L}$ & 30054 & 4,099 \\
$3045 \mathrm{C} 3,0 \mathrm{~L}$ & 42335 & 4,130 \\
\hline
\end{tabular}

Em função dos dados da Tabela 4.19, percebe-se que as misturas com CAP 30/45 apresentaram, sempre: (i) maiores valores de $\mathrm{k}_{1}$ (da ordem de $10^{4}$ para CAP $30 / 45$ e $10^{3}$ para CAP 50/70), indicando assim que as misturas com o ligante asfáltico mais consistente tenderam a apresentar maior vida de fadiga, e; (ii) maiores valores de $\mathrm{k}_{2}$, ou seja, as misturas com CAP 30/45 têm vidas de fadiga mais suscetíveis a alterações nas diferenças de tensões.

A adição de qualquer tipo de fíler tendeu a elevar a vida de fadiga (maiores valores de $\mathrm{k}_{1}$ ), a reduzir a susceptibilidade da vida de fadiga em função de $\Delta \sigma$ (menores valores de $\mathrm{k}_{2}$ ) nas misturas com CAP 50/70 e aumentar a susceptibilidade da vida de fadiga em função de $\Delta \sigma$ (maiores valores de $\mathrm{k}_{2}$ ) nas misturas com CAP 30/45. Especificamente: (i) a adição de caulim elevou $k_{1}$ e reduziu $k_{2}$ independentemente do tipo de ligante asfáltico; (ii) a adição de cal parece ter especial influência no valor de $\mathrm{k}_{2}$, pois as misturas $\mathrm{L}$ ou C3,0L apresentaram valores de $\mathrm{k}_{2}$ próximos entre si e distintos das misturas que não possuem cal, e; (iii) a adição concomitante de cal e caulim conduziu à maior elevação média de $\mathrm{k}_{1}$.

Quando se fez a análise das misturas C3,0 $x$ misturas de referência e C3,0L $x$ L, notou-se o aumento nos valores de $\mathrm{k}_{1}$ e redução nos valores de $\mathrm{k}_{2}$ quando da adição de caulim Estes resultados são muito interessantes pois indicaram que o rejeito de caulim introduzido como fíler 
fez com que as misturas apresentassem tendência de aumento na vida de fadiga e menor susceptibilidade da vida de fadiga em função da variação de $\Delta \sigma$.

\subsubsection{Comparação da vida de fadiga das misturas asfálticas}

Embora as análises dos coeficientes $\mathrm{k}_{1}$ e k2, efetuada na seção anterior, seja importante, não é correto comparar diretamente dois modelos de fadiga e, somente a partir deles, inferir sobre qual mistura asfáltica possui melhor desempenho à fadiga. Para ser possível efetuar comparações entre $\mathrm{N}$ de duas ou mais misturas asfálticas é necessário fazer um dos procedimentos descritos abaixo:

Arbitrar um valor para $\Delta \sigma$ e inseri-lo em todos os modelos de fadiga, facultando a comparação de qual mistura apresentará maior $\mathrm{N}$ para aquele determinado nível de diferença de tensão. Este processo é mais simples e indicado para comparações de desempenho das misturas sob diferentes cenários de valores de $\Delta \sigma$, ou;

> Efetuar análise mecanística de pavimentos para determinar o valor da diferença de tensões atuante na fibra inferior da camada asfáltica e incluir este valor no modelo de fadiga para então determinar N. Este processo é mais adequado quando já se conhece a estrutura do pavimento para o qual a mistura asfáltica está sendo projetada.

\subsection{Comparação da vida de fadiga em função do nível de diferença de tensões}

Na Tabela 4.20, são apresentadas as vidas de fadiga $(\mathrm{N})$ calculadas a partir das diferenças de tensões em seis níveis (variando de 0,5 a 3,0 MPa) e dos modelos de fadiga de cada mistura asfáltica. Ao lado do valor de $\mathrm{N}$, entre parênteses, encontra-se o ranking das misturas com melhor desempenho à fadiga para cada nível de tensão, por tipo de ligante asfáltico. Em negrito, estão destacadas as misturas com melhor desempenho à fadiga e em itálico, aquelas com pior desempenho. Na Figura 4.29 há uma representação gráfica dos dados contidos na Tabela 4.20. As linhas em cor preta representam o CAP 50/70 e as linhas em cor azul, o CAP 30/45.

Inicialmente discute-se a influência do tipo de ligante asfáltico e do tipo de fíler na vida de fadiga para em seguida avaliar-se os rankings de desempenho à fadiga, em função da $\Delta \sigma$ por tipo de ligante asfáltico. 
Tabela 4.20 - Variação da vida de fadiga em função do nível de diferença de tensões

\begin{tabular}{|c|c|c|c|c|c|c|}
\hline $\begin{array}{c}\text { Condição } \\
\text { Experimental }\end{array}$ & $\begin{array}{c}\mathrm{N} \\
(\Delta \sigma=0,5 \\
\mathrm{MPa})\end{array}$ & $\begin{array}{c}\mathrm{N} \\
(\Delta \sigma=1,0 \\
\mathrm{MPa})\end{array}$ & $\begin{array}{c}\mathrm{N} \\
(\Delta \sigma=1,5 \\
\mathrm{MPa})\end{array}$ & $\begin{array}{c}\mathrm{N} \\
(\Delta \sigma=2,0 \\
\mathrm{MPa})\end{array}$ & $\begin{array}{c}\mathrm{N} \\
(\Delta \sigma=2,5 \\
\mathrm{MPa}) \\
\end{array}$ & $\begin{array}{c}\mathrm{N} \\
(\Delta \sigma=3,0 \\
\mathrm{MPa})\end{array}$ \\
\hline & $37115\left(4^{\circ}\right)$ & $3.123\left(4^{\circ}\right)$ & $734\left(4^{\circ}\right)$ & $263\left(4^{\circ}\right)$ & $118\left(4^{\circ}\right)$ & $62\left(4^{\circ}\right)$ \\
\hline & & & & o) & & ॰) \\
\hline & & & & & & $\left.3^{\circ}\right)$ \\
\hline 5070 & & & $2.138\left(2^{\circ}\right)$ & 797( & ○) & $\left.2^{\circ}\right)$ \\
\hline & & & $5.620(4$ & 1055 & 62 & $441\left(3^{\circ}\right)$ \\
\hline & ) & 250060 & $5.702(3$ & $1.993\left(2^{\circ}\right)$ & $882\left(2^{\circ}\right)$ & $453\left(1^{\circ}\right)$ \\
\hline & $15.020(2)$ & $30.054\left(2^{\circ}\right)$ & $5.703\left(2^{\circ}\right)$ & $1.754\left(4^{\circ}\right)$ & $703\left(4^{\circ}\right)$ & $333\left(4^{\circ}\right)$ \\
\hline $3045 \mathrm{C} 3,0 \mathrm{~L}$ & $741.318\left(1^{\circ}\right)$ & $42.340\left(1^{\circ}\right)$ & $7.934\left(1^{\circ}\right)$ & $2.418\left(1^{\circ}\right)$ & $962\left(1^{\circ}\right)$ & $453\left(1^{\circ}\right)$ \\
\hline
\end{tabular}

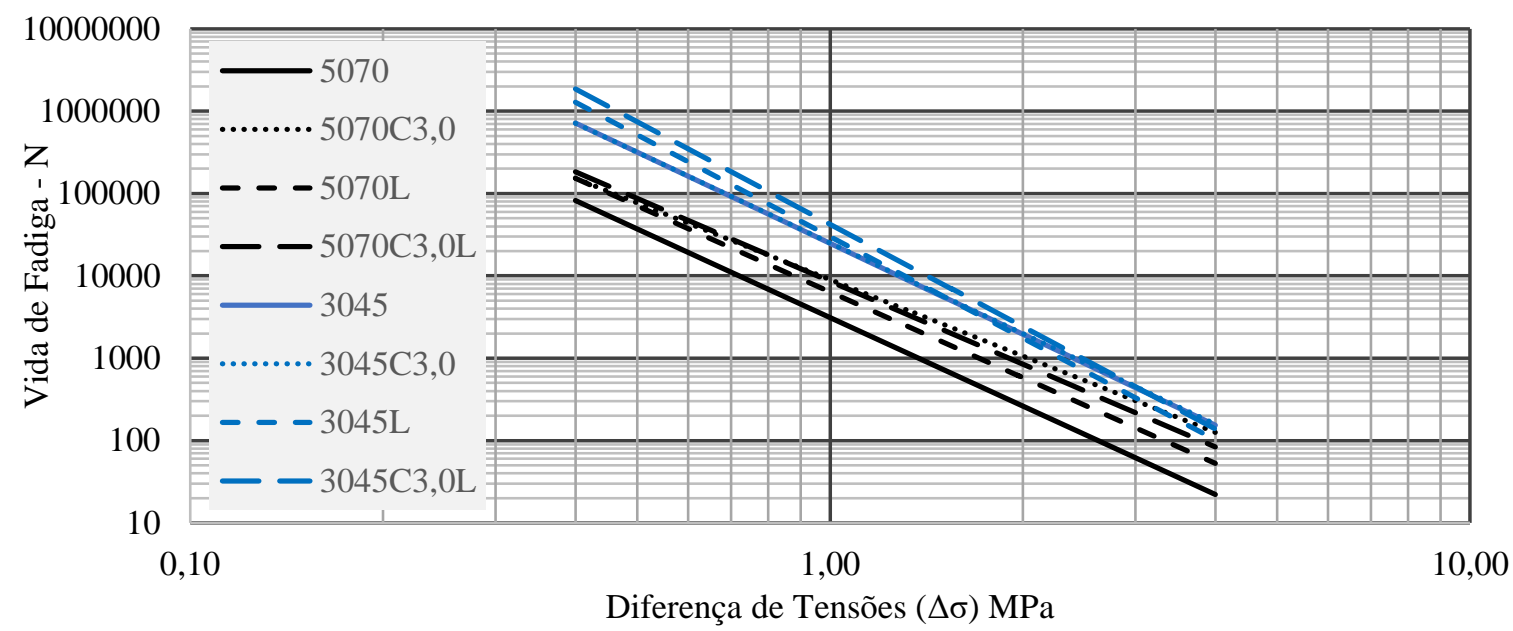

Figura 4.29 - Representação gráfica da comparação da vida de fadiga para diferentes níveis de tensão

O tipo de ligante asfáltico tem influência muito expressiva nos valores de N. As misturas com CAP 30/45 sempre apresentaram vidas de fadiga muito superiores às misturas com CAP 50/70. Tal comportamento é representado matematicamente pelo maior coeficiente $\mathrm{k}_{1}$ das misturas com CAP 30/45. Ao se analisar a Figura 4.29, percebe-se que as linhas em azul (CAP 30/45) convergem à medida que se aumenta $\Delta \sigma$. Já as linhas em preto (CAP 50/70) divergem com o aumento da diferença de tensões. Isto indica que: (i) para níveis baixos de $\Delta \sigma$, as misturas com CAP 30/45 apresentam N muito maiores do que as misturas com CAP 50/70, e; (ii) para níveis elevados de $\Delta \sigma$, a diferença entre os valores de $\mathrm{N}$ das misturas CAP 30/45 em relação às misturas CAP 50/70 vai ficando cada vez menor. O maior valor de $\mathrm{k}_{2}$ nos modelos das misturas com CAP 30/45 explica este fenômeno.

A adição de fíleres, de modo geral, ao enrijecer às misturas, também proporcionou incremento no desempenho à fadiga, sendo que: 
$>$ A adição de caulim aumentou, de forma importante, a vida de fadiga nas misturas com CAP 50/70, para todos os níveis de diferença de tensões. Para as misturas com CAP 30/45, os valores de $\mathrm{N}$ das misturas 3045 e 3045C3,0 são muito próximos em todos os níveis de tensão, o que era esperado em virtude da similaridade dos coeficientes $\mathrm{k}_{1}$ e $\mathrm{k}_{2}$ dos modelos de fadiga destas condições. Ainda assim, ocorre variação na mistura com melhor desempenho à fadiga. A mistura 3045 tem maior valor de $\mathrm{N}$ para $\Delta \sigma=0,5 \mathrm{MPa}$ e 3045C3,0 apresenta maior N nos demais níveis de diferença de tensão;

$>$ A adição de cal, quando associada ao CAP 50/70, sempre elevou os valores $\mathrm{N}$ em relação à mistura de referência 5070. À medida que se aumenta $\Delta \sigma$, ocorre maior elevação proporcional de N, na mistura 5070L. Em contraste, quando se trabalha com CAP 30/45, à medida que se aumenta o valor da diferença de tensão, ocorre redução proporcional nos valores de $\mathrm{N}$ da mistura 3045L. A mistura 3045L só apresenta vida de fadiga superior à mistura 3045 até $\Delta \sigma=1,5 \mathrm{MPa}$. A partir desse nível de tensão, os valores de $\mathrm{N}$ da mistura de referência 3045 são superiores. Estes resultados são explicados pelo valor mais elevados de $\mathrm{k}_{2}$ no modelo de fadiga da mistura 3045L;

$>\mathrm{O}$ uso concomitante de cal e caulim sempre aumentou a vida de fadiga, independentemente do tipo de ligante asfáltico e do nível de diferença de tensões. Tal comportamento era esperado em função do elevado valor de $\mathrm{k}_{1}$ dos modelos de fadiga destas misturas em relação às misturas de referência.

Com base no ranking de desempenho à fadiga em função da $\Delta \sigma$, para as misturas com CAP 50/70, tem-se que:

A mistura com caulim $(5070 \mathrm{C} 3,0)$ apresentou o melhor desempenho à fadiga, exceto no nível $\Delta \sigma=0,5 \mathrm{MPa}$, quando apresentou o segundo melhor desempenho. A mistura 5070C3,0L exibiu o segundo melhor desempenho, exceto no nível mais baixo de tensão no qual superou a mistura 5070C3,0 ficando em primeiro lugar. As misturas 5070L e 5070 ficaram, independentemente de $\Delta \sigma$, com o terceiro e pior desempenho, respectivamente. Estes resultados indicam que: (i) $\mathrm{O}$ uso de caulim foi considerado muito positivo. Ele contribuiu para elevar a vida de fadiga seja na comparação 5070C3,0 x 5070, seja na comparação 5070C3,0L x 5070L. Obteve-se, assim, mais um indício de que o uso de rejeito de caulim como fíler em misturas asfálticas, além de propiciar ganhos ambientais, pode incrementar as propriedades mecânicas e melhorar o desempenho da massa asfáltica; (ii) A contribuição da cal foi menos importante que a contribuição do caulim no sentido de elevar a vida de fadiga das misturas com CAP 50/70, e; 
(iii) A mistura 5070 destacou-se negativamente por apresentar, sempre, a menor vida de fadiga, consideravelmente inferior às demais condições, para todos os níveis de tensão.

Com base no ranking de desempenho à fadiga em função da $\Delta \sigma$, para as misturas com CAP 30/45, tem-se que:

A mistura 3045C3,0L exibiu sempre a maior vida de fadiga. No entanto, houve um intenso intercâmbio de posições entre as demais misturas no ranking de desempenho à fadiga em função do nível de tensão. A mistura 3045L teve o segundo melhor desempenho até $\Delta \sigma=1,5 \mathrm{MPa}$. Contudo, para níveis maiores de diferença de tensão, foi a pior mistura. A mistura 3045C3,0 foi subindo no ranking, à medida que se elevou $\Delta \sigma$, exibindo pior $\mathrm{N}$ para $\Delta \sigma=0,5 \mathrm{MPa}$, terceiro melhor desempenho quando a diferença de tensões foi de 1,0 e 1,5 MPa e foi a segunda melhor mistura, em relação à vida de fadiga, nos níveis mais elevados de tensão. A mistura de referência (3045) teve o pior desempenho quando $\Delta \sigma=1,0$ e $\Delta \sigma=1,5 \mathrm{MPa}$, ficando na $3^{\mathrm{a}}$ posição do ranking nos demais níveis de diferença de tensões.

Estes resultados indicam que: (i) O uso de caulim foi considerado muito positivo. Quando adicionado isoladamente $(\mathrm{C} 3,0)$, ele praticamente não alterou os valores de $\mathrm{N}$ em relação à mistura de referência. Em adição simultânea à cal $(\mathrm{C} 3,0 \mathrm{~L})$, elevou de forma importante à resistência à fadiga, fazendo com que a mistura 3045C3,0L apresentasse a maior vida de fadiga em todos os níveis de $\Delta \sigma$, e; (ii) $\mathrm{O}$ uso de cal prejudicou o desempenho à fadiga em relação à mistura de referência, para níveis elevados de diferença de tensões.

Por fim, cabe destacar que a grande variação de desempenho à fadiga em função da variação do nível de diferença de tensões corrobora a ideia de que não se deve analisar $\mathrm{N}$ com base somente nos modelos de fadiga.

\subsection{Comparação da vida de fadiga em função da análise mecanística de pavimentos}

Avaliou-se a vida de fadiga por meio de simulação de quatro pavimentos (A, B, C e D) no software mePADS, onde foram calculadas as tensões na estrutura dos pavimentos hipotéticos. As diferenças de tensões na fibra inferior da camada asfáltica, calculadas pelo software, foram inseridas nos modelos de fadiga de cada mistura para se descobrir os correspondentes valores de N. Não foram utilizados fatores campo laboratório (FCL) ou funções de transferência, pois 
pretende-se comparar o desempenho das misturas asfálticas e não efetuar verificação mecanística completa.

Os quatro pavimentos foram dimensionados pelo método do DNIT e resultaram da combinação de dois tipos de subleitos com CBR de 5 e $10 \%$, e dois níveis de tráfego $\left(\mathrm{N}=10^{6}\right.$ e $\left.\mathrm{N}=10^{7}\right)$. Arbitrou-se que os pavimentos seriam compostos apenas por capa asfáltica e base granular para reduzir o número de variáveis intervenientes. Para o carregamento, foi utilizado o eixo simples de rodas duplas (ESRD) com carga de $20 \mathrm{kN}$ por roda e pressão de enchimento de pneus de 560 $\mathrm{kgf} / \mathrm{cm}^{2}$. Os maiores valores de $\Delta \sigma$ ocorreram abaixo da roda interna do semi-eixo.

$\mathrm{Na}$ Tabela 4.21, são apresentadas as propriedades mecânicas e espessuras das camadas dos pavimentos A, B, C e D no cenário de referência, bem como o nível de tráfego utilizado para o dimensionamento. Os valores de MR e coeficiente de Poisson $(\mu)$ da base e do subleito foram adotados em conformidade com a Instrução de Projeto IP-DE-P00/001 do DER/SP. Os módulos de resiliência da capa foram os valores de $\mathrm{MR}$ a $25^{\circ} \mathrm{C}$ de cada mistura, conforme apresentado na seção 4.2.1. Para facilitar a leitura, os pavimentos A e C serão denominados de pavimentos com capa esbelta e os pavimentos B e D de pavimentos com capa espessa.

Tabela 4.21 - Propriedades mecânicas e espessuras das camadas dos pavimentos, no cenário de referência

\begin{tabular}{|c|c|c|c|c|}
\hline $\begin{array}{l}\text { Propriedades } \\
\text { Mecânicas e } \\
\text { Espessuras }\end{array}$ & $\begin{array}{c}\text { Pavimento } \\
\text { A } \\
\left(\mathrm{N}=10^{6}\right)\end{array}$ & $\begin{array}{c}\text { Pavimento } \\
\text { B } \\
\left(\mathrm{N}=\mathbf{1 0}^{7}\right)\end{array}$ & $\begin{array}{c}\text { Pavimento } \\
\text { C } \\
\left(\mathbf{N}=1^{6}\right)\end{array}$ & $\begin{array}{c}\text { Pavimento } \\
\text { D } \\
\left(\mathbf{N}=\mathbf{1 0}^{7}\right)\end{array}$ \\
\hline $\mathrm{MR}_{\text {Capa }}(\mathrm{MPa})$ & Variável & Variável & Variável & Variável \\
\hline$\mu_{\text {Сара }}$ & 0,30 & 0,30 & 0,30 & 0,30 \\
\hline $\operatorname{Espessura}_{\text {Capa }}(\mathrm{cm})$ & 5 & 10 & 5 & 10 \\
\hline $\mathrm{MR}_{\text {Base }}(\mathrm{MPa})$ & 225 & 225 & 225 & 225 \\
\hline$\mu_{\text {Base }}$ & 0,35 & 0,35 & 0,35 & 0,35 \\
\hline Espessura Base $(\mathrm{cm})$ & 48 & 47 & 29 & 24 \\
\hline CBR $(\%)$ & 5 & 5 & 10 & 10 \\
\hline $\mathrm{MR}_{\text {Subleito }}(\mathrm{MPa})$ & 60 & 60 & 95 & 95 \\
\hline$\mu_{\text {Subleito }}$ & 0,40 & 0,40 & 0,40 & 0,40 \\
\hline
\end{tabular}

Na Tabela 4.22, são mostrados os resultados dos cálculos realizados no mePADS, considerando o cenário de referência para cada pavimento. Apresentam-se o $\mathrm{MR}_{\mathrm{Capa}}$, a máxima diferença de tensões na fibra inferior da capa asfáltica $\left(\Delta \sigma_{\text {máx }}\right)$ e o valor de $\mathrm{N}$, em função do modelo de fadiga de cada mistura. Também há a indicação do ranking das misturas com melhor desempenho à fadiga para cada pavimento, por tipo de ligante asfáltico. Em negrito, estão destacadas as misturas com melhor desempenho à fadiga e em itálico, aquelas com pior desempenho. 
Tabela 4.22 - Diferenças de tensões na fibra inferior da capa e vida de fadiga, em função do tipo de pavimento e do tipo de mistura

\begin{tabular}{|c|c|c|c|c|c|c|c|c|c|}
\hline \multirow{2}{*}{$\begin{array}{l}\text { Tipo de } \\
\text { mistura } \\
\text { asfáltica }\end{array}$} & \multirow[b]{2}{*}{$\begin{array}{c}\mathbf{M R}_{\text {Capa }} \\
\text { (MPa) }\end{array}$} & \multicolumn{2}{|c|}{ Pavimento A } & \multicolumn{2}{|c|}{ Pavimento B } & \multicolumn{2}{|c|}{ Pavimento $\mathbf{C}$} & \multicolumn{2}{|c|}{ Pavimento D } \\
\hline & & $\begin{array}{c}\Delta \sigma_{\text {máx }} \\
(\mathrm{MPa})\end{array}$ & $\begin{array}{c}\mathrm{N} \\
\text { modelo }\end{array}$ & $\begin{array}{l}\Delta \sigma_{\text {máx }} \\
(\mathbf{M P a})\end{array}$ & $\begin{array}{c}\mathrm{N} \\
\text { modelo }\end{array}$ & $\begin{array}{c}\Delta \sigma_{\text {máx }} \\
(\mathbf{M P a})\end{array}$ & $\begin{array}{c}\mathrm{N} \\
\text { modelo }\end{array}$ & $\begin{array}{c}\Delta \sigma_{\text {máx }} \\
(\mathbf{M P a})\end{array}$ & $\begin{array}{c}\mathbf{N} \\
\text { modelo }\end{array}$ \\
\hline 5070 & 4865 & 2,095 & $222\left(4^{\circ}\right)$ & 1,380 & $988\left(4^{\circ}\right)$ & 2,144 & $204\left(4^{\circ}\right)$ & 1,441 & $847\left(4^{\circ}\right)$ \\
\hline $5070 \mathrm{C} 3,0$ & 5079 & 2,148 & $855\left(1^{\circ}\right)$ & 1,406 & $3167\left(1^{\circ}\right)$ & 2,199 & $795\left(1^{\circ}\right)$ & 1,468 & $2772\left(1^{\circ}\right)$ \\
\hline 5070L & 4538 & 2,011 & $570\left(3^{\circ}\right)$ & 1,339 & $2333\left(3^{\circ}\right)$ & 2,058 & $527\left(3^{\circ}\right)$ & 1,398 & $2011\left(3^{\circ}\right)$ \\
\hline $5070 \mathrm{C} 3,0 \mathrm{~L}$ & 5167 & 2,169 & $602\left(2^{\circ}\right)$ & 1,416 & $2606\left(2^{\circ}\right)$ & 2,221 & $555\left(2^{\circ}\right)$ & 1,478 & $2247\left(2^{\circ}\right)$ \\
\hline 3045 & 5365 & 2,217 & $1339\left(1^{\circ}\right)$ & 1,439 & $6551\left(3^{\circ}\right)$ & 2,271 & $1227\left(1^{\circ}\right)$ & 1,502 & $5589\left(3^{\circ}\right)$ \\
\hline $3045 C 3,0$ & 5506 & 2,250 & $1295\left(3^{\circ}\right)$ & 1,454 & $6382\left(4^{\circ}\right)$ & 2,305 & $1186\left(3^{\circ}\right)$ & 1,519 & $5449\left(4^{\circ}\right)$ \\
\hline 3045L & 5057 & 2,143 & $1322\left(2^{\circ}\right)$ & 1,403 & $7500\left(2^{\circ}\right)$ & 2,194 & $1200\left(2^{\circ}\right)$ & 1,465 & $6282\left(2^{\circ}\right)$ \\
\hline $3045 \mathrm{C} 3,0 \mathrm{~L}$ & 6074 & 2,378 & $1182\left(4^{\circ}\right)$ & 1,515 & $7614\left(1^{\circ}\right)$ & 2,438 & $1067\left(4^{\circ}\right)$ & 1,582 & $6370\left(1^{\circ}\right)$ \\
\hline
\end{tabular}

Analisando os dados da Tabela 4.22, notou-se que quanto mais rígida a capa asfáltica (maior

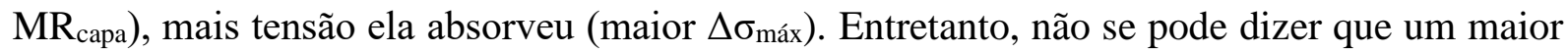
valor de $\mathrm{MR}_{\text {Capa }}$ conduziu à menor vida de fadiga, visto que as misturas mais rígidas (5070C3,0L e 3045C3,0L) apresentaram bom desempenho nos rankings de fadiga, exceto a mistura 3045C3,0L nos pavimentos de capa esbelta.

Primeiramente é analisada a influência do tipo de ligante asfáltico e tipo de fíler na vida de fadiga dos diferentes pavimentos. Em seguida, o ranking de desempenho à fadiga das misturas é discutido. Por fim, comparam-se as vidas de fadiga por tipo de pavimento no cenário de referência, ou seja, quando se adotam os valores de propriedades mecânicas e de espessuras conforme a Tabela 4.21 .

Na Figura 4.30, estão indicadas as variações percentuais da vida de fadiga de cada pavimento em função do uso de CAP 30/45. É possível identificar que o tipo de ligante asfáltico tem influência muito importante nos valores de vida de fadiga. As misturas com CAP 30/45 exibiram valores de $\mathrm{N}$ muito superiores às misturas com CAP 50/70, em todos os pavimentos, mesmo absorvendo maiores valores de diferença de tensões em função da maior rigidez. As maiores diferenças de valores de $\mathrm{N}$ ocorreram na comparação entre as misturas de referência, nos pavimentos com capa espessa, onde as vidas de fadiga da mistura 3045 foram, em média, $561 \%$ maiores que a vida de fadiga da mistura 5070. Por outro lado, a menor diferença entre as vidas de fadiga se deu na comparação entre as misturas contendo caulim (3045C3,0 / 5070C3,0), sendo o valor mínimo no Pavimento C, em que o N da mistura 3045C3,0 foi 49\% superior ao $\mathrm{N}$ de 5070C3,0. 


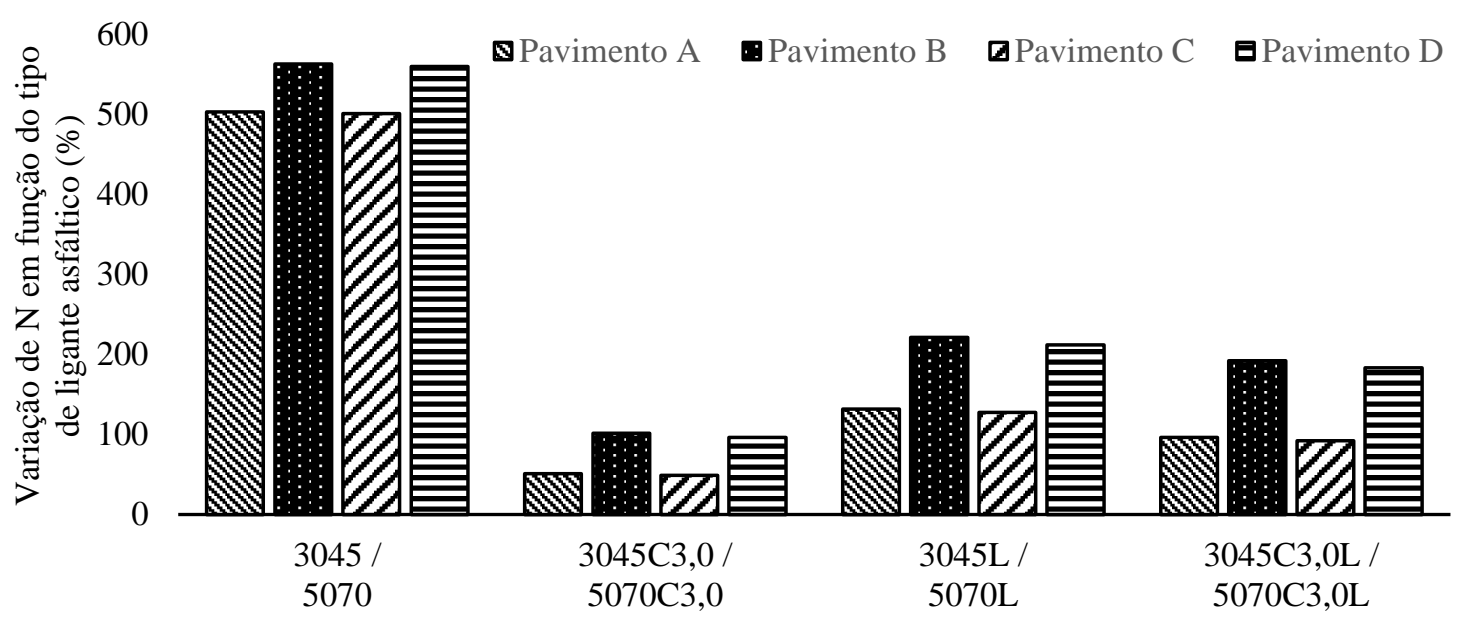

Figura 4.30 - Variação percentual da vida de fadiga em função do tipo de ligante asfáltico

$\mathrm{Na}$ Figura 4.31, estão indicadas as variações percentuais da vida de fadiga de cada pavimento em função do tipo de fíler: caulim (5070C3,0 / 5070 e 3045C3,0 / 3045), cal (5070L / 5070 e 3045L e 3045) e caulim e cal simultaneamente (5070C3,0L / 5070 e 3045C3,0L / 3045).

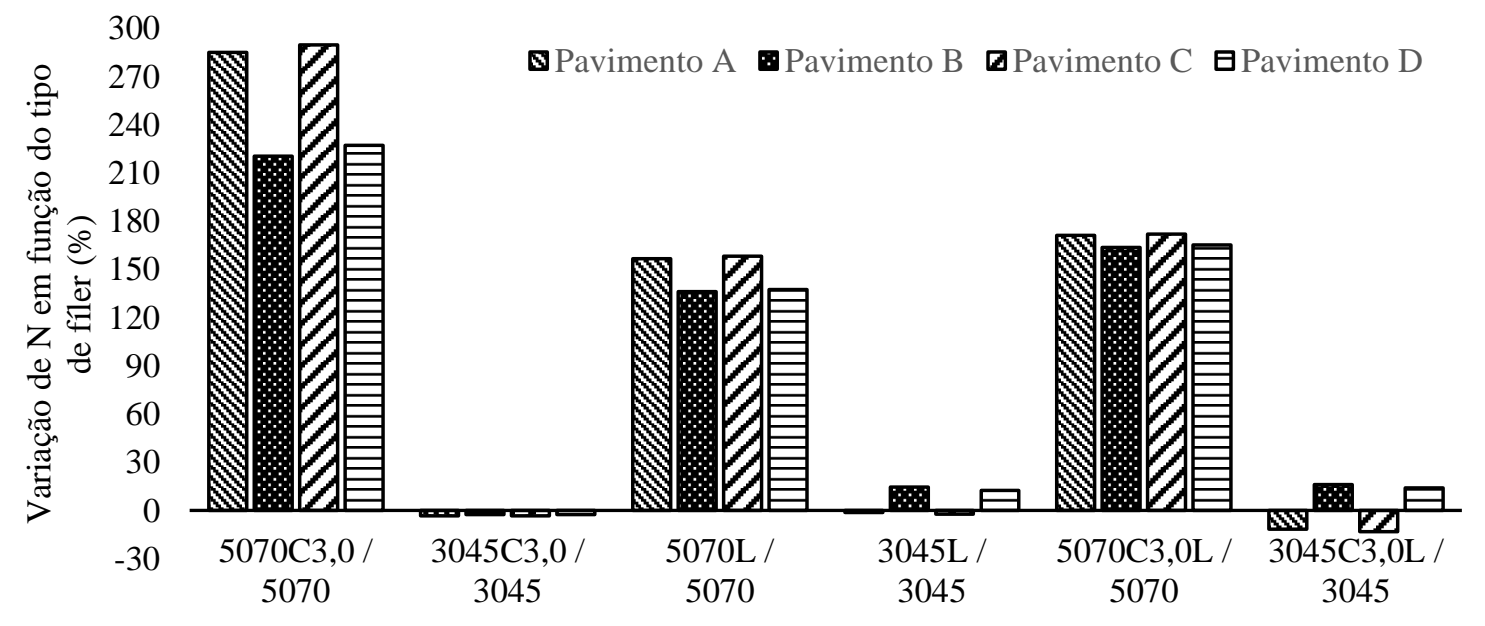

Figura 4.31 - Variação percentual da vida de fadiga em função do tipo de fíler

De maneira geral, a adição de fíleres aumentou a vida de fadiga, porém em intensidade menor do que o tipo de ligante asfáltico. Os fíleres elevaram de maneira importante a vida de fadiga das misturas com CAP 50/70 e não foram importantes para modificar os valores de $\mathrm{N}$ das misturas com CAP 30/45.

A adição de caulim aumentou, sobremaneira, a vida de fadiga nas misturas com CAP 50/70 para todos os pavimentos. O acréscimo de $\mathrm{N}$ é de cerca de $285 \%$ para os pavimentos de capa 
esbelta e de aproximadamente 225\% nos Pavimentos B e D. Nas misturas com CAP 30/45 a adição de caulim não provocou efeitos significativos.

A adição de cal elevou expressivamente a vida de fadiga, em todos os pavimentos, para as misturas com CAP 50/70. Os aumentos em N são da ordem de 150\%. A adição de cal também elevou, de forma menos relevante (incremento de 13\%), a vida de fadiga das misturas com CAP 30/45 nos pavimentos com capa espessa. Nos pavimentos com capa esbelta e com uso de CAP 30/45, a cal reduziu a vida de fadiga em 1,5\%, ou seja, não provocou alterações significativas.

O uso concomitante de cal e caulim aumentou significativamente a vida de fadiga das misturas com CAP 50/70 em todos os pavimentos, em cerca de 170\%. Nas misturas com CAP 30/45, a adição simultânea de cal e caulim provocou redução de $12 \%$ de $\mathrm{N}$ nos pavimentos com capa esbelta e acréscimo de $15 \%$ na vida de fadiga dos pavimentos de capa espessa.

No ranking de desempenho à fadiga em função da análise mecanística de pavimentos (Tabela 4.22), para as misturas com CAP 50/70, tem-se que:

A mistura 5070C3,0 apresentou o melhor desempenho à fadiga, para todos os pavimentos, sendo sucedida, nessa ordem, pelas misturas 5070C3,0L, 5070L e 5070. Estes resultados indicam que: (i) O uso de caulim foi considerado como muito positivo. Ele contribuiu para elevar a vida de fadiga seja no uso isolado, seja no uso combinado com cal. Constatou-se mais uma vez que a adição de rejeito de caulim como fíler em concreto asfáltico pode incrementar as propriedades mecânicas e melhorar o desempenho da massa asfáltica, além de ser solução sustentável; (ii) A contribuição da cal foi menos importante que a do caulim no aumento da vida de fadiga das misturas com CAP 50/70 para os pavimentos estudados, e; (iii) A mistura de referência teve desempenho à fadiga muito inferior às demais misturas.

Os rankings de desempenho à fadiga das misturas com CAP 50/70, seja em função da análise mecanística de pavimento, seja em função do nível de diferença de tensões, foram iguais.

No ranking de desempenho à fadiga em função da análise mecanística de pavimentos, para as misturas com CAP 30/45, tem-se que: 
Foram estabelecidos dois rankings distintos. Um para os pavimentos de capa esbelta, com valores de $\Delta \sigma$ mais elevados, e outro para os pavimentos de capa espessa, com menores valores de $\Delta \sigma$. Nos pavimentos de capa esbelta, a mistura com melhor resistência à fadiga foi 3045 , seguida de 3045L, 3045C3,0 e por último 3045C3,0L. Nos pavimentos com capa espessa, a mistura com melhor resistência à fadiga foi 3045C3,0L, seguida de 3045L, 3045 e por último 3045C3,0. Verificou-se que: (i) A adição de caulim nas misturas com CAP 30/45 reduziu os valores de $\mathrm{N}$ de todos os pavimentos analisados. Entretanto, as reduções foram pequenas, da ordem de 3\%, não podendo ser considerado como um mau resultado; (ii) $\mathrm{O}$ uso de cal prejudicou a vida de fadiga nos pavimentos de capa esbelta e incrementou os valores de $\mathrm{N}$ dos pavimentos de capa espessa, e; (iii) a adição simultânea de cal e caulim, por conferir maior rigidez à mistura, foi benéfica nos pavimentos de capa espessa ( $1^{\circ}$ lugar no ranking) e prejudicial nos pavimentos de capa esbelta (último lugar no ranking).

Não houve consonância entre os rankings de desempenho à fadiga construídos em função do nível de diferença de tensões e em função da análise mecanística de pavimentos para as misturas com CAP 30/45. Nos rankings em função do nível de diferença de tensão, a mistura 3045C3,0L sempre apresentou o melhor desempenho à fadiga. Entretanto, isto não ocorreu nos rankings em função da análise mecanística pois os valores de $\Delta \sigma$ atuantes na fibra inferior da capa asfáltica são diferentes entre as misturas, em função de suas rigidezes específicas. Considerando que a mistura 3045C3,0L tem a maior rigidez, dentre todas as misturas, as capas asfálticas construídas com essa mistura absorvem maior nível de $\Delta \sigma$. Como o modelo de fadiga da mistura $3045 \mathrm{C} 3,0$ tem elevado $\mathrm{k}_{2}, \mathrm{~N}$ é muito suscetível a variações nos valores de $\Delta \sigma$. Assim, entendese o fato de a mistura 3045C3,0L ter apresentado o melhor desempenho nos pavimentos de capa espessa e o pior desempenho nos pavimentos de capa esbelta.

Na Figura 4.32, elaborada a partir dos dados da Tabela 4.22, estão indicados os valores de vida de fadiga por tipo de pavimento no cenário de referência, de onde se depreende que: (i) os valores de $\mathrm{N}$ são similares entre si nos pavimentos de capa esbelta e que os valores de $\mathrm{N}$ também são similares entre si nos pavimentos de capa espessa. Isto indica que a vida de fadiga é pouco afetada pela espessura da base e pela rigidez do subleito, que são os elementos que diferenciam os pavimentos $\mathrm{A}$ do $\mathrm{C}$ e $\mathrm{B}$ do $\mathrm{D}$; (ii) os pavimentos de capa esbelta apresentam valores de $\mathrm{N}$ muito inferiores aos dos pavimentos de capa espessa, visto que nos pavimentos de capa esbelta os valores de $\Delta \sigma$ são muito maiores; (iii) A mistura que apresentou a menor variação de vida de fadiga por tipo de pavimento é 5070C3,0 e a mistura que exibiu a maior variação de vida de 
fadiga por tipo de pavimento é 3045C3,0L. Tais comportamentos podem ser explicados pelos respectivos valores de $\mathrm{k}_{2}$ dos modelos de fadiga destas misturas.

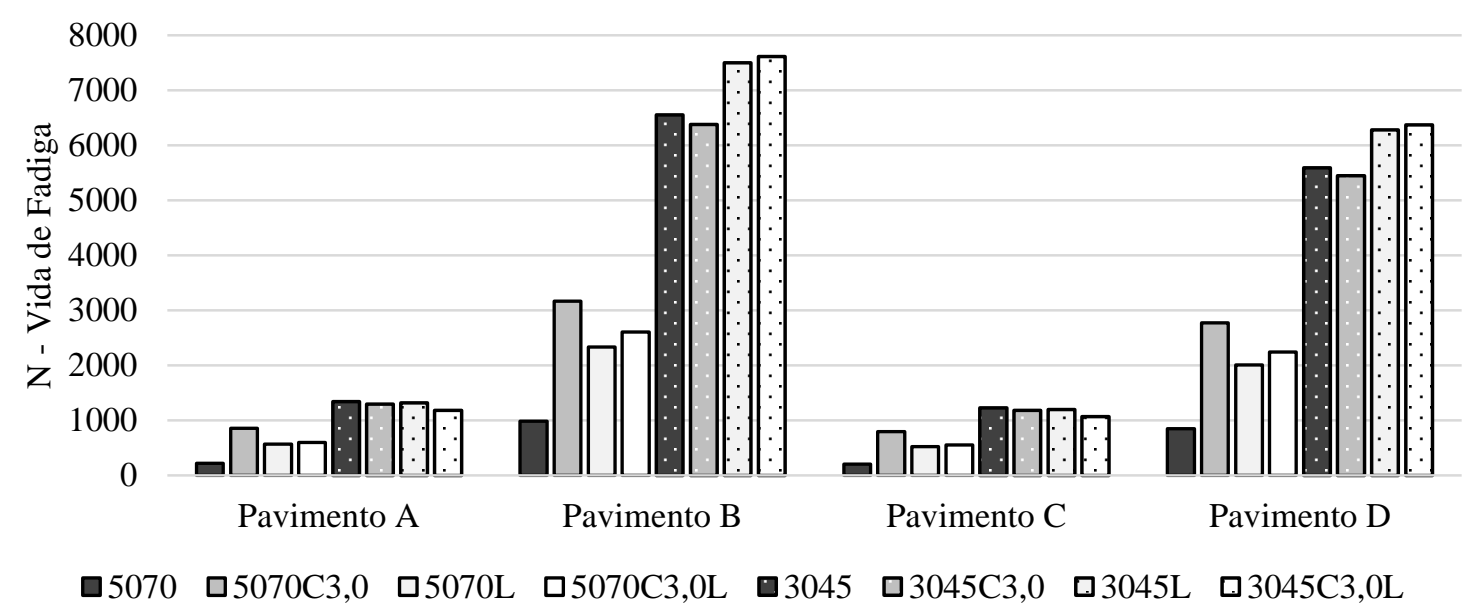

Figura 4.32 - Vida de fadiga por tipo de pavimento no cenário de referência

A vida de fadiga variou muito com as alterações da estrutura do pavimento. Por exemplo, a mistura $3045 \mathrm{C} 3,0$ possui $\mathrm{N}=1186$ no pavimento $\mathrm{C}$ e $\mathrm{N}=6382$ no pavimento $\mathrm{B}$, um crescimento de $438 \%$ na vida de fadiga, quando se alterou, simultaneamente, a espessura das camadas (capa e base) e o MR do subleito. Por isso, na seção seguinte, são discutidos os resultados da análise de sensibilidade da vida de fadiga em função de mudanças nas condições de carregamento, espessuras e propriedades mecânicas das camadas.

\subsubsection{Análise de sensibilidade da vida de fadiga}

É importante analisar a vida de fadiga em diferentes cenários, porque: (i) há grande variabilidade de carregamentos aos quais um pavimento está submetido, em virtude da diversidade da composição de tráfego; (ii) as propriedades mecânicas das camadas variam devido a alterações de temperatura, grau de compactação, teor de umidade e níveis de tensões atuantes na estrutura do pavimento, e; (iii) as espessuras das camadas também variam em função, por exemplo, da execução inadequada do pavimento.

Efetuou-se, portanto, um estudo de análise de sensibilidade da vida de fadiga em função da variação isolada de cada um dos dez parâmetros de entrada do software mePADS em $\pm 25 \%$ : 1

- Carga por roda, 2 - Pressão de enchimento dos pneus (condições de carregamento), 3 $\mathrm{MR}_{\text {Capa }}, 4-\mathrm{MR}_{\text {Base }}, 5-\mathrm{MR}_{\text {Subleito, }} 6-\mu_{\text {Capa }}, 7-\mu_{\text {Base }}, 8-\mu_{\text {Subleito }}$ (propriedades mecânicas), 9 
- Espessuracapa e 10 - EspessuraBase (Espessuras), mantendo-se os demais parâmetros utilizados na análise mecanística em seus valores de referência (Tabela 4.21).

A análise de sensibilidade envolveu 960 simulações, decorrentes de: 3 níveis de valores (- 25\%, cenário de referência (CR) e + 25\%); 10 parâmetros de entrada (listados no parágrafo anterior); 4 tipos de pavimento (A, B, C e D) e 8 tipos de mistura (todas da Etapa 3). Na Tabela 4.23, estão indicados os valores dos parâmetros de entrada necessários à análise de sensibilidade da vida de fadiga para os pavimentos A e C, com capas asfálticas constituídas pelas misturas 3045C3,0L e 3045C3,0, respectivamente, bem como os valores de N calculados em função dos modelos de fadiga dessas misturas.

Tabela 4.23 - Parâmetros de entrada para a análise de sensibilidade da vida de fadiga nos pavimentos de capa esbelta e valor correspondente de $\mathrm{N}$

\begin{tabular}{|c|c|c|c|c|c|c|}
\hline \multirow{2}{*}{$\begin{array}{c}\text { Parâmetros de } \\
\text { entrada }\end{array}$} & \multicolumn{3}{|c|}{ Pav. A - Mistura 3045C3,0L } & \multicolumn{3}{|c|}{ Pav. C - Mistura 3045C3,0 } \\
\hline & $-25 \%$ & $\mathbf{C R}$ & $+25 \%$ & $-25 \%$ & $\mathbf{C R}$ & $+25 \%$ \\
\hline Carga do eixo $(\mathrm{kN})$ & 15 & 20 & 25 & 15 & 20 & 25 \\
\hline$N$ & 1760 & 1182 & 918 & 1678 & 1186 & 950 \\
\hline Pressão - pneus (kPa) & 420 & 560 & 700 & 420 & 560 & 700 \\
\hline$N$ & 2826 & 1182 & 636 & 2567 & 1186 & 683 \\
\hline $\mathrm{MR}_{\text {Capa }}(\mathrm{MPa})$ & 4555 & 6074 & 7592 & 4219 & 5506 & 6882 \\
\hline$N$ & 2341 & 1182 & 713 & 2211 & 1186 & 749 \\
\hline $\mathrm{MR}_{\text {Base }}(\mathrm{MPa})$ & 169 & 225 & 281 & 169 & 225 & 281 \\
\hline$N$ & 621 & 1182 & 2015 & 682 & 1186 & 1894 \\
\hline $\mathrm{MR}_{\text {Subleito }}(\mathrm{MPa})$ & 45 & 60 & 75 & 71 & 95 & 119 \\
\hline$N$ & 1187 & 1182 & 1181 & 1157 & 1186 & 1210 \\
\hline$\mu_{\text {Сара }}$ & 0,22 & 0,30 & 0,37 & 0,22 & 0,30 & 0,37 \\
\hline$N$ & 1504 & 1182 & 903 & 1468 & 1186 & 934 \\
\hline$\mu_{\text {Base }}$ & 0,26 & 0,35 & 0,44 & 0,26 & 0,35 & 0,44 \\
\hline$N$ & 1389 & 1182 & 1027 & 1371 & 1186 & 1043 \\
\hline$\mu_{\text {Subleito }}$ & 0,30 & 0,40 & 0,50 & 0,30 & 0,40 & 0,50 \\
\hline$N$ & 1213 & 1182 & 1128 & 1224 & 1186 & 1131 \\
\hline Espessura $_{\text {Capa }}(\mathrm{mm})$ & 37,4 & 50 & 62,5 & 37,5 & 50 & 62,5 \\
\hline$N$ & 847 & 1182 & 1882 & 928 & 1186 & 1739 \\
\hline $\operatorname{Espessura}_{\text {Base }}(\mathrm{mm})$ & 360 & 480 & 600 & 217,5 & 290 & 362,5 \\
\hline$N$ & 1106 & 1182 & 1212 & 1076 & 1186 & 1246 \\
\hline
\end{tabular}

Optou-se por mostrar as análises de sensibilidade das vidas de fadiga dessas misturas pois elas possuem os valores extremos de $\mathrm{k}_{2}$ para o ligante CAP 30/45, ou seja, possuem a variação máxima $(3045 \mathrm{C} 3,0 \mathrm{~L})$ e mínima $(3045 \mathrm{C} 3,0)$ da vida de fadiga em função do nível de diferença de tensões. Assim, foi possível detectar a tendência geral de comportamento, uma vez que as respostas das misturas 3045 e 3045L ficam contidas no intervalo de variação de $\mathrm{N}$ das misturas $3045 \mathrm{C} 3,0$ e $3045 \mathrm{C} 3,0 \mathrm{~L}$. 
Na Figura 4.33, está ilustrada a variação percentual de N nos pavimentos A (3045C3,0L) e C $(3045 C 3,0)$, em função da alteração de $\pm 25 \%$ nas condições de carregamento (Carga por roda e pressão dos pneus), propriedades mecânicas das camadas (MR e $\mu$ ) e espessuras (capa e base) em relação aos respectivos cenários de referência. Estão destacados os valores mínimos e máximos da variação percentual de $\mathrm{N}$.

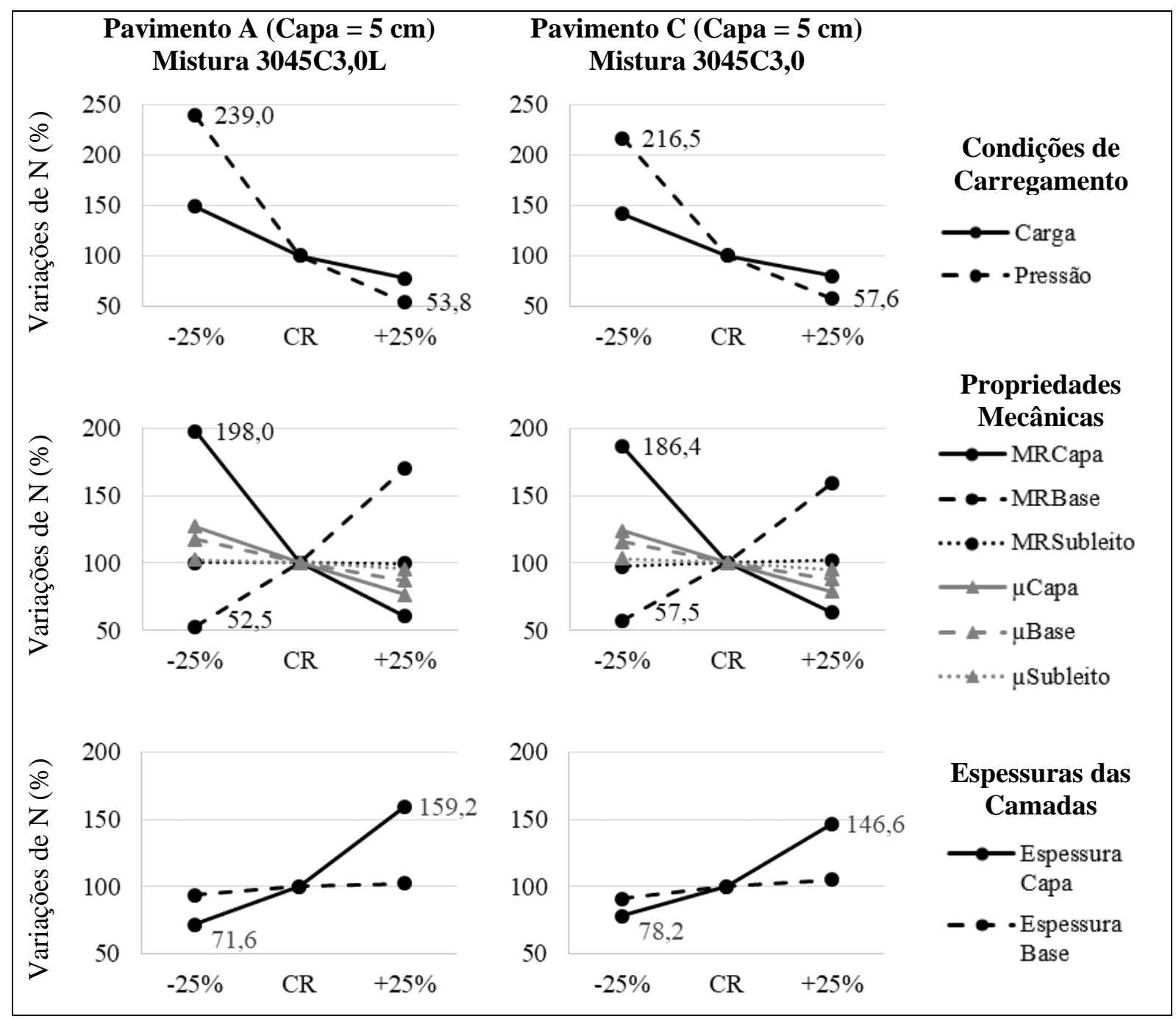

Figura 4.33 - Análise de sensibilidade dos pavimentos com capa esbelta

Observando a Figura 4.33, notou-se que a variação da vida de fadiga foi diretamente proporcional à variação de: $\mathrm{MR}_{\text {Base }}$ e espessuras (capa e base); e inversamente proporcional à variação de: carga do eixo, pressão dos pneus, $M_{\text {Capa }} \mu$ (capa, base e subleito), em ambos os pavimentos. As variações do MR Subleito, dos coeficientes de Poisson de qualquer camada e da espessura da base exerceram pouca influência no valor de $\mathrm{N}$ em ambos os pavimentos. 
Nos pavimentos com capa esbelta, os fatores que provocaram as maiores alterações na vida de fadiga foram a pressão de enchimento dos pneus (condições de carregamento) e $\mathrm{MR}_{\text {Base }}$ (propriedades mecânicas das camadas). Reduções de $25 \%$ na pressão de enchimento de pneus mais que dobraram a vida de fadiga, para ambos os pavimentos. Por outro lado, reduções de $25 \%$ no $\mathrm{MR}_{\mathrm{Base}}$, acarretaram reduções de quase $50 \%$ na vida de fadiga. Destaca-se também o importante incremento de N (da ordem de 90\%) quando se reduz MR Capa $\mathrm{em} 25 \%$.

Na Tabela 4.24, estão indicados os valores dos parâmetros de entrada necessários à análise de sensibilidade da vida de fadiga para os pavimentos B e D, com capas asfálticas constituídas pelas misturas 5070C3,0 e 5070, respectivamente, bem como os valores de $\mathrm{N}$ calculados em função dos modelos de fadiga dessas misturas. Optou-se por mostrar as análises de sensibilidade das vidas de fadiga dessas misturas pois elas possuem os valores extremos de $\mathrm{k}_{2}$ para o ligante CAP 50/70. Trabalhou-se com CAP 50/70 de modo a apresentar gráficos referentes aos dois tipos de ligante asfáltico da pesquisa.

Tabela 4.24 - Dados de entrada para a análise de sensibilidade da vida de fadiga nos pavimentos de capa espessa e valor correspondente de $\mathrm{N}$

\begin{tabular}{|c|c|c|c|c|c|c|}
\hline \multirow{2}{*}{ Dados de entrada } & \multicolumn{3}{|c|}{ Pav. B - Mistura 5070C3,0 } & \multicolumn{3}{|c|}{ Pav. D - Mistura 5070 } \\
\hline & $-25 \%$ & $\mathbf{C R}$ & $+25 \%$ & $-25 \%$ & CR & $+25 \%$ \\
\hline Carga do eixo $(\mathrm{kN})$ & 15 & 20 & 25 & 15 & 20 & 25 \\
\hline$N$ & 5521 & 3167 & 2109 & 1623 & 847 & 525 \\
\hline Pressão - pneus (kPa) & 420 & 560 & 700 & 420 & 560 & 700 \\
\hline$N$ & 4571 & 3167 & 2440 & 1283 & 847 & 630 \\
\hline $\mathrm{MR}_{\text {Capa }}(\mathrm{MPa})$ & 3809 & 5079 & 6348 & 3649 & 4865 & 6081 \\
\hline$N$ & 4661 & 3167 & 2377 & 1334 & 847 & 606 \\
\hline $\mathrm{MR}_{\text {Base }}(\mathrm{MPa})$ & 169 & 225 & 281 & 169 & 225 & 281 \\
\hline$N$ & 2247 & 3167 & 4224 & 608 & 847 & 1130 \\
\hline $\mathrm{MR}_{\text {Subleito }}(\mathrm{MPa})$ & 45 & 60 & 75 & 71 & 95 & 119 \\
\hline$N$ & 3112 & 3167 & 3215 & 775 & 847 & 907 \\
\hline$\mu_{\text {Capa }}$ & 0,22 & 0,30 & 0,37 & 0,22 & 0,30 & 0,37 \\
\hline$N$ & 3697 & 3167 & 2670 & 1016 & 847 & 693 \\
\hline$\mu_{\text {Base }}$ & 0,26 & 0,35 & 0,44 & 0,26 & 0,35 & 0,44 \\
\hline$N$ & 3463 & 3167 & 2921 & 929 & 847 & 778 \\
\hline$\mu_{\text {Subleito }}$ & 0,30 & 0,40 & 0,50 & 0,30 & 0,40 & 0,50 \\
\hline$N$ & 3229 & 3167 & 3075 & 879 & 847 & 812 \\
\hline Espessura $_{\text {Capa }}(\mathrm{mm})$ & 75 & 100 & 125 & 75 & 100 & 125 \\
\hline$N$ & 1636 & 3167 & 5922 & 397 & 847 & 1760 \\
\hline $\operatorname{Espessura}_{\text {Base }}(\mathrm{mm})$ & 352,5 & 470 & 687,5 & 180 & 240 & 300 \\
\hline$N$ & 2898 & 3167 & 3320 & 757 & 847 & 915 \\
\hline
\end{tabular}

Na Figura 4.34, está ilustrada a variação percentual de N nos pavimentos B $(5070 \mathrm{C} 3,0)$ e D (5070), em função da alteração de $\pm 25 \%$ nas condições de carregamento, propriedades 
mecânicas das camadas e espessuras em relação aos respectivos cenários de referência. Estão destacados os valores mínimos e máximos da variação percentual de $\mathrm{N}$.

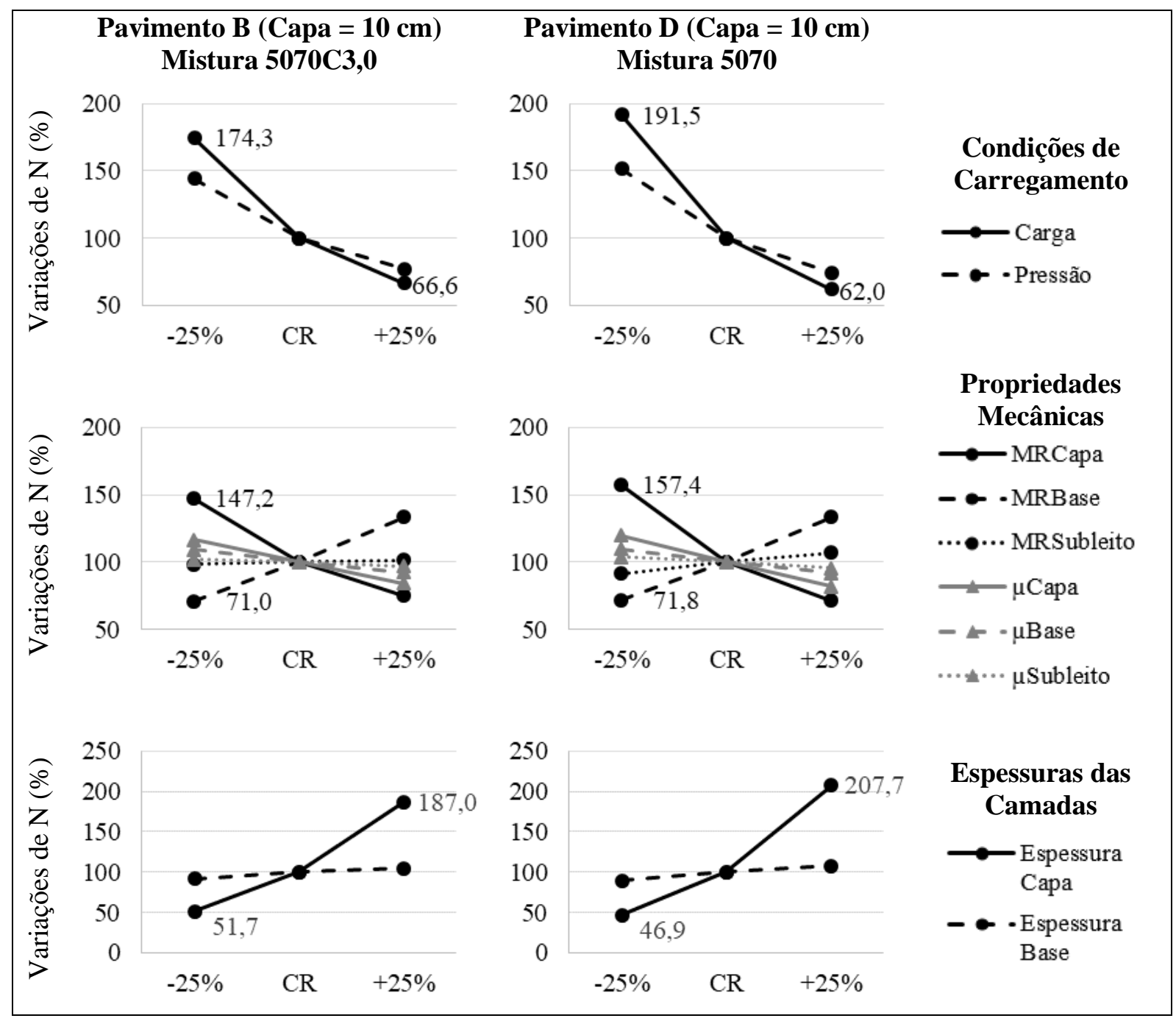

Figura 4.34 - Análise de sensibilidade dos pavimentos com capa espessa

Observando a Figura 4.34, percebeu-se que a variação da vida de fadiga foi inversamente proporcional à variação de: carga do eixo, pressão de enchimento dos pneus, $\mathrm{MR}_{\text {Capa }} \mathrm{e} \mu$ (capa, base e subleito); e diretamente proporcional à variação de: $\mathrm{MR}_{\text {Base, }} \mathrm{MR}_{\text {Subleito }}$ e espessuras (capa e base), em ambos os pavimentos. As variações do MRsubleito, dos coeficientes de Poisson de qualquer camada e da espessura da base exerceram influência consideravelmente menor no valor de $\mathrm{N}$ em relação aos parâmetros carga por roda, pressão de enchimento de pneus, $\mathrm{MR}_{\text {Capa, }}$ $\mathrm{MR}_{\text {Base }}$ e Espessuracapa.

Ao se comparar as Figuras 4.33 e 4.34, detectou-se que nos pavimentos de capa espessa a vida de fadiga é mais sensível à variação da carga por roda e da Espessuracapa, enquanto que nos 
pavimentos de capa esbelta, $\mathrm{N}$ é mais sensível à variação da pressão de enchimento dos pneus e do MR Base.

As alterações na Espessuracapa provocaram as maiores variações na vida de fadiga. Reduções de $25 \%$ na Espessura ${ }_{\text {Capa }}$ acarretaram reduções da ordem de $51 \%$ na vida de fadiga. Por outro lado, acréscimos de $25 \%$ na Espessuracapa implicaram em aumento da vida de fadiga de cerca de $97 \%$ (média para os dois pavimentos). Analogamente, as variações extremas de carregamento (carga por roda) provocaram reduções de aproximadamente $36 \%$ e aumentos da ordem de $83 \%$ na vida de fadiga. As variações em $\pm 25 \%$ nas propriedades mecânicas das camadas alteraram em menor intensidade a vida de fadiga dos pavimentos com capa espessa.

Conforme discutido na seção 4.4.1, as misturas asfálticas apresentam susceptibilidade térmica, ou seja, seus módulos de resiliência se modificam com alterações na temperatura. No intervalo de 10 a $40^{\circ} \mathrm{C}$, a rigidez das misturas desta pesquisa variou da ordem de 1.000 para $10.000 \mathrm{MPa}$. Esta alteração de rigidez provoca grande mudança no valor da vida de fadiga. Quando a rigidez da capa diminui, o que ocorre com a elevação da temperatura, há aumento de N. Quando a rigidez da capa asfáltica aumenta, o que ocorre com a redução da temperatura, há redução de N. Em virtude disso, é importante utilizar misturas que tenham pouca susceptibilidade térmica, especialmente no intervalo de $10 \mathrm{a} 25^{\circ} \mathrm{C}$, para preservar a vida útil do pavimento quanto à vida de fadiga e prevenir o aparecimento de trincas.

Constatou-se a importância de efetuar a análise de sensibilidade da vida de fadiga de pavimentos, visto que alterações de $\pm 25 \%$ nas condições de carregamento, espessuras ou propriedades mecânicas das camadas de um pavimento podem reduzir à metade ou mais que dobrar a vida de fadiga de misturas asfálticas.

4.4.2.4 Análise estatística da influência dos parâmetros de caracterização do fíler nos parâmetros da vida de fadiga

Na Tabela 4.25, são apresentados os valores de $\mathrm{R}^{2}$ das regressões lineares efetuadas entre os parâmetros de caracterização do fíler versus parâmetros de vida de fadiga. Também consta indicação se a relação entre as variáveis é direta (+) ou inversamente proporcional. Como na Etapa 3 há um único teor de caulim (3,0\%), os parâmetros de caracterização do fíler ficaram restritos a D10, D30, D60 e MF. 
Tabela 4.25 - Valores de $\mathrm{R}^{2}$ das regressões lineares entre parâmetros de vida de fadiga $\left(\mathrm{k}_{1}, \mathrm{k}_{2}\right.$ e valores de N) versus parâmetros de caracterização do fíler

\begin{tabular}{|c|c|c|c|c|c|c|c|c|c|}
\hline $\begin{array}{l}\text { Variável- } \\
\text { resposta }\end{array}$ & D10 & D30 & D60 & MF & $\begin{array}{l}\text { Variável- } \\
\text { resposta }\end{array}$ & D10 & D30 & D60 & MF \\
\hline $\mathrm{k}_{1}$ CAP 50/70 & 0,28 & 0,79 & 0,83 & 0,76 & $\mathrm{~N}_{\Delta \sigma=0,5} 5070$ & 0,07 & 0,66 & 0,80 & 0,61 \\
\hline $\mathrm{k}_{1}$ CAP 30/45 & 0,01 & 0,26 & 0,39 & 0,21 & $N_{\Delta \sigma=0,5} 3045$ & 0,06 & 0,16 & 0,29 & 0,12 \\
\hline $\mathrm{k}_{1}$ todas misturas & $0,00(-)$ & $0,05(-)$ & $0,06(-)$ & $0,04(-)$ & $\mathrm{N}_{\Delta \sigma=0,5}$ todas & $0,01(+)$ & $0,33(-)$ & $0,06(-)$ & $0,03(-)$ \\
\hline $\mathrm{k}_{2}$ CAP 50/70 & 0,59 & 0,46 & 0,37 & 0,49 & $\mathrm{~N}_{\Delta \sigma=1,0} 5070$ & 0,28 & 0,79 & 0,83 & 0,76 \\
\hline $\mathrm{k}_{2}$ CAP 30/45 & 0,31 & 0,01 & 0,07 & 0,00 & $\mathrm{~N}_{\Delta \sigma=1,0} 3045$ & 0,01 & 0,26 & 0,39 & 0,21 \\
\hline $\mathrm{k}_{2}$ todas misturas & $0,17(+)$ & $0,02(+)$ & $0,01(+)$ & $0,03(+)$ & $\mathrm{N}_{\Delta \sigma=1,0}$ todas & $0,00(-)$ & $0,05(-)$ & $0,06(-)$ & $0,04(-)$ \\
\hline N Pav A 5070 & 0,29 & 0,55 & 0,55 & 0,55 & $\mathrm{~N}_{\Delta \sigma=1,5} 5070$ & 0,40 & 0,78 & 0,77 & 0,77 \\
\hline N Pav A 3045 & 0,10 & 0,63 & 0,74 & 0,59 & $N_{\Delta \sigma=1,5} 3045$ & 0,02 & 0,41 & 0,52 & 0,37 \\
\hline N Pav A todas & $0,02(-)$ & $0,02(-)$ & $0,02(-)$ & $0,02(-)$ & $\mathrm{N}_{\Delta \sigma=1,5}$ todas & $0,01(-)$ & $0,07(-)$ & $0,08(-)$ & $0,06(-)$ \\
\hline N Pav B 5070 & 0,24 & 0,61 & 0,64 & 0,60 & $\mathrm{~N}_{\Delta \sigma=2,0} 5070$ & 0,47 & 0,75 & 0,72 & 0,75 \\
\hline N Pav B 3045 & 0,35 & 0,00 & 0,05 & 0,00 & $N_{\Delta \sigma=2,0} 3045$ & 0,21 & 0,55 & 0,58 & 0,54 \\
\hline N Pav B todas & $0,00(-)$ & $0,02(-)$ & $0,02(-)$ & $0,02(-)$ & $\mathrm{N}_{\Delta \sigma=2,0}$ todas & $0,05(-)$ & $0,09(-)$ & $0,09(-)$ & $0,09(-)$ \\
\hline N Pav C 5070 & 0,30 & 0,55 & 0,54 & 0,55 & $\mathrm{~N}_{\Delta \sigma=2,5} 5070$ & 0,51 & 0,72 & 0,67 & 0,73 \\
\hline N Pav C 3045 & 0,06 & 0,58 & 0,70 & 0,53 & $\mathrm{~N}_{\Delta \sigma=2,5} 3045$ & 0,53 & 0,52 & 0,44 & 0,54 \\
\hline $\mathrm{N}$ Pav C todas & $0,02(-)$ & $0,02(-)$ & $0,02(-)$ & $0,02(-)$ & $\mathrm{N}_{\Delta \sigma=025}$ todas & $0,09(-)$ & $0,11(-)$ & $0,10(-)$ & $0,12(-)$ \\
\hline N Pav D 5070 & 0,25 & 0,61 & 0,64 & 0,60 & $\mathrm{~N}_{\Delta \sigma=3,0} 5070$ & 0,54 & 0,70 & 0,64 & 0,71 \\
\hline N Pav D 3045 & 0,35 & 0,00 & 0,05 & 0,00 & $\mathrm{~N}_{\Delta \sigma=3,0} 3045$ & 0,71 & 0,36 & 0,24 & 0,40 \\
\hline N Pav D todas & $0,00(-)$ & $0,02(-)$ & $0,03(-)$ & $0,02(-)$ & $\mathrm{N}_{\Delta \sigma=3,0}$ todas & $0,14(-)$ & $0,14(-)$ & $0,11(-)$ & $0,14(-)$ \\
\hline
\end{tabular}

Observou-se que os parâmetros de caracterização do fíler apresentaram relação inversamente proporcional com o coeficiente $\mathrm{k}_{1}$ dos modelos de fadiga e com os valores de $\mathrm{N}$ calculados seja em função do nível de diferença de tensões, seja em função da análise mecanística de pavimentos. Portanto, quanto menores os valores de D10, D30, D60 e MF (fíler mais fino), maiores serão os valores de $\mathrm{N}$ e do coeficiente $\mathrm{k}_{1}$. Antagonicamente, os parâmetros de caracterização do fíler apresentaram relação diretamente proporcional com o coeficiente $\mathrm{k}_{2}$ dos modelos de fadiga. Logo, quanto mais grosso for o fíler, maior será o k2, e, consequentemente, haverá maior susceptibilidade da vida de fadiga em função da variação de $\Delta \sigma$.

No entanto, os valores de $\mathrm{R}^{2}$ das correlações são muito baixos e não houve quaisquer correlações válidas entre os parâmetros de caraterização do fíler versus parâmetros da vida de fadiga. De todas as análises estatísticas realizadas, os parâmetros de vida de fadiga exibiram as piores correlações com os parâmetros de caracterização do fíler, confirmando o papel preponderante do tipo de ligante asfáltico na diferenciação dos valores dos coeficientes dos modelos de fadiga e da vida de fadiga.

Em função da análise dos valores médios de $\mathrm{R}^{2}$ é possível dizer que, dentre os parâmetros de vida de fadiga: (i) $\mathrm{N}$ para $\Delta \sigma=2,5 \mathrm{MPa}$ e $\mathrm{k}_{2}$ foram, respectivamente, as variáveis-resposta melhor e pior explicadas pelos parâmetros de caracterização do fíler, e; (ii) D60 e D10 são, respectivamente, os parâmetros de caracterização do fíler que melhor e pior explicam, as variações nos valores dos parâmetros de vida de fadiga. 
4.4.2.5 Consolidação dos resultados de vida de fadiga

\section{Sobre os modelos de fadiga}

Todos os modelos de fadiga apresentaram ótimos valores de $\mathrm{R}^{2}(0,97$ a 0,99$)$;

$>\mathrm{O}$ uso de CAP 30/45 aumentou os valores dos coeficientes $\mathrm{k}_{1}$ e $\mathrm{k}_{2}$;

$>\mathrm{O}$ uso de caulim aumentou $\mathrm{k}_{1}$ e reduziu $\mathrm{k}_{2}$;

$>\mathrm{O}$ uso de cal parece ter especial relevância na definição de $\mathrm{k}_{2}$;

$>$ O uso simultâneo de cal e caulim elevou bastante o valor de $\mathrm{k}_{1}$;

$>$ Não houve boas correlações entre os parâmetros de caracterização do fíler e os coeficientes $\mathrm{k}_{1}$ e $\mathrm{k}_{2}$.

\section{Sobre a comparação da vida de fadiga em função do nível de diferença de tensões}

$>$ O uso de CAP 30/45 elevou bastante a vida de fadiga;

$>\mathrm{O}$ uso de caulim conferiu melhor resistência à fadiga;

$>$ Adição de cal proporcionou maiores valores de vida de fadiga quando associado ao CAP 50/70, mas os resultados foram inconclusivos quanto ao CAP 30/45;

$>$ O uso simultâneo de cal e caulim conferiu melhor resistência à fadiga;

> Não ocorreram boas correlações entre os parâmetros de caracterização do fíler e os valores de $\mathrm{N}$ no intervalo de diferenças de tensões avaliado (0,5 a 3,0 $\mathrm{MPa}$ );

$>$ Para as misturas com CAP 50/70, o ranking de desempenho à fadiga, da melhor para a pior foi 5070C3,0, 5070C3,0L, 5070L e 5070;

> Para o CAP 30/45, a mistura 3045C3,0L apresentou, sempre, a melhor resistência à fadiga, porém nas demais posições do ranking, houve intenso intercâmbio entre as demais misturas, não sendo possível identificar a pior mistura;

$>$ Destaca-se positivamente as misturas contendo caulim, pois apresentaram resultados muito satisfatórios quanto à resistência à fadiga;

$>$ Destaca-se negativamente a mistura 5070 pois apresentou desempenho muito aquém das demais misturas.

\section{Sobre a comparação da vida de fadiga em função da análise mecanística de pavimentos}

De modo geral, a influência do tipo de ligante asfáltico, tipo de fíler e parâmetros de caracterização do fíler apresentaram as mesmas tendências de resultados da comparação da vida de fadiga em função do nível de diferença de tensões; 
$>$ O ranking de desempenho à fadiga para as misturas com CAP 50/70 foi o mesmo para todos os pavimentos e igual ao ranking em função do nível de diferença de tensões, com as misturas 5070C3,0 e 5070 exibindo o melhor e o pior desempenho à fadiga, respectivamente.

Para as misturas com CAP 30/45, foram definidos dois rankings distintos. Um para os pavimentos com capa esbelta, nos quais a melhor mistura foi 3045, e outro para pavimentos com capa espessa, no qual a mistura 3045C3,0L apresentou a maior vida de fadiga. Os rankings estabelecidos em função do tipo de pavimento, além de diferentes entre si, também foram diferentes dos rankings estabelecidos em função do nível de diferença de tensões. A diferença entre os rankings pode ser explicada pelos elevados valores de $\mathrm{k}_{2}$;

Pavimentos com capa espessa apresentaram maior vida de fadiga do que pavimentos com capa esbelta.

\section{Sobre a análise de sensibilidade da vida de fadiga}

$>$ A variação da vida de fadiga foi diretamente proporcional à variação de: MR $_{\text {Base }}$, $\mathrm{MR}_{\text {Subleito, Espessura }}$ Capa $\mathrm{e}$ EspessuraBase;

A variação da vida de fadiga foi inversamente proporcional à variação de: Carga por roda, pressão de enchimento de pneus, $\mathrm{MR}_{\text {Capa }}, \mu_{\text {Capa }}, \mu_{\text {Base }}$ e $\mu_{\text {Subleito; }}$;

Nos pavimentos com capa esbelta, a vida de fadiga foi mais suscetível à variação da pressão de enchimento de pneus e do MR Base;

$>$ Nos pavimentos com capa espessa, a vida de fadiga foi mais suscetível à variação da Espessuracapa e da carga por roda;

MR $R_{\text {Subleito, }}$ coeficientes de Poisson e Espessurabase influíram pouco na variação da vida de fadiga;

Por fim, destaca-se que a análise de sensibilidade foi muito importante pois constatouse que alterações de apenas $25 \%$ nos parâmetros de entrada da análise mecanística (condições de carregamento, propriedades mecânicas e espessuras das camadas) podem mais que duplicar ou reduzir a menos da metade os valores de vida de fadiga.

\subsubsection{Fluência por compressão uniaxial estática - Creep estático}

A susceptibilidade à deformação permanente (DP) das misturas asfálticas foi avaliada em função dos resultados dos ensaios de fluência por compressão uniaxial estática ou creep 
estático, realizado a $40^{\circ} \mathrm{C}$ e com nível de tensão de $0,4 \mathrm{MPa}$. Os CPs utilizados nestes ensaios foram produzidos com $\mathrm{Vv} \approx 7 \%$, de modo a representar uma condição similar de grau de compactação de camadas asfálticas no início da vida de serviço, situação na qual as misturas asfálticas estão mais propensas a apresentar deformação permanente.

Foram avaliados cinco parâmetros do ensaio de creep: Deformação total da mistura (4500 s), Módulo de Fluência (4500 s), Recuperação da deformação, Inclinação do estágio secundário da curva de deformação versus tempo de carregamento (curva de fluência) e as próprias Curvas de fluência. A aquisição destes dados se deu por meio software Labview 7.1. Como não há normas de ensaio, nem recomendações de valores limites para os parâmetros do ensaio de creep estático, as análises foram processadas em função da comparação dos resultados de cada parâmetro entre as misturas.

A deformação total da mistura $\left(\mathrm{D}_{\mathrm{t}}\right)$, no instante $4500 \mathrm{~s}$, indica a deformação permanente ocorrida ao final do ensaio, após o período de carregamento de 3600 s e o período de repouso de 900 s. Assim, comparando-se as misturas, aquela que apresentar a menor $D_{t}$ será classificada como menos suscetível à deformação permanente.

O Módulo de fluência $\left(\mathrm{M}_{\mathrm{f}}\right)$, no instante $4500 \mathrm{~s}$, é calculado pela relação entre a tensão atuante $(0,4 \mathrm{MPa})$ e a deformação para o instante $4500 \mathrm{~s}$. Entende-se que este módulo indica a capacidade de a mistura resistir à deformação. Assim, maiores valores de $\mathrm{M}_{\mathrm{f}}$ representam misturas com menor susceptibilidade à DP.

A recuperação da deformação $(\mathrm{Rec})$ indica o percentual de deformação elástica que compõe a deformação total (elástica + plástica ou permanente) ao final do período de carregamento (3600 s), ou seja, o quanto o CP recupera de deformação no período de 3600 a 4500 s. Desta maneira, maiores valores de Rec indicam misturas que conseguem se deformar mais elasticamente e acumulam menos deformação permanente.

A inclinação do estágio secundário da curva de deformação versus tempo de carregamento ( $\mathrm{I}_{\text {curva }}$ ) indica a taxa ou "velocidade" de crescimento da deformação ao longo tempo. Ao se comparar misturas, aquela que exibir menor valor de $\mathrm{I}_{\text {curva }}$ tem menor susceptibilidade à deformação permanente. 
As curvas de fluência exprimem graficamente a relação entre a deformação no CP versus tempo no ensaio de creep estático. O comportamento típico desta curva é dividido em três estágios: (i) primário - crescimento intenso da deformação em curto período; (ii) secundário - crescimento suave das deformações ao longo do tempo com a manutenção do carregamento (fluência), e; (iii) terciário - após o término do período de carregamento (3600 s), as deformações vão reduzindo até sobrar somente a parcela da deformação permanente.

Inicialmente, discute-se a influência do tipo de ligante asfáltico e do tipo de fíler nos parâmetros do ensaio de creep estático. Em seguida, apresentam-se os rankings de susceptibilidade à deformação permanente construídos com base os parâmetros de ensaio. Posteriormente, são apresentadas as análises estatísticas da influência dos parâmetros de caracterização do fíler nos parâmetros do ensaio de creep estático.

4.4.3.1 Influência do tipo de ligante asfáltico e do tipo de fíler nos resultados dos ensaios de Creep estático

Na Tabela 4.26, são apresentados os valores médios de 3 CPs dos parâmetros do ensaio de creep estático, além do volume de vazios. Nenhum valor foi excluído pelo método de Grubbs.

Tabela 4.26 - Resultados dos ensaios de creep estático

\begin{tabular}{cccccc}
\hline Mistura & $\begin{array}{c}\mathbf{D}_{\mathbf{t}} \mathbf{4 5 0 0 s} \\
(\mathbf{m m} / \mathbf{m m})\end{array}$ & $\begin{array}{c}\mathbf{M}_{\mathbf{f}} \mathbf{4 5 0 0 s} \\
(\mathbf{M P a})\end{array}$ & $\begin{array}{c}\text { Rec } \\
(\mathbf{\%})\end{array}$ & $\mathbf{I}_{\text {curva }}$ & $\begin{array}{c}\text { Vv } \\
(\mathbf{\%})\end{array}$ \\
\hline 5070 & 0,00130 & 390,9 & 62,0 & 0,059 & 7,0 \\
$5070 \mathrm{C} 3,0$ & 0,00142 & 297,7 & 57,5 & 0,069 & 6,5 \\
5070L & 0,00139 & 344,4 & 58,1 & 0,063 & 7,1 \\
5070C3,0L & 0,00125 & 330,8 & 59,5 & 0,058 & 6,9 \\
\hline 3045 & 0,00115 & 373,9 & 62,2 & 0,058 & 7,3 \\
3045C3,0 & 0,00151 & 279,6 & 57,4 & 0,081 & 7,4 \\
3045L & 0,00128 & 324,3 & 59,7 & 0,069 & 7,4 \\
3045C3,0L & 0,00132 & 308,9 & 60,8 & 0,085 & 7,1 \\
\hline
\end{tabular}

De modo geral, as misturas de referência apresentaram-se menos susceptíveis à deformação permanente, pois tiveram os menores valores de $D_{t}$ e $I_{c u r v a}$ e os maiores valores de $M_{f}$ e Rec. Por outro lado, as misturas com caulim $(C 3,0)$ apresentaram maiores valores de $D_{t}$ e $I_{\text {curva }}$ e os menores valores de $\mathrm{M}_{\mathrm{f}}$ e Rec, portanto mostraram-se mais suscetíveis à DP. Cabe destacar, contudo, que, à luz do teste $t$ (Apêndice $C$ ), os valores médios de $D_{t}, M_{f}$ e Rec de todas as misturas podem ser assumidos como iguais. Somente no parâmetro $\mathrm{I}_{\text {curva }}$ foi possível identificar 
valores médios significativamente diferentes nas comparações entre as misturas $3045 x$ $3045 \mathrm{C} 3,0$ e $3045 \times 3045 \mathrm{C} 3,0 \mathrm{~L}$.

Nas Figuras 4.35, 4.36, 4.37 e 4.38 são mostrados, respectivamente, os valores médios de $D_{t}$, $\mathrm{M}_{\mathrm{f}}$, Rec e $\mathrm{I}_{\text {curva }}$ de cada mistura, linhas que representam os valores médios das misturas de referência e os valores individuais de cada $\mathrm{CP}$ utilizado no cálculo da média. Assim, é possível constatar visualmente o grande nível de dispersão dos resultados. Tais figuras dão suporte às análises da influência do tipo de ligante de asfáltico e do tipo de fíler nos parâmetros dos ensaios de creep estático.

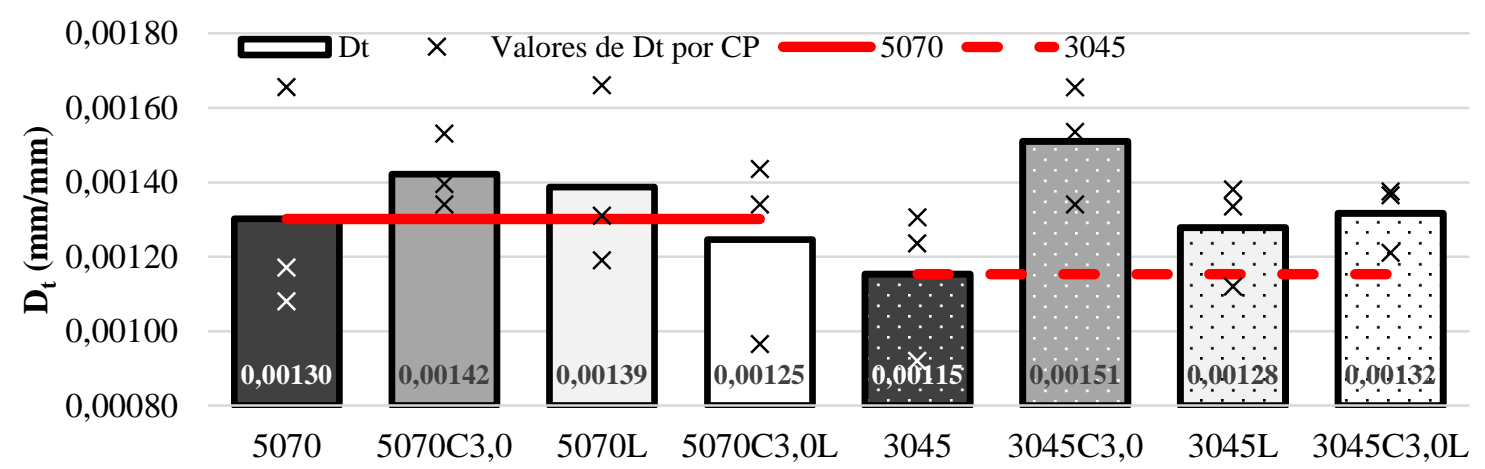

Figura 4.35 - Deformação total no ensaio de creep estático por tipo de mistura

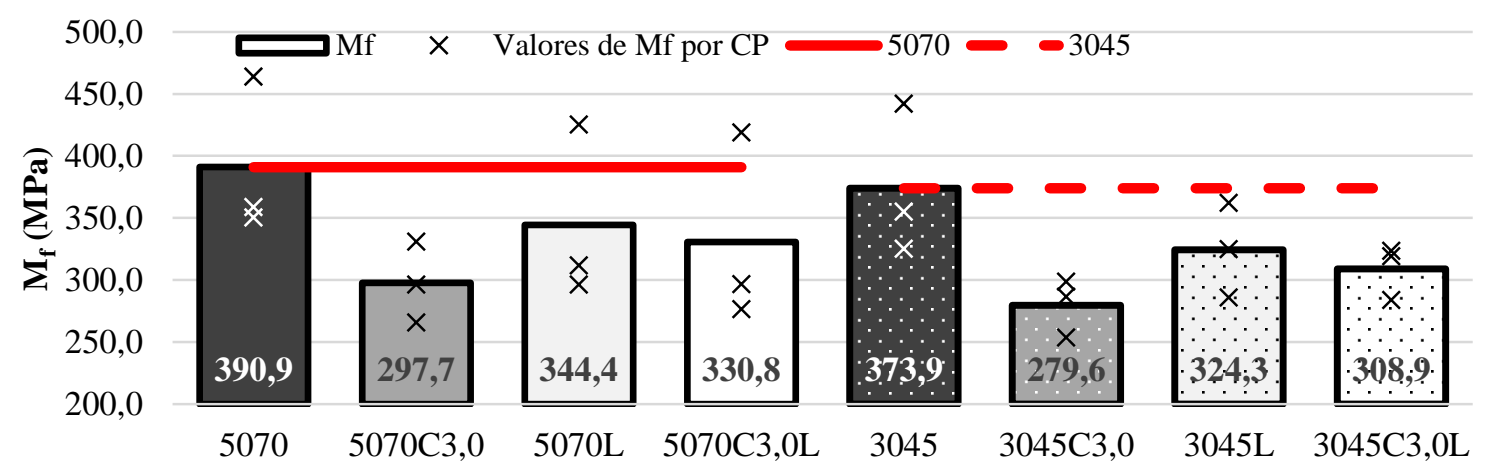

Figura 4.36 - Módulo de fluência no ensaio de creep estático por tipo de mistura 


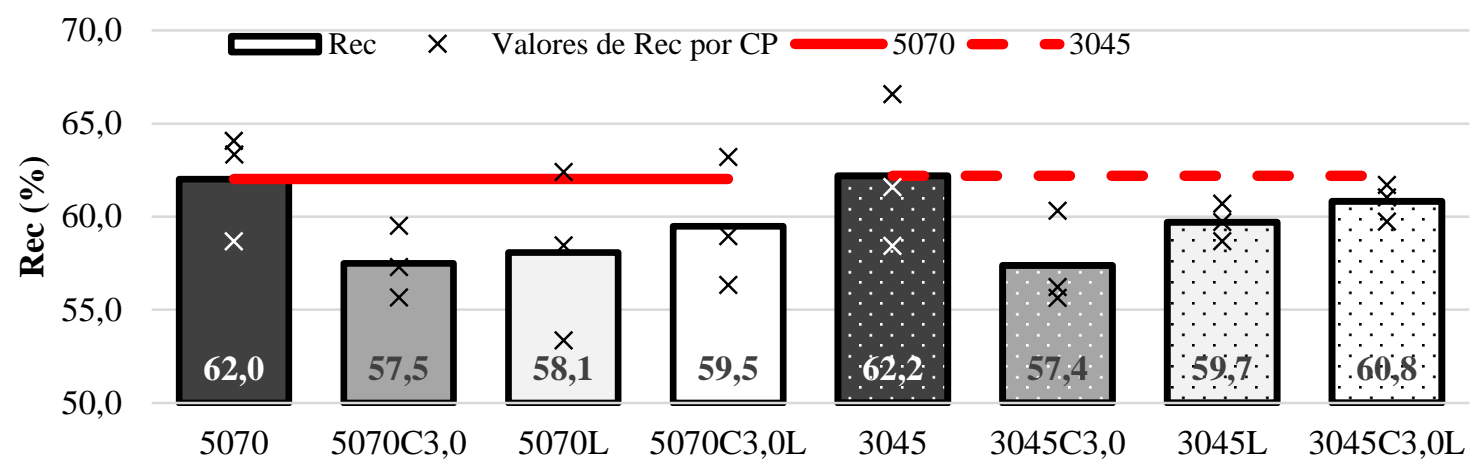

Figura 4.37 - Recuperação da deformação no ensaio de creep estático por tipo de mistura

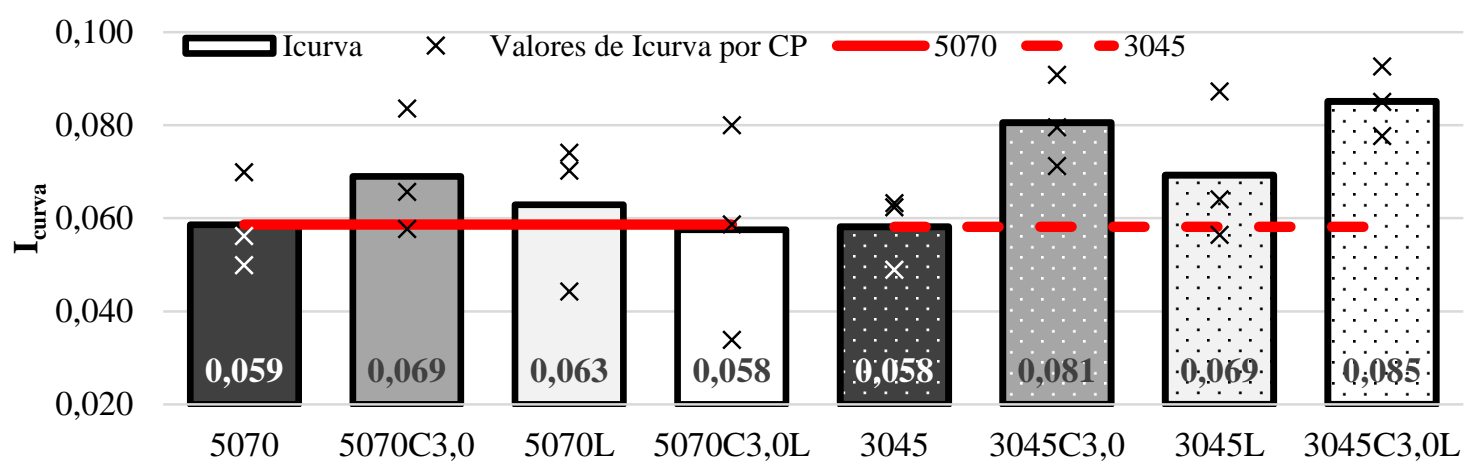

Figura 4.38 - Inclinação do estágio secundário da curva de fluência no ensaio de creep estático por tipo de mistura

Primeiramente será avaliada a influência do tipo de ligante asfáltico. Foi possível detectar que: (i) não houve tendência de comportamento de $\mathrm{D}_{\mathrm{t}}$ em função do tipo de ligante asfáltico; (ii) o uso de CAP 30/45 reduziu o $\mathrm{M}_{\mathrm{f}}$, em média, em 6\%; (iii) o tipo de ligante asfáltico praticamente não interferiu na Rec das misturas, havendo tendência de discreto aumento da ordem de $2 \%$ na recuperação com o uso de CAP 30/45, e; (iv) a maior influência do tipo de ligante asfáltico ocorreu na $\mathrm{I}_{\text {curva }}$, onde se verificou que as misturas com CAP 30/45 chegaram a exibir valores de $\mathrm{I}_{\text {curva }} 48 \%$ superiores à mistura correspondente com CAP 50/70 (3045C3,0L x 5070C3,0L).

Imaginava-se que as misturas com CAP 30/45 apresentassem menor susceptibilidade à DP do que as misturas correlatas com CAP 50/70, em virtude da maior consistência do primeiro ligante asfáltico, porém este comportamento só foi observado nas misturas de referência. Nas demais misturas, os resultados dos parâmetros $\mathrm{M}_{\mathrm{f}}$ e $\mathrm{I}_{\text {curva }}$, principalmente, indicaram que as misturas com CAP 50/70 foram menos propensas a se deformar de maneira permanente. Tais resultados podem ser entendidos pelo menor volume de vazios das condições com CAP 50/70, pois, 
segundo Little, Button e Youssef (1993) o volume de vazios é mais importante que o tipo de ligante asfáltico para alterar os resultados dos ensaios de creep estático.

Na Figura 4.39, estão indicadas as curvas de fluência das misturas, separadas par a par por tipo de ligante asfáltico.

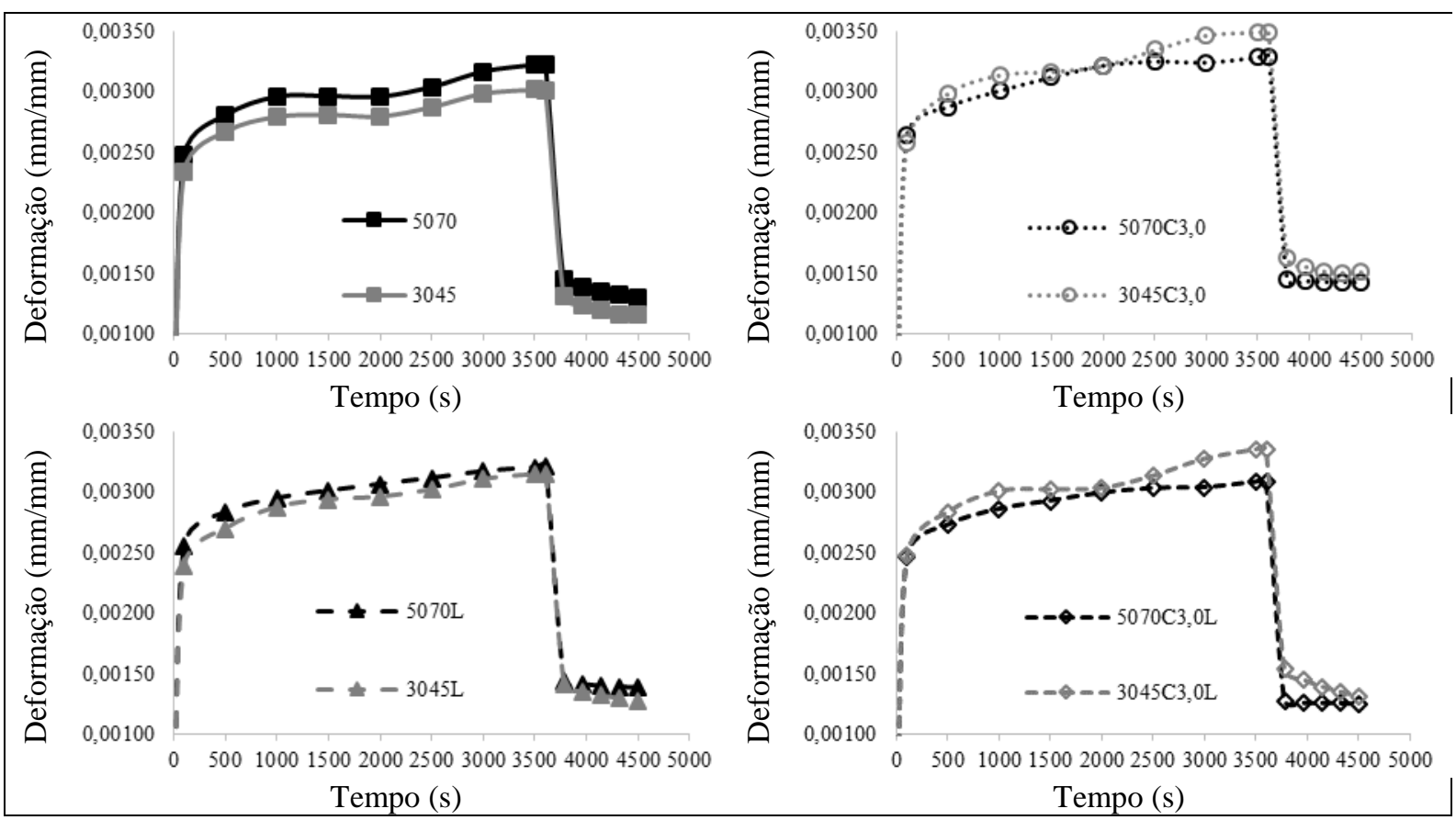

Figura 4.39 - Curvas de fluência do ensaio de creep estático por tipo de ligante asfáltico

É possível perceber que: (i) o comportamento das curvas de fluência ratificou as análises técnicas acerca da influência do tipo de ligante asfáltico nos parâmetros do ensaio de creep estático; (ii) a deformação total (4500 s) é apenas o último ponto da curva, porém consegue indicar o comportamento de toda a curva de fluência à luz do tipo de ligante asfáltico, ou seja, se a deformação total $\left(\mathrm{D}_{\mathrm{t}}\right)$ no tempo de $4500 \mathrm{~s}$ da mistura 3045 é inferior à da mistura 5070, a tendência é que a deformação da mistura 3045 medida em qualquer outro instante também seja inferior à da mistura 5070; (iii) as curvas de fluência mantêm-se próximas no período de descarregamento (após 3600 s), mostrando assim, a similaridade nos valores da recuperação da deformação independentemente do tipo de ligante asfáltico, e; (iv) há maior $\mathrm{I}_{\text {curva }}$ nas misturas com CAP 30/45, visto que nas misturas C3,0 e C3,0L, principalmente, os valores das deformações para o tempo $=1000 \mathrm{~s}$, são mais próximos entre si do que os valores das deformações para o tempo $=3600 \mathrm{~s}$, ou seja, a "velocidade" de crescimento da deformação em função do tempo foi maior nas misturas com o ligante mais consistente. 
Para discutir a influência do tipo de fíler nos parâmetros do ensaio de creep estático, além das Figuras 4.35 a 4.38 , foi elaborada a Figura 4.40 que exibe as curvas de fluência separadas por tipo de fíler em relação às misturas de referência.

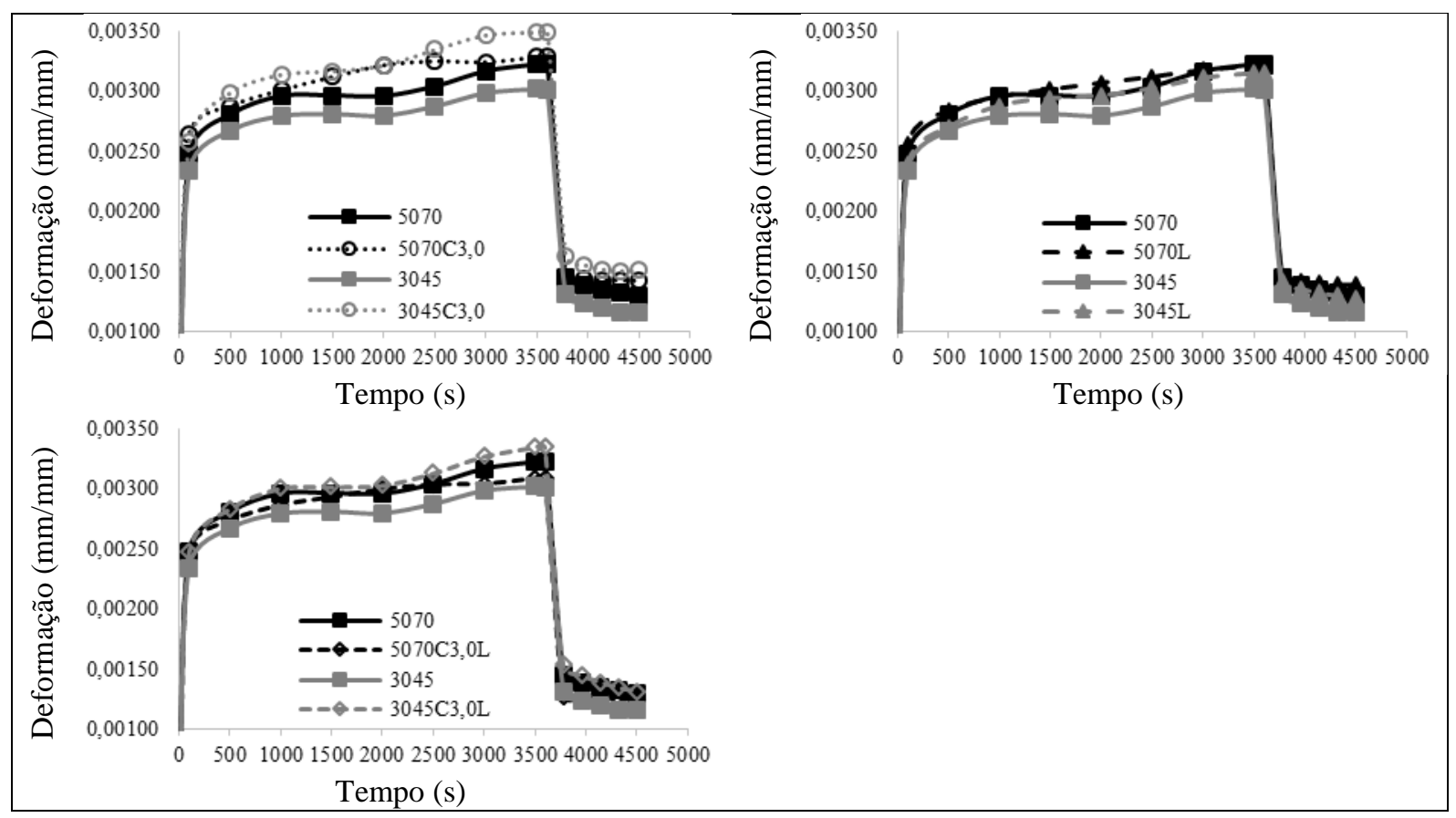

Figura 4.40 - Curvas de fluência do ensaio de creep estático por tipo de fíler

Com a adição de caulim houve: (i) importante elevação na $D_{t}$. Na maior diferença de valores, a mistura 3045C3,0 apresentou deformação total 31\% superior à mistura 3045; (ii) expressiva redução, da ordem de 25\%, no módulo de fluência, para ambos os ligantes; (iii) diminuição média de 7,5\% na recuperação da deformação, e; (iv) aumento na $\mathrm{I}_{\text {curva }}$, sendo que na situação de maior diferença de valores, $\mathrm{I}_{\text {curva }}$ da mistura 3045C3,0 foi 38\% superior à da mistura 3045 .

A adição de caulim produziu reduções de $\mathrm{M}_{\mathrm{f}}$ e Rec e elevação de $\mathrm{D}_{\mathrm{t}}$ e $\mathrm{I}_{\text {curva. }}$. Portanto, deixou as misturas mais propensas a apresentar deformação permanente. A Figura 4.40 também ajuda a entender esta maior susceptibilidade à DP das misturas com caulim, pois suas curvas de fluência (em traço pontilhado) estão sempre acima das curvas de fluência das misturas de referência, tanto no período de carregamento (indicando maior deformação), quanto no período de repouso (indicando menor recuperação). Estes resultados foram contrários aos encontrados por Zulkati, Diew e Delai (2012) os quais identificaram que misturas com caulim apresentaram menor susceptibilidade à deformação permanente em relação a misturas com fíler de cal e de granito em ensaios de creep dinâmico. 
Com a adição de cal ocorreu: (i) elevação na $\mathrm{D}_{\mathrm{t}}$. Na maior diferença de valores, a mistura 3045L apresentou deformação total $11 \%$ superior à mistura 3045; (ii) redução, da ordem de $12 \%$, no módulo de fluência, para ambos os ligantes; (iii) diminuição média de 5\% na Rec, e; (iv) aumento na $I_{\text {curva. }}$ A exemplo do que ocorreu na análise em função do tipo de ligante asfáltico, a $\mathrm{I}_{\text {curva }}$ foi o parâmetro do ensaio de creep mais sensível ao uso da cal. Houve aumento de $19 \%$ na inclinação do trecho secundário da curva de fluência na comparação entre as misturas 3045L x 3045. Os efeitos da adição de cal nos parâmetros do ensaio de creep foram menos importantes que os efeitos da adição de caulim.

A adição de cal deixou as misturas mais suscetíveis à deformação permanente, uma vez que $\mathrm{M}_{\mathrm{f}}$ e Rec reduziram e $D_{t}$ e $I_{c u r v a}$ aumentaram, como se observa visualmente na Figura 4.40, na qual as misturas com cal (tracejadas) estão sempre levemente acima das curvas de fluência das misturas de referência (traçadas em linha cheia). Em contraste com os resultados aqui apresentados, NG (2013) relatou redução na susceptibilidade à DP com a adição de cal, em condições muito semelhantes (misturas com CAP 50/70, agregados de granito, creep estático a $40^{\circ}$ com carga de $\left.0,4 \mathrm{MPa}\right)$, porém com teor de ligante inferior $\left(\mathrm{P}_{\mathrm{b}}=4,3 \%\right)$.

Com a adição concomitante de cal e caulim, observou-se que: (i) não houve tendência de comportamento em relação à $\mathrm{D}_{\mathrm{t}}$; (ii) ocorreu redução, da ordem de $16 \%$, no $\mathrm{M}_{\mathrm{f}}$; (iii) houve discreta diminuição, $3 \%$, na Rec, e; (iv) não houve tendência de comportamento em relação à I curva. A adição simultânea de cal e caulim, dentre os fíleres empregados, foi o que menos prejudicou a susceptibilidade à deformação permanente. Este resultado também é confirmado pelas curvas de fluência (Figura 4.40) onde se percebeu uma certa superposição das curvas, principalmente entre as misturas 5070 e $5070 \mathrm{C} 3,0 \mathrm{~L}$.

De modo geral, a adição de fíleres mais finos potencializou a susceptibilidade à deformação permanente, sendo mais danosa nas misturas com CAP 30/45.

4.4.3.2 Ranking de susceptibilidade permanente das misturas em função dos parâmetros do ensaio de creep estático

Foram elaborados rankings de susceptibilidade à DP das misturas (da menos suscetível para a mais suscetível) em função dos parâmetros: deformação total (4500 s), módulo de fluência 
(4500 s), recuperação da deformação e inclinação do estágio secundário da curva de deformação versus tempo de carregamento. Estes rankings estão apresentados na Tabela 4.27.

Tabela 4.27 - Ranking de susceptibilidade à deformação permanente das misturas em função dos parâmetros do ensaio de creep estático

\begin{tabular}{ccccc}
\hline Posição & $\mathbf{D}_{\mathbf{t}}$ & $\mathbf{M}_{\mathbf{f}}$ & $\mathbf{R e c}$ & $\mathbf{I}_{\text {curva }}$ \\
\hline $1^{\mathrm{a}}$ (Menos suscetível à DP) & 3045 & 5070 & 3045 & $5070 \mathrm{C} 3,0 \mathrm{~L}$ \\
$2^{\mathrm{a}}$ & $5070 \mathrm{C} 3,0 \mathrm{~L}$ & 3045 & 5070 & 3045 \\
$3^{\mathrm{a}}$ & $3045 \mathrm{~L}$ & $5070 \mathrm{~L}$ & $3045 \mathrm{C} 3,0 \mathrm{~L}$ & 5070 \\
$4^{\mathrm{a}}$ & 5070 & $5070 \mathrm{C} 3,0 \mathrm{~L}$ & $3045 \mathrm{~L}$ & $5070 \mathrm{~L}$ \\
$5^{\mathrm{a}}$ & $3045 \mathrm{C} 3,0 \mathrm{~L}$ & $3045 \mathrm{~L}$ & $5070 \mathrm{C} 3,0 \mathrm{~L}$ & $5070 \mathrm{C} 3,0$ \\
$6^{\mathrm{a}}$ & $5070 \mathrm{~L}$ & $3045 \mathrm{C} 3,0 \mathrm{~L}$ & $5070 \mathrm{~L}$ & $3045 \mathrm{~L}$ \\
$7^{\mathrm{a}}$ & $3045 \mathrm{C} 3,0$ & $5070 \mathrm{C} 3,0$ & $5070 \mathrm{C} 3,0$ & $3045 \mathrm{C} 3,0$ \\
$8^{\mathrm{a}}$ (Mais suscetível à DP) & $5070 \mathrm{C} 3,0$ & $3045 \mathrm{C} 3,0$ & $3045 \mathrm{C} 3,0$ & $3045 \mathrm{C} 3,0 \mathrm{~L}$ \\
\hline
\end{tabular}

O tipo de ligante asfáltico exerceu pouca influência na definição dos rankings visto que não há predominância de um determinado tipo de CAP nas primeiras ou nas últimas posições. O tipo de fíler, por sua vez, teve maior influência na definição dos rankings de susceptibilidade à deformação permanente. As misturas de referência apresentaram a menor susceptibilidade à DP, pois ocuparam quase sempre as primeiras posições nos rankings independentemente do parâmetro utilizado para classificar as misturas.

A adição de caulim provocou o efeito mais deletério na susceptibilidade à DP, tanto que as misturas 5070C3,0 e 3045C3,0 quase sempre ficaram nas duas últimas posições dos rankings. Embora este seja um mau resultado pontual da adição de rejeito de caulim como fíler em misturas asfálticas, não chega a constituir uma contraindicação do material, pois não há valores mínimos normativos para a aceitação de uma mistura em função dos parâmetros de ensaio de creep estático. Além disso, segundo os critérios propostos por Little, Button e Youssef (1993), apresentados na seção 2.1.2.2, todas as misturas analisadas exibiram elevada resistência à deformação permanente, pois, para $3600 \mathrm{~s}$ de ensaio, as deformações eram apenas da ordem de $0,00320 \mathrm{~mm} / \mathrm{mm}$ ou 0,32\% (Figuras 4.39 e 4.40), portanto, os módulos de fluência eram de aproximadamente $125 \mathrm{MPa}$, suportando tráfego entre $5.10^{6}$ e $10^{6}$.

Considerando que as misturas contendo caulim atenderam aos requisitos técnicos da especificação do DER/SP (parâmetros volumétricos, estabilidade, fluência, RT e RRT - quando associado à cal), apresentaram desempenho superior às misturas de referência quanto à fadiga e à susceptibilidade térmica e desempenho satisfatório quanto à DP, reuniram-se elementos suficientes para se indicar o uso de rejeito de caulim como fíler em misturas asfálticas. 
A adição de cal ou de cal e caulim simultaneamente provocou efeitos intermediários na susceptibilidade à DP, visto que estas misturas ocuparam posições médias nos rankings, sendo mais suscetíveis que as misturas de referência e menos suscetíveis à deformação permanente do que as misturas com caulim.

4.4.3.3 Análise estatística da influência dos parâmetros de caracterização do fíler e do volume de vazios nos parâmetros do ensaio de creep estático

Na Tabela 4.28 são apresentados os valores de $\mathrm{R}^{2}$ das regressões lineares efetuados entre os parâmetros de caracterização do fíler versus variáveis-resposta do ensaio de creep estático $\left(D_{t}\right.$, $\mathrm{M}_{\mathrm{f}}, \mathrm{Rec}$, e $\mathrm{I}_{\text {curva }}$ ). Também consta indicação se a relação entre as variáveis é direta (+) ou inversamente proporcional (-). Apenas os valores em negrito indicam que há relação linear entre as variáveis, a um nível de significância de 5\%, segundo a análise de variância (teste do valor da estatística F - Apêndice D). Adicionalmente, mostram-se os valores de $\mathrm{R}^{2}$ das correlações entre o Vv versus variáveis-resposta do ensaio de creep estático.

Tabela 4.28 - Valores de $\mathrm{R}^{2}$ das regressões lineares entre parâmetros de caracterização do fíler e Vv versus variáveis-resposta do ensaio de creep estático

\begin{tabular}{cccccc}
\hline Variável-resposta & D10 & D30 & D60 & MF & $\begin{array}{c}\text { Vv } \\
(\mathbf{\%})\end{array}$ \\
\hline $\mathrm{D}_{\mathrm{t}}$ CAP 50/70 & 0,02 & 0,01 & 0,02 & 0,01 & 0,19 \\
$\mathrm{D}_{\mathrm{t}}$ CAP 30/45 & 0,50 & 0,57 & 0,51 & 0,59 & 0,06 \\
$\mathrm{D}_{\mathrm{t}}$ todas as misturas & $0,23(-)$ & $0,19(-)$ & $0,15(-)$ & $0,20(-)$ & $0,02(-)$ \\
$\mathrm{M}_{\mathrm{f}}$ CAP 50/70 & 0,35 & 0,65 & 0,64 & 0,64 & 0,57 \\
$\mathrm{M}_{\mathrm{f}}$ CAP 304/5 & 0,66 & 0,65 & 0,66 & 0,65 & 0,01 \\
$\mathrm{M}_{\mathrm{f}}$ todas as misturas & $0,31(+)$ & $\mathbf{0 , 6 0}(+)$ & $\mathbf{0 , 6 0}(+)$ & $\mathbf{0 , 6 0}(+)$ & $0,00(+)$ \\
\hline Rec CAP 50/70 & 0,04 & 0,22 & 0,25 & 0,20 & 0,22 \\
Rec CAP 304/5 & 0,26 & 0,26 & 0,22 & 0,27 & 0,28 \\
Rec todas as misturas & $0,12(+)$ & $0,23(+)$ & $0,23(+)$ & $0,22(+)$ & $0,05(+)$ \\
\hline $\mathrm{I}_{\text {curva }}$ CAP 50/70 & $\mathbf{0 , 9 3 ( - )}$ & 0,37 & 0,21 & 0,42 & 0,52 \\
$\mathrm{I}_{\text {curva }}$ CAP 304/5 & 0,28 & 0,89 & $\mathbf{0 , 9 6}(-)$ & 0,85 & 0,16 \\
$\mathrm{I}_{\text {curva }}$ todas as misturas & $0,33(-)$ & $0,36(-)$ & $0,31(-)$ & $0,37(-)$ & $0,04(+)$ \\
\hline
\end{tabular}

Observou-se que os parâmetros de caracterização do fíler apresentaram: (i) relação

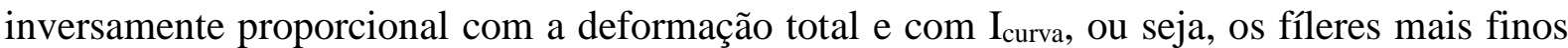
(menores valores de D10, D30, D60 e MF) exibiram maiores valores de $\mathrm{D}_{\mathrm{t}}$ e $\mathrm{I}_{\text {curva }}$, o que reflete maior susceptibilidade à DP, e; (ii) relação diretamente proporcional com $\mathrm{M}_{\mathrm{f}}$ e Rec, recaindo na mesma conclusão de que misturas com fíleres mais finos apresentaram maior susceptibilidade à deformação permanente, corroborando assim as análises técnicas acerca da 
influência do tipo de fíler nos parâmetros de creep estático e também os resultados de Kandhal, Lynn e Parker (1998).

Destaca-se que houve excelentes correlações lineares inversamente proporcionais entre $\mathrm{I}_{\text {curva }}$ das misturas com CAP 50/70 versus $\mathrm{D} 10\left(\mathrm{R}^{2}=0,93\right)$ e $\mathrm{I}_{\text {curva }}$ das misturas com CAP 30/45 versus com D60 $\left(R^{2}=0,96\right)$ e moderadas correlações lineares diretamente proporcionais $\left(R^{2}=0,60\right)$ entre o D30, D60 e MF versus $\mathrm{M}_{\mathrm{f}}$ quando se consideraram os dados de todas misturas.

Para o volume de vazios, tem-se que quanto maior o valor de $\mathrm{Vv}$ menor será $\mathrm{D}_{\mathrm{t}}$ e maiores serão $\mathrm{M}_{\mathrm{f}}$, Rec e $\mathrm{I}_{\text {curva. }}$ Portanto, os dados não ratificaram a hipótese que misturas com maior $\mathrm{Vv}$, dentro do intervalo de $\mathrm{V}_{\text {médio }} 7 \pm 1 \%$, tendem a apresentar maior deformação permanente.

É interessante observar que os parâmetros de caracterização do fíler apresentaram, de modo geral, maiores valores de $\mathrm{R}^{2}$ nas correlações com os parâmetros do ensaio de creep estático do que o volume de vazios das misturas. Assim, entende-se que a granulometria ou tipo de fíler afetou mais a susceptibilidade à DP das misturas asfálticas do que o volume de vazios, no intervalo de $\mathrm{Vv}=7 \pm 1 \%$.

Em função da análise dos valores médios de $\mathrm{R}^{2}$ é possível dizer que, dentre os parâmetros de creep estático: (i) $\mathrm{M}_{\mathrm{f}}$ e Rec foram, respectivamente, as variáveis-resposta melhor e pior explicadas pelos parâmetros de caracterização do fíler, e; (ii) MF e D10 são os parâmetros de caracterização do fíler que melhor e pior explicam, respectivamente, as variações nos valores dos parâmetros de creep estático.

\subsubsection{Consolidação dos resultados dos ensaios de creep estático}

Em suma, os principais resultados da análise de susceptibilidade à deformação permanente foram:

$>$ O tipo de ligante asfáltico teve pouca influência nos resultados do ensaio de creep estático. Apenas no parâmetro $\mathrm{I}_{\text {curva }}$ se detectou impacto importante do tipo de ligante asfáltico. Em relação à $\mathrm{I}_{\text {curva }}$, as misturas com CAP 30/45 se mostraram mais suscetíveis à deformação permanente; 
$>\mathrm{O}$ tipo de fíler teve impacto muito importante nos resultados dos ensaios de creep estático. A adição de qualquer tipo de fíler deixou as misturas mais suscetíveis à deformação permanente;

Ao se analisar os rankings de susceptibilidade à deformação permanente, de modo geral, percebeu-se que as misturas de referência apresentaram o melhor comportamento, enquanto que as misturas com caulim $(\mathrm{C} 3,0)$ exibiram o pior comportamento. As misturas com cal (L) ou cal e caulim simultaneamente (C3,0L) apresentaram desempenho intermediário;

> Os parâmetros de caracterização do fíler apresentaram correlações lineares com o Módulo de fluência e $\mathrm{I}_{\text {curva }}$, mostrando que quando o fíler é mais fino a susceptibilidade à deformação permanente da mistura é maior;

> Os parâmetros de caracterização do fíler explicaram mais o comportamento das misturas quanto aos parâmetros do ensaio de creep estático do que o Vv no intervalo de $7 \pm 1 \%$.

\subsubsection{RT após creep estático}

Apresentam-se os resultados e respectivas análises dos ensaios de resistência à tração por compressão diametral dos CPs moldados com $\mathrm{Vv} \approx 7 \%$ e que foram previamente submetidos aos ensaios de MR em três temperaturas para a avaliação da susceptibilidade térmica $(10,25$ e $40^{\circ} \mathrm{C}$ ) e aos ensaios de creep estático para avaliação da susceptibilidade à DP.

Na Figura 4.41 são mostrados os valores médios de $\mathrm{RT}_{\text {Creep }}$ de cada mistura, linhas que representam as $\mathrm{RT}_{\text {Creep }}$ das misturas de referência e o valor mínimo de 0,80 MPa preconizado pelo DER/SP, bem como os valores individuais de cada CP utilizado no cálculo das médias. Assim, é possível visualizar o nível de dispersão dos resultados. Nenhum valor foi excluído pelo teste de Grubbs.

Observou-se que a mistura 3045 apresentou $\mathrm{RT}_{\text {Creep }}$ 13\% superior à mistura 5070 e esta foi a única diferença significativa de valores de $\mathrm{RT}_{\text {Creep }}$ à luz do teste $\mathrm{t}$ (Apêndice $\mathrm{C}$ ). A exemplo do que ocorreu na Etapa 2, quando se estudou a RT de CPs com $\mathrm{Vv} \approx 4 \%$ e que tinham sido submetidos somente ao ensaio de MR a $25^{\circ}$, todas as misturas contendo o CAP 30/45 apresentaram maior valor de resistência à tração em relação às misturas correlatas com CAP 50/70, como resultado da maior consistência do CAP 30/45. 


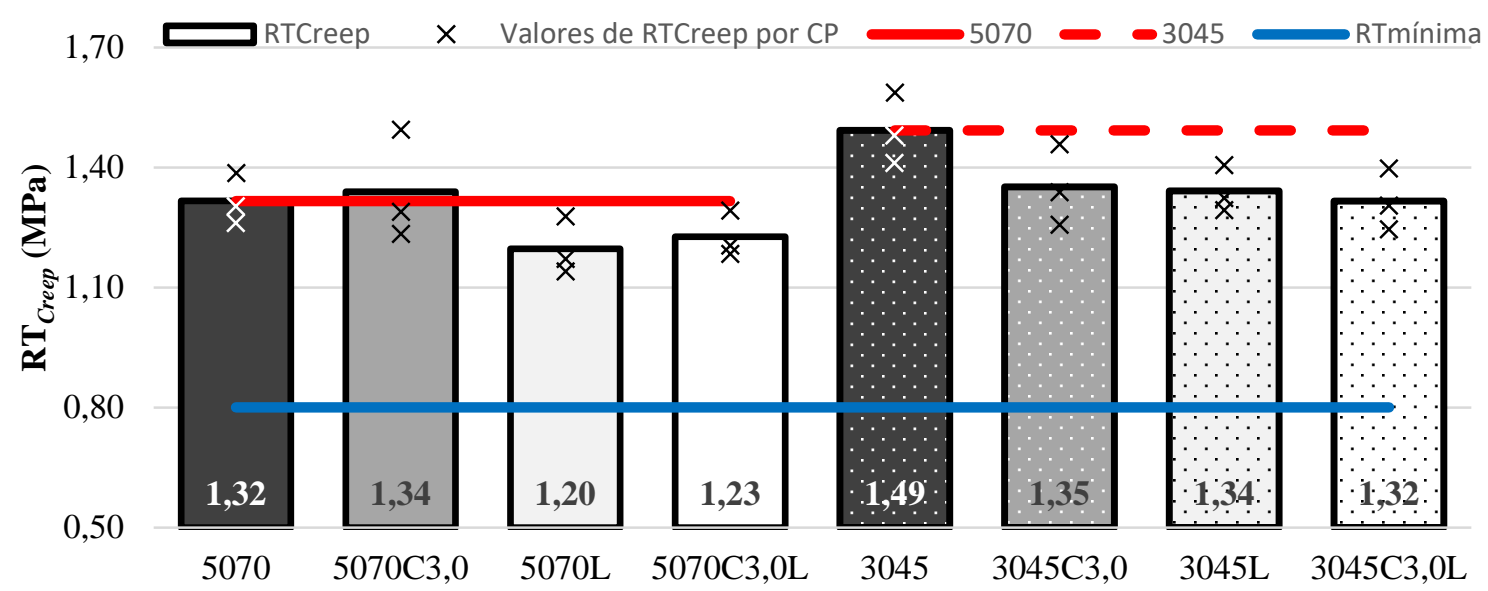

Figura 4.41 - Resistência à tração após o ensaio de creep estático por tipo de mistura

A adição de fíleres, de modo geral, reduziu a $\mathrm{RT}_{\text {Creep. }}$. Entretanto, à luz dos testes t, os valores médios de $\mathrm{RT}_{\text {Creep, }}$ nas comparações entre as misturas com adições de fíleres versus misturas de referência, podem ser considerados iguais, em função da variabilidade da resistência à tração de cada $\mathrm{CP}$ oriunda da grande heterogeneidade das misturas asfálticas com $\mathrm{Vv} \approx 7 \%$. Dentre os fíleres empregados, a adição de caulim provocou a menor redução de $\mathrm{RT}_{\text {Creep }}$ e a adição de cal proporcionou a maior redução.

Mesmo utilizando CPs com elevado volume de vazios e que já haviam sido submetidos a vários ensaios prévios, a resistência à tração de todas as misturas foi consideravelmente superior ao valor mínimo exigido pelo $\mathrm{DER} / \mathrm{SP}(\mathrm{RT} \geq 0,80 \mathrm{MPa})$. Trata-se de mais um indício de que a adição de rejeito de caulim como fíler em concretos asfálticos é viável do ponto de vista técnico, além de ser ambientalmente desejável.

Na Tabela 4.29 é apresentado o ranking de misturas por $\mathrm{RT}_{\text {Creep }}$, da mistura mais resistente para a menos resistente. Percebe-se que as misturas com CAP 30/45 exibiram maiores de $\mathrm{RT}_{\text {Creep }} \mathrm{e}$ que as misturas de referência e com caulim apresentaram maiores valores de resistência à tração, em relação às misturas L e C3,0L.

Não houve boa correlação entre os valores de $\mathrm{RT}_{\text {Creep }}$ e os parâmetros de caracterização do fíler, isto é, D10, D30, D60 e MF não conseguiram explicar adequadamente as diferenças de valores de $\mathrm{RT}_{\text {Creep }}$ entre as misturas testadas. Conforme relatado na Etapa 2, a variação de resistência à tração é mais bem explicada pelo tipo de ligante asfáltico do que pelo tipo de fíler. 
Tabela 4.29 - Ranking de $\mathrm{RT}_{\text {Creep }}$

\begin{tabular}{ccc}
\hline Posição & Condição & RT $_{\text {Creep }}$ \\
\hline $1^{\circ}$ & 3045 & 1,49 \\
$2^{\circ}$ & $3045 \mathrm{C} 3,0$ & 1,35 \\
$3^{\circ}$ & $3045 \mathrm{~L} / 5070 \mathrm{C} 3,0$ & 1,34 \\
& & \\
$5^{\circ}$ & $5070 / 3045 \mathrm{C} 3,0 \mathrm{~L}$ & 1,32 \\
$7^{\circ}$ & $5070 \mathrm{C} 3,0 \mathrm{~L}$ & 1,23 \\
$8^{\circ}$ & $5070 \mathrm{~L}$ & 1,20 \\
\hline
\end{tabular}

4.4.4.1 Considerações adicionais sobre as dimensões e volume de vazios dos CPs utilizados nos ensaios de creep estático

Por se tratar de ensaio não destrutivo, foi possível medir o diâmetro e a altura dos CPs antes e depois da execução do ensaio de creep estático para averiguar se a deformação permanente medida no ensaio se traduzia em alterações das dimensões dos CPs. Também foram medidas as massas dos CPs nas condições seco, na água e saturado com a superfície seca para se calcular os volumes de vazios antes e depois dos ensaios de creep, a fim de verificar se ocorreu redução no Vv (compactação) ou apenas deformação. Os valores das dimensões e volumes de vazios dos CPs antes e após o ensaio de creep estão contidas no Apêndice G.

A partir desta avaliação, constatou-se que: (i) houve aumento no diâmetro em todos os 24 CPs, sendo o aumento, em média, de 0,34 mm, que representa um aumento de 0,33\% no diâmetro; (ii) houve redução na altura em todos os $24 \mathrm{CPs}$, sendo a redução de, em média, 0,46 mm $(0,65 \%)$, e; (iii) não foi possível detectar tendência de comportamento em relação ao Vv, visto que foram observados: $1 \mathrm{CP}$ com elevação de 0,2 pontos percentuais no $\mathrm{Vv}, 9 \mathrm{CPs}$ com elevação de 0,1 ponto percentual no $\mathrm{Vv}, 11 \mathrm{CPs}$ sem alteração no volume de vazios e $3 \mathrm{CPs}$ com redução de 0,1 pontos percentuais no $\mathrm{Vv}$.

Assim, pode-se dizer que os corpos de prova se deformaram (achataram) sem ter havido tendência de redução no volume de vazios. Isto ocorreu pois no ensaio de creep estático o CP fica sem confinamento lateral, assim ao receber o esforço de compressão uniaxial estática o CP se deforma com redução da altura e alargamento do diâmetro, sem compactação adicional devida ao creep estático. Imagina-se que em campo, onde a camada asfáltica está confinada lateralmente, a aplicação de uma carga uniaxial estática por um longo período associada à elevada temperatura tende a promover compactação adicional e redução no Vv. 


\subsubsection{Consolidação dos resultados da Etapa 3}

Quanto à análise de desempenho das misturas (rankings) em relação à susceptibilidade térmica, resistência à fadiga, susceptibilidade à deformação permanente e resistência à tração após ensaio de creep estático, com ênfase nas misturas contendo caulim:

Não foi possível identificar uma mistura que tenha apresentado bom desempenho em todos os rankings simultaneamente, uma vez que os requisitos necessários para que uma mistura apresente baixa susceptibilidade à deformação permanente normalmente são opostos aos requisitos necessários para se ter boa resistência à fadiga. A seguir, discute-se o desempenho das misturas de referência, com caulim $(\mathrm{C}, 30)$, com cal (L), e com caulim e cal simultaneamente (C3,0L) em relação a: (i) susceptibilidade térmica; (ii) resistência à fadiga; (iii) susceptibilidade à deformação permanente, e; (iv) $\mathrm{RT}_{\text {creep }}$.

As misturas de referência (5070 e 3045) apresentaram, de modo geral:

(i) As maiores susceptibilidades térmicas no intervalo de 10 a $40^{\circ} \mathrm{C}$ para ambas as condições de volume de vazios ( $\mathrm{Vv} \approx 4 \% \mathrm{e} \mathrm{Vv} \approx 7 \%$ ), por tipo de ligante asfáltico;

(ii) Desempenho ruim no que tange à fadiga, sendo que a mistura 5070 exibiu, sempre, o pior desempenho dentre todas as misturas, seja na análise por diferença de tensões, seja na análise mecanística de pavimento;

(iii) As menores susceptibilidades à deformação permanente;

(iv) Bons valores de $\mathrm{RT}_{\text {Creep }}$, destacando positivamente a mistura 3045 que liderou o ranking geral.

As misturas com caulim (5070C3,0 e 3045C3,0) exibiram, via de regra:

(i) Bom desempenho em relação à susceptibilidade térmica, com resultados sempre melhores do que as misturas de referência;

(ii) Bom desempenho no que tange à fadiga, com destaque positivo para a mistura 5070C3,0 que apresentou, sempre, o melhor desempenho, seja na análise por diferença de tensões, seja na análise mecanística de pavimento, dentre as misturas com CAP 50/70;

(iii) As maiores susceptibilidades à deformação permanente, sendo que a mistura 3045C3,0 exibiu a maior susceptibilidade à DP dentre todas as misturas;

(iv) Bons valores de $\mathrm{RT}_{\text {Creep }}$, destacando positivamente a mistura 5070C3,0 que liderou o ranking das misturas com CAP 50/70. 
As misturas com caulim apresentaram bons desempenhos em três dos quatro parâmetros da caracterização mecânica complementar, em relação às misturas de referência. Esta constatação dá mais suporte à recomendação do uso de rejeito de caulim como fíler em misturas asfálticas, pois além de ser solução sustentável ao proporcionar uso de rejeito hoje inservível, a adição de caulim reduziu a susceptibilidade térmica, elevou a vida de fadiga e manteve a RT acima do valor mínimo estabelecido pelo DER/SP, mesmo após a execução do ensaio de MR em 3 temperaturas, do ensaio de creep estático e consequente acúmulo de danos nos CPs.

Por outro lado, a adição de caulim exibiu o mau resultado de tornar as misturas mais suscetíveis à deformação permanente, à luz dos resultados do ensaio de creep estático. Entretanto, como não há valores mínimos de parâmetros do ensaio de creep estático a serem atendidos, facultase o uso desse fíler, cabendo ao projetista do pavimento recomendar ou não a adição de caulim, em função das condições climáticas e do nível de tráfego aos quais o pavimento estará sujeito. Salienta-se que as misturas contendo caulim apresentam boa resistência à deformação permanente segundo os critérios propostos por Little, Button e Youssef (1993).

As misturas com cal (5070L e 3045L) exibiram o seguinte comportamento:

(i) Desempenho intermediário em relação à susceptibilidade térmica, sendo sempre menos suscetíveis do que as misturas de referência e na maioria das vezes mais suscetíveis do que as misturas C3,0L;

(ii) Desempenho intermediário em relação à fadiga. A mistura 5070L ficou sempre em $3^{\circ}$ lugar nos rankings de resistência à fadiga. A mistura 3045L apresentou a segunda melhor vida de fadiga do ranking em função dos tipos de pavimento, porém exibiu a menor vida de fadiga quando $\mathrm{N}$ foi analisado em função da diferença de tensões, para valores de $\Delta \sigma \geq 2,0 \mathrm{MPa}$;

(iii) Desempenho intermediário em relação à susceptibilidade à deformação permanente, sendo sempre mais suscetíveis que as misturas de referência e menos suscetíveis que as misturas com caulim $(\mathrm{C} 3,0)$;

(iv) Valores comparativamente baixos de $\mathrm{RT}_{\text {Creep }}$, com destaque negativo para a mistura 5070L que apresentou a menor $\mathrm{RT}_{\text {Creep }}$ dentre todas as misturas.

As misturas com caulim e cal simultaneamente (5070C3,0L e 3045C3,0L) exibiram, de modo geral: 
(i) Bom desempenho em relação à susceptibilidade térmica, tendo em vista que as misturas 5070C3,0L e 3045C3,0L apresentaram, respectivamente, a menor e a segunda menor susceptibilidade térmica, por tipo de ligante, independentemente do nível de Vv;

(ii) Bom desempenho em relação à fadiga. A mistura 5070C3,0L ficou sempre em $2^{\circ}$ lugar nos rankings de resistência à fadiga das misturas com CAP 50/70 e a mistura 3045C3,0L apresentou a maior vida de fadiga quando se fez o ranking em função da diferença de tensões;

(iii) Desempenho intermediário em relação à susceptibilidade à deformação permanente, sendo sempre mais suscetíveis que as misturas de referência e menos suscetíveis que as misturas com caulim;

(iv) Valores relativamente baixos de $\mathrm{RT}_{\text {Creep }}$, sempre inferiores às misturas de referência e com caulim, para ambos os tipos de ligante asfáltico.

$>$ Quanto à avaliação da influência do tipo de ligante asfáltico, tipo de fíler e parâmetros de caracterização do fíler nas variáveis-resposta da Etapa 3:

Na Tabela 4.30, é apresentado um resumo sobre a influência das variáveis de entrada (tipo de ligante asfáltico, tipo de fíler e parâmetros de caracterização do fíler) nas variáveis-resposta analisadas na Etapa $3\left(\mathrm{MR}\right.$ a 10, 25 e $40^{\circ} \mathrm{C}$, PST em diferentes $\Delta \mathrm{t}, \mathrm{k}_{1}, \mathrm{k}_{2}, \mathrm{~N} f(\Delta \sigma), \mathrm{N} f($ análise mecanística), $\mathrm{D}_{\mathrm{t}}, \mathrm{M}_{\mathrm{f}}, \mathrm{Rec}, \mathrm{I}_{\text {curva }}$ e $\mathrm{RT}_{\text {Creep }}$ ). O sinal (+) indica que a presença de CAP 30/45, cal, caulim, cal ou caulim simultaneamente aumentou os valores da variável-resposta em análise. Antagonicamente, o sinal (-) indica que a presença de CAP 30/45, cal, caulim, cal ou caulim simultaneamente reduziu os valores da variável-resposta em estudo.

Observando a Tabela 4.30, pode-se dizer que o tipo de ligante asfáltico (uso de CAP 30/45) foi a variável de entrada mais importante para modificar os valores de: módulo de resiliência a 25 e $40^{\circ} \mathrm{C}$, parâmetros de susceptibilidade térmica, vida de fadiga e $\mathrm{RT}_{\text {Creep }}$. O CAP 30/45 atuou de maneira importante no sentido de enrijecer as misturas, reduzir a susceptibilidade térmica, elevar a vida de fadiga e incrementar a resistência à tração após o ensaio de creep estático. $\mathrm{O}$ uso do CAP 30/45 também teve papel importante em parâmetros que implicam no aumento da susceptibilidade à deformação permanente, como o aumento de $\mathrm{I}_{\text {curva }}$, e a diminuição de $\mathrm{M}_{\mathrm{f}}$. 
Tabela 4.30 - Resumo da influência das variáveis de entrada nas variáveis-resposta da Etapa 3

\begin{tabular}{|c|c|c|c|c|c|}
\hline \multirow{3}{*}{$\begin{array}{l}\text { Variável } \\
\text { resposta }\end{array}$} & \multirow{3}{*}{$\begin{array}{c}\text { Tipo de ligante } \\
\text { asfáltico }\end{array}$} & \multicolumn{3}{|c|}{ Influência das variáveis de entrada } & \multirow{3}{*}{$\begin{array}{c}\text { Parâmetros de } \\
\text { caracterização } \\
\text { do fíler }\end{array}$} \\
\hline & & & Tipo de fíler & & \\
\hline & & Cal & Caulim & Cal e caulim & \\
\hline $\mathrm{MR}_{4} \% 10^{\circ} \mathrm{C}$ & Inconclusivo & Inconclusivo & $\begin{array}{c}\text { Muito } \\
\text { Importante (-) }\end{array}$ & Inconclusivo & Não Importante \\
\hline $\mathrm{MR} 7 \% 10^{\circ} \mathrm{C}$ & Importante $(-)$ & $\begin{array}{c}\text { Muito } \\
\text { Importante (-) }\end{array}$ & Inconclusivo & Inconclusivo & $\begin{array}{l}\text { D10 muito } \\
\text { importante } \\
\text { (CAP 50/70) }\end{array}$ \\
\hline $\mathrm{MR}_{4 \%} 25^{\circ} \mathrm{C}$ & $\begin{array}{c}\text { Muito } \\
\text { Importante (+) }\end{array}$ & Importante (-) & Importante $(+)$ & Importante (+) & Não Importante \\
\hline $\mathrm{MR}_{7 \%} 25^{\circ} \mathrm{C}$ & $\begin{array}{c}\text { Muito } \\
\text { Importante (+) }\end{array}$ & Inconclusivo & Inconclusivo & Inconclusivo & $\begin{array}{c}\text { D60 muito } \\
\text { importante } \\
\text { (CAP 50/70) }\end{array}$ \\
\hline $\mathrm{MR}_{4 \%} 40^{\circ} \mathrm{C}$ & $\begin{array}{c}\text { Muito } \\
\text { Importante (+) }\end{array}$ & Inconclusivo & Inconclusivo & Importante $(+)$ & $\begin{array}{c}\text { D30 e MF } \\
\text { muito } \\
\text { importantes } \\
\text { (CAP 30/45) }\end{array}$ \\
\hline $\mathrm{MR}_{7 \%} 40^{\circ} \mathrm{C}$ & $\begin{array}{c}\text { Muito } \\
\text { Importante (+) }\end{array}$ & Importante (-) & Inconclusivo & Importante (+) & Não Importante \\
\hline $\mathrm{PST}_{10,25 \mathrm{Vv} \approx 4 \%}$ & $\begin{array}{c}\text { Muito } \\
\text { Importante (-) }\end{array}$ & Inconclusivo & Importante (-) & Inconclusivo & Não Importante \\
\hline $\mathrm{PST}_{10,25 \mathrm{Vv} \approx 7 \%}$ & $\begin{array}{c}\text { Muito } \\
\text { Importante }\end{array}$ & Inconclusivo & Inconclusivo & Inconclusivo & Não Importante \\
\hline $\mathrm{PST}_{25,40 \mathrm{Vv}} \approx 4 \%$ & $\begin{array}{c}\text { Muito } \\
\text { Importante (-) }\end{array}$ & Importante (-) & Inconclusivo & Importante $(-)$ & Não Importante \\
\hline $\mathrm{PST}_{25,40 \mathrm{Vv} \approx 7 \%}$ & $\begin{array}{c}\text { Muito } \\
\text { Importante }(-)\end{array}$ & Inconclusivo & Inconclusivo & Importante $(-)$ & Não Importante \\
\hline $\mathrm{PST}_{10,40 \mathrm{Vv}} \approx 4 \%$ & $\begin{array}{c}\text { Muito } \\
\text { Importante (-) }\end{array}$ & Importante (-) & Importante $(-)$ & Importante (-) & Não Importante \\
\hline $\mathrm{PST}_{10,40 \mathrm{Vv}} \approx 7 \%$ & $\begin{array}{c}\text { Muito } \\
\text { Importante (-) }\end{array}$ & Importante (-) & Importante (-) & Importante (-) & Não Importante \\
\hline $\mathrm{k}_{1}$ & $\begin{array}{c}\text { Muito } \\
\text { Importante (+) }\end{array}$ & Importante (+) & Importante (+) & Importante $(+)$ & Não Importante \\
\hline $\mathrm{k}_{2}$ & $\begin{array}{c}\text { Muito } \\
\text { Importante (+) }\end{array}$ & Inconclusivo & Importante $(-)$ & Inconclusivo & Não Importante \\
\hline $\mathrm{N} f(\Delta \sigma)$ & $\begin{array}{c}\text { Muito } \\
\text { Importante }(+)\end{array}$ & Inconclusivo & Importante (+) & Importante (+) & Não Importante \\
\hline $\mathrm{N} f$ (Pavimento) & $\begin{array}{c}\text { Muito } \\
\text { Importante (+) }\end{array}$ & Importante (+) & Inconclusivo & Importante (+) & Não Importante \\
\hline $\mathrm{D}_{\mathrm{t}}$ & Inconclusivo & Importante $(+)$ & $\begin{array}{c}\text { Muito } \\
\text { Importante (+) }\end{array}$ & Inconclusivo & Não Importante \\
\hline $\mathrm{M}_{\mathrm{f}}$ & Importante (-) & Importante (-) & $\begin{array}{c}\text { Muito } \\
\text { Importante (-) }\end{array}$ & Importante $(-)$ & $\begin{array}{l}\text { D30, D60 e MF } \\
\text { importantes } \\
\text { (todas as } \\
\text { misturas) }\end{array}$ \\
\hline Rec & Importante (+) & Importante (-) & $\begin{array}{c}\text { Muito } \\
\text { Importante (-) }\end{array}$ & Importante (-) & Não Importante \\
\hline$I_{\text {curva }}$ & Importante (+) & Importante (+) & $\begin{array}{c}\text { Muito } \\
\text { Importante (+) }\end{array}$ & Inconclusivo & $\begin{array}{c}\text { D10 muito } \\
\text { importante } \\
\text { (CAP 50/70) e } \\
\text { D60 muito } \\
\text { importante } \\
\text { (CAP 30/45) }\end{array}$ \\
\hline $\mathrm{RT}_{\text {Creep }}$ & $\begin{array}{c}\text { Muito } \\
\text { Importante (+) }\end{array}$ & Importante (-) & Inconclusivo & Importante $(-)$ & Não Importante \\
\hline
\end{tabular}

${ }^{1}$ Muito importante para reduzir a dispersão dos dados, mas não há clara indicação de que o CAP 30/45 aumente ou reduza $\operatorname{PST}_{10,25 \mathrm{Vv} \approx 7 \%}$ 
Nota-se ainda que o tipo de fíler foi preponderante na definição dos valores de $\mathrm{MR}$ a $10^{\circ} \mathrm{C}$ e dos parâmetros do ensaio de creep estático que traduzem a susceptibilidade à deformação permanente.

A adição de caulim foi o parâmetro mais importante para determinar os valores $\mathrm{MR}_{4} \% 10^{\circ} \mathrm{C}$, $\mathrm{D}_{\mathrm{t}}, \mathrm{M}_{\mathrm{f}}, \operatorname{Rec}$ e $\mathrm{I}_{\mathrm{curva}}$, reduzindo a rigidez das misturas em baixa temperatura e aumentando, de maneira importante, a susceptibilidade à deformação permanente. O caulim também foi importante para: (i) aumentar os valores de $\mathrm{MR}_{4 \%}$ a $25^{\circ} \mathrm{C}, \mathrm{k}_{1}$ e $\mathrm{N} f(\Delta \sigma)$, e; (ii) reduzir os valores de $\operatorname{PST}_{10,25} \mathrm{Vv}_{\mathrm{v}} \approx 4 \%, \mathrm{PST}_{10,40 \mathrm{Vv}} \approx 4 \%, \mathrm{PST}_{10,40 \mathrm{Vv} \approx 7 \%} \mathrm{e} \mathrm{k}_{2}$. Assim, é possível dizer que a adição de caulim tendeu a reduzir a susceptibilidade térmica e aumentar a vida de fadiga, no entanto aumentou a susceptibilidade à deformação permanente. Não há clara influência da adição de caulim em relação à rigidez na temperatura de $40^{\circ} \mathrm{C}$ e à $\mathrm{RT}_{\text {Creep }}$.

A adição de cal foi o fator mais importante para determinar o valor de $\mathrm{MR}_{7 \%}$ a $10^{\circ} \mathrm{C}$, reduzindo a rigidez. A cal também foi importante para: (i) aumentar os valores de $\mathrm{k}_{1}, \mathrm{~N} f$ (análise mecanística), $\mathrm{D}_{\mathrm{t}}$, e $\mathrm{I}_{\text {curva }}$, e; (ii) reduzir os valores de $\mathrm{MR}_{4 \%}$ a $25^{\circ} \mathrm{C}, \mathrm{MR}_{7 \%}$ a $25^{\circ} \mathrm{C}, \mathrm{PST}_{25,40 \mathrm{Vv}} \approx$ $4 \%, \mathrm{PST}_{10,40 \mathrm{Vv} \approx 4 \%}, \mathrm{PST}_{10,40 \mathrm{Vv} \approx 7 \%}, \mathrm{M}_{\mathrm{f}}, \mathrm{Rec}_{\mathrm{e}} \mathrm{RT}_{\text {Creep }}$. Isto significa que a adição de cal reduziu a rigidez, a susceptibilidade térmica e a $\mathrm{RT}_{\text {Creep }}$ e aumentou a vida de fadiga e a susceptibilidade à deformação permanente.

A adição concomitante de cal e caulim não foi fator preponderante para nenhuma variávelresposta, sendo importante para: (i) aumentar os valores de $\mathrm{MR}_{4 \%}$ a $25^{\circ} \mathrm{C}, \mathrm{MR}_{4} \%$ a $40^{\circ} \mathrm{C}, \mathrm{MR} \%$ a $40^{\circ} \mathrm{C}, \mathrm{k}_{1}, \mathrm{~N} f(\Delta \sigma), \mathrm{N} f$ (análise mecanística), e; (ii) reduzir os valores de $\operatorname{PST}_{25,40 \mathrm{Vv}} \approx 4 \%$, $\mathrm{PST}_{25,40 \mathrm{Vv} \approx 7 \%}, \mathrm{PST}_{10,40 \mathrm{Vv} \approx 4 \%}, \mathrm{PST}_{10,40 \mathrm{Vv} \approx 7 \%}, \mathrm{M}_{\mathrm{f}}$, Rec, e RT $\mathrm{R}_{\text {Creep }}$. Desta forma, pode-se afirmar que a combinação de caulim + cal tendeu a enrijecer as misturas, reduzir a susceptibilidade térmica e aumentar a vida de fadiga, contudo aumentou a susceptibilidade à deformação permanente e reduziu a $\mathrm{RT}_{\text {Creep }}$.

Ocorreram correlações válidas entre os parâmetros de caracterização do fíler (D10, D30, D60 e MF) versus $\mathrm{MR}, \mathrm{M}_{\mathrm{f}}$ e $\mathrm{I}_{\text {curva }}$ somente. $\mathrm{D} 60$ foi o parâmetro de caracterização do fíler que melhor explicou as diferenças de valores das variáveis-resposta entre as misturas visto que obteve o maior número de boas correlações (3 casos - D60 $x \mathrm{MR}_{7 \%}$ a $25^{\circ} \mathrm{C}, \mathrm{D} 60 x \mathrm{M}_{\mathrm{f}}$ e D60 $x \mathrm{I}_{\text {curva }}$ ). Misturas com fíler mais fino exibiram maior rigidez, mas maior susceptibilidade à DP (menor $\mathrm{M}_{\mathrm{f}}$ e maior $\mathrm{I}_{\text {curva }}$ ). Os parâmetros de caracterização do fíler não foram importantes para a 
definição dos valores dos parâmetros de susceptibilidade térmica, parâmetros da vida de fadiga e $\mathrm{RT}_{\text {Creep }}$. Estes resultados são coerentes pois estas variáveis-resposta são mais bem explicadas pelo tipo de ligante asfáltico.

\subsection{ANÁLISES COMPLEMENTARES}

A execução do programa experimental gerou um grande volume de dados que não se vinculou diretamente com as respostas aos objetivos do trabalho, ou seja, verificar a viabilidade técnica do uso de rejeito de caulim como fíler em misturas asfálticas e contribuir para o entendimento do papel do tipo de ligante asfáltico e do tipo de fíler nos parâmetros da dosagem Marshall, nas propriedades mecânicas e nas susceptibilidades térmica e ao dano por umidade do concreto asfáltico, mas pode ser explorado, sob outros enfoques, gerando resultados interessantes.

As subseções seguintes relatam as análises complementares sobre: (i) estudos de possíveis correlações lineares entre as variáveis-resposta das três etapas da pesquisa; (ii) comparações de resultados dos ensaios de $\mathrm{RT}$ e $\mathrm{MR}$ a $25^{\circ} \mathrm{C}$, em função do nível de $\mathrm{Vv}$ (4 ou 7\%), envelhecimento das misturas ( $\operatorname{sim}$ ou não) e condicionamento térmico (sim ou não). Para a RT, foi feita uma verificação adicional em relação à execução de ensaios prévios no $\mathrm{CP}$, (apenas MR a $25^{\circ}$ ou MR em 3 temperaturas mais creep estático); (iii) para a vida de fadiga, foram testadas relações com Vv, MR e realização prévia de ensaios de MR em diferentes temperaturas.

\subsubsection{Estudo de correlações lineares entre as variáveis-resposta da pesquisa}

Nas Etapas 1, 2 e 3 sempre se procurou entender a influência dos fatores tipo de ligante asfáltico, tipo de fíler e parâmetros de caracterização do fíler nas diversas variáveis-resposta da pesquisa (parâmetros das dosagens Marshall, RT, MR, PST, fadiga e DP). Apresenta-se uma análise complementar com objetivo de entender o efeito de uma variável-resposta sobre outra. Para tanto, utilizou-se regressão linear simples e foram analisados os valores de $\mathrm{R}^{2}$, para se detectar a qualidade das relações, e os coeficientes angulares dos modelos, para identificar se as variáveis-resposta apresentavam variação direta ou inversamente proporcional. Maiores detalhes sobre estes procedimentos, bem como as tabelas contendo os valores de $\mathrm{R}^{2}$ e o sinal dos coeficientes angulares estão disponíveis no Apêndice H. O conteúdo deste apêndice ajuda a entender melhor as análises descritas nos itens 4.5.1.1 e 4.5.1.2. 
4.5.1.1 Correlações internas entre as variáveis-resposta das Etapa 1, 2 e 3

Na Figura 4.42, são apresentados os valores de $\mathrm{R}^{2}$ das regressões consideradas como lineares, a um nível de significância de 5\%, entre os parâmetros das dosagens Marshall (Etapa 1). A figura foi construída tomando por base os dados das 10 misturas da Etapa 1, mais os dados das misturas 5070C3,0L e 3045C3,0L, com os valores referentes aos teores de projeto de cada mistura. Os valores de $\mathrm{R}^{2}$ acima da linha vermelha $\left(\mathrm{R}^{2}>0,34\right.$, para 12 pontos correspondentes às 12 misturas) indicam que os modelos podem ser considerados como lineares, valores acima da linha verde $\left(\mathrm{R}^{2}>0,75\right)$ indicam boa correlação e valores acima da linha azul $\left(\mathrm{R}^{2}>0,90\right)$ representam excelentes correlações lineares.

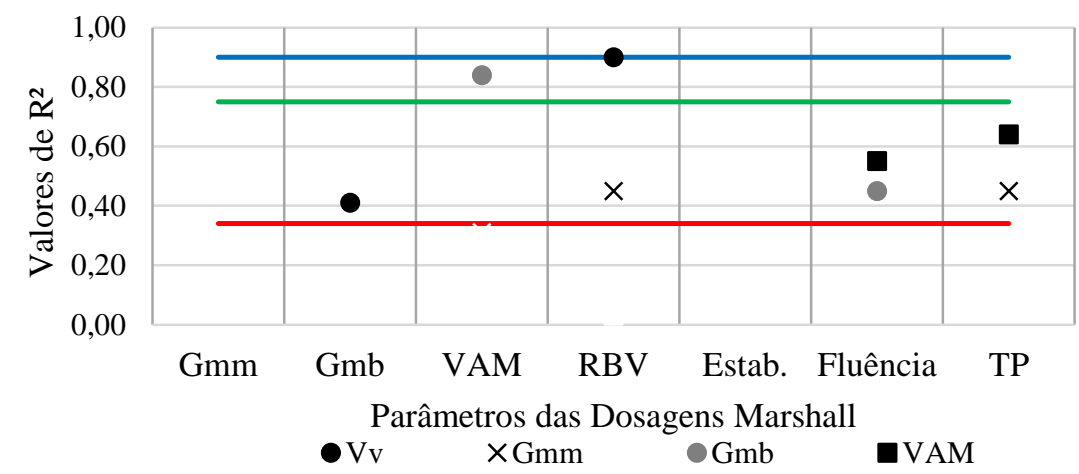

Figura 4.42 - Valores de $\mathrm{R}^{2}$ das regressões lineares entre os parâmetros das dosagens Marshall

Conforme indicado no Apêndice H, a maioria das correlações entre os parâmetros das Dosagens Marshall não pode ser considerada como linear em virtude dos baixos valores de $\mathrm{R}^{2}$. Dos 28 testes efetuados, apenas $8(28,6 \%)$ puderam ser considerados como lineares.

Foram estabelecidas correlações inversamente proporcionais entre $V_{v} \times G_{m b}\left(R^{2}=0,41\right.$, moderada) e Vv x RBV $\left(\mathrm{R}^{2}=0,90\right.$, excelente). Estes resultados já eram esperados à luz das relações matemáticas entre estes parâmetros nos cálculos das propriedades volumétricas das misturas. Foram detectadas correlações lineares inversamente proporcionais, entre $\mathrm{G}_{\mathrm{mm}} \mathrm{x}$ RBV e $G_{m m} \times T P\left(R^{2}=0,45\right.$ para ambas, moderadas), resultados coerentes pois misturas com mais ligante asfáltico, ou seja, maiores valores de RBV e TP, tem proporcionalmente menos agregados e consequentemente apresentam menores valores de densidade máxima teórica da mistura asfáltica solta $\left(\mathrm{G}_{\mathrm{mm}}\right)$. 
$\mathrm{G}_{\mathrm{mb}} \mathrm{X}$ VAM exibiram boa correlação, $\mathrm{R}^{2}=0,84$, inversamente proporcional, visto que à medida que a mistura fica mais densa (maior $\mathrm{G}_{\mathrm{mb}}$ ) diminuem-se os vazios do agregado mineral e $\mathrm{G}_{\mathrm{mb}} \mathrm{X}$ fluência apresentaram moderada correlação inversamente proporcional, $\mathrm{R}^{2}=0,45$, resultado coerente pois em misturas mais densas há maior entrosamento entre as partículas do esqueleto mineral, dificultando assim a ocorrência de deslocamento relativo entre as partículas (fluência). Foram encontradas relações diretamente proporcionais entre VAM x fluência (correlação moderada, $\left.\mathrm{R}^{2}=0,55\right)$ e VAM x TP (correlação moderada, $\left.\mathrm{R}^{2}=0,64\right)$. Houve, novamente, coerência nos resultados pois se há um grande volume de vazios no esqueleto mineral, facultase a entrada de mais ligante asfáltico (elevação no TP) e também a estrutura fica mais sujeita a se deformar (aumento na fluência).

Por fim, destaca-se que o VAM foi o parâmetro que melhor explicou as variações de valores dos parâmetros Marshall das misturas. O VAM foi importante para modificar os parâmetros volumétricos e a fluência das misturas asfálticas. Já a estabilidade não apresentou qualquer relação linear com os demais parâmetros das dosagens Marhsall.

Na Figura 4.43, construída com base nos dados das 12 misturas da Etapa 2, são apresentados apenas os valores de $\mathrm{R}^{2}$ das regressões entre os parâmetros da caracterização mecânica básica consideradas como lineares.

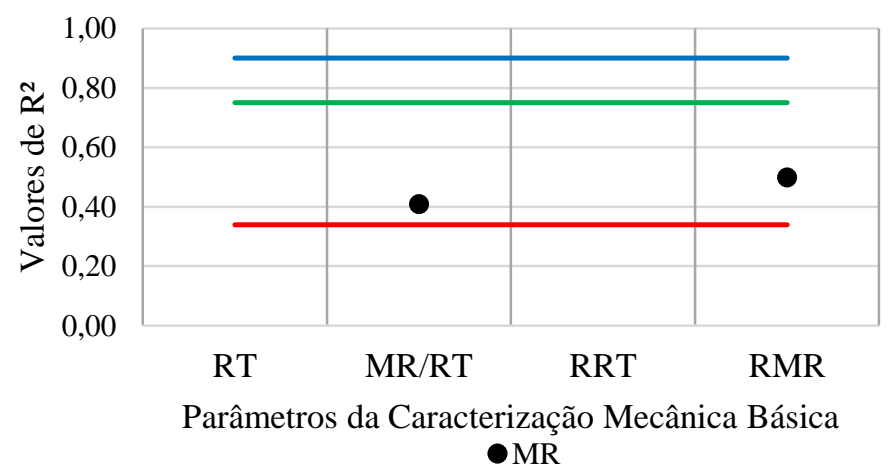

Figura 4.43 - Valores de $\mathrm{R}^{2}$ das regressões lineares entre os parâmetros caracterização mecânica básica

Verificou-se que o valores de $\mathrm{R}^{\mathbf{2}}$ das regressões lineares da Etapa 2 foram, em média, inferiores aos valores de $\mathrm{R}^{2}$ das regressões lineares da Etapa 1, portanto os parâmetros das dosagens Marshall exibem mais e melhores correlações entre si e do que os parâmetros da caracterização mecânica básica. 
Foram estabelecidas apenas duas correlações lineares entre MR x MR/RT e MR x RMR, ambas de qualidade moderada com $\mathrm{R}^{2}=0,41$ e $\mathrm{R}^{2}=0,50$, respectivamente. A relação diretamente proporcional entre MR x MR/RT é compreendida pela relação matemática que estes parâmetros possuem e a relação inversamente proporcional entre MR x RMR é explicada, principalmente, pelos resultados das misturas $\mathrm{C} 6,0$ e $\mathrm{C} 3,0 \mathrm{~L}$ as quais exibiram os maiores valores de rigidez e os menores valores de RMR.

O MR é o parâmetro que melhor explica a variação dos valores dos demais parâmetros da caracterização mecânica básica por tipo de mistura, e este resultado era esperado uma vez que três dos cinco parâmetros avaliados da Etapa 2 são medidas de rigidez (MR, MR/RT e RMR). Por outro lado, a RRT exibiu os menores valor de $\mathrm{R}^{2}$, logo é a variável-resposta menos explicada e a que menos explica as variações dos valores das demais variáveis-resposta da Etapa 2. Este resultado se dá em função de que a RRT foi regida, principalmente, pelo efeito produzido pela adição de cal. A RT também não apresentou correlações lineares com MR, RRT, RMR e relação MR/RT.

$\mathrm{Na}$ Etapa 3 foram produzidos $\mathrm{CPs}$ com $\mathrm{Vv} \approx 4 \%$, para as análises de fadiga e susceptibilidade térmica e CPs com $\mathrm{Vv} \approx 7 \%$, para as análises de susceptibilidades à deformação permanente $\mathrm{e}$

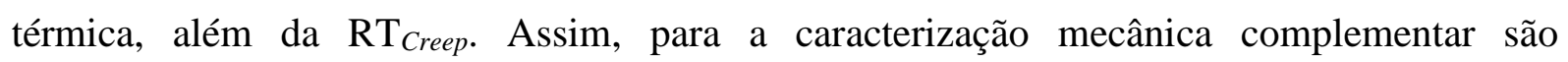
apresentadas duas figuras de correlações entre as variáveis-resposta, uma para $\mathrm{Vv} \approx 4 \%$ e outra para $\mathrm{Vv} \approx 7 \%$.

Na Figura 4.44, construída com base nos dados das 8 misturas da Etapa 3 referentes a $V v \approx 4 \%$, são apresentados os valores de $\mathrm{R}^{2}$ válidos das regressões lineares entre os $\mathrm{MR}$, parâmetros de susceptibilidade térmica e vida de fadiga. A tendência de comportamento da vida de fadiga em função de MR e PST foi a mesma, independentemente da forma de avaliação de $N(\Delta \sigma$ ou análise mecanística). Assim, na Figura 4.44 são mostradas apenas algumas correlações da vida de fadiga.

Em virtude da menor quantidade de misturas da Etapa 3 e, portanto, menor quantidade de pontos para a geração dos modelos, o valor mínimo de $\mathrm{R}^{2}$ para aceitação de linearidade foi de 0,50. Ainda assim, houve grande quantidade de relações lineares entre rigidez, parâmetro de susceptibilidade térmica e vida de fadiga. 


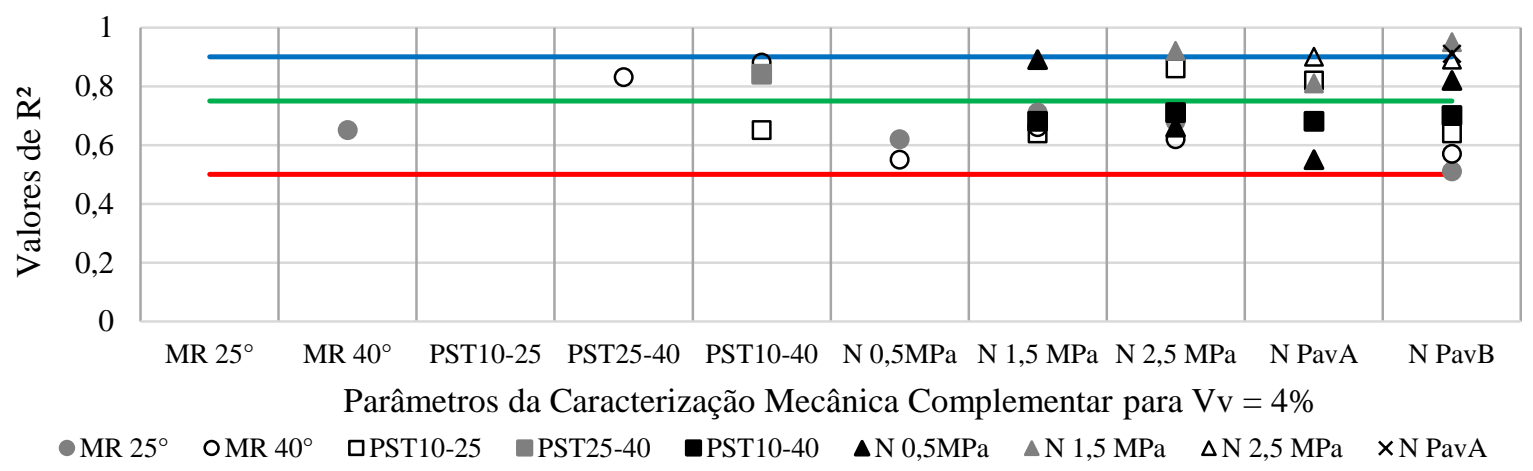

Figura 4.44 - Valores de $\mathrm{R}^{2}$ das regressões lineares entre os parâmetros da caracterização mecânica complementar, para $\mathrm{Vv}=4 \%$

As tendências gerais em relação à rigidez (Apêndice $H$ ) foram: (i) misturas com MR mais elevado em uma determinada temperatura tenderam a apresentar rigidez mais elevada nas demais temperaturas; (ii) misturas com maiores valores de MR, independentemente da temperatura na qual a rigidez foi avaliada, tenderam a exibir menor susceptibilidade térmica e maiores valores de vida de fadiga e; (iii) nas temperaturas que a rigidez foi medida, o MR a $25^{\circ} \mathrm{C}$ apresentou as melhores correlações lineares com a vida de fadiga $\left(0,51<\mathrm{R}^{2}<0,71\right)$ e tal resultado é coerente, pois, a vida de fadiga também foi medida à $25^{\circ} \mathrm{C}$.

Misturas com maior valor de PST em um determinado intervalo de temperatura $(\Delta \mathrm{t})$, tenderam a apresentar maiores valores de PST nos demais $\Delta \mathrm{t}$. Uma constatação muito interessante foi a identificação de relações lineares inversamente proporcionais entre PST e N, ou seja, misturas com menor susceptibilidade térmica apresentaram maior vida de fadiga. Ambos são comportamentos desejáveis para as misturas asfálticas e foram obtidos simultaneamente, principalmente em misturas mais rígidas.

De modo geral, PST $_{10,25}$ exibiu as melhores correlações com a vida de fadiga $\left(0,64<\mathrm{R}^{2}<0,86\right)$. Este resultado corrobora a premissa feita na seção 4.4.1.4 de que a avaliação de susceptibilidade térmica no intervalo de 10 a $25^{\circ} \mathrm{C}$ apresentaria, provavelmente, boa correlação com o desempenho à fadiga, visto que a formação de trincas por fadiga é potencializada em temperaturas mais baixas, pois a camada asfáltica enrijece e passa a absorver mais tensões e, em consequência, tende a se deformar mais, chegando, em determinado momento, a fissurar. Ao se trabalhar com misturas com menor susceptibilidade térmica, a variação de MR em função de $\Delta \mathrm{t}$ é menor, assim a capa tende a enrijecer proporcionalmente menos, absorvendo menos tensões e menos deformações, com isso aumenta-se a vida de fadiga. 
Os valores de $\mathrm{N}$ sempre apresentaram correlações lineares diretamente proporcionais entre si $\left(0,55<\mathrm{R}^{2}<0,92\right)$, ou seja, misturas que apresentaram maior vida de fadiga em uma determinada condição ( $\mathrm{N}$ para $\Delta \sigma=2,5 \mathrm{MPa}$, por exemplo), tendem a apresentar maior $\mathrm{N}$ em outras condições (N Pav A).

Na Figura 4.45, construída com base nos dados das 8 misturas da Etapa 3 referentes a $\mathrm{Vv} \approx 7 \%$, são apresentados os valores de $\mathrm{R}^{\mathbf{2}}$ válidos das regressões lineares entre os MR, PST, parâmetros do ensaio de creep estático e $\mathrm{RT}_{\text {creep }}$.

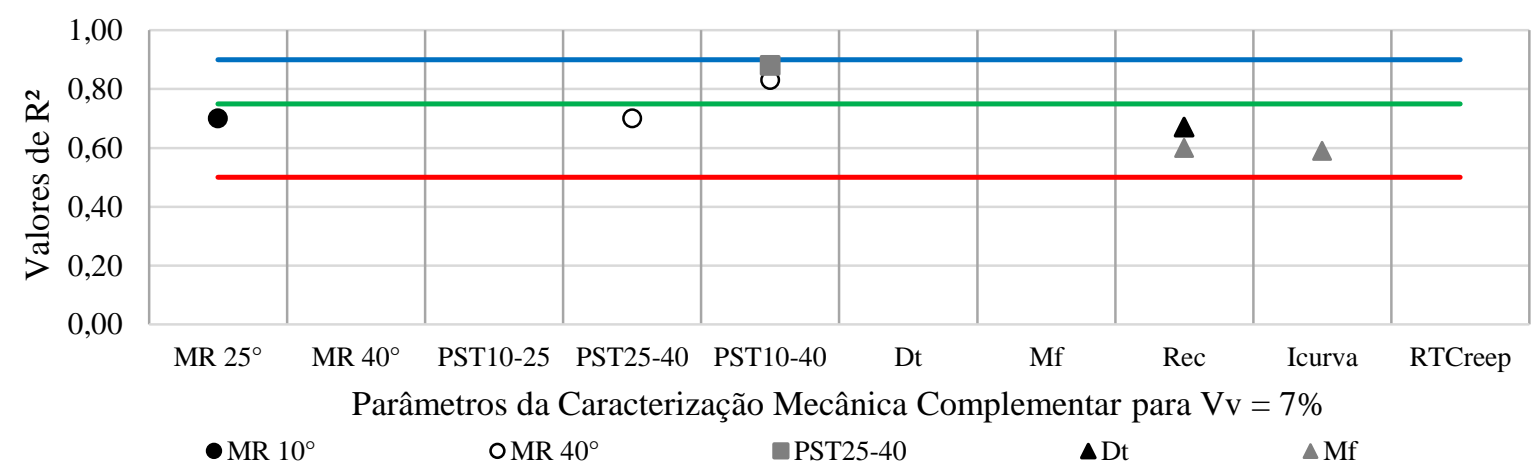

Figura 4.45 - Valores de $\mathrm{R}^{2}$ das regressões lineares entre os parâmetros da caracterização mecânica complementar, para $\mathrm{Vv}=7 \%$

Houve apenas 7 correlações lineares, indicando que a qualidade das correlações é bem inferior para $\mathrm{Vv}=7 \%$ em relação a $\mathrm{Vv}=4 \%$. Os valores de MR e PST não exibiram correlações lineares com $\mathrm{RT}_{\text {creep }}$, nem com os parâmetros do ensaio de creep estático.

Similarmente ao ocorrido para $\mathrm{Vv}=4 \%$, misturas com MR mais elevado em uma determinada temperatura tenderam a apresentar rigidez mais elevada nas demais temperaturas (Apêndice $\mathrm{H}$ ). Esperava-se encontrar boas correlações entre $\mathrm{MR}$ a $40^{\circ} \mathrm{C}$ e os parâmetros de creep estático, visto que as propriedades foram medidas na mesma temperatura, porém os valores de $\mathrm{R}^{2}$ foram muito baixos e não houve sequer a definição de tendência de que misturas mais rígidas fossem menos suscetíveis à DP.

Misturas com maior valor de PST em um determinado intervalo de temperatura $(\Delta \mathrm{t})$, tenderam a apresentar maiores valores de PST nos demais $\Delta \mathrm{t}$. Esperava-se encontrar boas correlações entre o $\mathrm{PST}_{25,40}$ e os parâmetros de creep estático, em função de que no intervalo mais elevado 
de temperatura ocorre propensão de haver deformação permanente. No entanto, além dos valores de $\mathrm{R}^{2}$ terem sido baixos, não houve sequer a definição de tendência de que misturas com maior susceptibilidade térmica sejam mais suscetíveis à deformação permanente.

Uma explicação para as baixas correlações observadas é que a rigidez das misturas e, em consequência, os valores de PST são controlados majoritariamente pelas características do ligante asfáltico, enquanto que os parâmetros do ensaio de creep estático foram mais bem explicados à luz do tipo de fíler. Além disso, podem surgir questões relacionadas ao tipo e a forma de carregamento desses ensaios.

Os parâmetros do ensaio de creep estático foram coerentes entre si pois misturas mais suscetíveis à deformação permanente sob determinado parâmetro, por exemplo misturas com maior $\mathrm{D}_{\mathrm{t}}$, tenderam a ser mais suscetíveis à $\mathrm{DP}$ nos demais parâmetros. Os valores de $\mathrm{R}^{\mathbf{2}}$ foram moderados $\left(0,59<R^{2}<0,67\right)$ para as correlações entre $D_{t} \times R e c, M_{f} \times$ Rec e $M_{f} \times I_{\text {curva }}$. Não houve correlação linear entre a susceptibilidade à deformação permanente e $\mathrm{RT}_{\text {creep }}$.

\subsubsection{Correlações entre as variáveis-resposta das Etapa 1, 2 e 3, Etapa versus Etapa}

Na Figura 4.46, elaborada a partir dos dados das 12 misturas das Etapas 1 e 2, são apresentados os valores de $\mathrm{R}^{2}$ válidos das correlações entre os parâmetros das dosagens Marshall versus parâmetros da caracterização mecânica básica.

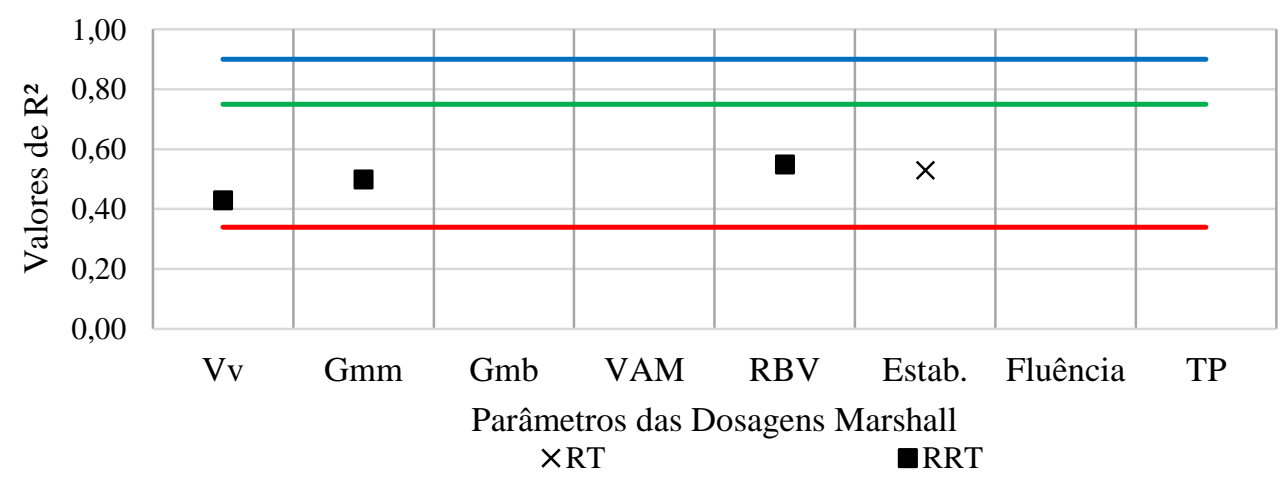

Figura 4.46 - Valores de $\mathrm{R}^{2}$ das regressões lineares entre os parâmetros da Etapa 1 x Etapa 2

Dos 40 testes efetuados entre os 8 parâmetros da Etapa $1 \times 5$ parâmetros da Etapa 2, apenas 4 $(10,0 \%)$ puderam ser considerados como lineares. Ocorreu moderada correlação diretamente proporcional $\left(\mathrm{R}^{2}=0,53\right)$ entre a estabilidade versus $\mathrm{RT}$. Assim, misturas que exibiram maiores 
valores de estabilidade tenderam a ter maiores valores de resistência a tração por compressão diametral. Este resultado é coerente, pois a estabilidade é um parâmetro empírico do ensaio Marshall utilizado para relacionado à resistência das misturas.

Três variáveis-resposta da Etapa 1, Vv, $\mathrm{G}_{\mathrm{mm}}$ e RBV, apresentaram correlações lineares com a RRT. Vv e $\mathrm{G}_{\mathrm{mm}}$ têm moderadas correlações inversamente proporcionais com a $\mathrm{RRT}\left(\mathrm{R}^{2}=0,43\right.$ e $\mathrm{R}^{2}=0,50$, respectivamente), ou seja, quanto maior o volume de vazios e quanto maior a densidade máxima teórica, menor será o valor de RRT. Por outro lado, RBV $x$ RRT tem moderada correlação diretamente proporcional $\left(\mathrm{R}^{2}=0,55\right)$, indicando que misturas mais ricas em ligante sçao mais resistentes ao dano por umidade. Embora os parâmetros da Etapa 1 sejam referentes a CPs com $\mathrm{Vv} \approx 4 \%$ e a RRT tenha sido medida em CPs com Vv $\approx 7 \%$, os resultados são coerentes pois: (i) misturas com maior $\mathrm{Vv}$ e, portanto, com maior espaço para alojar água, devem apresentar menor RRT; (ii) misturas com maior $\mathrm{G}_{\mathrm{mm}} \mathrm{e}$, portanto, menor teor de ligante asfáltico, devem exibir menores valores de RRT, e; (iii) misturas com maior RBV, ou mais ricas em ligante, devem resistir mais à ação da água e exibir maiores valores de RRT.

É interessante destacar que estabilidade e VAM haviam sido, respectivamente, as variáveisresposta com pior e melhor correlações em relação aos parâmetros das dosagens Marshall. Nas correlações entre Etapa 1 x Etapa 2, houve a inversão com a estabilidade se relacionando melhor com os parâmetros da caracterização mecânica básica, por ser um parâmetro mecânico da dosagem e VAM sendo a pior variável, ou seja, os vazios do agregado mineral foram importantes para a definição das propriedades volumétricas das misturas, mas não foram relevantes para as propriedades mecânicas.

Nas Figuras 4.47 e 4.48 são apresentados os valores de $\mathrm{R}^{2}$ das correlações lineares válidas entre os parâmetros da Etapa 1 versus Etapa 3 e Etapa 2 versus Etapa 3, respectivamente. Os gráficos foram construídos tomando por base os dados das 8 misturas da Etapa 3. Em virtude da grande quantidade de parâmetros desta etapa, são mostradas no eixo x apenas as correlações que puderam ser consideradas lineares. Os valores de $\mathrm{R}^{2}$ das correlações entre as variáveis-resposta das Etapas 1 e 2 versus todas as variáveis-resposta da Etapa 3 encontram-se no Apêndice H. 


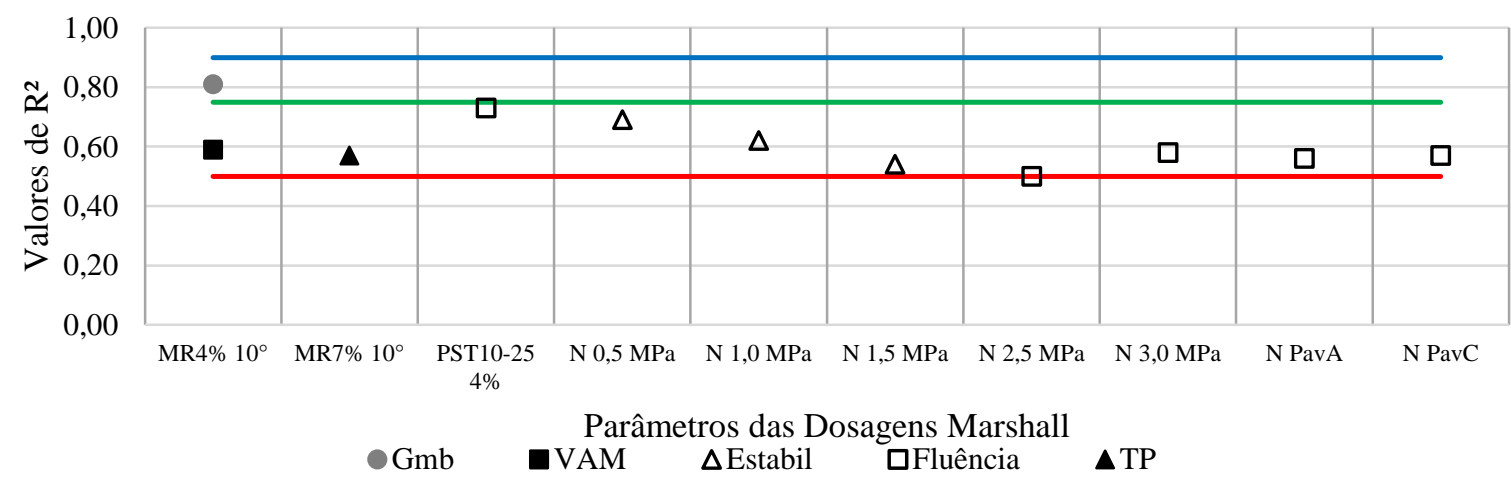

Figura 4.47 - Valores de $\mathrm{R}^{2}$ das regressões lineares entre os parâmetros da Etapa 1 x Etapa 3

$\mathrm{G}_{\mathrm{mb}}$ e VAM apresentaram relações lineares, direta e inversamente proporcionais respectivamente, com o $\mathrm{MR}_{4 \%}$ a $10^{\circ} \mathrm{C}$ e $\mathrm{TP}$ exibiu correlação linear inversamente proporcional com $\mathrm{MR}_{7 \%}$ a $10^{\circ} \mathrm{C}$. Tais resultados são coerentes pois a $10^{\circ} \mathrm{C}$, a rigidez da mistura asfáltica foi bastante influenciada pelo tipo de fíler. Portanto, misturas mais densas (maior $\mathrm{G}_{\mathrm{mb}}$ ) tendem a ser mais rígidas, misturas com maior VAM tendem a ser menos rígidas e misturas com alto TP e, proporcionalmente menos agregados, tendem a ser menos rígidas.

Ocorreu boa correlação $\left(\mathrm{R}^{2}=0,73\right)$, inversamente proporcional, entre a fluência e PST $10,25 \mathrm{Vv} \approx$ 4\%, ou seja, quanto maior a fluência, menor será a susceptibilidade térmica no intervalo de 10 a $25^{\circ} \mathrm{C}$. A fluência também apresentou correlações moderadas diretamente proporcionais com a vida de fadiga, para $\Delta \sigma$ elevadas. Estes resultados podem ser entendidos pela adição de fíleres, que, como relatado anteriormente, tendeu a aumentar a fluência, reduzir o PST e aumentar N.

A estabilidade se correlacionou de maneira diretamente proporcional com a vida de fadiga, especialmente para baixa $\Delta \sigma$. Este resultado é coerente pois a estabilidade é um parâmetro empírico, mas relacionado com a resistência da mistura.

Não foram encontradas correlações lineares, a um nível de significância de 5\%, entre os parâmetros das dosagens Marshall e parâmetros do ensaio de creep estático e $\mathrm{RT}_{\text {creep }}$. Além disso, destaca-se que $\mathrm{Vv}, \mathrm{G}_{\mathrm{mm}}$ e RBV não apresentaram quaisquer correlações lineares com as variáveis-resposta da Etapa 3.

Observando a Figura 4.48, notou-se que o MR apresentou correlações diretamente proporcionais com $\mathrm{MR}_{4 \%}$ a $40^{\circ} \mathrm{C}$ e com a vida de fadiga, para vários níveis de $\Delta \sigma$, e correlação inversamente proporcional com $\operatorname{PST}_{25,40}$ para $\mathrm{Vv}=7 \%$. Assim, misturas mais rígidas tendem 
a: (i) continuar mais rígidas em temperaturas mais elevadas; (ii) apresentar maior vida de fadiga, e; (iii) exibir menor susceptibilidade térmica.

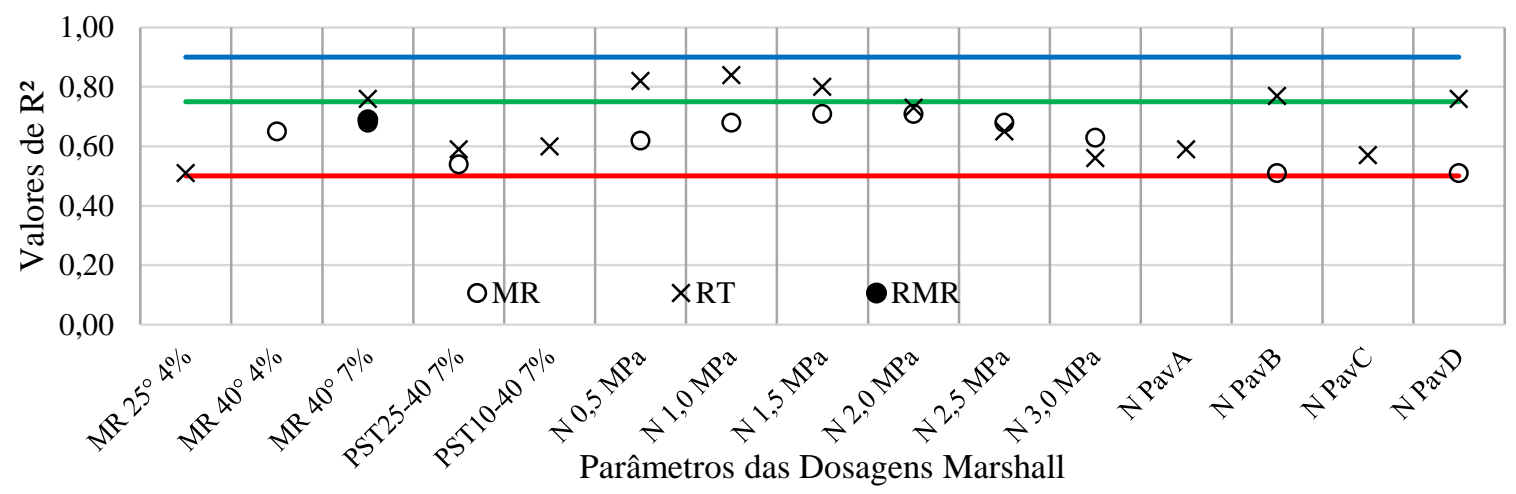

Figura 4.48 - Valores de $\mathrm{R}^{2}$ das regressões lineares entre os parâmetros da Etapa 2 x Etapa 3

A RT exibiu tendência de correlações diretamente proporcionais com os valores de MR e $\mathrm{N} \mathrm{e}$ inversamente proporcionais ao PST (Apêndice H). Logo, misturas com maior valor de RT apresentaram maior vida de fadiga, maior rigidez e menor susceptibilidade térmica. Estes resultados podem ser entendidos à luz do tipo de ligante asfáltico, pois as misturas com CAP 30/45 foram, simultaneamente, mais rígidas, com maior RT, com maior resistência à fadiga e com menor susceptibilidade térmica.

A RMR apresentou correlação linear inversamente proporcional $\left(\mathrm{R}^{2}=0,69\right)$ com $\mathrm{MR}_{7 \%} \mathrm{a} 40^{\circ}$. Esta constatação é melhor entendida à luz das misturas C3,0L que apresentaram as menores RMRs e os maiores valores de rigidez, por tipo de ligante asfáltico.

A RRT e relação MR/RT não apresentaram boas correlações com as propriedades medidas na caracterização mecânica complementar. Destaca-se negativamente a relação MR/RT, pois imaginava-se que ela poderia relacionar-se de forma inversamente proporcional com a vida de fadiga.

Os parâmetros do ensaio de creep estático e a $\mathrm{RT}_{\text {Creep }}$ também não apresentaram boas correlações com os parâmetros da caracterização mecânica básica, a exemplo do que já havia ocorrido na busca de correlações entre os resultados de creep versus parâmetros das dosagens Marshall e versus os parâmetros da Etapa 3, para Vv $=7 \%$. Assim, a susceptibilidade à deformação permanente e a $\mathrm{RT}_{\text {creep }}$ não podem ser explicadas ou ter o comportamento previsto em função de algum parâmetro da dosagem ou de resultados de ensaios mecânicos. 


\subsubsection{Comparações entre os resultados das diversas condições de ensaios de RT e MR}

O programa experimental envolveu a execução de ensaios de MR e RT em 4 condições, em função dos fatores: (i) volume de vazios (4 e 7\%); (ii) envelhecimento da mistura (Sim ou Não); (iii) condicionamento térmico (Sim ou Não), e; (iv) realização de ensaios prévios, no caso dos CPs destinados ao ensaio de RT (MR em 3 temperaturas + creep ou apenas MR a $25^{\circ} \mathrm{C}$ ). Os valores de MR e RT, por condições de ensaio, estão descritos nas Etapas 2 e 3.

Apresenta-se uma análise baseada nos testes t para verificar se as médias de valores de MR e RT, por condição de ensaio, são significativamente diferentes, considerando $\alpha=0,05$. As verificações foram processadas para cada tipo de mistura e por grupos de mistura em função do tipo de ligante asfáltico, para síntese dos resultados, conforme indicado nas Tabelas 4.31 e 4.32.

Tabela 4.31 - Resultados dos testes t de Student para verificar se as médias de MR por condição de ensaio são significativamente diferentes

\begin{tabular}{|c|c|c|c|c|c|c|}
\hline $\begin{array}{l}\text { Tipo de } \\
\text { Mistura }\end{array}$ & $\begin{array}{c}\text { MR x } \\
\text { MRDUI } \\
\text { controle }\end{array}$ & $\begin{array}{c}\text { MR x } \\
\text { MRduI } \\
\text { condicionado }\end{array}$ & $\begin{array}{c}\text { MR x } \\
\text { MR } \\
\text { creep }\end{array}$ & $\begin{array}{c}\text { MRDUIcontrole } \\
\text { x MRDUI } \\
\text { condicionado }\end{array}$ & $\begin{array}{l}\text { MRDUI } \\
\text { controle } \mathbf{x} \\
\text { MR }_{\text {creep }}\end{array}$ & $\begin{array}{c}\text { MRDUI } \\
\text { condicionado } \mathrm{X} \\
\text { MR }_{\text {creep }} \\
\end{array}$ \\
\hline 5070 & Sim & Não & Sim & Não & Não & Não \\
\hline $5070 \mathrm{C} 3,0$ & Sim & Sim & Sim & Não & Não & Não \\
\hline $5070 \mathrm{~L}$ & Sim & Não & Sim & Sim & Não & Sim \\
\hline $5070 \mathrm{C} 3,0 \mathrm{~L}$ & Sim & Sim & Sim & Sim & Não & Sim \\
\hline $\begin{array}{c}\text { Agrupado } \\
\mathbf{5 0 7 0}\end{array}$ & Sim & Sim & Sim & Não & Não & Não \\
\hline 3045 & $\mathrm{Sim}$ & Sim & $\mathrm{Sim}$ & Não & Sim & Não \\
\hline $3045 \mathrm{C} 3,0$ & Sim & Sim & Sim & Não & Não & Não \\
\hline $3045 \mathrm{~L}$ & Sim & Sim & Sim & Não & Sim & Não \\
\hline $3045 \mathrm{C} 3,0 \mathrm{~L}$ & Sim & Sim & Sim & Não & Não & Não \\
\hline $\begin{array}{c}\text { Agrupado } \\
3045\end{array}$ & Sim & Sim & Sim & Não & Não & Não \\
\hline
\end{tabular}

Tabela 4.32 - Resultados dos testes t de Student para verificar se as médias de RT por condição de ensaio são significativamente diferentes

\begin{tabular}{|c|c|c|c|c|c|c|}
\hline $\begin{array}{l}\text { Tipo de } \\
\text { Mistura }\end{array}$ & $\begin{array}{l}\text { RT x } \\
\text { RT } \\
\text { controle } \\
\end{array}$ & $\begin{array}{c}\text { RT x } \\
\text { RT }_{\text {DUI }} \\
\text { condicionado }\end{array}$ & $\begin{array}{c}\text { RT X } \\
\text { RT } \\
\text { creep }\end{array}$ & $\begin{array}{c}\text { RT }_{\text {DUIcontrole }} \\
\text { x RT } \\
\text { condicionado } \\
\text { d }\end{array}$ & $\begin{array}{c}\text { RT }_{\text {DUI }} \\
\text { controle } \mathbf{x} \\
\text { RT }_{\text {creep }}\end{array}$ & $\begin{array}{c}\mathbf{R T}_{\text {DUI }} \\
\text { condicionado } \mathbf{x} \\
\text { RT }_{\text {creep }}\end{array}$ \\
\hline 5070 & Sim & Sim & Sim & Sim & Não & Sim \\
\hline $5070 \mathrm{C} 3,0$ & Sim & Sim & Sim & Sim & Não & Sim \\
\hline $5070 \mathrm{~L}$ & Sim & Sim & Sim & Não & Não & Não \\
\hline $5070 \mathrm{C} 3,0 \mathrm{~L}$ & Sim & Sim & Sim & Sim & Não & Não \\
\hline $\begin{array}{c}\text { Agrupado } \\
\mathbf{5 0 7 0}\end{array}$ & Sim & Sim & Sim & Sim & Não & Sim \\
\hline 3045 & Sim & $\mathrm{Sim}$ & $\mathrm{Sim}$ & $\mathrm{Sim}$ & $\mathrm{Sim}$ & Sim \\
\hline $3045 \mathrm{C} 3,0$ & Sim & Sim & Sim & Sim & Não & Sim \\
\hline $3045 \mathrm{~L}$ & Sim & Sim & Sim & Não & Não & Não \\
\hline $3045 \mathrm{C} 3,0 \mathrm{~L}$ & Sim & Sim & Sim & Não & Não & Não \\
\hline $\begin{array}{c}\text { Agrupado } \\
3045\end{array}$ & Sim & Sim & Sim & Sim & Não & Sim \\
\hline
\end{tabular}


Ao interpretar os dados das Tabelas 4.31 e 4.32, tem-se que:

As três primeiras colunas indicam, principalmente, as verificações em função do $\mathrm{Vv}$, pois MR e RT (sem sufixos) foram medidas com $\mathrm{Vv} \approx 4 \%$ e as demais condições com $\mathrm{Vv} \approx 7 \%$. Assim, percebe-se que o $\mathrm{Vv}$ é muito importante para diferenciar as médias tanto de MR quanto de RT;

Na quarta coluna constam as verificações em função do condicionamento térmico, que foi importante para diferenciar as médias de RT, porém não foi importante para distinguir as médias de MR;

$>$ A quinta coluna indica a verificação em função do envelhecimento previsto na AASHTO T 283. Adicionalmente para a RT, também avalia a realização de ensaios prévios. Para o MR, o envelhecimento não foi importante. Para a RT, os valores médios de CP submetidos ao envelhecimento foram semelhantes aos valores médios de CPs não submetidos ao envelhecimento, porém submetidos a ensaios prévios de MR em 3 temperaturas e creep estático, ou seja, entende-se que o nível de dano causado ao $\mathrm{CP}$ pelo envelhecimento foi semelhante ao dano oriundo dos ensaios prévios, não sendo importante para diferenciar as médias de RT;

> Na última coluna constam as verificações em função do envelhecimento e do condicionamento térmico para o MR, quue não foram importantes. Para a RT também se avaliou o impacto da realização de ensaios prévios. Entende-se que o condicionamento térmico foi o fator mais relevante para tornar os resultados de RT significativamente diferentes;

$>$ Os resultados dos grupos de misturas, por tipo de ligante asfálticos, são semelhantes aos das misturas individualmente.

Para o MR, apenas o Vv foi importante para categorizar os valores de rigidez, visto que os valores de $M R_{\text {DUIcontrole }}, \mathrm{MR}_{\text {DUIcondicionado }}$ e $\mathrm{MR}_{\text {creep }}$ puderam ser considerados iguais. Para a RT, o Vv e o condicionamento térmico foram os fatores de diferenciação dos resultados. Para fins de síntese, e considerando que os dados agrupados por tipo de ligante asfáltico representaram bem o que ocorreu nas misturas individualmente, foram gerados modelos lineares, por tipo de ligante asfáltico, para correlacionar Vv x MR e Vv x RT.

Nos modelos Vv x MR entraram os dados de todos os CPs, pois para Vv $=7 \%$ todos os MR são iguais. Nos modelos de Vv x RT desprezaram-se os dados de RT DUIcondicionado, pois eles foram significativamente inferiores à $\mathrm{RT}_{\text {DUIcontrole }} \mathrm{e} \mathrm{RT}_{\text {creep. }}$ Os modelos estão apresentados na 
Figura 4.49. É possível perceber a melhor qualidade dos modelos de RT em relação aos modelos de MR, traduzidos em maiores valores de $\mathrm{R}^{2}$, e que os modelos das misturas com CAP 30/45 (MR e RT) são mais suscetíveis à variação de volume de vazios, em virtude dos maiores coeficientes angulares das retas. Estes dados reforçam a importância de se controlar o volume de vazios das misturas asfálticas, seja em pesquisas, seja em campo, de modo a não alterar substancialmente as propriedades mecânicas das misturas.
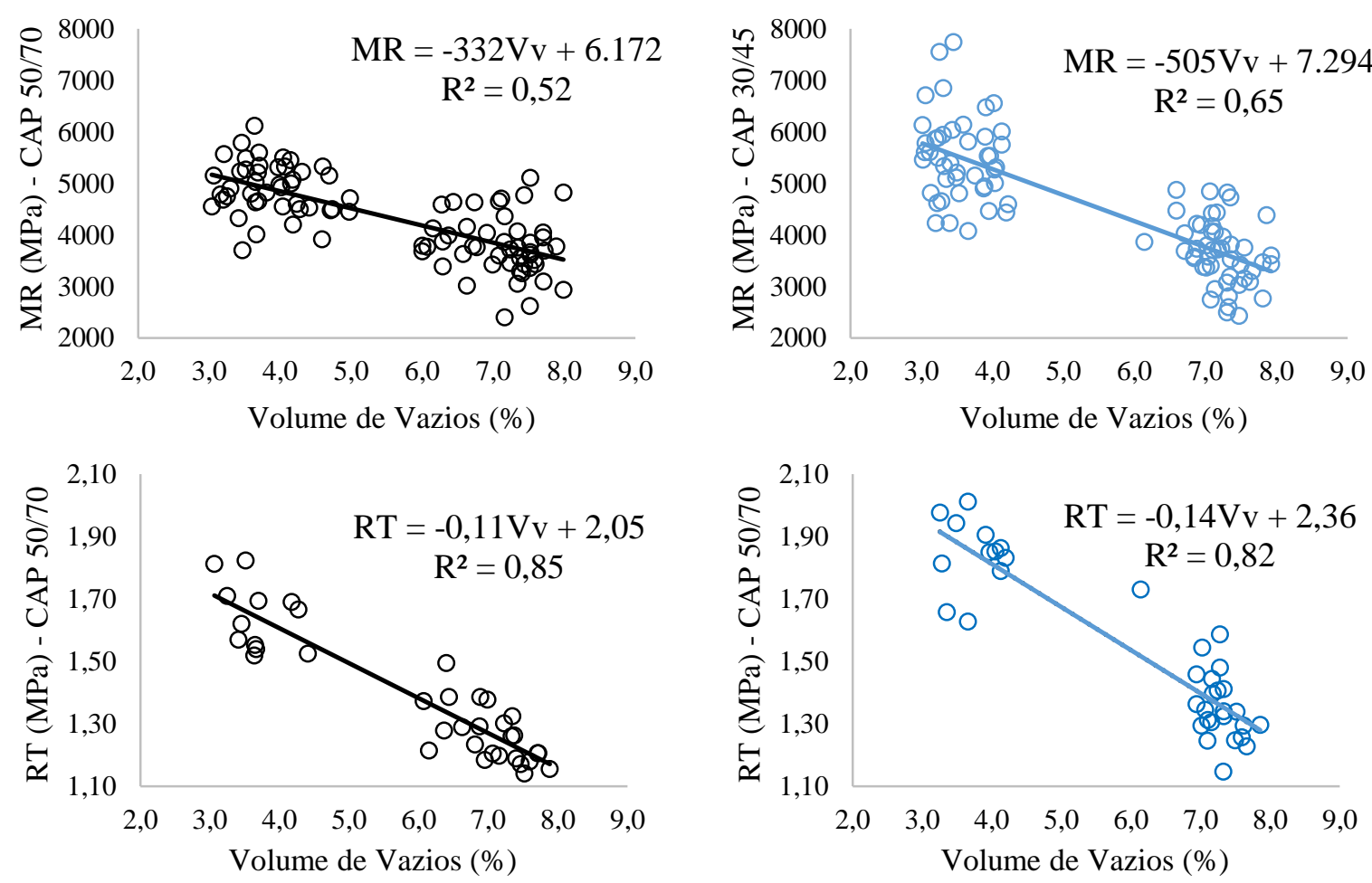

Figura 4.49 - Modelos de regressão linear MR x Vv e RT x Vv, por tipo de ligante asfáltico

No Apêndice I, encontram-se tabelas com os valores de $\mathrm{R}^{2}$, coeficientes a e b dos modelos de regressão linear MR x Vv e RT x Vv, por tipo de mistura asfáltica. Destaca-se que três modelos de RT x Vv apresentaram $\mathrm{R}^{2} \geq 0,90$.

\subsubsection{Relações entre a vida de fadiga $(\mathrm{N})$ versus $\mathrm{Vv}$, rigidez e realização prévia de ensaios de MR em diferentes temperaturas para avaliação da susceptibilidade térmica (ST)}

Durante a Etapa 3, foram produzidos 8 CPs por tipo de mistura para a avaliação de vida de fadiga e de susceptibilidade térmica $(S T)$ para $V_{v} \approx 4 \%$. Propositalmente, apenas metade dos CPs foram submetidos aos ensaios de MR a 10,25 e $40^{\circ} \mathrm{C}$ para a avaliação de $\mathrm{ST}$ e a outra metade foi submetida somente ao ensaio de $\mathrm{MR}$ a $25^{\circ} \mathrm{C}$, de modo a facultar a investigação da 
influência de ensaios prévios no CP nos resultados de N. No Apêndice J, encontram-se os resultados dos ensaios de fadiga por compressão diametral à tensão controlada, contendo os valores do $\mathrm{Vv}, \mathrm{MR}$ a $25^{\circ} \mathrm{C}$ e a indicação se o $\mathrm{CP}$ recebeu os ensaios para avaliação de $\mathrm{ST}$, de cada um dos 64 CPs submetidos aos ensaios de fadiga.

A Tabela 4.33 apresenta os resultados dos testes de hipóteses utilizados para verificar a aleatoriedade das relações entre a obtenção de maior vida de fadiga versus menor $\mathrm{Vv}$, maior MR e realização prévia de ensaios para investigar a ST. Imaginava-se que CPs com menor Vv, maior MR e que não tivessem recebido ensaios prévios de ST apresentassem maiores valores de N. No entanto, para a quase totalidade dos testes realizados, as relações entre menor $\mathrm{Vv}$ x maior N, maior MR x maior N e Não ST x maior N foram aleatórias. Destaca-se que estes testes supuseram as variáveis como categóricas (“-”, “+”, “S”, “N”), portanto não levaram em consideração a magnitude dos valores de Vv, MR e N.

Tabela 4.33 - Resultados dos testes de hipóteses para verificar a aleatoriedade das relações entre Vv, MR e ST versus $\mathrm{N}$, considerando $\pi=0,5, \alpha=0,05$ e distribuição binomial

\begin{tabular}{|c|c|c|c|c|c|c|c|c|c|}
\hline \multicolumn{2}{|c|}{ Condição de análise } & \multirow{2}{*}{$\begin{array}{c}\begin{array}{c}\mathbf{V} \mathbf{x} \mathbf{N} \\
(-+)\end{array} \\
17 \\
0,4300 \\
\text { Não }\end{array}$} & \multirow{2}{*}{$\begin{array}{c}\text { MR x N } \\
(++)\end{array}$} & \multirow{2}{*}{$\begin{array}{c}\begin{array}{c}\text { ST x N } \\
(\mathbf{N}+)\end{array} \\
17 \\
0,4300 \\
\text { Não }\end{array}$} & \multicolumn{2}{|c|}{ Condição de análise } & \multirow{2}{*}{$\begin{array}{c}\begin{array}{c}\operatorname{Vv} \times \mathbf{N} \\
(-+)\end{array} \\
3 \\
0,3633 \\
\text { Não }\end{array}$} & \multirow{2}{*}{$\begin{array}{c}\text { MR x N } \\
(++)\end{array}$} & \multirow{2}{*}{$\begin{array}{c}\begin{array}{c}\text { ST x N } \\
(\mathbf{N}+)\end{array} \\
4 \\
0,6367 \\
\text { Não }\end{array}$} \\
\hline $\begin{array}{c}\text { Todas as } \\
\text { misturas } \\
\mathrm{n}=32\end{array}$ & $\begin{array}{c}\mathrm{x} \\
\mathrm{p}(\mathrm{x}) \text { acum } \\
\text { Refuta } \mathrm{H}_{0} \text { ? }\end{array}$ & & & & $\begin{array}{c}\text { Misturas L } \\
\mathrm{n}=8\end{array}$ & $\begin{array}{c}\mathrm{x} \\
\mathrm{p}(\mathrm{x}) \text { acum } \\
\text { Refuta } \mathrm{H}_{0} \text { ? }\end{array}$ & & & \\
\hline $\begin{array}{l}\text { Misturas com } \\
\text { CAP } 30 / 45 \\
n=16\end{array}$ & $\begin{array}{c}\mathrm{x} \\
\mathrm{p}(\mathrm{x}) \text { acum } \\
\text { Refuta } \mathrm{H}_{0} \text { ? }\end{array}$ & $\begin{array}{c}7 \\
0,4018 \\
\text { Não }\end{array}$ & $\begin{array}{c}10 \\
0,2272 \\
\text { Não }\end{array}$ & $\begin{array}{c}11 \\
0,1051 \\
\text { Não }\end{array}$ & $\begin{array}{c}\text { Misturas } \\
\text { C3,0L } \\
n=8\end{array}$ & $\begin{array}{c}\mathrm{x} \\
\mathrm{p}(\mathrm{x}) \text { acum } \\
\text { Refuta } \mathrm{H}_{0} \text { ? }\end{array}$ & $\begin{array}{c}3 \\
0,3633 \\
\text { Não }\end{array}$ & $\begin{array}{c}5 \\
0,3633 \\
\text { Não }\end{array}$ & $\begin{array}{c}5 \\
0,3633 \\
\text { Não }\end{array}$ \\
\hline $\begin{array}{c}\text { Misturas com } \\
\text { CAP 50/70 } \\
n=16\end{array}$ & $\begin{array}{c}\mathrm{x} \\
\mathrm{p}(\mathrm{x}) \text { acum }) \\
\text { Refuta } \mathrm{H}_{0} \text { ? }\end{array}$ & $\begin{array}{c}10 \\
0,2272 \\
\text { Não }\end{array}$ & $\begin{array}{c}10 \\
0,2272 \\
\text { Não }\end{array}$ & $\begin{array}{c}6 \\
0,2272 \\
\text { Não }\end{array}$ & $\begin{array}{c}\text { Carga } \\
10 \% \text { da RT } \\
\mathrm{n}=8\end{array}$ & $\begin{array}{c}\text { x } \\
\text { p(x) acum } \\
\text { Refuta } \mathrm{H}_{0} \text { ? }\end{array}$ & $\begin{array}{c}5 \\
0,3633 \\
\text { Não } \\
\end{array}$ & $\begin{array}{c}7 \\
0,0352 \\
\text { Sim }\end{array}$ & $\begin{array}{c}2 \\
0,1445 \\
\text { Não }\end{array}$ \\
\hline $\begin{array}{l}\text { Misturas con- } \\
\text { tendo caulim } \\
\quad \mathrm{n}=16\end{array}$ & $\begin{array}{c}\mathrm{X} \\
\mathrm{p}(\mathrm{x}) \text { acum } \\
\text { Refuta } \mathrm{H}_{0} \text { ? }\end{array}$ & $\begin{array}{c}6 \\
0,2272 \\
\text { Não }\end{array}$ & $\begin{array}{c}11 \\
0,1051 \\
\text { Não }\end{array}$ & $\begin{array}{c}6 \\
0,2272 \\
\text { Não }\end{array}$ & $\begin{array}{c}\text { Carga } \\
20 \% \text { da RT } \\
\mathrm{n}=8\end{array}$ & $\begin{array}{c}\mathrm{x} \\
\mathrm{p}(\mathrm{x}) \text { acum } \\
\text { Refuta } \mathrm{H}_{0} \text { ? }\end{array}$ & $\begin{array}{c}4 \\
0,6367 \\
\text { Não }\end{array}$ & $\begin{array}{c}5 \\
0,3633 \\
\text { Não }\end{array}$ & $\begin{array}{c}6 \\
0,1445 \\
\text { Não }\end{array}$ \\
\hline $\begin{array}{c}\text { Misturas } \\
\text { contendo cal } \\
n=16\end{array}$ & $\begin{array}{c}\mathrm{x} \\
\mathrm{p}(\mathrm{x}) \text { acum } \\
\text { Refuta } \mathrm{H}_{0} \text { ? }\end{array}$ & $\begin{array}{c}8 \\
0,5982 \\
\text { Não }\end{array}$ & $\begin{array}{c}9 \\
0,4018 \\
\text { Não }\end{array}$ & $\begin{array}{c}9 \\
0,4018 \\
\text { Não } \\
\end{array}$ & $\begin{array}{c}\text { Carga } \\
30 \% \text { da RT } \\
\mathrm{n}=8\end{array}$ & $\begin{array}{c}\mathrm{x} \\
\mathrm{p}(\mathrm{x}) \text { acum } \\
\text { Refuta } \mathrm{H}_{0} \text { ? }\end{array}$ & $\begin{array}{c}3 \\
0,3633 \\
\text { Não } \\
\end{array}$ & $\begin{array}{c}5 \\
03633 \\
\text { Não } \\
\end{array}$ & $\begin{array}{c}4 \\
0,6367 \\
\text { Não }\end{array}$ \\
\hline $\begin{array}{l}\text { Misturas de } \\
\text { referência } \\
n=8\end{array}$ & $\begin{array}{c}\mathrm{x} \\
\mathrm{p}(\mathrm{x}) \text { acum } \\
\text { Refuta } \mathrm{H}_{0} \text { ? }\end{array}$ & $\begin{array}{c}6 \\
0,1445 \\
\text { Não }\end{array}$ & $\begin{array}{c}5 \\
0,3633 \\
\text { Não }\end{array}$ & $\begin{array}{c}2 \\
0,1445 \\
\text { Não }\end{array}$ & $\begin{array}{c}\text { Carga } \\
40 \% \text { da RT } \\
\mathrm{n}=8\end{array}$ & $\begin{array}{c}\mathrm{x} \\
\mathrm{p}(\mathrm{x}) \text { acum } \\
\text { Refuta } \mathrm{H}_{0} \text { ? }\end{array}$ & $\begin{array}{c}5 \\
0,3633 \\
\text { Não }\end{array}$ & $\begin{array}{c}3 \\
0,3633 \\
\text { Não }\end{array}$ & $\begin{array}{c}5 \\
0,3633 \\
\text { Não }\end{array}$ \\
\hline $\begin{array}{c}\text { Misturas C3,0 } \\
n=8\end{array}$ & $\begin{array}{c}\text { x } \\
\mathrm{p}(\mathrm{x}) \text { acum } \\
\text { Refuta } \mathrm{H}_{0} \text { ? }\end{array}$ & $\begin{array}{c}3 \\
0,3633 \\
\text { Não }\end{array}$ & $\begin{array}{c}6 \\
0,1445 \\
\text { Não }\end{array}$ & $\begin{array}{c}6 \\
0,1445 \\
\text { Não } \\
\end{array}$ & $\begin{array}{l}\text { x é o n }{ }^{\circ} \text { de c } \\
\text { maior } \mathrm{N} \text {; }\end{array}$ & $\begin{array}{l}\text { em que oco } \\
\text { aior MR e m } \\
\text { saio de aval }\end{array}$ & $\begin{array}{l}\text { simultan } \\
\text { r N, e (ii } \\
\text { o de ST }\end{array}$ & $\begin{array}{l}\text { nente: (i) } \\
\text { CP não uti } \\
\text { laior } \mathrm{N} \text {. }\end{array}$ & $\begin{array}{l}\text { or Vve } \\
\text { lo para }\end{array}$ \\
\hline
\end{tabular}

Especialmente na avaliação de $\mathrm{ST}$ x N, a comprovação da aleatoriedade foi interessante pois indicou que a realização dos ensaios de $\mathrm{MR}$ a $10^{\circ}$ e $40^{\circ} \mathrm{C}$ para avaliação de ST não teve influência importante nos resultados dos ensaios de vida de fadiga. Assim, recomenda-se a realização prévia de ensaios de MR antes da realização dos ensaios de fadiga para melhor entendimento e avaliação da susceptibilidade térmica das misturas, favorecendo a geração de cenários alternativos para a análise mecanística de pavimentos. 
Destaca-se também a adequação do teste estatístico utilizado, pois foi capaz de detectar que nas misturas ensaiadas com carga equivalente a $10 \%$ da RT, os CPs que apresentaram maior MR, resistiram a um maior número de aplicações de carga antes de romper, único resultado não aleatório da amostra. As cargas aplicadas para um nível de 10\% de RT no ensaio de fadiga por compressão diametral à tensão controlada são similares às cargas aplicadas no ensaio de MR, fazendo com que o CP apresente resposta mecânica parecida frente ao carregamento. Assim, pela relação fundamental entre módulo, tensão e deformação, para um mesmo nível de tensão, o CP com maior módulo deve apresentar menor deformação e, em consequência, maior vida de fadiga.

\subsubsection{Consolidação dos resultados das análises complementares}

As análises complementares acrescentaram informações relevantes ao conteúdo da pesquisa ao fazer o tratamento estatístico de alguns dados que não se vinculavam diretamente com as respostas aos objetivos principais da tese. Resumem-se os principais achados, a seguir.

A primeira análise complementar teve como objetivo efetuar regressões lineares entre as diversas propriedades das misturas asfálticas obtidas nas Etapas 1 (Dosagem Marshall), 2 (caracterização mecânica básica) e 3 (caracterização mecânica complementar). Foram detectadas diversas correlações lineares entre as variáveis-resposta da pesquisa, dentre as quais destacam-se: a estabilidade apresentou relação diretamente proporcional com a RT e com a vida de fadiga e a RT teve relações diretamente proporcionais com MR e vida de fadiga e inversamente proporcional com o PST. Estas relações permitem alguma inferência sobre a rigidez, o desempenho à fadiga e à susceptibilidade térmica das misturas, a partir da dosagem. Estes resultados são importantes, pois os ensaios de estabilidade e RT são simples, rápidos e disponíveis no território nacional.

Outro resultado a ser destacado foi a correlação linear inversamente proporcional entre o $\mathrm{PST}_{10,25}$ e a vida de fadiga, indicando que misturas que apresentaram menor susceptibilidade térmica no intervalo de 10 a $25^{\circ} \mathrm{C}$ apresentaram maiores $\mathrm{N}$, ou seja, um duplo desempenho positivo que é atingido mais facilmente quando do uso do CAP 30/45.

De modo geral, as propriedades mecânicas mensuradas em CPs com $\mathrm{Vv} \approx 4 \%$, RT, $\mathrm{MR}_{4} \%$, estabilidade, fluência, $\mathrm{N}$ e $\mathrm{PST}_{4} \%$ exibiram melhores correlações lineares do que as 
propriedades avaliadas em CPs com $\mathrm{Vv} \approx 7 \%$, tais como $\mathrm{MR}_{7}$, $\mathrm{PST}_{7 \%}$, parâmetros do ensaio de creep estático e $\mathrm{RT}_{\text {creep }}$. Isso se deu, provavelmente, em função da maior heterogeneidade das misturas com maior volume de vazios. Destaca-se que os parâmetros do ensaio de avaliação da deformação permanente (creep) não apresentaram correlações lineares com quaisquer outras variáveis-resposta da pesquisa.

A segunda análise complementar investigou as diferenças entre os valores de MR e RT em função das condições de ensaio destas propriedades, à luz do teste t. Houve ensaios de RT e MR em CPs com 4 e $7 \%$ de volume de vazios, submetidos ou não ao envelhecimento à $60^{\circ} \mathrm{C}$ em estufa ventilada por 16 horas, submetidos ou não ao condicionamento térmico previsto na norma do ensaio de dano por umidade induzida e, no caso da RT, em diferentes condições de uso prévio do CP. Dentre todos estes fatores o volume de vazios foi o mais importante para distinguir os valores de MR e RT entre as condições de ensaio. Para a RT, o condicionamento térmico também foi relevante. O envelhecimento e as condições de uso prévio do CP não foram importantes para diferenciar os valores médios de MR e RT.

Tendo em vista a maior importância do volume de vazios para diferenciar os valores de MR e RT e considerando que se trata de variável numérica, foram gerados modelos lineares para relacionar MR x Vv e RT x Vv. As correlações foram moderadas para a rigidez $\left(\mathrm{R}^{2}=0,52\right.$ para CAP 50/70 e $\mathrm{R}^{2}=0,65$ para CAP 30/45) e boas para a resistência à tração $\left(\mathrm{R}^{2}=0,85\right.$ para CAP $50 / 70$ e $\mathrm{R}^{2}=0,82$ para CAP 30/45).

A última análise complementar averiguou, mediante teste de hipóteses baseado na distribuição binomial, se os parâmetros: (i) menor Vv; (ii) maior MR, e (iii) uso prévio do CP para avaliação de susceptibilidade térmica tinham influência na obtenção de maiores valores de vida de fadiga. Os testes indicaram aleatoriedade entre estes parâmetros, o que foi considerado como muito positivo, pois obteve-se indícios de que a realização de ensaios prévios de $\mathrm{MR}$ a 10,25 e $40^{\circ} \mathrm{C}$ para a avaliação de ST não afetou a vida de fadiga. Assim, recomenda-se proceder à avaliação de susceptibilidade térmica previamente ao ensaio de fadiga com reaproveitamento dos CPs.

\subsection{CONSIDERAÇÕES FINAIS}

Nesta seção é apresentada uma consolidação dos principais achados da pesquisa e discussão destes resultados à luz do referencial teórico. 


\subsubsection{Sobre a viabilidade técnica do uso de rejeito de caulim como fíler em concreto asfáltico}

A verificação da viabilidade técnica do uso de rejeito de caulim como fíler foi efetuada ao se confrontar os valores dos parâmetros das dosagens Marshall, RT e RRT com aqueles exigidos pela especificação técnica ET-DE-P00/027 do DER/SP.

Foram dosadas 6 misturas contendo caulim (5070C1,5, 5070C3,0, 5070C6,0, 3045C1,5, 3045C3,0 e 3045C6,0). Todas atenderam a especificação normativa quanto ao teor de projeto, Vv, VAM, RBV, estabilidade e RT. No entanto, a mistura 3045C6,0 exibiu valor de fluência acima do máximo permitido e nenhuma mistura contendo caulim apresentou RRT $\geq 70 \%$. Entretanto, mesmo as misturas de referência não exibiram RRT satisfatória, em virtude da baixa adesividade entre o agregado de granito e os ligantes asfálticos convencionais. Assim, o caulim não foi o responsável pelos resultados insatisfatórios de dano por umidade induzida.

A fim de viabilizar tecnicamente a adição de rejeito de caulim como fíler foram produzidas misturas contendo simultaneamente caulim, no teor de 3,0\%, e cal, compondo as misturas 5070C3,0L e 3045C3,0L. Estas misturas atenderam a todos os requisitos normativos e mostraram-se tecnicamente viáveis.

Lucena (2009) e Zulkati, Diew e Delai (2013) obtiveram resultados satisfatórios nos ensaios de dano por umidade induzida com adição de caulim em misturas com agregado de granito, diferentemente do observado na atual pesquisa. Possivelmente, a explicação para a divergência entre resultados esteja nos métodos utilizados. Lucena (2009) efetuou adaptação ao condicionamento térmico previsto na AASHTO T 283 pois resfriou os CPs a apenas $10^{\circ} \mathrm{C}$. Zulkati, Diew e Delai (2012) mediram a relação de estabilidade Marshall (REM) ao invés da relação de resistência à tração (RRT).

A adição de 6,0\% de caulim prejudicou os valores de estabilidade, fluência, RT e RRT, em relação às misturas de referência. As adições de 1,5\% e 3,0\% de caulim não provocaram alterações significativas nos valores dos parâmetros das dosagens Marshall, porém o teor de $1,5 \%$ tem o inconveniente de ser um percentual baixo para um rejeito produzido em grande 
quantidade. Assim, entendeu-se 3,0\% de caulim como um teor "ótimo" de adição, pois utilizase uma boa quantidade de rejeito sem afetar negativamente as propriedades das misturas.

A limitação de teores de adição de materiais alternativos em misturas asfálticas é frequente (GOUVEIA, 2013; TAHAMI, ARABANI, MIRHOSSEINI, 2018). Costa (2006) já havia recomendado a limitação do percentual de substituição do agregado pétreo por caulim "grosso" a $25 \%$.

Na caracterização mecânica complementar as misturas com caulim exibiram boa vida de fadiga, baixa susceptibilidade térmica e bons valores de $\mathrm{RT}_{\text {creep}}$, porém apresentaram maior susceptibilidade à DP em relação às misturas de referência. Todavia, as diferenças de valores dos parâmetros do ensaio creep estático das misturas com caulim versus misturas de referência não foram significativas, além disso, todas as misturas apresentaram elevada resistência à deformação permanente, segundo critério proposto por Little, Button e Youssef (1993). Portanto, entende-se que não houve prejuízo à susceptibilidade à DP com o uso de rejeito de caulim.

Novamente houve discrepância em relação aos resultados obtidos por Zulkati, Diew e Delai (2012) que relataram ganho na resistência à deformação permanente com o uso de caulim, em ensaio de creep dinâmico. A provável causa da divergência foi alguma distinção na composição físico-química entre os caulins de Cingapura e os do estado do Pará, ou então, a diferença entre os métodos de ensaio.

Para as misturas testadas, a adição de caulim foi tecnicamente viável desde que em teores de até $3,0 \%$ e associada à cal. Alternativamente, pode ser testada a adição de melhorador de adesividade (dope), ou, quando disponível, a mudança dos agregados graníticos por outro tipo de agregado que não apresente problemas de adesividade com o ligante asfáltico. Do ponto de vista prático, seria possível utilizar o rejeito de caulim sem uso concomitante de cal em vias de baixo volume de tráfego e que atravessam regiões de baixa pluviosidade e/ou com excelentes condições de drenagem do pavimento de modo a prevenir a ocorrência de deformação permanente e danos por umidade. 


\subsubsection{Sobre a influência do tipo de ligante asfáltico}

O tipo de ligante asfáltico influenciou de forma importante boa parte das propriedades das misturas testadas, com contribuição mais relevante na caracterização mecânica básica, na susceptibilidade térmica e na vida de fadiga, tendo atuação menos destacada nos parâmetros das dosagens Marshall (exceto estabilidade) e dos ensaios de creep estático.

De maneira geral, o uso de CAP 30/45 fez as misturas apresentarem maiores valores de estabilidade, RT, RRT, MR, vida de fadiga e $\mathrm{RT}_{\text {creep }}$ e menores valores dos parâmetros de susceptibilidade térmica, ou seja, de modo geral, as misturas com ligante asfáltico mais consistente apresentaram melhor desempenho em relação à resistência e à durabilidade. Tais resultados vão ao encontro daqueles obtidos por Morilha Júnior (2004), Furlan (2006), Gigante (2007) e Nogueira (2008). De maneira contrária a Bernucci, Leite e Motta (2002), esta pesquisa não identificou ganho na resistência à deformação permanente com o uso de ligante mais consistente. Uma eventual explicação para a divergência de resultados pode ser o teor de ligante asfáltico, fixo naquele estudo, e com pequena variação de $0,2 \%$ nessa pesquisa.

\subsubsection{Sobre a influência do tipo de fíler}

O tipo de fíler influenciou significativamente os parâmetros das dosagens Marshall, a rigidez a $10^{\circ} \mathrm{C}$ e os parâmetros dos ensaios de creep estático, embora também tenha exercido influência nos valores de rigidez a 25 e $40^{\circ} \mathrm{C}$ e de vida de fadiga.

A adição de cal mudou sensivelmente os parâmetros volumétricos das dosagens Marshall, aumentando TP, Vv e VAM e reduzindo o valor de RBV. Ela também contribuiu para reduzir os valores de MR, PST e $\mathrm{RT}_{\text {creep }}$, elevar os valores de vida de fadiga e para deixar as misturas mais suscetíveis à deformação permanente. Destaca-se, contudo, que o efeito mais importante da adição de cal foi corrigir o problema da baixa adesividade entre os ligantes convencionais e os agregados de granito, fazendo com que as misturas passassem a atender os valores mínimos de RRT $\geq 70 \%$, conforme descrito por Hicks (1991) e observado, dentre outros, por Anitelli (2013).

A adição de caulim proporcionou os seguintes efeitos: (i) elevação de TP, Vv, VAM e fluência e redução de RBV e estabilidade nas dosagens Marshall, e; (ii) aumento de MR e diminuição 
de RT e RRT na caracterização mecânica básica. Estes efeitos foram potencializados à medida que se elevou o teor de caulim, resultados similares aos obtidos por Costa (2006). Via de regra, os valores dos parâmetros das dosagens Marshall e da caracterização mecânica básica das misturas 5070C6,0 e 3045C6,0 foram significativamente diferentes das misturas de referência, enquanto que os valores das misturas com $1,5 \%$ e $3,0 \%$ de caulim foram considerados estatisticamente iguais. Estes resultados ajudaram na escolha do teor "ótimo" de caulim de 3,0\%. Na Etapa 3, quando foram produzidas misturas com um único teor de caulim (5070C3,0 e 3045C3,0) observou-se tendência de redução da susceptibilidade térmica e aumento da vida de fadiga das misturas, porém houve maior susceptibilidade à deformação permanente. As misturas contendo 3,0\% de caulim apresentaram desempenho satisfatório em todos os ensaios realizados, exceto para o ensaio de dano por umidade induzida.

O uso de cal e caulim simultaneamente (C3,0L) ocorreu somente nas Etapas 2 e 3. Os principais efeitos da adição desse tipo de fíler foram: Aumentos na rigidez, especialmente em 25 e $40^{\circ} \mathrm{C}$, RT, RRT e vida de fadiga e reduções na susceptibilidade térmica e na $\mathrm{RT}_{\text {creep }}$. Além disso, ocorreu tendência de elevação na susceptibilidade à deformação permanente. De modo geral, o comportamento das misturas $\mathrm{C} 3,0$ e $\mathrm{C} 3,0 \mathrm{~L}$ foi parecido, com a vantagem de que nas misturas contendo caulim e cal simultaneamente, o problema da baixa adesividade entre o ligante asfáltico e o agregado de granito foi corrigido.

\subsubsection{Sobre os parâmetros de caracterização do fíler}

Adicionalmente às análises técnicas sobre a influência do tipo de fíler nos parâmetros das dosagens Marshall, propriedades mecânicas e de durabilidade do concreto asfáltico foram efetuadas regressões lineares simples tentando correlacionar as variáveis-resposta aos parâmetros de caracterização do fíler "teor de caulim" (apenas nas Etapas 1 e 2) e D10, D30, D60 e MF, que indicam aspectos da granulometria do fíler.

De modo geral, as análises estatísticas corroboraram as análises técnicas, pois quando o tipo de fíler foi relevante para mudar os valores de determinada propriedade, como fluência ou parâmetros do ensaio de creep estático, foram encontradas relações lineares entre a propriedade em estudo e os parâmetros de caracterização do fíler. Entretanto, não se encontraram correlações válidas de parâmetros de caracterização do fíler versus variáveis-resposta explicadas majoritariamente pelo tipo de ligante asfáltico, tais como, RT e vida de fadiga. 
Um resultado importante foi a correlação entre D30, D60 e MF versus módulo de fluência do ensaio de creep estático, a qual indicou que fíleres mais finos tendem a compor misturas que apresentam maior susceptibilidade à deformação permanente. Assim, em locais remotos, os ensaios de granulometria e sedimentação de fíleres podem ajudar a inferir sobre o comportamento à deformação permanente de misturas asfálticas. No entanto, tais resultados divergiram daqueles obtidos por Kandhal, Lynn e Parker (1998). Possivelmente, o tipo de ensaio para avaliação da deformação permanente foi responsável pela diferença de resultados. Nesta pesquisa utilizou-se o creep estático, enquanto que Kandhal, Lynn e Parker (1998) utilizaram creep dinâmico. As divergências de resultados entre os ensaios de creep estático e dinâmico também haviam sido relatadas por NG (2013). No ensaio de creep dinâmico, em função do rápido carregamento, a resposta a deformação permanente é mais influenciada pelo ligante asfáltico. Se este está enrijecido devido à presença de fíleres finos, tende a conferir maior resistência à DP. Por sua vez, no ensaio de creep estático, em função do carregamento de longa duração, a resposta à deformação permanente é mais influenciada pelo esqueleto pétreo, o qual está enfraquecido e com menos pontos de contato, em virtude do uso de fíleres finos.

O teor de caulim foi o parâmetro de caracterização do fíler que melhor se correlacionou com os parâmetros das dosagens Marshall e o módulo de finura (MF) exibiu as melhores correlações, em média, com as variáveis-resposta das Etapas 2 e 3.

\subsubsection{Sobre a Etapa 1 - Dosagem Marshall}

Foram dosadas 10 misturas asfálticas, resultantes da combinação do tipo de ligante asfáltico em 2 níveis e tipo de fíler em 5 níveis. Os teores de projeto foram definidos para um $\mathrm{Vv}=4 \%$. Todas as misturas atenderam à especificação do DER/SP para TP, Vv, VAM, RBV e estabilidade, exceto a mistura 3045C6,0 que excedeu o limite máximo de fluência. A exemplo do observado por Kavussi e Hicks (1997), houve aumento no TP à medida que se elevou o teor de caulim. Zulkati, Diew e Delai (2012) também reportaram maior TP nas misturas contendo caulim.

Ao término da Etapa 1, indicou-se a viabilidade técnica preliminar do uso de rejeito de caulim como fíler em concretos asfálticos, desde que em teores moderados, da ordem de 3,0\%, visto que essas misturas exibiram comportamentos típicos dos parâmetros de dosagem. Também 
foram definidos os teores de projetos das misturas, que variaram entre 5,3\% a 5,6\%. Com esses teores, foram produzidos os CPs das Etapas 2 e 3. Também foi possível aferir a influência do tipo de ligante asfáltico, tipo de fíler e parâmetros de caracterização do fíler nos parâmetros das dosagens Marshall, conforme indicado nas seções 4.6.2, 4.6.3 e 4.6.4.

\subsubsection{Sobre a Etapa 2 - Caracterização mecânica básica}

Foram produzidas 12 misturas asfálticas, no TP, resultantes da combinação do tipo de ligante asfáltico em 2 níveis e do tipo de fíler em 6 níveis, com inclusão da condição "caulim e cal simultaneamente - C3,0L", e foram processados os ensaios de MR, RT e DUI. Também foi efetuada a análise da influência do tipo de fíler, do tipo de ligante asfáltico e dos parâmetros de caracterização do fíler nos valores de MR, RT e DUI (seções 4.6.2, 4.6.3 e 4.6.4).

Ao término da Etapa 2, encontrou-se que todas as misturas apresentaram valor de RT muito superiores ao valor mínimo de $0,80 \mathrm{MPa}$, porém somente as misturas contendo cal apresentaram $\mathrm{RRT} \geq 70 \%$. Com isso, demonstrou-se que o uso de rejeito de caulim como fíler em concretos asfálticos é tecnicamente viável, desde que associado à cal.

\subsubsection{Sobre a Etapa 3 - Caracterização mecânica complementar}

Foram produzidas 8 misturas asfálticas, no TP, resultantes da combinação do tipo de ligante asfáltico em 2 níveis e do tipo de fíler em 4 níveis, com exclusão das condições C1,5 e C6,0, para os dois ligantes asfálticos, em relação à Etapa 2. Foram processados os ensaios de MR a 10,25 e $40^{\circ} \mathrm{C}$ para avaliação da susceptibilidade térmica, fadiga por compressão diametral à tensão controlada, creep estático para avaliação da deformação permanente e $\mathrm{RT}_{\text {creep }}$. Os principais resultados foram:

$>$ Os valores de rigidez a $10^{\circ} \mathrm{C}$ foram de 2 a 3 vezes superiores aos valores de rigidez a $25^{\circ} \mathrm{C}$, que por sua vez foram de 3 a 5 vezes maiores que os MRs a $40^{\circ} \mathrm{C}$, resultados similares aos de Gigante (2007) e Anittelli (2013);

$>$ De forma geral, as misturas $\mathrm{C} 3,0 \mathrm{~L}$ apresentaram a menor susceptibilidade térmica e as misturas de referência foram as mais suscetíveis, tendo as misturas Le C3,0 apresentado comportamento intermediário;

As misturas contendo caulim em sua composição, seja isoladamente $(\mathrm{C} 3,0)$ ou associado à cal $(\mathrm{C} 3,0 \mathrm{~L})$, apresentaram os melhores desempenhos quanto à vida de 
fadiga, independentemente se a análise de $\mathrm{N}$ foi em função do nível de $\Delta \sigma$ ou da análise mecanística de pavimentos. As misturas de referência exibiram o pior desempenho à fadiga e as misturas L exibiram comportamento intermediário;

> A análise de sensibilidade da vida de fadiga foi muito importante, pois mostrou que variações de $\pm 25 \%$ nas condições de carregamento, propriedades mecânicas (MR e $\mu$ ) ou espessuras das camadas podem reduzir à metade ou mais que dobrar a vida de fadiga da camada de revestimento asfáltico;

$>$ Antagonicamente aos resultados de vida de fadiga, as misturas de referência exibiram o melhor desempenho em relação à deformação permanente e as misturas $\mathrm{C} 3,0$ foram as mais suscetíveis à DP. Misturas L e C3,0L exibiram desempenhos intermediários;

Os valores de $\mathrm{RT}_{\text {creep }}$, mesmo após ensaios prévios, foram bastante superiores ao valor mínimo exigido de 0,80 MPa. De modo geral, as misturas de referência apresentaram os maiores valores de $\mathrm{RT}_{\text {creep }}$.

\subsubsection{Sobre as análises complementares}

A primeira análise complementar tinha como objetivo efetuar regressões lineares entre as diversas propriedades das misturas asfálticas obtidas nas Etapas 1 (Dosagem Marshall), 2 (caracterização mecânica básica) e 3 (caracterização mecânica complementar). Os resultados mais relevantes foram: (i) a estabilidade apresentou relação diretamente proporcional com a RT e com a vida de fadiga e a RT teve relações diretamente proporcionais com MR e vida de fadiga e inversamente proporcional com o PST, e (ii) identificação de correlação linear inversamente proporcional entre o PST $_{10,25}$ e a vida de fadiga, indicando que misturas que apresentaram menor susceptibilidade térmica no intervalo de 10 a $25^{\circ} \mathrm{C}$ apresentaram maiores $\mathrm{N}$, ou seja, um duplo desempenho positivo atribuído ao CAP 30/45.

A segunda análise complementar investigou as diferenças entre os valores de MR e RT em função das condições de ensaio destas propriedades, à luz do teste t. Os principais achados foram: (i) O MR depende fundamentalmente do Vv e a RT depende de Vv e da ocorrência ou não condicionamento térmico do ensaio AASHTO T 283; (ii) foi possível estabelecer modelos lineares de moderada a boa qualidade $\left(0,52<\mathrm{R}^{2}<0,81\right)$ entre MR x Vv por tipo de mistura, exceto para 5070L ( $\mathrm{R}^{2}=0,26$, não linear) e; (iii) foi possível estabelecer modelos lineares de boa a excelente qualidade $\left(0,81<\mathrm{R}^{2}<0,98\right)$ entre RT x Vv, por tipo de mistura. 
A terceira análise complementar averiguou, mediante teste de hipóteses baseado na distribuição binomial, se os parâmetros: (i) menor Vv; (ii) maior MR, e (iii) uso prévio do CP para avaliação de susceptibilidade térmica tinham influência na obtenção de maiores valores de vida de fadiga. Os testes indicaram aleatoriedade entre estes parâmetros, o que foi considerado positivo, pois obtiveram-se indícios de que a realização de ensaios prévios de MR a 10,25 e $40^{\circ} \mathrm{C}$ para a avaliação de ST não afetou a vida de fadiga. 


\section{CONCLUSÕES}

Apresentam-se, neste capítulo, as conclusões e sugestões de trabalhos futuros lastreados na exposição e discussão dos resultados efetuadas no capítulo anterior. O objetivo principal da pesquisa foi estudar a viabilidade do uso de rejeito de caulim como fíler em concretos asfálticos, com o objetivo secundário de entender a atuação do tipo de ligante asfáltico e do tipo de fíler nos parâmetros das dosagens Marshall, nas propriedades mecânicas e de durabilidade do concreto asfáltico. Para tal, a pesquisa investigou 12 tipos de misturas asfálticas oriundas da combinação de agregado de granito no centro da faixa III, com 2 tipos de ligante asfáltico (CAP 50/70 e CAP 30/45) e com 6 configurações de adição de fíler (apenas pó de pedra de granito, $1,5 \%$ de caulim, 3,0\% de caulim, 6,0\% de caulim, $1,5 \%$ de cal e 1,5\% cal e 3,0\% de caulim, simultaneamente), mediante a execução de dosagens Marshall (Etapa 1), caracterização mecânica básica, envolvendo os ensaios de MR, RT e DUI (Etapa 2) e caracterização mecânica complementar, englobando os ensaios de MR em diferentes temperaturas para a avaliação da susceptibilidade térmica, fadiga por compressão diametral à tensão controlada, creep estático e $\mathrm{RT}_{\text {creep }}$ (Etapa 3).

Em cada etapa, além de se procurar entender tecnicamente a influência do tipo de ligante asfáltico e do tipo de fíler nas propriedades e parâmetros avaliados, buscaram-se correlações entre estes resultados versus os parâmetros de caracterização do fíler (teor de caulim, D10, D30, D60 e MF). Adicionalmente, foram efetuadas três análises complementares: (i) busca de relações lineares entre as variáveis-resposta das 3 etapas da pesquisa; (ii) avaliações de MR e RT em função das condições de ensaio, e; (iii) investigação da influência de Vv, MR e uso prévio de CPs para avaliação de susceptibilidade térmica nos valores de vida de fadiga.

Após a execução do programa experimental foi possível responder a todas as perguntas inerentes a um estudo de viabilidade técnica do uso de determinado material "alternativo" em misturas asfálticas (objetivo principal):

$>$ Constatou-se que o rejeito de caulim apresentou características físicas semelhantes (graduação e massa específica, por exemplo) e os mesmos elementos químicos principais em relação ao fíler convencional de pó de pedra de granito;

> Foram identificados ganhos e perdas de propriedades mecânicas e de durabilidade com a adição de rejeito de caulim como fíler em concretos asfálticos. Dentre os ganhos, destacam-se a maior vida de fadiga, a menor susceptibilidade térmica e a maior rigidez, 
embora este último nem sempre constitua um resultado desejável. Dentre as perdas, há a maior dificuldade de compactação das misturas, requerendo mais ligante asfáltico, redução de resistência à tração e de estabilidade e aumento na fluência e na susceptibilidade à deformação permanente. Salienta-se, contudo, que mesmo com as perdas nestas propriedades, as misturas contendo caulim atenderam à especificação normativa do DER/SP;

As misturas de referência apresentaram elevada susceptibilidade ao dano por umidade, em função da má adesividade entre os CAPs convencionais e os agregados de granito, e este mau resultado também ocorreu nas misturas contendo caulim. Constatou-se que a adição de cal foi capaz de remediar o problema de adesividade e garantir baixa susceptibilidade ao dano por umidade tanto nas misturas de referência, como nas misturas com caulim;

Foi possível estabelecer o teor "ótimo" de 3,0\% para a adição de caulim, pois nesse teor os resultados dos ensaios mecânicos e de durabilidade e a quantidade de rejeito utilizada foram simultaneamente satisfatórios. Para o teor de 6,0\% de caulim, alguns resultados de ensaios mecânicos e de durabilidade foram insatisfatórios e para o teor de 1,5\% de caulim a quantidade de rejeito utilizada é pequena e, portanto, insatisfatória;

Foi possível estabelecer boas correlações entre o teor de caulim e os parâmetros das dosagens Marshall e também foram gerados modelos de fadiga que ajudam a inferir sobre o desempenho das misturas asfálticas em função da adição do rejeito de caulim.

O uso de rejeito de caulim como fíler em concretos asfálticos mostrou-se tecnicamente viável nas condições desta pesquisa, ou seja, com o uso de ligantes convencionais CAP 50/70 e CAP 30/45, agregados de granito no centro da Faixa III do DER/SP e associado à cal, de forma a remediar a baixa adesividade entre o ligante asfáltico e o agregado de granito. Esta constatação é interessante pois é possível dar destinação final adequada (uso sustentável) a um rejeito hoje inservível, com inerente benefício ambiental, além de, em tese, reduzir a exploração de novas jazidas e agregados. No contexto da Região Norte do Brasil, com sua reconhecida carência de materiais convencionais de pavimentação próximos aos grandes centros urbanos, a constatação de que um material alternativo tem viabilidade técnica ganha maior relevância.

Quanto ao objetivo secundário, observou-se que:

O uso do CAP 30/45, mais consistente, proporcionou às misturas maior estabilidade, maior rigidez, maior resistência à tração e à fadiga e menores susceptibilidades térmica 
e ao dano por umidade, melhorando as misturas asfálticas, de um modo geral. O tipo de ligante asfáltico teve pouca relevância nos parâmetros volumétricos das dosagens Marshall, na fluência e na resistência à deformação permanente, os quais foram mais dependentes do tipo de fíler;

- A adição de fíler, de modo geral, tende a dificultar a compactação das misturas, alterando as propriedades volumétricas e aumentando TP, reduzir a susceptibilidade térmica, aumentar a vida de fadiga e reduzir a resistência à deformação permanente. A cal reduziu de forma importante a susceptibilidade ao dano por umidade e reduziu a rigidez das misturas. A adição de caulim, por sua vez, aumentou o MR e a fluência.

Dentre as correlações obtidas em função dos parâmetros de caracterização do fíler, destacamse aquelas entre: (i) o teor de caulim versus parâmetros das dosagens Marshall, que indicaram que à medida que se elevou o teor de caulim houve aumento proporcional dos vazios, da fluência e do teor de projeto, e (ii) D30, D60 e MF versus parâmetros do ensaio de creep estático, indicando que misturas com fíler mais fino exibiram menor resistência à deformação permanente.

As análises complementares indicaram vários resultados interessantes, dentre os quais apontam-se: (i) boas correlações entre estabilidade, resistência à tração, módulo de resiliência, vida de fadiga e parâmetro de susceptibilidade térmica com a tendência geral de que misturas com maior RT, apresentem maior estabilidade, MR e vida de fadiga e menor susceptibilidade térmica; (ii) relações inversamente proporcionais entre volume de vazios versus $\mathrm{RT}$ e MR, e (iii) a não influência do ensaios prévios para avaliação de susceptibilidade térmica nos valores de vida de fadiga.

Por fim, ressalta-se a viabilidade técnica do uso de rejeito de caulim como fíler em concretos asfálticos, indicando o teor ótimo de adição de 3,0\%.

\subsection{SUGESTÕES PARA TRABALHOS FUTUROS}

Para dar continuidade a esta pesquisa, sugere-se:

associar o fíler de rejeito de caulim a outros tipos de agregado (basalto, seixo rolado, laterita, dentre outros), assim como a ligantes asfálticos modificados; 
$>$ utilizar outras faixas granulométricas para o agregado e/ou outros tipos de misturas asfálticas (pré-misturado à frio (PMF), Stone Matrix Asphalt (SMA));

efetuar ensaios de classificação do rejeito de caulim (lixiviação, solubilização e massa bruta);

produzir e ensaias misturas com teor de caulim de 4 e $5 \%$;

$>$ propor modelos (regressões lineares múltiplas) que correlacionem os parâmetros de dosagens Marshall e de caracterização mecânica, a fim de estimar com boa qualidade as propriedades mecânicas e de durabilidade do concreto asfáltico.

Além disso, pode ser interessante, para a ampliação da linha de pesquisa sobre o rejeito do caulim:

$>$ estudar os mástiques formados pelo fíler de rejeito caulim com o CAP 50/70 e o CAP 30/45, a partir de ensaios de caracterização dos ligantes asfálticos, e observar se há relação entre os parâmetros de desempenho obtidos com mástique e com as misturas asfálticas testadas;

$>$ avaliar a viabilidade do uso do rejeito do caulim em misturas com solo e solo-cimento para uso em camadas de base e sub-base de pavimentos, buscando utilizar quantidades maiores do rejeito;

identificar como seria e melhor forma de inserir o rejeito de caulim, em grande escala, em uma usina de asfalto.

Por fim, recomenda-se avaliar a resistência à deformação permanente à luz do ensaio uniaxial de carga repetida (flow number, NBR 16505/2016) visando contribuir para formação de banco de dados de deformação permanente de misturas asfálticas produzidas com diferentes materiais, à luz do novo método de dimensionamento nacional (MeDiNa) de pavimentos, ora em desenvolvimento. 


\section{REFERÊNCIAS ${ }^{2}$}

ADEDIMILA, A. S.; KENNEDY, T. W. Fatigue and resilient characteristics of asphalt mixtures by repeated-load indirect tensile test. Research Report Number 183-5. Texas State Department of highway and public transportation, 1975.

ALI, N.; CHAN, J. S.; SIMMS, S.; BUSHMAN, R.; BERGAN, A. T. Mechanistic evaluation of fly ash asphalt concrete mixtures. Journal of Materials in Civil Engineering. v. 8, n. 1, p. 19 - 25, 1996. doi: 10.1061/(ASCE)0899-1561(1996)8:1(19).

AMARAL, S. C. Estudos de misturas asfálticas densas com agregados do estado do Pará, utilizando asfalto convencional (CAP-40) e asfalto modificado com polímero SBS (Betuflex B 65/60). 2000. 218 p. Dissertação - Escola de Engenharia de São Carlos, Universidade de São Paulo, São Carlos, 2000. doi: 10.11606/D.18.2000.tde-07012003-194218.

Estudo de misturas laterita-asfalto da região metropolitana de Belém-PA para revestimentos de pavimentos. 2004. 198 p. Tese - Escola Politécnica, Universidade de São Paulo, São Paulo, 2004. doi: 10.11606/T.3.2004.tde-07102004-100043

AMERICAN ASSOCIATION OF STATE HIGHWAY TRANSPORTATION OFFICIALS. AASHTO T 283: Standard method of test resistance of compacted bituminous mixture to moisture induced damage. Washington, 1999, 9 p.

AMERICAN SOCIETY FOR TESTING AND MATERIALS. Use of waste materials in hot mix asphalt. Philadelphia, 1993, 306 p. ISBN 0-8031-1881-3. Edited by H. Fred Waller.

ASTM C 127 - 15: Standard test method for specific gravity and absorption of coarse aggregate. Philadelphia, 2015, 5 p.

ASTM C 128 - 15: Standard test method for specific gravity and absorption of fine aggregate. Philadelphia, 2015, 6 p.

ASTM D4402/D4402M - 15: Standard test method for viscosity determination of asphalt at elevated temperatures using a rotational viscometer. Philadelphia, 2015, 4 p.

ASTM D 4972 - 13: Standard test method for pH of Soils. Philadelphia, 2013, 3 p.

ANITELLI, A. Estudo do dano por umidade de misturas densas com ligantes asfálticos convencional e modificado por polímeros SBS. 2013. 107 p. Dissertação - Escola de Engenharia de São Carlos, Universidade de São Paulo, São Carlos, 2013. doi: 10.11606/D.18.2013.tde-17102013-100748.

ASPHALT INSTITUTE. Mix Design methods for asphalt concretes and other hot-mix types. Manual Series No 2 (MS-2). 6th ed. Lexington, KY: Asphalt Institute, 1995.

ASSIS, S. R. W. et al. Evaluation of limestone crushed dust aggregates in hot mix asphalt. Construction and Building Materials. v. 148, p. $659-665,2017$. Doi: 10.1016/j.conbuildmat.2017.05.107.

\footnotetext{
${ }^{2}$ De acordo com a Associação Brasileira de Normas Técnicas (ABNT NBR 6023)
} 
ASSOCIAÇÃO BRASILEIRA DE NORMAS TÉCNICAS. NBR 6459: Solo - Determinação do limite de liquidez. Rio de Janeiro, 2016. 9 p.

. NBR 7180: Solo - Determinação do limite de plasticidade. Rio de Janeiro, 2016. 7 p.

. NBR 7181: Solo - Análise granulométrica. Rio de Janeiro, 1984. 13 p.

. NBR 15087: Misturas asfálticas - determinação da resistência à tração por compressão diametral. Rio de Janeiro, 2012. 11 p.

. NBR 15617: Misturas asfálticas - determinação do dano por umidade induzida. Rio de Janeiro, 2016. 11 p.

NBR 15619: Misturas asfálticas - determinação da densidade máxima teórica e da massa específica máxima teórica em amostras não compactadas. Rio de Janeiro, 2012. 12 p.

NBR 16273: Misturas asfálticas - propriedades volumétricas de concreto asfáltico. Rio de Janeiro, 2014. 18 p.

NBR 16505: Misturas asfálticas - resistência à deformação permanente utilizando o ensaio uniaxial de carga repetida. Rio de Janeiro, 2016. 15 p.

BAHIA, H. U. et al. (2001) NCHRP Report 459: Characterization of modified asphalt binders in superpave mix design. Transportation Research Board. National Research Council, 53 p. Washington, D. C.

BALBO, J. T. Pavimentação Asfáltica: materiais, projeto e restauração, São Paulo - SP: Ed. Oficina de Textos, 2007. 558 p. ISBN 978-85-86238-56-7.

BARDINI, V. S. S. Influência do fíler mineral em propriedades de misturas asfálticas densas. 2013. 344 p. Tese - Escola de Engenharia de São Carlos, Universidade de São Paulo, São Carlos, 2013. doi: 10.11606/T.18.2013.tde-17052013-090958.

BERNUCCI, L. L. B et a. (2008) Efeito do teor e do tipo de ligante na formação de trilhas de roda em misturas asfáltica. In: Anais do $19^{\circ}$ Encontro do Asfalto, IBP, 2008, Rio de Janeiro.

BERNUCCI, L.B.; LEITE, L.M.; MOURA, E. Propriedades mecânicas em laboratório de misturas asfálticas convencionais e modificadas por polímeros. ENCONTRO DO ASFALTO, 16 p, 2002, Rio de Janeiro. Anais... Rio de Janeiro: IBP, 2002.

BERNUCCI, L.B.; MOTTA, L. M. G. da; CERATTI, J. A.; SOARES, J.B. Pavimentação Asfáltica: Formação Básica para Engenheiros, Rio de Janeiro - RJ: PETROBRÁS \& ABEDA, 2006. 504p.

BERTOLLO, S. A. M. Avaliação laboratorial de misturas asfálticas densas modificadas com borracha reciclada de pneus. 2002. Tese (Doutorado em Transportes) - Escola de Engenharia de São Carlos, Universidade de São Paulo, São Carlos, 2002. doi:10.11606/T.18.2002.tde-14122015-152916. 
BRASIL. DEPARTAMENTO NACIONAL DE PRODUÇÃO MINERAL - DNPM. Anuário Estadual Mineral - Pará, 2017 ano-base 2016. Brasília, 20 p. 2017.

BROWN, E.; KANDHAL, P. S. E.; ZHANG, J. (2001). Performance testing for hot mix asphalt. National Center for Asphalt Technology. Report 01-05, 79 p. 2001.

BUENO, L. D.; PEREIRA, D. S.; SPECHT, L. P.; OLIVEIRA, M. F. 2017. Influência da pressão de inflação dos pneus e da carga dos veículos comerciais na degradação dos pavimentos. Revista Pavimentação, Ano XII, nº 44, p. 38 - 57. 2017. ISSN 1809 - 1865.

CAMPOS, A. P. et al. Caulim. In. DEPARTAMENTO NACIONAL DE PRODUÇÃO MINERAL. Sumário Mineral 2016. Brasília, 2018, p 40-41. ISSN 0101-2053.

CHADBOURN, B. A.; SKOK, Jr., E. L.; CROW, B. L.; SPINDLER, S.; NEWCOMB, B. 2000. The effect of voids in mineral aggregate (VMA) on hot-mix asphalt pavements. Final Report $n^{\circ}$ 2000-13. Department of Transportation - Minnesota.

CHEN, M. et al. Thermal performance of asphalt mixtures using recycled tyre rubber as mineral filler. Road Materials and Pavement Design. v. 16, n. 2, p. 379 - 391, 2015. doi: 10.1080/14680629.2014.1002524.

COSTA, C. G. Incorporação do resíduo oriundo do beneficiamento de caulim em concreto asfáltico. 2006. 106 f. Mestrado (Dissertação) - Universidade Federal do Rio Grande Norte, Natal - RN, 2006.

COUTINHO NETO, B. Avaliação do reaproveitamento de areia de fundição como agregado em misturas asfálticas densas. 2004. Doutorado (Tese) - Escola de Engenharia de São Carlos, Universidade de São Paulo, São Carlos - SP, 2004. doi: 10.11606/D.18.2018.tde01022018-122501.

COUTINHO NETO, B.; FABBRI, G. T. P. Avaliação da reutilização da areia de fundição em misturas asfálticas densas. Revista Transportes. v. 12, n. 2, p. 50-57, 2004. doi: 10.14295/transportes.v12i2.39.

COSME, R. L.; ALTOE, A.; GOTTARDI, E. V.; TEIXEIRA, J. E. S. L.; CALMON, J. L. Previsão do comportamento mecânico de concretos asfálticos a partir da análise das propriedades de mástiques com fíler de resíduo de beneficiamento de rochas ornamentais e escórias de aciaria. In: XXVIII Congresso de Ensino e Pesquisa em Transportes ANPET, 2014, Curitiba.

CUNHA, M. J. A. da; SILVA, C. L da; LIMA, C. A. de P.; FROTA, C. A. da. Efeito da temperatura no comportamento mecânico de misturas asfálticas com agregados sinterizados de argila calcinada (ASAC). Matéria (Rio J.), Rio de Janeiro, v. 23, n. 1, 2018. http://dx.doi.org/10.1590/s1517-707620170001.0306.

DAVE, E. V.; BAKER, J. Moisture damage evaluation of asphalt mixes that contain mining byproducts: results from traditional and fracture energy tests. Transportation Research Record. v. 2371, p. 113 - 120, 2013. doi: 10.3141/2371-13. 
DEPARTAMENTO DE ESTRADAS DE RODAGEM DO ESTADO DE SÃO PAULO. M 120-60: Dosagem de misturas betuminosas pelo método Marshall. São Paulo, 1960. 11 p.

- M 3-61: Determinação da densidade real de da fração de solos, pelo picnômetro de 500 ml. São Paulo, 1961. 4 p.

. ET-DE-P00/027: Concreto asfáltico. São Paulo, 2005. 45 p.

. IP-DE-P00/001: Projeto de pavimentação. São Paulo, 2006. 53 p.

DEPARTAMENTO NACIONAL DE ESTRADAS DE RODAGEM. DNER-ME 043/95: Misturas betuminosas a quente - ensaio Marshall. Rio de Janeiro, 1995. 11 p.

. DNER-EM 367/97: Material de enchimento para misturas betuminosas. Rio de Janeiro, 1997, 3 p.

. DNER-ME 035/98: Agregados - determinação da Abrasão Los Angeles. Rio de Janeiro, 1998, 6 p.

Norma DNIT 031/2006 - ES: Pavimentos Flexíveis - Concreto Asfáltico Especificação de serviço. Rio de Janeiro, 2006. 14 p.

Norma DNIT 135/2010 - ME: Pavimentação asfáltica - misturas asfálticas determinação do módulo de resiliência - método de ensaio. Rio de Janeiro, 2010. 6 p.

Norma DNIT 183/2018 - ME: Pavimentação asfáltica - ensaio de fadiga por compressão diametral à tensão controlada - método de ensaio. Rio de Janeiro, 2018. 15 p.

EPPS, J. A. et al. (2000). Compatibility of a test for moisture-induced damage with superpave volumetric mix design. Transportation Research Board. National Research Council. Washington, D. D. 105 p. 2000.

FABBRI, G. T. P.; SILVA JÚNIOR, C. A. P.; GIGANTE, A. C.; FURLAN, A. P.; FONTENELE, $\mathrm{H}$. B. Reuse of refractory bauxite ore waste as aggregate in asphalt concrete paving mixtures. In: 5th ICEG Environmental Geotechnics, 2006, Cardiff - Wales. 5th ICEG Environmental Geotechnics. London - England: Thomas Telford Ltd, 2006. v. II. p. 1329-1336.

FIPE - FUNDAÇÃO INSTITUTO DE PESQUISAS ECONÔMICAS. Análise espacial da mineração no Pará. São Paulo, 2009. 31 p.

FRANCO, F. A. C. P. Método de Dimensionamento Mecanístico - Empírico de Pavimentos Asfálticos. (2007) Tese. Programa de Engenharia Civil da COPPE/UFRJ, Rio de Janeiro - RJ.

FREITAS, H. B. de; MOTTA, L. M. G. da. Uso de escória de aciaria em misturas asfálticas de módulo elevado. Revista Transportes. v. XVI, n. 2, p. 5-12, 2008.

FRITZEN, M. A. Desenvolvimento e validação de função de transferência para previsão do dano por fadiga em pavimentos asfálticos. 2016. 262 p. Tese - UFRJ / COPPE / Programa de Engenharia Civil, Rio de Janeiro, 2016. 
FURLAN, A. P. Considerações acerca da adesão e da susceptibilidade à umidade de misturas asfálticas densas à luz de algumas propriedades mecânicas. 2006. 127 f. Doutorado (Tese) - Escola de Engenharia de São Carlos, Universidade de São Paulo, São Carlos - SP, 2006. doi: 10.11606/T.18.2006.tde-12122006-215334.

FURLAN, A. P. et al. (2007) Influência do modo de preparo e do tipo de fíler nas propriedades de misturas asfálticas densas. In: Anais do XXI Congresso de Pesquisa e Ensino em Transportes, Associação Nacional de Pesquisa e Ensino em Transportes (ANPET), Rio de Janeiro.

GANDOMI, A. H.; ALAVI, A. H.; MIRZAHOSSEINI, M. R.; NEJAD, F. M. Nonlinear genetic based models for prediction of flow number of asphalt mixtures. Journal of Materials in Civil Engineering. V. 23, n. 3, p. 248 - 263, 2011. doi: 10.1061//(ASCE)MT.19435533.0000154.

GIGANTE, A. C. Avaliação da Susceptibilidade térmica e do efeito das condições ambientais no enrijecimento de misturas asfálticas densas à luz de seus comportamentos resilientes. 2007. 169 p. Dissertação - Escola de Engenharia de São Carlos, Universidade de São Paulo, São Carlos, 2007. 10.11606/D.18.2007.tde-19032008-135756.

GOUVEIA, L. T. Contribuições ao estudo da influência de propriedades de agregados no comportamento de misturas asfálticas densas. 2006. 309 f. Doutorado (Tese) - Escola de Engenharia de São Carlos, Universidade de São Paulo, São Carlos - SP, 2006. 10.11606/T.18.2006.tde-13022007-171503.

GOUVEIA, L. T.; FERNANDES JÚNIOR, J. L.; SOARES, J. B. Influência da energia de compactação no comportamento volumétrico e mecânico de misturas asfálticas. Revista Transportes. v. 15, n. 1, 2007. doi: 10.14295/transportes.v15i1.45.

GOUVEIA, F. P. Efeito da Adição de Fíler Gesso nas Propriedades dos Ligantes Asfálticos e Concretos Asfálticos. 2013. 159 f. Doutorado (Tese) - Departamento de Engenharia Civil e Ambiental, Universidade de Brasília, Brasília - DF, 2013.

GRANDE, W. R. de. Efeitos da cal hidratada e do ácido polifosfórico nas propriedades mecânicas e na susceptibilidade à umidade de misturas asfálticas densas. 2011. 159 p. Dissertação - Escola de Engenharia de São Carlos, Universidade de São Paulo, São Carlos, 2011. doi: 10.11606/D.18.2011.tde-14092011-103353.

HARTMAN, A. M.; GILCHRIST, M. D.; WALSH, G. Effect of mixture compaction on indirect tensile stiffness and fatigue. Journal of Transportation Engineering. v. 127, n. 5, p. 370 - 378, 2001. doi: 10.1061/(ASCE)0733-947X(2001)127:5(370).

HARVEY, J. t.; TSAI, B. Effects of asphalt content and air void content on mix fatigue and stiffness. Transportation Research Record. v. 1543, p. 38 - 45, 1996. doi: 10.3141/1543-05.

HICKS, G. H. (1991). NCHRP Report 175: Moisture damage in asphalt concrete. Transportation Research Board. National Research Council, 100 p. Washington, D. C.

HUANG, Y. H. Pavement Analysis and Design. $2^{\text {nd }}$ ed. Upper Saddle River: Pearson Prentice Hall, 2004. 
HUANG, B.; SHU, X.; CHEN, X. Effects of Mineral Fillers on Hot-Mix Asphalt LaboratoryMeasured Properties. International Journal of Pavement Engineering, v. 8, n. 1, pp. 1-9. 2006. doi: 10.1080/10298430600819170.

ICHIHAR, A. H. Caulim. In. DEPARTAMENTO NACIONAL DE PRODUÇÃO MINERAL. Sumário Mineral 2015. Brasília, 2016, p 42-43. ISSN 0101-2053.

IMERYS. 2016. Imerys no Pará. Disponível em: < http://imerysnopara.com.br/pagina >. Acesso em 01/07/2016.

IRFAN, M. et al. (2018). Rutting evaluation of asphalt mixtures using static, dynamic and repeated creep load tests. Arabian Journal for Science and Engineering. v. 43, n. 10, p. 5143 - 5155, 2018. doi: https://doi.org/10.1007/s13369-017-2982-4

IWANAGA, F. I. Avaliação da influência do tipo do agregado, do tipo de ligante, do tipo de moldagem e do tipo de fíler na vida de fadiga de misturas asfálticas densas. 2007. 120 p. Dissertação - Escola de Engenharia de São Carlos, Universidade de São Paulo, São Carlos, 2007. doi: 10.11606/D.18.2007.tde-21112007-111323.

KHALID, H. A. A comparision between bending and diametral fatigue test for bituminous materials. Materials and Structures, v. 33, p. 457 - 465, 2000. doi: 10.1007/BF02480666.

KALOUSH, K. E.; WITCZAK, M. W.; SULLIVAN, B. W. (2003). Simple performance test for permanent deformation evaluation of asphalt mixtures. Proceedings of the $6^{\text {th }}$ International RILEM Symposium. PTEBM'03, Zurich, p. 498 - 505, 2003.

KANDHAL, P. S.; LYNN, C. Y.; PARKER, F. Characterization tests for mineral fillers related to performance of asphalt paving mixtures. Transportation Research Record. v. 1638, p. 101 - 110, 1998. doi: 10.3141/1638-12.

KAVUSSI, A.; HICKS, R. G. Properties of bituminous mixtures containing different fillers. Journal of the Association of Asphalt Paving Technologists. v. 66, p. 153 - 186, 1997.

KLINSKY, L. M. G. Avaliação do reaproveitamento de areia de fundição residual em camadas de pavimentos. 2013. Tese (Doutorado em Infraestrutura de Transportes) - Escola de Engenharia de São Carlos, Universidade de São Paulo, São Carlos, 2013. doi:10.11606/T.18.2013.tde-17052013-095052.

LEITE, L. F. M.; MOTTA, L. M. G. da. (2002). O efeito do fíler nas características do ligante asfáltico. In: Anais do XVI Congresso de Pesquisa e Ensino em Transportes, Associação Nacional de Pesquisa e Ensino em Transportes (ANPET), p. 183-194. Natal.

LITTLE, D.N.; BUTTON, J.W.; YOUSSEF, H. Development of criteria to evaluate uniaxial creep data and asphalt concrete permanent deformation potential. Transportation Research Record. v. 1417, p. 49 - 57, 1993.

LOTTMAN, R. P. (1978). NCHRP Report 192: Predicting moisture-induced damage to asphaltic concrete. Transportation Research Board. National Research Council, 24 p. Washington, D. C. 
LOULIZI, A. et al. (2006). Comparing resiliente modulus and dynamic modulus of hot mix asphalt as material properties for flexible pavements design. Transportation Research Records. v. 1970, p. 161 - 170, 2006. doi: 10.3141/1970-19.

LUCENA, L. C. F. L. Verificação da influência do uso de resíduos industriais como fíler em misturas asfálticas sob o efeito da presença d'água. 2009. 138 p. Dissertação Universidade Federal de Campina Grande, Campina Grande - PB, 2009.

LUZ, A. B.; DAMASCENO, E. C. Caulim: Um mineral industrial importante. Rio de Janeiro, 1993. CETEM/CNPq. 29 p. ISBN 85-7227-041-8.

MAJIDZADEH, K.; BROVOLD, F. N. (1968). State of the art: Effect of water on bitumenaggregate mixtures. Highway Research Board, Special Report 98, 77 p.

MÁRTIRES, R. A. C. Caulim. In. DEPARTAMENTO NACIONAL DE PRODUÇÃO MINERAL. Economia Mineral 2008. Brasília, 2009, p 474-483.

MOHAMED, E.H.H.; YUE. Z. Criteria for evaluation of rutting potential based on repetitive uniaxial compression test. Transportation Research Record. V. 1454, p. 74 - 81, 1994.

MOHAMMAD, L. N. et al. Mechanistic evaluation of hydrated lime in hot-mix asphalt mixtures. Transportation Research Record. v. 1723, p. 26 - 36, 2000. doi: 10.3141/1723-04.

MAHMOUD, A. F. F; BAHIA, H. (2004) Using the gyratory compactor to measure mechanical stability of asphalt mixtures. Wisconsin Highway Research Program. Project Number 0092-01-02.

MORILHA JÚNIOR, A. Estudo sobre a ação de modificadores no envelhecimento dos ligantes asfálticos e nas propriedades mecânicas e de fadiga das misturas asfálticas. 2004. 165 p. Dissertação. Programa de pós-graduação em engenharia civil - Universidade Federal de Santa Catarina, Florianópolis, 2004.

MOTTA, L. M. G.; TONIAL, I.; LEITE, L. M.; CONSTANTINO, R. S. Princípios do projeto e análise Superpave de misturas asfálticas: Tradução comentada. Rio de Janeiro: IBP, 1996.

NG, A. K. Y. Contribuição ao estudo da deformação permanente de misturas asfálticas densas à luz de ensaios de fluência por compressão uniaxial estática e dinâmica. 2013. 148 p. Dissertação - Escola de Engenharia de São Carlos, Universidade de São Paulo, São Carlos, 2013. doi: 10.11606/D.18.tde-25032013-150426.

NOGUEIRA, M. G. Comparação do comportamento em campo de concretos asfálticos com CAP 30/45 e com CAP 50/70 para revestimentos de pavimentos. 2008. 170 p. Dissertação - Escola Politécnica, Universidade de São Paulo, São Paulo, 2008. doi: 10.11606/D.3.2008.tde-10112008-120420.

ODA, S. Análise da viabilidade técnica da utilização do ligante asfalto-borracha em obras de pavimentação. 2000. Tese (Doutorado em Transportes) - Escola de Engenharia de São Carlos, Universidade de São Paulo, São Carlos, 2000. doi:10.11606/T.18.2018.tde-30012018151928. 
ONOFRE, F. C. (2012). Avaliação do comportamento mecânico de misturas asfálticas produzidas com ligantes asfálticos modificados por ácido polifosfórico e polímeros. Dissertação (Mestrado) - Universidade Federal do Ceará, Fortaleza, CE. 160 f. 2012.

ONOFRE, F. C. et al. (2013). Avaliação do efeito de ligantes asfálticos modificados na resistência à deformação permanente nas misturas asfálticas densas. Revista Transportes v. 21 n. 3, 2013. doi: 10.4237/transportes.v2li3.685.

PINTO, S. Estudo do comportamento à fadiga de misturas betuminosas e aplicação na avaliação estrutural de pavimentos. 1991.478 p. Tese - Universidade de Federal do Rio de Janeiro, Rio de Janeiro, 1991.

PRUDENTE, C. Q. A. Estudo laboratorial de misturas asfálticas a quente utilizadas em Goiás. 2015. 113 p. Dissertação - Escola de Engenharia Civil, Universidade Federal de Goiás, Goiás, 2015.

REAL STATISTICS. 2013. Produced by Charles Zaionts. Disponível em: <http://www.realstatistics.com/students-t-distribution/identifying-outliers-using-t-distribution/grubbs-test/> .

Acesso em: 30 jun. 2016.

RAO TANGELLA, S. C. S. et al. Summary report on fatigue response of asphalt mixtures. Strategic Highway Research Program, Project A-003-A. Berkeley, California, 1990.

ROBERTS, F. L. et al. (1996). Hot mix asphalt materials, mixture design and construction. 2 ed. NAPA Education Foundation, Lanhan, Maryland (1996).

SANTOS, C. R. G. Avaliação das influências do tipo de ligante e do volume de vazios na vida de fadiga de algumas misturas asfálticas. 2005. 123 p. Dissertação - Escola de Engenharia de São Carlos, Universidade de São Paulo, São Carlos, 2005. doi: 10.11606/D.18.2005.tde-04102005-084310.

SILVA, R. K. A. Co-disposição e disposição compartilhada de rejeitos e estéreis em cava exaurida. 2014. 158 p. Dissertação - Universidade Federal de Ouro Preto, Ouro Preto, 2014.

SOUZA, J.B.; CRAUS, J.; MONISMITH, C.L (1991). Summary report on permanent deformation on asphalt concrete. SHRP-A/IR-91-104. Strategic Highway Program (SHRP)

TAHAMI, S. A.; ARABANI, M.; MIRHOSSEINI, A. F. Usage of two biomass ashes as filler in hot mix asphalt. Construction and Building Materials. v. 170, p. 547 - 556, 2018. doi: 10.1016/j.conbuildmat.2018.03.102.

TAHERKHANI, H.; ARSHADI, M. R. Investigating the mechanical properties of asphalt concrete containing waste polyethylene terephthalate. Road Materials and Pavement Design. v. 138 , p. 381 - 398, 2017. doi: 10.1080/14680629.2017.1395354.

TAIRA, C. Avaliação do desempenho em laboratório de misturas asfálticas densas utilizando asfalto convencional (CAP-20) e asfalto modificado com polímero SBS (Betuflex B 65/60). 2001. 153 p. Dissertação - Escola de Engenharia de São Carlos, Universidade de São Paulo, São Carlos, 2001. doi: 10.11606/D.18.2016.tde-09052016-111805. 
TAIRA, C.; FURLAN, A. P.; FABBRI, G. T. P. 2003. Efeito do asfalto modificado com polímero nas propriedades mecânicas de misturas asfálticas densas. In: XVII Congresso de Ensino e Pesquisa em Transportes ANPET, 2003, Rio de Janeiro.

TAYEBALI, A. A.; MALPASS, G. A.; KHOSLA, N. P. Effect of Mineral Filler Type and Amount on Design and Performance of Asphalt Concrete Mixtures. Transportation Research Record, Washington, v. 1609, pp. 36-43, 1998. doi: 10.3141/1609-5.

TUNNICLIFF, D. G.; ROOT, R. E. (1984) NCHRP Report 274: Use of antistripping additives in asphaltic concrete mixtures - laboratory phase, Transportation Research Board, National Research Council, Washington, D. C.

VALENÇA, P. de M. A. Desempenho mecânico de misturas asfálticas do tipo Stone Matrix Asphalt com uso de fibras amazônicas e agregados de resíduos de construção e demolição. 2012. 114 f. Dissertação - Universidade Federal do Amazonas, Manaus, 2012.

WANG, H.; et al. Effect of mineral filler characteristics on asphalt mastics and mixture rutting potential. Transportation Research Records: Journal of Transportation Research Board. v. 2208 , p. 33 - 39, 2011. doi: 10.3141/2208-05.

YILMAZ, M.; KÖK, B. V.; KULOĞLU, N. Investigating the resistance of asphaltite containing hot mix asphalt against fatigue and permanent deformation by cyclic tests. Canadian Journal of Civil Engineering, v. 40, p. 27 - 34, 2013. dx.doi.org/10.1139/cjce-2011-0354.

ZULKATI, A.; DIEW, W. Y.; DELAI, D. S. Effects of fillers on properties of asphalt-concrete mixtures. Journal of Transportation Engineering. v. 138, p. 902 - 910, 2012. doi: 10.1061/ (ASCE)TE.1943-5436.0000395 
APÊNDICE A - Dimensões, massas, parâmetros volumétricos, densidades, estabilidade e fluência dos corpos de prova da Etapa 1

Parâmetros - 5070: 75 golpes do soquete Marshall por face / Densidade do CAP 50/70 = 1,006 / Densidade aparente dos agregados $=2,601 / \mathrm{P}_{\mathrm{ba}}$ médio $=0,30 \%$.

Tabela A.1 - Resultados da dosagem Marshall para a mistura 5070

\begin{tabular}{|c|c|c|c|c|c|c|c|c|c|c|c|c|c|c|}
\hline $\mathrm{CP}$ & $\begin{array}{c}P_{b} \\
(\%)\end{array}$ & $\begin{array}{c}\mathrm{D} \\
(\mathrm{mm})\end{array}$ & $\begin{array}{c}\mathrm{H} \\
(\mathrm{mm})\end{array}$ & $\begin{array}{l}\mathbf{M}_{\mathrm{ar}} \\
(\mathrm{g}) \\
\end{array}$ & $\begin{array}{c}\mathrm{M}_{\mathrm{im}} \\
(\mathrm{g})\end{array}$ & $\begin{array}{c}M_{\text {SSS }} \\
(\mathrm{g})\end{array}$ & $\begin{array}{c}\mathrm{V} \\
\left(\mathrm{cm}^{3}\right)\end{array}$ & $\mathrm{G}_{\mathrm{mb}}$ & $\mathrm{G}_{\mathrm{mm}}$ & $\begin{array}{l}\mathrm{Vv} \\
(\%)\end{array}$ & $\begin{array}{c}\text { E } \\
(\mathrm{kgf})\end{array}$ & $\begin{array}{c}\mathrm{F} \\
(\mathrm{mm})\end{array}$ & $\begin{array}{c}\text { VAM } \\
(\%)\end{array}$ & $\begin{array}{l}\text { RBV } \\
(\%)\end{array}$ \\
\hline 1 & 4,5 & 101,62 & 69,39 & 1243,5 & 699,6 & 1248,0 & 548,4 & 2,268 & 2,445 & 7,3 & 854 & 1,70 & 16,7 & 56,6 \\
\hline 2 & 4,5 & 102,44 & 68,62 & 1245,7 & 701,2 & 1249,9 & 548,7 & 2,270 & 2,445 & 7,2 & 1138 & 2,65 & 16,6 & 57,0 \\
\hline 3 & 4,5 & 101,66 & 70,08 & 1248,2 & 702,9 & 1255,2 & 552,3 & 2,260 & 2,445 & 7,6 & 988 & 1,99 & 17,0 & 55,5 \\
\hline 4 & 5,0 & 101,72 & 68,83 & 1259,6 & 714,1 & 1261,1 & 547,0 & 2,303 & 2,425 & 5,1 & 1037 & 2,30 & 15,9 & 68,2 \\
\hline 5 & 5,0 & 101,71 & 68,28 & 1256,4 & 711,5 & 1257,2 & 545,7 & 2,302 & 2,425 & 5,1 & 1086 & 2,45 & 15,9 & 68,1 \\
\hline 6 & 5,0 & 102,53 & 68,03 & 1250,5 & 708,7 & 1252,0 & 543,3 & 2,302 & 2,425 & 5,1 & 938 & 2,58 & 15,9 & 68,0 \\
\hline 7 & 5,5 & 102,24 & 67,11 & 1258,0 & 719,9 & 1259,1 & 539,2 & 2,333 & 2,409 & 3,2 & 1144 & 2,94 & 15,2 & 79,3 \\
\hline 8 & 5,5 & 101,82 & 67,97 & 1256,2 & 715,4 & 1256,9 & 541,5 & 2,320 & 2,409 & 3,7 & 1020 & 2,92 & 15,7 & 76,4 \\
\hline 9 & 5,5 & 101,83 & 67,85 & 1263,0 & 719,7 & 1263,5 & 543,8 & 2,323 & 2,409 & 3,6 & 1073 & $2,34 *$ & 15,6 & 77,0 \\
\hline 10 & 6,0 & 102,22 & 67,24 & 1266,2 & 726,0 & 1266,7 & 540,7 & 2,342 & 2,395 & 2,2 & 983 & 2,79 & 15,4 & 85,6 \\
\hline 11 & 6,0 & 101,81 & 68,06 & 1268,0 & 727,3 & 1268,6 & 541,3 & 2,343 & 2,395 & 2,2 & 961 & 2,74 & 15,3 & 85,8 \\
\hline 12 & 6,0 & 101,81 & 67,61 & 1262,7 & 723,3 & 1263,1 & 539,8 & 2,339 & 2,395 & 2,3 & 981 & 2,47 & 15,5 & 85,0 \\
\hline 13 & 6,5 & 102,29 & 67,26 & 1267,2 & 726,7 & 1267,5 & 540,8 & 2,343 & 2,369 & 1,1 & 1059 & 3,44 & 15,8 & 93,1 \\
\hline 14 & 6,5 & 102,44 & 66,83 & 1264,3 & 725,1 & 1264,9 & 539,8 & 2,342 & 2,369 & 1,1 & 1145 & 3,64 & 15,8 & 92,9 \\
\hline 15 & 6,5 & 102,28 & 67,02 & 1263,3 & 723,1 & 1263,8 & 540,7 & 2,336 & 2,369 & 1,4 & 896 & 2,76 & 16,0 & 91,4 \\
\hline
\end{tabular}

* - Valor excluído pelo método de Grubbs

Tabela A.2 - Resultados dos ensaios RICE para a mistura 5070

\begin{tabular}{ccccccc}
\hline $\mathrm{CP}$ & $\mathrm{P}_{\mathrm{b}}(\%)$ & $\mathrm{M}_{\text {mistura }}(\mathrm{g})$ & $\mathrm{M}_{\text {mist+águatkita }}(\mathrm{g})$ & $\mathrm{T}_{\text {água }}\left({ }^{\circ} \mathrm{C}\right)$ & $\mathrm{M}_{\text {calibração }}(\mathrm{g})$ & $\mathrm{G}_{\mathrm{mm}}$ \\
\hline 16 & 4,5 & 1256,4 & 3996,2 & 18,0 & 3253,6 & 2,445 \\
17 & 5,0 & 1259,2 & 3993,8 & 17,5 & 3253,8 & 2,425 \\
18 & 5,5 & 1263,3 & 3992,9 & 17,0 & 3254,0 & 2,409 \\
19 & 6,0 & 1269,7 & 3992,2 & 20,0 & 3252,7 & 2,395 \\
20 & 6,5 & 1269,5 & 3987,2 & 18,0 & 3253,6 & 2,369 \\
\hline
\end{tabular}

Parâmetros - 5070C1,5: 75 golpes do soquete Marshall por face / Densidade do CAP 50/70 = 1,006 / Densidade aparente dos agregados $=2,602 / \mathrm{P}_{\mathrm{ba}}$ médio $=0,29 \%$.

Tabela A.3 - Resultados da dosagem Marshall para a mistura 5070C1,5

\begin{tabular}{|c|c|c|c|c|c|c|c|c|c|c|c|c|c|c|}
\hline $\mathrm{CP}$ & $\begin{array}{l}\mathrm{P}_{\mathrm{b}} \\
(\%)\end{array}$ & $\begin{array}{c}\mathrm{D} \\
(\mathrm{mm})\end{array}$ & $\begin{array}{c}\mathrm{H} \\
(\mathrm{mm})\end{array}$ & $\begin{array}{c}M_{a r} \\
(\mathrm{~g})\end{array}$ & $\begin{array}{c}M_{\text {im }} \\
(\mathrm{g})\end{array}$ & $\begin{array}{c}\mathrm{M}_{\mathrm{SSS}} \\
(\mathrm{g})\end{array}$ & $\begin{array}{c}\mathrm{V} \\
\left(\mathrm{cm}^{3}\right)\end{array}$ & $\mathrm{G}_{\mathrm{mb}}$ & $\mathrm{G}_{\mathrm{mm}}$ & $\begin{array}{l}\mathrm{Vv} \\
(\%)\end{array}$ & $\begin{array}{c}E \\
(\mathrm{kgf})\end{array}$ & $\begin{array}{c}\mathrm{F} \\
(\mathrm{mm})\end{array}$ & $\begin{array}{c}\text { VAM } \\
(\%)\end{array}$ & $\begin{array}{c}\text { RBV } \\
(\%)\end{array}$ \\
\hline 21 & 5,0 & 102,32 & 68,41 & 1249,5 & 705,5 & 1251,6 & 546,1 & 2,288 & 2,425 & 5,6 & 795 & 2,41 & 16,5 & 65,7 \\
\hline 22 & 5,0 & 101,91 & 68,89 & 1252,8 & 709,1 & 1254,5 & 545,4 & 2,297 & 2,425 & 5,3 & 744 & 2,02 & 16,1 & 67,3 \\
\hline 23 & 5,0 & 102,50 & 68,29 & 1257,1 & 713,0 & 1258,6 & 545,6 & 2,304 & 2,425 & 5,0 & 1082 & 3,19 & 15,9 & 68,6 \\
\hline 24 & 5,5 & 102,29 & 67,65 & 1257,5 & 715,5 & 1258,2 & 542,7 & 2,317 & 2,410 & 3,9 & 886 & 2,85 & 15,8 & 75,7 \\
\hline 25 & 5,5 & 101,95 & 68,12 & 1263,8 & 723,2 & 1264,5 & 541,3 & 2,335 & 2,410 & 3,1 & 1017 & 2,99 & 15,2 & 79,5 \\
\hline 26 & 5,5 & 101,98 & 68,08 & 1260,8 & 720,0 & 1262,0 & 542,0 & 2,326 & 2,410 & 3,5 & 853 & 2,72 & 15,5 & 77,6 \\
\hline 27 & 6,0 & 101,93 & 68,09 & 1268,5 & 727,7 & 1269,0 & 541,3 & 2,343 & 2,391 & 2,0 & 1030 & 3,83 & 15,3 & 86,9 \\
\hline 28 & 6,0 & 101,88 & 67,97 & 1264,8 & 723,0 & 1265,7 & 542,7 & 2,331 & 2,391 & 2,5 & 924 & 3,84 & 15,8 & 83,9 \\
\hline 29 & 6,0 & 102,43 & 67,94 & 1269,3 & 725,0 & 1270,0 & 545,0 & 2,329 & 2,391 & 2,6 & 875 & 3,69 & 15,9 & 83,6 \\
\hline
\end{tabular}

Tabela A.4 - Resultados dos ensaios RICE para a mistura 5070C1,5

\begin{tabular}{ccccccc}
\hline $\mathrm{CP}$ & $\mathrm{P}_{\mathrm{b}}(\%)$ & $\mathrm{M}_{\text {mistura }}(\mathrm{g})$ & $\mathrm{M}_{\text {mist+águatkita }}(\mathrm{g})$ & $\mathrm{T}_{\text {água }}\left({ }^{\circ} \mathrm{C}\right)$ & $\mathrm{M}_{\text {calibração }}(\mathrm{g})$ & $\mathrm{G}_{\mathrm{mm}}$ \\
\hline 30 & 5,0 & 1253,0 & 3989,5 & 19,0 & 3253,2 & 2,425 \\
31 & 5,5 & 1263,8 & 3989,8 & 24,5 & 3250,4 & 2,410 \\
32 & 6,0 & 1269,8 & 3992,6 & 17,5 & 3253,8 & 2,391 \\
\hline
\end{tabular}

Parâmetros - 5070C3,0: 75 golpes do soquete Marshall por face / Densidade do CAP 50/70 = 1,006 / Densidade aparente dos agregados $=2,603 / \mathrm{P}_{\mathrm{ba}}$ médio $=0,18 \%$. 
Tabela A.5 - Resultados da dosagem Marshall para a mistura 5070C3,0

\begin{tabular}{|c|c|c|c|c|c|c|c|c|c|c|c|c|c|c|}
\hline CP & $\begin{array}{c}\mathrm{P}_{\mathrm{b}} \\
(\%) \\
\end{array}$ & $\begin{array}{c}\mathrm{D} \\
(\mathrm{mm})\end{array}$ & $\begin{array}{c}\mathrm{H} \\
(\mathrm{mm})\end{array}$ & $\begin{array}{l}\mathrm{M}_{\mathrm{ar}} \\
(\mathrm{g}) \\
\end{array}$ & $\begin{array}{c}\mathrm{M}_{\mathrm{im}} \\
(\mathrm{g})\end{array}$ & $\begin{array}{c}\mathrm{M}_{\mathrm{SSS}} \\
(\mathrm{g}) \\
\end{array}$ & $\begin{array}{c}\mathrm{V} \\
\left(\mathrm{cm}^{3}\right) \\
\end{array}$ & $\mathrm{G}_{\mathrm{mb}}$ & $\mathrm{G}_{\mathrm{mm}}$ & $\begin{array}{l}\mathrm{Vv} \\
(\%) \\
\end{array}$ & $\begin{array}{c}\mathrm{E} \\
(\mathrm{kgf})\end{array}$ & $\begin{array}{c}\mathrm{F} \\
(\mathrm{mm})\end{array}$ & $\begin{array}{c}\text { VAM } \\
(\%) \\
\end{array}$ & $\begin{array}{c}\text { RBV } \\
(\%) \\
\end{array}$ \\
\hline 33 & 5,0 & 101,77 & 68,85 & 1249,7 & 706,8 & 1251,8 & 545,0 & 2,293 & 2,423 & 5,4 & 860 & 2,93 & 16,3 & 67,2 \\
\hline 34 & 5,0 & 101,95 & 68,74 & 1252,4 & 707,1 & 1253,7 & 546,6 & 2,291 & 2,423 & 5,4 & 896 & 3,31 & 16,4 & 66,9 \\
\hline 35 & 5,0 & 102,52 & 67,88 & 1252,9 & 708,6 & 1254,1 & 545,5 & 2,297 & 2,423 & 5,2 & 1063 & 3,20 & 16,2 & 67,9 \\
\hline 36 & 5,5 & 101,80 & 68,19 & 1261,1 & 719,0 & 1261,8 & 542,8 & 2,323 & 2,401 & 3,2 & 1042 & 3,07 & 15,7 & 79,3 \\
\hline 37 & 5,5 & 101,90 & 68,57 & 1262,9 & 719,2 & 1263,8 & 544,6 & 2,319 & 2,401 & 3,4 & 1134 & 3,86 & 15,8 & 78,3 \\
\hline 38 & 5,5 & 101,79 & 67,70 & 1257,1 & 716,8 & 1257,6 & 540,8 & 2,325 & 2,401 & 3,2 & 1012 & 3,64 & 15,6 & 79,5 \\
\hline 39 & 6,0 & 102,39 & 67,26 & 1267,5 & 725,4 & 1268,0 & 542,6 & 2,336 & 2,387 & 2,1 & 947 & 3,89 & 15,6 & 86,3 \\
\hline 40 & 6,0 & 101,63 & 68,51 & 1260,9 & 719,4 & 1261,6 & 542,2 & 2,326 & 2,387 & 2,6 & 984 & 3,51 & 16,0 & 83,9 \\
\hline 41 & 6,0 & 102,33 & 67,36 & 1265,0 & 724,5 & 1265,5 & 541,0 & 2,338 & 2,387 & 2,0 & 1043 & 3,77 & 15,6 & 86,9 \\
\hline
\end{tabular}

Tabela A.6 - Resultados dos ensaios RICE para a mistura 5070C3,0

\begin{tabular}{ccccccc}
\hline $\mathrm{CP}$ & $\mathrm{P}_{\mathrm{b}}(\%)$ & $\mathrm{M}_{\text {mistura }}(\mathrm{g})$ & $\mathrm{M}_{\text {mist+água+kita }}(\mathrm{g})$ & $\mathrm{T}_{\text {água }}\left({ }^{\circ} \mathrm{C}\right)$ & $\mathrm{M}_{\text {calibração }}(\mathrm{g})$ & $\mathrm{G}_{\mathrm{mm}}$ \\
\hline 42 & 5,0 & 1259,6 & 3993,7 & 17,0 & 3254,0 & 2,423 \\
43 & 5,5 & 1266,2 & 3992,5 & 18,0 & 3253,6 & 2,401 \\
44 & 6,0 & 1271,6 & 3992,9 & 17,0 & 3254,0 & 2,387 \\
\hline
\end{tabular}

Parâmetros - 5070C6,0: 75 golpes do soquete Marshall por face / Densidade do CAP 50/70 = 1,006 / Densidade aparente dos agregados $=2,604 / \mathrm{P}_{\mathrm{ba}}$ médio $=0,29 \%$.

Tabela A.7 - Resultados da dosagem Marshall para a mistura 5070C6,0

\begin{tabular}{|c|c|c|c|c|c|c|c|c|c|c|c|c|c|c|}
\hline $\mathrm{CP}$ & $\begin{array}{c}\mathrm{P}_{\mathrm{b}} \\
(\%)\end{array}$ & $\begin{array}{c}\mathrm{D} \\
(\mathrm{mm})\end{array}$ & $\begin{array}{c}\mathrm{H} \\
(\mathrm{mm})\end{array}$ & $\begin{array}{l}\mathrm{M}_{\mathrm{ar}} \\
(\mathrm{g})\end{array}$ & $\begin{array}{c}\mathrm{M}_{\mathrm{im}} \\
(\mathrm{g})\end{array}$ & $\begin{array}{c}\mathrm{M}_{\text {SSS }} \\
(\mathrm{g})\end{array}$ & $\begin{array}{c}\mathrm{V} \\
\left(\mathrm{cm}^{3}\right)\end{array}$ & $\mathrm{G}_{\mathrm{mb}}$ & $\mathrm{G}_{\mathrm{mm}}$ & $\begin{array}{l}\text { Vv } \\
(\%)\end{array}$ & $\begin{array}{c}\mathrm{E} \\
\text { (kgf) }\end{array}$ & $\begin{array}{c}\mathrm{F} \\
(\mathrm{mm})\end{array}$ & $\begin{array}{l}\text { VAM } \\
(\%)\end{array}$ & $\begin{array}{l}\text { RBV } \\
(\%)\end{array}$ \\
\hline 45 & 5,0 & 102,31 & 68,94 & 1246,0 & 701,8 & 1251,5 & 549,7 & 2,267 & 2,432 & 6,8 & 690 & 2,70 & 17,3 & 60,8 \\
\hline 46 & 5,0 & 102,17 & 68,06 & 1246,1 & 702,3 & 1247,5 & 545,2 & 2,286 & 2,432 & 6,0 & 746 & 2,85 & 16,6 & 63,9 \\
\hline 47 & 5,0 & 101,73 & 69,21 & 1252,2 & 708,6 & 1255,2 & 546,6 & 2,291 & 2,432 & 5,8 & 852 & 2,87 & 16,4 & 64,8 \\
\hline 48 & 5,5 & 101,78 & 68,51 & 1258,0 & 715,6 & 1259,4 & 543,8 & 2,313 & 2,413 & 4,1 & 802 & 3,95 & 16,0 & 74,3 \\
\hline 49 & 5,5 & 102,38 & 67,96 & 1257,9 & 716,3 & 1258,7 & 542,4 & 2,319 & 2,413 & 3,9 & 854 & 3,47 & 15,8 & 75,5 \\
\hline 50 & 5,5 & 101,77 & 68,85 & 1263,0 & 717,9 & 1264,5 & 546,6 & 2,311 & 2,413 & 4,2 & 869 & 3,70 & 16,1 & 73,8 \\
\hline 51 & 6,0 & 101,83 & 67,83 & 1262,3 & 720,9 & 1262,8 & 541,9 & 2,329 & 2,387 & 2,4 & 781 & 3,40 & 15,9 & 84,7 \\
\hline 52 & 6,0 & 102,36 & 67,61 & 1265,9 & 723,3 & 1266,4 & 543,1 & 2,331 & 2,387 & 2,4 & $896^{*}$ & 3,73 & 15,9 & 85,1 \\
\hline 53 & 6,0 & 101,91 & 68,06 & 1257,9 & 717,2 & 1258,7 & 541,5 & 2,323 & 2,387 & 2,7 & 774 & 3,58 & 16,1 & 83,3 \\
\hline
\end{tabular}

* - Valor excluído pelo método de Grubbs

Tabela A.8 - Resultados dos ensaios RICE para a mistura 5070C6,0

\begin{tabular}{ccccccc}
\hline $\mathrm{CP}$ & $\mathrm{P}_{\mathrm{b}}(\%)$ & $\mathrm{M}_{\text {mistura }}(\mathrm{g})$ & $\mathrm{M}_{\text {misttáguatkita }}(\mathrm{g})$ & $\mathrm{T}_{\text {água }}\left({ }^{\circ} \mathrm{C}\right)$ & $\mathrm{M}_{\text {calibracăo }}(\mathrm{g})$ & $\mathrm{G}_{\mathrm{mm}}$ \\
\hline 54 & 5,0 & 1255,4 & 3989,3 & 25,0 & 3250,2 & 2,432 \\
55 & 5,5 & 1262,6 & 3990,6 & 23,0 & 3251,3 & 2,413 \\
56 & 6,0 & 1270,3 & 3991,6 & 18,5 & 3253,4 & 2,387 \\
\hline
\end{tabular}

Parâmetros - 5070L: 75 golpes do soquete Marshall por face / Densidade do CAP 50/70 = 1,006 / Densidade aparente dos agregados $=2,602 / \mathrm{P}_{\mathrm{ba}}$ médio $=0,18 \%$.

Tabela A.9 - Resultados da dosagem Marshall para a mistura 5070L

\begin{tabular}{|c|c|c|c|c|c|c|c|c|c|c|c|c|c|c|}
\hline $\mathrm{CP}$ & $\begin{array}{c}\mathrm{P}_{\mathrm{b}} \\
(\%)\end{array}$ & $\begin{array}{c}\mathrm{D} \\
(\mathrm{mm})\end{array}$ & $\begin{array}{c}\mathrm{H} \\
(\mathrm{mm})\end{array}$ & $\begin{array}{c}M_{a r} \\
(g)\end{array}$ & $\begin{array}{c}\mathrm{M}_{\mathrm{im}} \\
(\mathrm{g})\end{array}$ & $\begin{array}{c}\mathrm{M}_{\mathrm{SSS}} \\
(\mathrm{g})\end{array}$ & $\begin{array}{c}\mathrm{V} \\
\left(\mathrm{cm}^{3}\right)\end{array}$ & $\mathrm{G}_{\mathrm{mb}}$ & $\mathrm{G}_{\mathrm{mm}}$ & $\begin{array}{l}\text { Vv } \\
(\%)\end{array}$ & $\begin{array}{c}E \\
(\mathrm{kgf})\end{array}$ & $\begin{array}{c}\mathrm{F} \\
(\mathrm{mm})\end{array}$ & $\begin{array}{c}\text { VAM } \\
(\%)\end{array}$ & $\begin{array}{c}\text { RBV } \\
(\%)\end{array}$ \\
\hline 57 & 5,0 & 101,56 & 69,59 & 1249,5 & 703,3 & 1252,5 & 549,2 & 2,275 & 2,422 & $6,1^{*}$ & 871 & 1,99 & $16,9 *$ & $64,1^{*}$ \\
\hline 58 & 5,0 & 101,78 & 69,28 & 1255,0 & 708,7 & 1256,8 & 548,1 & 2,290 & 2,422 & 5,5 & 978 & 2,44 & 16,4 & 66,6 \\
\hline 59 & 5,0 & 102,23 & 68,86 & 1258,2 & 710,3 & 1259,7 & 549,4 & 2,290 & 2,422 & 5,5 & 1120 & 3,16 & 16,4 & 66,7 \\
\hline 60 & 5,5 & 101,78 & 68,57 & 1260,9 & 716,0 & 1261,7 & 545,7 & 2,311 & 2,402 & 3,8 & 1130 & 3,06 & 16,1 & 76,3 \\
\hline 61 & 5,5 & 101,83 & 68,72 & 1262,5 & 717,1 & 1263,4 & 546,3 & 2,311 & 2,402 & 3,8 & 1021 & 2,84 & 16,1 & 76,3 \\
\hline 62 & 5,5 & 101,82 & 68,48 & 1255,3 & 712,0 & 1256,4 & 544,4 & 2,306 & 2,402 & 4,0 & 968 & 2,32 & 16,3 & 75,3 \\
\hline 63 & 6,0 & 101,82 & 68,33 & 1265,1 & 720,9 & 1265,7 & 544,8 & 2,322 & 2,384 & 2,6 & 1060 & 3,31 & 16,1 & 83,9 \\
\hline 64 & 6,0 & 102,25 & 67,76 & 1263,6 & 720,9 & 1264,3 & 543,4 & 2,325 & 2,384 & 2,5 & 994 & 3,43 & 16,0 & 84,6 \\
\hline 65 & 6,0 & 102,29 & 67,76 & 1267,0 & 723,0 & 1267,6 & 544,6 & 2,326 & 2,384 & 2,4 & 1129 & 3,08 & 16,0 & 84,9 \\
\hline
\end{tabular}

* - Valores excluídos pelo método de Grubbs

Tabela A.10 - Resultados dos ensaios RICE para a mistura 5070L

\begin{tabular}{ccccccc}
\hline $\mathrm{CP}$ & $\mathrm{P}_{\mathrm{b}}(\%)$ & $\mathrm{M}_{\text {mistura }}(\mathrm{g})$ & $\mathrm{M}_{\text {mist+água+kita }}(\mathrm{g})$ & $\mathrm{T}_{\text {água }}\left({ }^{\circ} \mathrm{C}\right)$ & $\mathrm{M}_{\text {calibração }}(\mathrm{g})$ & $\mathrm{G}_{\mathrm{mm}}$ \\
\hline 66 & 5,0 & 1259,2 & 3992,6 & 19,0 & 3253,2 & 2,422 \\
67 & 5,5 & 1264,1 & 3989,2 & 23,0 & 3251,3 & 2,402 \\
68 & 6,0 & 1264,5 & 3987,9 & 17,5 & 3253,8 & 2,384 \\
\hline
\end{tabular}


Parâmetros - 3045: 75 golpes do soquete Marshall por face / Densidade do CAP 30/45 = 1,009 / Densidade aparente dos agregados $=2,601 / \mathrm{P}_{\mathrm{ba}}$ médio $=0,27 \%$.

Tabela A.11 - Resultados da dosagem Marshall para a mistura 3045

\begin{tabular}{|c|c|c|c|c|c|c|c|c|c|c|c|c|c|c|}
\hline $\mathrm{CP}$ & $\begin{array}{l}\mathrm{P}_{\mathrm{b}} \\
(\%)\end{array}$ & $\begin{array}{c}\mathrm{D} \\
(\mathrm{mm})\end{array}$ & $\begin{array}{c}\mathrm{H} \\
(\mathrm{mm})\end{array}$ & $\begin{array}{c}M_{a r} \\
(g)\end{array}$ & $\begin{array}{c}\mathrm{M}_{\mathrm{im}} \\
(\mathrm{g})\end{array}$ & $\begin{array}{c}\mathrm{M}_{\mathrm{SSS}} \\
(\mathrm{g})\end{array}$ & $\begin{array}{c}\mathrm{V} \\
\left(\mathrm{cm}^{3}\right)\end{array}$ & $\mathrm{G}_{\mathrm{mb}}$ & $\mathrm{G}_{\mathrm{mm}}$ & $\begin{array}{l}\text { Vv } \\
(\%)\end{array}$ & $\begin{array}{c}E \\
(\mathrm{kgf})\end{array}$ & $\begin{array}{c}\mathrm{F} \\
(\mathrm{mm})\end{array}$ & $\begin{array}{c}\text { VAM } \\
(\%)\end{array}$ & $\begin{array}{l}\text { RBV } \\
(\%)\end{array}$ \\
\hline 69 & 4,5 & 102,36 & 67,37 & 1245,2 & 706,9 & 1247,1 & 540,2 & 2,305 & 2,451 & 6,0 & 1351 & 2,95 & 15,4 & 61,3 \\
\hline 70 & 4,5 & 102,15 & 68,85 & 1246,9 & 703,2 & 1252,7 & 549,5 & 2,269 & 2,451 & 7,4 & 1092 & 2,81 & 16,7 & 55,6 \\
\hline 71 & 4,5 & 101,84 & 69,38 & 1250,2 & 706,1 & 1254,1 & 548,0 & 2,281 & 2,451 & 6,9 & 1264 & 2,98 & 16,2 & 57,4 \\
\hline 72 & 5,0 & 102,27 & 68,61 & 1258,2 & 711,6 & 1259,4 & 547,8 & 2,297 & 2,428 & 5,4 & 1239 & 3,70 & 16,1 & 66,4 \\
\hline 73 & 5,0 & 101,83 & 68,86 & 1253,4 & 710,0 & 1254,8 & 544,8 & 2,301 & 2,428 & 5,3 & 1194 & 3,15 & 16,0 & 67,1 \\
\hline 74 & 5,0 & 101,75 & 69,05 & 1256,7 & 710,1 & 1258,1 & 548,0 & 2,293 & 2,428 & 5,6 & 1067 & 2,83 & 16,2 & 65,8 \\
\hline 75 & 5,5 & 101,53 & 68,45 & 1264,8 & 723,1 & 1265,2 & 542,1 & 2,333 & 2,406 & 3,0 & 1201 & 3,09 & 15,2 & 80,0 \\
\hline 76 & 5,5 & 101,88 & 68,27 & 1258,8 & 715,5 & 1259,4 & 543,9 & 2,314 & 2,406 & 3,8 & 1148 & 3,05 & 15,9 & 75,9 \\
\hline 77 & 5,5 & 102,33 & 67,65 & 1261,6 & 718,2 & 1262,1 & 543,9 & 2,320 & 2,406 & 3,6 & 1271 & 3,64 & 15,7 & 77,0 \\
\hline 78 & 6,0 & 101,84 & 68,62 & 1265,1 & 722,4 & 1265,8 & 543,4 & 2,328 & 2,385 & 2,4 & 1071 & 2,95 & 15,9 & 84,8 \\
\hline 79 & 6,0 & 101,91 & 68,21 & 1266,0 & 722,7 & 1266,3 & 543,6 & 2,329 & 2,385 & 2,4 & 1246 & 3,52 & 15,8 & 85,0 \\
\hline 80 & 6,0 & 102,41 & 68,08 & 1262,4 & 719,0 & 1263,0 & 544,0 & 2,321 & 2,385 & 2,7 & 1183 & 3,86 & 16,1 & 83,1 \\
\hline 81 & 6,5 & 101,87 & 67,94 & 1264,2 & 722,1 & 1264,4 & 542,3 & 2,331 & 2,370 & 1,6 & 1155 & 4,11 & 16,2 & 89,9 \\
\hline 82 & 6,5 & 102,35 & 67,40 & 1265,7 & 724,4 & 1266,0 & 541,6 & 2,337 & 2,370 & 1,4 & 1250 & 4,04 & 16,0 & 91,3 \\
\hline 83 & 6,5 & 102,48 & 67,45 & 1266,3 & 724,3 & 1266,7 & 542,4 & 2,335 & 2.370 & 1,5 & 1006 & 3,55 & 16,1 & 90,7 \\
\hline
\end{tabular}

Tabela A.12 - Resultados dos ensaios RICE para a mistura 3045

\begin{tabular}{ccccccc}
\hline $\mathrm{CP}$ & $\mathrm{P}_{\mathrm{b}}(\%)$ & $\mathrm{M}_{\text {mistura }}(\mathrm{g})$ & $\mathrm{M}_{\text {mist+água+kita }}(\mathrm{g})$ & $\mathrm{T}_{\text {água }}\left({ }^{\circ} \mathrm{C}\right)$ & $\mathrm{M}_{\text {calibraç̃o }}(\mathrm{g})$ & $\mathrm{G}_{\mathrm{mm}}$ \\
\hline 84 & 4,5 & 1250,7 & 3993,4 & 19,5 & 3253,0 & 2,451 \\
85 & 5,0 & 1252,0 & 3991,2 & 19,5 & 3254,8 & 2,428 \\
86 & 5,5 & 1259,8 & 3989,3 & 19,5 & 3253,0 & 2,406 \\
87 & 6,0 & 1274,8 & 3993,6 & 19,0 & 3253,2 & 2,385 \\
88 & 6,5 & 1276,3 & 3988,0 & 25,0 & 3250,2 & 2,370 \\
\hline
\end{tabular}

Parâmetros - 3045C1,5: 75 golpes do soquete Marshall por face / Densidade do CAP 30/45 = 1,009 / Densidade aparente dos agregados $=2,602 / \mathrm{P}_{\mathrm{ba}}$ médio $=0,18 \%$.

Tabela A.13 - Resultados da dosagem Marshall para a mistura 3045C1,5

\begin{tabular}{|c|c|c|c|c|c|c|c|c|c|c|c|c|c|c|}
\hline $\mathrm{CP}$ & $\begin{array}{c}\mathrm{P}_{\mathrm{b}} \\
(\%)\end{array}$ & $\begin{array}{c}\mathrm{D} \\
(\mathrm{mm})\end{array}$ & $\begin{array}{c}\mathrm{H} \\
(\mathrm{mm})\end{array}$ & $\begin{array}{l}M_{a r} \\
(\mathrm{~g}) \\
\end{array}$ & $\begin{array}{c}\mathbf{M}_{\mathrm{im}} \\
(\mathrm{g})\end{array}$ & $\begin{array}{c}\mathrm{M}_{\mathrm{SSS}} \\
(\mathrm{g})\end{array}$ & $\begin{array}{c}\mathrm{V} \\
\left(\mathrm{cm}^{3}\right) \\
\end{array}$ & $\mathrm{G}_{\mathrm{mb}}$ & $\mathrm{G}_{\mathrm{mm}}$ & $\begin{array}{l}\text { Vv } \\
(\%)\end{array}$ & $\begin{array}{c}\text { E } \\
(\mathrm{kgf})\end{array}$ & $\begin{array}{c}\mathrm{F} \\
(\mathrm{mm})\end{array}$ & $\begin{array}{c}\text { VAM } \\
(\%)\end{array}$ & $\begin{array}{c}\text { RBV } \\
(\%)\end{array}$ \\
\hline 89 & 5,0 & 101,76 & 69,22 & 1249,8 & 705,2 & 1251,2 & 546,0 & 2,289 & 2,420 & 5,4 & 922 & 2,57 & 16,4 & 67,0 \\
\hline 90 & 5,0 & 101,61 & 68,72 & 1252,0 & 708,2 & 1252,7 & 544,5 & 2,299 & 2,420 & 5,0 & 1043 & 2,83 & 16,0 & 68,9 \\
\hline 91 & 5,0 & 102,41 & 68,78 & 1255,3 & 709,2 & 1257,3 & 548,1 & 2,290 & 2,420 & 5,4 & 1163 & 3,43 & 16,4 & 67,2 \\
\hline 92 & 5,5 & 101,87 & 68,18 & 1257,6 & 718,1 & 1258,2 & 540,1 & 2,328 & 2,403 & 3,1 & 1369 & 4,34 & 15,4 & 79,8 \\
\hline 93 & 5,5 & 102,27 & 67,55 & 1260,0 & 719,6 & 1260,7 & 541,1 & 2,329 & 2,403 & 3,1 & 1270 & 3,63 & 15,4 & 79,8 \\
\hline 94 & 5,5 & 101,88 & 68,12 & 1258,8 & 717,9 & 1259,8 & 541,9 & $2,323^{*}$ & 2,403 & 3,4 & 1099 & 3,19 & $15,6^{*}$ & $78,6^{*}$ \\
\hline 95 & 6,0 & 101,91 & 67,98 & 1266,7 & 725,2 & 1267,2 & 542,0 & 2,337 & 2,389 & 2,2 & 1098 & 3,92 & 15,6 & 86,1 \\
\hline 96 & 6,0 & 101,94 & 67,43 & 1263,5 & 723,5 & 1264,1 & 540,6 & 2,337 & 2,389 & 2,2 & 1191 & 4,30 & 15,6 & 86,2 \\
\hline 97 & 6,0 & 102,33 & 67,22 & 1265,8 & 724,7 & 1266,6 & 541,9 & 2,336 & 2,389 & 2,2 & 1114 & 4,21 & 15,6 & 85,8 \\
\hline
\end{tabular}

* - Valores excluídos pelo método de Grubbs

Tabela A.14 - Resultados dos ensaios RICE para a mistura 3045C1,5

\begin{tabular}{ccccccc}
\hline $\mathrm{CP}$ & $\mathrm{P}_{\mathrm{b}}(\%)$ & $\mathrm{M}_{\text {mistura }}(\mathrm{g})$ & $\mathrm{M}_{\text {mist+águatkita }}(\mathrm{g})$ & $\mathrm{T}_{\text {água }}\left({ }^{\circ} \mathrm{C}\right)$ & $\mathrm{M}_{\text {calibração }}(\mathrm{g})$ & $\mathrm{G}_{\mathrm{mm}}$ \\
\hline 98 & 5,0 & 1261,4 & 3992,5 & 21,0 & 3252,3 & 2,420 \\
99 & 5,5 & 1265,2 & 3992,8 & 17,0 & 3254,0 & 2,403 \\
100 & 6,0 & 1267,9 & 3989,4 & 21,0 & 3252,3 & 2,389 \\
\hline
\end{tabular}

Parâmetros - 3045C3,0: 75 golpes do soquete Marshall por face / Densidade do CAP 30/45 = 1,009 / Densidade aparente dos agregados $=2,603 / \mathrm{P}_{\mathrm{ba}}$ médio $=0,28 \%$. 
Tabela A.15 - Resultados da dosagem Marshall para a mistura 3045C3,0

\begin{tabular}{|c|c|c|c|c|c|c|c|c|c|c|c|c|c|c|}
\hline $\mathrm{CP}$ & $\begin{array}{l}P_{b} \\
(\%)\end{array}$ & $\begin{array}{c}\mathrm{D} \\
(\mathrm{mm})\end{array}$ & $\begin{array}{c}\mathrm{H} \\
(\mathrm{mm})\end{array}$ & $\begin{array}{c}M_{a r} \\
(g)\end{array}$ & $\begin{array}{c}M_{\text {im }} \\
(\mathrm{g})\end{array}$ & $\begin{array}{c}M_{\text {SSS }} \\
(\mathrm{g})\end{array}$ & $\begin{array}{c}\mathrm{V} \\
\left(\mathrm{cm}^{3}\right)\end{array}$ & $\mathrm{G}_{\mathrm{mb}}$ & $\mathrm{G}_{\mathrm{mm}}$ & $\begin{array}{l}\mathrm{Vv} \\
(\%)\end{array}$ & $\begin{array}{c}\text { E } \\
(\mathrm{kgf})\end{array}$ & $\begin{array}{c}\mathrm{F} \\
(\mathrm{mm})\end{array}$ & $\begin{array}{c}\text { VAM } \\
(\%)\end{array}$ & $\begin{array}{c}\text { RBV } \\
(\%)\end{array}$ \\
\hline 101 & 5,0 & 102,19 & 68,54 & 1247,5 & 702,9 & 1249,7 & 546,8 & 2,281 & 2,428 & 6,0 & 987 & 3,19 & 16,7 & 64,0 \\
\hline 102 & 5,0 & 102,33 & 68,17 & 1255,0 & 708,3 & 1255,8 & 547,5 & 2,292 & 2,428 & 5,6 & 986 & 3,76 & 16,3 & 65,9 \\
\hline 103 & 5,0 & 102,17 & 68,05 & 1254,4 & 710,2 & 1256,0 & 545,8 & 2,298 & 2,428 & 5,3 & $1138^{*}$ & 3,41 & 16,1 & 66,9 \\
\hline 104 & 5,5 & 101,59 & 68,85 & 1261,5 & 717,5 & 1262,2 & 544,7 & 2,316 & 2,408 & 3,8 & 1035 & 3,69 & 15,9 & 76,0 \\
\hline 105 & 5,5 & 101,92 & 68,98 & 1259,7 & 713,3 & 1260,4 & 547,1 & 2,303 & 2,408 & 4,4 & 1020 & 3,31 & 16,4 & 73,3 \\
\hline 106 & 5,5 & 101,90 & 68,93 & 1263,9 & 718,6 & 1264,9 & 546,3 & 2,314 & 2,408 & 3,9 & 977 & 3,57 & 16,0 & 75,5 \\
\hline 107 & 6,0 & 102,32 & 67,85 & 1268,0 & 724,7 & 1268,5 & 543,8 & 2,332 & 2,394 & 2,6 & 1018 & 3,88 & 15,8 & 83,5 \\
\hline 108 & 6,0 & 101,82 & 68,30 & 1267,3 & 723,6 & 1268,0 & 544,4 & 2,328 & 2,394 & 2,8 & 1055 & 3,99 & 15,9 & 82,6 \\
\hline 109 & 6,0 & 102,37 & 67,22 & 1264,6 & 721,2 & 1265,1 & 543,9 & 2,325 & 2,394 & 2,9 & 1026 & 3,79 & 16,0 & 82,0 \\
\hline
\end{tabular}

* - Valor excluído pelo método de Grubbs

Tabela A.16 - Resultados dos ensaios RICE para a mistura 3045C 3,0

\begin{tabular}{ccccccc}
\hline $\mathrm{CP}$ & $\mathrm{P}_{\mathrm{b}}(\%)$ & $\mathrm{M}_{\text {mistura }}(\mathrm{g})$ & $\mathrm{M}_{\text {mist+água+kita }}(\mathrm{g})$ & $\mathrm{T}_{\text {água }}\left({ }^{\circ} \mathrm{C}\right)$ & $\mathrm{M}_{\text {calibração }}(\mathrm{g})$ & $\mathrm{G}_{\mathrm{mm}}$ \\
\hline 110 & 5,0 & 1261,2 & 3992,5 & 24,0 & 3250,8 & 2,428 \\
111 & 5,5 & 1263,2 & 3991,8 & 19,0 & 3253,2 & 2,408 \\
112 & 6,0 & 1261,8 & 3986,1 & 23,0 & 3251,3 & 2,394 \\
\hline
\end{tabular}

Parâmetros - 3045C6,0: 75 golpes do soquete Marshall por face / Densidade do CAP 30/45 = 1,009 / Densidade aparente dos agregados $=2,604 / \mathrm{P}_{\mathrm{ba}}$ médio $=0,20 \%$.

Tabela A.17 - Resultados da dosagem Marshall para a mistura 3045C6,0

\begin{tabular}{|c|c|c|c|c|c|c|c|c|c|c|c|c|c|c|}
\hline $\mathrm{CP}$ & $\begin{array}{c}\mathrm{P}_{\mathrm{b}} \\
(\%)\end{array}$ & $\begin{array}{c}\mathrm{D} \\
(\mathrm{mm})\end{array}$ & $\begin{array}{c}\mathrm{H} \\
(\mathrm{mm})\end{array}$ & $\begin{array}{l}\mathbf{M}_{\mathrm{ar}} \\
(\mathrm{g})\end{array}$ & $\begin{array}{c}M_{\mathrm{im}} \\
(\mathrm{g})\end{array}$ & $\begin{array}{c}M_{\text {SSS }} \\
(\mathrm{g})\end{array}$ & $\begin{array}{c}\mathrm{V} \\
\left(\mathrm{cm}^{3}\right)\end{array}$ & $\mathrm{G}_{\mathrm{mb}}$ & $\mathrm{G}_{\mathrm{mm}}$ & $\begin{array}{l}\text { Vv } \\
(\%)\end{array}$ & $\begin{array}{c}\mathrm{E} \\
(\mathrm{kgf})\end{array}$ & $\begin{array}{c}\mathrm{F} \\
(\mathrm{mm})\end{array}$ & $\begin{array}{c}\text { VAM } \\
(\%)\end{array}$ & $\begin{array}{l}\text { RBV } \\
(\%)\end{array}$ \\
\hline 113 & 5,0 & 102,58 & 69,07 & 1256,0 & 709,6 & 1257,3 & 547,7 & 2,293 & 2,423 & 5,4 & 1013 & 3,41 & 16,3 & 67,2 \\
\hline 114 & 5,0 & 101,97 & 68,75 & 1251,9 & 707,0 & 1253,1 & 546,1 & 2,292 & 2,423 & 5,4 & 1068 & 3,52 & 16,4 & 67,0 \\
\hline 115 & 5,0 & 102,05 & 69,06 & 1254,4 & 706,3 & 1254,5 & 548,2 & 2,288 & 2,423 & 5,6 & 1097 & 3,07 & 16,5 & 66,3 \\
\hline 116 & 5,5 & 101,96 & 69,30 & 1260,5 & 712,4 & 1261,5 & 549,1 & 2,296 & 2,408 & 4,7 & 1052 & $3,43 *$ & 16,7 & 72,1 \\
\hline 117 & 5,5 & 102,13 & 68,43 & 1260,1 & 715,1 & 1260,7 & 545,6 & 2,310 & 2,408 & 4,1 & $1122 *$ & 4,11 & 16,2 & 74,8 \\
\hline 118 & 5,5 & 102,36 & 68,24 & 1257,0 & 709,5 & 1257,8 & 548,3 & 2,293 & 2,408 & 4,8 & 1049 & 4,13 & 16,8 & 71,5 \\
\hline 119 & 6,0 & 101,92 & 68,11 & 1261,2 & 717,2 & 1261,7 & 544,5 & 2,316 & 2,389 & 3,0 & 1071 & $3,68 *$ & 16,4 & 81,5 \\
\hline 120 & 6,0 & 102,19 & 68,15 & 1269,5 & 724,3 & 1270,1 & 545,8 & 2,326 & 2,389 & 2,6 & 1053 & 4,33 & 16,0 & 83,6 \\
\hline 121 & 6,0 & 101,83 & 68,65 & 1264,3 & 720,2 & 1264,8 & 544,6 & 2,322 & 2,389 & 2,8 & 1119 & 4,32 & 16,2 & 82,6 \\
\hline
\end{tabular}

* - Valores excluídos pelo método de Grubbs

Tabela A.18 - Resultados dos ensaios RICE para a mistura 3045C6,0

\begin{tabular}{ccccccc}
\hline $\mathrm{CP}$ & $\mathrm{P}_{\mathrm{b}}(\%)$ & $\mathrm{M}_{\text {mistura }}(\mathrm{g})$ & $\mathrm{M}_{\text {misttágua+kita }}(\mathrm{g})$ & $\mathrm{T}_{\text {água }}\left({ }^{\circ} \mathrm{C}\right)$ & $\mathrm{M}_{\text {calibração }}(\mathrm{g})$ & $\mathrm{G}_{\mathrm{mm}}$ \\
\hline 122 & 5,0 & 1255,9 & 3990,4 & 20,0 & 3252,8 & 2,423 \\
123 & 5,5 & 1264,3 & 3993,6 & 16,0 & 3254,4 & 2,408 \\
124 & 6,0 & 1272,5 & 3992,6 & 20,0 & 3252,8 & 2,389 \\
\hline
\end{tabular}

Parâmetros - 3045L: 75 golpes do soquete Marshall por face / Densidade do CAP 30/45 = 1,009 / Densidade aparente dos agregados $=2,602 / \mathrm{P}_{\mathrm{ba}}$ médio $=0,20 \%$.

Tabela A.19 - Resultados da dosagem Marshall para a mistura 3045L

\begin{tabular}{|c|c|c|c|c|c|c|c|c|c|c|c|c|c|c|}
\hline $\mathrm{CP}$ & $\begin{array}{c}\mathrm{P}_{\mathrm{b}} \\
(\%)\end{array}$ & $\begin{array}{c}\mathrm{D} \\
(\mathrm{mm})\end{array}$ & $\begin{array}{c}\mathrm{H} \\
(\mathrm{mm})\end{array}$ & $\begin{array}{c}M_{\text {ar }} \\
(\mathrm{g})\end{array}$ & $\begin{array}{c}M_{\text {im }} \\
(\mathrm{g})\end{array}$ & $\begin{array}{c}\mathrm{M}_{\text {SSS }} \\
(\mathrm{g})\end{array}$ & $\begin{array}{c}\mathrm{V} \\
\left(\mathrm{cm}^{3}\right)\end{array}$ & $\mathrm{G}_{\mathrm{mb}}$ & $\mathrm{G}_{\mathrm{mm}}$ & $\begin{array}{c}\mathrm{Vv} \\
(\%)\end{array}$ & $\begin{array}{c}E \\
(\mathrm{kgf})\end{array}$ & $\begin{array}{c}\mathrm{F} \\
(\mathrm{mm})\end{array}$ & $\begin{array}{c}\text { VAM } \\
(\%)\end{array}$ & $\begin{array}{c}\text { RBV } \\
(\%)\end{array}$ \\
\hline 125 & 5,0 & 101,77 & 69,06 & 1248,2 & 701,8 & 1250,4 & 548,6 & 2,275 & 2,422 & 6,0 & 997 & 2,58 & 16,9 & 64,3 \\
\hline 126 & 5,0 & 102,25 & 68,81 & 1254,7 & 707,8 & 1256,6 & 548,8 & 2,286 & 2,422 & 5,6 & 1088 & 2,69 & 16,5 & 66,2 \\
\hline 127 & 5,0 & 102,27 & 68,62 & 1257,9 & 711,4 & 1258,9 & 547,5 & 2,298 & 2,422 & 5,1 & 1256 & 3,30 & 16,1 & 68,2 \\
\hline 128 & 5,5 & 101,63 & 68,87 & 1261,1 & 715,4 & 1261,7 & 546,3 & 2,308 & 2,405 & 4,0 & 1035 & 2,85 & 16,2 & 75,2 \\
\hline 129 & 5,5 & 101,76 & 68,78 & 1263,4 & 717,8 & 1264,3 & 546,5 & 2,312 & 2,405 & 3,9 & 1157 & 2,96 & 16,0 & 75,9 \\
\hline 130 & 5,5 & 102,53 & 67,85 & 1264,5 & 719,0 & 1265,0 & 546,0 & 2,316 & 2,405 & 3,7 & 1215 & 3,75 & 15,9 & 76,7 \\
\hline 131 & 6,0 & 101,87 & 68,30 & 1266,9 & 723,3 & 1267,3 & 544,0 & 2,329 & 2,389 & 2,5 & 1068 & 3,35 & 15,9 & 84,2 \\
\hline 132 & 6,0 & 101,79 & 68,64 & 1270,6 & 725,2 & 1271,3 & 546,1 & 2,327 & 2,389 & 2,6 & 1237 & 3,97 & 15,9 & 83,7 \\
\hline 133 & 6,0 & 102,20 & 67,54 & 1265,7 & 723,3 & 1266,3 & 543,0 & 2,331 & 2,389 & 2,4 & 1243 & 3,52 & 15,8 & 84,7 \\
\hline
\end{tabular}

* - Valor excluído pelo método de Grubbs

Tabela A.20 - Resultados dos ensaios RICE para a mistura 3045L

\begin{tabular}{ccccccc}
\hline $\mathrm{CP}$ & $\mathrm{P}_{\mathrm{b}}(\%)$ & $\mathrm{M}_{\text {mistura }}(\mathrm{g})$ & $\mathrm{M}_{\text {mist+águatkita }}(\mathrm{g})$ & $\mathrm{T}_{\text {água }}\left({ }^{\circ} \mathrm{C}\right)$ & $\mathrm{M}_{\text {calibração }}(\mathrm{g})$ & $\mathrm{G}_{\mathrm{mm}}$ \\
\hline 134 & 5,0 & 1258,3 & 3992,3 & 18,0 & 3253,6 & 2,422 \\
135 & 5,5 & 1267,8 & 3994,6 & 17,0 & 3254,0 & 2,405 \\
136 & 6,0 & 1276,0 & 3995,8 & 17,0 & 3254,0 & 2,389 \\
\hline
\end{tabular}


APÊEDICE B - Gráficos das Dosagens Marshall
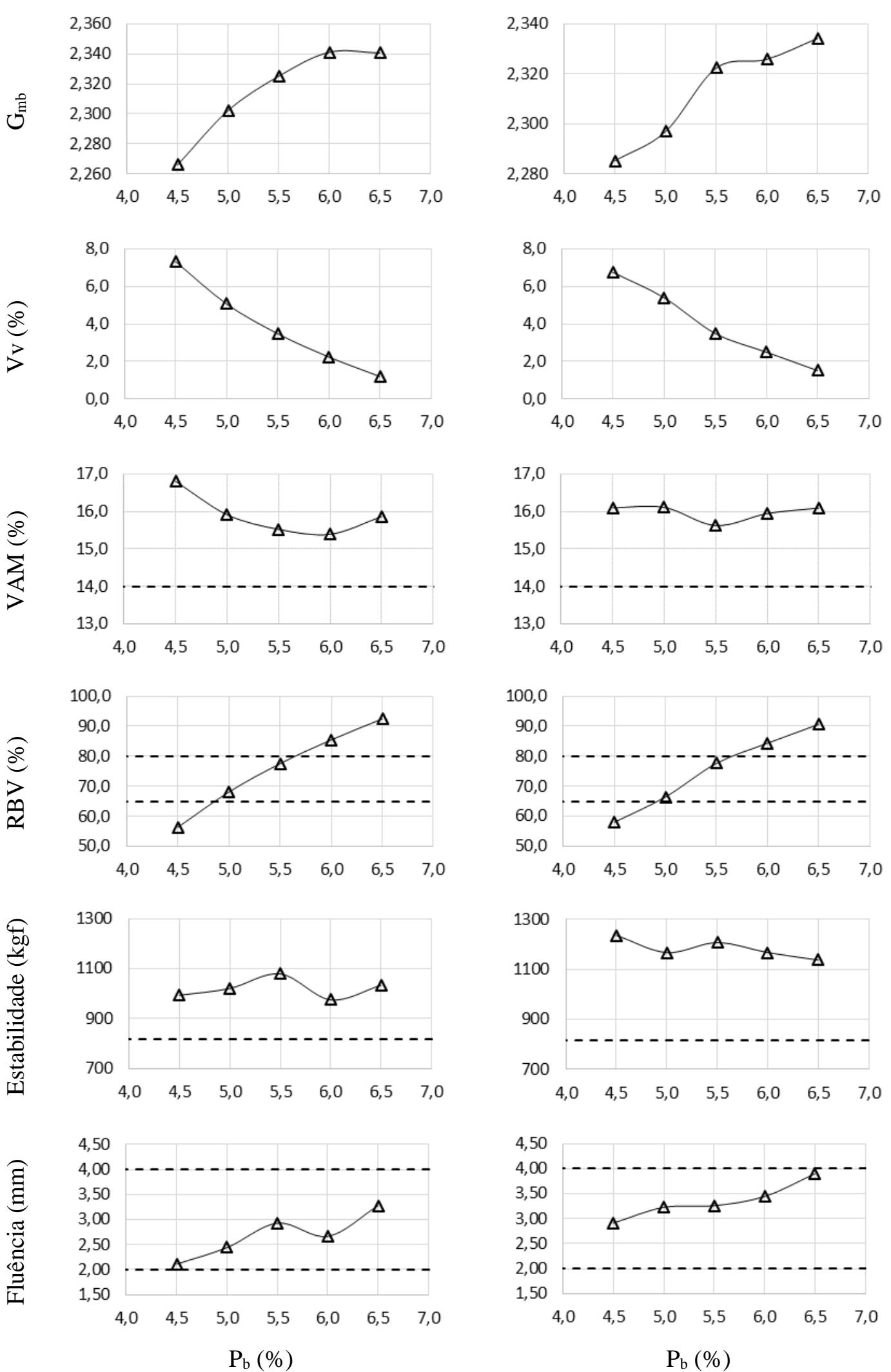

Mistura 5070

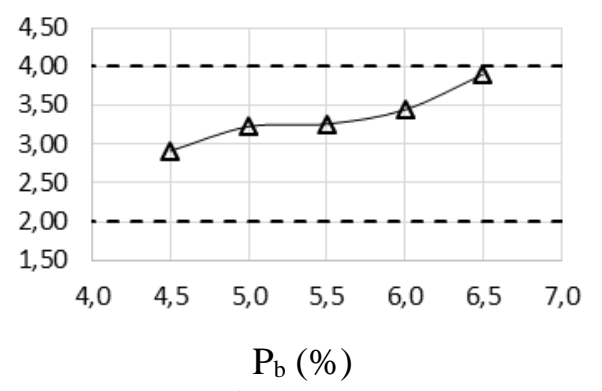

Mistura 3045

Figura B.1 - Gráficos das Dosagens Marshall para as misturas de referência (5070 e 3045) 

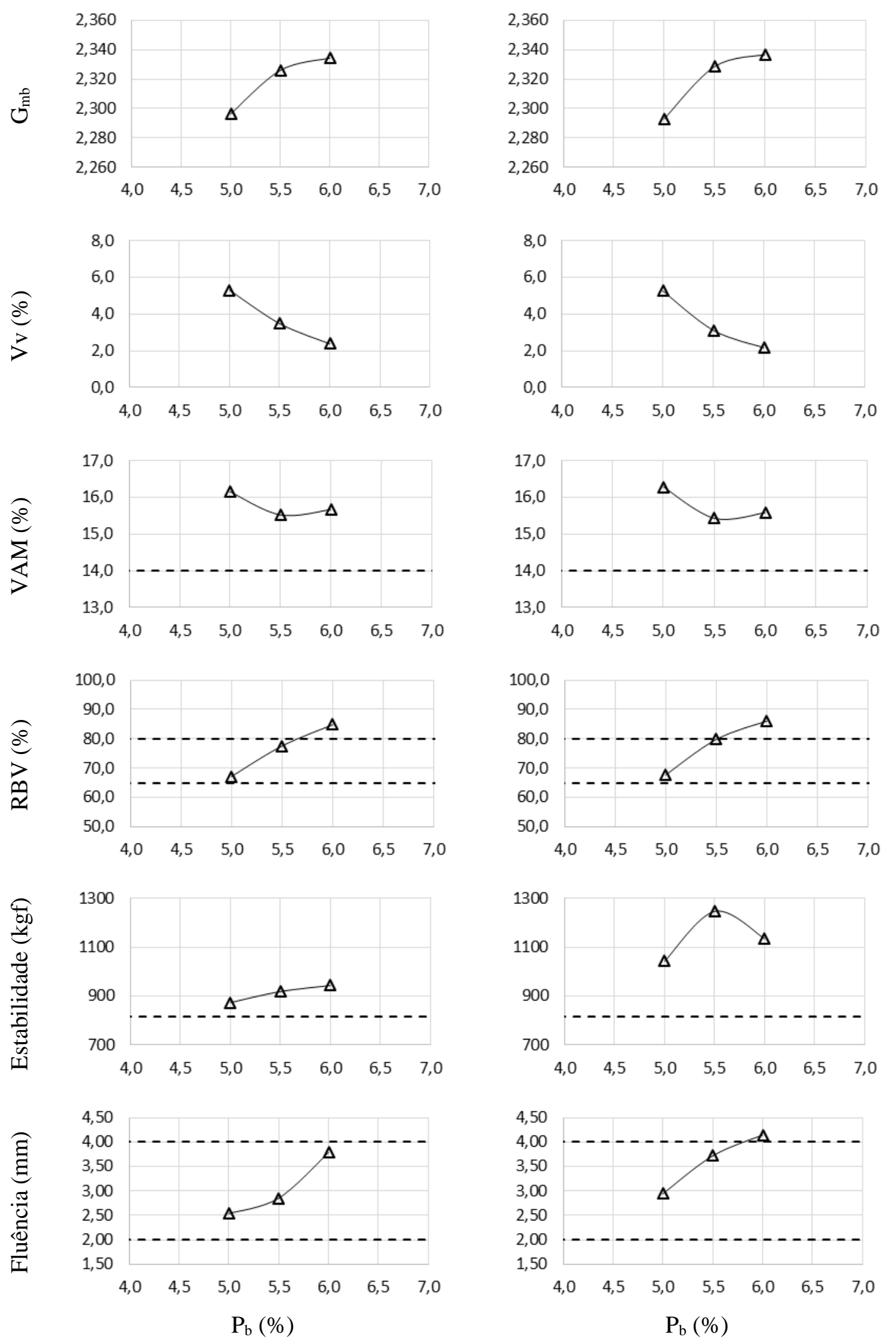

Mistura 5070C1,5

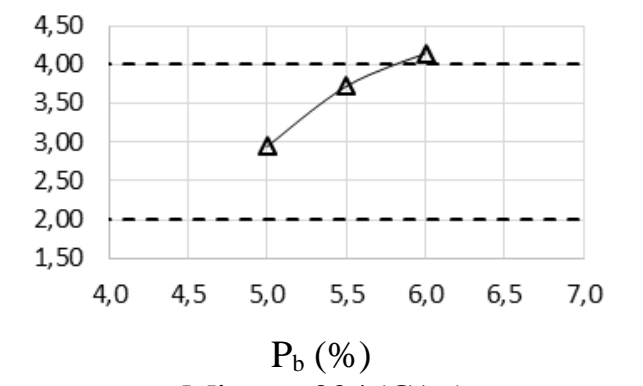

Mistura 3045C1,5

Figura B.2 - Gráficos das Dosagens Marshall para as misturas com 1,5\% de caulim (5070C1,5 e $3045 \mathrm{C} 1,5)$ 

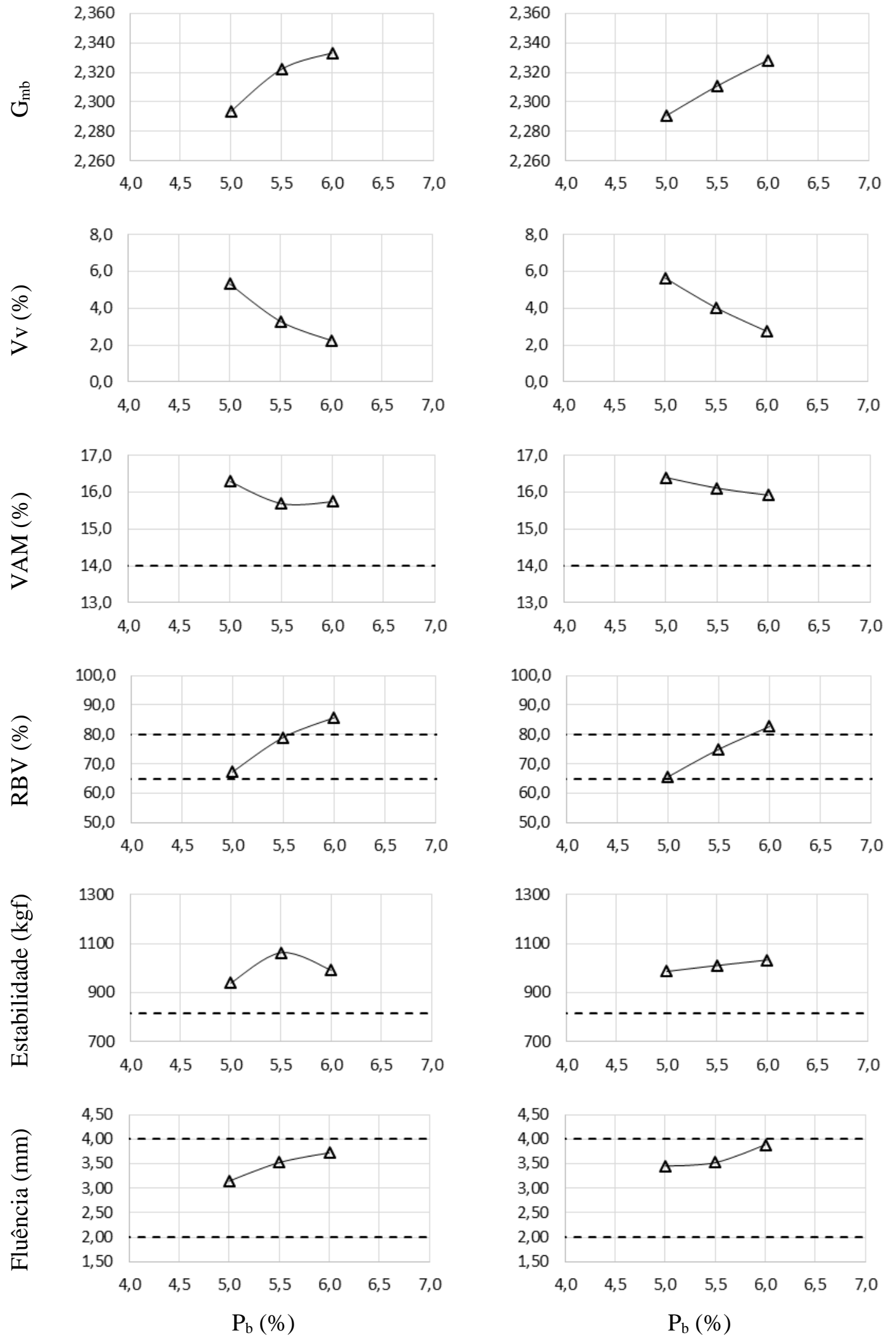

Mistura 5070C3,0

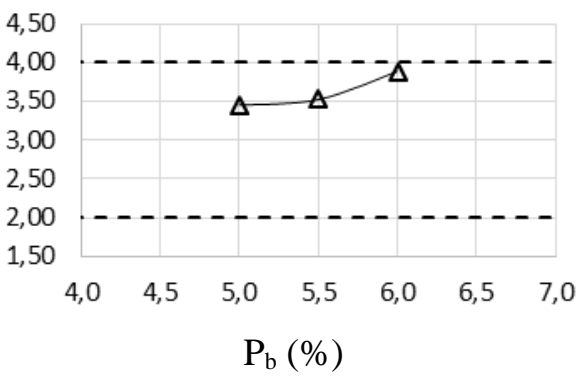

Mistura 3045C3,0

Figura B.3 - Gráficos das Dosagens Marshall para as misturas com 3,0\% de caulim (5070C3,0 e $3045 \mathrm{C} 3,0)$ 

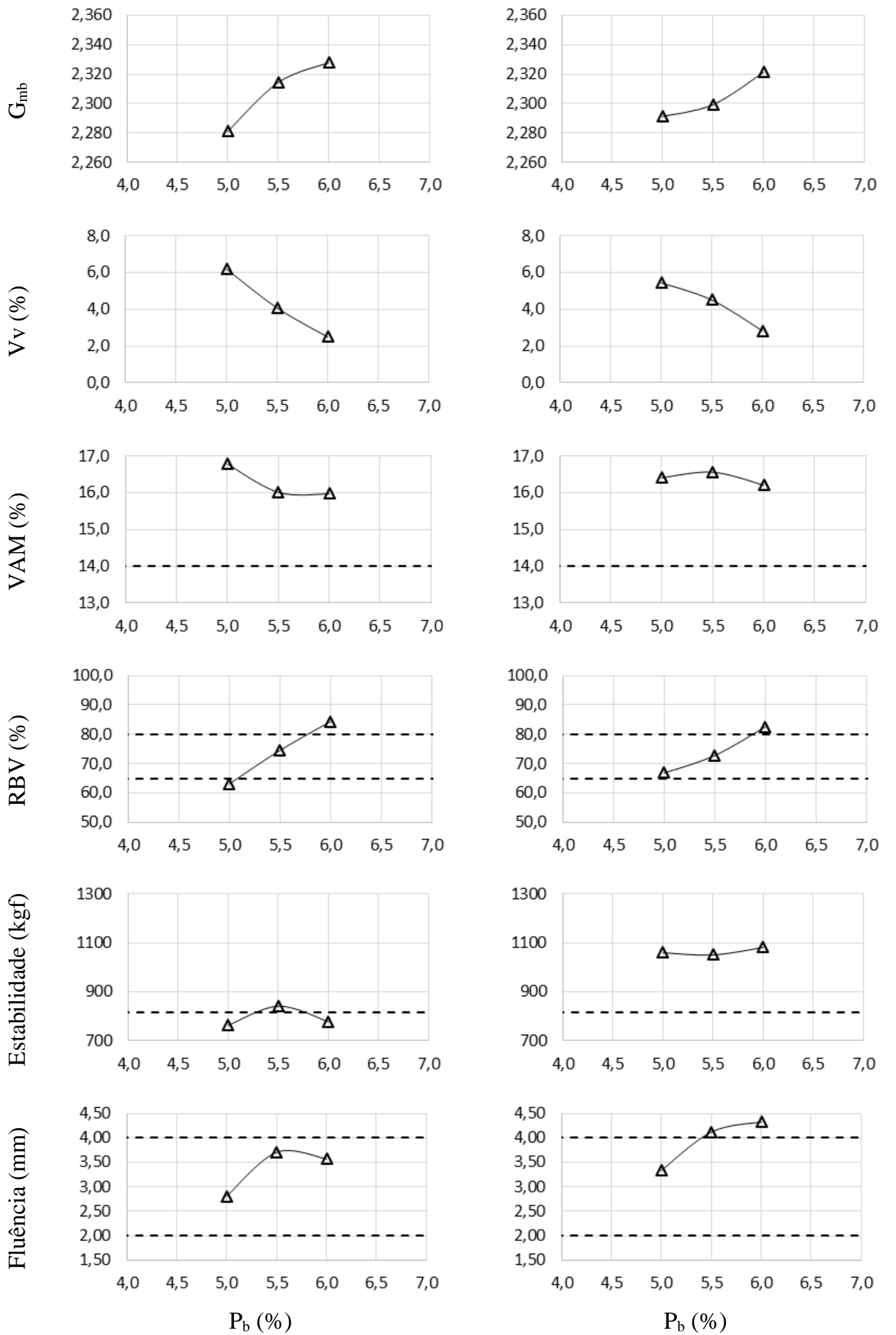

Mistura 5070C6,0

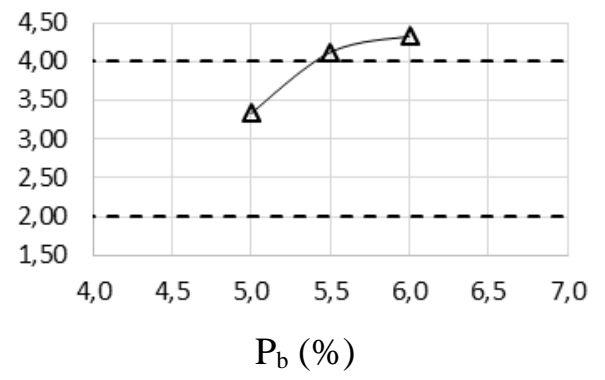

Mistura 3045C6,0

Figura B.4 - Gráficos das Dosagens Marshall para as misturas com 6,0\% de caulim (5070C6,0 e 3045C6,0) 

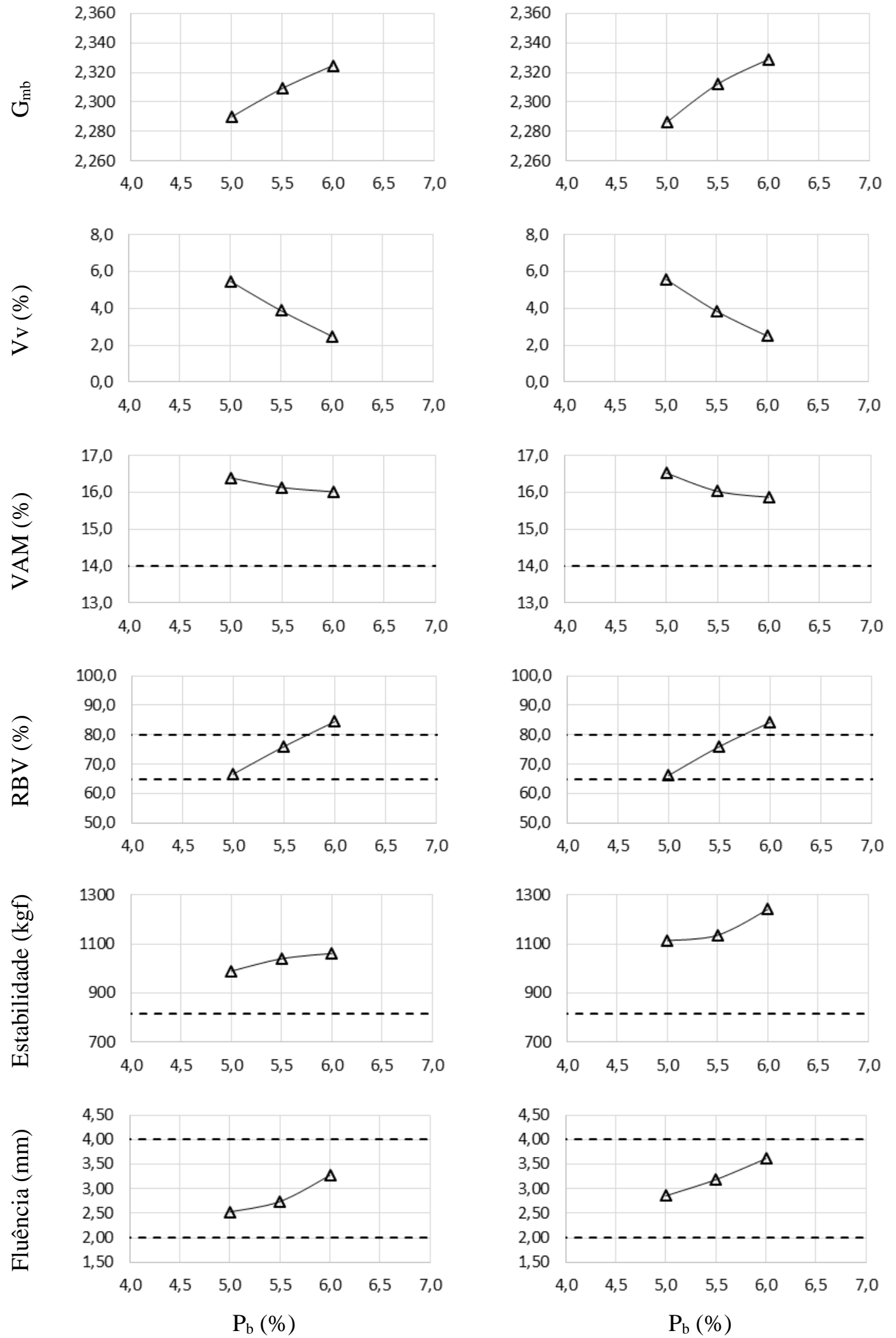

Mistura 5070L

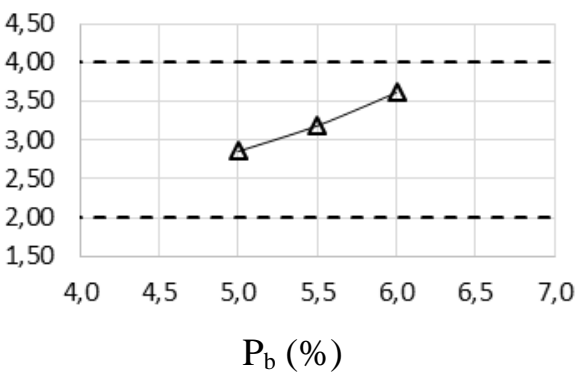

Mistura 3045L

Figura B.5 - Gráficos das Dosagens Marshall para as misturas com 1,5\% de cal (5070L e 3045L) 


\section{APÊEDICE C - Testes t de Student}

Os testes $\mathrm{t}$ de Student foram realizados com o intuito de dar suporte estatístico às análises técnicas sobre a variação dos valores das diversas variáveis-resposta das 3 etapas da pesquisa (parâmetros das dosagens Marshall, MR, RT, parâmetros dos ensaios de creep estático, dentre outros) à luz da variação do tipo de fíler e do tipo de ligante asfáltico (variáveis de entrada).

Foi utilizado o teste t para amostras independentes cuja estatística t é dada pela equação C.1. O valor da estatística t e o grau de liberdade (gl), dado pela equação C.2, são inseridos na distribuição t de Student, bicaudal, para o cálculo do valor p. Se p > 0,05, a diferença entre as médias não é significativa. Se $\mathrm{p} \leq 0,05$, as médias em análise são consideradas diferentes. Este procedimento foi efetuado no software IBM SPSS Statistcs v. 22.

$$
\begin{gathered}
t=\left(X_{1}-X_{2}\right) \times \sqrt{\frac{n}{2 S_{a}^{2}}} \\
g l=2 n-2
\end{gathered}
$$

Em que: $\mathrm{X}_{1}$ é a média da amostra 1 / $\mathrm{X}_{2}$ é a média da amostra 2 / n é o tamanho da amostra em cada grupo / $\mathrm{Sa}_{2}$ é a variância agregada das duas amostras.

Para a validade do teste é necessário que os dois conjuntos de dados cujas médias se quer testar provenham de distribuições normais e possuam a mesma variância. Assim, o primeiro passo foi testar no SPSS a condição de normalidade para os conjuntos de dados, conforme ilustrado na Figura C.1. Em todos os testes realizados, o nível de significância foi superior à 0,05 , portanto não se rejeitou a hipótese de que os dados sejam oriundos de distribuições normais.

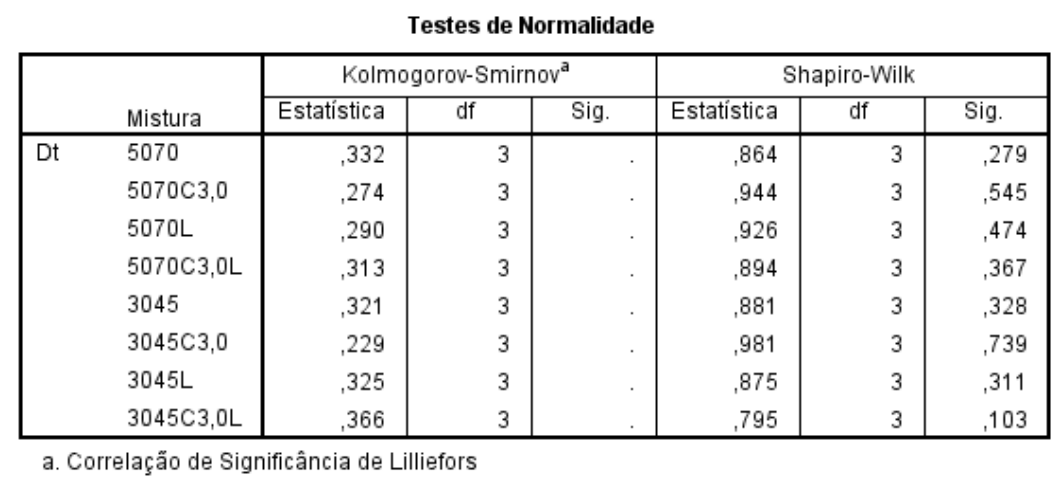

Figura C.1 - Verificação de normalidade dos dados de deformação total do ensaio creep 
Foram testados somente os pares de misturas que diferiam entre si pelo tipo de ligante asfáltico ou tipo de fíler, por exemplo 5070 x 3045 e 5070 x 5070C3,0. Assim, foi possível aferir a influência isolada do fator na propriedade em análise. Não foram efetuados testes $t$ quando o tipo de ligante asfáltico e tipo de fíler variavam simultaneamente, como em 5070 x 3045L. Na Figura C.2 apresenta-se uma tela do software SPSS, onde se verificam as estatísticas de grupo (média, desvio-padrão) e o teste de amostras independentes (estatística $\mathrm{t} / \mathrm{df}$ - degrees of freedom ou graus de liberdade / Sig. ( 2 extremidades - valor $\mathrm{p}$, bicaudal). Como neste caso $\mathrm{p}$ $>0,05(\mathrm{p}=0,118)$ os valores médios de MR das misturas 3045 e 3045C3,0L podem ser considerados iguais.

Estatísticas de grupo

\begin{tabular}{|ll|r|c|c|c|}
\hline & Grupo & $\mathrm{N}$ & Média & $\begin{array}{c}\text { Desvio } \\
\text { Padrã̃o }\end{array}$ & $\begin{array}{c}\text { Erro padrão } \\
\text { da média }\end{array}$ \\
\hline MR & 3045 & 3 & 4491,333 & 495,3881 & 286,0124 \\
& $3045 \mathrm{C} 3,0 \mathrm{~L}$ & 3 & 3823,000 & 309,1747 & 178,5021 \\
\hline
\end{tabular}

\begin{tabular}{|c|c|c|c|c|c|c|c|c|c|c|}
\hline \multicolumn{11}{|c|}{ Teste de amostras independentes } \\
\hline & & \multicolumn{2}{|c|}{$\begin{array}{l}\text { Teste de Levene para } \\
\text { igualdade de variâncias }\end{array}$} & \multicolumn{7}{|c|}{ teste-t para Igualdade de Médias } \\
\hline & & \multirow[b]{2}{*}{$\mathrm{z}$} & \multirow[b]{2}{*}{ Sig. } & \multirow[b]{2}{*}{$t$} & \multirow[b]{2}{*}{ df } & \multirow{2}{*}{$\begin{array}{c}\text { Sig. (2 } \\
\text { extremidades } \\
\text { ) }\end{array}$} & \multirow{2}{*}{$\begin{array}{l}\text { Diferençaa } \\
\text { média }\end{array}$} & \multirow{2}{*}{$\begin{array}{l}\text { Erro padrão } \\
\text { de diferença }\end{array}$} & \multicolumn{2}{|c|}{$\begin{array}{l}\text { 95\% Intervalo de Confiança da } \\
\text { Diferença }\end{array}$} \\
\hline & & & & & & & & & Inferior & Superior \\
\hline MR & $\begin{array}{l}\text { Variâncias iguais } \\
\text { assumidas }\end{array}$ & 1,479 & 291 & 1,982 & 4 & ,118 & 668,3333 & 337,1441 & $-267,7286$ & 1604,3953 \\
\hline & $\begin{array}{l}\text { Variâncias iguais não } \\
\text { assumidas }\end{array}$ & & & 1,982 & 3,353 & ,132 & 668,3333 & 337,1441 & $-343,4837$ & 1680,1504 \\
\hline
\end{tabular}

Figura C.2 - Tela do SPSS contendo o teste t dos valores de MR das misturas 3045 x 3045C3,0L

O processo mostrado na Figura C.2 foi repetido para todas as variáveis-resposta e para todas os pares de misturas asfálticas e os resultados estão sumarizados nas Tabelas C.1 a C.17. As células preenchidas com "Sim" indicam pares de misturas cujas médias são significativamente diferentes, para a propriedade em análise. As células preenchidas com "NA" indicam que os pares de médias de Vv não foram avaliados. As células do primeiro e terceiro quadrantes das tabelas indicam os resultados dos testes t em função do tipo de fíler, enquanto que as células do segundo quadrante indicam os resultados em função do tipo de ligante asfáltico.

Tabela C.1 - Resultados dos testes t para o Volume de Vazios, $\mathrm{P}_{\mathrm{b}}=5,5 \%$ (Etapa 1)

\begin{tabular}{|c|c|c|c|c|c|c|c|c|c|c|}
\hline $\begin{array}{l}\text { Tipo de } \\
\text { Mistura }\end{array}$ & 5070 & $5070 \mathrm{C} 1,5$ & $5070 \mathrm{C} 3,0$ & $5070 \mathrm{C} 6,0$ & 5070L & 3045 & $3045 \mathrm{C} 1,5$ & $3045 \mathrm{C} 3,0$ & 3045 C6,0 & 3045L \\
\hline 5070 & - & Não & Não & Sim & Não & Não & NA & NA & NA & NA \\
\hline $5070 \mathrm{C} 1,5$ & & - & Não & Não & Não & NA & Não & NA & NA & NA \\
\hline $5070 \mathrm{C} 3,0$ & & & - & Sim & Sim & NA & NA & Sim & NA & NA \\
\hline $5070 \mathrm{C} 6,0$ & & & & - & Não & NA & NA & NA & Não & NA \\
\hline $5070 \mathrm{~L}$ & & & & & - & NA & NA & NA & NA & Não \\
\hline 3045 & & & & & & - & Não & Não & Sim & Não \\
\hline $3045 \mathrm{C} 1,5$ & & & & & & & - & Sim & Sim & Sim \\
\hline $3045 \mathrm{C} 3,0$ & & & & & & & & - & Não & Não \\
\hline $3045 \mathrm{C} 6,0$ & & & & & & & & & - & Não \\
\hline \multirow[t]{2}{*}{ 3045L } & & & & & & & & & & - \\
\hline & $7 / 20$ & $\%$ dos teste & ndicaram m & ias $\neq$ por tif & le fíler & $1 / 5$ & $\%$ dos teste & dicaram méc & $\neq$ p por tipo & zante \\
\hline
\end{tabular}


Tabela C. 2 - Resultados dos testes t para o VAM, $\mathrm{P}_{\mathrm{b}}=5,5 \%$ (Etapa 1 )

\begin{tabular}{|c|c|c|c|c|c|c|c|c|c|c|}
\hline $\begin{array}{l}\text { Tipo de } \\
\text { Mistura }\end{array}$ & $\mathbf{5 0 7 0}$ & $5070 \mathrm{C} 1,5$ & $5070 \mathrm{C} 3,0$ & $5070 \mathrm{C} 6,0$ & 5070L & 3045 & $3045 \mathrm{C} 1,5$ & $3045 \mathrm{C} 3,0$ & $3045 \mathrm{C} 6,0$ & $3045 \mathrm{~L}$ \\
\hline 5070 & - & Não & Não & Sim & Sim & Não & NA & NA & NA & NA \\
\hline $5070 \mathrm{C} 1,5$ & & - & Não & Não & Sim & NA & Não & NA & NA & NA \\
\hline $5070 \mathrm{C} 3,0$ & & & - & Sim & Sim & NA & NA & Não & NA & NA \\
\hline $5070 \mathrm{C} 6,0$ & & & & - & Não & NA & NA & NA & Não & NA \\
\hline $5070 L$ & & & & & - & NA & NA & NA & NA & Não \\
\hline \multirow{6}{*}{$\begin{array}{c}3045 \\
3045 C 1,5 \\
3045 C 3,0 \\
3045 C 6,0 \\
\text { 3045L }\end{array}$} & & & & & & - & Não & Não & Sim & Não \\
\hline & & & & & & & - & Sim & Sim & Sim \\
\hline & & & & & & & & - & Não & Não \\
\hline & & & & & & & & & - & Não \\
\hline & & & & & & \multirow{2}{*}{\multicolumn{5}{|c|}{$0 / 5-0 \%$ dos testes indicaram médias $\neq$ por tipo de ligante }} \\
\hline & \multicolumn{5}{|c|}{$9 / 20-45 \%$ dos testes indicaram médias $\neq$ por tipo de fíler } & & & & & \\
\hline
\end{tabular}

Tabela C. 3 - Resultados dos testes t para o RBV, $\mathrm{P}_{\mathrm{b}}=5,5 \%$ (Etapa 1)

\begin{tabular}{|c|c|c|c|c|c|c|c|c|c|c|}
\hline $\begin{array}{l}\text { Tipo de } \\
\text { Mistura }\end{array}$ & 5070 & $5070 \mathrm{C} 1,5$ & $5070 \mathrm{C} 3,0$ & $5070 \mathrm{C6}, 0$ & 5070L & 3045 & $3045 \mathrm{C} 1,5$ & $3045 C 3,0$ & $3045 \mathrm{C6}, 0$ & 3045L \\
\hline $\mathbf{5 0 7 0}$ & - & Não & Não & Sim & Não & Não & NA & NA & NA & NA \\
\hline $5070 \mathrm{C} 1,5$ & & - & Não & Não & Não & NA & Não & NA & NA & NA \\
\hline $5070 \mathrm{C} 3,0$ & & & - & Sim & Sim & NA & NA & Sim & NA & NA \\
\hline $5070 \mathrm{C} 6,0$ & & & & - & Não & NA & NA & NA & Não & NA \\
\hline $5070 \mathrm{~L}$ & & & & & - & NA & NA & NA & NA & Não \\
\hline 3045 & & & & & & - & Não & Não & Sim & Não \\
\hline $3045 \mathrm{C} 1,5$ & & & & & & & - & Sim & Sim & Sim \\
\hline $3045 \mathrm{C} 3,0$ & & & & & & & & - & Não & Não \\
\hline $3045 \mathrm{C} 6,0$ & & & & & & & & & - & Sim \\
\hline 3045L & & & diø r & & & & & & & - \\
\hline
\end{tabular}

Tabela C. 4 - Resultados dos testes t para a estabilidade, $\mathrm{P}_{\mathrm{b}}=5,5 \%$ (Etapa 1)

\begin{tabular}{|c|c|c|c|c|c|c|c|c|c|c|}
\hline $\begin{array}{l}\text { Tipo de } \\
\text { Mistura }\end{array}$ & 5070 & $5070 \mathrm{C} 1,5$ & $5070 \mathrm{C} 3,0$ & $5070 \mathrm{C} 6,0$ & 5070L & 3045 & $3045 \mathrm{C} 1,5$ & $3045 \mathrm{C} 3,0$ & $3045 \mathrm{C} 6,0$ & $3045 \mathrm{~L}$ \\
\hline 5070 & - & Não & Não & Sim & Não & Não & NA & NA & NA & NA \\
\hline $5070 \mathrm{C} 1,5$ & & - & Não & Não & Não & NA & Sim & NA & NA & NA \\
\hline $5070 \mathrm{C} 3,0$ & & & - & Sim & Não & NA & NA & Não & NA & NA \\
\hline $5070 \mathrm{C6}, 0$ & & & & - & Sim & NA & NA & NA & Sim & NA \\
\hline $5070 \mathrm{~L}$ & & & & & - & NA & NA & NA & NA & Não \\
\hline 3045 & & & & & & - & Não & Sim & Sim & Não \\
\hline $3045 \mathrm{C} 1,5$ & & & & & & & - & Sim & Não & Não \\
\hline 3045C3,0 & & & & & & & & - & Não & Não \\
\hline \multirow{3}{*}{$\begin{array}{c}\text { 3045C6,0 } \\
\text { 3045L }\end{array}$} & & & & & & & & & - & Não \\
\hline & & & & & & & & & & - \\
\hline & \multicolumn{5}{|c|}{$6 / 20-30 \%$ dos testes indicaram médias $\neq$ por tipo de fíler } & \multicolumn{5}{|c|}{$2 / 5-40 \%$ dos testes indicaram médias $\neq$ por tipo de ligante } \\
\hline
\end{tabular}

Tabela C. 5 - Resultados dos testes t para a fluência, $\mathrm{P}_{\mathrm{b}}=5,5 \%$ (Etapa 1)

\begin{tabular}{|c|c|c|c|c|c|c|c|c|c|c|}
\hline $\begin{array}{l}\text { Tipo de } \\
\text { Mistura }\end{array}$ & 5070 & $5070 \mathrm{C} 1,5$ & $5070 \mathrm{C} 3,0$ & $5070 \mathrm{C} 6,0$ & $5070 \mathrm{~L}$ & 3045 & $3045 \mathrm{C} 1,5$ & $3045 \mathrm{C} 3,0$ & $3045 \mathrm{C} 6,0$ & $3045 \mathrm{~L}$ \\
\hline 5070 & - & Não & Não & Sim & Não & Não & NA & NA & NA & NA \\
\hline $5070 \mathrm{C} 1,5$ & & - & Não & Sim & Não & NA & Não & NA & NA & NA \\
\hline $5070 \mathrm{C} 3,0$ & & & - & Não & Não & NA & NA & Não & NA & NA \\
\hline $5070 \mathrm{C} 6,0$ & & & & - & Sim & NA & NA & NA & Não & NA \\
\hline $5070 \mathrm{~L}$ & & & & & - & NA & NA & NA & NA & Não \\
\hline \multirow{6}{*}{$\begin{array}{c}3045 \\
3045 C 1,5 \\
3045 C 3,0 \\
3045 C 6,0 \\
3045 \mathrm{~L}\end{array}$} & & & & & & - & Não & Não & Sim & Não \\
\hline & & & & & & & - & Não & Não & Não \\
\hline & & & & & & & & - & Sim & Não \\
\hline & & & & & & & & & - & Não \\
\hline & & & & & & & & & & - \\
\hline & $5 / 20$ & $\%$ dos teste & ndicaram $\mathrm{m}$ & ias $\neq$ por ti & le fíler & & 0 dos testes & icaram méc & $\neq$ por tipo d & ante \\
\hline
\end{tabular}

Tabela C. 6 - Resultados dos testes t para a $\mathrm{MR}_{4 \%}, 25^{\circ} \mathrm{C}$ (Etapas 2 e 3)

\begin{tabular}{|c|c|c|c|c|c|c|c|c|c|c|c|c|}
\hline $\begin{array}{c}\text { Tipo de } \\
\text { Mistura }\end{array}$ & 5070 & $\mathbf{5 0 7 0 C 1 , 5}$ & $5070 \mathrm{C} 3,0$ & $5070 \mathrm{C6}, 0$ & $5070 \mathrm{~L}$ & $\begin{array}{c}5070 \\
\text { C3,0L }\end{array}$ & 3045 & $3045 \mathrm{Cl} 1,5$ & $3045 \mathrm{C} 3,0$ & $3045 \mathrm{C} 6,0$ & 3045L & $\begin{array}{r}3045 \\
\text { C3,0L } \\
\end{array}$ \\
\hline 5070 & - & Não & Não & Sim & Não & Não & Sim & NA & NA & NA & NA & NA \\
\hline $5070 \mathrm{C} 1,5$ & & - & Não & Sim & Não & Não & NA & Não & NA & NA & NA & NA \\
\hline $5070 \mathrm{C} 3,0$ & & & - & Sim & Sim & Não & NA & NA & Não & NA & NA & NA \\
\hline $5070 \mathrm{C} 6,0$ & & & & - & Sim & Sim & NA & NA & NA & Não & NA & NA \\
\hline 5070L & & & & & - & Sim & NA & NA & NA & NA & Sim & NA \\
\hline $5070 \mathrm{C} 3,0 \mathrm{~L}$ & & & & & & - & NA & NA & NA & NA & NA & Sim \\
\hline \multirow{7}{*}{$\begin{array}{c}3045 \\
3045 \mathrm{C} 1,5 \\
3045 \mathrm{C} 3,0 \\
3045 \mathrm{C} 6,0 \\
3045 \mathrm{~L} \\
3045 \mathrm{C} 3,0 \mathrm{~L} \\
\end{array}$} & & & & & & & - & Não & Não & Não & Não & Sim \\
\hline & & & & & & & & - & Não & Não & Não & Não \\
\hline & & & & & & & & & - & Não & Não & Não \\
\hline & & & & & & & & & & - & Não & Não \\
\hline & & & & & & & & & & & - & Sim \\
\hline & & & & & & & & & & & & - \\
\hline & \multicolumn{6}{|c|}{$8 / 30-26,7 \%$ dos testes indicaram médias $\neq$ por tipo de fíler } & $3 /$ & $50 \% \operatorname{dos} t$ & es indicaran & médias $\neq \mathrm{pc}$ & tipo de 1 & ante \\
\hline
\end{tabular}


Tabela C.7 - Resultados dos testes t para a RT (Etapa 2)

\begin{tabular}{|c|c|c|c|c|c|c|c|c|c|c|c|c|}
\hline $\begin{array}{c}\text { Tipo de } \\
\text { Mistura }\end{array}$ & 5070 & $5070 \mathrm{C} 1,5$ & $5070 \mathrm{C} 3,0$ & $5070 \mathrm{C} 6,0$ & $5070 \mathrm{~L}$ & $\begin{array}{c}5070 \\
\mathrm{C3,0L}\end{array}$ & 3045 & $3045 \mathrm{C} 1,5$ & $3045 \mathrm{C} 3,0$ & $3045 \mathrm{C} 6,0$ & 3045L & $\begin{array}{r}3045 \\
\text { C3,0L }\end{array}$ \\
\hline 5070 & - & Não & Não & Não & Não & Não & Sim & NA & NA & NA & NA & NA \\
\hline $5070 \mathrm{C} 1,5$ & & - & Não & Não & Não & Não & NA & Não & NA & NA & NA & NA \\
\hline $5070 \mathrm{C} 3,0$ & & & - & Não & Não & Não & NA & NA & Não & NA & NA & NA \\
\hline $5070 \mathrm{C6}, 0$ & & & & - & Não & Não & NA & NA & NA & Sim & NA & NA \\
\hline 5070L & & & & & - & Não & NA & NA & NA & NA & Não & NA \\
\hline $5070 \mathrm{C} 3,0 \mathrm{~L}$ & & & & & & - & NA & NA & NA & NA & NA & Sim \\
\hline \multirow{7}{*}{$\begin{array}{c}3045 \\
3045 \mathrm{C} 1,5 \\
3045 \mathrm{C} 3,0 \\
3045 \mathrm{C} 6,0 \\
3045 \mathrm{~L} \\
\text { 3045C3,0L } \\
\end{array}$} & & & & & & & - & Não & Não & Não & Não & Não \\
\hline & & & & & & & & - & Não & Sim & Sim & Sim \\
\hline & & & & & & & & & - & Sim & Não & Sim \\
\hline & & & & & & & & & & - & Não & Não \\
\hline & & & & & & & & & & & - & Sim \\
\hline & & & & & & & & & & & & - \\
\hline & \multicolumn{6}{|c|}{$6 / 30-20 \%$ dos testes indicaram médias $\neq$ por tipo de fíler } & $3 / 6$ & $50 \%$ dos te & s indicaran & médias $\neq$ po & tipo de li & Inte \\
\hline
\end{tabular}

Tabela C. 8 - Resultados dos testes t para $\mathrm{MR}_{7 \%}, 25^{\circ} \mathrm{C}$ (Etapa 3)

\begin{tabular}{|c|c|c|c|c|c|c|c|c|}
\hline $\begin{array}{l}\text { Tipo de } \\
\text { Mistura }\end{array}$ & 5070 & $5070 \mathrm{C} 3,0$ & 5070L & $5070 \mathrm{C} 3,0 \mathrm{~L}$ & 3045 & $3045 \mathrm{C} 3,0$ & 3045L & $3045 \mathrm{C} 3,0 \mathrm{~L}$ \\
\hline 5070 & - & Não & Não & Não & Não & NA & NA & NA \\
\hline $5070 \mathrm{C} 3,0$ & & - & Não & Não & NA & Não & NA & NA \\
\hline 5070L & & & - & Não & NA & NA & Não & NA \\
\hline $5070 \mathrm{C} 3,0 \mathrm{~L}$ & & & & - & NA & NA & NA & Não \\
\hline 3045 & & & & & - & Sim & Sim & Não \\
\hline $3045 \mathrm{C} 3,0$ & & & & & & - & Não & Não \\
\hline 3045L & & & & & & & - & Não \\
\hline \multirow{2}{*}{$3045 \mathrm{C} 3,0 \mathrm{~L}$} & & & & & & & & - \\
\hline & $2 / 12-16$ & s testes indi & médias & tipo de fíler & $0 / 4-0$ & estes indicar & $\operatorname{dias} \neq \mathrm{pc}$ & de ligante \\
\hline
\end{tabular}

Tabela C. 9 - Resultados dos testes t para $\mathrm{MR}_{4 \%}, 10^{\circ} \mathrm{C}$ (Etapa 3)

\begin{tabular}{|c|c|c|c|c|c|c|c|c|}
\hline $\begin{array}{c}\text { Tipo de } \\
\text { Mistura }\end{array}$ & 5070 & $5070 \mathrm{C} 3,0$ & $5070 \mathrm{~L}$ & $5070 \mathrm{C} 3,0 \mathrm{~L}$ & 3045 & $3045 \mathrm{C} 3,0$ & $3045 \mathrm{~L}$ & $3045 \mathrm{C} 3,0 \mathrm{~L}$ \\
\hline 5070 & - & Não & Não & Não & Não & NA & NA & NA \\
\hline $5070 \mathrm{C} 3,0$ & & - & Não & Não & NA & Não & NA & NA \\
\hline 5070L & & & - & Não & NA & NA & Não & NA \\
\hline $5070 \mathrm{C3}, 0 \mathrm{~L}$ & & & & - & NA & NA & NA & Não \\
\hline 3045 & & & & & - & Não & Não & Sim \\
\hline $3045 C 3,0$ & & & & & & - & Não & Não \\
\hline 3045L & & & & & & & - & Não \\
\hline \multirow{2}{*}{$3045 \mathrm{C} 3,0 \mathrm{~L}$} & & & & & & & & - \\
\hline & $1 / 12-8$, & testes indic & médias 7 & tipo de fíler & $0 / 4-0$ & estes indica & $\operatorname{dias} \neq p$ & de ligante \\
\hline
\end{tabular}

Tabela C. 10 - Resultados dos testes t para $\mathrm{MR}_{7 \%}, 10^{\circ} \mathrm{C}$ (Etapa 3)

\begin{tabular}{|c|c|c|c|c|c|c|c|c|}
\hline $\begin{array}{l}\text { Tipo de } \\
\text { Mistura }\end{array}$ & 5070 & $5070 \mathrm{C} 3,0$ & $5070 \mathrm{~L}$ & $5070 \mathrm{C} 3,0 \mathrm{~L}$ & 3045 & $3045 \mathrm{C} 3,0$ & 3045L & $3045 \mathrm{C} 3,0 \mathrm{~L}$ \\
\hline 5070 & - & Não & Não & Não & Não & NA & NA & NA \\
\hline $5070 \mathrm{C} 3,0$ & & - & Não & Não & NA & Sim & NA & NA \\
\hline 5070L & & & - & Não & NA & NA & Não & NA \\
\hline $5070 \mathrm{C} 3,0 \mathrm{~L}$ & & & & - & NA & NA & NA & Não \\
\hline 3045 & & & & & - & Não & Não & Não \\
\hline $3045 \mathrm{C} 3,0$ & & & & & & - & Não & Não \\
\hline 3045L & & & & & & & - & Não \\
\hline \multirow[t]{2}{*}{$3045 \mathrm{C} 3,0 \mathrm{~L}$} & & & & & & & & - \\
\hline & $0 / 12-$ & testes indic & nédias $\neq$ & go de fíler & $1 / 4-25^{\circ}$ & stes indicar & édias $\neq p$ & o de ligante \\
\hline
\end{tabular}

Tabela C. 11 - Resultados dos testes t para $\mathrm{MR}_{4 \%}, 40{ }^{\circ} \mathrm{C}$ (Etapa 3)

\begin{tabular}{|c|c|c|c|c|c|c|c|c|}
\hline $\begin{array}{l}\text { Tipo de } \\
\text { Mistura }\end{array}$ & 5070 & $5070 \mathrm{C} 3,0$ & 5070L & $5070 \mathrm{C} 3,0 \mathrm{~L}$ & 3045 & $3045 \mathrm{C} 3,0$ & 3045L & $3045 \mathrm{C} 3,0 \mathrm{~L}$ \\
\hline 5070 & $\overline{-}$ & Não & Não & Não & Não & NA & $\mathrm{NA}$ & $\overline{\mathrm{NA}}$ \\
\hline $5070 \mathrm{C} 3,0$ & & - & Não & Não & NA & Sim & NA & NA \\
\hline $5070 \mathrm{~L}$ & & & - & Não & NA & NA & Sim & NA \\
\hline $5070 \mathrm{C} 3,0 \mathrm{~L}$ & & & & - & NA & NA & NA & Sim \\
\hline 3045 & & & & & - & Não & Não & Sim \\
\hline $3045 C 3,0$ & & & & & & - & Não & Não \\
\hline 3045L & & & & & & & - & Sim \\
\hline \multirow[t]{2}{*}{$3045 \mathrm{C} 3,0 \mathrm{~L}$} & & & & & & & & - \\
\hline & $2 / 12-1$ & os testes ind & médias 7 & ipo de fíler & $3 / 4-75 \%$ & estes indica & édias $\neq 1$ & o de ligante \\
\hline
\end{tabular}


Tabela C. 12 - Resultados dos testes t para $\mathrm{MR}_{7 \%}, 40^{\circ} \mathrm{C}$ (Etapa 3)

\begin{tabular}{|c|c|c|c|c|c|c|c|c|}
\hline $\begin{array}{l}\text { Tipo de } \\
\text { Mistura }\end{array}$ & 5070 & $5070 \mathrm{C} 3,0$ & $5070 \mathrm{~L}$ & $5070 \mathrm{C} 3,0 \mathrm{~L}$ & 3045 & $3045 \mathrm{C} 3,0$ & $3045 \mathrm{~L}$ & $3045 \mathrm{C} 3,0 \mathrm{~L}$ \\
\hline 5070 & - & Não & Não & Não & Não & NA & NA & NA \\
\hline $5070 \mathrm{C} 3,0$ & & - & Não & Não & NA & Não & NA & NA \\
\hline $5070 \mathrm{~L}$ & & & - & Sim & NA & NA & Sim & NA \\
\hline $5070 \mathrm{C} 3,0 \mathrm{~L}$ & & & & - & NA & NA & NA & Não \\
\hline 3045 & & & & & - & Não & Não & Não \\
\hline $3045 \mathrm{C} 3,0$ & & & & & & - & Não & Não \\
\hline 3045L & & & & & & & - & Não \\
\hline \multirow[t]{2}{*}{$3045 \mathrm{C} 3,0 \mathrm{~L}$} & & & & & & & & - \\
\hline & $1 / 12-$ & s testes ind & médias 7 & po de fíler & $4-25$ & stes indica & dias $\neq$ & o de ligante \\
\hline
\end{tabular}

Tabela C.13 - Resultados dos testes t para Dt - creep estático (Etapa 3)

\begin{tabular}{|c|c|c|c|c|c|c|c|c|}
\hline $\begin{array}{c}\text { Tipo de } \\
\text { Mistura }\end{array}$ & 5070 & $5070 \mathrm{C} 3,0$ & $5070 \mathrm{~L}$ & $5070 \mathrm{C} 3,0 \mathrm{~L}$ & 3045 & $3045 C 3,0$ & 3045L & $3045 \mathrm{C} 3,0 \mathrm{~L}$ \\
\hline 5070 & - & Não & Não & Não & Não & NA & NA & NA \\
\hline $5070 \mathrm{C} 3,0$ & & - & Não & Não & NA & Não & NA & NA \\
\hline 5070L & & & - & Não & NA & NA & Não & NA \\
\hline $5070 \mathrm{C} 3,0 \mathrm{~L}$ & & & & - & NA & NA & NA & Não \\
\hline 3045 & & & & & - & Não & Não & Não \\
\hline $3045 C 3,0$ & & & & & & - & Não & Não \\
\hline 3045L & & & & & & & - & Não \\
\hline \multirow[t]{2}{*}{$3045 \mathrm{C} 3,0 \mathrm{~L}$} & & & & & & & & - \\
\hline & $0 / 12-$ & testes indic & nédias $\neq 1$ & po de fíler & $0 / 4-$ & estes indicar & dias $\neq$ po & de ligante \\
\hline
\end{tabular}

Tabela C.14 - Resultados dos testes t para $\mathrm{M}_{\mathrm{f}}$ - creep estático (Etapa 3)

\begin{tabular}{|c|c|c|c|c|c|c|c|c|}
\hline $\begin{array}{l}\text { Tipo de } \\
\text { Mistura }\end{array}$ & 5070 & $5070 \mathrm{C} 3,0$ & $5070 \mathrm{~L}$ & $5070 \mathrm{C} 3,0 \mathrm{~L}$ & 3045 & $3045 C 3,0$ & $3045 \mathrm{~L}$ & $3045 \mathrm{C} 3,0 \mathrm{~L}$ \\
\hline 5070 & - & Não & Não & Não & Não & NA & NA & NA \\
\hline $5070 \mathrm{C} 3,0$ & & - & Não & Não & NA & Não & NA & NA \\
\hline 5070L & & & - & Não & NA & NA & Não & NA \\
\hline $5070 \mathrm{C} 3,0 \mathrm{~L}$ & & & & - & NA & NA & NA & Não \\
\hline 3045 & & & & & - & Não & Não & Não \\
\hline $3045 \mathrm{C} 3,0$ & & & & & & - & Não & Não \\
\hline 3045L & & & & & & & - & Não \\
\hline \multirow[t]{2}{*}{$3045 \mathrm{C} 3,0 \mathrm{~L}$} & & & & & & & & - \\
\hline & $0 / 12$ & testes indi & nédias $\neq$ & o de filer & $0 / 4-1$ & estes indica & $\operatorname{dias} \neq p$ & de ligante \\
\hline
\end{tabular}

Tabela C.15 - Resultados dos testes t para Recuperação - creep estático (Etapa 3)

\begin{tabular}{|c|c|c|c|c|c|c|c|c|}
\hline $\begin{array}{r}\text { Tipo de } \\
\text { Mistura } \\
\end{array}$ & 5070 & $5070 \mathrm{C} 3,0$ & 5070L & $5070 \mathrm{C} 3,0 \mathrm{~L}$ & 3045 & $3045 \mathrm{C} 3,0$ & 3045L & $3045 C 3,0 L$ \\
\hline 5070 & - & Não & Não & Não & Não & NA & NA & NA \\
\hline $5070 \mathrm{C} 3,0$ & & - & Não & Não & NA & Não & NA & NA \\
\hline 5070L & & & - & Não & NA & NA & Não & NA \\
\hline 5070C3,0L & & & & - & NA & NA & NA & Não \\
\hline \multirow{5}{*}{$\begin{array}{c}3045 \\
3045 \mathrm{C3}, 0 \\
3045 \mathrm{~L} \\
\text { 3045C3,0L }\end{array}$} & & & & & - & Não & Não & Não \\
\hline & & & & & & - & Não & Não \\
\hline & & & & & & & - & Não \\
\hline & & & & & & & & - \\
\hline & $0 / 12-$ & testes indic & nédias $\neq$ & o de filer & $0 / 4-c$ & estes indica & $\operatorname{dias} \neq p$ & de ligante \\
\hline
\end{tabular}

Tabela C.16 - Resultados dos testes t para $\mathrm{I}_{\text {curva }}$ - creep estático (Etapa 3)

\begin{tabular}{|c|c|c|c|c|c|c|c|c|}
\hline $\begin{array}{l}\text { Tipo de } \\
\text { Mistura }\end{array}$ & 5070 & $5070 \mathrm{C} 3,0$ & $5070 \mathrm{~L}$ & $5070 \mathrm{C} 3,0 \mathrm{~L}$ & 3045 & $3045 \mathrm{C} 3,0$ & 3045L & $3045 \mathrm{C} 3,0 \mathrm{~L}$ \\
\hline 5070 & - & Não & Não & Não & Não & NA & NA & NA \\
\hline $5070 \mathrm{C} 3,0$ & & - & Não & Não & NA & Não & NA & NA \\
\hline 5070L & & & - & Não & NA & NA & Não & NA \\
\hline $5070 \mathrm{C} 3,0 \mathrm{~L}$ & & & & - & NA & NA & NA & Não \\
\hline 3045 & & & & & - & Sim & Não & Sim \\
\hline $3045 C 3,0$ & & & & & & - & Não & Não \\
\hline 3045L & & & & & & & - & Não \\
\hline \multirow{2}{*}{$3045 \mathrm{C} 3,0 \mathrm{~L}$} & & & & & & & & - \\
\hline & $2 / 12-16$ & $s$ testes indi & médias & tipo de fíler & $0 / 4-0$ & estes indicar & $\operatorname{dias} \neq \mathrm{pc}$ & de ligante \\
\hline
\end{tabular}


Tabela C.17 - Resultados dos testes t para $\mathrm{RT}_{\text {creep }}$ (Etapa 3)

\begin{tabular}{|c|c|c|c|c|c|c|c|c|}
\hline $\begin{array}{l}\text { Tipo de } \\
\text { Mistura } \\
\end{array}$ & 5070 & $5070 \mathrm{C} 3,0$ & 5070L & $5070 \mathrm{C} 3,0 \mathrm{~L}$ & 3045 & $3045 C 3,0$ & 3045L & $3045 \mathrm{C} 3,0 \mathrm{~L}$ \\
\hline 5070 & - & Não & Não & Não & Sim & NA & NA & $\mathrm{NA}$ \\
\hline $5070 \mathrm{C} 3,0$ & & - & Não & Não & NA & Não & NA & NA \\
\hline $5070 \mathrm{~L}$ & & & - & Não & $\mathrm{NA}$ & NA & Não & NA \\
\hline $5070 \mathrm{C} 3,0 \mathrm{~L}$ & & & & - & NA & $\mathrm{NA}$ & NA & Não \\
\hline \multirow{5}{*}{$\begin{array}{c}3045 \\
3045 \mathrm{C} 3,0 \\
3045 \mathrm{~L} \\
3045 \mathrm{C} 3,0 \mathrm{~L} \\
\end{array}$} & & & & & - & Nâo & Nâo & Não \\
\hline & & & & & & - & Não & Não \\
\hline & & & & & & & & Não \\
\hline & & & & & & & & - \\
\hline & $0 / 12$ & testes indic & nédias $\neq$ & oo de filer & $1 / 4-25^{\circ}$ & estes indica & édias $\neq 1$ & oo de ligante \\
\hline
\end{tabular}


APÊNDICE D - Cálculo dos parâmetros D10, D30, D60 e MF para cada tipo de mistura e procedimentos para regressões lineares entre os parâmetros de caracterização do fíler versus variáveis-resposta

Os parâmetros D10, D30, D60 e MF de cada tipo de mistura foram calculados tomando por base os valores destes parâmetros de cada fíler (indicados na seção 3.1.5) e suas respectivas proporções nas misturas, conforme indicado na Tabela D.1.

Tabela D.1 - Cálculo dos parâmetros D10, D30, D60 e MF para as misturas asfálticas

\begin{tabular}{|c|c|c|c|c|c|c|c|c|c|}
\hline Parâmetro & $\begin{array}{c}\text { Granito } \\
\text { G }\end{array}$ & $\begin{array}{c}\text { Caulim } \\
\text { C }\end{array}$ & $\begin{array}{c}\text { Cal } \\
\text { L }\end{array}$ & $\begin{array}{c}\mathbf{5 0 7 0} \\
\mathbf{3 0 4 5} \\
100 \% \mathrm{G} \\
0 \% \mathrm{C} \\
0 \% \mathrm{~L}\end{array}$ & $\begin{array}{c}\mathbf{5 0 7 0 C 1 , 5} \\
\mathbf{3 0 4 5 C 1 , 5} \\
75 \% \mathrm{G} \\
25 \% \mathrm{C} \\
0 \% \mathrm{~L}\end{array}$ & $\begin{array}{c}\mathbf{5 0 7 0 C 3 , 0} \\
\mathbf{3 0 4 5 C 3 , 0} \\
50 \% \mathrm{G} \\
50 \% \mathrm{C} \\
0 \% \mathrm{~L}\end{array}$ & $\begin{array}{c}\mathbf{5 0 7 0 C 6 , 0} \\
\mathbf{3 0 4 5 C 6 , 0} \\
0 \% \mathrm{G} \\
100 \% \mathrm{C} \\
0 \% \mathrm{~L}\end{array}$ & $\begin{array}{l}\text { 5070L } \\
\text { 3045L } \\
75 \% \mathrm{G} \\
0 \% \mathrm{C} \\
25 \% \mathrm{~L}\end{array}$ & $\begin{array}{c}\mathbf{5 0 7 0 C 3 , 0 L} \\
\mathbf{3 0 4 5 C 3 , 0 L} \\
25 \% \mathrm{G} \\
50 \% \mathrm{C} \\
25 \% \mathrm{~L}\end{array}$ \\
\hline $\mathrm{D} 10(\mathrm{~mm})$ & 0,00441 & 0,00008 & 0,01050 & 0,00441 & 0,00333 & 0,00225 & 0,00008 & 0,00593 & 0,00377 \\
\hline $\mathrm{D} 30(\mathrm{~mm})$ & 0,01515 & 0,00027 & 0,01258 & 0,01515 & 0,01143 & 0,00771 & 0,00027 & 0,01451 & 0,00707 \\
\hline $\mathrm{D} 60(\mathrm{~mm})$ & 0,03640 & 0,00157 & 0,01799 & 0,03640 & 0,02769 & 0,01899 & 0,00157 & 0,03180 & 0,01438 \\
\hline MF & 4,92 & 1,24 & 4,71 & 4,92 & 4,00 & 3,08 & 1,24 & 4,87 & 3,03 \\
\hline
\end{tabular}

As regressões lineares foram efetuadas no software Excel, com o uso da ferramenta Análise de Dados - Regressão. Além dos valores de $\mathrm{R}^{2}$, também se indicou, por meio de análise de variância, se a relação entre as variáveis em estudo pode ser considerada como linear a um nível de significância de 5\%. Para tanto, comparou-se a estatística $\mathrm{F}$ do teste com $\alpha=0,05$. Se $\mathrm{F} \leq \alpha$, a relação é considerada linear. Adotou-se o seguinte critério para classificar a qualidade da correlação:

$>$ se o valor de $\mathrm{R}^{2} \geq 0,90$ a correlação é classificada como excelente;

$>$ se $0,75 \leq \mathrm{R}^{2}<0,90$ a correlação é classificada como boa, e;

$>$ se $\mathrm{R}^{2}<0,75$ a relação é classificada como moderada, desde que considerada válida pela análise de variância.

Estes processos estão ilustrados na Figura D.1, onde se verifica a moderada correlação linear entre o teor de caulim e o teor de projeto de todas as misturas $\left(\mathrm{R}^{2}=0,73\right.$ e $\mathrm{F}=0,007 \rightarrow$ linear $)$ e a ausência de correlação linear $\left(\mathrm{R}^{2}=0,01\right.$ e $\mathrm{F}=0,899 \rightarrow$ Não linear) entre D10 e teor de projeto das misturas com CAP 50/70. 


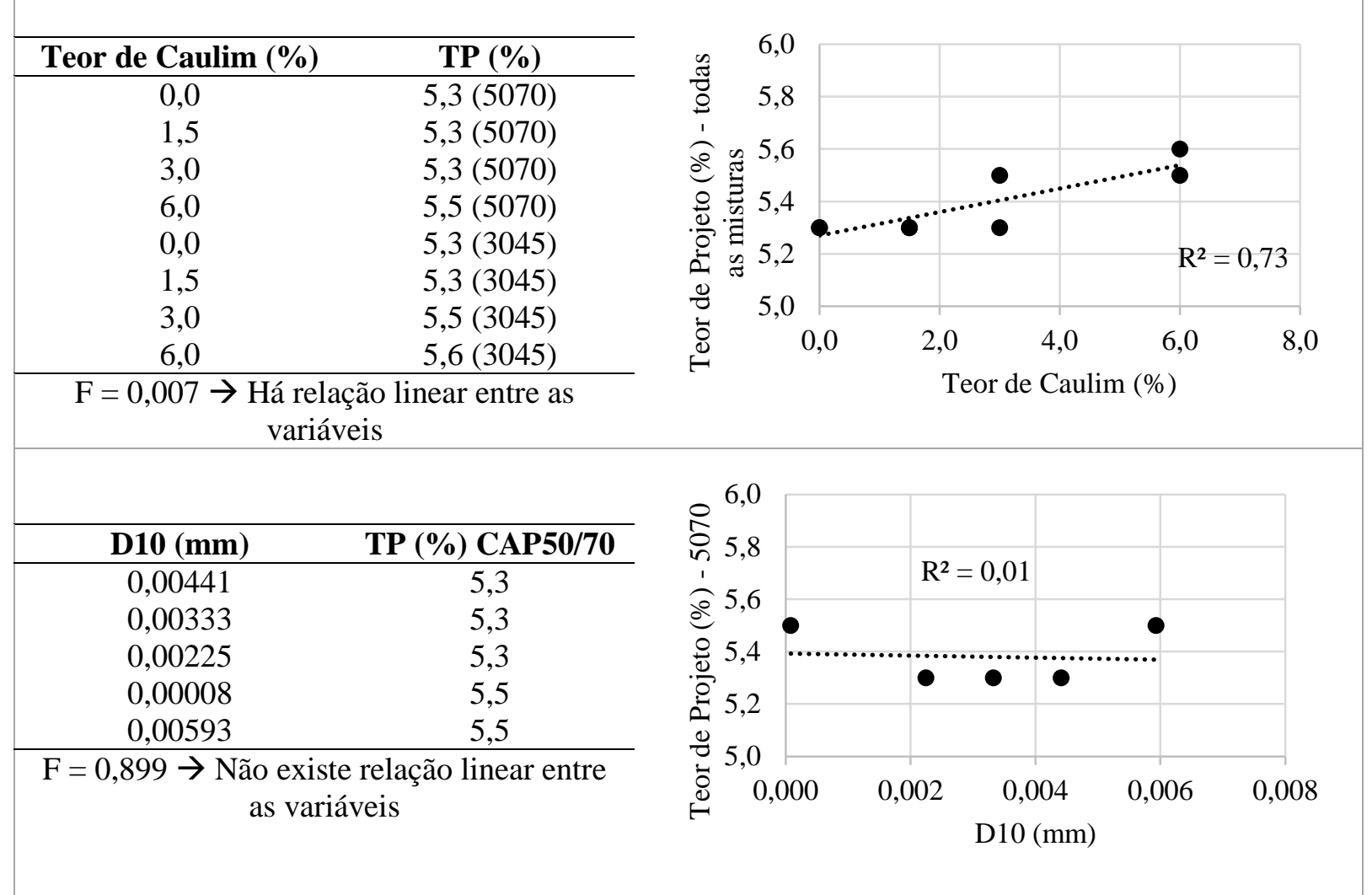

Figura D.1 - Exemplos de regressões lineares entre os parâmetros de caracterização do fíler versus TP 
APÊNDICE E - Dimensões, volume de vazios e propriedades mecânicas de cada corpo de prova utilizado da Etapa 2, agrupados por tipo de mistura asfáltica.

Tabela E.1 - Resultados da caracterização mecânica básica para a mistura 5070 (TP = 5,3\%)

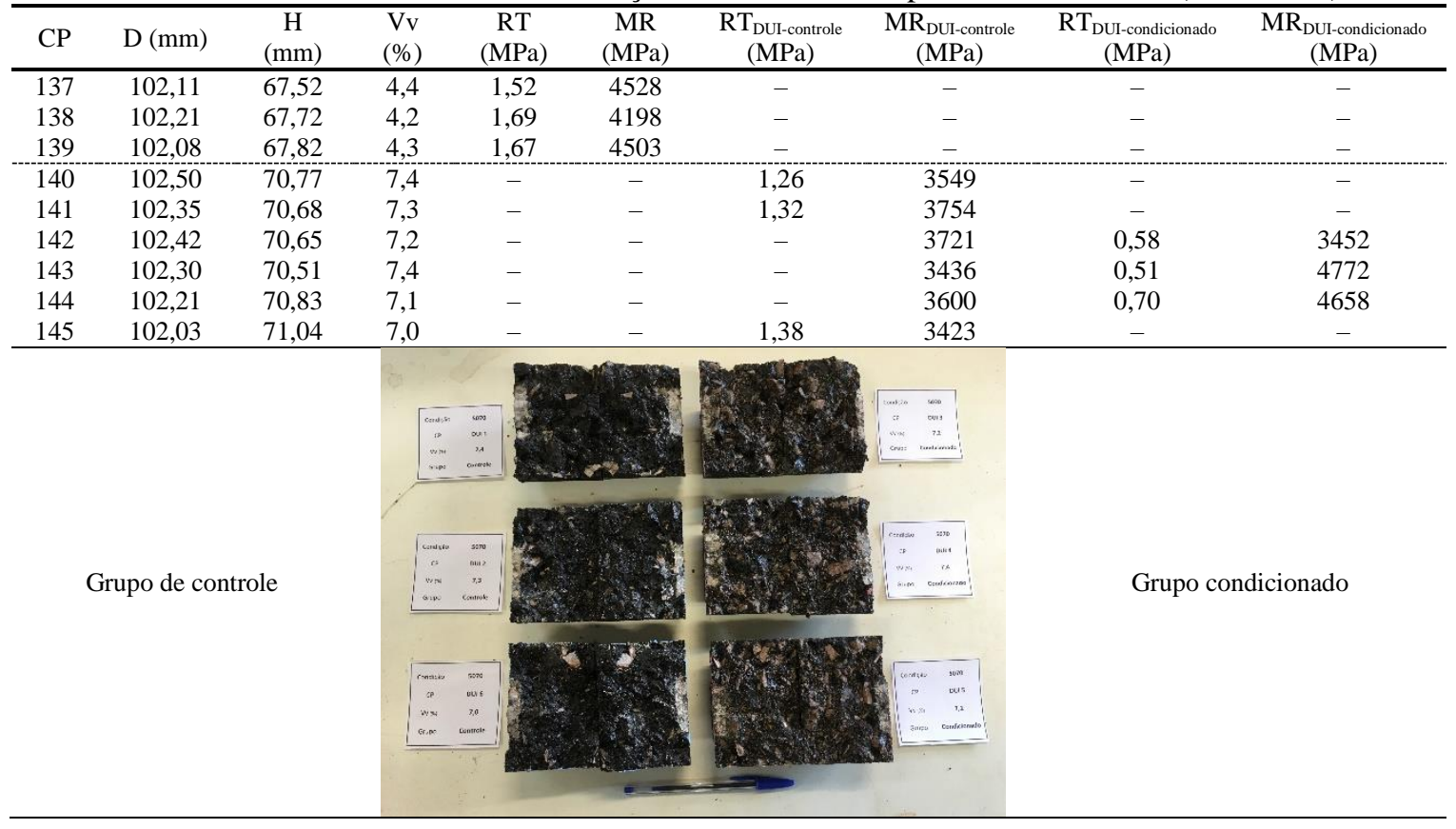

Tabela E.2 - Resultados da caracterização mecânica básica para a mistura 5070C1,5 (TP = 5,3\%)

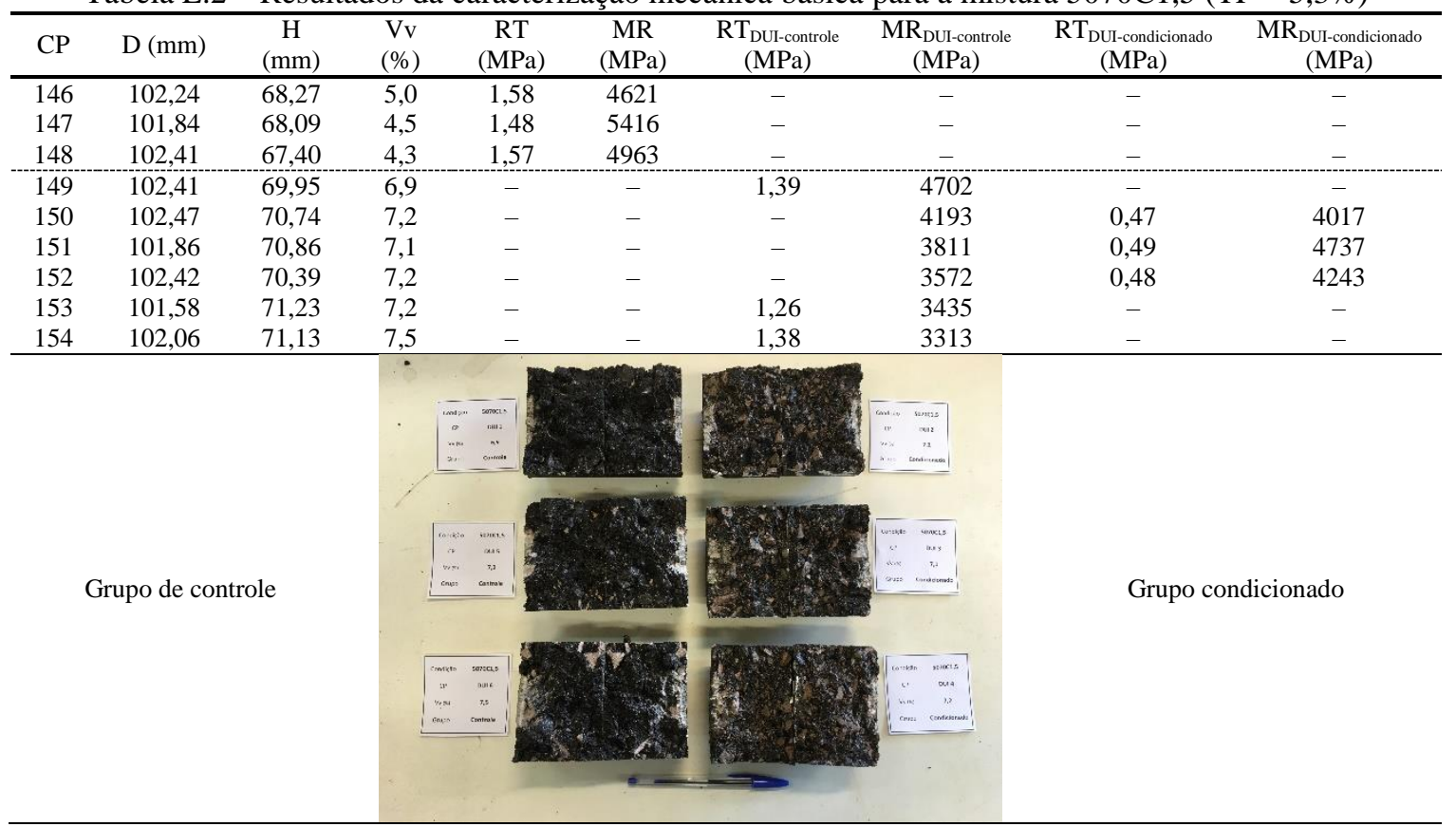


Tabela E.3 - Resultados da caracterização mecânica básica para a mistura 5070C3,0 (TP = 5,3\%)

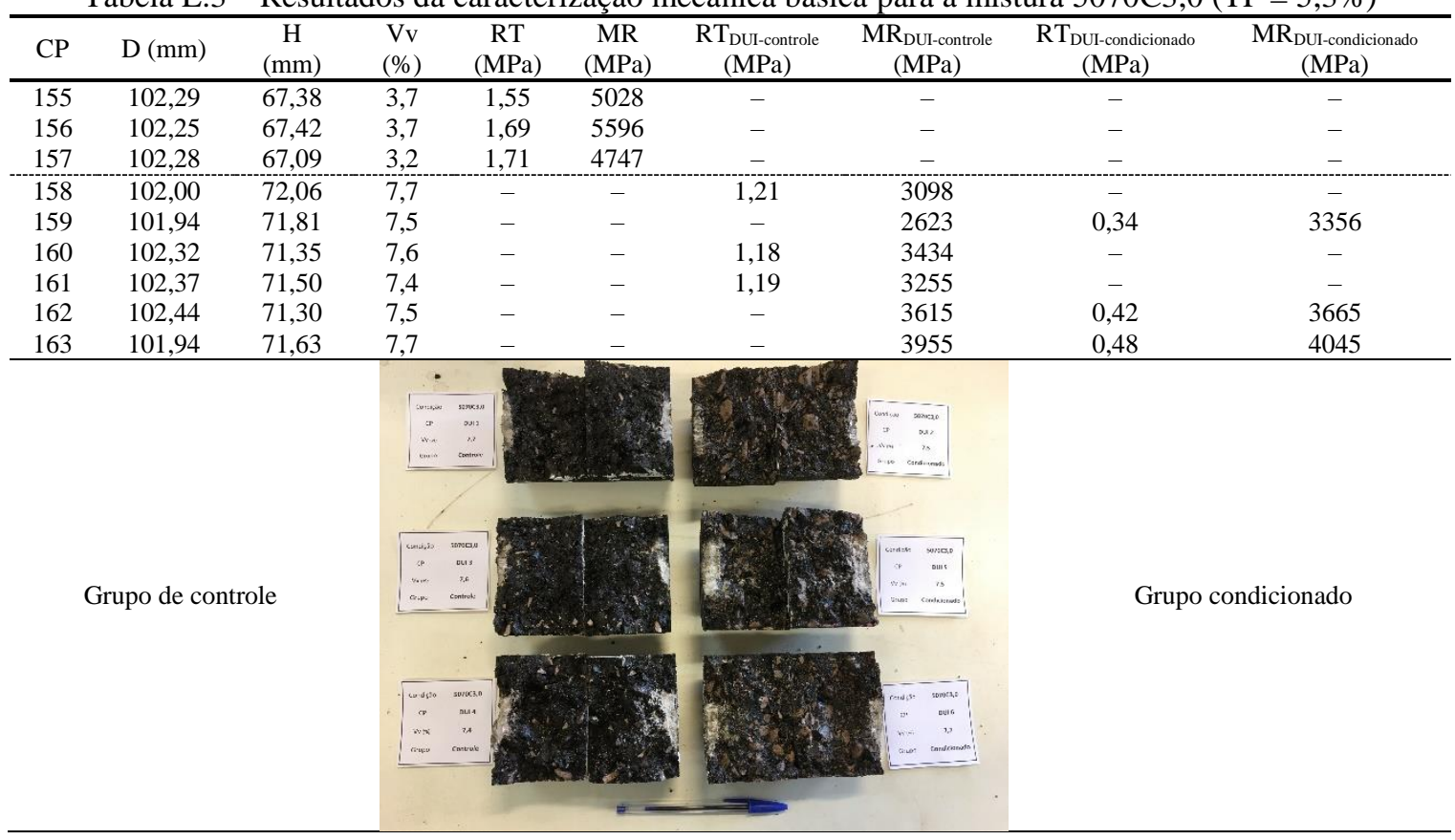

Tabela E.4 - Resultados da caracterização mecânica básica para a mistura 5070C6,0 (TP = 5,5\%)

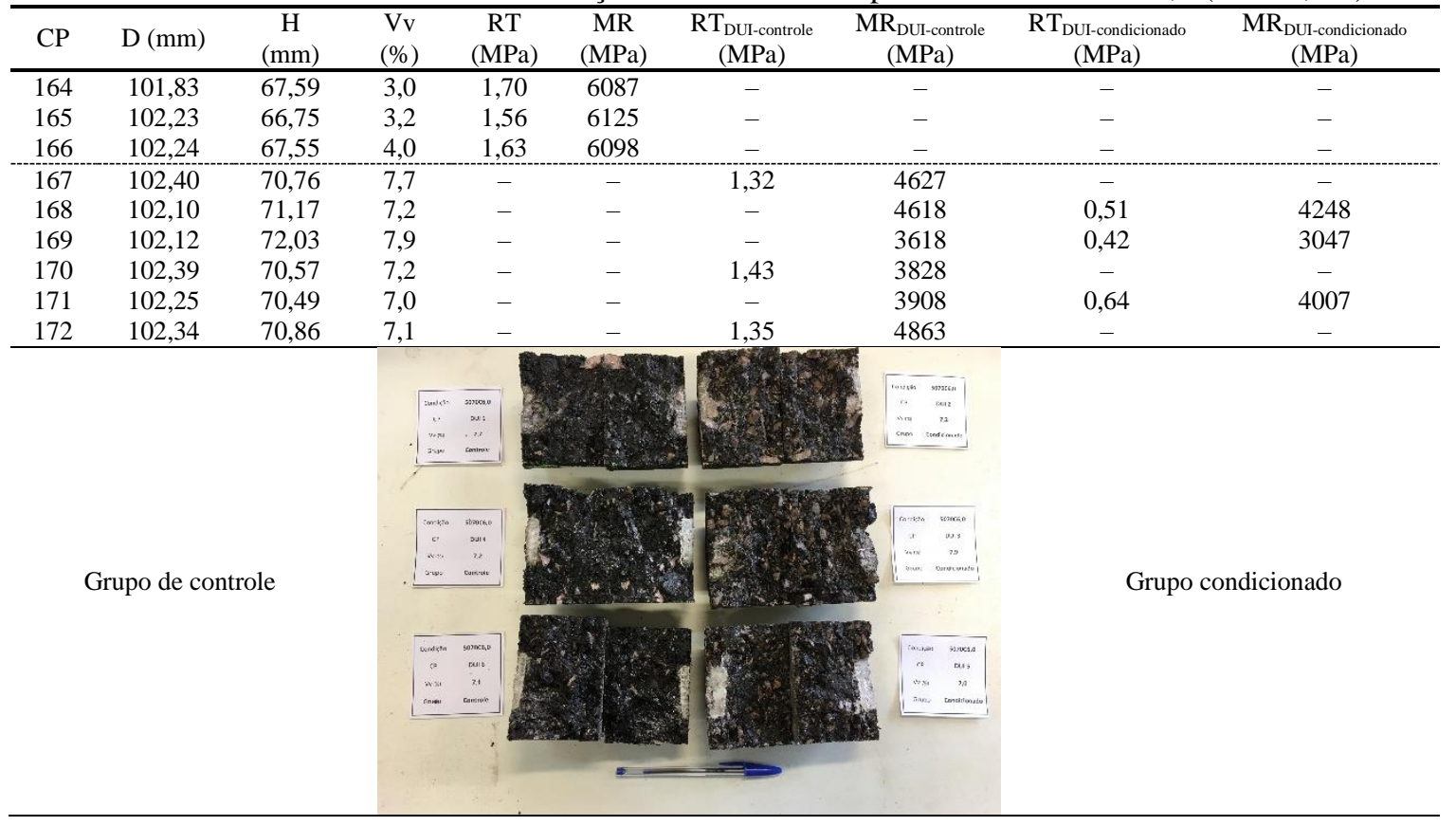


Tabela E.5 - Resultados da caracterização mecânica básica para a mistura 5070L (TP = 5,5\%)

\begin{tabular}{|c|c|c|c|c|c|c|c|c|c|}
\hline $\mathrm{CP}$ & $\mathrm{D}(\mathrm{mm})$ & $\begin{array}{c}\mathrm{H} \\
(\mathrm{mm})\end{array}$ & $\begin{array}{l}\text { Vv } \\
(\%)\end{array}$ & $\begin{array}{c}\mathrm{RT} \\
(\mathrm{MPa})\end{array}$ & $\begin{array}{c}\text { MR } \\
(\mathrm{MPa})\end{array}$ & $\begin{array}{c}\mathrm{RT}_{\text {DUI-controle }} \\
(\mathrm{MPa})\end{array}$ & $\begin{array}{l}\mathrm{MR}_{\text {DUI-controle }} \\
(\mathrm{MPa})\end{array}$ & $\begin{array}{c}\mathrm{RT}_{\text {DUI-condicionado }} \\
(\mathrm{MPa})\end{array}$ & $\begin{array}{l}\mathrm{MR}_{\text {DUI-condicionado }} \\
\text { (MPa) }\end{array}$ \\
\hline 173 & 102,34 & 67,59 & 3,7 & 1,54 & 4011 & - & - & - & - \\
\hline 174 & 102,26 & 67,78 & 3,4 & 1,57 & 4326 & - & - & - & - \\
\hline 176 & 102,33 & 71,96 & 7,9 & - & - & 1,16 & 3776 & - & - \\
\hline 177 & 102,18 & 71,91 & 7,5 & - & - & - & 3851 & 0,99 & 5108 \\
\hline 178 & 102,40 & 71,47 & 7,7 & - & - & 1,21 & 3697 & - & - \\
\hline 180 & 101,87 & 72,66 & 7,2 & - & - & 1,20 & 4362 & - & - \\
\hline 181 & 102,32 & 71,51 & 7,3 & - & - & - & 3049 & $1,19 *$ & 4070 \\
\hline
\end{tabular}

Grupo de controle

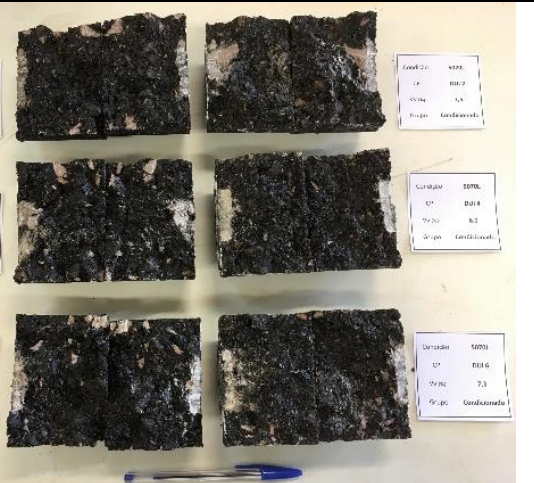

Grupo condicionado

* - valor excluído pelo método de Grubbs.

Tabela E.6 - Resultados da caracterização mecânica básica para a mistura 5070C3,0L (TP = 5,3\%)

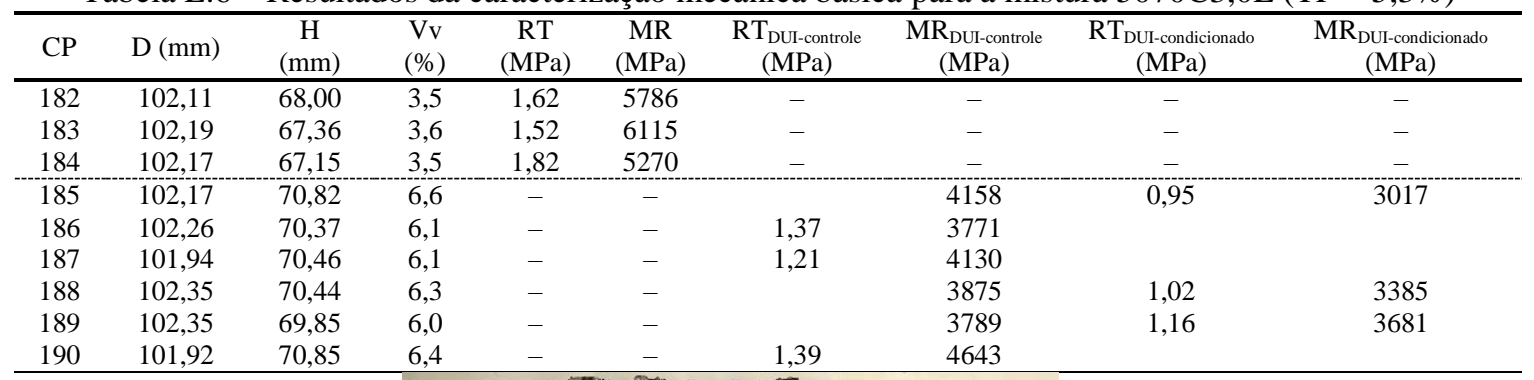

Grupo de controle

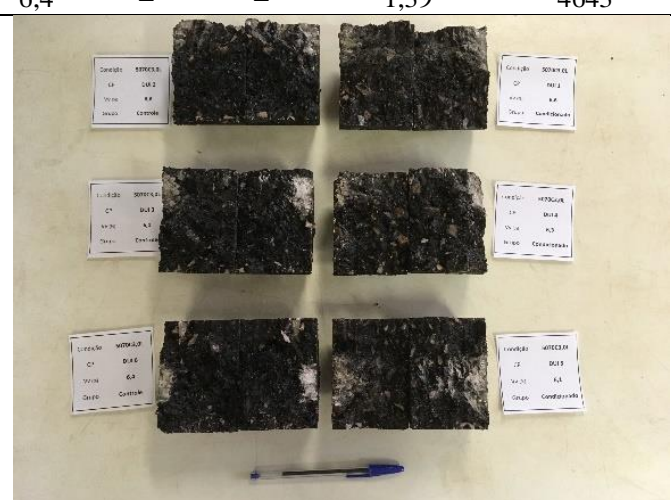

Grupo condicionado

Tabela E.7 - Resultados da dosagem Marshall para a mistura 5070C3,0L

\begin{tabular}{|c|c|c|c|c|c|c|c|c|c|c|c|c|c|c|}
\hline $\mathrm{CP}$ & $\begin{array}{c}\mathrm{P}_{\mathrm{b}} \\
(\%)\end{array}$ & $\mathrm{D}(\mathrm{mm})$ & $\begin{array}{c}\mathrm{H} \\
(\mathrm{mm})\end{array}$ & $\mathrm{M}_{\mathrm{ar}}(\mathrm{g})$ & $\begin{array}{c}\mathrm{M}_{\mathrm{im}} \\
(\mathrm{g})\end{array}$ & $\mathrm{M}_{\text {SSS }}(\mathrm{g})$ & $\begin{array}{c}\mathrm{V} \\
\left(\mathrm{cm}^{3}\right)\end{array}$ & $\mathrm{G}_{\mathrm{mb}}$ & $\mathrm{G}_{\mathrm{mm}}$ & $\begin{array}{l}\mathrm{Vv} \\
(\%)\end{array}$ & $\begin{array}{c}\text { E } \\
(\mathrm{kgf})\end{array}$ & $\begin{array}{c}\mathrm{F} \\
(\mathrm{mm})\end{array}$ & $\begin{array}{c}\text { VAM } \\
(\%)\end{array}$ & $\begin{array}{c}\text { RBV } \\
(\%)\end{array}$ \\
\hline 191 & 5,3 & 102,48 & 67,18 & 1248,3 & 713,3 & 1250,4 & 537,1 & 2,324 & 2,408 & 3,5 & 1015 & 3,01 & 15,4 & 77,5 \\
\hline 192 & 5,3 & 101,83 & 67,24 & 1251,9 & 715,8 & 1255,0 & 539,2 & 2,322 & 2,408 & 3,6 & 901 & 1,96 & 15,5 & 76,9 \\
\hline 193 & 5,3 & 102,21 & 66,78 & 1257,6 & 721,6 & 1262,7 & 541,1 & 2,324 & 2,408 & 3,5 & 1100 & 3,10 & 15,4 & 77,5 \\
\hline
\end{tabular}

O CP 194 foi utilizado no ensaio RICE, o qual resultou em $\mathrm{G}_{\mathrm{mm}}=2,408$ 
Tabela E.8 - Resultados da caracterização mecânica básica para a mistura $3045(\mathrm{TP}=5,3 \%)$

\begin{tabular}{|c|c|c|c|c|c|c|c|c|c|}
\hline $\mathrm{CP}$ & $\mathrm{D}(\mathrm{mm})$ & $\begin{array}{c}\mathrm{H} \\
(\mathrm{mm})\end{array}$ & $\begin{array}{l}\mathrm{Vv} \\
(\%)\end{array}$ & $\begin{array}{c}\mathrm{RT} \\
(\mathrm{MPa})\end{array}$ & $\begin{array}{c}\text { MR } \\
(\mathrm{MPa})\end{array}$ & $\begin{array}{c}\mathrm{RT}_{\text {DUI-controle }} \\
(\mathrm{MPa})\end{array}$ & $\begin{array}{l}\mathrm{MR}_{\text {DUI-controle }} \\
(\mathrm{MPa})\end{array}$ & $\begin{array}{l}\mathrm{RT}_{\text {DUI-condicionado }} \\
\text { (MPa) }\end{array}$ & $\begin{array}{c}\mathrm{MR}_{\text {DUI-condicionado }} \\
\text { (MPa) }\end{array}$ \\
\hline 195 & 102,12 & 67,35 & 4,1 & 1,86 & 6010 & - & - & - & - \\
\hline 196 & 101,62 & 67,39 & 3,7 & 2,01 & 5809 & - & - & - & - \\
\hline 198 & 101,86 & 71,42 & 7,0 & - & - & 1,29 & 3367 & - & - \\
\hline 199 & 102,62 & 71,06 & 7,5 & - & - & 1,25 & 3420 & - & - \\
\hline 202 & 101,98 & 70,82 & 7,1 & - & - & 1,31 & 3708 & - & - \\
\hline 203 & 101,94 & 70,82 & 7,1 & - & - & - & 2742 & 0,76 & 3404 \\
\hline
\end{tabular}

Tabela E.9 - Resultados da caracterização mecânica básica para a mistura 3045C1,5 (TP = 5,3\%)

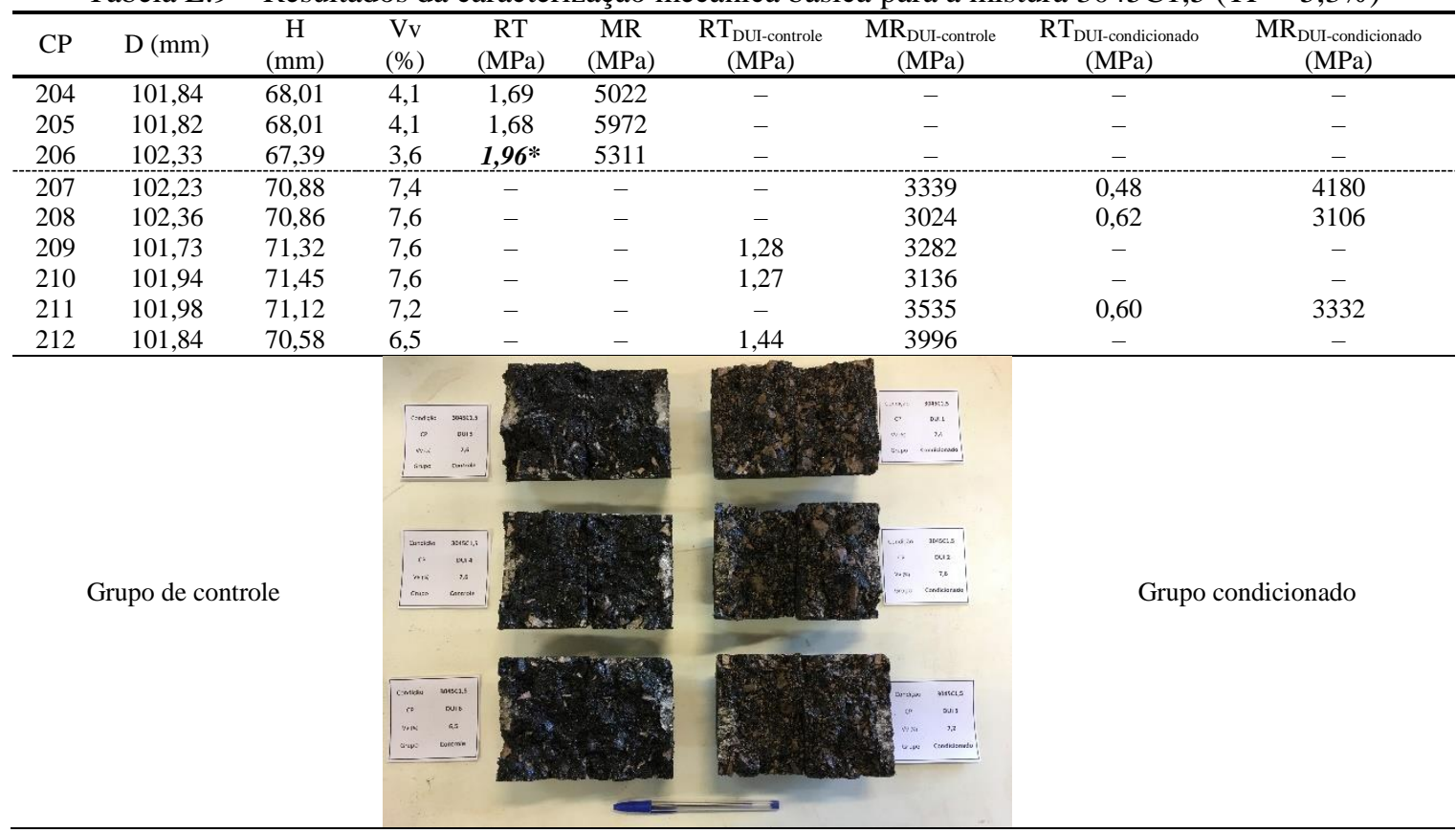

* - valor excluído pelo método de Grubbs. 
Tabela E.10 - Resultados da caracterização mecânica básica para a mistura 3045C3,0 (TP = 5,5\%)

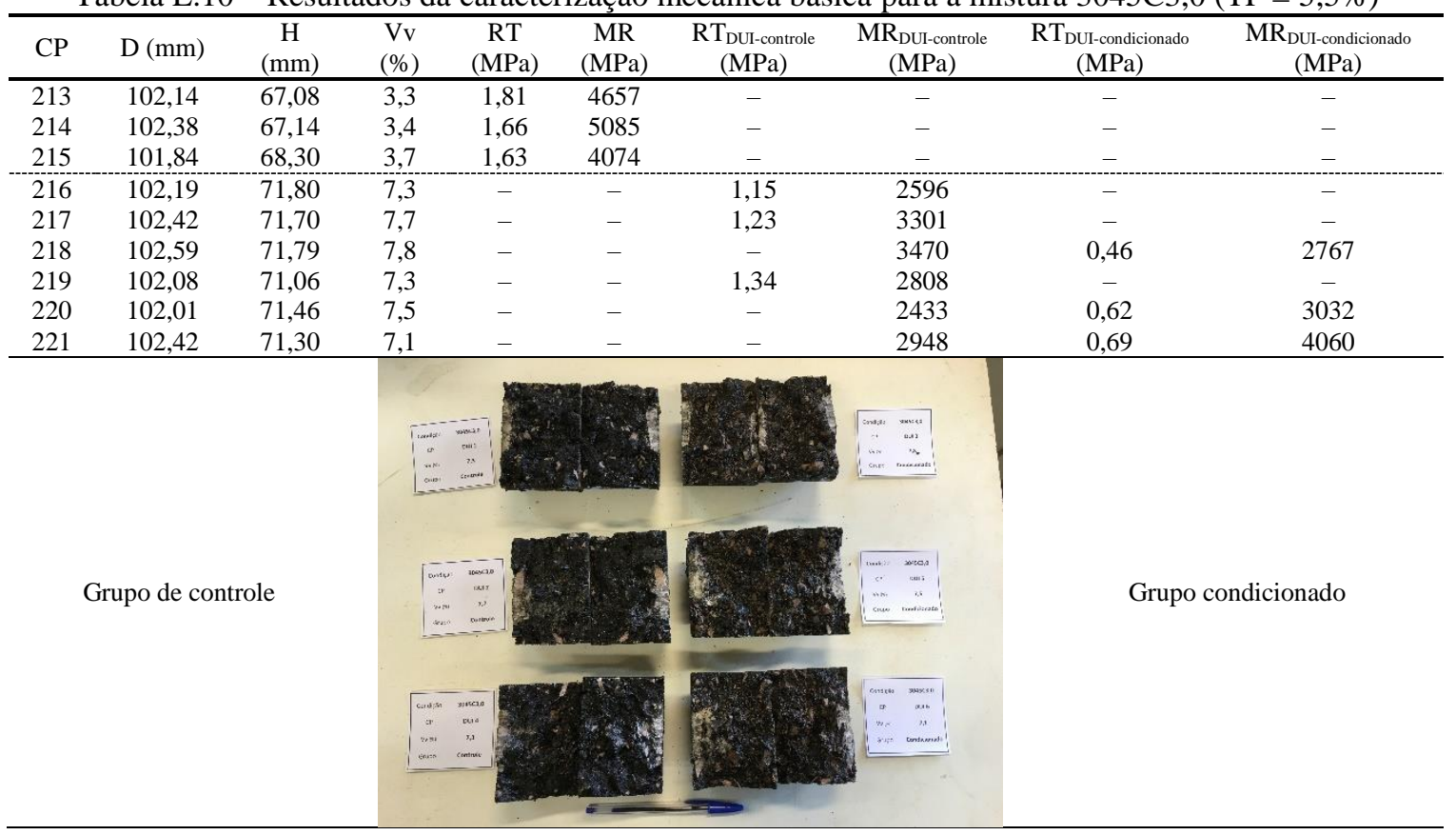

Tabela E.11 - Resultados da caracterização mecânica básica para a mistura 3045C6,0 (TP = 5,6\%)

\begin{tabular}{|c|c|c|c|c|c|c|c|c|c|}
\hline $\mathrm{CP}$ & $\mathrm{D}(\mathrm{mm})$ & $\begin{array}{c}\mathrm{H} \\
(\mathrm{mm})\end{array}$ & $\begin{array}{l}\mathrm{Vv} \\
(\%)\end{array}$ & $\begin{array}{c}\mathrm{RT} \\
(\mathrm{MPa})\end{array}$ & $\begin{array}{c}\mathrm{MR} \\
(\mathrm{MPa})\end{array}$ & $\begin{array}{l}\mathrm{RT}_{\text {DUI-controle }} \\
\text { (MPa) }\end{array}$ & $\begin{array}{c}\mathrm{MR}_{\text {DUI-controle }} \\
(\mathrm{MPa})\end{array}$ & $\begin{array}{c}\mathrm{RT}_{\text {DUI-condicionado }} \\
(\mathrm{MPa})\end{array}$ & $\begin{array}{c}\mathrm{MR}_{\text {DUI-condicionado }} \\
\text { (MPa) }\end{array}$ \\
\hline 222 & 101,86 & 67,67 & 3,1 & 1,95 & 4111 & - & - & - & - \\
\hline 223 & 101,58 & 67,85 & 3,4 & 1,87 & 6099 & - & - & - & - \\
\hline 224 & 102,34 & 67,01 & 3,2 & 1,90 & 5885 & - & - & - & - \\
\hline 225 & 102,37 & 71,42 & 7,2 & - & - & 1,28 & 4179 & - & - \\
\hline 226 & 102,48 & 71,90 & 7,9 & - & - & - & 3065 & $0,51 *$ & 2719 \\
\hline 227 & 101,90 & 71,56 & 6,7 & - & - & 1,57 & 4107 & - & - \\
\hline 228 & 102,41 & 70,62 & 6,6 & - & - & - & 4420 & 0,93 & 4004 \\
\hline 229 & 101,86 & 71,59 & 6,8 & - & - & 1,52 & 3498 & - & - \\
\hline 230 & 102,31 & 70,73 & 6,6 & - & - & - & 4974 & 0,92 & 3861 \\
\hline
\end{tabular}

Grupo de controle

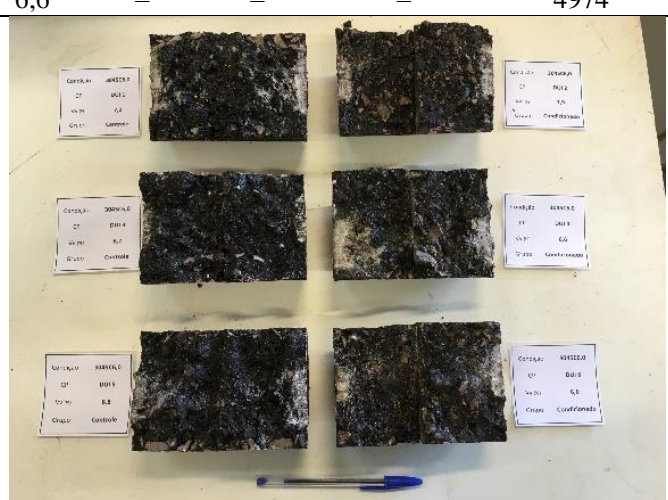

Grupo condicionado

* - valor excluído pelo método de Grubbs. 
Tabela E.12 - Resultados da caracterização mecânica básica para a mistura 3045L (TP = 5,5\%)

\begin{tabular}{|c|c|c|c|c|c|c|c|c|c|}
\hline $\mathrm{CP}$ & $\mathrm{D}(\mathrm{mm})$ & $\begin{array}{c}\mathrm{H} \\
(\mathrm{mm})\end{array}$ & $\begin{array}{l}\mathrm{Vv} \\
(\%)\end{array}$ & $\begin{array}{c}\mathrm{RT} \\
(\mathrm{MPa})\end{array}$ & $\begin{array}{c}\text { MR } \\
(\mathrm{MPa})\end{array}$ & $\begin{array}{l}\mathrm{RT}_{\text {DUI-controle }} \\
(\mathrm{MPa})\end{array}$ & $\begin{array}{l}\mathrm{MR}_{\text {DUI-controle }} \\
(\mathrm{MPa})\end{array}$ & $\begin{array}{l}\mathrm{RT}_{\text {DUI-condicionado }} \\
(\mathrm{MPa})\end{array}$ & $\begin{array}{c}\mathrm{MR}_{\text {DUI-condicionado }} \\
(\mathrm{MPa})\end{array}$ \\
\hline 231 & 102,13 & 67,85 & 4,2 & 1,83 & 4436 & - & - & - & - \\
\hline 232 & 101,78 & 68,70 & 4,0 & 1,85 & 5532 & - & - & - & - \\
\hline 233 & 102,31 & 68,03 & 4,1 & 1,85 & 5316 & - & - & - & - \\
\hline 234 & 101,99 & 70,37 & 6,6 & - & - & - & 4471 & 1,26 & 4871 \\
\hline 235 & 102,13 & 70,54 & 7,2 & - & - & 1,44 & 4436 & - & - \\
\hline 236 & 101,81 & 70,59 & 6,9 & - & - & 1,36 & 4192 & - & - \\
\hline 237 & 102,02 & 71,36 & 7,9 & - & - & 1,30 & 4382 & - & - \\
\hline 238 & 102,18 & 70,89 & 7,4 & - & - & - & 3529 & 1,10 & 3812 \\
\hline 239 & 102,31 & 70,52 & 7,9 & - & - & - & 3435 & 1,33 & 3604 \\
\hline \multicolumn{3}{|c|}{ Grupo de controle } & & & & & 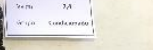 & \multicolumn{2}{|c|}{ Grupo condicionado } \\
\hline
\end{tabular}

Tabela E.13 - Resultados da caracterização mecânica básica para a mistura 3045C3,0L (TP = 5,5\%)

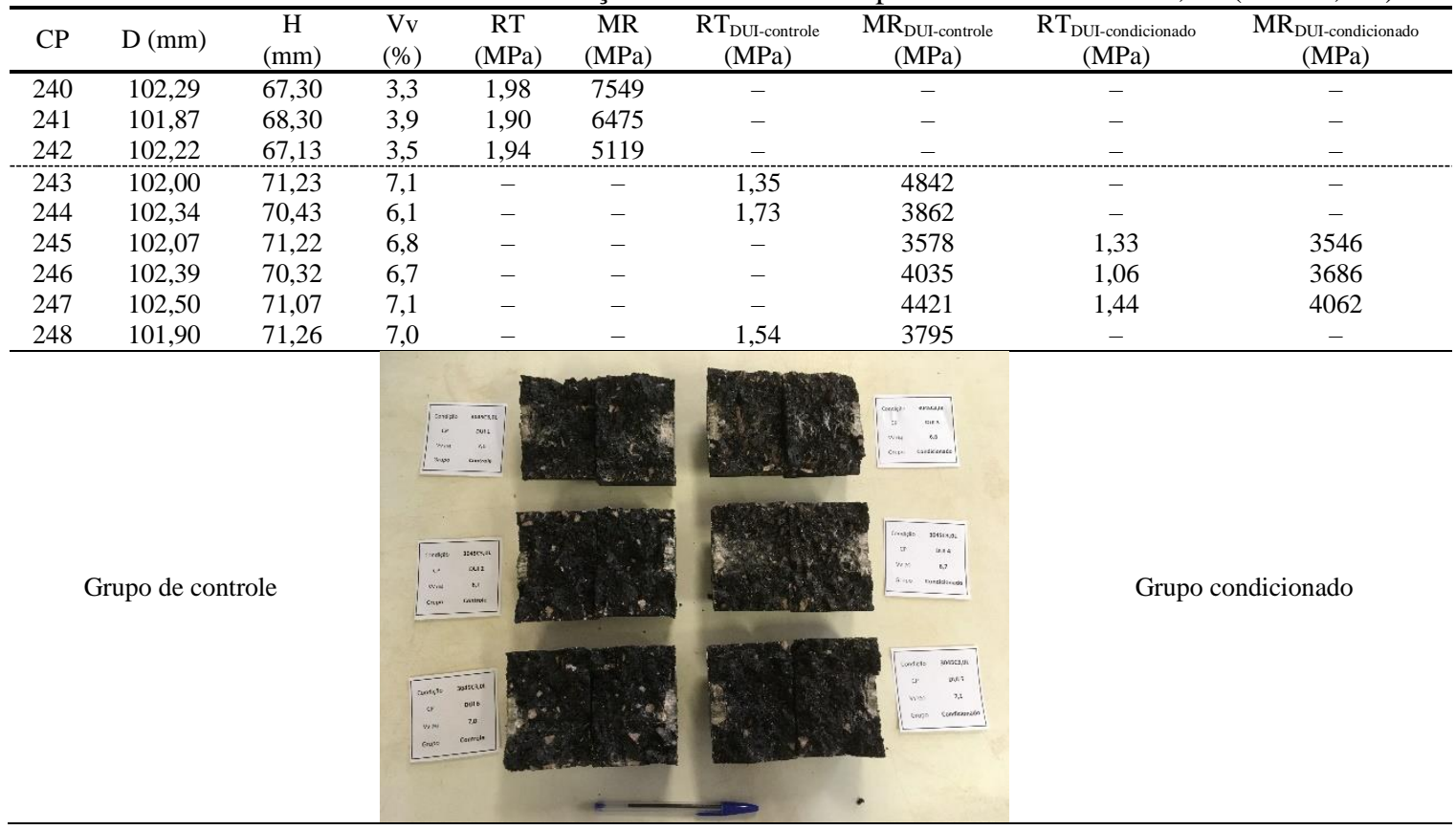

Tabela E.14 - Resultados da dosagem Marshall para a mistura 3045C3,0L

\begin{tabular}{|c|c|c|c|c|c|c|c|c|c|c|c|c|c|c|}
\hline $\mathrm{CP}$ & $\begin{array}{l}\mathrm{P}_{\mathrm{b}} \\
(\%)\end{array}$ & $\mathrm{D}(\mathrm{mm})$ & $\begin{array}{c}\mathrm{H} \\
(\mathrm{mm})\end{array}$ & $\mathrm{M}_{\mathrm{ar}}(\mathrm{g})$ & $\begin{array}{c}M_{\text {im }} \\
(\mathrm{g})\end{array}$ & $\begin{array}{c}M_{\text {SSS }} \\
(\mathrm{g})\end{array}$ & $\begin{array}{c}\mathrm{V} \\
\left(\mathrm{cm}^{3}\right)\end{array}$ & $\mathrm{G}_{\mathrm{mb}}$ & $\mathrm{G}_{\mathrm{mm}}$ & $\begin{array}{c}\mathrm{VV} \\
(\%)\end{array}$ & $\begin{array}{c}E \\
\text { (kgf) }\end{array}$ & $\begin{array}{c}\mathrm{F} \\
(\mathrm{mm})\end{array}$ & $\begin{array}{c}\text { VAM } \\
(\%)\end{array}$ & $\begin{array}{c}\text { RBV } \\
(\%)\end{array}$ \\
\hline 249 & 5,5 & & 67,89 & 1250,4 & 709,4 & 1251,1 & 541,7 & 2,308 & 2,407 & 4,1 & 1208 & 3,06 & 16,2 & 74,7 \\
\hline 250 & 5,5 & 102,37 & 67,14 & 1251,0 & 712,9 & 1251,7 & 538,8 & 2,322 & 2,407 & 3,5 & 1321 & 2,90 & 15,7 & 77,5 \\
\hline 251 & 5,5 & 102,37 & 66,58 & 1250,2 & 714,8 & 1250,6 & 535,8 & 2,333 & 2,407 & 3,1 & 1390 & 3,18 & 15,3 & 80,0 \\
\hline
\end{tabular}

O CP 252 foi utilizado no ensaio RICE, o qual resultou em $\mathrm{G}_{\mathrm{mm}}=2,407$ 
APÊNDICE F - Dimensões, volume de vazios, MR $\left(10,25\right.$ e $\left.40^{\circ} \mathrm{C}\right)$, parâmetros do ensaio de fadiga, parâmetros do ensaio de creep estático e $\mathrm{RT}_{\text {creep }}$ de cada corpo de prova da Etapa 3, agrupados por tipo de mistura asfáltica.

Tabela F.1 - Resultados da caracterização mecânica complementar para a mistura $5070(\mathrm{TP}=5,3 \%)$

\begin{tabular}{|c|c|c|c|c|c|c|c|c|c|c|c|c|}
\hline $\mathrm{CP}$ & $\mathrm{D}(\mathrm{mm})$ & $\begin{array}{c}\mathrm{H} \\
(\mathrm{mm})\end{array}$ & $\begin{array}{l}\mathrm{Vv} \\
(\%)\end{array}$ & $\begin{array}{c}\mathrm{MR} \\
10^{\circ} \mathrm{C} \\
(\mathrm{MPa})\end{array}$ & $\begin{array}{c}\mathrm{MR} \\
25^{\circ} \mathrm{C} \\
(\mathrm{MPa})\end{array}$ & $\begin{array}{c}\mathrm{MR} \\
40^{\circ} \mathrm{C} \\
(\mathrm{MPa})\end{array}$ & $\begin{array}{c}\mathrm{N} \\
\text { (fadiga) }\end{array}$ & $\begin{array}{c}\mathrm{D}_{\mathrm{t}} \\
(\mathrm{mm} / \mathrm{mm})\end{array}$ & $\begin{array}{c}\mathrm{M}_{\mathrm{f}} \\
(\mathrm{MPa})\end{array}$ & $\begin{array}{l}\operatorname{Rec} \\
(\%)\end{array}$ & $I_{\text {curva }}$ & $\begin{array}{l}\mathrm{RT}_{\text {creep }} \\
(\mathrm{MPa})\end{array}$ \\
\hline 253 & 101,89 & 70,55 & 6,8 & 8814 & 3761 & 1025 & - & 0,00108 & 358,6 & 63,3 & 0,056 & 1,39 \\
\hline 254 & 101,49 & 71,33 & 7,2 & 10815 & 3897 & 774 & - & 0,00117 & 463,8 & 64,1 & 0,050 & 1,30 \\
\hline 255 & 101,79 & 70,89 & 7,2 & 6921 & 2403 & 478 & - & 0,00166 & 350,3 & 58,7 & 0,070 & 1,26 \\
\hline 256 & 101,79 & 68,52 & 5,0 & 11700 & 4715 & 859 & 15773 & - & - & - & - & - \\
\hline 257 & 102,13 & 67,49 & 4,1 & - & 5455 & - & 701 & - & - & - & - & - \\
\hline 258 & 102,16 & 67,69 & 4,3 & 14329 & 5227 & 1076 & 149 & - & - & - & - & - \\
\hline 259 & 101,75 & 67,87 & 4,2 & 14451 & 4600 & 1019 & 211 & - & - & - & - & - \\
\hline 260 & 102,08 & 67,07 & 3,5 & 15261 & 5487 & 1171 & 1704 & - & - & - & - & - \\
\hline 261 & 101,77 & 67,75 & 4,1 & - & 5326 & - & 131 & - & - & - & - & - \\
\hline 262 & 102,13 & 68,13 & 4,7 & - & 4477 & - & 195 & - & - & - & - & - \\
\hline 263 & 101,56 & 68,31 & 4,1 & - & 4995 & - & 16575 & - & - & - & - & - \\
\hline
\end{tabular}

Tabela F.2 - Resultados da caracterização mecânica complementar para a mistura 5070C3,0 (TP = 5,3\%)

\begin{tabular}{|c|c|c|c|c|c|c|c|c|c|c|c|c|}
\hline $\mathrm{CP}$ & $\mathrm{D}(\mathrm{mm})$ & $\begin{array}{c}\mathrm{H} \\
(\mathrm{mm})\end{array}$ & $\begin{array}{l}\mathrm{Vv} \\
(\%)\end{array}$ & $\begin{array}{c}\mathrm{MR} \\
10^{\circ} \mathrm{C} \\
(\mathrm{MPa})\end{array}$ & $\begin{array}{c}\mathrm{MR} \\
25^{\circ} \mathrm{C} \\
(\mathrm{MPa})\end{array}$ & $\begin{array}{c}\mathrm{MR} \\
40^{\circ} \mathrm{C} \\
(\mathrm{MPa})\end{array}$ & $\begin{array}{c}\mathrm{N} \\
\text { (fadiga) }\end{array}$ & $\begin{array}{c}\mathrm{D}_{\mathrm{t}} \\
(\mathrm{mm} / \mathrm{mm})\end{array}$ & $\begin{array}{c}\mathrm{M}_{\mathrm{f}} \\
(\mathrm{MPa})\end{array}$ & $\begin{array}{l}\operatorname{Rec} \\
(\%)\end{array}$ & $\mathrm{I}_{\text {curva }}$ & $\begin{array}{l}\mathrm{RT}_{\text {creep }} \\
(\mathrm{MPa})\end{array}$ \\
\hline 264 & 101,53 & 71,05 & 6,6 & 9471 & 3631 & 785 & - & 0,00153 & 265,9 & 55,7 & 0,066 & 1,29 \\
\hline 265 & 101,83 & 70,60 & 6,7 & 9778 & 3786 & 927 & - & 0,00140 & 296,3 & 57,3 & 0,084 & 1,23 \\
\hline 266 & 101,59 & 71,14 & 6,3 & 10090 & 4592 & 972 & - & 0,00134 & 331,0 & 59,5 & 0,058 & 1,49 \\
\hline 267 & 101,81 & 68,83 & 5,0 & - & 4452 & - & 29152 & - & - & - & - & - \\
\hline 268 & 102,08 & 68,21 & 4,7 & 12029 & 4501 & 788 & 3092 & - & - & - & - & - \\
\hline 269 & 102,05 & 68,16 & 4,7 & 12110 & 5149 & 1024 & 1271 & - & - & - & - & - \\
\hline 270 & 101,69 & 68,08 & 3,7 & 14077 & 5210 & 967 & 38218 & - & - & - & - & - \\
\hline 271 & 102,02 & 67,34 & 4,0 & - & 4973 & - & 1206 & - & - & - & - & - \\
\hline 272 & 102,35 & 67,47 & 4,0 & 12531 & 5313 & 1085 & 415 & - & - & - & - & - \\
\hline 273 & 101,69 & 67,82 & 3,2 & - & 5572 & - & 3931 & - & - & - & - & - \\
\hline 274 & 101,73 & 68,68 & 4,6 & - & 5331 & - & 452 & - & - & - & - & - \\
\hline
\end{tabular}

Tabela F.3 - Resultados da caracterização mecânica complementar para a mistura 5070L $(\mathrm{TP}=5,5 \%)$

\begin{tabular}{|c|c|c|c|c|c|c|c|c|c|c|c|c|}
\hline $\mathrm{CP}$ & $\mathrm{D}(\mathrm{mm})$ & $\begin{array}{c}\mathrm{H} \\
(\mathrm{mm})\end{array}$ & $\begin{array}{l}\mathrm{Vv} \\
(\%)\end{array}$ & $\begin{array}{c}\mathrm{MR} \\
10^{\circ} \mathrm{C} \\
(\mathrm{MPa}) \\
\end{array}$ & $\begin{array}{c}\mathrm{MR} \\
25^{\circ} \mathrm{C} \\
(\mathrm{MPa}) \\
\end{array}$ & $\begin{array}{c}\mathrm{MR} \\
40^{\circ} \mathrm{C} \\
(\mathrm{MPa}) \\
\end{array}$ & $\begin{array}{c}\mathrm{N} \\
\text { (fadiga) }\end{array}$ & $\begin{array}{c}\mathrm{D}_{\mathrm{t}} \\
(\mathrm{mm} / \mathrm{mm})\end{array}$ & $\begin{array}{c}\mathrm{M}_{\mathrm{f}} \\
(\mathrm{MPa})\end{array}$ & $\begin{array}{l}\operatorname{Rec} \\
(\%)\end{array}$ & $\mathrm{I}_{\text {curva }}$ & $\begin{array}{l}\mathrm{RT}_{\text {creep }} \\
(\mathrm{MPa})\end{array}$ \\
\hline 275 & 101,72 & 70,81 & 6,4 & 9181 & 3991 & 744 & - & 0,00119 & 425,3 & 62,4 & 0,070 & 1,28 \\
\hline 276 & 102,47 & 71,23 & 7,6 & 7780 & 3516 & 763 & - & 0,00131 & 311,7 & 58,4 & 0,044 & 1,14 \\
\hline 277 & 101,89 & 71,51 & 7,4 & 7904 & 3291 & 713 & - & 0,00166 & 296,3 & 53,4 & 0,074 & 1,17 \\
\hline 278 & 101,70 & 68,78 & 4,0 & 11208 & 4552 & 888 & 2334 & - & - & - & - & - \\
\hline 279 & 102,21 & 67,11 & 3,2 & 13582 & 4789 & 1119 & 742 & - & - & - & - & - \\
\hline 280 & 101,77 & 67,90 & 3,5 & - & 3702 & - & 282 & - & - & - & - & - \\
\hline 281 & 102,25 & 67,90 & 3,7 & - & 4658 & - & 25676 & - & - & - & - & - \\
\hline 282 & 101,79 & 67,90 & 3,7 & - & 4630 & - & 2033 & - & - & - & - & - \\
\hline 283 & 101,59 & 68,28 & 3,2 & 13120 & 4685 & 1024 & 32058 & - & - & - & - & - \\
\hline 284 & 102,18 & 68,60 & 4,6 & 11710 & 3915 & 874 & 166 & - & - & - & - & - \\
\hline 285 & 102,03 & 68,22 & 4,0 & - & 5503 & - & 693 & - & - & - & - & - \\
\hline
\end{tabular}


Tabela F.4 - Resultados da caracterização mecânica complementar para a mistura 5070C3,0L $(\mathrm{TP}=5,3 \%)$

\begin{tabular}{|c|c|c|c|c|c|c|c|c|c|c|c|c|}
\hline $\mathrm{CP}$ & $\mathrm{D}(\mathrm{mm})$ & $\begin{array}{c}\mathrm{H} \\
(\mathrm{mm})\end{array}$ & $\begin{array}{l}\mathrm{Vv} \\
(\%)\end{array}$ & $\begin{array}{c}\mathrm{MR} \\
10^{\circ} \mathrm{C} \\
(\mathrm{MPa})\end{array}$ & $\begin{array}{c}\mathrm{MR} \\
25^{\circ} \mathrm{C} \\
(\mathrm{MPa})\end{array}$ & $\begin{array}{c}\mathrm{MR} \\
40^{\circ} \mathrm{C} \\
(\mathrm{MPa})\end{array}$ & $\begin{array}{c}\mathrm{N} \\
\text { (fadiga) }\end{array}$ & $\begin{array}{c}\mathrm{D}_{\mathrm{t}} \\
(\mathrm{mm} / \mathrm{mm})\end{array}$ & $\begin{array}{c}\mathrm{M}_{\mathrm{f}} \\
(\mathrm{MPa})\end{array}$ & $\begin{array}{l}\operatorname{Rec} \\
(\%)\end{array}$ & $I_{\text {curva }}$ & $\begin{array}{l}\mathrm{RT}_{\text {creep }} \\
(\mathrm{MPa})\end{array}$ \\
\hline 286 & 101,70 & 70,72 & 6,9 & 9088 & 4040 & 976 & - & 0,00134 & 296,8 & 58,9 & 0,059 & 1,18 \\
\hline 287 & 102,01 & 70,68 & 7,1 & 8551 & 4708 & 1303 & - & 0,00144 & 276,5 & 56,3 & 0,080 & 1,21 \\
\hline 288 & 102,09 & 70,23 & 6,7 & 10616 & 4632 & 949 & - & 0,00097 & 419,0 & 63,2 & 0,034 & 1,29 \\
\hline 289 & 102,02 & 67,29 & 3,7 & - & 5344 & - & 316 & - & - & - & - & - \\
\hline 290 & 101,83 & 67,81 & 3,8 & 14515 & 4825 & 975 & 42250 & - & - & - & - & - \\
\hline 291 & 101,78 & 68,05 & 4,0 & 13244 & 4926 & 996 & 2143 & - & - & - & - & - \\
\hline 292 & 102,38 & 66,86 & 3,0 & - & 4553 & - & 2940 & - & - & - & - & - \\
\hline 293 & 102,18 & 67,48 & 3,6 & - & 4801 & - & 37484 & - & - & - & - & - \\
\hline 294 & 101,87 & 67,61 & 3,3 & 13696 & 4906 & 1273 & 763 & - & - & - & - & - \\
\hline 295 & 101,57 & 67,60 & 3,4 & 14179 & 5232 & 1303 & 389 & - & - & - & - & - \\
\hline 296 & 102,31 & 67,70 & 4,2 & - & 5075 & - & 800 & - & - & - & - & - \\
\hline
\end{tabular}

Tabela F.5 - Resultados da caracterização mecânica complementar para a mistura 3045 (TP = 5,3\%)

\begin{tabular}{|c|c|c|c|c|c|c|c|c|c|c|c|c|}
\hline $\mathrm{CP}$ & $\mathrm{D}(\mathrm{mm})$ & $\begin{array}{c}\mathrm{H} \\
(\mathrm{mm})\end{array}$ & $\begin{array}{l}\mathrm{Vv} \\
(\%)\end{array}$ & $\begin{array}{c}\mathrm{MR} \\
10^{\circ} \mathrm{C} \\
(\mathrm{MPa})\end{array}$ & $\begin{array}{c}\mathrm{MR} \\
25^{\circ} \mathrm{C} \\
(\mathrm{MPa})\end{array}$ & $\begin{array}{c}\mathrm{MR} \\
40^{\circ} \mathrm{C} \\
(\mathrm{MPa})\end{array}$ & $\begin{array}{c}\mathrm{N} \\
\text { (fadiga) }\end{array}$ & $\begin{array}{c}\mathrm{D}_{\mathrm{t}} \\
(\mathrm{mm} / \mathrm{mm})\end{array}$ & $\begin{array}{c}\mathrm{M}_{\mathrm{f}} \\
(\mathrm{MPa})\end{array}$ & $\begin{array}{l}\operatorname{Rec} \\
(\%)\end{array}$ & $\mathrm{I}_{\text {curva }}$ & $\begin{array}{l}\mathrm{RT}_{\text {creep }} \\
(\mathrm{MPa})\end{array}$ \\
\hline 297 & 101,46 & 71,52 & 7,4 & 9244 & 4728 & 1245 & - & 0,00092 & 442,0 & 66,6 & 0,049 & 1,48 \\
\hline 298 & 102,21 & 70,46 & 7,3 & 13150 & 4824 & 1098 & - & 0,00131 & 325,0 & 58,4 & 0,063 & 1,59 \\
\hline 299 & 102,13 & 71,20 & 7,2 & 8382 & 3967 & 1127 & - & 0,00124 & 354,8 & 61,6 & 0,062 & 1,41 \\
\hline 300 & 101,77 & 67,63 & 4,0 & 13014 & 5007 & 1123 & 4431 & - & - & - & - & - \\
\hline 301 & 102,38 & 67,24 & 4,0 & 12723 & 5267 & 1192 & 94328 & - & - & - & - & - \\
\hline 302 & 101,78 & 67,89 & 3,9 & 12808 & 4900 & 1333 & 1382 & - & - & - & - & - \\
\hline 303 & 102,21 & 67,08 & 3,3 & - & 5332 & - & 63628 & - & - & - & - & - \\
\hline 304 & 102,24 & 66,48 & 3,2 & - & 5496 & - & 4808 & - & - & - & - & - \\
\hline 305 & 101,66 & 68,14 & 3,9 & 12357 & 4939 & 1072 & 712 & - & - & - & - & - \\
\hline 306 & 102,25 & 68,00 & 4,2 & - & 4593 & - & 808 & - & - & - & - & - \\
\hline 307 & 101,52 & 68,28 & 3,9 & - & 5908 & - & 388 & - & - & - & - & - \\
\hline
\end{tabular}

Tabela F.6 - Resultados da caracterização mecânica complementar para a mistura 3045C3,0 (TP = 5,5\%)

\begin{tabular}{|c|c|c|c|c|c|c|c|c|c|c|c|c|}
\hline $\mathrm{CP}$ & $\mathrm{D}(\mathrm{mm})$ & $\begin{array}{c}\mathrm{H} \\
(\mathrm{mm})\end{array}$ & $\begin{array}{l}\mathrm{Vv} \\
(\%)\end{array}$ & $\begin{array}{c}\mathrm{MR} \\
10^{\circ} \mathrm{C} \\
(\mathrm{MPa})\end{array}$ & $\begin{array}{c}\mathrm{MR} \\
25^{\circ} \mathrm{C} \\
(\mathrm{MPa})\end{array}$ & $\begin{array}{c}\mathrm{MR} \\
40^{\circ} \mathrm{C} \\
(\mathrm{MPa}) \\
\end{array}$ & $\mathrm{N}$ (fadiga) & $\begin{array}{c}\mathrm{D}_{\mathrm{t}} \\
(\mathrm{mm} / \mathrm{mm})\end{array}$ & $\begin{array}{c}\mathrm{M}_{\mathrm{f}} \\
(\mathrm{MPa})\end{array}$ & $\begin{array}{l}\operatorname{Rec} \\
(\%)\end{array}$ & $\mathrm{I}_{\text {curva }}$ & $\begin{array}{l}\mathrm{RT}_{\text {creep }} \\
(\mathrm{MPa})\end{array}$ \\
\hline 308 & 102,32 & 71,41 & 7,5 & 8710 & 3756 & 1134 & - & 0,00154 & 286,5 & 56,2 & 0,071 & 1,34 \\
\hline 309 & 102,28 & 70,50 & 7,0 & 7767 & 3378 & 1077 & - & 0,00134 & 298,7 & 60,3 & 0,080 & 1,46 \\
\hline 310 & 101,77 & 71,81 & 7,5 & 8906 & 3151 & 816 & - & 0,00166 & 253,6 & 55,6 & 0,091 & 1,26 \\
\hline 311 & 101,64 & 67,86 & 4,0 & 10351 & 4464 & 1356 & 70771 & - & - & - & - & - \\
\hline 312 & 102,01 & 67,18 & 3,4 & 13661 & 7741 & 1969 & 8605 & - & - & - & - & - \\
\hline 313 & 102,10 & 67,68 & 3,6 & - & 6143 & - & 1758 & - & - & - & - & - \\
\hline 314 & 102,30 & 66,81 & 3,1 & 12549 & 4813 & 1273 & 1680 & - & - & - & - & - \\
\hline 315 & 101,79 & 67,04 & 3,0 & 13909 & 6136 & 1754 & 596 & - & - & - & - & - \\
\hline 316 & 101,58 & 67,93 & 3,9 & - & 5535 & - & 722 & - & - & - & - & - \\
\hline 317 & 102,17 & 66,73 & 3,1 & - & 6714 & - & 139379 & - & - & - & - & - \\
\hline 318 & 101,50 & 68,00 & 3,5 & - & 5209 & - & 9475 & - & - & - & - & - \\
\hline
\end{tabular}

Tabela F.7 - Resultados da caracterização mecânica complementar para a mistura 3045L $(\mathrm{TP}=5,5 \%)$

\begin{tabular}{|c|c|c|c|c|c|c|c|c|c|c|c|c|}
\hline $\mathrm{CP}$ & $\mathrm{D}(\mathrm{mm})$ & $\begin{array}{c}\mathrm{H} \\
(\mathrm{mm})\end{array}$ & $\begin{array}{l}\mathrm{Vv} \\
(\%)\end{array}$ & $\begin{array}{c}\mathrm{MR} \\
10^{\circ} \mathrm{C} \\
(\mathrm{MPa})\end{array}$ & $\begin{array}{c}\mathrm{MR} \\
25^{\circ} \mathrm{C} \\
(\mathrm{MPa})\end{array}$ & $\begin{array}{c}\text { MR } \\
40^{\circ} \mathrm{C} \\
(\mathrm{MPa})\end{array}$ & $\mathrm{N}$ (fadiga) & $\begin{array}{c}\mathrm{D}_{\mathrm{t}} \\
(\mathrm{mm} / \mathrm{mm})\end{array}$ & $\begin{array}{c}\mathrm{M}_{\mathrm{f}} \\
(\mathrm{MPa})\end{array}$ & $\begin{array}{l}\operatorname{Rec} \\
(\%)\end{array}$ & $I_{\text {curva }}$ & $\begin{array}{l}\mathrm{RT}_{\text {creep }} \\
(\mathrm{MPa})\end{array}$ \\
\hline 319 & 102,09 & 71,00 & 7,3 & 6305 & 3192 & 1044 & - & 0,00112 & 362,2 & 60,7 & 0,056 & 1,32 \\
\hline 320 & 102,45 & 71,42 & 7,6 & 7119 & 3090 & 1132 & - & 0,00138 & 285,9 & 58,7 & 0,087 & 1,29 \\
\hline 321 & 101,73 & 71,59 & 7,2 & 9448 & 3741 & 1279 & - & 0,00134 & 324,9 & 59,7 & 0,064 & 1,41 \\
\hline 322 & 102,18 & 67,51 & 3,2 & 11560 & 4259 & 1110 & 3342 & - & - & - & - & - \\
\hline 323 & 101,66 & 67,06 & 3,0 & - & 5457 & - & 411 & - & - & - & - & - \\
\hline 324 & 102,13 & 67,27 & 3,1 & 14099 & 5604 & 1388 & 179932 & - & - & - & - & - \\
\hline 325 & 101,72 & 68,04 & 3,5 & 12563 & 4808 & 1164 & 404 & - & - & - & - & - \\
\hline 326 & 101,80 & 67,70 & 3,2 & - & 4618 & - & 5184 & - & - & - & - & - \\
\hline 327 & 101,61 & 67,68 & 3,1 & 13354 & 5784 & 1294 & 1046 & - & - & - & - & - \\
\hline 328 & 102,27 & 67,49 & 3,4 & - & 4231 & - & 88503 & - & - & - & - & - \\
\hline 329 & 101,61 & 67,76 & 3,2 & - & 5609 & - & 1572 & - & - & - & - & - \\
\hline
\end{tabular}


Tabela F.8 - Resultados da caracterização mecânica complementar para a mistura 3045C3,0L $(\mathrm{TP}=5,5 \%)$

\begin{tabular}{|c|c|c|c|c|c|c|c|c|c|c|c|c|}
\hline $\mathrm{CP}$ & $\mathrm{D}(\mathrm{mm})$ & $\begin{array}{c}\mathrm{H} \\
(\mathrm{mm})\end{array}$ & $\begin{array}{l}\mathrm{Vv} \\
(\%)\end{array}$ & $\begin{array}{c}\mathrm{MR} \\
10^{\circ} \mathrm{C} \\
(\mathrm{MPa}) \\
\end{array}$ & $\begin{array}{c}\mathrm{MR} \\
25^{\circ} \mathrm{C} \\
(\mathrm{MPa})\end{array}$ & $\begin{array}{c}\mathrm{MR} \\
40^{\circ} \mathrm{C} \\
(\mathrm{MPa})\end{array}$ & $\mathrm{N}$ (fadiga) & $\begin{array}{c}\mathrm{D}_{\mathrm{t}} \\
(\mathrm{mm} / \mathrm{mm})\end{array}$ & $\begin{array}{c}\mathrm{M}_{\mathrm{f}} \\
(\mathrm{MPa})\end{array}$ & $\begin{array}{l}\operatorname{Rec} \\
(\%)\end{array}$ & $\mathrm{I}_{\text {curva }}$ & $\begin{array}{l}\mathrm{RT}_{\text {creep }} \\
(\mathrm{MPa})\end{array}$ \\
\hline 330 & 102,15 & 71,03 & 7,0 & 9503 & 3580 & 1264 & - & 0,00121 & 323,7 & 61,7 & 0,078 & 1,25 \\
\hline 331 & 102,44 & 71,04 & 7,1 & 8935 & 4171 & 1412 & - & 0,00138 & 319,2 & 61,0 & 0,093 & 1,30 \\
\hline 332 & 101,48 & 72,02 & 7,2 & 8861 & 3718 & 1195 & - & 0,00137 & 283,9 & 59,7 & 0,085 & 1,40 \\
\hline 333 & 101,99 & 67,20 & 3,4 & 14037 & 6035 & 1529 & 208384 & - & - & - & - & - \\
\hline 334 & 102,19 & 67,49 & 3,2 & - & 5886 & - & 102283 & - & - & - & - & - \\
\hline 335 & 101,85 & 67,84 & 4,0 & - & 6559 & - & 5100 & - & - & - & - & - \\
\hline 336 & 101,86 & 67,58 & 3,8 & 15030 & 5152 & 1468 & 487 & - & - & - & - & - \\
\hline 337 & 102,33 & 67,16 & 3,3 & 16940 & 5940 & 1569 & 4290 & - & - & - & - & - \\
\hline 338 & 102,05 & 67,59 & 3,3 & 13619 & 6850 & 1382 & 1192 & - & - & - & - & - \\
\hline 339 & 101,72 & 67,59 & 3,2 & - & 5860 & - & 819 & - & - & - & - & - \\
\hline 340 & 101,83 & 67,68 & 3,4 & - & 5391 & - & 1354 & - & - & - & - & - \\
\hline
\end{tabular}


APÊNDICE G - Dimensões e Vv dos CPs antes e após o ensaio de creep estático

Tabela G.1 - Diâmetro, altura e Vv dos CPs antes e após o ensaio de creep estático

\begin{tabular}{|c|c|c|c|c|c|c|c|c|c|c|}
\hline \multirow[b]{2}{*}{ Mistura } & \multirow[b]{2}{*}{$\mathrm{CP}$} & \multicolumn{3}{|c|}{ Antes de creep } & \multicolumn{3}{|c|}{ Após creep } & \multirow[b]{2}{*}{$\begin{array}{c}\text { Avaliação } \\
\text { D }\end{array}$} & \multirow[b]{2}{*}{$\begin{array}{c}\text { Avaliação } \\
\text { H }\end{array}$} & \multirow[b]{2}{*}{$\begin{array}{c}\text { Avaliação } \\
\text { Vv }^{2}\end{array}$} \\
\hline & & $\begin{array}{c}\mathrm{D} \\
(\mathrm{mm})\end{array}$ & $\begin{array}{c}\mathrm{H} \\
(\mathrm{mm})\end{array}$ & $\begin{array}{l}\mathrm{Vv} \\
(\%) \\
\end{array}$ & $\begin{array}{c}\mathrm{D} \\
(\mathrm{mm})\end{array}$ & $\begin{array}{c}\mathrm{H} \\
(\mathrm{mm})\end{array}$ & $\begin{array}{l}\mathrm{Vv} \\
(\%) \\
\end{array}$ & & & \\
\hline 5070 & 253 & 101,81 & 70,20 & 6,8 & 102,11 & 69,97 & 6,9 & Aumentou & Reduziu & $+0,1 \%$ \\
\hline 5070 & 254 & 101,64 & 71,01 & 7,2 & 101,91 & 70,56 & 7,2 & Aumentou & Reduziu & Igual \\
\hline 5070 & 255 & 101,96 & 70,64 & 7,2 & 102,30 & 70,13 & 7,3 & Aumentou & Reduziu & $+0,1 \%$ \\
\hline $5070 \mathrm{C} 3,0$ & 264 & 101,68 & 70,83 & 6,6 & 101,97 & 70,32 & 6,6 & Aumentou & Reduziu & Igual \\
\hline $5070 \mathrm{C} 3,0$ & 265 & 101,99 & 70,50 & 6,7 & 102,30 & 70,01 & 6,8 & Aumentou & Reduziu & $+0,1 \%$ \\
\hline $5070 \mathrm{C} 3,0$ & 266 & 101,79 & 70,82 & 6,3 & 102,09 & 70,41 & 6,4 & Aumentou & Reduziu & $+0,1 \%$ \\
\hline $5070 \mathrm{~L}$ & 275 & 101,66 & 70,44 & 6,4 & 102,06 & 70,00 & 6,4 & Aumentou & Reduziu & Igual \\
\hline $5070 \mathrm{~L}$ & 276 & 102,30 & 71,00 & 7,6 & 102,63 & 70,48 & 7,5 & Aumentou & Reduziu & $-0,1 \%$ \\
\hline $5070 \mathrm{~L}$ & 277 & 102,02 & 71,31 & 7,4 & 102,33 & 70,79 & 7,5 & Aumentou & Reduziu & $+0,1 \%$ \\
\hline $5070 \mathrm{C} 3,0 \mathrm{~L}$ & 286 & 101,83 & 70,45 & 6,9 & 102,24 & 69,96 & 6,9 & Aumentou & Reduziu & Igual \\
\hline $5070 \mathrm{C} 3,0 \mathrm{~L}$ & 287 & 102,14 & 70,35 & 7,1 & 102,65 & 69,92 & 7,1 & Aumentou & Reduziu & Igual \\
\hline $5070 \mathrm{C} 3,0 \mathrm{~L}$ & 288 & 102,11 & 69,86 & 6,7 & 102,77 & 69,33 & 6,9 & Aumentou & Reduziu & $+0,2 \%$ \\
\hline 3045 & 297 & 101,67 & 71,32 & 7,4 & 101,88 & 70,91 & 7,3 & Aumentou & Reduziu & $-0,1 \%$ \\
\hline 3045 & 298 & 102,40 & 70,31 & 7,3 & 102,59 & 69,89 & 7,3 & Aumentou & Reduziu & Igual \\
\hline 3045 & 299 & 102,36 & 70,99 & 7,2 & 102,52 & 70,28 & 7,3 & Aumentou & Reduziu & $+0,1 \%$ \\
\hline $3045 \mathrm{C} 3,0$ & 308 & 102,21 & 71,08 & 7,5 & 102,65 & 70,67 & 7,5 & Aumentou & Reduziu & Igual \\
\hline $3045 \mathrm{C} 3,0$ & 309 & 102,46 & 70,24 & 7,0 & 102,69 & 69,90 & 6,9 & Aumentou & Reduziu & $-0,1 \%$ \\
\hline $3045 \mathrm{C} 3,0$ & 310 & 102,09 & 71,54 & 7,5 & 102,35 & 71,10 & 7,6 & Aumentou & Reduziu & $+0,1 \%$ \\
\hline $3045 \mathrm{~L}$ & 319 & 102,26 & 70,80 & 7,3 & 102,58 & 70,36 & 7,3 & Aumentou & Reduziu & Igual \\
\hline $3045 \mathrm{~L}$ & 320 & 102,48 & 71,23 & 7,6 & 102,56 & 70,74 & 7,6 & Aumentou & Reduziu & Igual \\
\hline $3045 \mathrm{~L}$ & 321 & 101,78 & 71,37 & 7,2 & 102,22 & 70,91 & 7,2 & Aumentou & Reduziu & Igual \\
\hline $3045 \mathrm{C} 3,0 \mathrm{~L}$ & 330 & 102,15 & 70,67 & 7,0 & 102,60 & 70,30 & 7,1 & Aumentou & Reduziu & $+0,1 \%$ \\
\hline $3045 \mathrm{C} 3,0 \mathrm{~L}$ & 331 & 102,40 & 70,75 & 7,1 & 102,82 & 70,30 & 7,2 & Aumentou & Reduziu & $+0,1 \%$ \\
\hline $3045 \mathrm{C} 3,0 \mathrm{~L}$ & 332 & 101,55 & 71,71 & 7,2 & 102,01 & 71,16 & 7,2 & Aumentou & Reduziu & Igual \\
\hline
\end{tabular}

Em $1 \mathrm{CP}$ houve aumento de 0,2\% no Vv / em 9 Cps houve aumento de 0,1\% no Vv / em 11 não houve alteração no Vv / em apenas 3 CPs houve redução no Vv após o creep estático. 
APÊEDICE H - Procedimentos para efetuar as regressões lineares entre as variáveisresposta da pesquisa e tabelas de $\mathrm{R}^{2}$ e coeficiente angular

As regressões lineares foram efetuadas no software Excel, com o uso da ferramenta Análise de Dados - Regressão. Além dos valores de $\mathrm{R}^{2}$ e do sinal do coeficiente angular da reta de regressão, também se indicou, por meio de análise de variância, se a relação entre as variáveis em estudo pode ser considerada linear a um nível de significância de 5\%. Para tanto, comparouse a estatística $\mathrm{F}$ do teste $\operatorname{com} \alpha=0,05$. Se $\mathrm{F} \leq \alpha$, a relação é considerada linear. Coeficientes angulares positivos (+) indicam relações diretamente proporcionais entre as variáveis e coeficiente angulares negativos (-) indicam relações inversamente proporcionais. Adotou-se o seguinte critério para classificar a qualidade da correlação:

$>$ se o valor de $\mathrm{R}^{2} \geq 0,90$ a correlação é classificada como excelente;

$>$ se $0,75 \leq \mathrm{R}^{2}<0,90$ a correlação é classificada como boa, e;

$>$ se $\mathrm{R}^{2}<0,75$ a relação é classificada como moderada, desde que considerada válida pela análise de variância.

Estes processos estão ilustrados na Figura H.1, onde se verifica a moderada correlação linear entre a estabilidade, da Etapa 1, e o MR, da Etapa 2, $\left(\mathrm{R}^{2}=0,53\right.$, coeficiente angular positivo e $\mathrm{F}=0,0074 \rightarrow$ linear).

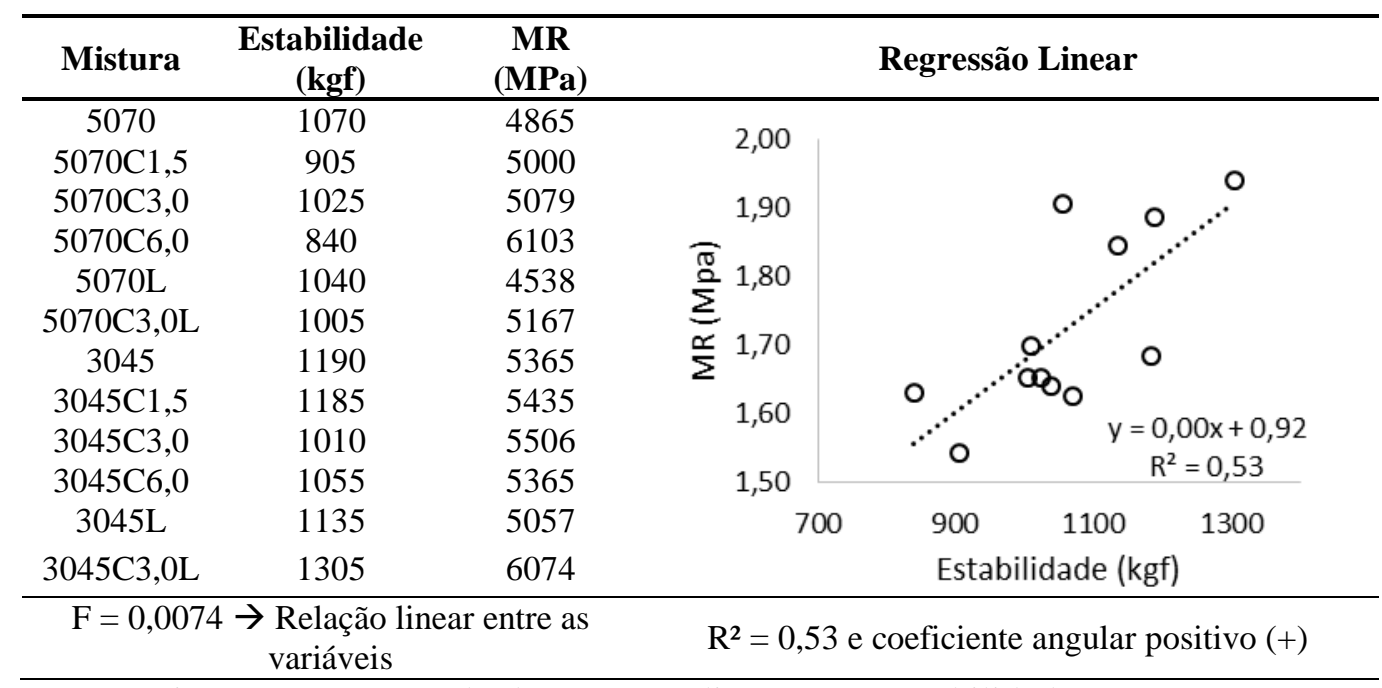

Figura H.1 - Exemplo de regressão linear entre Estabilidade versus MR

Os procedimentos indicados na Figura H.1 foram repetidos para todos os pares possíveis de variáveis-resposta das Etapas 1, 2 e 3 e os resultados estão sumarizados nas Tabelas H.1 a H.8. As correlações válidas estão destacadas em negrito. 
Tabela H.1 - Valores de $\mathrm{R}^{2}$ e sinal do coeficiente angular das regressões lineares entre os parâmetros das dosagens Marshall (Etapa 1)

\begin{tabular}{ccccccccc}
\hline $\begin{array}{l}\text { Variáveis } \\
\text { resposta }\end{array}$ & $\mathbf{V v}$ & $\mathbf{G}_{\mathbf{m m}}$ & $\mathbf{G}_{\mathbf{m b}}$ & $\mathbf{V A M}$ & $\mathbf{R B V}$ & Estabilidade & Fluência & TP \\
\hline $\mathbf{V v}$ & - & $0,20(+)$ & $\mathbf{0 , 4 1}(-)$ & $0,17(+)$ & $\mathbf{0 , 9 0}(-)$ & $0,10(-)$ & $0,18(+)$ & $0,00(-)$ \\
$\mathbf{G} \mathbf{m m}$ & & - & $0,15(+)$ & $0,31(-)$ & $\mathbf{0 , 4 5}(-)$ & $0,06(-)$ & $0,06(-)$ & $\mathbf{0 , 4 5}(-)$ \\
$\mathbf{G m b}$ & & & - & $\mathbf{0 , 8 4}(-)$ & $0,17(+)$ & $0,02(+)$ & $\mathbf{0 , 4 5}(-)$ & $0,25(-)$ \\
VAM & & & & - & $0,03(-)$ & $0,03(-)$ & $\mathbf{0 , 5 5}(+)$ & $\mathbf{0 , 6 4}(+)$ \\
$\mathbf{R B V}$ & & & & & - & $0,11(+)$ & $0,06(-)$ & $0,08(+)$ \\
Estabilidade & & & & & & - & $0,00(-)$ & $0,00(-)$ \\
Fluência & & & & & & & - & $0,29(+)$ \\
TP & & & & & & & & - \\
\hline
\end{tabular}

8 relações lineares em 28 testes $\rightarrow 28,6 \%$

Tabela H.2 - Valores de $\mathrm{R}^{2}$ e sinal do coeficiente angular das regressões lineares entre os parâmetros da caracterização mecânica básica (Etapa 2)

\begin{tabular}{cccccc}
\hline $\begin{array}{c}\text { Variáveis } \\
\text { resposta }\end{array}$ & MR & $\mathbf{R T}$ & MR/RT & RRT & RMR \\
\hline MR & - & $0,16(+)$ & $\mathbf{0 , 4 1 ( + )}$ & $0,02(-)$ & $\mathbf{0 , 5 0 ( - )}$ \\
RT & & - & $0,21(-)$ & $0,27(+)$ & $0,16(-)$ \\
MR/RT & & & - & $0,33(-)$ & $0,14(-)$ \\
RRT & & & & - & $0,01(-)$ \\
RMR & & & & & - \\
\hline
\end{tabular}

2 relações lineares em 10 testes $\rightarrow 20,0 \%$

Tabela H.3 - Valores de $\mathrm{R}^{2}$ e sinal do coeficiente angular das regressões lineares entre os parâmetros da Etapa 1 x Etapa 2

\begin{tabular}{cccccc}
\hline $\begin{array}{c}\text { Variáveis } \\
\text { resposta }\end{array}$ & MR & $\mathbf{R T}$ & MR/RT & RRT & RMR \\
\hline $\mathbf{V v}$ & $0,02(-)$ & $0,03(-)$ & $0,00(+)$ & $\mathbf{0 , 4 3 ( - )}$ & $0,11(+)$ \\
$\mathbf{G}_{\mathbf{m m}}$ & $0,01(+)$ & $0,15(-)$ & $0,19(+)$ & $\mathbf{0 , 5 0}(-)$ & $0,00(-)$ \\
$\mathbf{G}$ mb & $0,05(+)$ & $0,04(-)$ & $0,12(+)$ & $0,01(+)$ & $0,14(-)$ \\
$\mathbf{V A M}$ & $0,00(+)$ & $0,11(+)$ & $0,05(-)$ & $0,01(+)$ & $0,03(+)$ \\
$\mathbf{R B V}$ & $0,02(+)$ & $0,05(+)$ & $0,01(-)$ & $\mathbf{0 , 5 5}(+)$ & $0,08(-)$ \\
Estabilidade & $0,04(+)$ & $\mathbf{0 , 5 3}(+)$ & $0,26(-)$ & $0,22(+)$ & $0,01(-)$ \\
Fluência & $0,24(+)$ & $0,18(+)$ & $0,02(+)$ & $0,06(-)$ & $0,12(-)$ \\
TP & $0,09(+)$ & $0,22(+)$ & $0,01(-)$ & $0,20(+)$ & $0,00(-)$ \\
\hline
\end{tabular}

4 relações lineares em 40 testes $\rightarrow 10,0 \%$ 
Tabela H.4 - Valores de $\mathrm{R}^{2}$ e sinal do coeficiente angular das regressões lineares entre os parâmetros da caracterização mecânica complementar (Etapa 3) - Parte 1

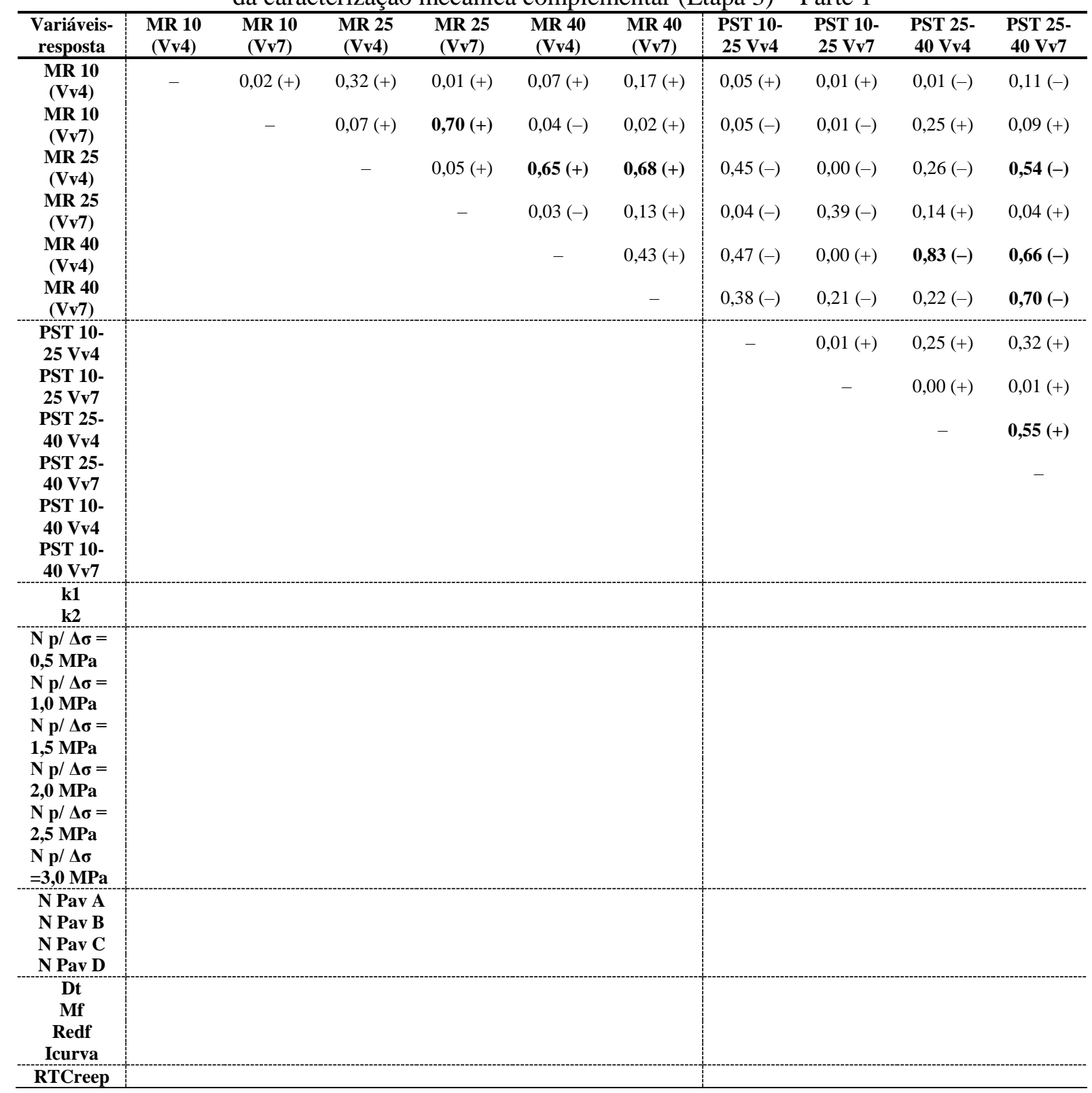


Tabela H.5 - Valores de $\mathrm{R}^{2}$ e sinal do coeficiente angular das regressões lineares entre os parâmetros da caracterização mecânica complementar (Etapa 3) - Parte 2

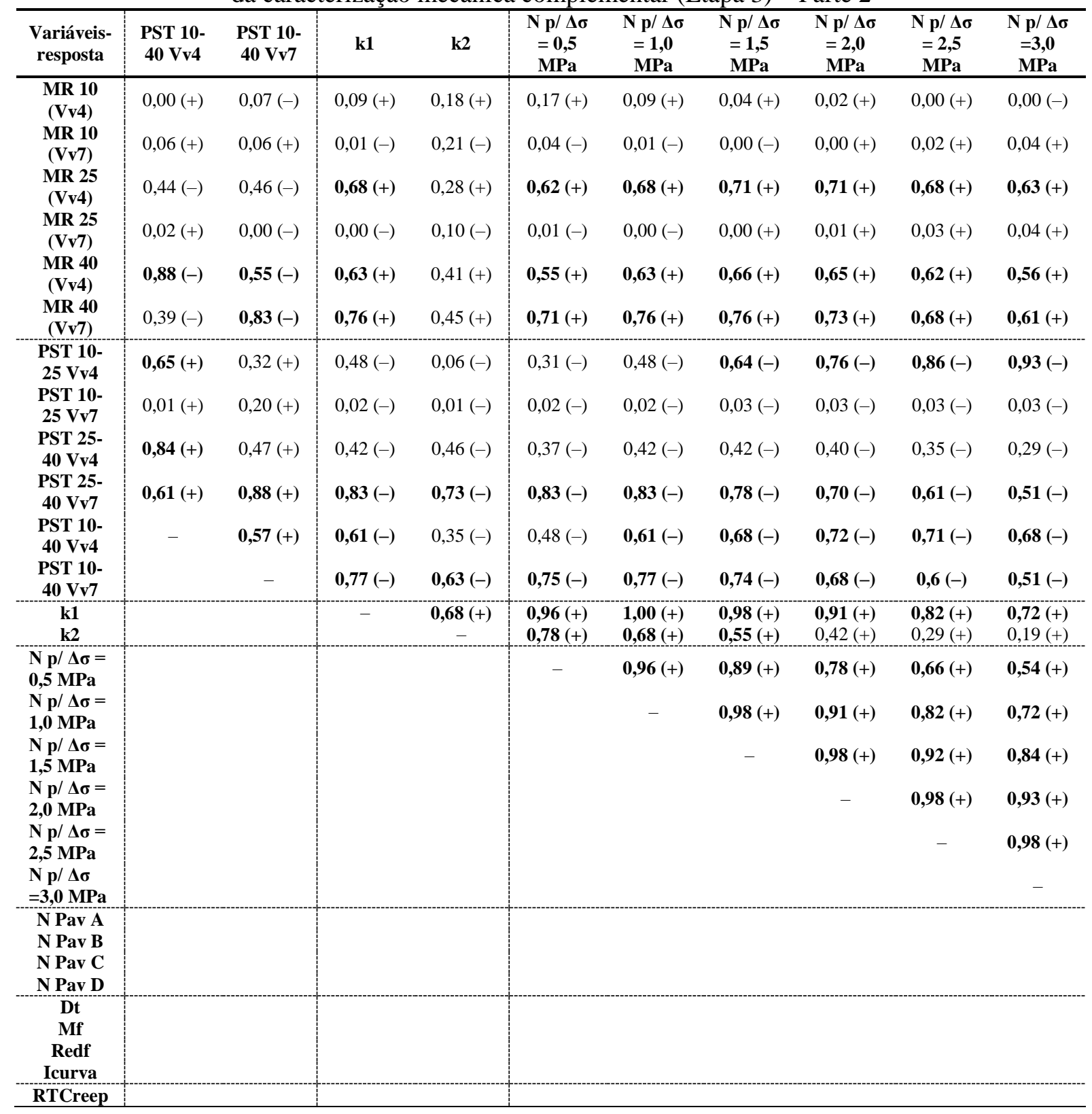


Tabela H.6 - Valores de $\mathrm{R}^{2}$ e sinal do coeficiente angular das regressões lineares entre os parâmetros da caracterização mecânica complementar (Etapa 3) - Parte 3

\begin{tabular}{|c|c|c|c|c|c|c|c|c|c|}
\hline $\begin{array}{l}\text { Variáveis- } \\
\text { resposta }\end{array}$ & N Pav A & N Pav B & N Pav C & N Pav D & Dt & Mf & Redf & Icurva & RTCreep \\
\hline $\begin{array}{c}\text { MR 10 } \\
(\mathrm{Vv} 4)\end{array}$ & $0,04(-)$ & $0,00(+)$ & $0,05(-)$ & $0,00(+)$ & $0,08(-)$ & $0,01(+)$ & $0,26(+)$ & $0,06(+)$ & $0,03(-)$ \\
\hline $\begin{array}{c}\text { MR 10 } \\
\text { (Vv7) }\end{array}$ & $0,00(-)$ & $0,02(-)$ & $0,00(-)$ & $0,01(-)$ & $0,14(-)$ & $0,04(+)$ & $0,09(+)$ & $0,08(-)$ & $0,20(+)$ \\
\hline $\begin{array}{c}\text { MR 25 } \\
(\text { Vv4) }\end{array}$ & $0,38(+)$ & $0,51(+)$ & $0,37(+)$ & $0,51(+)$ & $0,00(-)$ & $0,19(-)$ & $0,04(+)$ & $0,50(+)$ & $0,16(+)$ \\
\hline $\begin{array}{c}\text { MR 25 } \\
\text { (Vv7) }\end{array}$ & $0,01(+)$ & $0,00(-)$ & $0,01(+)$ & $0,00(+)$ & $0,30(-)$ & $0,01(+)$ & $0,04(+)$ & $0,14(-)$ & $0,05(+)$ \\
\hline $\begin{array}{c}\text { MR 40 } \\
(\text { Vv4) }\end{array}$ & $0,45(+)$ & $0,57(+)$ & $0,44(+)$ & $0,57(+)$ & $0,06(+)$ & $0,29(-)$ & $0,00(-)$ & $0,60(+)$ & $0,07(+)$ \\
\hline $\begin{array}{c}\text { MR 40 } \\
(\text { Vv7) }\end{array}$ & $0,58(+)$ & $0,72(+)$ & $0,57(+)$ & $0,71(+)$ & $0,16(-)$ & $0,09(-)$ & $0,09(+)$ & $0,20(+)$ & $0,19(+)$ \\
\hline $\begin{array}{l}\text { PST 10- } \\
25 \text { Vv4 }\end{array}$ & $\mathbf{0 , 8 2}(-)$ & $0,64(-)$ & $\mathbf{0 , 8 3}(-)$ & $0,66(-)$ & $0,04(-)$ & $0,36(+)$ & $0,05(+)$ & $0,36(-)$ & $0,40(-)$ \\
\hline $\begin{array}{c}\text { PST 10- } \\
25 \text { Vv7 }\end{array}$ & $0,07(-)$ & $0,05(-)$ & $0,07(-)$ & $0,05(-)$ & $0,20(+)$ & $0,01(+)$ & $0,01(+)$ & $0,05(+)$ & $0,03(+)$ \\
\hline $\begin{array}{c}\text { PST 25- } \\
40 \text { Vv4 }\end{array}$ & $0,33(-)$ & $0,43(-)$ & $0,32(-)$ & $0,43(-)$ & $0,06(-)$ & $0,16(+)$ & $0,01(+)$ & $0,36(-)$ & $0,01(-)$ \\
\hline $\begin{array}{c}\text { PST 25- } \\
40 \text { Vv7 }\end{array}$ & $0,58(-)$ & $0,79(-)$ & $0,56(-)$ & $0,78(-)$ & $0,01(+)$ & $0,16(+)$ & $0,03(-)$ & $0,44(-)$ & $0,13(-)$ \\
\hline $\begin{array}{c}\text { PST 10- } \\
40 \text { Vv4 }\end{array}$ & $0,68(-)$ & $\mathbf{0 , 7 0}(-)$ & $0,67(-)$ & $0,70(-)$ & $0,05(-)$ & $0,30(+)$ & $0,02(+)$ & $0,47(-)$ & $0,14(-)$ \\
\hline $\begin{array}{c}\text { PST 10- } \\
40 \text { Vv7 }\end{array}$ & $0,62(-)$ & $0,78(-)$ & $0,6(-)$ & $\mathbf{0 , 7 7}(-)$ & $0,05(+)$ & $0,17(+)$ & $0,01(-)$ & $0,28(-)$ & $0,07(-)$ \\
\hline $\mathbf{k 1}$ & $0,71(+)$ & $0,92(+)$ & $0,69(+)$ & $0,91(+)$ & $0,01(-)$ & $0,15(-)$ & $0,03(+)$ & $\mathbf{0 , 5 3}(+)$ & $0,19(+)$ \\
\hline k2 & $0,28(+)$ & $0,55(+)$ & $0,26(+)$ & $0,53(+)$ & $0,08(-)$ & $0,00(-)$ & $0,18(+)$ & $0,22(+)$ & $0,04(+)$ \\
\hline $\begin{array}{l}\mathbf{N} \text { / } / \Delta \sigma= \\
0,5 \mathrm{MPa}\end{array}$ & $0,55(+)$ & $0,82(+)$ & $0,53(+)$ & $0,8(+)$ & $0,02(-)$ & $0,11(-)$ & $0,05(+)$ & $0,51(+)$ & $0,10(+)$ \\
\hline $\begin{array}{l}\mathrm{N} \text { p/ } \Delta \sigma= \\
1,0 \mathrm{MPa}\end{array}$ & $0,71(+)$ & $0,92(+)$ & $0,69(+)$ & $0,91(+)$ & $0,01(-)$ & $0,15(-)$ & $0,03(+)$ & $0,53(+)$ & $0,19(+)$ \\
\hline $\begin{array}{l}\mathrm{N} p / \Delta \sigma= \\
1,5 \mathrm{MPa}\end{array}$ & $\mathbf{0 , 8 1}(+)$ & $0,95(+)$ & $0,8(+)$ & $0,95(+)$ & $0,00(-)$ & $0,19(-)$ & $0,02(+)$ & $0,52(+)$ & $0,26(+)$ \\
\hline $\begin{array}{l}\text { N p/ } / \Delta \sigma= \\
2,0 \mathrm{MPa}\end{array}$ & $0,87(+)$ & $0,93(+)$ & $0,86(+)$ & $0,94(+)$ & $0,00(-)$ & $0,23(-)$ & $0,00(+)$ & $0,50(+)$ & $0,32(+)$ \\
\hline $\begin{array}{l}\mathrm{N} \text { p/ } \Delta \sigma= \\
2,5 \mathrm{MPa}\end{array}$ & $0,90(+)$ & $0,89(+)$ & $0,89(+)$ & $0,9(+)$ & $0,00(+)$ & $0,27(-)$ & $0,00(+)$ & $0,47(+)$ & $0,36(+)$ \\
\hline $\begin{array}{l}\mathbf{N} \text { p/ } \Delta \sigma \\
=3,0 \mathrm{MPa}\end{array}$ & $0,89(+)$ & $0,82(+)$ & 0,89 (+) & $0,83(+)$ & $0,00(+)$ & $0,30(-)$ & $0,00(-)$ & $0,43(+)$ & $0,40(+)$ \\
\hline N Pav A & - & $0,91(+)$ & $1,00(+)$ & $0,92(+)$ & $0,00(-)$ & $0,23(-)$ & $0,00(-)$ & $0,30(+)$ & $0,39(+)$ \\
\hline N Pav B & & - & $0,9(+)$ & $1,00(+)$ & $0,01(-)$ & $0,18(-)$ & $0,01(+)$ & $0,41(+)$ & $0,30(+)$ \\
\hline N Pav C & & & - & $0,91(+)$ & $0,00(-)$ & $0,24(-)$ & $0,01(-)$ & $0,30(+)$ & $0,40(+)$ \\
\hline N Pav D & & & & - & $0,01(-)$ & $0,18(-)$ & $0,01(+)$ & $0,40(+)$ & $0,30(+)$ \\
\hline Dt & & & & & - & $0,48(-)$ & $0,67(-)$ & $0,32(+)$ & $0,11(-)$ \\
\hline Mf & & & & & & - & $0,6(+)$ & $0,59(-)$ & $0,02(+)$ \\
\hline Redf & & & & & & & - & $0,12(-)$ & $0,19(+)$ \\
\hline Icurva & & & & & & & & - & $0,00(+)$ \\
\hline RTCreep & & & & & & & & & - \\
\hline
\end{tabular}

157 relações lineares em 406 testes $\rightarrow$ 38,7\% 
Tabela H.7 - Valores de $\mathrm{R}^{2}$ e sinal do coeficiente angular das regressões lineares entre os parâmetros da Etapa 1 x Etapa 3

\begin{tabular}{|c|c|c|c|c|c|c|c|c|}
\hline $\begin{array}{c}\text { Variáveis- } \\
\text { resposta }\end{array}$ & $\mathbf{V v}$ & Gmm & Gmb & VAM & RBV & Estabil & Fluência & $\mathbf{T P}$ \\
\hline $\begin{array}{c}\text { MR 10 } \\
(\text { Vv4) }\end{array}$ & $0,37(-)$ & $0,04(+)$ & $0,81(+)$ & $0,59(-)$ & $0,26(+)$ & $0,28(+)$ & $0,17(-)$ & $0,00(-)$ \\
\hline $\begin{array}{c}\text { MR } 10 \\
(\text { Vv7) }\end{array}$ & $0,01(+)$ & $0,36(+)$ & $0,10(+)$ & $0,25(-)$ & $0,10(-)$ & $0,02(+)$ & $0,01(+)$ & $0,57(-)$ \\
\hline $\begin{array}{c}\text { MR 25 } \\
(\text { Vv4) }\end{array}$ & $0,10(-)$ & $0,01(+)$ & $0,22(+)$ & $0,05(-)$ & $0,07(+)$ & $0,43(+)$ & $0,17(+)$ & $0,04(+)$ \\
\hline $\begin{array}{c}\text { MR 25 } \\
\text { (Vv7) }\end{array}$ & $0,04(-)$ & $0,06(+)$ & $0,15(+)$ & $0,22(-)$ & $0,00(+)$ & $0,01(+)$ & $0,01(-)$ & $0,36(-)$ \\
\hline $\begin{array}{c}\text { MR 40 } \\
\left(V_{v} 4\right)\end{array}$ & $0,07(-)$ & $0,01(-)$ & $0,03(+)$ & $0,02(+)$ & $0,05(+)$ & $0,15(+)$ & $0,21(+)$ & $0,32(+)$ \\
\hline $\begin{array}{c}\text { MR 40 } \\
(\mathrm{Vv} 7)\end{array}$ & $0,15(-)$ & $0,00(-)$ & $0,18(+)$ & $0,04(-)$ & $0,11(+)$ & $0,48(+)$ & $0,10(+)$ & $0,04(+)$ \\
\hline $\begin{array}{l}\text { PST 10- } \\
25 \text { Vv4 }\end{array}$ & $0,02(-)$ & $0,00(+)$ & $0,06(+)$ & $0,17(-)$ & $0,02(+)$ & $0,09(-)$ & $0,73(-)$ & $0,08(-)$ \\
\hline $\begin{array}{c}\text { PST 10- } \\
25 \text { Vv7 }\end{array}$ & $0,29(+)$ & $0,20(+)$ & $0,05(-)$ & $0,01(+)$ & $0,23(-)$ & $0,00(-)$ & $0,05(+)$ & $0,00(-)$ \\
\hline $\begin{array}{c}\text { PST 25- } \\
40 \text { Vv4 }\end{array}$ & $0,02(+)$ & $0,05(+)$ & $0,00(+)$ & $0,10(-)$ & $0,04(-)$ & $0,04(-)$ & $0,09(-)$ & $0,48(-)$ \\
\hline $\begin{array}{c}\text { PST 25- } \\
40 \text { Vv7 }\end{array}$ & $0,06(+)$ & $0,01(+)$ & $0,04(-)$ & $0,00(-)$ & $0,08(-)$ & $0,36(-)$ & $0,19(-)$ & $0,26(-)$ \\
\hline $\begin{array}{c}\text { PST 10- } \\
40 \text { Vv4 }\end{array}$ & $0,00(+)$ & $0,03(+)$ & $0,01(+)$ & $0,16(-)$ & $0,01(-)$ & $0,09(-)$ & $0,36(-)$ & $0,37(-)$ \\
\hline $\begin{array}{c}\text { PST 10- } \\
40 \text { Vv7 }\end{array}$ & $0,17(+)$ & $0,07(+)$ & $0,07(-)$ & $0,00(-)$ & $0,18(-)$ & $0,30(-)$ & $0,10(-)$ & $0,24(-)$ \\
\hline k1 & $0,08(-)$ & $0,03(-)$ & $0,02(+)$ & $0,02(+)$ & $0,07(+)$ & $0,62(+)$ & $0,21(+)$ & $0,31(+)$ \\
\hline k2 & $0,04(-)$ & $0,02(-)$ & $0,04(+)$ & $0,00(+)$ & $0,08(+)$ & $0,56(+)$ & $0,00(+)$ & $0,38(+)$ \\
\hline $\begin{array}{l}\mathbf{N} / \Delta \sigma= \\
0,5 \mathrm{MPa}\end{array}$ & $0,08(-)$ & $0,04(-)$ & $0,04(+)$ & $0,01(+)$ & $0,13(+)$ & $0,69(+)$ & $0,11(+)$ & $0,35(+)$ \\
\hline $\begin{array}{l}\mathbf{N} / \Delta \sigma= \\
1,0 \mathrm{MPa}\end{array}$ & $0,08(-)$ & $0,03(-)$ & $0,02(+)$ & $0,02(+)$ & $0,07(+)$ & $0,62(+)$ & $0,21(+)$ & $0,31(+)$ \\
\hline $\begin{array}{l}\mathrm{N} p / \Delta \sigma= \\
1,5 \mathrm{MPa}\end{array}$ & $0,04(-)$ & $0,02(-)$ & $0,00(+)$ & $0,04(+)$ & $0,03(+)$ & $0,53(+)$ & $0,31(+)$ & $0,26(+)$ \\
\hline $\begin{array}{l}\mathbf{N} \text { p/ } \Delta \sigma= \\
2,0 \mathrm{MPa}\end{array}$ & $0,02(-)$ & $0,01(-)$ & $0,00(+)$ & $0,06(+)$ & $0,01(+)$ & $0,44(+)$ & $0,41(+)$ & $0,21(+)$ \\
\hline $\begin{array}{l}\mathrm{N} / \mathrm{p} / \Delta \sigma= \\
2,5 \mathrm{MPa}\end{array}$ & $0,01(-)$ & $0,00(-)$ & $0,00(-)$ & $0,07(+)$ & $0,00(+)$ & $0,35(+)$ & $0,50(+)$ & $0,16(+)$ \\
\hline $\begin{array}{l}\mathrm{N} \mathbf{p} / \Delta \sigma \\
=3,0 \mathrm{MPa}\end{array}$ & $0,00(+)$ & $0,00(-)$ & $0,01(-)$ & $0,08(+)$ & $0,00(-)$ & $0,26(+)$ & $0,58(+)$ & $0,11(+)$ \\
\hline N Pav A & $0,01(+)$ & $0,02(-)$ & $0,06(-)$ & $0,18(+)$ & $0,00(-)$ & $0,22(+)$ & $0,56(+)$ & $0,18(+)$ \\
\hline N Pav B & $0,00(-)$ & $0,03(-)$ & $0,01(-)$ & $0,10(+)$ & $0,01(+)$ & $0,43(+)$ & $0,36(+)$ & $0,28(+)$ \\
\hline N Pav C & $0,01(+)$ & $0,02(-)$ & $0,06(-)$ & $0,19(+)$ & $0,00(-)$ & $0,21(+)$ & $\mathbf{0 , 5 7}(+)$ & $0,17(+)$ \\
\hline N Pav D & $0,00(-)$ & $0,03(-)$ & $0,01(-)$ & $0,10(+)$ & $0,01(+)$ & $0,41(+)$ & $0,38(+)$ & $0,28(+)$ \\
\hline Dt & $0,00(+)$ & $0,17(-)$ & $0,18(-)$ & $0,34(+)$ & $0,01(+)$ & $0,22(-)$ & $0,14(+)$ & $0,20(+)$ \\
\hline Mf & $0,13(+)$ & $0,32(+)$ & $0,01(+)$ & $0,19(-)$ & $0,21(-)$ & $0,02(+)$ & $0,33(-)$ & $0,23(-)$ \\
\hline Redf & $0,01(-)$ & $0,46(+)$ & $0,20(+)$ & $0,39(+)$ & $0,08(-)$ & $0,38(+)$ & $0,10(-)$ & $0,13(-)$ \\
\hline Icurva & $0,06(-)$ & $0,14(-)$ & $0,00(-)$ & $0,13(+)$ & $0,14(+)$ & $0,15(+)$ & $0,28(+)$ & $0,48(+)$ \\
\hline RTCreep & $0,40(+)$ & $0,40(+)$ & $0,04(-)$ & $0,00(+)$ & $0,49(-)$ & $0,17(+)$ & $0,45(+)$ & $0,06(-)$ \\
\hline
\end{tabular}

\section{2 relações lineares em 232 testes $\rightarrow 5,2 \%$}


Tabela H.8 - Valores de $\mathrm{R}^{2}$ e sinal do coeficiente angular das regressões lineares entre os parâmetros da Etapa 2 x Etapa 3

\begin{tabular}{|c|c|c|c|c|c|}
\hline $\begin{array}{l}\text { Variáveis- } \\
\text { resposta }\end{array}$ & MR & RT & MR/RT & RRT & RMR \\
\hline $\begin{array}{c}\text { MR 10 } \\
(\mathrm{Vv4})\end{array}$ & $0,32(+)$ & $0,10(+)$ & $0,17(+)$ & $0,07(+)$ & $0,30(-)$ \\
\hline $\begin{array}{c}\text { MR 10 } \\
(\text { Vv7) }\end{array}$ & $0,07(+)$ & $0,01(+)$ & $0,08(+)$ & $0,26(-)$ & $0,11(-)$ \\
\hline $\begin{array}{c}\text { MR 25 } \\
(\mathrm{Vv4})\end{array}$ & $-*$ & $0,51(+)$ & $0,33(+)$ & $0,00(+)$ & $0,43(+)$ \\
\hline $\begin{array}{c}\text { MR 25 } \\
\text { (Vv7) }\end{array}$ & $0,05(+)$ & $0,03(+)$ & $0,01(+)$ & $0,00(-)$ & $0,30(-)$ \\
\hline $\begin{array}{c}\text { MR 40 } \\
(\mathrm{Vv4})\end{array}$ & $0,65(+)$ & $0,29(+)$ & $0,26(+)$ & $0,02(+)$ & $0,15(-)$ \\
\hline $\begin{array}{c}\text { MR 40 } \\
(\text { Vv7) }\end{array}$ & $0,68(+)$ & $0,76(+)$ & $0,03(+)$ & $0,15(-)$ & $0,69(-)$ \\
\hline $\begin{array}{l}\text { PST 10- } \\
25 \text { Vv4 }\end{array}$ & $0,45(-)$ & $0,32(-)$ & $0,10(-)$ & $0,04(+)$ & $0,10(+)$ \\
\hline $\begin{array}{c}\text { PST 10- } \\
25 \text { Vv7 }\end{array}$ & $0,00(-)$ & $0,06(-)$ & $0,05(+)$ & $0,40(-)$ & $0,25(+)$ \\
\hline $\begin{array}{c}\text { PST 25- } \\
40 \mathrm{Vv} 4\end{array}$ & $0,26(-)$ & $0,15(-)$ & $0,07(-)$ & $0,09(-)$ & $0,04(+)$ \\
\hline $\begin{array}{c}\text { PST 25- } \\
40 \mathrm{Vv} 7\end{array}$ & $0,54(-)$ & $0,59(-)$ & $0,02(-)$ & $0,13(-)$ & $0,33(+)$ \\
\hline $\begin{array}{c}\text { PST 10- } \\
40 \mathrm{Vv} 4\end{array}$ & $0,44(-)$ & $0,30(-)$ & $0,09(-)$ & $0,02(-)$ & $0,09(+)$ \\
\hline $\begin{array}{c}\text { PST 10- } \\
40 \text { Vv7 }\end{array}$ & $0,46(-)$ & $0,60(-)$ & $0,00(-)$ & $0,30(-)$ & $0,48(+)$ \\
\hline k1 & $0,68(+)$ & $\mathbf{0 , 8 4}(+)$ & $0,01(+)$ & $0,13(+)$ & $0,23(-)$ \\
\hline k2 & $0,28(+)$ & $0,62(+)$ & $0,03(-)$ & $0,37(+)$ & $0,11(-)$ \\
\hline $\begin{array}{l}\mathbf{N} / \Delta \sigma= \\
0,5 \mathrm{MPa}\end{array}$ & $0,62(+)$ & $0,82(+)$ & $0,00(+)$ & $0,22(+)$ & $0,22(-)$ \\
\hline $\begin{array}{l}\mathbf{N} \text { p/ } \Delta \sigma= \\
1,0 \mathrm{MPa}\end{array}$ & $0,68(+)$ & $0,84(+)$ & $0,01(+)$ & $0,13(+)$ & $0,23(-)$ \\
\hline $\begin{array}{l}\mathbf{N} \text { p/ } \Delta \sigma= \\
1,5 \mathrm{MPa}\end{array}$ & $0,71(+)$ & $0,80(+)$ & $0,02(+)$ & $0,07(+)$ & $0,23(-)$ \\
\hline $\begin{array}{l}\mathbf{N} / \Delta \sigma= \\
2,0 \mathrm{MPa}\end{array}$ & $0,71(+)$ & $0,73(+)$ & $0,04(+)$ & $0,03(+)$ & $0,22(-)$ \\
\hline $\begin{array}{l}\mathrm{N} \text { p/ } \Delta \sigma= \\
2,5 \mathrm{MPa}\end{array}$ & $0,68(+)$ & $0,65(+)$ & $0,05(+)$ & $0,01(+)$ & $0,21(-)$ \\
\hline $\begin{array}{l}\mathbf{N} \mathbf{p} / \Delta \sigma \\
=3,0 \mathrm{MPa}\end{array}$ & $0,63(+)$ & $0,56(+)$ & $0,07(+)$ & $0,00(-)$ & $0,19(-)$ \\
\hline N Pav A & $0,38(+)$ & $0,59(+)$ & $0,00(-)$ & $0,02(+)$ & $0,15(-)$ \\
\hline N Pav B & $0,51(+)$ & $0,77(+)$ & $0,00(-)$ & $0,09(+)$ & $0,20(-)$ \\
\hline N Pav C & $0,37(+)$ & $0,57(+)$ & $0,00(-)$ & $0,01(+)$ & $0,14(-)$ \\
\hline N Pav D & $0,51(+)$ & $0,76(+)$ & $0,00(-)$ & $0,08(+)$ & $0,19(-)$ \\
\hline Dt & $0,00(-)$ & $0,21(-)$ & $0,21(+)$ & $0,09(-)$ & $0,23(+)$ \\
\hline Mf & $0,19(-)$ & $0,00(-)$ & $0,29(-)$ & $0,00(-)$ & $0,04(+)$ \\
\hline Redf & $0,04(+)$ & $0,22(+)$ & $0,07(-)$ & $0,01(+)$ & $0,09(-)$ \\
\hline Icurva & $0,50(+)$ & $0,19(+)$ & $0,23(+)$ & $0,01(+)$ & $0,02(-)$ \\
\hline RTCreep & $0,16(+)$ & $0,32(+)$ & $0,00(-)$ & $0,21(-)$ & $0,05(-)$ \\
\hline
\end{tabular}

* - São os mesmos valores.

28 relações lineares em 144 testes $\rightarrow 19,4 \%$ 
APÊNDICE I - Modelos de regressão linear entre MR x Vv e RT x Vv

Tabela I.1 - Modelos de regressão linear MR x Vv por tipo de mistura

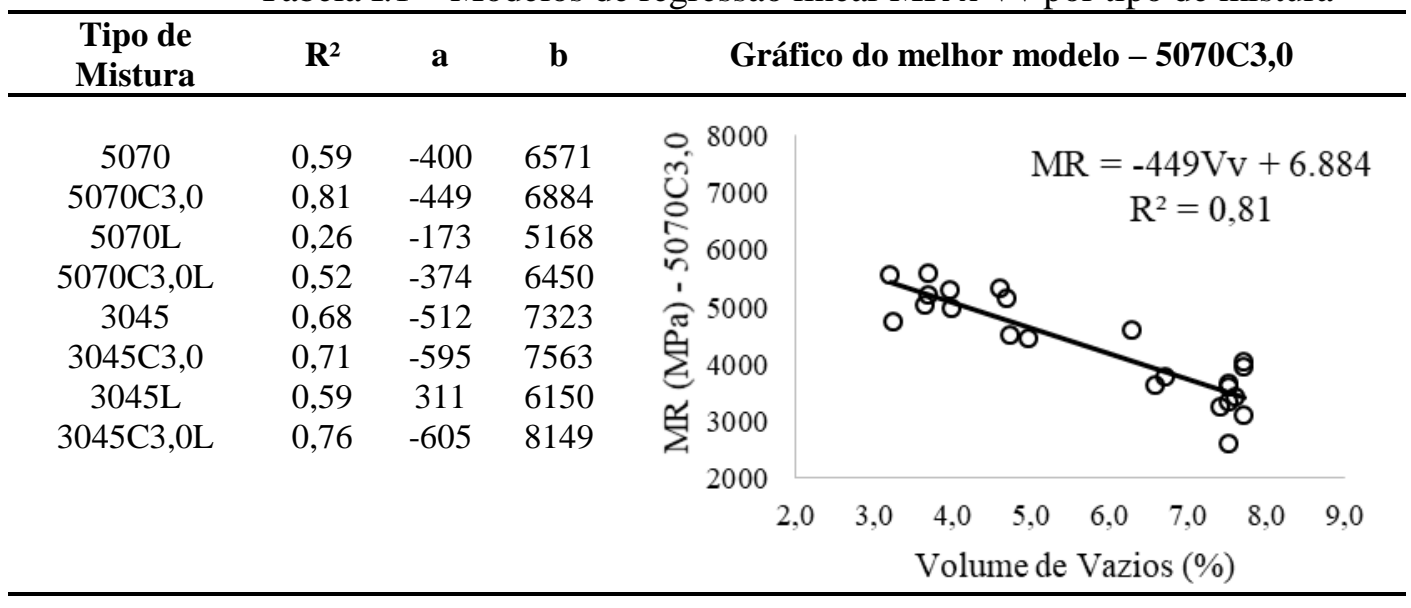

Tabela I.2 - Modelos de regressão linear RT x Vv por tipo de mistura

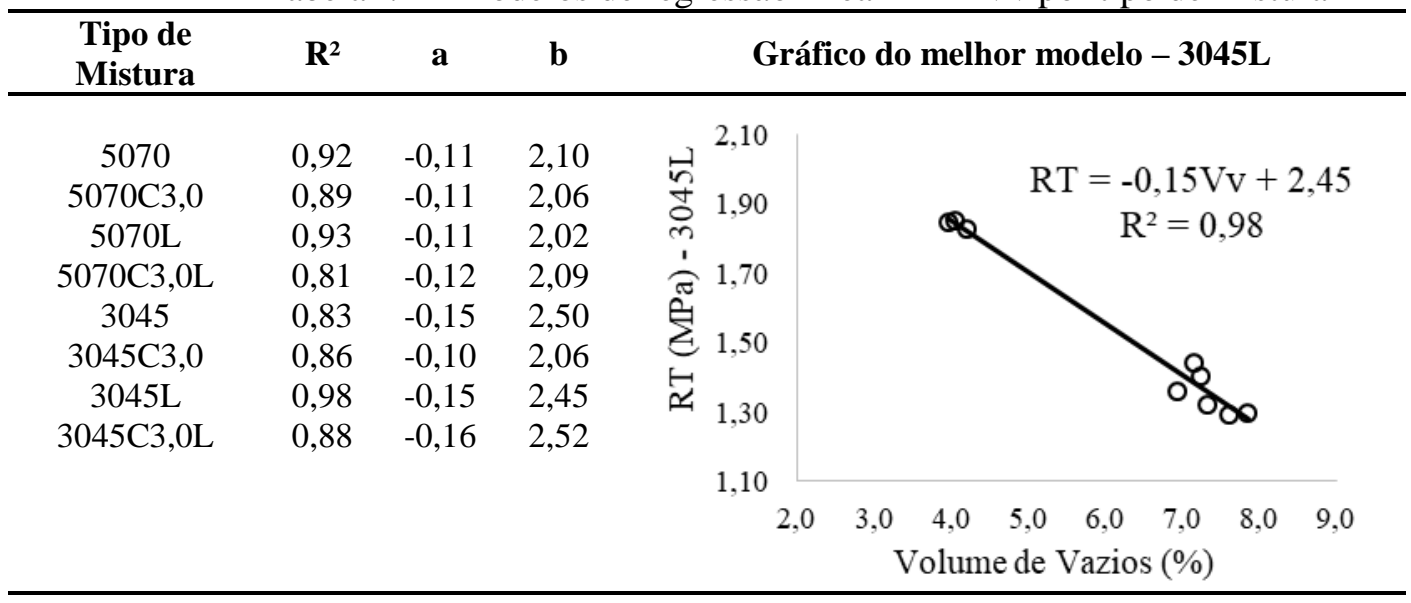


APÊNDICE J - Análise complementar da vida de fadiga

Tabela J.1 - Resultados completos dos ensaios de fadiga por compressão diametral à tensão controlada

\begin{tabular}{|c|c|c|c|c|c|c|c|c|c|c|c|}
\hline Condição & $\mathbf{C P}$ & $\mathbf{V v}(\%)$ & $\begin{array}{c}\text { MR } \\
\text { (MPa) }\end{array}$ & $\begin{array}{l}\text { Ensaios } \\
\text { de ST? }\end{array}$ & $\begin{array}{c}\% \\
\text { RT }\end{array}$ & $\begin{array}{c}\text { Carga } \\
\text { Aplicada } \\
\text { (Kgf) }\end{array}$ & $\begin{array}{c}\Delta \sigma \\
(\mathbf{M P a})\end{array}$ & $\mathbf{N}$ & $\begin{array}{c}\mathbf{V v} \\
\mathbf{X} \\
\mathbf{N} \\
\end{array}$ & $\begin{array}{c}\text { MR } \\
\mathbf{x} \\
\mathbf{N} \\
\end{array}$ & $\begin{array}{c}\text { ST } \\
\mathbf{x} \\
\mathbf{N}\end{array}$ \\
\hline 3045 & 301 & $4,03(+)$ & $5267(-)$ & Sim $(\mathrm{S})$ & 10 & 208 & 0,76 & 94.328 & ++ & -+ & $\mathrm{S}+$ \\
\hline 3045 & 303 & 3,32 & 5332 & Não & 10 & 207 & 0,76 & 63.628 & & & \\
\hline 3045 & 304 & $3,23(-)$ & $5496(+)$ & Não (N) & 20 & 412 & 1,51 & 4.808 & -+ & ++ & $\mathrm{N}+$ \\
\hline 3045 & 300 & 4,03 & 5007 & Sim & 20 & 417 & 1,51 & 4.431 & & & \\
\hline 3045 & 302 & $3,87(-)$ & $4900(+)$ & $\operatorname{Sim}(\mathrm{S})$ & 30 & 627 & 2,27 & 1.382 & -+ & ++ & $\mathrm{S}+$ \\
\hline 3045 & 306 & 4,22 & 4593 & Não & 30 & 631 & 2,27 & 808 & & & \\
\hline 3045 & 305 & $3,89(-)$ & $4939(-)$ & $\operatorname{Sim}(\mathrm{S})$ & 40 & 837 & 3,02 & 712 & -+ & -+ & $\mathrm{S}+$ \\
\hline 3045 & 307 & 3,90 & 5908 & Não & 40 & 839 & 3,02 & 388 & & & \\
\hline $3045 \mathrm{C} 3,0$ & 317 & $3,10(-)$ & $6714(+)$ & Não (N) & 10 & 186 & 0,68 & 139.379 & -+ & ++ & $\mathrm{N}+$ \\
\hline $3045 \mathrm{C} 3,0$ & 311 & 3,95 & 4464 & Sim & 10 & 188 & 0,68 & 70.771 & & & \\
\hline $3045 \mathrm{C} 3,0$ & 318 & $3,50(+)$ & $5209(-)$ & Não (N) & 20 & 376 & 1,36 & 9.475 & ++ & -+ & $\mathrm{N}+$ \\
\hline $3045 \mathrm{C} 3,0$ & 312 & 3,45 & 7741 & Sim & 20 & 373 & 1,36 & 8.605 & & & \\
\hline $3045 \mathrm{C} 3,0$ & 313 & $3,59(+)$ & $6143(+)$ & Não (N) & 30 & 565 & 2,04 & 1.758 & ++ & ++ & $\mathrm{N}+$ \\
\hline $3045 \mathrm{C} 3,0$ & 314 & 3,13 & 4813 & $\mathrm{Sim}$ & 30 & 557 & 2,04 & 1.680 & & & \\
\hline $3045 \mathrm{C} 3,0$ & 316 & $3,93(+)$ & $5535(-)$ & Não (N) & 40 & 753 & 2,72 & 722 & ++ & -+ & $\mathrm{N}+$ \\
\hline $3045 \mathrm{C} 3,0$ & 315 & 3,07 & 6136 & Sim & 40 & 743 & 2,72 & 596 & & & \\
\hline $3045 \mathrm{~L}$ & 324 & $3,05(-)$ & $5604(+)$ & Sim $(\mathrm{S})$ & 10 & 202 & 0,73 & 179.932 & -+ & ++ & $\mathrm{S}+$ \\
\hline $3045 \mathrm{~L}$ & 328 & 3,40 & 4231 & Não & 10 & 203 & 0,74 & 88.503 & & & \\
\hline $3045 \mathrm{~L}$ & 326 & $3,22(+)$ & $4618(+)$ & Não (N) & 20 & 406 & 1,47 & 5.184 & ++ & ++ & $\mathrm{N}+$ \\
\hline $3045 \mathrm{~L}$ & 322 & 3,20 & 4229 & Sim & 20 & 405 & 1,47 & 3.342 & & & \\
\hline $3045 \mathrm{~L}$ & 329 & $3,12(+)$ & $5609(-)$ & Não (N) & 30 & 610 & 2,21 & 1.572 & ++ & -+ & $\mathrm{N}+$ \\
\hline $3045 \mathrm{~L}$ & 327 & 3,06 & 5784 & Sim & 30 & 608 & 2,21 & 1.046 & & & \\
\hline $3045 \mathrm{~L}$ & 323 & $3,05(-)$ & $5457(+)$ & Não (N) & 40 & 808 & 2,94 & 411 & -+ & ++ & $\mathrm{N}+$ \\
\hline $3045 \mathrm{~L}$ & 325 & 3,53 & 4808 & Sim & 40 & 817 & 2,94 & 404 & & & \\
\hline $3045 \mathrm{C} 3,0 \mathrm{~L}$ & 333 & $3,44(+)$ & $6035(+)$ & Sim $(S)$ & 10 & 213 & 0,78 & 208.384 & ++ & ++ & $\mathrm{S}+$ \\
\hline $3045 \mathrm{C} 3,0 \mathrm{~L}$ & 334 & 3,23 & 5886 & Não & 10 & 213 & 0,77 & 102.283 & & & \\
\hline $3045 \mathrm{C} 3,0 \mathrm{~L}$ & 335 & $4,02(+)$ & $6559(+)$ & Não (N) & 20 & 429 & 1,55 & 5.100 & ++ & ++ & $\mathrm{N}+$ \\
\hline $3045 \mathrm{C} 3,0 \mathrm{~L}$ & 337 & 3,30 & 5940 & Sim & 20 & 427 & 1,55 & 4.290 & & & \\
\hline $3045 \mathrm{C} 3,0 \mathrm{~L}$ & 340 & $3,41(+)$ & $5391(-)$ & Não (N) & 30 & 641 & 2,33 & 1.354 & ++ & -+ & $\mathrm{N}+$ \\
\hline $3045 \mathrm{C} 3,0 \mathrm{~L}$ & 338 & 3,31 & 6850 & Sim & 30 & 641 & 2,33 & 1.192 & & & \\
\hline $3045 \mathrm{C} 3,0 \mathrm{~L}$ & 339 & $3,19(-)$ & $5860(+)$ & Não (N) & 35 & 755 & 2,74 & 819 & -+ & ++ & $\mathrm{N}+$ \\
\hline $3045 \mathrm{C} 3,0 \mathrm{~L}$ & 336 & 3,75 & 5152 & Sim & 40 & 857 & 3,10 & 487 & & & \\
\hline 5070 & 263 & $4,15(-)$ & $4995(+)$ & Não (N) & 10 & 181 & 0,65 & 16.575 & -+ & ++ & $\mathrm{N}+$ \\
\hline 5070 & 256 & 4,95 & 4715 & $\operatorname{Sim}$ & 10 & 182 & 0,65 & 15.773 & & & \\
\hline 5070 & 260 & $3,51(-)$ & $5487(+)$ & $\operatorname{Sim}(\mathrm{S})$ & 20 & 358 & 1,30 & 1.704 & -+ & ++ & $\mathrm{S}+$ \\
\hline 5070 & 257 & 4,14 & 5455 & Não & 20 & 361 & 1,31 & 701 & & & \\
\hline 5070 & 259 & $4,23(-)$ & $4600(+)$ & $\operatorname{Sim}(\mathrm{S})$ & 30 & 542 & 1,96 & 211 & -+ & ++ & $\mathrm{S}+$ \\
\hline 5070 & 262 & 4,71 & 4477 & Não & 30 & 543 & 1,96 & 195 & & & \\
\hline 5070 & 258 & $4,30(+)$ & $5227(-)$ & $\operatorname{Sim}(\mathrm{S})$ & 40 & 724 & 2,61 & 149 & ++ & -+ & $\mathrm{S}+$ \\
\hline 5070 & 261 & 4,07 & 5326 & Não & 40 & 720 & 2,61 & 131 & & & \\
\hline $5070 \mathrm{C} 3,0$ & 270 & $3,69(-)$ & $5210(+)$ & Sim (S) & 10 & 183 & 0,66 & 38.218 & -+ & ++ & $\mathrm{S}+$ \\
\hline $5070 \mathrm{C} 3,0$ & 267 & 4,93 & 4452 & Não & 10 & 185 & 0,66 & 29.152 & & & \\
\hline $5070 \mathrm{C} 3,0$ & 273 & $3,21(-)$ & $5572(+)$ & Não (N) & 20 & 364 & 1,32 & 3.931 & -+ & ++ & $\mathrm{N}+$ \\
\hline $5070 \mathrm{C} 3,0$ & 268 & 4,73 & 4501 & Sim & 20 & 369 & 1,32 & 3.092 & & & \\
\hline $5070 \mathrm{C} 3,0$ & 269 & $4,69(+)$ & $5149(+)$ & $\operatorname{Sim}(\mathrm{S})$ & 30 & 552 & 1,98 & 1.271 & ++ & ++ & $\mathrm{S}+$ \\
\hline $5070 \mathrm{C} 3,0$ & 271 & 3,99 & 4973 & Não & 30 & 547 & 1,98 & 1.206 & & & \\
\hline $5070 \mathrm{C} 3,0$ & 274 & $4,60(+)$ & $5331(+)$ & Não (N) & 40 & 738 & 2,64 & 452 & ++ & ++ & $\mathrm{N}+$ \\
\hline $5070 \mathrm{C} 3,0$ & 272 & 3,97 & 5313 & Sim & 40 & 730 & 2,64 & 415 & & & \\
\hline $5070 \mathrm{~L}$ & 283 & $3,20(-)$ & $4685(+)$ & Sim (S) & 10 & 182 & 0,66 & 32.058 & -+ & ++ & $\mathrm{S}+$ \\
\hline $5070 \mathrm{~L}$ & 281 & 3,69 & 4658 & Não & 10 & 182 & 0,66 & 25.676 & & & \\
\hline $5070 \mathrm{~L}$ & 278 & $4,03(+)$ & $4552(-)$ & $\operatorname{Sim}(\mathrm{S})$ & 20 & 367 & 1,31 & 2.334 & ++ & -+ & $\mathrm{S}+$ \\
\hline $5070 \mathrm{~L}$ & 282 & 3,65 & 4630 & Não & 20 & 363 & 1,31 & 2.033 & & & \\
\hline $5070 \mathrm{~L}$ & 279 & $3,16(-)$ & $4789(-)$ & $\operatorname{Sim}(\mathrm{S})$ & 30 & 539 & 1,97 & 742 & -+ & -+ & $\mathrm{S}+$ \\
\hline $5070 \mathrm{~L}$ & 285 & 4,04 & 5503 & Não & 30 & 548 & 1,97 & 693 & & & \\
\hline $5070 \mathrm{~L}$ & 280 & $3,47(-)$ & $3702(-)$ & Não (N) & 40 & 726 & 2,62 & 282 & -+ & -+ & $\mathrm{N}+$ \\
\hline $5070 \mathrm{~L}$ & 284 & 4,58 & 3915 & Sim & 40 & 733 & 2,62 & 166 & & & \\
\hline $5070 \mathrm{C} 3,0 \mathrm{~L}$ & 290 & $3,81(+)$ & $4825(+)$ & Sim $(\mathrm{S})$ & 10 & 184 & 0,67 & 42.250 & ++ & ++ & $\mathrm{S}+$ \\
\hline $5070 \mathrm{C} 3,0 \mathrm{~L}$ & 293 & 3,59 & 4801 & Não & 10 & 184 & 0,67 & 37.484 & & & \\
\hline $5070 \mathrm{C} 3,0 \mathrm{~L}$ & 292 & $3,03(-)$ & $4553(-)$ & Não (N) & 20 & 363 & 1,33 & 2.940 & -+ & -+ & $\mathrm{N}+$ \\
\hline $5070 \mathrm{C} 3,0 \mathrm{~L}$ & 291 & 4,01 & 4926 & Sim & 20 & 367 & 1,33 & 2.143 & & & \\
\hline $5070 \mathrm{C} 3,0 \mathrm{~L}$ & 296 & $4,17(+)$ & $5075(+)$ & Não (N) & 30 & 551 & 1,99 & 800 & ++ & ++ & $\mathrm{N}+$ \\
\hline $5070 \mathrm{C} 3,0 \mathrm{~L}$ & 294 & 3,30 & 4906 & Sim & 30 & 548 & 1,99 & 763 & & & \\
\hline $5070 \mathrm{C} 3,0 \mathrm{~L}$ & 295 & $3,43(-)$ & $5232(-)$ & $\operatorname{Sim}(\mathrm{S})$ & 40 & 729 & 2,66 & 389 & -+ & -+ & $\mathrm{S}+$ \\
\hline $5070 \mathrm{C} 3,0 \mathrm{~L}$ & 289 & 3,70 & 5344 & Não & 40 & 731 & 2,66 & 316 & & & \\
\hline \multirow{2}{*}{\multicolumn{9}{|c|}{$\begin{array}{l}\text { Total }++ \text { ou } S+ \\
\text { Total }-+ \text { ou } N+\end{array}$}} & 15 & 20 & 15 \\
\hline & & & & & & & & & 17 & 12 & 17 \\
\hline
\end{tabular}


